UNIVERSIDADE DE SÃO PAULO

INSTITUTO DE QuímiCa DE SÃo CaRLOS

Pós-Graduação em Química - Área: Físico-Química

\title{
EXPERIMENTAÇÃO NO ENSINO DE QUÍMICA: CONTRIBUIÇÕES DO PROJETO EXPERIMENTOTECA PARA A PRÁTICA E PARA A FORMAÇÃO DOCENTE
}

Rafael Cava Mori

SÃO CARLOS

2014 
UNIVERSIDADE DE SÃO PAULO

INSTITUTO de QuíMICA de SÃo CARLOS

Pós-Graduação em Química - Área: Físico-Química

\title{
EXPERIMENTAÇÃO NO ENSINO DE QUÍMICA: CONTRIBUIÇÕES DO PROJETO EXPERIMENTOTECA PARA A PRÁTICA E PARA A FORMAÇÃO DOCENTE
}

\author{
Rafael Cava Mori
}

Tese apresentada ao Instituto de Química de São Carlos da Universidade de São Paulo como parte dos requisitos para obtenção do título de Doutor em Ciências.

Orientador: Prof. Dr. Antonio Aprigio da Silva Curvelo.

\section{Exemplar revisado}

O exemplar original encontra-se em acervo reservado na Biblioteca do IQSC-USP

SÃO CARLOS

2014 
Autorizo a divulgação total ou parcial deste trabalho por qualquer meio (convencional ou eletrônico), para fins de estudo ou pesquisa, desde que citada a fonte.

Autorizo também a reprodução total ou parcial, via impressão ou fotocópia.

\section{Rafael Cava Mori}

Data: 18 de novembro de 2014 .

Ficha Catalográfica elaborada pela Seção de Referência e Atendimento ao Usuário do SBI/IQSC

Mori, Rafael Cava

Experimentação no ensino de Química: contribuições do Projeto

Experimentoteca para a prática e para a formação docente. / Rafael Cava

Mori. - São Carlos, 2014.

$430 \mathrm{f}$

Tese (Doutorado em Físico-Química) - Instituto de Química de São Carlos / Universidade de São Carlos, 2014.

Orientador: Prof. Dr. Antonio Aprigio Da Silva Curvelo

1. Experimentação no ensino. 2. Museus de ciências naturais. 3. Pedagogia Histórico-Crítica. 4. Psicologia Histórico-Cultural. 5. Formação de professores. I. Título. 
À Cristiane,

por sua paciência, sua entrega e seu afeto. 


\section{AGRADECIMENTOS}

À Universidade de São Paulo e, especificamente, ao Instituto de Química de São Carlos, por oportunizar este doutoramento.

À CAPES, pela bolsa de estudos.

Especialmente:

À família e aos amigos, pelo apoio nem sempre correspondido à altura.

Ao professor Aprigio, por mais uma vez confiar e indicar a direção.

Às professoras a quem recorri na busca por mais conhecimentos e experiências durante este curso de pós-graduação: da USP, Elaine Sampaio Araujo, da Faculdade de Filosofia, Ciências e Letras de Ribeirão Preto, e Martha Marandino, da Faculdade de Educação; do Programa de Pós-Graduação em Educação da Universidade Federal de São Carlos, Aline Maria de Medeiros Rodrigues, Regina Maria Simões Puccinelli e Rosa Maria Moraes Anunciato.

Às professoras Miriam Cardoso Utsumi e Salete Linhates Queiroz, pela participação e pelas sugestões no exame de qualificação.

Às professoras Joana de Jesus Andrade, Denise de Freitas e Alessandra Arce Hai, além da professora Salete novamente, pela participação na defesa do trabalho, ocasião em que contribuíram com valorosos apontamentos.

Aos diretores, professores e demais trabalhadores das escolas do município de São Carlos, que possibilitaram a coleta de dados em seus estabelecimentos, e aos pesquisadores que gentilmente cederam seus depoimentos.

Ao Centro Acadêmico Armando de Salles Oliveira (CAASO), onde encontrei a atmosfera perfeita para elaboração de grande parte deste trabalho. Em especial, agradeço à Bibliotecaaso, na figura de sua bibliotecária Tia Celly.

À equipe do Centro de Divulgação Científica e Cultural, pela convivência.

Aos trabalhadores da USP e às suas lutas. 


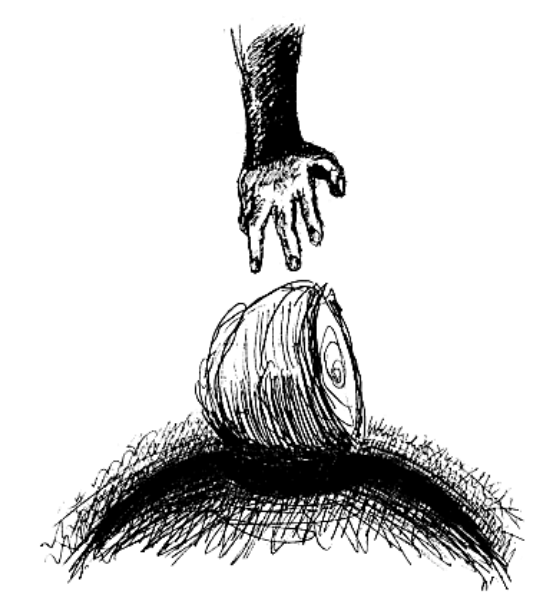

a título de epIGRAFE...

"PEGUE UMA CEBOLA"1

pegue uma cebola e corte no meio. então olhe bem para ela com olhos de criança. SE VOCE NÃO SABE O QUE E O OLHAR DE uMA CRIANCA, lEIA O POETA ALBERTO CAEIRO PARA APRENDER...

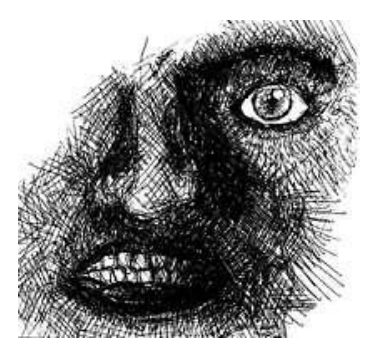

UMA PACIENTE MINHA, DOS TEMPOS EM QUE EU EXERCIA A PSICANÁLISE, OLHOU COM OLHOS DE CRIANCA PARA uMA CEBOLA CORTADA AO MEIO E fICOU TÃo ESPANTADA COM O QUE VIU QUE PENSOU QUE ESTAVA FICANDO LOUCA.

UMA CEBOLA CORTADA É MESMO UM ESPANTO. PABLO NERUDA, OLHANDO PARA uMA CEBOLA, ESCREVEU: "ROSA DE ÁGUA COM ESCAMAS DE CRISTAL...".

AGORA, FIGURE QUE UMA CEBOLA CORTADA É UM MODELO DO MUNDO. BEM NO CENTRO, LÃ ONDE O PRIMEIRO ANEL É TÃO PEQUENO QUE NÃO CHEGOU A SER ANEL, PONHA UMA CRIANCCA. IMAGINE QUE OS ANEIS SÃO OS MUNDOS QUE ELA PRECISA CONHECER PARA VIVER.

MAS não é pOSSÍvel comer o que está longe. não é pOSSÍvel PULAR ANEIS. SÓ SE PODE COMER O QUARTO ANEL DEPOIS QUE SE COMEU O PRIMEIRO, O SEGUNDO E O TERCEIRO ANEIS.
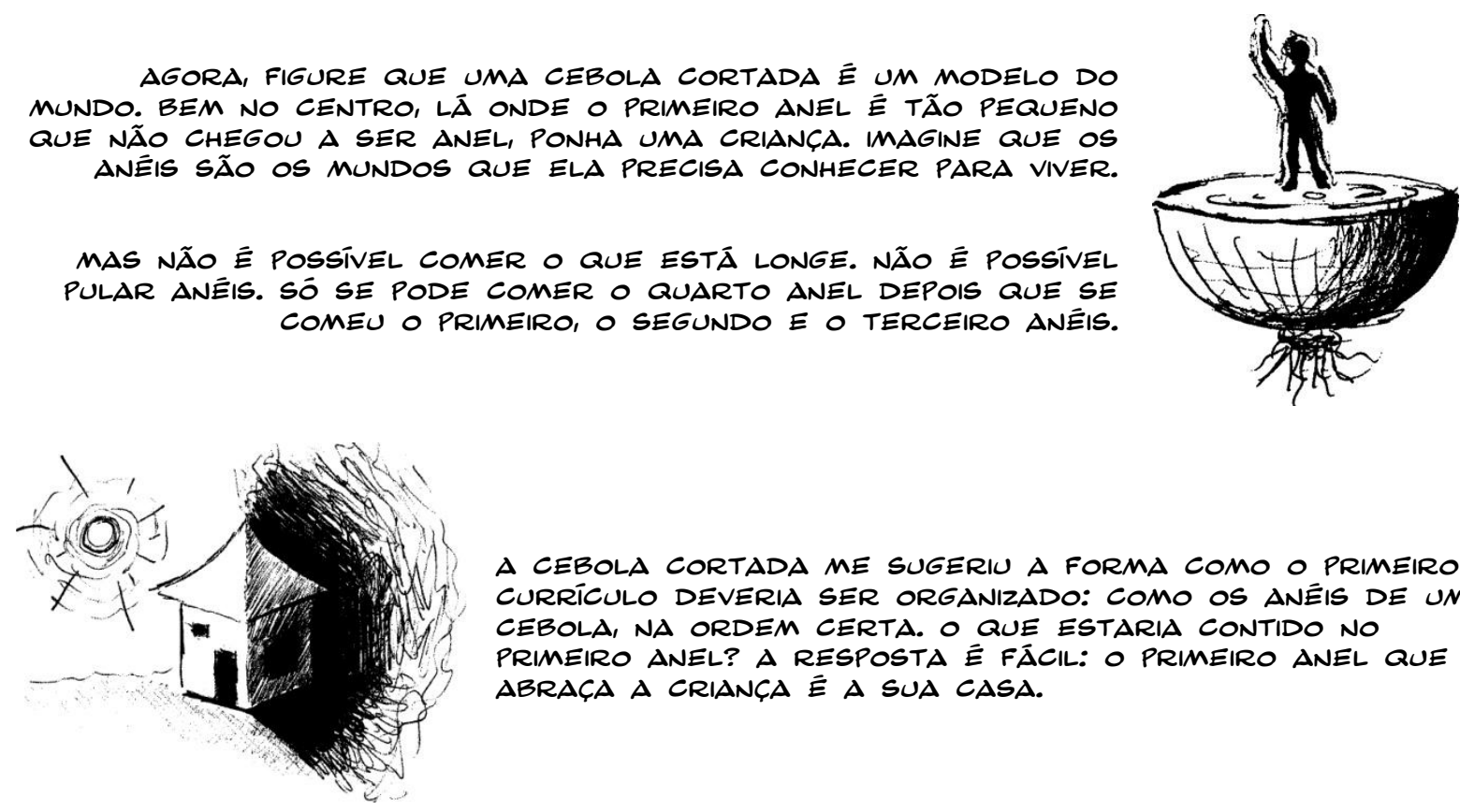

A CEBOLA CORTADA ME SUGERIU A FORMA COMO O PRIMEIRO CURRÍCULO DEVERIA SER ORGANIZADO: COMO OS ANEEIS DE UMA CEBOLA, NA ORDEM CERTA. O QUE ESTARIA CONTIDO NO PRIMEIRO ANEL? A RESPOSTA É FÁCIL: O PRIMEIRO ANEL QUE ABRAÇA A CRIANÇA E A SUA CASA.

${ }^{1}$ Crônica de Rubem Alves. Referência:

ALVES, R. Pegue uma cebola. Folha de S. Paulo, São Paulo, $1^{\circ}$ jun. 2010. Folha Ribeirão, Caderno 3, p. 2. 


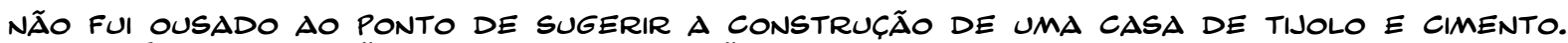
MAS É a IMAGINACÃ̃ QUE FAZ O QUE NÃO EXISTE EXISTIR! PENSEI QUE A CASA ONDE UMA CRIANÇA MORA, O PRIMEIRO ANEL DA SUA CEBOLA, É UM UNIVERSO IMENSO, CHEIO DE PROVOCAÇÕES AO CONHECIMENTO.

PRIMEIRO, A CASA COMO OBJETO MATEMĀTICO: ÃNGULOS, TRIĀNGULOS, LINHAS HORIZONTAIS, VERTICAIS E PARALELAS, PROPORÇÕES E SIMETRIAS.

DEPOIS, COMO OBJETO DA FÍSICA: A COMPOSICÃO DE Forças no TRAVAMENTO DO TELHADO, O PRUMO, O NIIVEL, AS CAIXAS DE FERRAMENTAS, O MARTELO, O SERROTE, A

PUA, A FISICA DOS MATERIAIS, A MADEIRA, O VIDRO, A CERĀMICA, O PLÁSTICO, A ELETRICIDADE QUE ESQUENTA E QUE ESFRIA, A ELETRICIDADE QUE FAZ GIRAR, QUE ILUMINA E PRODUZ MÚSICA.

ESSE LABORATÓRIO DE QUIMMICA CHAMADO COZINHA: O FOGO, OS ALIMENTOS, OS TEMPEROS.

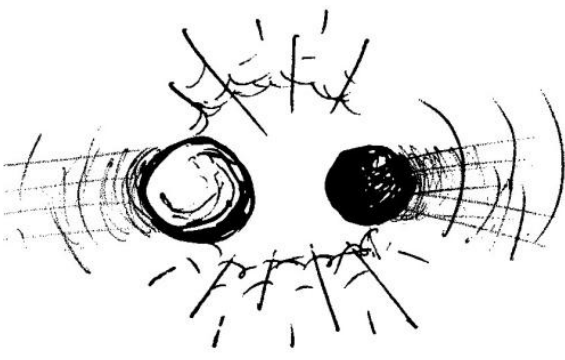

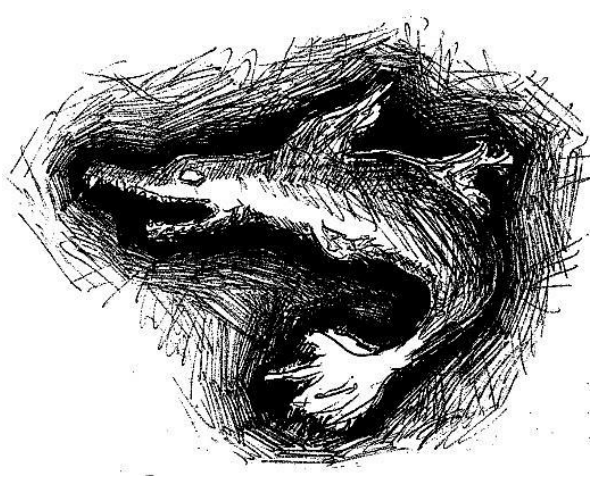

- MUNDO DAS colsas VIVAS: as baratas, as TRACAS, OS TATUZINHOS, OS PIOLHOS, OS PÁSSAROS, AS ARANHAS, OS CACHORROS, OS GATOS, OS PEIXES, OS PERNILONGOS, OS MOSQUITOS DA DENGUE, OS CARAMUJOS.

- MUNDO das DOENÇAS E dA SAÚdE. OS PRIMEIROSSOCORROS. O LIXO, AS PRIVADAS... OUSE IMAGINAR quANTAS TONELADAS DE COCÓ POR ANO OS HUMANOS COLOCAM NA NOSSA TERRA...

E, AO TOMAR O SEU branCo E PURO LEITINHO, IMAGINE QUANTAS TONELADAS DE BOSTA DE VACA E QUANTOS METROS CÚBICOS DE GASES FÉTIDOS SÃO LANCCADOS NA ATMOSFERA DIARIAMENTE PELOS BOVINOS INOCENTES.

- mundo da cultura: as revistas, os livros, a televisão, o jardim, os quadros.

GOSTARIA DE CONHECER A CASA EM QUE MORO, MAS NÃO CONHECO. APERTO UMA INFINIDADE DE BOTÕES QUE FAZEM AS COISAS ACONTECEREM, MAS NÃO SEI POR QUE ELAS ACONTECEM, E, QUANDO NÃO ACONTECEM, FICO PERDIDO E TENHO DE CHAMAR UM TÉCNICO.

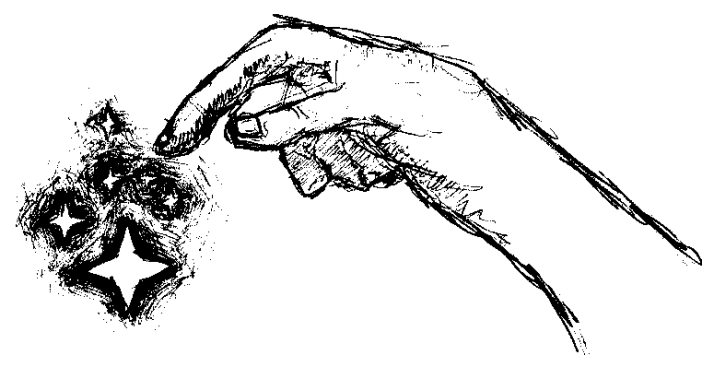

PENSEI QUE AS CRIANCAAS GOSTARIAM DA IDEIA ASSIM COMO EU GOSTEI. APRENDENDO SOBRE A CASA APRENDEMOS SOBRE O MUNDO TODO. POIS O MUNDO TODO É A GRANDE CASA EM que moramos, O ÚlTiMO ANEL da CEBOLA... 


\section{RESUMO}

MORI, R. C. Experimentação no ensino de Química: contribuições do Projeto Experimentoteca para a prática e para a formação docente. 2014. 430 f. Tese (Doutorado em Química)-Instituto de Química de São Carlos, Universidade de São Paulo, São Carlos, 2014.

Este trabalho compila, descreve, analisa e discute as contribuições da Experimentoteca, um projeto do Centro de Divulgação Científica e Cultural (CDCC-USP), para a prática e para a formação de professores de Química. Partindo de uma visão de mundo enraizada no materialismo histórico e dialético, o trabalho adota como referencial teórico a Pedagogia Histórico-Crítica, formulada pelo educador brasileiro Dermeval Saviani. Além disso, entendese que a Psicologia Histórico-Cultural, associada principalmente a Lev Semionovitch Vigotski e Aleksei Nikolaevitch Leontiev, estabeleça uma unidade psicopedagógica com a teoria de Saviani. O trabalho é composto por sete capítulos, constituídos por estudos com diferentes naturezas e objetivos. O primeiro capítulo descreve a Pedagogia Histórico-Crítica e a situa no quadro das tendências pedagógicas contemporâneas, destacando seu caráter socialista de inspiração marxista. O capítulo 2 apresenta a Psicologia Histórico-Cultural (teoria também inspirada no materialismo dialético) considerando-a como uma tendência contraposta ao ideário do construtivismo. Após analisar as contribuições desta psicologia para o entendimento da educação, o capítulo se encerra com um estudo de revisão bibliográfica sobre as apropriações de obras da "Escola de Vigotski" por educadores químicos brasileiros. Recolhendo contribuições de autores diversos, e de textos fundamentais da Pedagogia Histórico-Crítica e da Psicologia Histórico-Cultural, o capítulo 3 elabora uma visão críticodialética sobre a experimentação no ensino de ciências. O capítulo 4 relata um estudo de campo que levantou as condições dos laboratórios científicos das escolas estaduais de São Carlos, e discute as dificuldades materiais destas escolas conforme categorias propostas por Saviani. A Experimentoteca, provendo os estabelecimentos escolares com materiais para o ensino experimental, se confirma como iniciativa de grande relevância em São Carlos e em outros municípios. Assim, investiga-se no capítulo 5 a gênese, o passado, os desafios e perspectivas desta ação educativa do CDCC, discutindo-se também o papel de museus e centros de ciências na educação escolar. O capítulo 6 analisa "O livro da Experimenteca", publicação que estabelece os fundamentos pedagógicos do projeto, concentrando sua atenção em três das tendências atuais da Educação em Química adotadas por esta obra. Finalmente, o capítulo 7 levanta as contribuições da Experimentoteca para a formação de professores de ciências e de Química, apontando possibilidades e orientações para um processo formativo em acordo com uma concepção crítica e transformadora, decorrente do referencial teórico adotado no trabalho.

Palavras-chave: experimentação no ensino de Química. Experimentoteca. Centros e museus de ciências. Pedagogia Histórico-Crítica. Psicologia Histórico-Cultural. Formação de professores. 


\begin{abstract}
MORI, R. C. Experiments in Chemistry teaching: contributions of the Projeto Experimentoteca to teaching practice and teacher education. 2014. $430 \mathrm{f}$. Thesis (Doctor's degree in Chemistry)-Instituto de Química de São Carlos, Universidade de São Paulo, São Carlos, 2014.
\end{abstract}

This thesis compiles, describes, analyzes, and discusses the contributions of Experimentoteca, a project undertaken by Centro de Divulgação Científica e Cultural, to Chemistry teachers' practice and education. From a world vision rooted in the historical and dialectical materialism, the theoretical framework adopted is the Historical-Critical Pedagogy, formulated by Brazilian educator Dermeval Saviani. Furthermore, the study has interpreted the Historical-Cultural Psychology, which is primarily associated with the works of Lev Semionovitch Vigotski and Aleksei Nikolaevitch Leontiev, has established a psychoeducational oneness with Saviani's theory. The manuscript comprises seven chapters with of studies of different natures and objectives. The first chapter describes the HistoricalCritical Pedagogy, as well as its contextualization within the framework of contemporary pedagogical theories and its Marxist-socialist character. Chapter 2 presents the HistoricalCultural Psychology (which is also based on dialectical materialism) as a trend opposed to the ideas of constructivism. After analyzing the contributions of the above-mentioned theory towards the understanding of educational issues, the chapter is concluded by a review of the interpretations of works of "Vigotski School" by Brazilian chemical educators. By compiling contributions from several authors and fundamental texts of Historical-Critical Pedagogy and Historical-Cultural Psychology, a critical-dialectical view of experimentation in science education is elaborated in chapter 3. Chapter 4 reports on a field study that surveyed the material conditions of scientific laboratories of public schools of São Carlos and discusses the difficulties of these schools according to categories extracted from Saviani's works. Experimentoteca, which aims at providing basic education schools with didactic materials so that experiments can be conducted in science classes, has been confirmed, by this study, as an enterprise of high importance in São Carlos and other cities. Therefore, chapter 5 investigates Experimentoteca's genesis, past, challenges, and perspectives and discusses the role played by science centers and museums in schooling. Chapter 6 examines "O livro da Experimentoteca", which established the pedagogical frameworks of the project, focusing on three of the contemporary tendencies of Chemistry Education mentioned in the book. Finally, chapter 7 addresses the contributions of Experimentoteca to Sciences/Chemistry teachers' education and possibilities and guidelines for training processes in accordance with a critical and transformative conception, derived from the theoretical framework adopted in this research.

Keywords: experiments in Chemistry teaching. Experimentoteca. Science centers and museums. Historical-Critical Pedagogy. Historical-Cultural Psychology. Teacher education. 


\section{LISTA DE ILUSTRAÇÕES}

Figura 1: quadro com tendências pedagógicas conforme as obras de Mizukami, Libâneo e Saviani, considerando as nomenclaturas adotadas e a indicação de alguns de seus formuladores

Figura 2: quadro com um sumário das diferenças entre a pedagogia da essência (tradicional) e a pedagogia da existência (nova).

Figura 3: quadro com outras teorias e tendências pedagógicas abordadas pelas obras de Mizukami, Libâneo e Saviani, considerando novamente nomenclaturas e formuladores.

Figura 4: quadro que sumariza posições da pedagogia tradicional, da nova e da Pedagogia Histórico-Crítica.... 60

Figura 5: diagrama das posições construtivistas, entre as dimensões pessoal/social e relativismo/objetivismo... 70

Figura 6: quadro com os artigos que fazem referência a obras da Psicologia Histórico-Cultural publicados em QNEsc, dispondo autores e anos, títulos e seções em que foram incluídos..

Figura 7: quadro com informações sobre as obras de autores da Psicologia Histórico-Cultural referenciadas pelos artigos de QNESC.

Figura 8: quadro com autores e anos dos artigos que fazem referência a obras da Psicologia Histórico-Cultural publicados em $Q N E S c$, e as palavras-chaves que indicam.

Figura 9: palavras-chaves dos artigos de QNEsc que fazem referência a obras da Psicologia Histórico-Cultural, distribuídas pelas categorias âmbito, docência, métodos e recursos didáticos, currículo e avaliação e psicologia.

Figura 10: quadro sobre os períodos e/ou modalidades da experimentação no ensino de ciências e a importância dos domínios semânticos das palavras experimentar, experimentação, experiência e experimento (MORI, 2009, p. 77).

Figura 11: esquema que representa a articulação hierárquica das diferentes formas de práxis no âmbito do ensino: experimental, educativa e política

Figura 12: esquema das interações recíprocas entre sujeito, objeto e instrumento, na atividade instrumentada (VERILLON, 1995, p. 85)......

Figura 13: quadro com as contribuições dos domínios semânticos das palavras experimentar, experimentação, experiência e experimento para se entender a visão crítico-dialética da experimentação no ensino de ciências. 189

Figura 14: quadro-síntese dos materiais obtidos com a coleta de dados, com exposição dos códigos adotados para identificá-los.

Figura 15: quadro-síntese dos guias de observação dos laboratórios escolares de São Carlos, apresentando os itens presentes (células hachuradas) e ausentes (x) em cada escola visitada.

Figura 16: detalhamento de itens ausentes e de outros itens presentes nos laboratórios escolares de São Carlos, mas não contemplados no guia de observações.

Figura 17: vidrarias com indicações de uso infrequente, fora dos armários e contendo restos de reagentes (f-

A12).

Figura 18: mosaico com fotos de materiais para exposição de diversas disciplinas, mas não expostos (f-A8, f-D1, f-B4).

Figura 19: mosaico exibindo um dos kits com material para laboratório enviado pela Secretaria de Estado, e uma caracterização do conteúdo da mesma caixa, conforme impresso em uma de suas faces (f-E3 e f-E4)...... 
Figura 20: fachada do CDCC, à Rua Nove de Julho.

Figura 21: mosaico de fotos do Jardim da Percepção, na parte externa do prédio do CDCC.

Figura 22: mosaico com fotos da fachada da casa onde funciona o setor do CDCC responsável pela Experimentoteca (Fonte: José Braz Mania).

Figura 23: mosaico com fotos da Experimentoteca em uma de suas primeiras versões (SCHIEL, 1991). 241

Figura 24: mosaico com fotos do interior e do exterior do design atual da Experimentoteca (SCHIEL, 1991). 242

Figura 25: mosaico com fotos da disposição dos materiais em kits para o ensino fundamental (SCHIEL, 1991).

Figura 26: fotos de dois kits de material desenvolvidos pelo CDCC para o Mão na Massa (CENTRO DE DIVULGAÇÃO CIENTÍFICA E CULTURAL, [200-]).

Figura 27: quadro com a relação dos temas e subtemas dos kits da Experimentoteca para o ensino de Química.

Figura 28: características das modalidades educacionais que se situam no contínuo do "formal" ao "informal", passando pelo "não formal” (MARANDINO, 2008, p. 15).

Figura 29: diagrama das modalidades de educação entre as dimensões escolar/não escolar e

assistemática/sistematizada.

Figura 30: quadro que expõe o modo como diferentes autores elaboram considerações sobre a Experimentoteca, a partir de suas próprias referências no campo da educação ..... 296

Figura 31: capa do volume 1 d'O livro da Experimentoteca

Figura 32: quadro com características das divisões d'O livro da Experimentoteca analisadas neste trabalho. .. 298

Figura 33: esquema das inter-relações entre ciência, tecnologia e sociedade, apresentado em $O$ livro da Experimentoteca (TOMAZELLO; SCHIEL, 2000, v. 1, p. 9).

Figura 34: esquema das inter-relações entre ciência, tecnologia e sociedade, sem as adaptações apresentadas em O livro da Experimentoteca (HOFSTEIN; AIKENHEAD; RIQUARTS, 1988, p. 358).....

Figura 35: instrumento para classificação de atividades experimentais de acordo com o grau de participação do estudante em sua condução (adaptado de Pella (1961))..

Figura 36: foto dos materiais que compõem o kit “A dimensão do átomo”, da Experimentoteca para o ensino fundamental.

Figura 37: caixa furada.

Figura 38: caixa de gavetas, que funcionam como peneiras, seus orifícios apresentando diferentes diâmetros. 327

Figura 39: diagrama das modalidades de formação docente entre as dimensões acadêmica/não acadêmica e assistemática/sistematizada. 348

Figura 40: quadrilátero sobre as relações entre teoria, prática, ativismo e verbalismo. 356 


\section{LISTA DE ABREVIATURAS E SIGLAS}

$\mathrm{CDCC}$

$\mathrm{CNPq}$

CTS

Enem

Eneq

Fapesp

FFCLRP-USP

Funbec

IBECC

IQSC-USP

PCN

Pibid

PNLD

PADCT

PUC-SP

QNEsc

UFSCar

Unesp

Unicamp

USP
Centro de Divulgação Científica e Cultural

Conselho Nacional de Desenvolvimento Científico e Tecnológico

(Movimento) Ciência, Tecnologia e Sociedade

Exame Nacional do Ensino Médio

Encontro Nacional de Ensino de Química

Fundação de Amparo à Pesquisa do Estado de São Paulo

Faculdade de Filosofia, Ciências e Letras de Ribeirão Preto

Fundação Brasileira para o Desenvolvimento do Ensino de Ciências

Instituto Brasileiro de Educação, Ciência e Cultura

Instituto de Química de São Carlos

Parâmetros Curriculares Nacionais

Programa Institucional de Bolsa de Iniciação à Docência

Programa Nacional do Livro Didático

Programa de Aperfeiçoamento do Desenvolvimento Científico e Tecnológico

Pontifícia Universidade Católica de São Paulo

Química Nova na Escola

Universidade Federal de São Carlos

Universidade Estadual Paulista Júlio de Mesquita Filho

Universidade Estadual de Campinas

Universidade de São Paulo 


\section{SUMÁRIO}

APRESENTAÇÃO

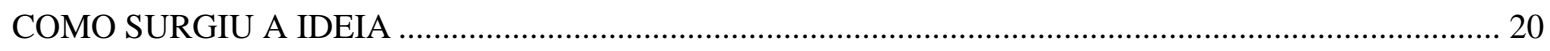

DECIDINDO POR UM REFERENCIAL TEÓRICO …........................................................................... 25

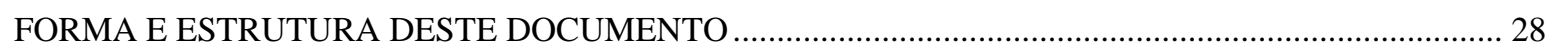

CAPÍTULO 1 - PEDAGOGIA HISTÓRICO-CRÍTICA: tendência contemporânea e progressista ............... 32

1.1 TIPOLOGIAS DAS TENDÊNCIAS PEDAGÓGICAS CONTEMPORÂNEAS ........................................ 34

1.2 PEDAGOGIA DA ESSÊNCIA VERSUS PEDAGOGIA DA EXISTÊNCIA............................................. 40

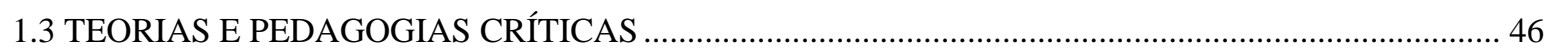

1.4 A PEDAGOGIA HISTÓRICO-CRÍTICA ENQUANTO PEDAGOGIA PROGRESSISTA ..................... 52

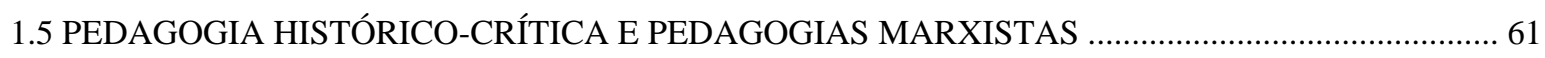

CAPÍTULO 2 - PSICOLOGIA HISTÓRICO-CULTURAL: articulações com a Pedagogia Histórico-Crítica

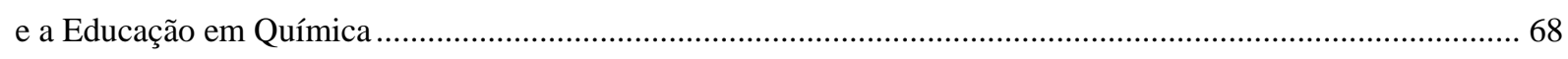

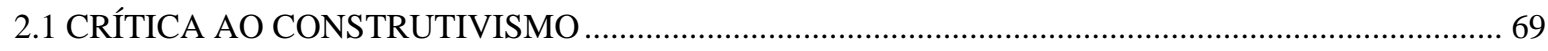

2.1.1 Do psicológico ao pedagógico: um entusiasmo imprudente ............................................................ 73

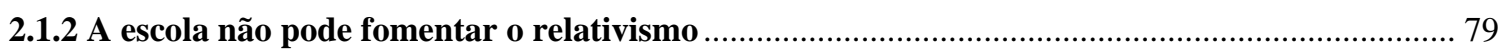

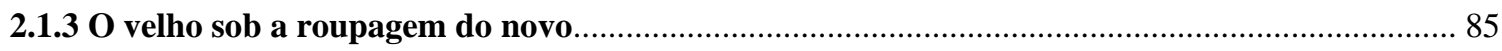

2.2 PSICOLOGIA HISTÓRICO-CULTURAL: teoria objetivista, dialética, crítica ....................................... 91

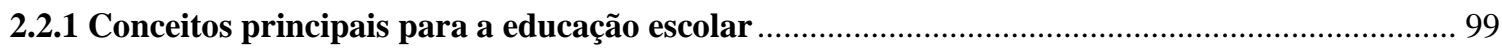

2.2.2 Psicologia Histórico-Cultural e Pedagogia Histórico-Crítica: uma unidade psicopedagógica ... 106 2.3 APROPRIAÇÕES DA PSICOLOGIA HISTÓRICO-CULTURAL POR PESQUISAS DA EDUCAÇÃO

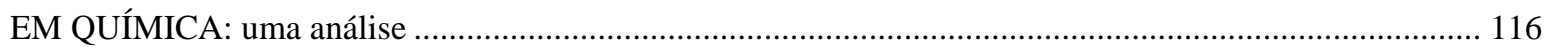

2.3.1 Artigos de Química Nova na Escola: características e critérios de seleção para este estudo .......... 117

2.3.2 Fontes e autores da Psicologia Histórico-Cultural referenciados .............................................. 121

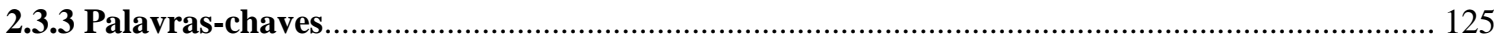

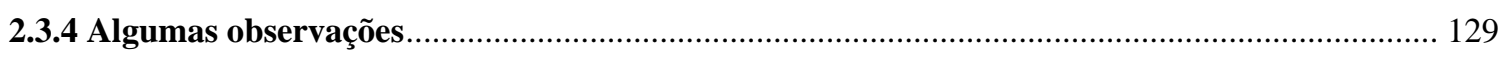

CAPÍTULO 3 - EXPERIMENTAÇÃO NO ENSINO DE CIÊNCIAS: uma visão crítico-dialética ............ 131

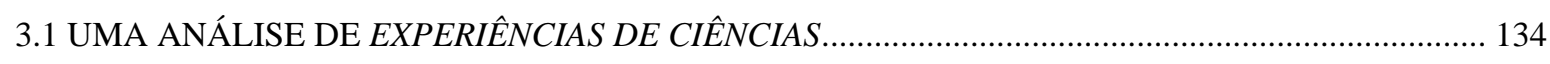

3.2 CONTRIBUIÇÕES DE AUTORES PRÓXIMOS À PEDAGOGIA HISTÓRICO-CRÍTICA.................. 143

3.3 CONTRIBUIÇÕES DO PRESENTE TRABALHO ...................................................................... 149

3.3.1 Teoria do conhecimento à luz do materialismo histórico e dialético ............................................ 149

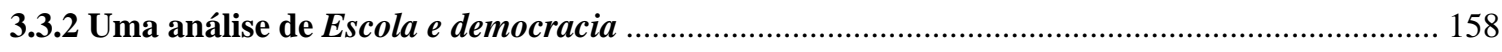

3.3.3 A importância dos instrumentos e uma análise de $O$ desenvolvimento do psiquismo ................. 167 


\section{CAPÍTULO 4 - O LABORATÓRIO DIDÁTICO E A MATERIALIDADE DO ENSINO DE CIÊNCIAS:}

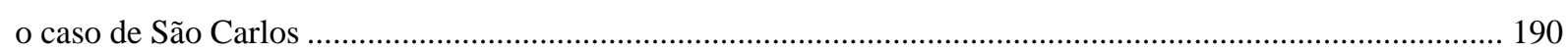

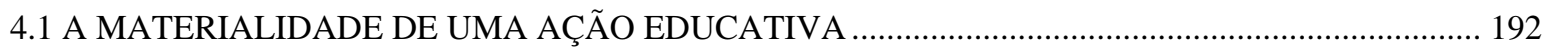

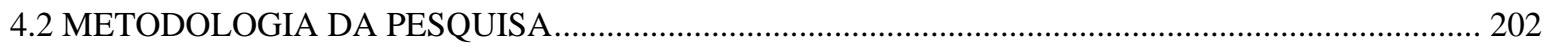

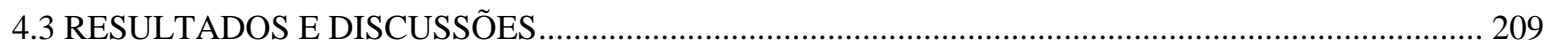

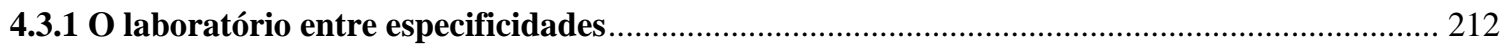

4.3.2 A questão da (des)continuidade e da estrutura organizacional da educação ………………..... 216

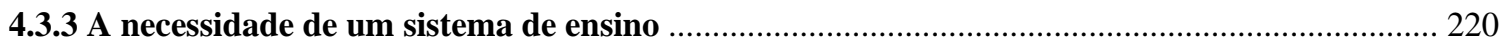

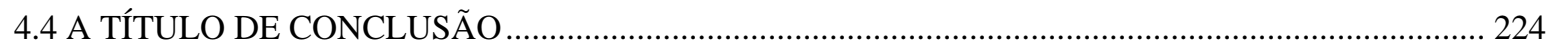

CAPÍTULO 5 - A EXPERIMENTOTECA, I: uma ação educativa de um centro de ciências à luz da

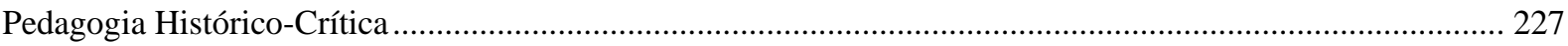

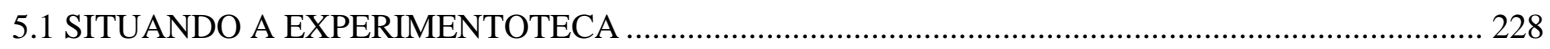

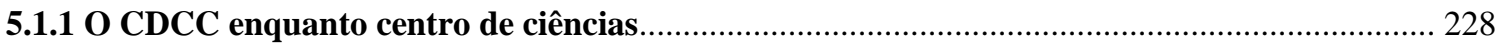

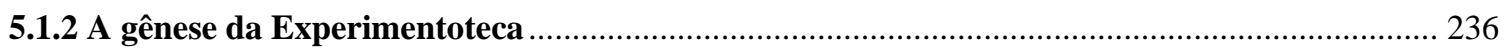

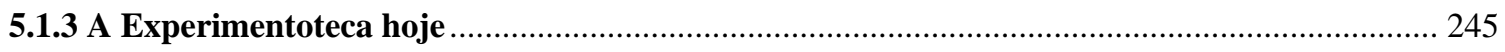

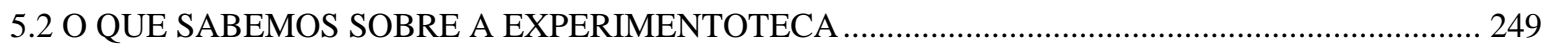

5.3 A EXPERIMENTOTECA E A PEDAGOGIA HISTÓRICO-CRÍTICA ………….................................... 263

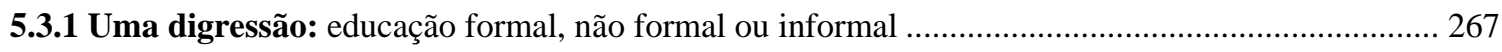

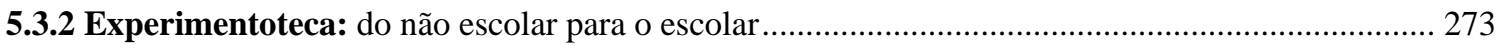

CAPÍTULO 6 - A EXPERIMENTOTECA, II: por uma fundamentação pedagógica .................................... 281

6.1 A NECESSIDADE DE FUNDAMENTOS TEÓRICOS NA PRÁTICA EDUCATIVA ........................... 283

6.2 O LIVRO DA EXPERIMENTOTECA E AS TENDÊNCIAS DA EDUCAÇÃO EM QUÍMICA ............. 291

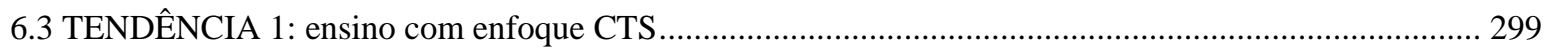

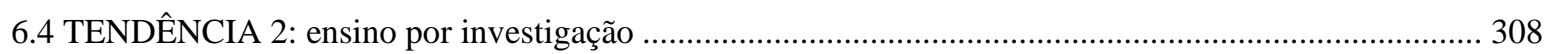

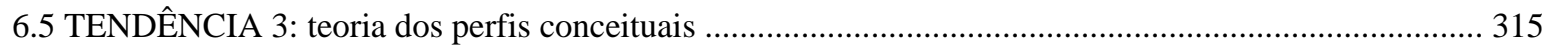

CAPÍTULO 7 - A EXPERIMENTOTECA E A FORMAÇÃO DE PROFESSORES DE QUÍMICA ..... 336

7.1 A FOBIA TEÓRICA NO CAMPO DA FORMAÇÃO DE PROFESSORES …………............................ 337

7.2 ALTERNATIVAS CRÍTICAS À FORMAÇÃO DOCENTE COMO “APRENDER A APRENDER” . 346

7.2.1 A formação de professores e a Pedagogia Histórico-Crítica .......................................................... 352

7.2.2 A formação de professores e a Psicologia Histórico-Cultural: em foco a teoria da atividade .... 359

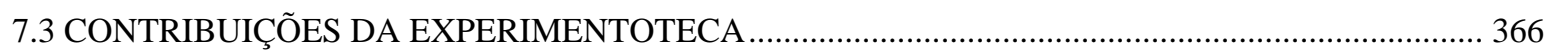

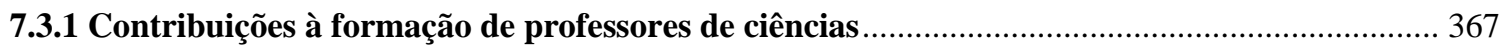

7.3.2 Contribuições à formação inicial de professores de Química ..................................................... 373 
ANEXOS

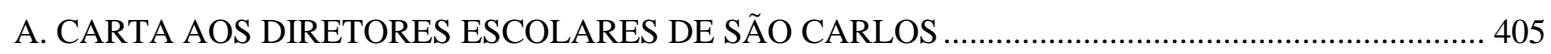

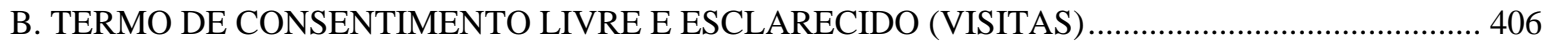

C. TERMO DE CONSENTIMENTO LIVRE E ESCLARECIDO (ENTREVISTAS - PESQUISADOR E

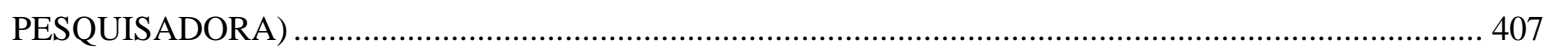

D. GUIA DE OBSERVAÇÕES ESTRUTURADAS NOS LABORATÓRIOS ESCOLARES ...................... 408

E. ROTEIROS (ENTREVISTAS - PESQUISADOR E PESQUISADORA),................................................ 409

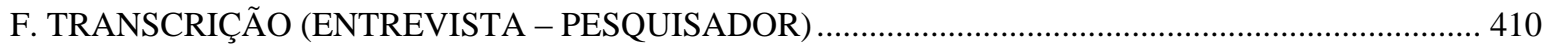

G. TRANSCRIÇÃO (ENTREVISTA - PESQUISADORA) ................................................................. 417

H. TERMO DE CONSENTIMENTO LIVRE E ESCLARECIDO (ENTREVISTA -

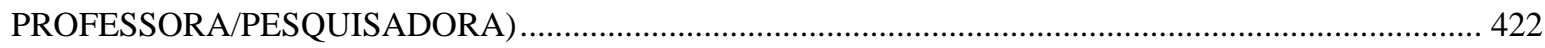

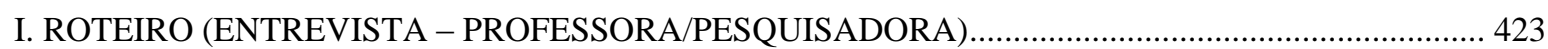

J. TRANSCRIÇÃO (ENTREVISTA - PROFESSORA/PESQUISADORA) .............................................. 424 


\section{NOTAS PRÉVIAS}

A elaboração deste trabalho procurou obedecer às seguintes publicações da Associação Brasileira de Normas Técnicas: NBR 6023:2002 (Referências), NBR 6024:2002 (Numeração progressiva das seções de um documento escrito), NBR 6027:2003 (Sumário), NBR 6028:2003 (Resumo), NBR 10520:2002 (Citações em documentos) e 14724:2011 (Trabalhos acadêmicos). As referências foram conferidas individualmente pelo Setor de Referência do Serviço de Biblioteca e Informação do Instituto de Química de São Carlos.

Algumas orientações destes documentos, no entanto, não foram seguidas à risca.

Embora os usos de palavras como "idem", "ibidem" e "loc. cit." sejam indicados para referências subsequentes em notas de rodapé, decidi empregá-las normalmente na referenciação realizada no próprio texto.

Assim, utilizei a palavra "idem" para indicar "mesmo autor", como em: "Segundo o trabalho consultado (SILVA, 2000), [...]. Este autor também trata do assunto em outro trabalho (idem, 2001)."

A palavra "ibidem" significa "na mesma obra". Embora se recomende o uso de "idem, ibidem”, utilizarei apenas “ibidem”, pois já está presumido que a referência se trata de um documento do mesmo autor.

Por outro lado, decidi empregar a expressão "loc. cit." sempre após “ibidem", indicando a referência a um fragmento anterior em que foi mencionada a mesma página. 
Estas palavras foram empregadas visando proporcionar ao leitor um maior senso de continuidade entre as citações subsequentes de um mesmo autor, de uma mesma obra ou de um mesmo trecho de obra.

Quando da reprodução literal de fragmentos de um dado texto, omiti o sinal "[...]” nos inícios de oração. Assim, quando, após a abertura de aspas, o fragmento transcrito se iniciar com letra minúscula, já está subentendido que o início da frase citada foi omitido, como em "embora o autor não tenha se atentado ao fato [...]". No caso deste mesmo exemplo, a presença de "[...]" ao final da transcrição indica que o fragmento foi reproduzido de modo incompleto, sem sua conclusão em ponto final.

Da mesma forma, nas reproduções literais com mais de quatro linhas (recuadas por 4 cm em relação à margem), não inseri o sinal “[...]” no início da transcrição, quando se tratou de uma oração cujo início foi omitido. Exemplo:

todos os trabalhos citados concordam com as conclusões dos autores estudados no primeiro capítulo [...] (SANTOS, 1990, p. 10).

No fragmento acima, é evidente que a transcrição omitiu palavras anteriores a "todos". Como no caso do penúltimo exemplo, a presença de "[...]" ao final da transcrição indica que ela foi concluída antes do término da oração em ponto final, na fonte consultada.

Todo o texto foi redigido conforme o Novo Acordo Ortográfico da Língua Portuguesa, salvo nas reproduções literais de obras publicadas conforme outras ortografias. 


\section{APRESENTAÇÃO}

Em março de 2010, fora convidado a participar de um curso, ministrado no Centro de Divulgação Científica e Cultural (CDCC-USP, São Carlos), sobre o projeto $A B C$ da Educação Científica - Mão na Massa. Na ocasião, acompanhei com entusiasmo algumas discussões sobre esta iniciativa, mas que inevitavelmente eram extrapoladas por nós, participantes, a outras questões sobre a educação em ciências. Impossível que, por exemplo, a experimentação no ensino não tivesse sido debatida; muitos de nós, inclusive, havíamos sido atraídos para aquela situação devido a algum interesse sobre o tema.

Algo que ficou marcado desta experiência e que desejo compartilhar nesta apresentação foi a dinâmica que deu início ao curso. Sobre a bancada do laboratório científico do CDCC, estavam dispostas algumas laranjas comuns, que deveríamos observar atentamente para, então, fazer um registro escrito sobre toda e qualquer impressão que o fruto causasse a nós. Compartilhando os registros de cada dupla de participantes, conseguimos preencher ao menos metade de um quadro negro - e como é enorme aquele do auditório do CDCC, para onde migrou a dinâmica após a breve visita ao laboratório - com juízos diversos sobre as laranjas. É arredondada; tem uma casca com alguns milímetros de espessura; dispõe-se em gomos; exala uma essência cítrica; é formada por minúsculas "garrafinhas" de sumo etc.

A seguir, recebemos alguns exemplares de laranjas "falsas", isto é, imitações plásticas, mas bastante fiéis à realidade, ao menos numa primeira impressão. Destes modelos, quando 
retomamos a atividade dos registros, pudemos escrever um número reduzidíssimo de afirmações, em comparação com a etapa anterior. Aquelas meras paródias nos diziam apenas que as laranjas poderiam ser arredondadas, com casca irregular e de cor alaranjada. Nenhuma informação poderiam fornecer a respeito da massa destes frutos, de suas propriedades odoríferas ou de sua composição.

$\mathrm{Na}$ etapa seguinte, fomos estimulados pela exibição de uma fotografia, uma imagem bidimensional do mesmo fruto, a laranja. E o que poderíamos dizer sobre as laranjas em geral, observando apenas aquela representação impressa em papel branco? O detalhe das minúsculas irregularidades da casca se perdera com a baixíssima resolução do impresso, e nem mesmo seu diâmetro médio - estimado em uns sete centímetros, pela apreciação do modelo plástico seria possível inferir, já que a foto não apresentava nenhum tipo de escala.

Encerrando a dinâmica, apresentou-se a nós um último estímulo, o mais minimalista: a palavra "L A R A N J A", também impressa em papel branco. Ora, se nunca tivéssemos nos deparado com o tal fruto em toda nossa existência, jamais poderíamos dizer qualquer coisa a respeito desta única palavra (por um acaso tautológico, talvez arriscaríamos dizer que se trataria de um objeto de cor alaranjada). Por outro lado, não é interessante que este único signo possa abrigar em seu interior todo aquele conjunto de juízos elencados no quadro negro, no início daquela nossa dinâmica?

Certamente que isso nos parece óbvio, mas fora justamente por intermédio desta obviedade que pude organizar alguns pensamentos, até então desorientados, sobre o projeto do doutorado que defendo nesta tese, e que àquela altura já fora iniciado.

Tendo optado por trabalhar novamente com o tema da experimentação no ensino de ciências $^{2}$, a vivência daquela dinâmica ajudara a erigir em novas bases meu entendimento acerca desta questão. Posso sintetizar esta compreensão nova - para mim - com o seguinte encadeamento de raciocínios, ou "teses":

1. O ensino de ciências brasileiro, no momento atual, é reconhecido como ineficiente, falho, incapaz de prover os alunos de conhecimentos que possam ser úteis para que tomem decisões na vida prática de forma fundamentada.

\footnotetext{
${ }^{2}$ Digo "novamente" em referência a meu mestrado, que lidou com propostas de experimentos de ciências veiculadas em livros didáticos.
} 
2. A experimentação no ensino, na medida em que contribui para atenuar a distância entre a linguagem complexa das ciências e os objetos e fenômenos que tomam lugar na realidade próxima dos estudantes reveste-se, assim, de uma função pedagógica importantíssima.

3. Ela - a experimentação - é, então, um instrumento com grande poder para preencher de significados os signos científicos apresentados no ensino formal (e dispersos também pelos meios educacionais ditos informais).

4. A função primordial do experimento no ensino de ciências é contribuir para este processo de significação, ou seja, ele deve se apresentar a serviço, antes de tudo, da aprendizagem dos conteúdos científicos apresentados na escola.

Pareceu-me mais claro, assim, que o ensino de ciências praticado nas escolas brasileiras, em geral, enfatiza a palavra impressa em um papel branco - quando muito, uma foto bidimensional -, mas se afasta das ordinárias laranjas (e cebolas ${ }^{3}$ ), sem as quais não podemos emitir mais do que três ou quatro pobres juízos.

Falemos um pouco, agora, sobre a gênese do projeto de doutorado a que este relatório se refere.

\section{COMO SURGIU A IDEIA}

Em 2008, dirigia-me para Campinas-SP, na companhia do Prof. Luiz Henrique Ferreira, da Universidade Federal de São Carlos (UFSCar). Naquela manhã de maio ocorreria na Universidade Estadual de Campinas mais um evento dos Fóruns Permanentes de Desafios do Magistério. O tema do encontro era $O$ professor e o livro didático e interessava muito a nós dois - o livro didático era simplesmente o principal objeto de pesquisa de meu mestrado, em andamento à época.

A viagem, que deveria ser curta, teve sua duração prolongada devido a um congestionamento em uma das rodovias por que passamos. Conhecia o Prof. Luiz havia apenas dois anos e aproveitei a oportunidade para satisfazer minha curiosidade acerca de seu peculiar percurso profissional: de bacharel em Química a pesquisador de reconhecimento na área de Educação em Ciências. Calma e gentilmente, ele se pôs a narrar fatos de sua época de

\footnotetext{
${ }^{3}$ Vide a crônica de Rubem Alves que tomei como epígrafe para esta tese.
} 
graduação e de sua participação no CDCC, ainda nos anos 1980. Já naquele momento, disseme o professor, seu interesse pelas questões sobre ensino e aprendizagem do conhecimento químico pôde ser estimulado pelos projetos de que participara neste centro de ciências.

Em praticamente toda minha experiência como aluno da educação básica em São Carlos, estive em contato com um destes projetos, a Experimentoteca. Lembro com saudade das aulas em que os professores adentravam as salas com as enormes caixas de experimentos. Quanta expectativa até descobrirmos o que elas guardavam!

Despretensiosamente, perguntei ao Prof. Luiz em que medida ele havia participado do desenvolvimento daqueles kits. A resposta veio com apenas uma palavra: Totalmente! E talvez por reflexo, quis confirmar uma de minhas impressões, aproveitando que a pessoa com quem dialogava poderia falar com propriedade sobre o assunto: Não há muitos estudos, em nível de pós-graduação, sobre a Experimentoteca, não é mesmo, professor? Por algum acaso, eu tinha ciência de duas dissertações de mestrado sobre o tema, defendidas em 1992, e o Prof. Luiz confirmara aquilo que eu havia inferido. Ao mesmo tempo, esta sua resposta verdadeiramente abria uma perspectiva para meu doutoramento. Guardei a ideia comigo.

Defendi o mestrado em 13 de abril de 2009 e, dois dias depois, estava formalmente matriculado no curso de doutorado. Continuaria sob a orientação do Prof. Antonio Aprigio da Silva Curvelo, no Instituto de Química de São Carlos (IQSC-USP), permanecendo no campo da Educação em Ciências.

Recuperei da memória a conversa "rodoviária" com o Prof. Luiz e esbocei um projeto que então deveria apresentar para o programa de pós-graduação. Embora não houvesse esgotado os estudos com os livros didáticos, a escolha de um novo objeto pareceu-me imperativa. Seria uma oportunidade para acrescentar à minha formação outras possibilidades investigativas, a vivência de outras metodologias, o contato com outros autores. Também, a possibilidade de sair a campo para coletar dados era sedutora. Trabalhar com a Experimentoteca parecia um caminho natural, frutífero e, mais que isso, necessário.

Ao mesmo tempo, lembrei que no segundo semestre de 2008, graças à disciplina de Psicologia da Educação, no curso de Licenciatura em Ciências Exatas ${ }^{4}$, já havia me deparado com a Experimentoteca em uma situação investigativa.

Nesta disciplina sob a responsabilidade da Prof. Cibelle Celestino Silva, do Instituto de Física de São Carlos (IFSC-USP), fora solicitada como trabalho uma pesquisa que deveria investigar dois contextos, o das escolas públicas e o das escolas privadas, em São Carlos. O

\footnotetext{
${ }^{4}$ De 2007 a 2010 fui aluno deste curso noturno da USP. Nesta época era, portanto, pós-graduando à luz do dia e graduando durante as noites.
} 
grupo de que participei adotou o tema da experimentação no ensino de ciências, decidindo verificar em que medida a prática dos professores estaria fundamentada em referenciais teóricos que estudávamos no curso de Psicologia. Por exemplo, desejávamos investigar se estes docentes buscavam elementos na teoria de Jean Piaget para justificar suas escolhas metodológicas, observando especialmente o caso da realização de experimentos didáticos.

Os resultados que obtivemos nos pareceram bastante surpreendentes.

$\mathrm{Na}$ escola pública encontramos um docente que demonstrava entendimento das teorias de aprendizagem comumente abordadas nas licenciaturas em ciências. Para ele, o objetivo do ensino era proporcionar aos alunos experiências que levassem à investigação construtiva, do ponto de vista cognitivo. Mas além deste depoimento, que registramos em nossa entrevista, este "cognitivista" não pôde contribuir mais substantivamente com nossa investigação. $\mathrm{O}$ motivo era simples: suas aulas não envolviam a experimentação.

Já no ambiente da escola privada, encontramos uma professora que nos disse nem lembrar quais eram os teóricos do campo da aprendizagem estudados em sua formação inicial. Seu referencial era apenas a prática de já algumas décadas de atuação no magistério. Mas quanto à experimentação, estávamos diante de uma grande entusiasta dos experimentos didáticos. Inclusive nosso primeiro encontro, no âmbito da investigação realizada, ocorrera durante uma aula no laboratório científico da escola.

Chamara nossa atenção o fato daquela aula ter sido desenvolvida integralmente com o apoio de um dos kits da Experimentoteca. A este respeito, a docente nos relatou ter grande familiaridade com o projeto do CDCC, e que suas aulas em escolas públicas também costumavam envolver o trabalho com os kits.

Ao fim de nossa investigação, apresentamos a seguinte interpretação sobre as situações em estudo:

Concluímos que as práticas inovadoras, capazes de alterar a rotina escolar quanto ao ensino de ciências, têm a possibilidade de penetrar na estrutura escolar, a exemplo do que observamos na escola privada. Pré-requisito para isto é que dificuldades, quase sempre de caráter técnico, possam ser eliminadas. A facilidade quanto ao acesso e utilização e a familiaridade da docente com o Projeto Experimentoteca foram cruciais para sua incorporação ao cotidiano das aulas experimentais da escola privada. Na escola pública, a ausência de um laboratório científico em constante uso e manutenção parece ser um fator decisivo para a predominância das aulas expositivas na prática do docente entrevistado. ${ }^{5}$

\footnotetext{
${ }^{5}$ Em 2009, submetemos nossos resultados ao V Encontro Paulista de Pesquisa em Ensino de Química, realizado em Ribeirão Preto (SP). O trabalho foi aceito para a comunicação oral e figura nos anais do evento (FERREIRA; PINTO JUNIOR; MORI, 2009), de onde extraí este fragmento.
} 
Esta experiência de investigar concepções e práticas de professores, em minha formação inicial, influenciou enormemente aquele primeiro projeto para o doutorado. Tive a certeza de que a expressão "formação docente" deveria figurar no título, até porque já havia tangenciado o assunto no capítulo final de minha dissertação de mestrado.

Estava delineado o projeto. Mas o detalhamento de quais estudos seriam realizados, quais métodos para as coletas de dados seriam empregados, até mesmo o referencial teórico, tudo aparecia de modo incipiente naquela primeira proposta de trabalho.

No decorrer de 2009 dediquei-me a cumprir os créditos referentes às disciplinas da pós-graduação e a manter-me a par das pesquisas correntes em Educação em Ciências. Enquanto isso, releguei o projeto, propositadamente, a uma espécie de ostracismo. Senti a necessidade de distanciar-me daquele texto por um tempo suficientemente longo para que o reencontro fosse marcado por um estranhamento.

Nesse ínterim, fui à UFSCar aprofundar meus estudos na subárea da formação de professores e, no mesmo semestre, aproveitei a oportunidade de conhecer princípios teóricometodológicos de Psicologia Histórico-Cultural, em um curso na Faculdade de Filosofia, Ciências e Letras de Ribeirão Preto (FFCLRP-USP).

Em 2010, dei continuidade a estas atividades. Paralelamente, cursava o último ano da Licenciatura em Ciências Exatas, restando-me cumprir os estágios supervisionados nos ensinos fundamental e médio. Pensei que neste contexto poderia iniciar alguns estudos exploratórios, agregando contribuições para o projeto de doutorado, ainda "em suspenso".

Armei-me de dois kits da Experimentoteca e iniciei as regências em uma escola no município de Ibaté, a poucos quilômetros de São Carlos. As quatro aulas experimentais de Química - para os três terceiros anos e para uma sala do primeiro - foram bem sucedidas. Antes, porém, eu havia inquirido os alunos, inspirando-me em uma daquelas duas dissertações de mestrado sobre a Experimentoteca, o trabalho de Diniz (1992). Adaptando um questionário utilizado pelo autor em sua coleta de dados, propus 13 questões aos estudantes, recebendo 103 questionários respondidos. Após uma Análise de Conteúdo, extraí destas respostas as seguintes conclusões:

- A maioria dos alunos afirma gostar das aulas de Química. Reconhecem que ela pode ser importante para o seu dia-a-dia e para seu futuro, associando-a principalmente, neste caso, ao exercício profissional ou ao acesso à qualificação para o trabalho (pois a disciplina é solicitada em exames vestibulares e concursos); 
- Identificam como o tipo de aula predominante, em seu ensino, aquelas dedicadas à resolução de exercícios. Afirmam gostar destas aulas e entendem sua importância. Não estão habituados a outras estratégias de ensino, como leituras e discussões de textos, debates, trabalho em grupo e atividade prática, pois quase não mencionam estas modalidades em suas respostas;

- Afirmam lembrar-se de conteúdos estudados durante o ano, enumerando-os corretamente. Porém, como observado no momento da aplicação dos questionários, muitos dos alunos recorreram ao caderno para responder às questões. Assim, pode-se inferir, no máximo, que a maioria copia os conteúdos passados no quadro negro;

- Em geral, aceitam o material didático utilizado nas aulas de Química, os cadernos do aluno da Proposta Curricular do Estado de SP, mas um número significativo de respostas manifesta insatisfação para com ele;

- Não estão habituados a formas de avaliação diferentes das provas escritas somativas, exceto os exercícios e trabalhos corriqueiros dos bimestres. Apresentam até dificuldades em pensar em alternativas a estes procedimentos. Demonstram também grande dependência das notas de aula para os estudos;

- Quanto à realização de experimentos, muitos acreditam que as atividades experimentais exercem o papel de tornar concretos os aspectos abstratos da disciplina e que (talvez por isso) podem aumentar sua motivação para os estudos. Entre as alternativas às avaliações escritas, os experimentos são mencionados por um número maior de alunos. Em muitas das respostas, não necessariamente relacionadas a questões que poderiam tratar da experimentação no ensino de ciências, manifestava-se o desejo de que a escola dispusesse de um laboratório científico, e que fosse usado.

Em fins de 2010, assim estavam iluminadas, portanto, duas questões: a da experimentação no ensino de Química, pela pesquisa elaborada na disciplina de Psicologia da Educação, pelo curso sobre o Mão na Massa no CDCC e pelos 103 questionários respondidos por alunos do ensino médio; e a das possibilidades de trabalho com a Experimentoteca - pelas mesmas experiências, mais o diálogo fundamental com o Prof. Luiz Henrique. 


\section{DECIDINDO POR UM REFERENCIAL TEÓRICO}

Faltava a decisão, improrrogável à altura, de que referencial teórico poderia proporcionar um olhar produtivo sobre estas questões.

Participante desde 2004 do movimento estudantil, eu atravessava um período de dúvidas, em 2009, resultante de algumas decepções com o pensamento de esquerda. Assim, neste ano em que dera início ao doutoramento, não havia a menor possibilidade de que um referencial fundamentado em bases marxistas, por exemplo, viesse a me entusiasmar. Ter cursado a disciplina sobre Psicologia Histórico-Cultural, em Ribeirão Preto, se deveu antes a uma combinação fortuita de contingências do que a um grande interesse pelo trabalho de soviéticos como Vigotski, Leontiev e Luria, cujos nomes me eram familiares desde a licenciatura.

No entanto, ao final de 2010 eu completara um ciclo de estudos "voluntários" em três disciplinas do curso de Pedagogia, da UFSCar - Filosofia da Educação I, Filosofia da Educação II e Escola e Currículo -, que se mostrou crucial. Depois da leitura da obra Documentos de identidade: uma introdução às teorias do currículo, de Tomaz Tadeu da Silva, na última destas três disciplinas, um profundo incômodo abateu-me. Aquele livro, escrito numa linguagem tão clara, traduzia exatamente meus posicionamentos no campo da educação, em especial nos capítulos dedicados a expor as concepções contemporâneas sobre currículo escolar. Com o perdão do trocadilho, o texto de Tomaz Tadeu convertera-se mesmo num "documento de identidade" meu. Ao contrário de Narciso, entretanto, vendo-me tão bem refletido pelas águas límpidas das palavras daquele autor, longe de apaixonar-me pelo que vi, senti mesmo um desapontamento. E a razão deste pesar era simples: ao reconhecer-me tão "pós-estruturalista", tão convicto de que a realidade não passaria de um enredado - envolto em "complexidade" - de "discursos" e "micropoderes", tão apaziguado pelo "fim das grandes narrativas"... enfim, tão pós-modernamente relativista, percebi como meu desencanto pela crítica havia me levado à pós-crítica, e me imobilizado.

Senão, vejamos: a realidade é "produzida discursivamente", pois o ato de descrever um objeto, em si, já estaria participando de sua criação; um discurso sobre a realidade, decorre daí, teria o mesmo valor ontológico que a própria realidade; se é assim, concluamos o silogismo, toda a realidade, todos os objetos e fenômenos que dela participam, nada mais são do que emanações dos mais heterogêneos discursos, são dados provisórios, cambiantes, 
fragmentários e, portanto, fugazes, refratários à sua captação "teórica" pelo pensamento e à sua transformação "prática" pelas mãos do homem. Em resumo, se não há nada que não seja discurso, tudo é permitido. E ser des-responsabilizado é o primeiro passo para se tornar irresponsável. O livro de Tomaz Tadeu, ele próprio, não me deixa mentir; "discursivizando" a realidade, nos eximimos:

- De teorizar, pois

Uma teoria supostamente descobre e descreve um objeto que tem uma existência independente relativamente à teoria. Um discurso, em troca, produz seu próprio objeto: a existência do objeto é inseparável da trama linguística que supostamente o descreve. [...] Do ponto de vista do conceito pós-estruturalista de discurso, a "teoria" está envolvida num processo circular: ela descreve algo que ela própria criou. Ela primeiro cria e depois descobre, mas, por um artifício retórico, aquilo que ela cria acaba aparecendo como uma descoberta (SILVA, 2011, p. 12, grifos meus).

- De discernir o real do irreal, e de investirmos num real "possível”, já que

A noção de discurso [...] nos dispensaria de fazer o esforço de separar [...] asserções sobre a realidade de asserções sobre como deveria ser a realidade. [...] supostas asserções sobre a realidade acabam funcionando como se fossem asserções sobre como a realidade deveria ser. Elas têm o mesmo efeito: o de fazer com que a realidade se torne o que elas dizem que é ou deveria ser (ibidem, p. 13).

- E por fim, de definir precisamente nosso objeto de estudo. Isto implicaria, no caso do objeto "currículo", por exemplo, em mostrar que

as definições de currículo não são utilizadas para capturar, finalmente, o verdadeiro significado de currículo, para [se] decidir qual delas mais se aproxima daquilo que o currículo essencialmente é, mas, em vez disso, para mostrar que aquilo que o currículo é depende precisamente da forma como ele é definido pelos diferentes autores e teorias. Uma definição não nos revela o que é, essencialmente, o currículo: uma definição nos revela o que uma determinada teoria pensa o que o currículo é (ibidem, p. 14).

Não é preciso um grande esforço, nem retórico, nem lógico, para se perceber que a noção pós-estruturalista de discurso, ela mesma, se enreda nas próprias armadilhas. Se a teorização é vã, na medida em que se mostra “envolvida num processo circular", então qual o valor de tal concepção de discurso, já que a mesma não surgiu espontaneamente, não se materializou como mágica nas mentes dos pensadores contemporâneos das ciências humanas, mas, pelo contrário, ela mesma foi teorizada em algum momento? E haveria maior circularidade do que a manifesta no próprio conceito de "discurso", nada menos que uma 
asserção sobre um dado objeto da realidade, ou seja um "discurso sobre discursos", noção inaceitavelmente metalinguística, recursiva e, afinal, vaga?

Como químico, como aceitar uma concepção segundo a qual a existência de uma realidade objetiva, independente do pensamento humano, fosse um dado questionável? Não é evidente que, independente do que eu pense deles, e do que eu fale sobre eles, átomos e moléculas continuem a se ricochetear em todos os cantos do Universo? Pois, se assim não for, que possibilidade eu teria de realizar ciência? Para o pós-estruturalista, um discurso que profiro a respeito de uma dada transformação química, por exemplo a oxidação de um metal exposto à atmosfera, teria um papel nada desprezível para a constituição do próprio fenômeno. Ora, os metais se oxidavam da mesma maneira que o fazem hoje, antes mesmo que um primeiro hominídeo pudesse balbuciar qualquer rudimento de palavra a respeito disto.

E como educador, como eu poderia aceitar a interconversão entre real e simulacro, justificada pela equivalência ontológica entre a realidade e as "asserções sobre a realidade"? Se desejo que educação contribua para transformações sociais - e não conheço educador contemporâneo que não deseje algo semelhante -, minha militância se vê sem escapatória, pois primeiro necessito discernir a realidade objetiva da realidade produzida discursivamente. Mas dado que as diferenças entre ambas são ocultadas por "relações de poder", por outros agentes que "discursam" e só tornam mais "complexas" as determinações sobre a constituição desta realidade, preciso recorrer a um exercício de abstração - e, portanto, de teorização para a apreensão dos dados essenciais que se ocultam sobre a multiplicidade dos discursos. Mas ao teorizar, estarei interferindo na própria constituição da realidade! Portanto, quanto mais desejo conhecer minha realidade, mais me afasto do dado objetivo, e consequentemente, mais impossibilitado estou de interferir em sua determinação.

A esta altura, já estará claro ao leitor que a perspectiva pós-estruturalista não poderia me servir. E entre novas leituras, e re-leituras, voltei a um texto que muito havia me tocado, ainda no início de minha formação docente, em 2007: o pequeno livro de Dermeval Saviani, Escola e democracia. Livro, inclusive, a que recorri para suportar minhas conclusões no trabalho do mestrado. Deste reencontro, nasceu a certeza de que a teoria pedagógica de Saviani, uma teoria socialista de inspiração marxista, a Pedagogia Histórico-Crítica, seria capaz de, simultaneamente: resolver os impasses a que o pós-estruturalismo me conduzia; fazer minhas pazes com o pensamento progressista, com a superação de minhas decepções passadas, agora devidamente reexaminadas; e trazer nova luz para os objetos de estudo deste 
doutorado, a experimentação no ensino de Química e, mais especificamente, o papel da Experimentoteca na prática e na formação docente.

Mais elementos se acrescentaram a este renovado entusiasmo: a lembrança de que o estudo da Psicologia Histórico-Cultural, na FFCLRP-USP em 2009, também levava diretamente à filosofia de Marx, Engels e Lênin; a proximidade entre esta psicologia soviética e a teoria de Saviani; o contato com outros textos já clássicos sobre a Pedagogia HistóricoCrítica; e a percepção de que pouquíssimos colegas educadores químicos estariam interessados em assumir-se adeptos de um referencial teórico clara e inequivocamente compromissado com o pensamento marxista.

Esta tese, em suma, se presta a este compromisso.

\section{FORMA E ESTRUTURA DESTE DOCUMENTO}

Minha intenção inicial, ao começar a redigir este relatório, era estruturá-lo conforme o estilo adotado em grande parte dos países europeus, apresentando-o como um conjunto de estudos mais ou menos articulados. Ao contrário da maneira em que se costuma apresentar teses no Brasil, portanto, aquela forma de estruturação dispensa a existência de um capítulo específico para a "introdução", outro para os "objetivos e justificativas", outro para os "materiais e métodos", e assim por diante.

O primeiro "estudo" a ser apresentado seria a articulação da Pedagogia HistóricoCrítica com a Psicologia Histórico-Cultural e os elementos mais específicos da educação científica, visando a uma concepção crítico-dialética da experimentação para o ensino de Química. Seria nosso primeiro capítulo.

No entanto, a necessidade de diferenciar precisamente a concepção pedagógica de Saviani de outras teorias e tendências educacionais levou a que esta divisão pudesse se estender por quase 100 páginas. Assim, decidi dividi-la em duas: uma tratando especificamente da Pedagogia Histórico-Crítica; e uma segunda, ainda trazendo escritos de Saviani e outros colaboradores desta teoria, mas dedicada a aproximar a experimentação para o ensino de Química da Psicologia Histórico-Cultural. Novamente, este segundo capítulo veio a se estender demasiadamente, e foi novamente dividido: em um para apresentar a Psicologia 
Histórico-Cultural, e em outro para a construção de uma teoria sobre a experimentação no ensino.

Assim, dispondo já de três capítulos de caráter mais teórico, encerrei este momento da tese apresentando um quarto capítulo, resultante de um estudo de campo, sobre a questão dos laboratórios científicos escolares em São Carlos.

Quase que por uma questão de simetria, decidi que o restante da tese deveria contemplar também mais três capítulos, desta vez com um caráter mais prático - no sentido de já lidar, efetivamente, com o principal objeto de pesquisa do trabalho, a Experimentoteca do CDCC.

"Teórico" e "prático", como usei estas palavras no parágrafo anterior, não devem ser entendidas de modo tão estreito. Embora todos os estudos agrupados nos três primeiros capítulos tenham se restringido a investigações de caráter bibliográfico, analítico e comparativo, nem por isso deixam de resvalar em questões práticas a respeito da Educação em geral, da Educação em Química e da experimentação no ensino de ciências. Da mesma maneira, os três estudos finais, embora digam respeito à concepção e ao uso da Experimentoteca, não puderam prescindir de longas reflexões "teóricas", nem de imersões e análises da literatura concernente - à Educação em Museus, às concepções mais atuais sobre a Educação em Ciências, ou ao campo específico da formação de professores.

Ficamos, afinal, com a seguinte organização:

O primeiro capítulo parte de um estudo comparativo entre três tipologias das teorias educacionais e, discorrendo sobre critérios para distinguir tais teorias, expõe o conflito entre as "pedagogias da essência" e as "pedagogias da existência". A partir daí, a Pedagogia Histórico-Crítica é apresentada, de sua gênese a seus conceitos principais, como uma teoria superadora destas correntes em litígio.

O segundo capítulo se inicia com uma crítica ao construtivismo, identificado com a corrente escolanovista da pedagogia da existência, e então apresenta a Psicologia HistóricoCultural como uma alternativa crítica. Os conceitos principais desta psicologia, quanto ao âmbito da educação escolar, são apresentados, recorrendo-se principalmente ao texto de Vigotski Michlenie $i$ retch. Encerrando o capítulo, relata-se um estudo de revisão bibliográfica sobre artigos do periódico Química Nova na Escola. Esta pesquisa buscou compreender, e analisar criticamente, as maneiras como os conceitos de Vigotski, e de outros colaboradores da Psicologia Histórico-Cultural, são apropriados por educadores químicos brasileiros. 
Encerrando este "polo da teoria" da tese, o capítulo 3 procura desenvolver uma teoria sobre a experimentação no ensino de ciências consoante com a unidade psicopedagógica estabelecida entre a Psicologia Histórico-Cultural e a Pedagogia Histórico-Crítica (unidade esta que é explicitada no capítulo anterior). Em seu interior constam diversos estudos, especialmente na forma de análises do conteúdo de obras de reconhecimento nos campos da Educação em Ciências (Experiências de ciências, de Alberto Gaspar), da Educação (Escola e democracia, de Saviani) e da Psicologia ( $O$ desenvolvimento do psiquismo, de A. N. Leontiev). Este capítulo, afinal, acaba por justificar a pertinência do tema da tese, pois apresenta argumentos a favor da realização de experimentos na educação científica escolar objetivo principal de um projeto do caráter da Experimentoteca.

No que poderia ser chamado de "polo das condições materiais", consta apenas o capítulo 4, que demarca uma descontinuidade entre os assuntos dos três primeiros e dos três últimos capítulos da tese. Aqui, relata-se um estudo de campo que investigou a situação dos laboratórios científicos escolares do município de São Carlos. Esta pesquisa se valeu de visitas aos estabelecimentos escolares, de conversações com gestores e professores, e de entrevistas com pesquisadores universitários com projetos ligados aos laboratórios. Como argumento no interior do capítulo, para se dimensionar adequadamente a importância de uma ação como a Experimentoteca é preciso, antes de tudo, avaliar se a presença de um projeto como este, conduzido por um centro de ciências, é dispensável ou indispensável para o incremento da qualidade da educação científica praticada no município.

Inaugurando o "polo da prática", o quinto capítulo assume, com base no capítulo anterior, que a Experimentoteca é sim uma iniciativa de grande relevância para São Carlos e para outras localidades. Recuperam-se, aqui, parte da história que levou ao surgimento do CDCC e deste que é seu projeto de maior difusão, assim como as conclusões de estudos que já o tomaram como objeto. O capítulo é encerrado com uma contribuição original às áreas de Educação em geral e de Educação em Museus: uma discussão sobre as possibilidades de se compreender o papel de museus e centros de ciências a partir da Pedagogia Histórico-Crítica, tomando-se a Experimentoteca como objeto de ponderação.

Se o capítulo 5 possui um caráter de "síntese" - de registros históricos, de considerações da literatura, de discussões entre diferentes campos do conhecimento -, o capítulo seguinte se apresenta como um momento de "análise". Partindo de uma apreciação favorável a que a atuação educativa esteja sempre adequadamente fundamentada em referenciais teóricos - apreciação esta que é decorrente das premissas tanto da Pedagogia 
Histórico-Crítica, quanto da Psicologia Histórico-Cultural -, faz-se aqui uma espécie de "exegese" da obra que condensa os fundamentos teóricos da Experimentoteca, O livro da Experimentoteca. Sempre a partir de nossa posição crítico-dialética - assumidamente marxista, conforme nossos próprios fundamentos explicitados nos capítulos iniciais da tese -, são examinadas três tendências atuais da Educação em Ciências/Química, apropriadas por este material do CDCC. A análise, neste ponto, abranda o caráter polêmico que marcou momentos anteriores da tese, e busca apontar para rumos futuros a serem tomados no contínuo desenvolvimento da Experimentoteca.

Finalmente, o capítulo 7 mapeia as contribuições da Experimentoteca para a formação de professores, com especial empenho à questão da formação inicial de professores de Química. Contraponho, aqui, o modelo de formação docente que atualmente se mostra mais difundido nos meios acadêmicos e não acadêmicos - baseado na chamada "epistemologia da prática” -, a contribuições esparsas da Pedagogia Histórico-Crítica e da Psicologia HistóricoCultural para a subárea da formação de professores. Com base em tais considerações teóricas, detecto as possíveis contribuições da Experimentoteca, tanto para a formação inicial e continuada de professores de ciências, o que é feito através de um estudo de revisão bibliográfica; quanto para a formação inicial de professores químicos, graças ao depoimento de uma professora/pesquisadora universitária, que atua no curso de Licenciatura em Ciências Exatas da USP, campus de São Carlos.

Assim organizados, os capítulos da tese espelham o título do trabalho: os quatro primeiros sedimentam um entendimento sobre a experimentação no ensino de ciências, e especificamente, no ensino de Química; os capítulos 5 e 6 tratam das contribuições da Experimentoteca para a prática docente; e o capítulo final versa sobre tais contribuições no âmbito da formação de professores. 


\section{CAPÍTULO 1}

\section{PEDAGOGIA HiSTÓRICO-CRÍTICA: \\ tendência contemporânea e progressista}

Comprometer-se com a Pedagogia Histórico-Crítica implica assumir uma posição firme, coerente e radical, em total acordo com uma concepção: a de que o mundo necessita de uma transformação profunda para que, a cada indivíduo, esteja assegurado seu direito de desenvolver-se plenamente.

Esta sentença inaugural, que pouco parece diferir de "slogans" de outras pedagogias, se lida apressadamente, numa análise mais aprofundada condensa muitas das ideias que nos serão fundamentais daqui por diante, e com as quais os partidários destas outras teorias pedagógicas não poderão concordar.

Adotar uma "posição firme, coerente e radical" é manter-se fiel ao propósito de contribuir para o avanço desta pedagogia, sem escapismos diante de dificuldades impostas pela prática (firmeza); negando-se à tentação dos ecletismos, com a adesão simultânea a compreensões sobre a educação estranhas aos princípios marxistas (coerência); e não se furtando às análises que vão além da superfície das questões enfrentadas, dirigindo-se a suas "raízes" (radicalidade).

Assumir que o mundo precisa de uma "transformação profunda" para que os indivíduos possam “desenvolver-se plenamente" é mais do que admitir que isto - já entendido como um direito universal - não vem se concretizando. É ter a firme convicção de que não basta transformar consciências; é necessário transformar a própria prática e, por conseguinte, 
as relações sociais nela engendradas. Ou, como questionam Marx e Engels no Manifesto do Partido Comunista,

Será necessária uma percepção profunda para entender que, com as relações de vida dos homens, com os seus relacionamentos sociais, com a sua existência social, também se modificam as suas representações, as suas concepções e os seus conceitos, em uma palavra, também a sua consciência?

Que outra coisa prova a história das idéias senão que a produção intelectual se reconfigura com a produção material? (1998, p. 27).

Por fim, o "direito de desenvolver-se plenamente", que deve estar assegurado a cada indivíduo, se refere à possibilidade de que todo ser humano possa ter acesso ao saber objetivado na produção material e não-material produzida pelo coletivo dos homens. Tornando-se detentor destas "objetivações do gênero humano" - como diria Newton Duarte, depois de Saviani, talvez o nome principal da Pedagogia Histórico-Crítica na atualidade - este indivíduo terá as condições de desenvolver-se em sua onilateralidade, diferentemente do que acontece com a maioria dos sujeitos submetidos ao capitalismo, para os quais só é possível um desenvolvimento unilateral, especializado ou no campo da prática, ou no campo do intelecto.

Ao longo deste capítulo - e do próximo também -, deverá ficar cada vez mais claro ao leitor do que se trata, afinal, a Pedagogia Histórico-Crítica. Considerando imprescindível uma caracterização tão detalhada quanto possível desta pedagogia, de modo a diferenciá-la de outras tendências educacionais também críticas, buscaremos nos aproximar dela lenta e progressivamente, sem descuidar da especificidade deste trabalho: sua preocupação com o ensino de ciências.

O capítulo está dividido em cinco seções.

Na primeira, apresentamos um brevíssimo estudo comparativo de três tipologias das teorias educacionais, propostas por autores brasileiros. O objetivo desta seção inaugural é dar relevo a alguns critérios utilizados por estes autores para classificar e denominar estas teorias, assim como discutir as diferenças observáveis em seus sistemas de categorização, os quais também orientarão as seções seguintes.

A segunda seção trata do embate entre as chamadas "pedagogias da essência" e "pedagogias da existência", representadas atualmente pela escola tradicional e pelo escolanovismo, tendências discutidas na seção anterior. Conforme argumentaremos, a existência deste que é o conflito principal da história da educação exige uma solução teórica e prática superadora de ambas as pedagogias. 
As próximas seções tratam das tentativas de se elaborar esta solução.

A terceira seção apresenta as chamadas teorias crítico-reprodutivistas, cuja importância reside em seu reconhecimento dos condicionamentos sociais da educação, elemento ausente nas pedagogias da essência e da existência; e as teorias críticas nãoreprodutivistas, que ao contrário das anteriores, concebem a educação como prática passível de participar das transformações sociais.

A Pedagogia Histórico-Crítica, uma destas teorias críticas não-reprodutivistas, proposta como uma pedagogia socialista de inspiração marxista, será apresentada na seção seguinte, em que destacaremos sua história e seu contexto de elaboração, assim como o que entendemos serem alguns de seus conceitos principais.

Finalmente, observaremos como esta pedagogia formulada por Saviani se enquadra entre outras propostas educacionais com fundamentação marxista, em especial as tentativas de se extrair uma concepção pedagógica dos próprios escritos de Marx e Engels.

\subsection{TIPOLOGIAS DAS TENDÊNCIAS PEDAGÓGICAS CONTEMPORÂNEAS}

Variados autores já propuseram tipologias para a classificação das tendências pedagógicas, com finalidades igualmente diversas. Alguns deles estabelecem a constituição de um dado "tipo" observando o entendimento destas tendências frente a conceitos como mundo, homem, escola, aprendizagem, aluno. Outras evocam razões históricas para caracterizar as tendências que constituem o ideário pedagógico de uma dada época ou de um momento político, no âmbito mundial ou de modo mais localizado. Outros ainda se esforçam para captar os aspectos filosóficos subjacentes a estas tendências, ou melhor dizendo, os sistemas filosóficos a que elas poderiam ser consideradas como filiadas. Não raro, estes procedimentos aparecem mesclados.

No quadro da Figura 1 reunimos as características de três destas tipologias, elaboradas por autores brasileiros - no nosso entender, as mais conhecidas por parte dos educadores do Brasil: a proposta por Mizukami (1986), a de Libâneo (1988) e a de Saviani (1993). 


\begin{tabular}{|c|c|c|c|}
\hline Tendência & Autor $(a)$ & Nomenclatura & Formuladores \\
\hline \multirow{3}{*}{ tradicional } & Mizukami & “abordagem tradicional" & - \\
\hline & Libâneo & "tendência liberal tradicional" & - \\
\hline & Saviani & "pedagogia tradicional" & Herbart \\
\hline \multirow{3}{*}{ tecnicista } & Mizukami & "abordagem comportamentalista" & Skinner \\
\hline & Libâneo & "tendência liberal tecnicista" & Skinner, Gagné, Bloom \\
\hline & Saviani & "pedagogia tecnicista" & - \\
\hline \multirow{3}{*}{ humanista } & Mizukami & "abordagem humanista" & Roger, Neill \\
\hline & Libâneo & $\begin{array}{l}\text { "tendência liberal renovada não- } \\
\text { diretiva" }\end{array}$ & Roger, Neill, Combs \\
\hline & Saviani & - & - \\
\hline \multirow{3}{*}{ nova } & Mizukami & $\begin{array}{l}\text { "abordagem escolanovista"/ } \\
\text { "didaticista" }\end{array}$ & $\begin{array}{c}\text { signatários do Manifesto dos pioneiros da } \\
\text { Educação Nova }\end{array}$ \\
\hline & Libâneo & $\begin{array}{c}\text { "tendência liberal renovada } \\
\text { progressivista" }\end{array}$ & Dewey, Montessori, Decroly, Cousinet, Piaget \\
\hline & Saviani & "pedagogia nova" & $\begin{array}{c}\text { Decroly, Montessori, signatários do Manifesto } \\
\text { dos pioneiros }\end{array}$ \\
\hline
\end{tabular}

Figura 1: quadro com tendências pedagógicas conforme as obras de Mizukami, Libâneo e Saviani, considerando as nomenclaturas adotadas e a indicação de alguns de seus formuladores.

O leitor reparará que o quadro parece incompleto. Propositadamente, deixamos de lado outras pedagogias, que serão apresentadas mais adiante. Estão representadas quatro tendências, agrupando as nomenclaturas um pouco diversas adotadas pelos autores. Indicamse também alguns dos formuladores destas tendências pedagógicas, conforme o entendimento de cada autor. As obras consultadas, em geral, trazem mais nomes do que os indicados na Figura 1, e aqui estamos reproduzindo apenas os que julgamos terem maior reconhecimento. As designações das tendências - "tradicional", "tecnicista", "humanista" e "nova" - são de nossa responsabilidade.

Não é necessário explicarmos detalhadamente quais as características de cada tendência, amplamente conhecidas no meio educacional. Em vez disso, reparemos na forma como o quadro foi organizado, e analisemos seu conteúdo.

Em geral, os três autores adotam uma terminologia semelhante, mas nunca idêntica. Mizukami prefere chamar de "abordagem" - pois a autora se refere, em sua obra, às maneiras como o ensino é "abordado" - cada uma das "tendências", que é o termo empregado por Libâneo, sendo que Saviani se refere a "pedagogias" propriamente. Como o leitor pode ter reparado, nesta tese iremos oscilar entre o uso destes dois últimos termos.

As denominações de cada tendência apresentam-se mais diversificadas: enquanto que as tendências tradicional e tecnicista recebem designações quase idênticas (apenas Mizukami se refere a esta última como "abordagem comportamentalista"), as tendências humanista e nova constam com algumas diferenças. A tendência humanista, que não é abordada por

\footnotetext{
${ }^{6}$ Por sinal, o título de sua obra é Ensino: as abordagens do processo.
} 
Saviani, é descrita por Libâneo como "renovada não-diretiva", diferenciando-se da "renovada progressivista", que corresponderia à "pedagogia nova". Esta, no entanto, não é descrita pormenorizadamente por Mizukami, ao contrário das demais ${ }^{7}$.

Chamemos a atenção para um aspecto. Apenas Saviani indica o nome de um possível “formulador" ou "inspirador" da tendência tradicional: Johann Friedrich Herbart (1776-1841). Já entre os estudiosos associados à pedagogia nova, os nomes indicados pelas três referências são quase incontáveis, pois estariam inclusos todos os signatários do Manifesto dos pioneiros da Educação Nova. Apesar disso, é legítimo considerarmos que as referências se reportam a John Dewey (1859-1952) como o formulador da pedagogia nova, visto que o Manifesto retoma suas ideias, assim como os demais nomes associados ao escolanovismo.

E qual seria a justificativa para a não indicação de uma origem "teórica" para a tendência tradicional? Mizukami fornece a resposta, afirmando tratar-se de

uma abordagem do processo de ensino-aprendizagem que não se fundamenta implícita ou explicitamente em teorias empiricamente validadas, mas numa prática educativa e na sua transmissão através dos anos. [...] Nessa abordagem, podem-se apenas fazer inferências quanto aos conceitos de homem, mundo, sociedade/cultura, conhecimento, pois não há nenhuma teoria claramente explicitada e a abordagem engloba aspectos diversos de tendências caracterizadas como "ensino tradicional" (1986, p. 7-8).

Esta posição, que assume ser a pedagogia tradicional uma espécie de "senso comum pedagógico", aparece bem disseminada pelo meio educacional brasileiro. Uma das razões para isto talvez seja a dificuldade em se associar o ensino tradicional a algum representante de uma teoria psicológica. Com efeito, se a pedagogia humanista deriva das ideias de Carl Rogers, a tecnicista remete ao comportamentalismo de Skinner e o escolanovismo se inspira em Dewey, em qual psicólogo estaria fundamentada a pedagogia tradicional? Afinal, pode haver uma pedagogia sem uma psicologia que lhe dê suporte? (Adiantamos que esta questão será um dos motes do próximo capítulo).

\footnotetext{
${ }^{7}$ No prólogo de seu livro, Mizukami explica que este trabalho decorre de sua tese de doutorado. Nela, as abordagens do processo de ensino tomadas em consideração foram selecionadas não apenas por sua pertinência teórica e histórica na educação brasileira, mas principalmente por terem sido manifestadas no discurso de professores de escolas públicas que participaram de sua pesquisa. Assim, com este respaldo empírico, foram selecionadas cinco abordagens - tradicional, comportamentalista, humanista, cognitivista e sócio-cultural - para serem descritas em detalhe, conforme 10 categorias consideradas básicas para sua compreensão (homem, mundo, sociedade-cultura, conhecimento, educação, escola, ensino-aprendizagem, professor-aluno, metodologia e avaliação). Assim, para justificar a ausência da abordagem "escolanovista" (a autora também sugere a designação "didaticista" devido à importância conferida aos aspectos didáticos pelo Movimento da Escola Nova), Mizukami menciona a ausência de "evidência empírica" e ainda "pelo fato dela advogar diretrizes incluídas em outras abordagens" (p. 5).
} 
Ora, examinando um pouco detidamente a obra de Herbart, torna-se evidente que esta posição - a de que a pedagogia tradicional se origina puramente de uma prática irrefletida dos professores - é (que ironia!) ela mesma um senso comum pedagógico. Vejamos.

No antelóquio da edição portuguesa da Pedagogia geral (HERBART, 2003), Manuel Ferreira Patrício afirma que "Herbart é um homem de formação filosófica, discípulo de Kant, de Fitche [sic] e de Schiller. A sua pedagogia vai se alimentar, desde a raiz, pela filosofia" (p. v). Na página seguinte, será dito que "Muito kantianamente, Herbart quis estabelecer sobre o alicerce sólido da razão a ciência da Pedagogia". Assim, guiado por esta necessidade de fundamentar científica e racionalmente a pedagogia, ele irá eleger como fundações da educação a ética (o homem no seu dever) e a psicologia (o homem no seu ser), esta entendida como uma física do mundo da psique. Três elementos orientarão a pedagogia e, mais especificamente, a relação professor-aluno para Herbart: o governo, o interesse e a disciplina. O governo representa o controle das disposições interiores do sujeito; sempre é algo externo, sendo imposto pelos pais e pelo educador. O interesse tem um caráter dinâmico e se constitui na ferramenta fundamental para motivar o educando a conquistar o conhecimento. A disciplina seria como que uma internalização da moral, controlando as disposições do indivíduo agora por dentro, ao contrário do governo. Dirá Herbart que

O objetivo da formação moral não pretende outra coisa senão que as ideias de justiça e bem, em todo o seu rigor e pureza, se tornem os verdadeiros objetos da vontade e que, de acordo com eles, se determine o conteúdo íntimo e real do caráter, bem como o cerne profundo da personalidade, relegando para último lugar qualquer outra arbitrariedade (p. 50).

Para Herbart, a educação é um processo necessariamente doloroso para o educando, mas necessário e recompensador. O educador, portanto, ainda que necessite deixar a individualidade do educando tão intacta quanto possível, não deve se furtar a explicitar sua posição superior em relação a este, sob a pena de fracassar enquanto modelo para o aprendiz. Neste processo, se preciso, caberá o uso até de certos castigos - "os castigos que são educacionais" -, desde que sua finalidade seja assegurar a disciplina e, por conseguinte, o próprio processo de ensino.

Os parágrafos anteriores não deixam dúvidas: a visão de uma pedagogia tradicional carente de elaboração teórica não se sustenta. Apesar disso, ela permanece se manifestando no 
discurso de muitos educadores ${ }^{8}$, que recorrem a este expediente para tratar de modo depreciativo a tendência tradicional, descrita comumente em formas caricaturais.

Quanto à pedagogia humanista, no Brasil, podemos considerar que ela não conseguiu sensibilizar suficientemente os educadores, quase não penetrando no mundo escolar. Em vez disso, alguns de seus pressupostos foram absorvidos por outras tendências afins. Como Libâneo (1988) indica, tanto a pedagogia nova quanto a humanista se tratam de tendências "renovadas", isto, elaboradas em contraposição às concepções "velhas", "ultrapassadas", "desgastadas" da pedagogia tradicional. Assim, não causa espanto que certos princípios da pedagogia não-diretivista de Carl Rogers e Alexander Neill tenham encontrado no solo do escolanovismo um terreno fértil para florescer, já que ambas as tendências consideram o aluno como aspecto central do processo de ensino.

Já a pedagogia tecnicista se tornou uma tendência explicitamente criticada em documentos oficiais brasileiros e abordada nos cursos de formação inicial de professores como que por mera formalidade. Parece haver uma recusa generalizada, por parte dos educadores, em se permitir quaisquer concessões a ela; talvez uma espécie de ressentimento, devido às marcas indeléveis deixadas pela legislação que a implantou oficialmente na rede escolar do país. Estamos nos referindo à Lei n. 5.540, de 1968, e mais especificamente, à Lei n. 5.692, de 1971. A primeira realizou a chamada Reforma Universitária, alterando completamente a organização da educação superior, extinguindo as cátedras, criando os departamentos e instituindo o regime de créditos e as matrículas semestrais. Já a segunda, atuando na educação básica, tentou fazer do ensino secundário uma etapa terminal e profissionalizante, no aspecto formativo; no aspecto organizacional, buscou transpor os princípios da racionalidade, da eficiência, da otimização e da produtividade, oriundos do ambiente industrial, para o ambiente escolar. Saviani (1993), ao tratar desta pedagogia, estabelece a seguinte analogia. O modo de produção burguês dissolve o caráter subjetivo do trabalho (instrumentos de trabalho dispostos em função do trabalhador) e opera sua objetivação (trabalhador disposto em função dos instrumentos de trabalho), aumentando a eficiência produtiva. A pedagogia tecnicista busca fazer o mesmo na rede escolar, minimizando as interferências subjetivas que pudessem comprometer a eficiência do processo. Como consequência, instalou-se na estrutura educacional do país um aparato burocrático que deslocou a atenção das atividades-fins para as atividades-meios das escolas. Esta estrutura, que permanece operante até hoje, apesar do tecnicismo estar excluído dos

\footnotetext{
${ }^{8}$ Eu mesmo aderi a esta posição em minha dissertação de mestrado (MORI, 2009, p. 61).
} 
discursos pedagógicos hegemônicos, deixou ainda dois resquícios: o "princípio da flexibilidade", a chave e principal inovação da Lei n. 5.692, permitiu o aligeiramento da formação básica a certos estratos vulneráveis da população - como diz Saviani, "naqueles lugares em que não há condições de se ter escola de oito anos, então que se organize esse conteúdo para seis anos, em outros para quatro ou para dois, e assim por diante [...]" (ibidem, p. 65) -; e a reformulação curricular na forma de "atividades e áreas de estudos" levou à diluição dos conteúdos, prejudicando, novamente, aqueles estratos mais vulneráveis. Assim, apesar de rechaçado pelo debate educacional especializado, o tecnicismo permanece presente na educação brasileira, já que os reflexos das referidas leis ainda se fazem sentir no ambiente escolar, tanto pela organização física e administrativa das escolas e dos órgãos a que estão vinculadas, quanto em práticas decorrentes desta organização e mesmo externas a elas, como é o caso das políticas mais amplas de avaliação de "rendimento".

Ao atribuir uma relativa inocuidade às tendências humanista e tecnicista, quanto a suas participações nos debates educacionais contemporâneos, o que fizemos nos dois últimos parágrafos, estamos enfatizando que o principal embate pedagógico contemporâneo, a despeito da existência de tendências mais diversas que as quatro expostas no quadro da Figura 1, ainda se resume à contraposição entre a pedagogia tradicional e a pedagogia nova. Continua, portanto, atualíssima a seguinte constatação de Saviani, publicada pela primeira vez em 1983:

nós estamos hoje, no âmbito da política educacional e no âmbito do interior da escola, na verdade nos digladiando com duas posições antitéticas e que, via de regra, convencionalmente são traduzidas em termos do novo e do velho, da pedagogia nova e da pedagogia tradicional. Essa pedagogia tradicional é uma pedagogia que se funda numa concepção filosófica essencialista, ao passo que a pedagogia nova se funda numa concepção filosófica que privilegia a existência sobre a essência (1993, p. 49).

Assim considerada a questão, vejamos, nas próximas seções, em que termos se dá este embate entre a chamada "pedagogia da essência" e a "pedagogia da existência", e como ele é encarado por outras tendências pedagógicas.

\footnotetext{
${ }^{9}$ Penha (1986), tratando da contraposição entre os termos "essência" e "existência", informa-nos que "Historicamente, a palavra essência é anterior. Essentia, forma latina, deriva do verbo esse, ser. Quando os latinos se entregavam à meditação filosófica, a pensar aquilo que é, diziam estar pensando na essência da coisa. Só muito mais tarde surgiria em latim a palavra existentia, existência, derivada de existere, que significa sair de uma casa, um domínio, um esconderijo. Mais precisamente: existência, na origem, é sinônimo de mostrar-se, exibir-se, movimento para fora. Daí, denominar-se existencialista toda filosofia que trata diretamente da existência humana" (p. 13-14, grifos do autor).
} 


\subsection{PEDAGOGIA DA ESSÊNCIA VERSUS PEDAGOGIA DA EXISTÊNCIA}

A obra de Saviani a que viemos nos referindo até o momento, Escola e democracia (SAVIANI, 1993), reúne quatro textos, sendo que o primeiro deles, "As teorias da educação e o problema da marginalidade", foi de onde extraímos grande parte das considerações que iniciaram este capítulo, e que aparecem condensadas no quadro da Figura 1. Os dois textos seguintes, "Escola e democracia I - a teoria da curvatura da vara" e "Escola e democracia II para além da curvatura da vara", fornecerão a substância da presente seção ${ }^{10}$.

Retomemos nossa principal observação quanto ao modo como autores brasileiros se referem às possíveis fundamentações das diferentes tendências pedagógicas: a noção, amplamente difundida, de que a pedagogia tradicional careceria de tais fundamentos, não sendo possível identificar uma matriz teórica que justificasse seus procedimentos. Saviani, filósofo e historiador da educação, apontou o nome de Herbart como formulador desta matriz, e recorrendo a sua Pedagogia geral, pudemos apresentar ao leitor alguns dos conceitos principais da teoria pedagógica sobre a escola tradicional.

Se não é possível negar, portanto, a existência de uma formulação científica e racional para a pedagogia tradicional, por que a persistência desta negação no discurso de tantos educadores? A que e a quem interessa o escamoteamento deste aspecto?

Nos textos supracitados, Saviani se debruçará sobre esta questão, com "uma abordagem centrada mais no aspecto polêmico do que no aspecto gnosiológico", não realizando "uma exposição exaustiva e sistemática", mas indicando "caminhos para a crítica do existente e para a descoberta da verdade histórica" (ibidem, p. 8-9). Assim, serão enunciadas por ele três teses (p. 48; 69-70):

1. Tese filosófico-histórica: Do caráter revolucionário da pedagogia da essência (pedagogia tradicional) e do caráter reacionário da pedagogia da existência (pedagogia nova).

2. Tese pedagógico-metodológica: Do caráter científico do método tradicional e do caráter pseudocientífico dos métodos novos.

3. Tese especificamente política: De como, quanto menos se falou em democracia no interior da escola mais ela esteve articulada com a constituição de uma

\footnotetext{
${ }^{10} \mathrm{O}$ primeiro texto também será aqui retomado, e adianto que o quarto e último texto, "Onze teses sobre educação e política”, a ser comentado brevemente na seção 1.4, será analisado detidamente no capítulo 3.
} 
ordem democrática; e quanto mais se falou em democracia no interior da escola menos ela foi democrática.

A primeira tese desmente o senso comum de que a pedagogia da essência é um produto da época medieval. Saviani demonstra que a concepção essencialista desta pedagogia não tem origens na Antiguidade ou na Idade Média, épocas em que se recorria a uma essência humana (de homem livre ou de escravo, na época antiga; e de homem enquanto criação divina e com destino predeterminado, no período medieval) para se justificar as diferenças entre os homens; pelo contrário, é na Idade Moderna, com a ruptura com o modo de produção feudal e o estabelecimento do capitalismo através da Revolução Industrial, que se gesta um conceito de essência baseado nos ideais de igualdade entre os homens. Portanto, estes ideais burgueses, àquele momento, possuíam nítido caráter revolucionário, pois se chocavam com os interesses do clero e da nobreza, indo a favor do desenvolvimento da história. Serão eles que nortearão, no campo propriamente pedagógico, a estruturação dos sistemas nacionais de ensino e sua universalização, quer dizer, a democratização do acesso à escola. A identificação (bastante iluminista, por sinal, e, portanto, produto deste momento histórico) entre ignorância e marginalidade fará com que se eleja esta escola, assim, como "o grande instrumento para converter os súditos em cidadãos", sendo seu papel

difundir a instrução, transmitir os conhecimentos acumulados pela humanidade e sistematizados logicamente. O mestre-escola será o artífice dessa grande obra. A escola se organiza, pois, como uma agência centrada no professor, o qual transmite, segundo uma gradação lógica, o acervo cultural aos alunos. A estes cabe assimilar os conhecimentos que lhes são transmitidos (ibidem, p. 18).

Convém entender o porquê da pedagogia nova ser chamada de pedagogia da existência, antes de se apresentar os argumentos de Saviani para tratá-la como reacionária.

Observemos que, se Herbart analisa o processo educacional quase sempre do ponto de vista do professor, Dewey colocará em relevo o mundo infantil. Será feita, assim, uma denúncia do ensino que desconsidera a disjunção entre o universo do adulto e a vida das crianças, com seus interesses particulares e limitações inerentes a seu estado de imaturidade. Dirá Dewey, em Vida e educação, que

A mentalidade adulta está tão familiarizada [...] com uma noção de ordem lógica dos fatos que não reconhece [...] o espantoso trabalho de separação, de abstração e manipulação, que têm que sofrer os fatos de experiência direta para que possam aparecer como "matéria" ou um ramo do saber (1978, p. 44). 
À página seguinte, ele concluirá, tratando da questão do currículo escolar, que

Temos [...] suficientes divergências fundamentais [entre "criança" e "currículo"]: primeiro, o mundo pequeno e pessoal da criança contra o mundo impessoal da escola, infinitamente extenso, no tempo e no espaço; segundo, a unidade da vida da criança, toda afeição, contra as especializações e divisões do programa; terceiro, a classificação lógica de acordo com um princípio abstrato, contra os laços práticos e emocionais da vida infantil (ibidem, p. 45).

Tantas menções à palavra "vida" - inclusive no título desta obra de Dewey - atestam o primado da "existência humana" na formulação de sua pedagogia. Nos termos de Saviani, "Tal concepção centra-se na vida, na existência, na atividade, por oposição à concepção tradicional que se centrava no intelecto, na essência, no conhecimento" (1993, p. 71, grifos do autor $)^{11}$.

Voltemos de nossa digressão. Se a pedagogia da essência é revolucionária porque entende a escola como condição para o estabelecimento de uma ordem democrática, no momento de ascensão da burguesia como classe dominante, a pedagogia da existência se mostrará reacionária na medida em que, nascida do próprio seio desta classe, servirá a ela como instrumento para a recomposição de sua hegemonia. Expliquemos. O desenvolvimento da sociedade burguesa leva, progressivamente, a que as contradições nela engendradas se tornem mais agudas. Este recrudescimento, que põe em xeque a própria perpetuação desta sociedade, obriga a classe dominante a elaborar mecanismos para conter o desenvolvimento histórico, para se pôr contra a história. Assim, se a pedagogia da essência propõe-se como solução para a correção das desigualdades, como antídoto para o problema da marginalidade, como ferramenta para a equalização da sociedade, a pedagogia da existência, pelo contrário, será uma pedagogia de legitimação das desigualdades. Reconhecendo que os homens são essencialmente diferentes, ela se apresentará com a função de

ajustar, de adaptar os indivíduos à sociedade, incutindo neles o sentimento de aceitação dos demais e pelos demais. Portanto, a educação será um instrumento de correção da marginalidade na medida em que contribuir para a constituição de uma sociedade cujos membros, não importam as diferenças de quaisquer tipos, se aceitem mutuamente e se respeitem na sua individualidade específica (ibidem, p. 20).

\footnotetext{
${ }^{11}$ Recorrendo a um texto mais antigo, publicado em 1980, Saviani dirá que esta pedagogia da existência admite que a educação "segue o ritmo vital que é variado, determinado pelas diferenças existenciais ao nível dos indivíduos; admite idas e vindas com predominância do psicológico sobre o lógico [...]” (SAVIANI, 1980, p. 26 apud SAVIANI, 1993, p. 72, grifos meus).
} 
Estão aí postos os motivos do caráter revolucionário da pedagogia tradicional, e do caráter reacionário da pedagogia nova.

A segunda tese, sobre o caráter científico do método tradicional e do caráter pseudocientífico dos métodos novos, se volta novamente para a questão das matrizes conceituais de ambas as pedagogias. Para defender esta tese, Saviani recorre novamente a Herbart, demonstrando que o método expositivo, adotado pela pedagogia tradicional, assentase sobre os chamados "cinco passos formais", elaborados pelo educador alemão. Estes passos - preparação, apresentação, assimilação-comparação, generalização e aplicação - por sua vez, encontram correspondências com o método da indução de Bacon: os três primeiros passos equivaleriam ao processo de observação; segue-se, tanto no método expositivo quanto no indutivo, uma generalização dos conhecimentos anteriormente observados; e por fim, a aplicação herbatiana cumpriria o mesmo papel da confirmação no método de Bacon. Eis o caráter científico do método tradicional, tratando-se de um processo estruturado conforme as etapas de obtenção de conhecimentos pensadas na perspectiva do empirismo inglês. No entanto, a transposição do método científico para a sala de aula, pelo método expositivo da pedagogia tradicional, não descuida da especificidade do processo educativo. Trata-se de um método de transmissão de conhecimentos, que pressupõe o domínio do saber por parte do professor, e sua ausência por parte dos alunos.

A pedagogia da existência também disporia de seus próprios "cinco passos", formulados por Dewey e contrapostos simetricamente aos passos do ensino tradicional: atividade, problematização, levantamento de dados, formulação de hipóteses e experimentação. Mas eis que uma análise do significado destes passos leva-nos a concluir que a pedagogia nova confunde ensino com pesquisa; em verdade, o ensino é mesmo estruturado como um projeto de pesquisa, em que professor e alunos partem do desconhecimento e aspiram ao conhecimento. Dado que a pedagogia da existência dissolve a relação vertical entre professores e alunos, característica do ensino tradicional, para dispor no mesmo nível hierárquico ambos os sujeitos da educação, não há propriamente um professor que ensine e um aluno que aprenda; docente e estudantes caminham juntos em direção ao conhecimento. $\mathrm{O}$ resultado final desta busca chega a ser desimportante frente ao próprio empreendimento que coloca os alunos em atividade e os faz interagir com a realidade, a experimentá-la, a investigá-la.

Em resumo, a pedagogia da essência se volta para o conteúdo, para sua organização lógica enquanto conhecimento já sistematizado, à espera de ser transmitido; a pedagogia da 
existência se volta para o método, para o processo de obtenção do saber que ainda não se sistematizou. Mas, para Saviani,

O ensino não é um processo de pesquisa. Querer transformá-lo num processo de pesquisa é artificializá-lo. Daí o meu prefixo pseudo ao científico dos métodos novos. [...] se a pesquisa é incursão no desconhecido, e por isso ela não pode estar atrelada a esquemas rigidamente lógicos e preconcebidos, também é verdade que: primeiro, o desconhecido só se define por confronto com o conhecido, isto é, se não se domina o já conhecido, não é possível detectar o ainda não conhecido, a fim de incorporá-lo, mediante a pesquisa, ao domínio do já conhecido (ibidem, p. 58).

Finalmente, a tese especificamente política - quanto menos se falou em democracia na escola, mais ela se voltou à constituição de uma ordem democrática, e vice-versa - se torna evidente depois de tudo o que se disse sobre as duas teses anteriores. Afinal, um elemento óbvio da pedagogia nova é a defesa intransigente do estabelecimento de um regime democrático na própria sala de aula. Como dissemos, esta pedagogia pretende anular as diferenças de hierarquia entre professor e alunos, contrapondo-se ao caráter autoritário do docente da escola tradicional e instaurando, assim, uma democracia escolar, que se espera refletir no fortalecimento de uma ordem democrática fora da sala de aula. Entretanto,

hoje nós sabemos, com certa tranqüilidade, já, a quem serviu essa democracia e quem se beneficiou dela, quem vivenciou esses procedimentos democráticos e essa vivência democrática no interior das escolas novas. Não foi o povo, não foram os operários, não foi o proletariado. Essas experiências ficaram restritas a pequenos grupos, e nesse sentido elas se constituíram, via de regra, em privilégios para os já privilegiados, legitimando as diferenças. Em contrapartida, os homens do povo [...] continuaram a ser educados basicamente segundo o método tradicional, e, mais do que isso, não só continuaram a ser educados, à revelia dos métodos novos, como também jamais reivindicaram tais procedimentos (ibidem, p. 59).

Embora não se falasse em democracia no interior da escola tradicional, nem se dispusesse sua estrutura a fim de consolidar relações democráticas ali; embora os métodos tradicionais se apoiassem na relação autoritária entre professor e alunos, em que aos mestres facultava-se até mesmo o tratamento violento, se necessário para a consecução do objetivo final, a aprendizagem dos conteúdos; embora a pedagogia da essência seja uma pedagogia mais da heteronomia do que da autonomia; ainda assim, ela contribuiu mais para a democratização da sociedade do que a pedagogia da existência. No cumprimento de sua função especificamente pedagógica - transmitir os conteúdos sistematizados às novas gerações - ela deu cabo de seu propósito revolucionário, que era concretizar a igualdade formal entre os homens, ideal da burguesia enquanto classe em ascensão. 
A escola nova, tomando como pressuposto as diferenças entre os homens, e não sua igualdade, e lançando mão de métodos pseudo-científicos ao fazer da sala de aula um local de pesquisa, contribuiu verdadeiramente para aprofundar as diferenças entre as classes sociais. Aqueles que experimentaram os métodos novos já vinham de um ambiente familiar culturalmente mais rico, podendo se apropriar de saberes sistematizados desde a tenra idade, e frequentando a escola com o porte de alguns destes saberes. No espaço escolar, podiam pôr à prova tais conhecimentos através das investigações proporcionadas pela pedagogia da existência, aprimorando assim seu domínio sobre eles, e colocando-se em inegável vantagem diante daqueles que ou experimentaram os métodos novos sem provirem de ambientes culturalmente mais estimulantes, ou jamais conheceram tais métodos. Respondendo a pergunta do início desta seção, fazer da pedagogia da essência uma concepção "précientífica", remetendo sua origem para a Idade Média, serviu aos interesses da classe dominante, que pôde assim desestimular a transmissão pela escola dos conteúdos sistematizados, processo que passou a ser depreciado, em favor dos métodos novos.

Em suma, podemos reunir todas as considerações acima - das quais buscamos preservar o tom polêmico do texto original de Saviani, fazendo de suas teses verdadeiras antíteses, dado o modo como elas se contrapõem ao senso comum pedagógico - no quadro da Figura 2.

\begin{tabular}{|c|c|}
\hline Pedagogia da essência (tradicional) & Pedagogia da existência (nova) \\
\hline supõe os homens essencialmente iguais & supõe os homens essencialmente diferentes \\
\hline $\begin{array}{l}\text { concebe a marginalidade como resultante da } \\
\text { ignorância; para corrigi-la, é preciso instruir }\end{array}$ & $\begin{array}{c}\text { concebe a marginalidade como resultante da rejeição; } \\
\text { para corrigi-la, é preciso levar à aceitação das } \\
\text { diferenças }\end{array}$ \\
\hline $\begin{array}{c}\text { valoriza o intelectual, o conteúdo, o professor, o } \\
\text { esforço, a disciplina, o diretivismo, a quantidade de } \\
\text { conhecimentos transmitidos }\end{array}$ & $\begin{array}{l}\text { valoriza o afetivo, o método, o aluno, o interesse, a } \\
\text { espontaneidade, o não-diretivismo, a qualidade dos } \\
\text { conhecimentos obtidos }\end{array}$ \\
\hline privilegia o processo de transmissão do conhecimento & privilegia o processo de obtenção do conhecimento \\
\hline $\begin{array}{l}\text { articula o processo de ensino com os produtos da } \\
\text { ciência }\end{array}$ & $\begin{array}{l}\text { articula o processo de ensino com o processo de } \\
\text { desenvolvimento da ciência }\end{array}$ \\
\hline tem inspiração filosófica, centrada na ciência da lógica & $\begin{array}{l}\text { tem inspiração experimental, baseada principalmente } \\
\text { na psicologia }\end{array}$ \\
\hline $\begin{array}{c}\text { canaliza interesses revolucionários da burguesia, } \\
\text { pondo-se na direção da história }\end{array}$ & $\begin{array}{c}\text { canaliza interesses reacionários da burguesia, pondo- } \\
\text { se contra a história }\end{array}$ \\
\hline $\begin{array}{l}\text { não se importando com o estabelecimento de uma } \\
\text { ordem democrática no interior da escola, contribuiu } \\
\text { com a democratização da sociedade }\end{array}$ & $\begin{array}{c}\text { se importando com o estabelecimento de uma ordem } \\
\text { democrática no interior da escola, contribuiu para o } \\
\text { aprofundamento das desigualdades }\end{array}$ \\
\hline
\end{tabular}

Figura 2: quadro com um sumário das diferenças entre a pedagogia da essência (tradicional) e a pedagogia da existência (nova). 
Assim contrapostas, tem-se a impressão de não haver nada de que estas duas tendências pedagógicas compartilhassem em comum. No entanto, o fato de termos tratado até o momento, neste capítulo, exclusivamente delas, além das pedagogias humanista e tecnicista, teve a intenção de apartá-las de outras tendências, que serão alvo das próximas seções. Frente a elas, as quatro tendências vistas até o momento constituirão um bloco mais homogêneo, sob o critério de sua posição frente aos condicionantes sociopolíticos da escola: como explicita a nomenclatura adotada por Libâneo e reproduzida na Figura 1, as pedagogias tradicional, nova, humanista e tecnicista são tendências liberais:

\begin{abstract}
O termo liberal não tem o sentido de "avançado", "democrático", "aberto", como costuma ser usado. A doutrina liberal apareceu como justificação do sistema capitalista que, ao defender a predominância da liberdade e dos interesses individuais na sociedade, estabeleceu uma forma de organização social baseada na propriedade privada dos meios de produção [...]. A pedagogia liberal, portanto, é uma manifestação própria desse tipo de sociedade (LIBÂNEO, 1988, p. 21).
\end{abstract}

Trata-se, portanto, de pedagogias voltadas para o ajustamento e a adaptação, para a exaltação da liberdade individual e dos interesses privados, para a crença numa sociedade com igualdade de condições e para a manutenção da ordem social.

\title{
1.3 TEORIAS E PEDAGOGIAS CRÍTICAS
}

A percepção de que a pedagogia tradicional e a pedagogia nova não conseguiram avanços quanto ao problema da marginalidade encaminhou diversos autores a um exame teórico da realidade, visando a identificar os motivos para este fracasso. A partir deste exame, evidenciou-se que estas pedagogias liberais entendiam a educação como instância autônoma em relação à sociedade, autonomia esta que lhe conferiria um poder absoluto e eficaz, donde emanaria sua capacidade de intervir nas injustiças sociais.

Estes autores, então, passaram a desenvolver o entendimento inverso, ou seja, o de que não seria possível compreender a educação à parte de seus condicionantes sociais. Esta interpretação, no entanto, tomou duas orientações distintas: a da subordinação da escola aos interesses hegemônicos da sociedade, isto é, aos interesses da classe dominante; e a da determinação recíproca entre sociedade e escola. 
Analogamente ao que fizemos com as pedagogias liberais, vejamos como os diferentes autores - Mizukami (1986), Libâneo (1988) e Saviani (1993) - tratam destas teorias. Sumarizamos este tratamento no quadro da Figura 3.

\begin{tabular}{|c|c|c|c|}
\hline Tendência ou teoria & Autor (a) & Nomenclatura & Formuladores \\
\hline \multirow{3}{*}{$\begin{array}{l}\text { teorias crítico- } \\
\text { reprodutivistas }\end{array}$} & \multirow{3}{*}{ Saviani } & $\begin{array}{l}\text { "teoria do sistema de ensino enquanto violência } \\
\text { simbólica" }\end{array}$ & $\begin{array}{l}\text { Bourdieu e } \\
\text { Passeron }\end{array}$ \\
\hline & & $\begin{array}{l}\text { "teoria da escola enquanto aparelho ideológico de } \\
\text { Estado" }\end{array}$ & Althusser \\
\hline & & "teoria da escola dualista" & $\begin{array}{l}\text { Baudelot e } \\
\text { Establet }\end{array}$ \\
\hline \multirow{3}{*}{ libertadora } & Mizukami & "abordagem sócio-cultural" & Paulo Freire \\
\hline & Libâneo & "tendência progressista libertadora" & Paulo Freire \\
\hline & Saviani & $\begin{array}{l}\text { "Escola Nova Popular"/“"Movimento Paulo Freire } \\
\text { de Educação" }\end{array}$ & Paulo Freire \\
\hline \multirow{3}{*}{ libertária } & Mizukami & - & - \\
\hline & Libâneo & "tendência progressista libertária" & Lobrot, Freinet \\
\hline & Saviani & "Escola Nova Popular"//"Pedagogia Freinet" & Freinet \\
\hline
\end{tabular}

Figura 3: quadro com outras teorias e tendências pedagógicas abordadas pelas obras de Mizukami, Libâneo e Saviani, considerando novamente nomenclaturas e formuladores.

Uma diferença entre os quadros da Figura 1 e da Figura 3 está no nome dado à primeira coluna: se naquele constava "Tendência", neste escrevemos "Tendência ou teoria". Esta ressalva precisou ser feita em função do conteúdo do quadro, que apresenta teorias que não são consideradas tendências pedagógicas. São elas que representam a primeira orientação referida há pouco, isto é, o entendimento da escola como subordinada aos interesses da classe dominante ${ }^{12}$.

Saviani, dos três autores em revista, é o único que se refere a estas teorias, intitulandoas como crítico-reprodutivistas. A razão deste nome é simples: críticas, pois reconhecem a escola como determinada pela sociedade, ao contrário das pedagogias liberais, que quanto a este aspecto seriam ingênuas (Saviani prefere chamá-las, no entanto, apenas de "teorias nãocríticas); e reprodutivistas por entenderem que cabe à educação apenas a reprodução da sociedade, perpetuando ou até aprofundando as desigualdades sociais, realizando a manutenção de uma determinada classe no poder (a burguesia) e reforçando o modo de produção capitalista.

Num outro texto (SAVIANI, 2008) o autor fornece mais detalhes sobre a gênese da concepção crítico-reprodutivista da educação, que estaria localizada entre as consequências do movimento de maio de 68, na França (que também se organizou simultaneamente em outros

\footnotetext{
${ }^{12}$ Como veremos, dados seus pressupostos, elas só podem ser "teorias sobre a educação" e não "teorias $d a$ educação". Assim, no âmbito da educação, se toda pedagogia corresponde a uma teoria, nem toda teoria redunda numa pedagogia.
} 
países, inclusive no Brasil). Segundo Saviani, o fracasso da revolução cultural dos jovens levou a uma reação por parte dos setores conservadores da sociedade, que se traduziu na exacerbação do autoritarismo tecnocrático (no caso brasileiro, com um componente militar). Assim, as teorias crítico-reprodutivistas vieram explicar este fracasso, colocando em evidência

\begin{abstract}
a impossibilidade de se fazer uma revolução social pela revolução cultural. No fundo, os reprodutivistas raciocinam mais ou menos nos seguintes termos: tal movimento fracassou e não podia ser diferente. Com efeito, a cultura (e em seu bojo, a educação) é um fenômeno superestrutural; integra, pois, a instância ideológica, sendo assim determinado pela base material. Portanto, não tem o poder de alterar a base material. Logo, era inevitável que as estruturas materiais prevalecessem sobre essas pretensões acionadas no âmbito da cultura. De fato, não parece por acaso que estas teorias tenham surgido logo após o movimento francês de 1968 (ibidem, p. $66)^{13}$.
\end{abstract}

Eis o porquê destas teorias não serem tratadas como pedagogias; seu ceticismo diante da possibilidade da escola poder alterar as estruturas sociais, logicamente, exclui que delas possa ser extraída qualquer proposta pedagógica.

Ainda que Saviani, em Escola e democracia, se refira a uma abordagem "mais polêmica que gnosiológica" como característica de seu segundo texto ("Escola e democracia I - a teoria da curvatura da vara"), acreditamos que este comentário possa se estender também ao primeiro, "As teorias da educação e o problema da marginalidade", que introduz o termo "crítico-reprodutivistas" para tratar das teorias de Bourdieu e Passeron, Althusser e Baudelot e Establet. Como observa Cunha (1994), uma análise rigorosa da tipologia proposta por Saviani demonstra a existência de ao menos quatro limites ou inconsistências: 1) classificadas sob um mesmo rótulo, ressalta-se o que as teorias têm em comum, mas ignoram-se suas - nada desprezíveis - diferenças; 2) o "reprodutivismo", imputado às teorias, deve ser relativizado, uma vez que elas podem sim orientar a ação docente, ainda que não no interior da escola, para o combate da exploração capitalista; 3) o "reprodutivismo", mais uma vez, não pode ser tomado como critério para uma avaliação objetiva destas teorias, pois se critica um suposto efeito do construto teórico no lugar de se julgar, por exemplo, sua coerência interna e sua adequação à prática; e 4) a crítica ao "reprodutivismo" não conseguiu mobilizar os agentes da educação na direção de uma nova teoria que, sendo crítica, também pudesse prever uma ação pedagógica transformadora.

\footnotetext{
${ }^{13}$ Althusser, Ideologia e aparelhos ideológicos de Estado, 1969-70; Bourdieu e Passeron, A reprodução, 1970; Baudelot e Establet, A escola capitalista na França, 1971.
} 
Feita esta ressalva, analisemos as teorias e tendências pedagógicas que expusemos até o momento. Começamos por tratar das pedagogias de inspiração liberal (tradicional, tecnicista, humanista e nova), que foram chamadas por Saviani de "teorias não-críticas", dado que ignoram os condicionamentos sociais da educação. A seguir, mencionamos três "teorias crítico-reprodutivistas" (da violência simbólica, dos aparelhos ideológicos de Estado e da escola dualista), por reconhecerem estes condicionamentos, mas os tomarem como insuperáveis. Outro autor, Cortella (2009) irá se referir a estes dois tipos de teorias com ainda outra terminologia, que julgamos interessante apresentar.

O primeiro grupo se refere à concepção chamada de otimismo ingênuo, que

atribui à Escola uma missão salvífica, ou seja, ela teria um caráter messiânico; nessa concepção, o educador se assemelharia a um sacerdote, teria uma tarefa quase religiosa e, por isso, seria portador de uma vocação. [...] Essa concepção é otimista porque valoriza a Escola, mas é ingênua pois atribui à ela uma autonomia absoluta na sua inserção social e na capacidade de extinguir a pobreza e a miséria que não foram por ela originalmente criadas. [...] a Escola seria suprassocial, não estando ligada a nenhuma classe social específica e servindo a todas indistintamente; assim, o educador desenvolveria uma atividade marcada pela neutralidade, não estando à serviço de nenhum grupo social, político, partidário etc. (ibidem, p. 110-111, grifos do autor) ${ }^{14}$.

O segundo grupo, por sua vez, recebe o apelido de pessimismo ingênuo:

Por contraposição à concepção anterior, esta defende a idéia de que a função da Escola é a de reprodutora da desigualdade social, com um caráter dominador; nela, o educador é um agente da ideologia dominante, ou seja, um mero funcionário das elites. Dessa forma, por ser a Sociedade impregnada de diferenças garantidas por um Poder comprometido, a relação da Escola com ela é a de ser um aparelho ideológico do Estado, destinado a perpetuar o "sistema". [...]

O pessimismo dessa posição vem por conta de sua compreensão do papel unicamente discriminatório da Escola, desvalorizando sua capacidade como ferramenta para a conquista da justiça social; no entanto, dela surgiu uma grande contribuição que foi a de chamar a atenção para o fato de a Educação não ser uma atividade socialmente neutra, estando envolvida no conjunto da atividade política de uma estrutura social e, assim, o educador é um profissional politicamente comprometido (com consciência ou não disso).

No entanto, essa concepção é também ingênua, pois ela não radicaliza a análise e sim a sectariza, ao obscurecer a existência de contradições no interior das instituições sociais, atribuindo-lhes um perfil exclusivamente conservador; as instituições sociais, por não serem monolíticas, são permeáveis aos conflitos sociais e às mudanças contínuas do tecido político em confronto nas sociedades de classes (ibidem, p. 112-113, grifos do autor).

\footnotetext{
${ }^{14}$ Nesta obra, são utilizados dois tipos de grifos: usando itálico e usando itálico com negrito. Reproduziremos apenas este último.
} 
Vislumbra-se, naturalmente, uma concepção com os aspectos positivos destes dois grupos de teorias. Seria possível tal otimismo crítico? Caberia e ele

\begin{abstract}
apontar a natureza contraditória das instituições sociais e, aí, a possibilidade de mudanças; a Educação, dessa maneira, teria uma função conservadora e uma função inovadora ao mesmo tempo. A Escola pode, sim, servir para reproduzir as injustiças mas, concomitantemente, é também capaz de funcionar como instrumento de mudanças; as elites a utilizam para garantir seu poder mas, por não ser asséptica, ela também serve para enfrentá-las. As elites controlam o sistema educacional, controlando salários, condições de trabalho, burocracia etc., estruturando, com isso, a conservação; porém, mesmo que não queira, a Educação por elas permitida contém espaços de inovação a partir das contradições sociais. Não é casual que as elites evitem ao máximo a universalização qualitativa da Escola em nosso país (ibidem, p. 114 , grifos do autor).
\end{abstract}

Em direção a isto é que, a partir dos anos 1980, começaram a se popularizar no Brasil as pedagogias chamadas por Libâneo de progressistas, isto é, as

tendências que, partindo de uma análise crítica das realidades sociais, sustentam implicitamente as finalidades sociopolíticas da educação. Evidentemente a pedagogia progressista não tem como institucionalizar-se numa sociedade capitalista; daí ser ela um instrumento de luta dos professores ao lado de outras práticas sociais $(1988$, p. 32).

No quadro da Figura 3 são apresentadas duas tendências pedagógicas progressistas, conforme abordadas pelo trio de autores consultados: as tendências libertadora e libertária, associadas, respectivamente, aos nomes de Paulo Freire (1921-1997) e Célestin Freinet (18961966).

Embora a Pedagogia Freinet, como ficou conhecida, tenha angariado seguidores e orientado os projetos políticos-pedagógicos de algumas escolas, a corrente iniciada com o pernambucano Paulo Freire foi a que se tornou mais conhecida dos educadores brasileiros, conseguindo também se propagar para outros países.

Vários nomes foram atribuídos a esta concepção freireana; além daqueles apresentados na Figura 3 ("abordagem sócio-cultural", "tendência libertadora", "Movimento Paulo Freire de Educação"), poderíamos listar "pedagogia do oprimido", "pedagogia dialógica", "método Paulo Freire", entre muitos outros. O fato de termos assinalado que tanto esta tendência quanto a pedagogia libertária são referidas, por Saviani, como vertentes de uma "Escola Nova Popular", se deve ao fato delas se inspirarem na "concepção humanista moderna de filosofia da educação", na qual se inscreve o escolanovismo. No entanto, a tendência libertadora não se identifica com a pedagogia nova: 
Parte-se [esta tendência] da crítica à pedagogia tradicional (pedagogia bancária) caracterizada pela passividade, transmissão de conteúdos, memorização, verbalismo etc. e advoga-se uma pedagogia ativa, centrada na iniciativa dos alunos, no diálogo (relação dialógica), na troca de conhecimentos. A diferença, entretanto, em relação à Escola Nova propriamente dita, consiste no fato de que Paulo Freire se empenhou em colocar essa concepção pedagógica a serviço dos interesses populares. Seu alvo inicial foi, com efeito, os adultos analfabetos (SAVIANI, 1993, p. 77-78).

Como ressalta Libâneo, "Embora as formulações teóricas de Paulo Freire se restrinjam ou à educação de adultos ou à educação popular em geral, muitos professores vêm tentando colocá-las em prática em todos os graus de ensino formal” (1988, p. 35). No entanto, parecenos que a popularização desta pedagogia não foi acompanhada, por parte da maioria dos educadores, de compreendê-la em seus fundamentos e seus limites de aplicação prática, o que sem dúvidas seria uma empreitada de vulto. Especialmente quanto às bases filosóficas do empreendimento de Paulo Freire, ressaltamos a enorme complexidade das sínteses, absolutamente ricas e originais, que o educador brasileiro conseguiu articular a partir de filosofias tão díspares quanto a fenomenologia e o marxismo ${ }^{15}$.

Transparece também na tendência libertadora a influência do existencialismo cristão, via Mounier, Marcel e Jaspers. O fato da religião, da fé e de Deus participarem, portanto, de seu cenário de análise, levará alguns educadores, situados também numa perspectiva crítica, a questionarem as contribuições de Paulo Freire para a consecução dos fins que almeja alcançar através de sua pedagogia, entre os quais a emancipação do ser humano e o exercício de sua "vocação ontológica" para "ser mais". No âmbito da Pedagogia Histórico-Crítica, que é o assunto da próxima seção, alguns educadores reagirão, ironicamente, com profunda descrença diante dos comprometimentos teológicos da obra freireana - Suze Scalcon, autora que visitaremos no próximo capítulo, chega a perguntar, sem meias palavras: "como articular religião e revolução, fé e criticidade num mesmo projeto político-pedagógico?” (2002, p. 88).

\footnotetext{
${ }^{15}$ Há um texto em que Saviani lamenta este desconhecimento por parte dos educadores em formação: "Tenho insistido e até lamentado que os nossos alunos de pedagogia [...] não conheçam os clássicos da nossa história pedagógica como, por exemplo, Fernando de Azevedo, Lourenço Filho, Anísio Teixeira, Paulo Freire. E o mais lamentável é que, mesmo conhecendo alguns desses autores, esse conhecimento é apenas do nome e não da obra, como é, mais precisamente, o caso de Paulo Freire. Não se pode dizer que os alunos o conheçam. Apenas ouviram falar. Se se fizer uma enquete para saber quem leu alguma coisa dele, será difícil obter uma resposta positiva no que se refere aos textos fundamentais. Talvez os alunos tenham lido um ou outro texto ou uma entrevista em alguma revista. Mas dificilmente encontraremos alguém que tenha lido os textos-chave, como Educação como prática da liberdade e Pedagogia do oprimido" (SAVIANI, 2008, p. 147). Entendo que o problema seja ainda mais grave, já que até no âmbito da pós-graduação, e mesmo entre docentes da educação superior, paira este desconhecimento - quando muito, um conhecimento superficial. Veremos uma expressão análoga deste fato no próximo capítulo, com o caso dos autores da Psicologia Histórico-Cultural.
} 


\subsection{A PEDAGOGIA HISTÓRICO-CRÍTICA ENQUANTO PEDAGOGIA PROGRESSISTA}

Apesar dos questionamentos de alguns partidários da Pedagogia Histórico-Crítica aos escritos de Paulo Freire, pode-se considerar que a tendência libertadora participou decisivamente do momento em que se gestava esta teoria crítica da educação, sob os punhos de Dermeval Saviani (nascido em 1943). Ele conta, na obra Pedagogia Histórico-Crítica: primeiras aproximações, coletânea de textos lançada em 1991, que na busca teórica por uma concepção dialética do processo educacional, à época em que começava a identificar os autores crítico-reprodutivistas em meio às pedagogias críticas (1977), deparou-se com o texto Ação cultural para a liberdade:

Fixei-me nesse texto de Paulo Freire porque nos anteriores não se configurava uma abordagem dialética da educação; há, sim, referência à dialética, mas é uma dialética idealista, uma dialética de consciências. Em Ação cultural para a liberdade, ele refere-se explicitamente à luta de classes, à revolução, à ação cultural como um trabalho que precede a mudança da estrutura social e à revolução cultural como um trabalho que se desenvolve após a mudança da estrutura social. Na verdade, esse texto é inspirado na experiência maoista da Revolução Cultural chinesa (SAVIANI, 2008, p. 68).

Sob o impulso, portanto, deste texto de Paulo Freire ${ }^{16}$, e buscando uma alternativa aos autores crítico-reprodutivistas, Saviani começa a elaborar uma "pedagogia dialética". Chega mesmo a cogitar este nome para a tendência pedagógica de inspiração marxista que tem em mente, mas desiste diante das confusões a que o adjetivo "dialética" poderia induzir. $\mathrm{Na}$ mesma obra, Saviani afirma que 1979 marca a configuração mais clara de sua concepção histórico-crítica sobre a educação, sendo legítimo situarmos seu nascimento neste ano.

\footnotetext{
${ }^{16}$ Sugiro a leitura do livro Interlocuções pedagógicas (SAVIANI, 2010), que é aberto por um "Diálogo com Paulo Freire e Adriano Nogueira", o registro de uma tarde de conversas entre Saviani e os dois educadores. Na obra é reproduzida também uma entrevista de Saviani à Revista Neo Mondo, com o título "Paulo Freire em destaque". Acredito que estes textos explicitam as proximidades entre os pensamentos de Saviani e de Freire. E se a teoria do educador pernambucano não é a Pedagogia Histórico-Crítica, com certeza se trata de uma pedagogia histórico-crítica. Alguns autores, no entanto, de modo imprudente e apressado, insistem em dispor ambas as teorias em confronto - veja-se, por exemplo, o capítulo "Pedagogia do oprimido versus pedagogia dos conteúdos", nos Documentos de identidade de Tomaz Tadeu da Silva (SILVA, 2011, p. 57-64), que afirma que Saviani teria "contestado" o "predomínio de Paulo Freire no campo educacional brasileiro" e realizado uma "oposição a Paulo Freire". Silva afirma também que "Saviani critica tanto as pedagogias activas mais liberais quanto a pedagogia libertadora freireana por enfatizar não a aquisição do conhecimento mas os métodos de sua aquisição". Mas vejamos as palavras do próprio Saviani: "Passei a bater-me contra a tendência a diferenciar as escolas: a das massas e das elites, qualitativamente mais desenvolvida. Isso me colocou num certo momento em um embate com os seguidores de Paulo Freire, que viam nas minhas formulações uma contraposição a esse educador, embora minha crítica não se dirigisse propriamente a Paulo Freire, mas a essa visão de escola que secundarizava a importância do saber elaborado" (SAVIANI, 2010, p. 168).
} 
Conforme explica, é então que sua preocupação em abordar dialeticamente o fenômeno educativo passa a se tornar um trabalho mais amplo e coletivo, envolvendo seus orientandos, à época, na primeira turma do doutorado em Educação na Pontifícia Universidade Católica (PUC-SP).

Se 1979 é o ano de seu nascimento, 1983 aparece como o momento em que esta teoria ganha contornos mais nítidos, com o lançamento de Escola e democracia. Como vimos, este livro começa por apresentar a tipologia das teorias da educação divididas entre não-críticas e críticas, para depois expor o conflito entre as pedagogia tradicional e nova, sob um ponto de vista polêmico.

Acompanhamos os raciocínios de Saviani com base na associação destas tendências, respectivamente, aos nomes de "pedagogia da essência" e "pedagogia da existência" e, embora tenhamos passado ao largo desta questão quando expusemos o conflito assinalado, deve-se ao educador polonês Bogdan Suchodolski (1903-1992) esta terminologia. Em sua obra A pedagogia e as grandes correntes filosóficas, de 1960, enuncia-se pela primeira vez o "conflito fundamental do pensamento pedagógico": identificam-se as pedagogias essencialistas que remontam a Platão e Aristóteles, desenvolvendo-se na Idade Média com as contribuições de São Tomás de Aquino; até que uma concepção oposta, que coloca em relevo a existência empírica dos homens, começa a ganhar contornos a partir do Renascimento, se materializando de fato na obra de Rousseau, o primeiro grande nome da pedagogia da existência. A partir daí, até o século XX, diversas versões destas pedagogias serão elaboradas, chegando-se às diferenciações no interior de cada uma e, finalmente, ao predomínio da pedagogia da existência.

Saviani, pois, parte do descobrimento do caráter reacionário que esta pedagogia veio a expressar, na forma de pedagogia nova. Os textos em que se refere à metáfora da "curvatura da vara" (os dois escritos mais internos de Escola e democracia) visavam a restabelecer as ideias pedagógicas num ponto de equilíbrio entre as tendências tradicional e nova, de modo a desmanchar o excessivo entusiasmo dos educadores pelos métodos escolanovistas. Havia a necessidade premente de se desfazer as concepções de que à pedagogia tradicional caberiam todos os vícios e nenhuma virtude, e de que à pedagogia nova caberiam todas as virtudes e nenhum vício. Não bastaria, no entanto, trazer a "vara" para seu ponto intermediário; seria necessário superar dialeticamente ${ }^{17}$ ambas as tendências pedagógicas, se se quisesse elaborar

\footnotetext{
${ }^{17}$ Segundo Konder (2008), a acepção dialética da palavra "superação" deve ser encontrada no emprego por Hegel do termo alemão aufheben, verbo que significa "suspender" e se manifesta em três sentidos diferentes: o primeiro, como negação, anulação, cancelamento ("o estudante foi suspenso das aulas"; "o passeio foi suspenso
} 
uma pedagogia crítica não-reprodutivista, em direção ao preconizado por Suchodolski ao final de sua obra:

\begin{abstract}
A pedagogia devia ser simultaneamente pedagogia da existência e pedagogia da essência, mas esta síntese exige certas condições que a sociedade burguesa não preenche, exige também que se criem perspectivas de elevação da vida quotidiana acima do nível actual. O ideal não deve nem sancionar a vida actual, nem tomar uma forma totalmente alheia a essa vida (SUCHODOLSKI, 1984, p. 117).
\end{abstract}

Saviani, com Escola e democracia, realiza o seguinte movimento: anuncia a necessidade desta teoria crítica não-reprodutivista no primeiro texto; prepara esta nova tendência ao contrapor as pedagogias da essência e da existência, no texto seguinte; e a esboça em suas características básicas e encaminhamentos metodológicos, finalmente, no terceiro texto. Neste momento, já está delineada a "pedagogia revolucionária", nome provisório que dá à nova corrente: uma teoria sensível às determinações recíprocas entre a realidade objetiva e as práticas sociais, em que a educação é tomada como uma destas práticas, devendo estar articulada com os interesses dos dominados e não dos dominantes.

O quarto e último texto, "Onze teses sobre educação e política", apresenta as condições de elaboração e operação desta pedagogia na sociedade atual, em que a política se sobressai, enquanto prática social, em relação à educação. Assim, Saviani demarca a especificidade pedagógica da prática social educativa, ressaltando a impossibilidade ontológica dela ser confundida com outras práticas - em especial, a política, evidentemente. Podemos assim resumir as 11 teses ali enunciadas:

- Não há identidade entre educação e política; a dissolução de uma na outra configura o "politicismo pedagógico" ou o "pedagogismo político";

- Educação e política apresentam em comum o fato de serem práticas sociais;

- Política é a verdade do poder; educação, o poder da verdade; toda educação, portanto, é revolucionária ${ }^{18}$.

Pelas palavras de Saviani,

em virtude da chuva"); o segundo, como elevação visando à preservação (“os móveis suspensos não foram danificados pelo alagamento"); e o terceiro, como elevação da qualidade, movimento para um plano superior ("suspender o nível"). "Pois bem: Hegel emprega a palavra com os três sentidos diferentes ao mesmo tempo. Para ele, a superação dialética é simultaneamente a negação de uma determinada realidade, a conservação de algo de essencial que existe nessa realidade negada e a elevação dela a um nível superior” (ibidem, p. 25, grifo do autor).

18 “A verdade histórica é sempre revolucionária”, dizia Lênin. 
a importância política da educação reside na sua função de socialização do conhecimento. É, pois, realizando-se na especificidade que lhe é própria que a educação cumpre sua função política. Daí [...] que ao se dissolver a especificidade da contribuição pedagógica anula-se, em consequiência, a sua importância política (SAVIANI, 1993, p. 98).

Após o impacto de Escola e democracia em 1983, Libâneo publica Democratização da escola pública no ano seguinte, já se considerando um colaborador para a elaboração da tendência pedagógica iniciada por Saviani. Na tipologia das pedagogias apresentada nesta obra, ele se refere a uma "tendência progressista crítico-social dos conteúdos" (LIBÂNEO, 1988, p. 38-43). Tratar-se-ia de uma concepção que compreende a escola como importante para a "preparação do aluno para o mundo adulto e suas contradições, fornecendo-lhe um instrumental, por meio da aquisição de conteúdos e da socialização, para uma participação organizada e ativa na democratização da sociedade", sendo estes conteúdos realidades exteriores ao aluno (possuindo, portanto, objetividade) e devendo ser tratados considerando sua "significação humana e social". Ainda, não haveria oposição entre cultura popular e cultura erudita, mas antes uma linha de continuidade, "em que, progressivamente, se passa da experiência imediata e desorganizada ao conhecimento sistematizado". Seriam privilegiados, nesta concepção, métodos de ensino que se subordinem aos conteúdos, relacionando-os com a prática vivida pelos alunos, em aulas que começam "pela constatação da prática real, havendo, em seguida, a consciência dessa prática no sentido de referi-la aos termos do conteúdo proposto, na forma de um confronto entre a experiência e a explicação do professor”. Está excluída, naturalmente, a postura de não-diretividade por parte do mestre: "Não são suficientes o amor, a aceitação, para que os filhos dos trabalhadores adquiram o desejo de estudar mais, de progredir; é necessária a intervenção do professor para levar o aluno a acreditar nas suas possibilidades, a ir mais longe, a prolongar a experiência vivida"19.

\footnotetext{
${ }^{19}$ Anos mais tarde, Libâneo dirá: "Para mim estava muito claro que o meu trabalho era um desdobramento do pensamento pedagógico lançado pioneiramente por ele [Saviani], fundamentado no materialismo histórico e dialético" (1994, p. 30). Na mesma página, também é esclarecida a proposta do nome "pedagogia crítico-social dos conteúdos": "Dermeval tinha já falado em pedagogia dialética e, às vezes, em pedagogia revolucionária, mas ele mesmo não gostava dessas denominações. Da minha parte, influenciado por Snyders, cunhei inicialmente minha proposta de 'pedagogia dos conteúdos culturais' e, depois, inspirado pelo livro Mistificação pedagógica de Charlot, que falava em pedagogia social, optei pela denominação 'pedagogia crítico-social dos conteúdos'. Dermeval incentivou-me a ir em frente. Pouco tempo depois cunhou sua própria proposta de 'Pedagogia histórico-crítica'. De vez em quando em minhas palestras as pessoas perguntam sobre a diferença entre essas denominações. Minha resposta é: nenhuma". Newton Duarte, no entanto, discorda, afirmando ser essencial estabelecer as distinções entre as propostas de Saviani e de Libâneo: "Entendemos [...] que existem grandes diferenças entre essas duas abordagens, diferenças essas que já existiam na década de 1980 mas que num primeiro momento foram obscurecidas pela busca de união de esforços na tentativa de construção de uma pedagogia crítica. Atualmente essas diferenças mostram-se de forma bastante acentuada, particularmente no que se refere ao distanciamento entre as posições de José Carlos Libâneo e uma perspectiva educacional socialista e marxista" (2006, p. 57, nota de rodapé).
} 
No mesmo ano de 1984, Saviani ministra, ainda na PUC-SP, uma disciplina com nome "Pedagogia Histórico-Crítica", e passa a adotá-lo para representar a tendência pedagógica que continua elaborando. Esta designação busca ressaltar a contraposição desta pedagogia à concepção crítico-reprodutivista: "É crítica, como esta, mas diferentemente dela, não é reprodutivista, mas enraizada na história" (SAVIANI, 2008, p. 141).

Como já dissemos, em 1991 Saviani apresenta a obra Pedagogia Histórico-Crítica: primeiras aproximações. No capítulo introdutório são expostas as bases desta pedagogia: trata-se de uma concepção que exige uma perspectiva historicizadora da prática educativa, porquanto uma pedagogia socialista de inspiração marxista; ela toma a natureza da educação enquanto trabalho do tipo "não-material", cujo produto não se separa do ato de produção; e considera que os homens não se fazem homens naturalmente, precisando, para isso, assimilar a experiência humana, fixada nos diferentes tipos de saberes. Assim,

A natureza humana não é dada ao homem mas é por ele produzida historicamente sobre a base da natureza biofísica. Consequientemente, o trabalho educativo é o ato de produzir, direta e intencionalmente, em cada indivíduo singular, a humanidade que é produzida histórica e coletivamente pelo conjunto dos homens (ibidem, p. 7).

Cabe à escola, conforme esta concepção, proporcionar a apropriação, pelos seres humanos em formação (estudantes), de um saber que não é qualquer saber: é o saber elaborado, sistematizado, que se contrapõe ao saber espontâneo. Esta é a finalidade da educação escolar; seu cumprimento é que determina o cumprimento de sua função política. Então dizemos que à educação cabe o papel de instrumentalizar as classes populares, pois se considera o domínio da ciência, do saber erudito, da cultura sistematizada, condição para o exercício da liberdade.

É neste aspecto que a Pedagogia Histórico-Crítica se diferencia das teorias críticoreprodutivistas. Ela garante a existência de um espaço para ação política, a partir da educação, que revolucione a prática social global, implodindo o modo de produção capitalista. Neste processo revolucionário, a educação é posta como condição necessária, embora não suficiente, para a derrocada da exploração das classes proletárias pela minoria que detém os instrumentos de produção. Mas para isso é preciso instrumentalizar, elevar o nível cultural destas camadas exploradas,

Justamente porque o domínio da cultura constitui instrumento indispensável para a participação política das massas. Se os membros das camadas populares não dominam os conteúdos culturais, eles não podem fazer valer seus interesses, porque ficam desarmados contra os dominadores, que se servem exatamente desses 
conteúdos culturais para legitimar e consolidar sua dominação. [...] o dominado não se liberta se ele não vier a dominar aquilo que os dominantes dominam. Então, dominar o que os dominantes dominam é condição de libertação (idem, 1993, p. 66).

Ao contrário, portanto, de algumas concepções mais atuais sobre o currículo escolar e sobre o papel da escola, a Pedagogia Histórico-Crítica não despreza os conteúdos culturais considerados "clássicos". De acordo com aquelas concepções, em especial as derivadas do pós-estruturalismo, a educação escolar deveria buscar maneiras de valorizar cada vez mais as realidades locais dos alunos, sob a pena de perpetuar relações de dominação através da divulgação e inculcação de conteúdos alheios aos interesses destas comunidades, e contrastantes com as modalidades de cultura popular nelas desenvolvidas e transmitidas ao longo das gerações. Seria uma forma, entendem os defensores desta visão, de não se render às pretensões totalizantes de um currículo "eurocêntrico" e, por conseguinte, de caráter "colonialista"; afinal, os tempos pós-modernos exigem o reconhecimento da "diversidade", das "subjetividades", do "fim das grandes narrativas". Ora, para a Pedagogia HistóricoCrítica, não existe propriamente uma cultura burguesa (ou "eurocêntrica", ou “colonialista"...), mas uma apropriação de certos elementos da cultura por parte da burguesia; a cultura - e, logo, a ciência, as artes, a filosofia - é, antes de tudo, um patrimônio da humanidade. Se é dever da instituição escolar transmitir a experiência acumulada pelas gerações anteriores às novas gerações, ela não pode se recusar, sob qualquer pretexto, a ser um espaço para a socialização destes conhecimentos. Não se trata de desprezar a cultura popular, ou de substituí-la, pura e simplesmente, pela cultura erudita. Acontece que a cultura popular, apesar (e além) de seu valor intrínseco enquanto cultura, permeia-se, não raro, de crendices, fetichismos e idolatrias, levando a associações e estabelecimentos de nexos causais infundados e em flagrante contradição com os conhecimentos científicos ${ }^{20}$. Trata-se, isto sim, de promover a erudição das camadas populares, até porque seus saberes próprios, constituídos

\footnotetext{
${ }^{20}$ Lembro-me de um fato levantado no livro Com a palavra, o autor, de Francisco Sampaio e Aloma de Carvalho (SAMPAIO; CARVALHO, 2010), em que estes autores de livros didáticos para a educação básica fazem uma crítica dos pareceres do Programa Nacional do Livro Didático (PNLD)-2010 sobre quatro de suas produções, que foram reprovadas nesta avaliação oficial de livros e, assim, impedidas de serem distribuídas às escolas públicas. No caso de um de seus livros da disciplina de Ciências, uma das justificativas dos pareceristas para reprová-lo no PNLD seria o tratamento dos conhecimentos populares, predominantemente, como atitudes reprováveis, especialmente na apresentação dos conteúdos sobre ofidismo. Entre os motivos desta reprimenda aos autores estaria a reprodução, no referido livro didático, de algumas recomendações do Instituto Butantan sobre procedimentos a serem tomados após a ocorrência de um acidente ofídico, por exemplo, não fazer um torniquete no local da picada, ou não aplicar-lhe preparações caseiras, álcool ou querosene. Denunciando o equívoco dos pareceristas, os autores se defendem: "os avaliadores do PNLD 2010 não têm a qualificação necessária para avaliar questões relativas ao conhecimento popular e também desconhecem que uma das principais tarefas do ensino de Ciências é, sim, informar o aluno sobre procedimentos corretos e alertar quando crendices e superstições colocam em risco sua saúde e sua integridade física" (p. 63).
} 
em sua experiência de vida, podem se enriquecer em contato com as formais mais sistematizadas de conhecimento.

Prezando pela fidelidade para com as palavras de Saviani, reproduzimos o longo fragmento abaixo, sobre a questão central do parágrafo acima, que achamos necessário enfatizar. Destacamos entre colchetes os termos gregos, relacionados ao "fenômeno do conhecimento", a partir dos quais Saviani defende a transmissão do saber pela escola:

\begin{abstract}
a opinião, o conhecimento que produz palpites [doxa], não justifica a existência da escola. Do mesmo modo, a sabedoria baseada na experiência de vida [sofia] dispensa e até mesmo desdenha a experiência escolar [...] É a exigência de apropriação do conhecimento sistematizado [episteme] por parte das novas gerações que torna necessária a existência da escola.

A escola existe, pois, para propiciar a aquisição dos instrumentos que possibilitam o acesso ao saber elaborado (ciência), bem como o próprio acesso aos rudimentos desse saber. As atividades da escola básica devem organizar-se a partir dessa questão. Se chamarmos isso de currículo, poderemos então afirmar que é a partir do saber sistematizado que se estrutura o currículo da escola elementar. Ora, o saber sistematizado, a cultura erudita, é uma cultura letrada. Daí que a primeira exigência para o acesso a esse tipo de saber seja aprender a ler e escrever. Além disso, é preciso conhecer também a linguagem dos números, a linguagem da natureza e a linguagem da sociedade. Está aí o conteúdo fundamental da escola elementar: ler, escrever, contar, os rudimentos das ciências naturais e das ciências sociais (história e geografia).

A essa altura vocês podem estar afirmando: mas isso é o óbvio. Exatamente, é o óbvio. E como é freqüente acontecer com tudo o que é óbvio, ele acaba sendo esquecido ou ocultando, na sua aparente simplicidade, problemas que escapam à nossa atenção. Esse esquecimento e essa ocultação acabam por neutralizar os efeitos da escola no processo de democratização (idem, 2008, p. 15).
\end{abstract}

Estes são alguns dos aspectos principais, a nosso entender, da Pedagogia HistóricoCrítica. Ao longo da tese, continuaremos caracterizando esta tendência pedagógica, já que um esforço iniciado em 1979, e considerado ainda em andamento, não pode ter seu produto condensado em poucas páginas.

Encerrando esta seção, podemos realizar uma comparação entre a teoria iniciada com Saviani e as pedagogias da essência e da existência, isto é, as tendências tradicional e nova. Afinal, a Pedagogia Histórico-Crítica se apresenta como teoria superadora destas pedagogias liberais, e este superar (aufheben - vide a nota de rodapé 17), simultaneamente, as nega, preserva e eleva.

Ela nega estas pedagogias na medida em que reconhece algumas de suas críticas recíprocas, isto é, entende como legítimas tanto acusações dos escalonovistas frente aos entusiastas dos métodos tradicionais, quanto argumentos destes contra a investida dos métodos novos. A pedagogia nova teve o mérito de apontar que a escola tradicional veiculava conteúdos distantes da realidade dos alunos e não valorizava uma postura ativa por parte 
destes. Também apontou corretamente que esta instituição colaborava para abusos de autoridade, pelos professores e dirigentes educacionais, inculcando nos estudantes uma postura de submissão, que poderia vir a sufocar o florescimento de seu potencial e levar à formação de adultos conformistas e resignados. No entanto, priorizando os métodos de aquisição do conhecimento, no lugar da transmissão, a pedagogia nova acabou por distanciar a escola de sua função específica. O relaxamento das regras de governo e disciplina também veio a dificultar a tarefa escolar de socialização de conhecimentos. Entregue aos interesses dos próprios estudantes, a instituição escolar não poderia fazê-los ultrapassar a consciência do senso comum, pois é justamente missão dos mestres, dos mais velhos, dos adultos, vir a despertar os interesses dos jovens para a cultura elaborada.

A Pedagogia Histórico-Crítica, então, preserva as contribuiçõos de ambas as correntes pedagógicas, tanto a essencialista quanto a existencialista. Se a escola não pode descuidar de transmitir o legado cultural humano, também não deve ignorar que os estudantes estão situados em uma prática social global, com contradições e percalços passíveis de serem analisados, e resolvidos, à luz do saber escolar. O erro da pedagogia nova foi superestimar a capacidade deles, achando que a captação destes problemas práticos seria possível logo no início de sua atividade discente. Ora, para se analisar a prática é preciso, antes de tudo, armarse com instrumentos teóricos. Não se pode esperar que os estudantes já os dominem previamente à experiência escolar; se assim o fosse, em todos os casos, não seriam estudantes, não haveria o que pudessem aprender. Então a tarefa específica da escola é transmitir estes conteúdos. Mas a pedagogia nova tem razão ao apontar que este saber se mostra, com os métodos tradicionais, quase sempre de forma dogmática, acabada, inquestionável. Concordando com esta crítica, a Pedagogia Histórico-Crítica prezará pela transmissão dos conhecimentos, mas reconhecendo seu cunho ideológico, seu estatuto epistemológico e a variabilidade de seu caráter axiológico conforme os contextos de sua produção/recepção.

Finalmente, a pedagogia dialética de Saviani eleva estas contribuições tradicionais e novas, pois as coloca a serviço dos interesses das camadas populares. Ela propõe que a escola seja o espaço em que se problematiza a prática social e se instrumentaliza os estudantes para lidarem com estes problemas, de modo que eles se apropriem das ferramentas culturais necessárias para se libertar da situação de opressão em que vivem. $\mathrm{O}$ momento em que a prática social é, então, captada em suas múltiplas determinações, em que se vislumbra a "unidade na diversidade", à luz destes novos instrumentos, é verdadeiramente um momento catártico. A partir de então, é chegada a hora de se retornar à prática social, que adquire um 
novo sentido. Afinal, os estudantes, com sua consciência do senso comum, aferrada mais ao transitório que ao permanente, mais ao contingente que ao necessário, mais ao acessório que ao essencial, adentram a escola com um entendimento sincrético da prática em que estão situados. Mas devidamente instrumentalizados e em posição de atuar nesta prática, sua consciência ascende ao nível da síntese - nível em que já se encontrava, ainda que de modo precário, o professor no início do ensino. Assim, a escola, pelos passos que seguem da prática social, passando pela problematização, instrumentalização e catarse, e retornando à prática social, faz os alunos se movimentarem da síncrese para a síntese, mediante a análise. Este é o caminho que vai do senso comum à consciência filosófica ${ }^{21}$, ou nos termos de Marx, do empírico ao concreto, pela mediação do abstrato.

Podemos sumarizar o discutido até aqui em mais um quadro (Figura 4), sem a pretensão de esgotar estas considerações, nem de substituí-las por uma forma diagramática.

\begin{tabular}{|c|c|c|c|}
\hline Elemento & $\begin{array}{l}\text { Pedagogia da essência } \\
\text { (tradicional) }\end{array}$ & $\begin{array}{c}\text { Pedagogia da existência } \\
\text { (nova) }\end{array}$ & Pedagogia Histórico-Crítica \\
\hline escola & $\begin{array}{l}\text { local para a transmissão do } \\
\text { conhecimento de } \\
\text { professores para alunos }\end{array}$ & $\begin{array}{l}\text { local para a aquisição do } \\
\text { conhecimento, por } \\
\text { professores e alunos em } \\
\text { interação, e de vivência da } \\
\text { democracia }\end{array}$ & $\begin{array}{c}\text { local para a transmissão do } \\
\text { conhecimento, de professores } \\
\text { para alunos, visando à atuação } \\
\text { na prática social }\end{array}$ \\
\hline professor & $\begin{array}{l}\text { detém o conhecimento e } \\
\text { deve transmiti-lo }\end{array}$ & $\begin{array}{c}\text { orienta os alunos a adquirirem } \\
\text { o conhecimento }\end{array}$ & $\begin{array}{c}\text { possui um entendimento } \\
\text { sintético da prática social, ainda } \\
\text { que precário }\end{array}$ \\
\hline alunos & $\begin{array}{c}\text { não detém conhecimentos } \\
\text { e devem ser disciplinados } \\
\text { para isto }\end{array}$ & $\begin{array}{c}\text { adentram a escola com uma } \\
\text { experiência prévia, que } \\
\text { precisa ser valorizada, e que } \\
\text { dirige seus interesses }\end{array}$ & $\begin{array}{l}\text { possuem um entendimento } \\
\text { sincrético da prática social }\end{array}$ \\
\hline conhecimento & $\begin{array}{l}\text { patrimônio da humanidade; } \\
\text { sua posse é condição } \\
\text { necessária e suficiente para } \\
\text { o indivíduo integrar a } \\
\text { sociedade democrática }\end{array}$ & $\begin{array}{c}\text { emerge da experiência de vida } \\
\text { do sujeito; sua posse é } \\
\text { condição necessária e } \\
\text { suficiente para o indivíduo } \\
\text { integrar a sociedade } \\
\text { democrática }\end{array}$ & $\begin{array}{l}\text { patrimônio da humanidade, } \\
\text { instrumento para a apreensão da } \\
\text { prática social como síntese de } \\
\text { múltiplas determinações; se } \\
\text { orienta de e para esta prática }\end{array}$ \\
\hline $\begin{array}{l}\text { passos do } \\
\text { método de } \\
\text { ensino }^{22}\end{array}$ & $\begin{array}{ll}\text { 1. } & \text { preparação } \\
\text { 2. } & \text { apresentação } \\
\text { 3. } & \text { assimilação } \\
\text { 4. } & \text { generalização } \\
\text { 5. } & \text { aplicação }\end{array}$ & $\begin{array}{ll}\text { 1. } & \text { atividade } \\
\text { 2. } & \text { problematização } \\
\text { 3. } & \text { coleta de dados } \\
\text { 4. } & \text { formulação de } \\
& \text { hipóteses } \\
\text { 5. } & \text { experimentação } \\
\end{array}$ & $\begin{array}{l}\text { 1. } \text { prática social } \\
\text { 2. problematização } \\
\text { 3. instrumentalização } \\
\text { 4. catarse } \\
\text { 5. prática social }\end{array}$ \\
\hline $\begin{array}{l}\text { consequências } \\
\text { esperadas do } \\
\text { ensino }\end{array}$ & $\begin{array}{l}\text { levar da ignorância à } \\
\text { sapiência }\end{array}$ & $\begin{array}{c}\text { levar da heteronomia à } \\
\text { autonomia }\end{array}$ & $\begin{array}{l}\text { levar da síncrese à síntese, pela } \\
\text { mediação da análise }\end{array}$ \\
\hline
\end{tabular}

Figura 4: quadro que sumariza posições da pedagogia tradicional, da nova e da Pedagogia Histórico-Crítica.

\footnotetext{
${ }^{21}$ Não à toa, este é o título de uma importante obra de Saviani, que conheceremos mais adiante.

${ }^{22}$ A título de comparação, o método de Paulo Freire também pode ser descrito em cinco passos, conforme as palavras de Saviani (2010): 1. vivência da situação popular; 2. identificação de seus problemas e escolha dos “temas geradores"; 3. problematização; 4. conscientização; 5. ação social e política.
} 


\subsection{PEDAGOGIA HISTÓRICO-CRÍTICA E PEDAGOGIAS MARXISTAS}

Para finalizar este capítulo, convém esclarecer de que maneira a Pedagogia HistóricoCrítica pode estar situada entre outros esforços para a elaboração de uma teoria marxista da educação.

Primeiro, há de se lembrar que Marx e Engels nunca se dedicaram a tratar longa e especificamente sobre a questão educacional. O que existe, no amplo conjunto de suas obras, são referências esparsas a alguns aspectos relacionados à educação, como a necessidade de se universalizar o acesso da escola pública para o proletariado, a articulação do ensino com o trabalho e a laicidade da escolarização oficial. Existem, já traduzidas para o português, coletâneas dedicadas a reunir estas considerações dispersas na produção dos pais do socialismo científico, como a antologia Crítica da educação e do ensino (MARX; ENGELS, 1978), organizada (e ricamente comentada) por Roger Dangeville. No caso específico desta obra, a adoção de um critério "frouxo" para a seleção de seus textos componentes, por parte do organizador, fez com que outros temas gerais da produção de Marx e Engels fossem quase tão bem contemplados quanto a própria educação.

Numa perspectiva diferente, realizando uma análise dos textos marx-engelsianos, estão disponíveis no Brasil dois livros que avançam mais concretamente na discussão sobre uma teoria marxista da educação apoiada na produção destes pensadores: o do italiano Mario Alighiero Manacorda, Marx e a pedagogia moderna, cuja primeira edição é de 1966; e o de Maria Alice Nogueira, Educação, saber e produção em Marx e Engels, de 199023.

O livro de Manacorda apresenta um estudo que pretende indagar "se e como se configura uma pedagogia marxiana", isto é, "inerente ao pensamento de Karl Marx" (MANACORDA, 2010, p. 25), desconsiderando-se uma possibilidade de pedagogia marxista, elaborada com contribuições de seus seguidores. Um dos pressupostos do autor, e que vale a pena reproduzir em suas palavras, já foi apresentado aqui conforme a visão de Saviani, e se refere à educabilidade do homem:

O homem não nasce homem: isto o sabem hoje tanto a fisiologia quanto a psicologia. Grande parte do que transforma o homem em homem forma-se durante a sua vida, ou melhor, durante o seu longo treinamento por tornar-se ele mesmo, em que se acumulam sensações, experiências e noções, formam-se habilidades, constroem-se estruturas biológicas - nervosas e musculares - não dadas a priori pela

\footnotetext{
${ }^{23}$ Ambas as obras são prefaciadas por Dermeval Saviani.
} 
natureza, mas fruto do exercício que se desenvolve nas relações sociais, graças às quais o homem chega a executar atos, tanto "humanos" quanto "não naturais", como falar e o trabalhar segundo um plano e um objetivo (ibidem, p. 26).

O estudo passa a se realizar, então, a partir de uma pesquisa de caráter filológico que encontra, nas obras de Marx e Engels (consideradas inseparáveis), textos explicitamente pedagógicos, pouco numerosos, é verdade, mas dotados de coerência e importância diante da história do movimento operário, e dispostos num intervalo de 30 anos. Haveria, assim, três núcleos de que se irradiariam estas considerações de cunho educacional: a) o primeiro movimento histórico de revolução proletária (fundação do Partido Comunista), entre 1847 e 1848; b) a organização da I Associação Internacional dos Trabalhadores, em 1866; e c) a unificação dos partidos mais progressistas alemães no Primeiro Partido Operário Unitário, em 1875. O primeiro conjunto de textos, dispostos nos Princípios do comunismo de Engels e, mais tarde, na revisão deste escrito por Marx que originaria o Manifesto do Partido Comunista, incidirá no dilema unilateralidade/onilateralidade. Concebe-se que só a abolição da divisão do trabalho (e sua decorrência, a propriedade privada dos meios de produção) pode levar à recuperação da onilateralidade do homem, superando sua condição atual, restrita ao desenvolvimento unilateral de suas habilidades. Já o segundo conjunto de textos será constituído principalmente pelas Instruções aos delegados do comitê provisório londrino do I Congresso da Associação Internacional dos Trabalhadores, em Genebra (1866), e pelo célebre O Capital (1867). Neste momento da produção marxiana ganha relevo, no âmbito da questão educacional, uma primeira definição de conteúdo programático para a educação socialista, contemplando o ensino propriamente intelectual, a educação física através de exercícios militares e o adestramento tecnológico, possibilitando o conhecimento dos fundamentos científicos dos processos industriais de produção e, simultaneamente, o manejo dos instrumentos elementares dos ofícios. Finalmente, o terceiro conjunto de textos estaria representado pelas Notas à margem ao programa do partido operário alemão (Crítica ao programa de Gotha), de 1875. Aqui, confirmar-se-iam os temas fundamentais da pedagogia marxiana: a união do ensino com o trabalho produtivo e a exigência de escolas técnicas que articulem teoria e prática.

Após analisar estes conjuntos de escritos, Manacorda parte para considerações à luz de alguns termos importantes para uma análise marxiana da sociedade e da história, como a contradição fundamental trabalho humanizador/trabalho desumano e a relação entre tempo livre e exploração do tempo de trabalho alheio. Evidencia-se, nesse momento, a necessidade 
histórica de uma reorganização das forças produtivas, assim como o papel da ciência (e logo, do saber a ser transmitido durante a escolarização) para este fim:

\begin{abstract}
A propriedade privada dos meios coletivos de produção, que é apropriação de trabalho alheio, tem significado, também, apropriação privada da ciência e sua separação do trabalho; esta tem mesmo negado o preexistente vínculo entre ciência e ação, próprio da limitada produção artesanal, mas criou, por sua vez, as condições para a sua própria superação. Torna inevitável a recuperação de uma identidade entre ciência e trabalho; e tal recuperação não pode realizar-se a não ser como reapropriação da ciência por parte de todos os indivíduos no processo coletivo da produção moderna, do moderno domínio do homem sobre a natureza (ibidem, p. 79, grifo nosso).
\end{abstract}

Ou seja, Manacorda entende que, se a produção industrial moderna, com a exacerbada divisão do trabalho em mental e manual (este, em inegável desvantagem), desvincula ciência de ação (a teoria da prática), simultânea e contraditoriamente também leva a exigir a restituição deste vínculo, à medida que se elevam as capacidades produtivas e que se exige, dos trabalhadores, mais e mais conhecimentos sobre os diferentes ramos do saber. É o próprio capital, portanto, o "demiurgo involuntário" deste processo, dada a relação contraditória entre concentração da riqueza e elevação de suas forças produtivas (e consequentemente, democratização dos meios de produção). Neste sentido, a fábrica se assume como modelo de instituição educativa:

isso significa uma recolocação do processo educativo no processo de trabalho, num processo de trabalho - a fábrica moderna - por sua natureza total, plena e dinâmica. Falar do vínculo ensino-trabalho fora dessa colocação significa ficar nas palavras e não compreender absolutamente a posição marxiana: significa confundi-la com as várias didáticas honestamente imaginadas pelos pedagogos voluntariosos, mas que nada têm a ver com a tentativa marxiana de interpretar o processo real e as contradições que incessantemente o solicitam (ibidem, p. 81).

O estudo de Manacorda tangencia ainda outros aspectos sobre os quais não iremos nos deter, como a já mencionada laicidade do ensino, a objetividade dos conteúdos escolares e, afinal, quais deveriam ser estes conteúdos.

Falemos um pouco a respeito do livro de Maria Alice Nogueira. Ao contrário de Manacorda, que realiza um estudo com caráter quase tão filológico quanto historiográfico, aqui a autora se aprofunda no conhecimento da situação concreta e objetiva em que os textos de Marx e Engels, em seus esparsos comentários sobre educação, foram redigidos. Por exemplo, as considerações destes pensadores a respeito do trabalho infantil são analisadas, por Nogueira, no contexto da escravização dos menores em jornadas de trabalho desumanas mesmo para os adultos, e acompanhando-se as sucessivas leis que vieram a intervir no 
problema, leis estas que também se referiam às possibilidades de escolarização destas crianças.

Nogueira também considera a união do trabalho com o ensino o núcleo geral das formulações de Marx e Engels sobre educação. Identificando que o sentido deste trabalho é expresso em diversos termos, em seus textos - "trabalho físico", "trabalho manual", "trabalho fabril”, "produção material” -, Nogueira demonstra já estar presente, aí, uma concepção emancipadora de educação:

são os conhecimentos técnicos necessários à compreensão do processo de produção no seu todo que permitirão aos trabalhadores controlar esse processo - controle do qual foram historicamente expropriados. O que significa que o controle do saber dentro da fábrica constitui o ponto nevrálgico do controle do processo de trabalho pelos trabalhadores.

Nesse contexto, a educação assume, para os dois [Marx e Engels], o significado de uma arma importante nesse combate. Faz-se necessário que o trabalhador consiga não somente ter acesso a esse saber, mas que possa ainda chegar a controlar o processo de produção/reprodução (as condições de transmissão) dos conhecimentos científicos e técnicos (NOGUEIRA, 1993, p. 91).

É importante notar que Nogueira não recusa o termo "educação politécnica", ao contrário de Manacorda, que prefere "educação tecnológica" (e o defende considerando a etimologia de tecnologia, que explicita a imbricação entre teoria e prática). O termo que Nogueira evita é outro, "polivalência", entendida como a capacidade de um trabalhador ocupar diferentes postos de trabalho, circulando entre eles. Para ela, a politecnia, embora abranja a polivalência, a ultrapassa, pois implica a ideia de um trabalho complexo ${ }^{24}$.

Outro autor de relevância que se propôs a contribuir para uma teoria marxista da educação é Suchodolski, cujos esforços nesta direção estão reunidos nos três volumes da obra intitulada, simplesmente, Teoria marxista da educação (SUCHODOLSKI, 1976). Sua exposição é entremeada por algumas citações das obras clássicas do marxismo, em nove capítulos que vão da "Evolução dos problemas pedagógicos nas obras de Marx e Engels" a "O significado de Marx e Engels para a história da pedagogia". Também há espaço para a polêmica entre as pedagogias da essência e da existência, que teremos a oportunidade de retomar no próximo capítulo.

Lombardi, comentando os textos destes quatro autores - a coletânea de Dangeville, mais os livros de Manacorda, Nogueira e Suchodolski - irá afirmar que esta produção permite organizar a contribuição de Marx à educação em três grandes direções:

\footnotetext{
${ }^{24}$ Não vamos nos inserir junto a esta polêmica terminológica. Mas vale a pena destacar que o artigo de Nosella (2008) apresenta razões de ordens semântica, histórica e política para se evitar o termo "politecnia".
} 
1. Crítica à educação, ao ensino e à qualificação profissional burguesa. Analogamente à crítica da economia política, Marx e Engels também dirigiram ao ensino burguês uma aguda e profunda crítica, desnudando a relação entre a educação e as condições de vida das classes fundamentais da sociedade burguesa.

2. Relação do proletariado com a ciência, a cultura e a educação. O tratamento de Marx e Engels dado à problemática da relação do proletariado com a cultura e a ciência explicitava como entendiam a ciência a serviço do capital, o processo de alienação resultante do processo de trabalho industrial e o aparelhamento burguês da escola, bem como a importância da educação para a formação da consciência.

3. Educação comunista e formação integral do homem - a educação como articuladora do fazer e do pensar - a superação da monotecnia pela politecnia. A concepção educacional marxiana-engelsiana tinha como ponto de partida a crítica da sociedade burguesa, a proclamação da necessária superação dessa mesma sociedade e como ponto de chegada a constituição do reino da liberdade. Com a instauração do comunismo a educação estará a serviço do homem e, rearticulando o trabalho manual e a atividade intelectual, deverá voltar-se plenamente à formação integral do homem $\left(2008\right.$, p. 10) ${ }^{25}$.

O leitor deverá ter reparado que, apesar de termos apresentado a Pedagogia HistóricoCrítica também como uma teoria marxista, a caracterizamos, na subseção anterior, sem recorrer aos termos empregados pelos autores examinados nesta subseção. Quer dizer, não falamos em educação fabril, nem em politecnia, nem na oposição unilateralidade/onilateralidade.

O que acontece é que Saviani, ao elaborar sua proposta pedagógica de caráter dialético, não procedeu ao modo exegeta de extrair citações das obras clássicas do marxismo e a partir delas derivar os fundamentos de sua teoria. Sua preocupação maior esteve em, a partir do método de Marx - baseado não numa dialética idealista, mas sim num entendimento materialista em que o processo de trabalho é a própria expressão da dialética, processo através do qual o homem cria sua própria natureza, e que na sociedade capitalista se apresenta também como forma de alienação -, investigar as raízes dos problemas da educação burguesa, expressos no embate entre a pedagogia da essência e a pedagogia da existência.

É assim, por exemplo, que ele mobiliza os conceitos de empírico, abstrato e concreto - conceitos que nos remetem à Contribuição à crítica da economia política, de Marx - e os converte em instrumentos para a crítica das pedagogias liberais e para a formulação de uma pedagogia progressista. Se a pedagogia tradicional entende os indivíduos humanos de modo abstrato, supondo sua igualdade formal, essencial, a pedagogia nova se atém à existência imediata do ser homem, à sua singularidade empírica. Ambas as pedagogias promovem um entendimento a-histórico da individualidade humana, pois uma supõe uma essencialidade

\footnotetext{
${ }^{25}$ A bem da verdade, esta organização de Lombardi em três grandes eixos ou direções, quanto às contribuições de Marx à educação, corresponde à ordem e aos títulos dos capítulos na antologia organizada por Dangeville.
} 
universal, e a outra canaliza toda sua atenção a um viver esquecido de seus condicionantes sociais. Superando estas tendências, na busca por concretizar a igualdade real entre os homens, uma pedagogia concreta não entenderá os conteúdos escolares como necessários em si, nem deixará seu estudo à mercê dos interesses imediatos dos alunos, mas entenderá a necessidade destes conteúdos de um ponto de vista histórico:

a pedagogia histórico-crítica considera que os educandos, enquanto indivíduos concretos, manifestam-se como unidade da diversidade, "uma rica totalidade de determinações e relações numerosas", síntese de relações sociais. Portanto, o que é do interesse deste aluno concreto diz respeito às condições em que se encontra e que ele não escolheu. Assim, também a geração atual não escolhe os meios e as relações de produção que herda da geração anterior e sua criatividade não é absoluta, mas se faz presente. [...] Isto anula a ideia de que o aluno pode fazer tudo pela sua própria escolha. Essa ideia não corresponde à realidade humana.

Daí, a grande importância de distinguir, na compreensão dos interesses dos alunos, entre o aluno empírico e o aluno concreto, firmando-se o princípio de que o atendimento aos interesses dos alunos deve corresponder sempre aos interesses do aluno concreto. O aluno empírico pode querer determinadas coisas, pode ter interesses que não necessariamente correspondem a seus interesses concretos. É nesse âmbito que se situa o problema do conhecimento sistematizado, que é produzido historicamente e integra o conjunto dos meios de produção. Esse conhecimento sistematizado pode não ser do interesse do aluno empírico, ou seja, o aluno, em termos imediatos, pode não ter interesse no domínio desse conhecimento; mas ele corresponde diretamente aos interesses do aluno concreto, pois enquanto síntese das relações sociais, o aluno está situado numa sociedade que põe a exigência do domínio desse tipo de conhecimento. E é, sem dúvida, tarefa precípua da escola viabilizar o acesso a esse tipo de saber (SAVIANI, 2012, p. 79-80).

A Pedagogia Histórico-Crítica propõe, além disso, uma interpretação da teoria marxista fundamentada na prática que se desenvolve diariamente nas escolas brasileiras, pois toma a educação escolar como a forma principal do fenômeno educativo na sociedade contemporânea. Este pressuposto está de acordo com o método marxiano, que é "condensado" na famosa passagem, também da Contribuição à crítica da economia política: "A anatomia do homem é a chave da anatomia do macaco" (MARX, 2013, p. 264).

Finalmente, vale mencionar que, além dos textos principais do marxismo, Saviani busca contribuições em obras de autores bastante diversos (SAVIANI, 2008): os filósofos e educadores do Leste Europeu, como o já citado Suchodolski, além de Karel Kosik (19262003), Anton Semionovich Makarenko (1888-1939) e Moisey Mikhaylovich Pistrak (18881940); o francês Georges Snyders (1917-2011), no âmbito especificamente pedagógico, e mesmo certos conceitos dos já citados teóricos crítico-reprodutivistas, como Bourdieu; da Itália, especialmente Antonio Gramsci (1891-1937) e seus intérpretes, além de Manacorda; e no contexto latino-americano, Adolfo Sánchez Vázquez (1915-2011). 
A partir dos anos 1990, o formulador da Pedagogia Histórico-Crítica passou a reconhecer que, entre os aspectos de sua teoria que requeriam maior desenvolvimento e elaboração, estava a "articulação de elementos psicológicos" (ibidem, p. 105). Nos últimos 20 anos, os esforços dos colaboradores desta tendência pedagógica conseguiram promover estes aportes teóricos e práticos da psicologia. Naturalmente, tais nexos só poderiam ocorrer caso se buscasse a aproximação com uma ciência psicológica também de cunho marxista, que tomasse a formação do psiquismo humano como um processo histórico, enraizado no contexto em que estão postas certas relações de produção.

A partir desta aproximação, já não foi possível deixar de incluir, na listagem do parágrafo acima, os nomes da chamada Escola de Vigotski, colaboradores da corrente que ficou conhecida como Psicologia Histórico-Cultural. Sem sombra de dúvidas, é este o próprio referencial psicológico da Pedagogia Histórico-Crítica, dada a proximidade conceitual e metodológica entre ambas as teorias.

Assim, esta psicologia dialética será o principal assunto do próximo capítulo, em que também será possível, finalmente, trazer a nosso texto aspectos da Educação em Química, sem se perder de vista as ideias pedagógicas desenvolvidas no capítulo que aqui se encerra. 


\title{
CAPÍTULO 2
}

\author{
PSICOLOGIA HISTÓRICO-CULTURAL: \\ articulações com a Pedagogia Histórico-Crítica e a Educação em Química
}

\begin{abstract}
Para tratar da Psicologia Histórico-Cultural, é evidente que as considerações especificamente pedagógicas, marca do capítulo anterior, terão de ser acrescidas de preocupações de outra ordem. Mas o teor de nosso texto continuará o mesmo: polêmico em confronto com certas noções que se cristalizaram como um senso comum pedagógico; e zeloso pelas questões de cunho educacional. Felizmente, estas são características da própria psicologia soviética que será objeto de nossas considerações a partir de agora.
\end{abstract}

Neste capítulo, seguiremos o seguinte percurso.

$\mathrm{Na}$ primeira seção será elaborada uma crítica ao construtivismo, entendido como corrente hegemônica no ideário pedagógico contemporâneo, e com grandes proximidades com a pedagogia nova em termos teóricos e práticos. Esta crítica será necessária visto que a maioria dos educadores tende a considerar as ideias construtivistas como uma apologia à liberdade, à autonomia e à democratização da sociedade e do espaço escolar. A atribuição de um caráter progressista a esta pedagogia, no entanto, não resistirá ao desmascaramento de sua visão espontaneísta sobre o desenvolvimento humano (que remete a uma desvalorização da instituição escolar e da transmissão do saber elaborado) e de suas bases filosóficas idealistas e a-históricas, muito convenientes, como iremos demonstrar, à filosofia neoliberal e ao pósmodernismo, ambos legitimadores da perspectiva liberalizante que sustenta o sistema capitalista. A Psicologia Histórico-Cultural será apresentada, então, como a alternativa a uma 
fundamentação psicológica crítica para a educação, inconciliável com o ideário do construtivismo.

A seção seguinte será dedicada, primeiramente, a contarmos o processo de desenvolvimento histórico desta corrente psicológica, e depois, a apresentarmos alguns de seus conceitos relacionados com a questão do ensino escolar e, por conseguinte, com a teoria pedagógica tomada como referencial teórico desta tese, a Pedagogia Histórico-Crítica. Como já mencionamos, esta psicologia também se assenta sobre o materialismo histórico e dialético de Marx e Engels. Dada a ausência de um interesse por questões psicológicas nos textos primevos de Saviani, vários de seus seguidores encontraram nos trabalhos de Vigotski, Leontiev, Luria e outros estudiosos os elos entre o desenvolvimento das funções psíquicas superiores e a compreensão do fenômeno da educação escolar numa perspectiva crítica e dialética, preenchendo assim esta lacuna.

Após apresentarmos, portanto, estes elos, encerraremos o capítulo analisando criticamente as apropriações da Psicologia Histórico-Cultural por autores do campo da Educação em Ciências e, em especial, da Educação em Química. Ao mesmo tempo em que realizaremos este "estado da arte", teremos a oportunidade de conhecer alguns conceitos não explorados nas seções anteriores, trazendo também novas polêmicas ao texto.

\subsection{CRÍTICA AO CONSTRUTIVISMO}

Não há espaço, neste trabalho, para discutirmos em profundidade o que caracterizaria uma determinada postura educacional como construtivista. Na realidade, este tema bem que poderia demandar a redação de uma tese inteira, ou quem sabe, se constituir numa linha de pesquisa a ser conduzida por muitos anos.

Sob o guarda-chuva do termo "construtivismo" se abrigam tendências diversas, diversidade esta que pode implicar até o uso de terminologias diferentes para a explicação dos mesmos fenômenos educacionais. Good, Wandersee e St. Julien (1993), citados por Geelan (1997), teriam observado na literatura o registro das seguintes "variedades" construtivistas: contextual, dialético, empírico, humanista, de processamento de informações, metodológico, moderado, piagetiano, pós-epistemológico, pragmático, radical, racional, realista, social e sociocultural. No mesmo artigo, Geelan discute seis construtivismos (pessoal, radical, crítico, 
contextual e duas formas de construtivismo social) e propõe uma tipologia baseada em combinações de qualidades, atribuíveis às formas construtivistas, entre as dimensões pessoal/social e relativismo/objetivismo. Esta tipologia pode ser ilustrada como um plano cartesiano, em que os quadrantes indicariam o lugar das quatro combinações possíveis (Figura $5)$.

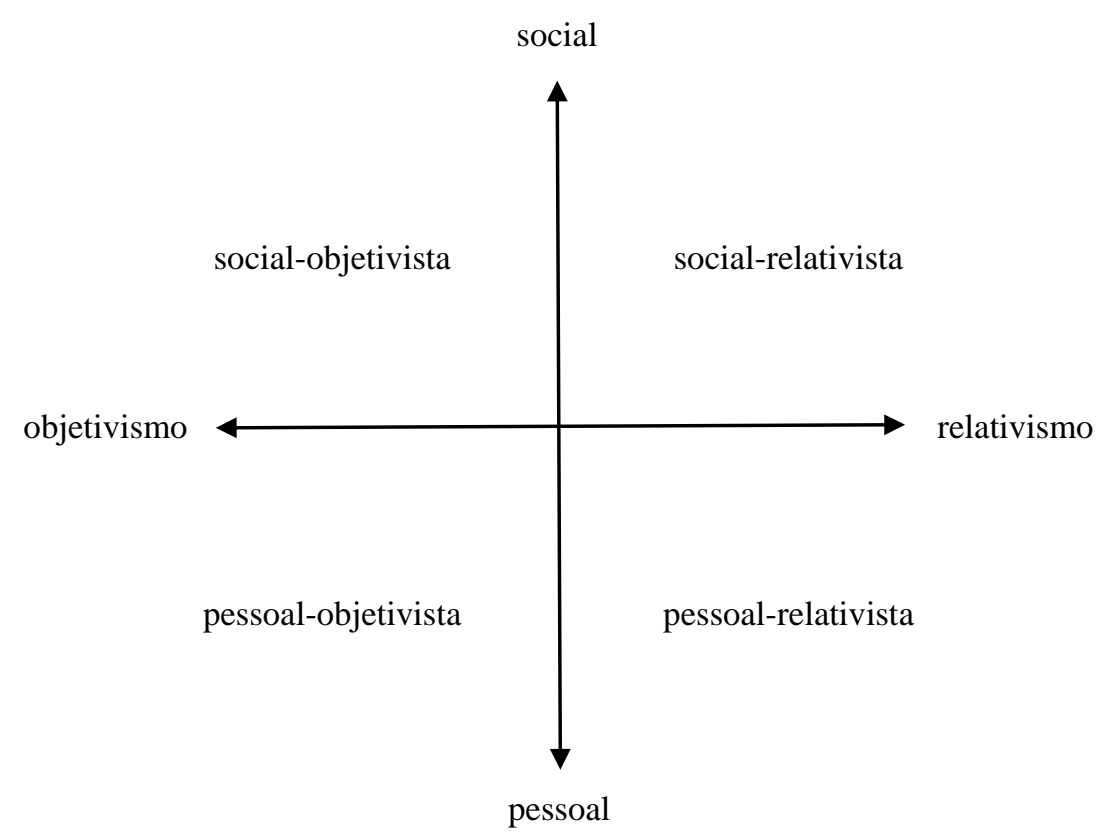

Figura 5: diagrama das posições construtivistas, entre as dimensões pessoal/social e relativismo/objetivismo.

El-Hani e Bizzo (2002), cientes desta tipologia ou "modelo bidimensional", como chamam, examinam duas tendências construtivistas situadas em quadrantes opostos: a mudança conceitual, modelo proposto por Posner e colaboradores em 1982, que seria do tipo pessoal-objetivista; e o construtivismo contextual, elaborado por Cobern na década seguinte, de caráter social-relativista. O quadrante pessoal-relativista estaria representado pelo construtivismo radical de Glasersfeld, enquanto que as tendências do tipo social-objetivista seriam aquelas influenciadas, em alguma medida, pelas ideias de Vigotski. Mais adiante, veremos que esta última associação - a que liga o nome de Vigotski ao construtivismo - é no mínimo imprópria. Importa, neste momento, ressaltar que apesar das diferenças expostas por El-Hani e Bizzo na análise de duas formas influentes de construtivismo, ambas apresentam concordâncias com certo "núcleo" de proposições sobre a aprendizagem. Estas proposições, que caracterizariam portanto qualquer concepção construtivista, são apresentadas por estes autores, em diferentes momentos de seu artigo, na forma de cinco enunciados, sendo duas 
teses e três princípios. As teses seriam a de que o conhecimento é uma construção do sujeito cognoscente, em vez de algo que ele receba passivamente do meio; e que o ato de conhecer é um processo de adaptação, que organiza as experiências deste sujeito, mas incapaz de conduzir à descoberta de uma realidade independente da mente que a conhece. Os três princípios seriam o de que o aluno não meramente reproduz o que lhe foi ensinado, mas torna suas experiências significativas, ao aprender (isto é, constrói significados); que compreender algo supõe o estabelecimento de relações entre o que se está aprendendo e o que já se sabe; e que, portanto, toda aprendizagem depende de conhecimentos prévios.

Convém reproduzir algumas palavras destes autores. Em referência ao artigo de Geelan e sua tipologia, eles fazem a ressalva de que apesar da existência de um eixo objetivismo/relativismo, "nenhuma perspectiva construtivista pode ser considerada inteiramente objetivista", o que "seria praticamente uma contradição em termos", e que as perspectivas situadas nos quadrantes objetivistas são aquelas em que o enfoque de seus proponentes "recai sobre as interações sociais na sala de aula, de modo que eles tendem a não problematizar o conhecimento científico, tratando-o como uma construção consensual na qual os estudantes devem ser socializados" (ibidem, p. 5). Ainda,

\footnotetext{
A teoria construtivista da aprendizagem tem como consequiência o requisito de que os conteúdos sejam ensinados de tal maneira que, em cada contexto particular, a probabilidade de envolvimento ativo dos aprendizes seja maximizada, dado que, quanto isto ocorre, é mais provável que eles tenham sucesso no trabalho intelectual necessário para a construção e reconstrução de significados (ibidem, p. 6).
}

Observando as duas teses e os três princípios, percebe-se que sua abrangência se estende para além do domínio da aprendizagem, avançando para uma verdadeira epistemologia. De fato, poderíamos nomear os dois eixos do diagrama da Figura 5 como "eixo da aprendizagem" (pessoal/social) e "eixo do conhecimento" ou "eixo epistemológico" (relativismo/objetivismo).

Sob o risco de enfastiar o leitor, apresentamos mais uma listagem de princípios ou "afirmações construtivistas", relacionadas tanto ao âmbito da aprendizagem quanto ao do conhecimento, e compiladas por Laburú e Silva (2000) a partir de uma listagem de Matthews (1994) que, por sua vez, extrai grande parte destes princípios da obra do construtivista radical Glasersfeld:

1. O conhecimento não se refere a um observador independente do mundo.

2. O conhecimento não é uma representação do mundo; pensar que as teorias correspondam a ele é um equívoco. 
3. O conhecimento é criado pelos indivíduos, num contexto histórico e cultural.

4. Conhecer é um processo de adaptação que organiza o nosso mundo da experiência. Não há a descoberta de um mundo independente e preexistente fora da mente. Portanto, não há uma realidade ontológica.

5. O conhecimento é ativamente construído por um sujeito que pensa e não passivamente recebido do ambiente.

6. O conhecimento é constituído pela estrutura conceitual dos indivíduos.

7. As estruturas conceituais constituem conhecimento quando os indivíduos as consideram como viáveis em relação às suas experiências: o construtivismo é uma forma de pragmatismo.

8. Não há uma estrutura conceitual epistêmica preferencial.

9. O conhecimento é o ordenamento apropriado da realidade vivencial.

10. Não há uma realidade extravivencial racionalmente acessível.

11. As proposições observacionais são sempre dependentes de um sistema teórico particular. Há uma diferença entre "estar vendo" e "estar vendo como". Esta última - uma proposição observacional - é dependente da linguagem e da teoria.

12. Numa teoria, a distinção entre termos observacionais e teóricos somente pode ser feita sob bases pragmáticas e não sob bases epistêmicas.

13. As observações, por si próprias, são dependentes ou determinadas teoricamente; o que as pessoas notam é influenciado pelo que elas querem ver ou pelo que elas consideram como relevante para uma investigação.

14. As teorias são sempre sub-determinadas pela evidência empírica, não importando quanta evidência tem-se acumulado ${ }^{26}$. Para qualquer conjunto de dados, inúmeras teorias que impliquem naqueles dados podem ser construídas; para todo conjunto de pontos experimentais sobre um gráfico, qualquer número de curvas pode ser desenhado sobre eles.

15. As teorias são imunes à contraprova ou falsificação empírica porque é sempre possível fazer ajustes para acomodar a evidência discordante; não há experimentos cruciais na ciência.

16. A construção de conceitos e significados pode ser acelerada pela interação social, mas ela é um processo essencialmente individual.

\footnotetext{
${ }^{26}$ Na redação de Matthews, consta: "Theories are always underdetermined by empirical evidence, no matter how much such evidence is accumulated" (1994, p. 140).
} 
17. Os elementos da linguagem (ideias, conceitos, palavras e significados) não podem ser transferidos de um usuário a outro.

18. Mesmo com interação social, os conceitos, ideias e significados precisam ser subtraídos da experiência individual.

Estes princípios nos são, por ora, suficientes para clarificar nossas ideias a respeito do que seria a perspectiva construtivista afinal. Deve-se ter claro que estas afirmações de 1 a 18 constituem enunciados mais ou menos típicos das teorias que se apresentam sob o rótulo de construtivistas. Alguns deles se adéquam mais, por exemplo, às propostas inseridas no quadrante social-relativista da Figura 5; outros são tomados menos seriamente por elas.

Assim caracterizado o construtivismo, vejamos, nas próximas subseções, as críticas que podemos fazer a esta perspectiva, que partirão de três frentes: a primeira, de aspecto "metodológico", analisando o modo como resultados do âmbito da psicologia são apressadamente transpostos para a realidade escolar por esta corrente; a segunda, de aspecto "gnosiológico", tratando do relativismo inerente a toda vertente construtivista; e a terceira, de aspecto "político", retomando alguns argumentos anteriores e estabelecendo uma ligação com as considerações do capítulo anterior.

\subsubsection{Do psicológico ao pedagógico: um entusiasmo imprudente}

Já vimos que Herbart, na busca por um fundamento racional para sua proposta pedagógica, recorrera aos conhecimentos da psicologia por considerá-la como uma espécie de física da psique. E por aquelas páginas, diante da frequente associação de uma dada autoridade do campo psicológico a cada tendência psicológica - Skinner à tendência tecnicista, Rogers à humanista, Dewey ao escolanovismo - perguntamos: Afinal, pode haver uma pedagogia sem uma psicologia que lhe dê suporte?

A importância que estamos conferindo à Psicologia Histórico-Cultural, neste capítulo, já explicita que nossa resposta a esta questão é NÃO. Não é possível que uma pedagogia considerando que seja uma pedagogia séria, consistente, com a pretensão de se inserir nos estabelecimentos educacionais reais mundo afora - prescinda dos conhecimentos psicológicos. 
Se a psicologia, no entanto, compõe um corpo de conhecimentos necessários de se levar em consideração na proposta de uma pedagogia, por outro lado, não se tratam de conhecimentos suficientes para a consecução desta finalidade. A pedagogia não se reduz à psicologia, falando mais diretamente. E eis que surge daí uma primeira dificuldade que compromete a consistência do construtivismo enquanto doutrina que se pretende científica e racional: seu entusiasmo apressado e, portanto, imprudente em extrair diretamente da ciência psicológica os elementos para sua concepção do ato educativo.

Expliquemos. Os princípios 1 a 18, elencados há pouco, considerados como orientadores das diversas concepções construtivistas sobre aprendizagem e conhecimento, inspiram-se, indiscutivelmente, nos trabalhos do biólogo e psicólogo suíço Jean Piaget (18961980). Sua epistemologia genética investigou desde a elaboração, pelas crianças, de noções como as de tempo, espaço, causalidade e número, até a formação dos juízos morais, investigações estas que foram continuadas por demais pesquisadores da chamada Escola de Genebra, e mais tarde por estudiosos de todo o mundo. Para Carvalho,

poderíamos [...] caracterizar o discurso educacional construtivista - distinguindo-o da linha de pesquisa empírica em psicologia - como um esforço no sentido da transposição e aplicação, para o âmbito escolar, de certos resultados das investigações de Piaget, de seus colaboradores e de outros pesquisadores, nos quais se apresentam as conseqüências ou implicações educacionais de conceitos gerais extraídos dessas pesquisas. Assim, os resultados de pesquisas sobre o desenvolvimento cognitivo - em seus aspectos gerais ou em um campo específico são, muitas vezes, tomados como pontos de referência e fontes de inspiração para orientação da ação educativa, transformando-se em matrizes conceituais de um discurso educacional - inclusive com funções prescritivas e programáticas alheias ao discurso psicológico da qual se originaram (2001, p. 45, grifos do autor).

É verdade que nenhuma destas investigações foi planejada e executada para compreender o contexto escolar ou prescrever uma linha de ação aos sujeitos do processo educativo formal. No entanto, graças a comentaristas, e mesmo a certas declarações desses estudiosos - incluindo o próprio Piaget, mediante algumas de suas obras como Psicologia e pedagogia e Para onde vai a educação? - originou-se este "discurso educacional construtivista" a que Carvalho se refere. E como a transcrição acima deixa explícito, a principal crítica desse autor ao construtivismo se refere ao esquecimento, por parte desta concepção, da especificidade da escola e dos sujeitos nela dispostos e atuantes ${ }^{27}$. Eis algumas de suas declarações a respeito desse aspecto:

\footnotetext{
${ }^{27}$ Não à toa, a obra de Carvalho se chama Construtivismo: uma pedagogia esquecida da escola.
} 
os problemas educacionais têm especificidades cujo equacionamento exige muito mais do que uma visão geral de mundo. Há certas características das instituições e dos problemas educacionais cuja compreensão não pode ser lograda por simples analogias ou transposições de conceitos de uma área a outra (ibidem, p. 20).

há aspectos fundamentais da compreensão e das tomadas de posição em face das ações educacionais - como as escolhas de formas de ensino, as opções curriculares e as opções de sistemas de avaliação e promoção, por exemplo -, que exigem reflexão e justificativa no âmbito valorativo específico do contexto escolar e das políticas e dos valores educacionais em que eles se inserem. Estão, assim, sujeitos a critérios de aceitação ou rejeição próprios a esse tipo de discurso, que não se reduzem à apresentação de dados empíricos, nem à simples transposição e adaptação de conceitos oriundos de doutrinas filosóficas gerais ou investigações científicas elaboradas a partir de perspectivas exteriores ao contexto escolar (ibidem, p. 26-27).

\title{
Carvalho dirá ainda que o modo como o construtivismo se esquece da especificidade do espaço escolar o faz incorrer num erro resultante de uma abstração. Vale a pena transcrevermos mais alguns fragmentos, apesar de longos:
}

\begin{abstract}
Ainda que as pesquisas psicológicas se debrucem sobre questões relativas ao desenvolvimento cognitivo e à aprendizagem, quando o fazem a partir de perspectivas e interesses psicológicos gerais, elas incidem sobre esses aspectos em contextos não-escolares. É evidente que, em Piaget e em outros psicólogos do desenvolvimento, as questões relativas aos processos de desenvolvimento cognitivo, à inteligência e mesmo à aprendizagem são colocadas em abstração das instituições escolares. Não lhes interessa, em geral, a aprendizagem de capacidades, valores ou fatos tipicamente ligados à cultura escolar nem à sua aprendizagem como fruto específico da exposição a essas instituições. Ao contrário, o que se busca em tais pesquisas ou teorias são grandes traços gerais desses aspectos. Assim, o domínio do cognitivo e da aprendizagem - objeto dessas teorias - é abordado em seu desenvolvimento no indivíduo e em caráter genérico, de acordo com o propósito dessas investigações (ibidem, p. 34-35, grifo nosso).
\end{abstract}

\section{E arremata com a seguinte colocação:}

procede-se nesses discursos pedagógicos como se fosse possível compreender o aluno pela simples transposição ou adição de descrições de um sujeito psicológico ou epistêmico; enfim, de referenciais que perdem a sua concretude se abstraídos das redes conceituais e dos interesses descritivos a partir dos quais foram elaborados. É evidente que todos esses esforços intelectuais nos fornecem conhecimentos sobre um ser que, entre outras características e relações, pertence a uma instituição escolar. Alguns desses conhecimentos podem ser de maior ou menor importância para suas atividades e condutas nessa instituição. Não obstante, é preciso ressaltar que a especificidade de sua condição de aluno não pode ser reduzida a nenhum desses aspectos, nem tampouco sua compreensão ser lograda através da simples adição de várias perspectivas, sem levar em consideração o contexto social em que ele, como criança, se constitui como aluno, um novo ser, com novas relações sociais (ibidem, p. 35, grifos do autor).

Estas considerações nos remetem ao fragmento de Saviani apresentado no final do capítulo passado, aquele em que se defende a proposta de uma pedagogia concreta, isto é, que 
compreenda os estudantes como "síntese de múltiplas determinações", ao contrário do entendimento abstrato de aluno encampado pela pedagogia tradicional, e da pedagogia nova, centrada na existência empírica e imediata de um aprendiz alienado das relações sociais.

Não se trata, também, da posição de um único estudioso. Matthews (1994) afirma algo muito semelhante:

[há] um problema com o construtivismo: ele frequentemente deseja ir além de si mesmo. Ele se utiliza de afirmações sobre aprendizagem e psicologia do desenvolvimento (o núcleo original do construtivismo) para estabelecer posições educacionais e sociais mais amplas. O currículo, por exemplo, não decorre simplesmente de uma teoria da aprendizagem. Uma teoria da aprendizagem pode indicar como algo pode ser ensinado, mas o quê e quanto deve ser ensinado para quem, isto se estabelece a partir de considerações diferentes ou adicionais. Entre elas estariam os juízos sobre as necessidades sociais e pessoais, sobre a importância dos diferentes domínios do conhecimento e da experiência e, finalmente, aqueles devidos a decisões políticas (p. 145, grifos do autor, tradução nossa).

O perigo dessa posição construtivista está em se tomar como verdadeiras certas afirmações que apenas parecem óbvias, mas que num exame mais detido se mostram fragilmente assentadas em fatos. Um exemplo é a comum associação, por parte dos construtivistas, entre o ensino por transmissão, característica da escola tradicional, e o autoritarismo. Ora, "Não há nenhuma conexão automática entre o modelo de educação por transmissão e a pedagogia alienante e autoritária", afirma novamente Matthews (2000, p. 287). Também muitos termos do ideário construtivista se mostram por demais vagos, abrangentes e esquivos às definições: frequentemente se fala em "desenvolver todas as potencialidades de cada criança", "métodos ativos", "ação espontânea” etc. Ao longo de seu livro, Carvalho (2001) cuida de questionar estas e outras expressões: sobre as potencialidades da criança, citando Scheffler (1978), lembra-se que nem todas elas podem ser desenvolvidas, já que umas podem inibir outras, ou contradizê-las; quanto aos métodos ativos, mesmo a aula expositiva poderia ser assim considerada, caso propusesse aos alunos a execução de "operações" reflexivas, na terminologia de Piaget; e o grau de espontaneidade de uma ação é um critério difícil de ser julgado, já que não se pode determinar se um dado interesse infantil teria sido um resultado puramente intelectual, reflexivo, ou se foi suscitado por fatores externos, como a mídia, seja de modo consciente ou inconsciente. El-Hani e Bizzo (2002) dirão que "as teses nucleares do construtivismo são tão genéricas que se mostram consistentes com uma diversidade de abordagens pedagógicas" (p. 7), tendo afirmado, algumas páginas antes, que 
O construtivismo tem-se valido, na esfera educacional, de "slogans" dos quais é difícil discordar, mas que, com o tempo passaram a ter entendimento cada vez mais literal, até esvaziarem-se de significado. Por exemplo, o slogan de que "o professor deve trabalhar a partir dos interesses dos alunos" encerra, em si, muita ambiguidade e pode acabar sendo entendido, como de fato já o foi em diversos contextos, como uma certa forma de premonição sobre o papel dos alunos no próprio planejamento das atividades de sala de aula (p. 4).

Antes de encerrarmos esta subseção, queremos falar de duas contradições de caráter lógico, que também consideramos redundar em erros metodológicos, ambas decorrentes de uma investida apressada e imprudente do construtivismo na esfera educacional.

A primeira se refere à postura construtivista de estabelecer uma separação entre o aspecto psicossocial e o aspecto espontâneo do desenvolvimento intelectual. Piaget (1978) afirma que o primeiro se refere aos aprendizados por transmissão familiar, escolar, "educativa em geral"; o segundo, que seria o desenvolvimento da inteligência propriamente dita, se trata do que a criança aprende por ela mesma. Logo após esta definição o psicólogo suíço demarca o âmbito de suas considerações:

é sobre o aspecto espontâneo da inteligência que estudarei, sendo o único do qual falarei, porque sou psicólogo e não educador; e também, porque do ponto de vista da ação do tempo, é precisamente esse desenvolvimento espontâneo que constitui a condição preliminar evidente e necessária para o desenvolvimento escolar, por exemplo (p. 212).

Já havíamos assinalado, em outro trabalho ${ }^{28}$, que Piaget (1972), tratando dos métodos ativos, afirma que estes não podem limitar as situações de ensino e aprendizagem apenas à manipulação de objetos por parte dos estudantes. Para ele, no entanto, mesmo nestas manipulações podem ser extraídas noções lógico-matemáticas elementares, através das ações dos sujeitos e de suas coordenações. Muitos outros fragmentos semelhantes poderiam ser aqui reunidos, consultando-se a vasta obra piagetiana. Esta pequena amostra é suficiente para ilustrar a maneira construtivista de se encarar os objetivos educacionais: trata-se de incentivar que os educandos se tornem cada vez menos dependentes dos adultos e que possam, por sua livre atividade, interagir com o ambiente para, através de processos de abstração - "abstração empírica" e "abstração reflexiva", nos termos do próprio Piaget - progredir até o chamado "período das operações formais", em que serão capazes de... raciocinar em termos abstratos. Ou seja, para "funcionar", o construtivismo supõe que o estudante detenha, desde o início de

\footnotetext{
${ }^{28}$ Texto encaminhado para o VIII Encontro Nacional de Pesquisa em Educação em Ciências, realizado em 2011 em Campinas (SP). O trabalho foi aceito para a comunicação oral e consta nos anais do evento (SOUZA et al., 2012).
} 
uma dada situação educacional, certas habilidades que viriam a se consolidar apenas ao final do desenvolvimento do sujeito. Matthews (1994) transcreve as seguintes palavras de Suchting, crítico do construtivismo de Glasersfeld, sobre este paradoxo:

as teorias da abstração em geral são essencialmente circulares, porque o alegado processo de abstração pressupõe o conceito que seria formado como um resultado deste processo. Por exemplo, se devo aprender o significado de "vermelho" pela "abstração" da propriedade "vermelhidão" [redness] de vários itens que são desta cor, presume-se que eu já consiga organizar uma classe de coisas "vermelhas" das quais a abstração precisa ser feita. Mas isto claramente assume que já sou competente em distinguir coisas vermelhas de outras coisas (SUCHTING, 1992, p. 239-240, grifos do autor, tradução nossa).

A outra inconsistência lógica do construtivismo se refere a seu desprezo pela teorização ou, no mínimo, a desconfiança para com o valor de verdade de uma dada teoria, valor este que se submete, na perspectiva construtivista, antes a critérios pragmáticos que epistemológicos:

Impõe-se aos construtivistas um "dilema da evidência": eles desejam recorrer à natureza das realidades cognitivas (os processos de aprendizagem) e das realidades epistemológicas [...] para fundamentar suas propostas epistemológicas, curriculares e pedagógicas; porém, simultaneamente afirmam que tal realidade não pode ser conhecida e, para alguns, ela nem mesmo existe (MATTHEWS, 2000, p. 280).

O paradoxo resultante deste tipo de visão é evidente. Como pode o construtivismo se apresentar como uma perspectiva cientificamente fundamentada para orientar o ato educativo, se ele concebe a ciência como uma série de "construções" a respeito de uma realidade que não se deixa captar pelo pensamento, pela teorização; uma realidade que permanece refém das experiências - isoladas, individualistas, fragmentárias - de cada sujeito cognoscente?

É claro que podemos, ao propor tais questionamentos, sermos acusados pelos partidários do construtivismo de interpretá-lo de modo distorcido, antipático e insensível. Bastaria objetarmos que, do próprio ponto de vista construtivista, nossa interpretação é tão legítima quanto qualquer outra, visto ser uma construção pessoal, à luz de nossos referenciais (“estruturas conceituais prévias"), adequada às finalidades a que se propõe (eis o critério pragmático, novamente), não sendo relevante, portanto, se ater a seu nível de correspondência com a realidade - se é que existiria uma realidade independente de nossas observações.

Isto nos leva ao segundo aspecto ao qual endereçaremos uma crítica a tal concepção: sua visão gnosiológica relativista. 


\subsubsection{A escola não pode fomentar o relativismo}

Um dos slogans construtivistas mais conhecidos é aquele de que "a criança (ou o aluno) constrói seu próprio conhecimento". Para Carvalho (2001), embora nem esta sentença, nem o próprio termo "construtivismo" tenham origens nos textos de Piaget, é inegável que ela, de modo sintético e aparentemente claro, apresenta "uma de suas [de Piaget] principais imagens descritivas do processo de desenvolvimento do conhecimento e das estruturas cognitivas do sujeito" (p. 101). Carvalho, no mesmo trabalho, faz uma análise detida deste slogan e propõe o exercício de nele "substituir por conteúdos e objetivos escolares canônicos a expressão abstrata 'conhecimento"”:

\footnotetext{
Qual poderia ser, por exemplo, o significado das frases "a criança constrói seu próprio conceito de comutatividade", ou "fala sua própria língua", ou "desenvolve seus próprios padrões de conduta moral"? Em todos esses casos, é evidente que temos em mente padrões sociais de significação, uso, procedimentos e valores em que um aluno se inicia e a partir dos quais julgamos a adequação de seu desempenho pessoal no uso de um conceito ou na escolha de um procedimento. Em outras palavras, em todos esses casos, temos em mente tradições públicas - e não construções de representações mentais individuais - nas quais um aluno deve ser iniciado a fim de que possamos dizer que ele tem domínio de uma determinada área de conhecimento (p. 113, grifos do autor).
}

Fazer com que o objetivo do ensino seja a "construção própria" de certas noções e conteúdos é um dos principais - e com consequências mais graves - corolários da postura relativista adotada pelo construtivismo. Sobre isto, Matthews (2000) se questiona: "se o conhecimento não pode ser comunicado, se o conhecimento é uma questão de construção pessoal, então como as crianças podem alcançar o conhecimento de esquemas conceituais complexos que demoraram centenas de anos para serem construídos?” (p. 286). Explicitando as diferenças entre conceitos científicos e o senso comum - como noções abstratas de velocidade, aceleração, força e gene; ou elementos distantes da experiência cotidiana dos alunos, como proposições sobre a estrutura atômica, processos celulares e eventos astronômicos -, Matthews afirma algo semelhante ao fragmento que transcrevemos de Carvalho, acima:

Os conceitos científicos são construções históricas e sociais, eles são definidos; e definições não são descobertas ou construídas. Os alunos não descobrem, muito menos constroem, o que significa momento, potência, aceleração, valência, força, massa, peso, oxidação e assim por diante; eles aprendem o que estes termos significam. Eles podem aprender mais ou menos satisfatoriamente a depender de seu 
preparo e de os conceitos serem bem, ou mal, apresentados; e eles têm que se esforçar em sua aprendizagem. Mas isto tudo fica bem distante da idéia de os alunos construírem suas próprias definições de conceitos científicos e, há anos-luz de distância da possibilidade de os alunos serem árbitros da verdade, ou de grupos de alunos negociarem verdades (ibidem p. 287, grifos do autor).

Matthews fala também de uma confusão, por parte dos construtivistas, entre o que seriam objetos teóricos e objetos reais, confusão esta que seria um dos elementos constituintes da postura relativista que, como se subentende do comentário que fizemos a respeito da Figura 5, está sempre presente em qualquer tendência construtivista, já que um construtivismo totalmente objetivista seria uma contradição em termos. Vejamos sua argumentação, que parte da constatação do construtivista Wheatley de que "os objetos não se encontram por aí, mundo afora, de forma pronta, mas são constructos [ou construções] mentais":

\begin{abstract}
Wheatley está parcialmente correto quando afirma que os objetos da ciência não estão simplesmente "por aí". Onde ele, e a maior parte dos construtivistas, em companhia de Aristóteles e os empiristas, erram, está em não distinguir os objetos teóricos da ciência, que realmente não estão por aí, dos objetos reais da ciência, que estão sim por aí e caem sobre nossas cabeças. A queda de uma maçã real é representada na física como uma massa pontual incolor e como uma variável em uma equação, e é sobre este objeto, a equação, que a física opera, não na maçã caindo. [...] É importante lembrar que o objeto teórico, uma vez produzido, adquire realidade, apesar de não estar exatamente situado "por aí". [...] A mecânica de Newton, a teoria evolucionária de Darwin e a genética de Mendel, todas elas existem e podem afetar e ser apreendidas por pensadores posteriores. Mas elas não se confundem com maçãs em queda, tartarugas de Galápagos ou plantações de ervilhas; nem devem ser confundidas com os processos de pensamento que ocorreram nas cabeças de Newton, Darwin e Mendel. A cabeça de Newton estava repleta de toda sorte de pensamentos que iam e vinham - alguns claros, outros menos claros. Estes pensamentos não poderiam ser tachados de verdadeiros ou falsos; os conteúdos destes pensamentos, conforme expressos em proposições ou afirmações, é que são verdadeiros ou falsos (idem, 1994, p. 152, tradução nossa).
\end{abstract}

É verdade que, por serem construções sociais e históricas, as teorias científicas estão sujeitas a questionamentos. A "nova filosofia da ciência", desde que redescobriu a obra fundamental de Karl Popper A lógica da descoberta científica, já nos anos 1960, tratou de pôr abaixo o dogma de que a ciência constituiria um conjunto de proposições imutáveis e eternas, como se, através de seus procedimentos, fosse possível a elaboração de um mapa exato da realidade. No entanto, não é correto afirmar que o conhecimento científico, por ser falível, não possa ser tomado como uma referência para a exploração do real. O grau de avanço científico-tecnológico que nossa sociedade atingiu é a prova eloquente do poder do homem sobre a natureza, poder proporcionado justamente por estes conhecimentos. Cabe aqui fazer uma breve digressão, trazendo novamente para nosso diálogo um autor marxista. Henri 
Lefebvre, por exemplo, não nega a relatividade do conhecimento científico, mas propõe que ela seja examinada de modo dialético:

O pensamento não-dialético oscila entre o dogmatismo, que afirma a verdade absoluta, e a negação igualmente absoluta dessa verdade, sob o nome de "ceticismo" ou "relativismo". [...]

[Pelo contrário,] O relativismo dialético admite a relatividade de nossos conhecimentos, não no sentido de uma negação da verdade objetiva, mas no sentido de uma perpétua superação dos limites de nosso conhecimento.

Assim como não existe separação absoluta entre a verdade e o erro, tampouco existe linha de demarcação entre a verdade absoluta e a verdade relativa. Cada etapa do desenvolvimento do conhecimento traz consigo novos grãos, e "grãos" de uma verdade cada vez mais aguçada e precisa, mais extensa, para essa colheita de verdades. Cada verdade atingida é relativa; mas o conjunto das verdades atingidas e determinadas como relativas faz parte do conhecimento objetivo absoluto. [...] Uma verdade científica, portanto, é relativa num sentido; é destinada a transformarse, a aparecer sob novos aspectos, a ser superada por leis ou teorias mais precisas, de maior aproximação.

Mas, em certo sentido, é absoluta. Superação não significa supressão. Essa verdade subsistirá em seu lugar, em seu grau de objetividade e de precisão, em certa escala. No plano do conhecimento, o que precede encontra sua verdade naquilo que se segue. [...]

Portanto, uma mesma verdade é - ao mesmo tempo - relativa e absoluta (LEFEBRVE, 1983, p. 97-99, grifos do autor).

Negar a possibilidade de se transmitir conhecimentos, em proveito de uma hipotética construção pessoal, supondo-se que a verdade é sempre relativa, é algo no mínimo desprovido de sentido. Ou, como dizem Laburú e Silva (2000, p. 133, grifos nossos):

a asserção que afirma que o conhecimento não pode ser transferido ou transmitido vai de encontro ao bom senso; é incontestável que os pais instruem as crianças numa série enorme de assuntos, os professores, em matérias complexas como matemática, ciências e história. Quem de nós não leu um bom livro e constatou que aprendeu muito com as idéias novas transmitidas pela linguagem escrita do autor. Também é fácil verificar que quase a totalidade da comunicação e troca de informação interpessoal do dia a dia se dá via transmissão verbal direta, sem que exista nenhuma técnica construtivista por detrás. Além do mais, sabemos que a maior parte da tradição científica é passada de mão em mão e não reinventada por cada geração. Como poderia qualquer aprendiz reinventar conceitos e conhecimentos quando as melhores e as mais privilegiadas cabeças da história levaram anos ou séculos para elaborá-los? O legado construtivista, indicando que a transferência de significado através da linguagem não implica que se possa aprender tudo o que é ensinado, é inegável. Mas, aí em dizer que significados não são passíveis de transferência, de que eu não posso fornecer às pessoas, numa audiência, qualquer novo conceito, mas apenas estimá-los [estimulá-los?] a combinar de diferentes maneiras os conceitos com as palavras que eu estou usando, é afrontar as evidências.

Não obstante estas óbvias incoerências, persiste no discurso construtivista a ideia de que, por seu caráter relativo, o conhecimento científico não pode ser considerado como superior a outras formas de conhecimento. Esta posição, em si mesma, e apesar nos opormos 
a ela em muitos aspectos, não é problemática. Ela passa a ser questionável se utilizada para justificar que a escola renuncie a sua função de socializadora do saber elaborado, vindo a colaborar para que outras modalidades de conhecimento, como as crendices, as meras opiniões, a religião - o senso comum em geral - sejam legitimados, equiparados e até elevados a uma posição superior em relação à cultura elaborada. Na literatura brasileira sobre Educação em Ciências abundam as pesquisas que vêm adotando esta perspectiva.

Um exemplo é o trabalho de Baptista (2010), que busca apresentar a importância de uma "demarcação de saberes" no ensino de ciências para sociedades ditas "tradicionais" - por exemplo, comunidades indígenas e populações rurais. A autora parte do pressuposto de que, por serem as salas de aula espaços "multiculturais", os professores de ciências necessitam "estarem atentos às diversas concepções prévias dos estudantes, para que possam direcionar suas aulas às necessidades destes indivíduos e das sociedades onde vivem” (p. 680). Nos termos a que já recorremos, trata-se novamente do primado do aluno empírico, que possui interesses e necessidades próprios, visto de forma isolada das relações sociais que condicionam estes mesmos interesses e necessidades. Além disso, transparece neste discurso a seguinte incoerência da postura relativista, apontada por Carvalho:

\footnotetext{
é muito pouco provável que em uma sala de aula composta por dezenas de alunos provenientes de meios sociais e culturais diversos, haja uma grande variedade de interesses extra-escolares comuns. Caso existam, é igualmente pouco provável que o professor seja capaz de sempre aproveitá-los em atividades ou conteúdos relevantes do ponto de vista escolar (2001, p. 101).
}

Mas prossigamos. A autora considera ainda que a abordagem das ciências nas salas de aula das escolas urbanas, quando estas recebem estudantes vindos de sociedades tradicionais, pode conduzir estes alunos "a conflitos entre as explicações científicas e as explicações oriundas dos seus meios socioculturais" (p. 681). De fato, é isto o que ocorre, e com todos os alunos - ou o que deveria acontecer em uma instituição chamada escola, que possui justamente este papel. Logo depois (na mesma página), citando autores construtivistas como Cobern, Baptista propõe que "nas salas de aula cujos saberes culturais dos estudantes são diferentes dos saberes científicos, é importante que o objetivo de ensinar ciências seja a demarcação, e não a anulação dos saberes", já que o que se deseja é que "os estudantes compreendam os conceitos científicos, ou seja, dominem esses conceitos, em vez de tê-los como válidos ou verdadeiros em suas vidas". Ora, seria muito difícil encontrar uma sala de aula em que os saberes dos estudantes fossem idênticos aos saberes científicos. E indo além de enunciar uma obviedade, a autora, mui "construtivistamente", sugere que os estudantes 
simplesmente possam "compreender" os conceitos científicos sem perspectivas de que sejam "válidos ou verdadeiros". Matthews, novamente, nos traz palavras que se chocam a este visão:

Se certas formas particulares de pensamento virão a constituir conhecimento de fato, não é uma decisão de âmbito individual; ou se assim se decide, é em confronto com um padrão público [public standard]. Os professores é que fazem a mediação entre os estudantes e este padrão público. Ausentes tais critérios públicos, a palavra "conhecimento" é reduzível a "crença". O que constitui conhecimento e o que torna algo conhecimento são questões de grande importância epistemológica e política. Em uma visão de conhecimento complacente [facile], pessoal, construtivista, estas questões se evaporam. (1994, p. 159-160, tradução nossa).

Mas Baptista não reconhece isto. Parece-nos que a autora enxerga como uma mácula o fato do conhecimento científico ter origens "ocidentais" e aspirar a "graus elevados de abstração"; já aos conhecimentos tradicionais caberiam todas as virtudes, por serem "guiados por critérios de validade locais, podendo sofrer variações regionais e culturais, e fortemente vinculadas aos contextos nos quais foram produzidas" (p. 683, grifo nosso). Para ela, "é lamentável o fato de que as realidades das escolas para as sociedades tradicionais ainda insistem na transmissão de conhecimentos científicos como se fossem os únicos conhecimentos válidos" (p. 685). E logo abaixo, após tachar tal ensino de "cientificista", a autora parte para conclusões que, no mínimo, mereceriam uma investigação mais detida, antes de serem afirmadas tão peremptoriamente:

Na prática pedagógica [...] o que acontece é que, quando a cultura da ciência que está sendo ensinada se harmoniza com a cultura dos estudantes, as visões de mundo desses indivíduos são consideradas. Ao contrário, quando a cultura dos estudantes é incompatível com a cultura da ciência, o ensino tende a não aceitar as visões de mundo dos estudantes, forçando-os a rejeitarem os seus pensamentos. Como consequência disto, os estudantes terminam por não compreenderem a natureza do conhecimento científico, sendo levados a crer que a ciência é propriedade de alguns sábios, ao invés de um produto passível de revisão social.

Novamente citando Cobern, a autora encerra suas considerações de modo triunfante:

A ciência é uma herança cultural que pertence a todos os povos, mas não é o único constituinte dessa herança e nem está colocada no topo de uma suposta pirâmide epistemológica, que inferioriza todos os demais sistemas de saberes forçando-os a uma tentativa de homogeneização cultural [...] (p. 685-686).

As ideias de Baptista não são novas, ecoando textos anteriores, como o de El-Hani e Bizzo (2002), já citado aqui. Nele os autores afirmam, de modo mais ponderado, que "O reconhecimento e a explicitação de domínios particulares do discurso nos quais as concepções 
científicas e as idéias dos alunos têm, cada qual no seu contexto, alcance e validade" (p. 20) parece uma estratégia "mais adequada" para a educação científica. De toda forma, trata-se de uma visão questionável. Afinal, os "conhecimentos tradicionais" possuem espaços específicos para sua transmissão - como o espaço das relações familiares e os espaços de caráter religioso -, em que podem ser livremente defendidos, justificados, analisados e, afinal, aplicados. Já à escola, cabe uma tarefa inteiramente diferente. Como dirá Carvalho,

Trata-se [...] de ressaltar a peculiaridade da tarefa educacional em instituições escolares, que é a de desenvolver no aluno capacidades como, por exemplo, a do espírito crítico, mas através de procedimentos e áreas de conhecimento que lhe são peculiares. Assim definida, a tarefa educacional, vista a partir de uma perspectiva escolar, não se resume a buscar o desenvolvimento individual, como sugerem as perspectivas fundadas em psicologias do desenvolvimento [como o construtivismo, por exemplo], mas procura levar a cabo a iniciação dos jovens nessas tradições públicas [...] consideradas por uma determinada sociedade como valiosas e merecedoras de preservação e continuidade (2001, p. 67, grifos nossos).

Descurar desse aspecto é ignorar a tarefa legada à instituição escolar, desrespeitando os trabalhadores que atuam neste espaço (e que investiram anos de suas vidas buscando uma formação específica para seu exercício profissional) e destituindo-os da importância que a sociedade confere - ou deveria conferir - a sua missão. E se é inegável que há tradições populares merecedoras de serem transmitidas às novas gerações, é igualmente incontestável que o conhecimento erudito mereça um espaço apropriado e o cuidado de profissionais especificamente habilitados para sua devida socialização. A postura relativista que equipara o conhecimento científico (episteme) à sabedoria (sofia) ou à crença/opinião (doxa) esquece que a ciência se reporta a escrutínios públicos, visando à abrangência, à apreensão da totalidade e a uma visão coerente de vida e de mundo. Ao apropriar-se do conhecimento científico, um indivíduo se apropria também de toda uma experiência histórica da humanidade, desenrolada em séculos de avanços, retrocessos e rupturas, experiência esta que, não obstante todas as limitações que se possam atribuir à ciência, ainda assim necessita ser apreendida como parte dos requisitos para uma efetiva participação na sociedade contemporânea. A escola que fomenta o relativismo, mesmo que objetivando o respeito à diversidade dos contextos culturais de onde provêm os alunos, acaba mesmo levando ao culto das experiências fragmentadas, desconectas, fugazes; em última análise, realiza um verdadeiro "fetichismo da individualidade", como diria Newton Duarte. Em um de seus textos (DUARTE, 2010b), este educador reforça os argumentos de Saviani, apresentados no capítulo anterior, contrários à existência de uma cultura - ou arte, ou ciência - inerentemente burguesa ou colonizadora, que 
é justamente um dos pressupostos que os defensores do relativismo cultural evocam para justificar a valorização dos conhecimentos populares locais no espaço escolar. Duarte afirma também que esta posição, contrária à universalização da ciência e da arte pela escola, carrega consigo um preconceito e uma romantização:

\begin{abstract}
O preconceito é o de que a classe trabalhadora não saberia conferir novo significado ao conhecimento adquirido. Curiosamente, os defensores de tal tipo de argumento são, normalmente, os primeiros a louvar a criatividade da cultura popular e o potencial que tem de "ressignificar" ideias, práticas, crenças, rituais etc. A idealização romântica está na própria ideia de que existe um cotidiano no qual a cultura popular existe sem a intervenção colonizadora da cultura burguesa. É curioso que relativistas culturais argumentam contra a distinção entre alta cultura e cultura de massas, não se cansem de valorizar os fenômenos da cultura popular e não considerem um problema a influência marcante exercida pelos meios de comunicação de massa sobre essa cultura, mas, quando se trata de transmissão do conhecimento científico pela escola, não revelem a mesma confiança na criatividade e capacidade de "ressignificação" por parte do povo (ibidem, p. 114).
\end{abstract}

\title{
2.1.3 O velho sob a roupagem do novo
}

Atentemo-nos a um detalhe presente no quadro da Figura 1 que até o momento não fora comentado: o fato de Libâneo, em sua tipologia das tendências pedagógicas, incluir Piaget como um dos representantes da tendência liberal renovada progressivista, isto é, a pedagogia nova. Daí poderíamos inferir, portanto, que o construtivismo guardaria semelhanças com o escolanovismo. Mas será isto justo e legítimo?

Temos razões suficientes para acreditar que sim. Primeiramente, porque o próprio Piaget não parecia opor suas concepções, quando ousava falar sobre o âmbito especificamente educacional, às dos proponentes dos "métodos novos". Isto fica especialmente claro na exposição do autor, sobre estes métodos, em Psicologia e pedagogia (PIAGET, 1972). E em segundo lugar porque o construtivismo, para se firmar como concepção hegemônica no ideário educacional contemporâneo, acabou por recorrer a expedientes idênticos àqueles mobilizados pelo escolanovismo, desde Dewey e Decroly, para afrontar a pedagogia tradicional.

Por exemplo, vimos, no decorrer das subseções anteriores, o modo como autores construtivistas falam a favor da fundamentação científica de seus métodos, sem se atentar para o caráter pseudocientífico deles; ou sua defesa intransigente da democracia, inclusive dentro do espaço escolar, ignorando que este posicionamento reflete uma simplificação da 
ideia de democracia que é, aliás, ela própria estranha à constituição e à função especificamente pedagógica da escola ${ }^{29}$. Qualquer semelhança com as teses enunciadas por Saviani em Escola e democracia, e dirigidas à crítica ao escolanovismo enquanto pedagogia da existência, não é mera coincidência.

Newton Duarte vai mais longe: não apenas a pedagogia nova e o construtivismo se referem a concepções semelhantes, como, junto de outras tendências (a pedagogia das competências, a pedagogia dos projetos, a pedagogia do professor reflexivo ou da epistemologia da prática docente) se tratam de versões de uma ampla e heterogênea corrente pedagógica, a que nomeia como pedagogias do aprender a aprender (DUARTE, 2006, 2008). Ao tratar do "aprender a aprender" como lema orientador destas pedagogias, Duarte procura mostrar que ele

\begin{abstract}
não se limita a defender o papel ativo do alunos nos processos educativos escolares. Se assim fosse não haveria o que objetar ao mesmo. Afinal, quem se pronunciaria contrariamente a esse papel ativo, isto é, quem sairia em defesa de uma pedagogia que propugnasse a passividade do aluno? Também o lema "aprender a aprender" não se limita a defender que a educação escolar deve desenvolver nos alunos a autonomia intelectual e o interesse inesgotável pela aquisição de novos conhecimentos. Quem defenderia uma pedagogia que tivesse por objetivo formar indivíduos incapazes de buscarem novos conhecimentos por sua própria iniciativa? [...] O ocorre que o lema "aprender a aprender" sintetiza uma concepção pedagógica que vai muito além da defesa do caráter ativo do aluno ou da formação da autonomia intelectual (idem, 2008, p. 214-215).
\end{abstract}

Duarte, então, verifica a existência de quatro princípios ou posicionamentos valorativos contidos neste lema (idem, 2006):

1. A aprendizagem que o indivíduo realiza por si mesmo, sem a interferência de outrem, é a mais desejável.

2. É mais importante que o aluno desenvolva um método de aquisição de conhecimentos do que aprenda os conhecimentos descobertos ou elaborados por outras pessoas.

3. Uma atividade verdadeiramente educativa é aquela impulsionada pelos interesses e necessidades do próprio indivíduo que está sendo educado.

\footnotetext{
${ }^{29}$ Carvalho (2001) propõe mais um exercício interessante: e se falássemos do cultivo da democracia não no espaço interno da escola, mas num outro âmbito, por exemplo, o das relações familiares? Talvez concluíssemos que "A igualdade que pais e filhos eventualmente têm como cidadãos não pode ser transferida para o seio da instituição familiar, sob pena de os pais não cumprirem suas responsabilidades" (p. 85-86). Com a escola, portanto, se passaria algo análogo: "a igualdade no plano político democrático não pode ser transposta de modo automático para a escola, sob pena de ela se furtar a cumprir seus papeis fundamentais, inclusive com resultados eventualmente contrários aos ideais de construção da autonomia e da cidadania" (p. 86).
} 
4. A educação deve preparar os indivíduos para que possam acompanhar as mudanças incessantes da sociedade contemporânea.

O primeiro princípio fora também acusado por outros autores, como Carvalho (2001) e Matthews (1994, 2000). Ele se assenta na frágil suposição de que os métodos baseados na transmissão de conteúdos impliquem em alunos passivos, já que não estariam envolvidos em atividades "desequilibradoras", de acordo com o jargão piagetiano. Supõe-se também que a observação e a curiosidade poderiam levar à obtenção de conhecimentos confiáveis. Evidentemente, trata-se da concepção empirista ingênua que os autores construtivistas preservaram da pedagogia tecnicista e sua "aprendizagem por descoberta", justamente uma das tendências pedagógicas à qual se colocaram como opositores.

O princípio seguinte provoca uma cisão entre conteúdo e método, também criticada por estudiosos diversos. Saviani (2008), por exemplo, mostrando a falsidade de algumas dicotomias que supostamente são reforçadas pela Pedagogia Histórico-Crítica, conforme afirmam críticos desta tendência, examina a relação entre saber e consciência. Rebatendo os argumentos de que a pedagogia a que propõe atribui maior importância à aquisição do saber que à formação da consciência crítica, ele assim se manifesta: "Ora, tal objeção pressupõe que é possível desenvolver a consciência à margem do saber. É como se o acesso ao saber pudesse ser feito de forma inconsciente" (p. 78). Mais adiante ele trata desta questão tomando como exemplo o caso do ensino de História:

Se o fundamental é que o aluno aprenda o método, ou seja, como se situar historicamente, como apreender o movimento da história, então se trata aí do método da história. E ele só irá apreender isso através da familiaridade com a história propriamente dita. Logo, com os conteúdos históricos.

Os conteúdos históricos sempre serão importantes e, de certo ângulo, determinantes, porque é pelo caminho deles que se apreende a perspectiva histórica, o modo de situar-se historicamente. De fato, como posso proceder segundo o método histórico fazendo abstração da história? Algo semelhante ocorre com as demais disciplinas (p. 145).

O princípio de número 3 já foi examinado por nós em outras ocasiões. Lembremos que uma pedagogia orientada apenas pelos interesses e necessidades imediatas dos estudantes é uma pedagogia empírica (e não concreta), que negligencia a especificidade da escola e ignora seu papel social.

Finalmente, o quarto e último princípio, de acordo com Duarte (2006), acaba por revelar o verdadeiro núcleo do "aprender a aprender" - a formação da capacidade adaptativa dos indivíduos: 
Quando educadores e psicólogos apresentam o "aprender a aprender" como síntese de uma educação destinada a formar indivíduos criativos, é importante atentar para um detalhe fundamental: essa criatividade não deve ser confundida com busca de transformações radicais na realidade social, busca de superações da sociedade capitalista, mas sim criatividade em termos de capacidade de encontrar novas formas de ação que permitam melhor adaptação aos ditames do processo de produção e reprodução do capital (ibidem, p. 42).

Este princípio também sugere, erroneamente, que são tantas e tão profundas as mudanças se processando nos tempos contemporâneos que os conteúdos clássicos da escola deveriam ser revistos, dando lugar a novos conteúdos que melhor refletissem este vertiginoso movimento.

Transparece como marca do construtivismo - e das demais pedagogias do "aprender a aprender" - a importância da iniciativa livre e individual para a conquista do conhecimento. Facci (2011) elenca algumas consequências deste primado do individualismo: coloca-se a ênfase nos aspectos biológicos e maturacionais do desenvolvimento humano, o meio ambiente atuando como seu "disparador", na medida em que o sujeito interage com objetos que lhe rodeiam e, assim, dá início aos processos de adaptação e equilibração; concebe-se uma ontogênse que recapitula a filogênese, em que a produção individual do conhecimento deve ser análoga à elaboração histórica deste conhecimento pela humanidade; o aspecto social se posta como algo externo ao desenvolvimento, e não como algo que lhe é inerente; o desenvolvimento psicológico atravessa etapas universais e a-históricas, variando de indivíduo para indivíduo apenas quanto ao ritmo e a qualidade das transformações nas estruturas mentais; e fortalece-se uma concepção negativa da escola e, principalmente, do professor, que ou se anula ou se vê reduzido a "animador", “orientador", “organizador", "facilitador", "colaborador".

$\mathrm{O}$ “aprender a aprender" se estabelece a partir do diagnóstico de uma suposta "crise do conhecimento" ou "crise da razão", cujas maneiras como costuma ser apresentada são assim levantadas por Marilena Chauí (1993, p. 22-23 apud DUARTE, 2006, p. 77):

- negação de que haja uma esfera da objetividade. Esta é considerada um mito da razão, em seu lugar surge a figura da subjetividade narcísica desejante;

- negação de que a razão possa propor uma continuidade temporal e captar o sentido imanente da história. O tempo é visto como descontínuo, a história é local e descontínua, desprovida de sentido e necessidade, tecida pela contingência;

- negação de que a razão possa captar núcleos de universalidade no real. A realidade é constituída por diferenças e alteridades, e a universalidade é um mito totalitário da razão;

- negação de que o poder se realiza à distância do social, através de instituições que lhe são próprias e fundadas tanto na lógica da dominação quanto na busca da liberdade. Em seu lugar existem micropoderes invisíveis e capilares que disciplinam o social. 
Eis aí o universo pós-moderno em que florescem as pedagogias do "aprender a aprender". A razão, ideal clássico retomado pelo Iluminismo, passa ser encarada como "mito", dado que seria impossível, a ela, dar conta da diversidade de um mundo veloz, acelerado ainda mais pela rapidez das comunicações e pela sucessão de "discursos". Cria-se a imagem de uma "aldeia global", constituída por ocas isoladas, daí a recorrência de aspectos como descontinuidade e fragmentação, que passam a ser atributos tanto do espaço quanto do tempo. Neste "deserto do real", onde individualidade se converte em individualismo, os interesses públicos e privados se intercambiam: surgem as celebridades instantâneas com seus 15 minutos de fama. Realidade e ficção - ou melhor, "simulacro" - chegam a se (con)fundir. Não se distingue o necessário do contingente e a existência se esvazia de sentido. Vem à tona o absurdo denunciado (cultuado?) pela literatura existencialista, temperado por uma liberdade cruelmente reduzida a mera relação comercial: forma de pagamento. Tudo é efêmero - dos produtos, descartáveis desde a embalagem, até os relacionamentos - e a subjetividade, ao mesmo tempo em que é tida como riqueza maior do indivíduo, se apresenta subtraída de seu sentido histórico e, portanto, de sua responsabilidade perante o mundo. O homem pósmoderno não faz escolhas; deixa que as circunstâncias escolham por ele e conduzam sua vida. Neste cenário, as "grandes narrativas" já não são funcionais; podem ser também descartadas inclusive, pode-se até decretar um "fim da história" - em proveito das narrativas locais, provincianas, descentralizadas.

Daí o pós-modernismo ser a ideologia do modelo neoliberal. Seus valores se ajustam perfeitamente às necessidades do capitalismo contemporâneo, da produção flexível à mundialização dos mercados. No campo da educação, a ideia construtivista de um sujeito que deve ser livre para aprender qualquer conhecimento que deseje/necessite tem seu correspondente econômico no conceito de livre iniciativa. O esvaziamento da escola e a anulação do professor são justificados, de acordo com esta visão, quando se examina atentamente a constituição histórica da instituição escolar e o papel social a que lhe foi atribuído: ela é a instância socializadora da cultura elaborada por excelência, mas esta função não corresponde a uma necessidade do capitalismo, senão em "doses homeopáticas". Daí o construtivismo e as demais pedagogias do "aprender a aprender" terem se tornado hegemônicos no discurso educacional, constituindo a fundamentação teórica de documentos oficiais das instâncias mais locais ao âmbito mundial. (No Brasil, veja-se, por exemplo, o caso dos Parâmetros Curriculares Nacionais - PCN, além das diretrizes curriculares da educação básica e superior). Já mencionamos, no capítulo anterior, que o escolanovismo serviu como 
um mecanismo de recomposição da hegemonia da classe burguesa, dado o desempenho da pedagogia tradicional, disposta revolucionariamente no sentido do movimento histórico, que começou a ameaçar esta hegemonia. Com as pedagogias do "aprender a aprender", e com o construtivismo em especial, o mesmo mecanismo parece ter encontrado uma expressão em forma nova, mas com o mesmo velho conteúdo. Em resumo,

O lema "aprender a aprender", ao contrário de ser um caminho para a superação do problema, isto é, um caminho para uma formação plena dos indivíduos, é um instrumento ideológico da classe dominante para esvaziar a educação escolar destinada à maioria da população enquanto, por outro lado, são buscadas formas de aprimoramento da educação das elites (DUARTE, 2006, p. 8).

Infelizmente os educadores não têm se mostrado suficientemente esclarecidos sobre este caráter reacionário do construtivismo e de outras posturas educacionais afins às concepções pós-modernas. Muitos deles, inclusive, acreditam que sua adesão a tais ideários, quando se afirmam como "pós-estruturalistas", "multiculturalistas", "pós-colonialistas", demarca um claro posicionamento progressista. Conforme entendem estes estudiosos, se tornou insustentável a manutenção de uma posição à esquerda, no espectro ideológico, calcada no pensamento crítico que se originou com Marx, já que a derrocada do "socialismo real" no Leste Europeu teria demonstrado, de uma vez por todas, a infecundidade do marxismo. Assim sendo, as teorias pós-modernas seriam as herdeiras desta tradição crítica, fazendo do marxismo um objeto anacrônico no século XXI. Mas é curioso notar, como afirma Saviani, que já os germens do pós-modernismo tinham sido “desconstruídos” pelo próprio Marx, quando de sua crítica a Max Stirner ${ }^{30}$ :

\begin{abstract}
Stirner não admite nenhuma "grande narrativa". É interessante observar que essa voga pós-moderna, que se reporta a autores como Foucault, e daí, a Nietzsche, teria sido antecipada por Max Stirner a cuja crítica Marx se dedicou, estendendo-se por quase dois terços d'A ideologia alemã. O livro de Stirner, $O$ único e sua propriedade, objeto da contestação de Marx, foi publicado em 1844. Para lá de irônico, parece-me algo que exige detida meditação o fato de que uma concepção que hoje relega o marxismo a uma visão ultrapassada, própria do século XIX, tenha sido minuciosamente criticada por Marx em 1845 (SAVIANI, 2012, p. 71-72).
\end{abstract}

Duarte (2007) traça o seguinte diagnóstico: para a maioria dos educadores, é ponto pacífico que a educação se trata de um processo não neutro, traduzido em posicionamentos políticos e situado socio-historicamente; mas no que respeita à formação dos indivíduos propriamente dita, seus entendimentos se mostram largamente comprometidos com

\footnotetext{
${ }^{30}$ Para Suchodolski, um "trágico e esquecido precursor" (1976, v. 3, p. 82) de Nietzsche.
} 
concepções a-históricas da individualidade humana, em especial, com o construtivismo. "Isso significa que os educadores dificilmente defendem, quando se trata de analisar o indivíduo, os mesmos paradigmas que empregam ao analisarem a educação em geral” (p. 14-15), resume o autor.

A questão que se impõe, quanto a esta situação paradoxal, é: pode haver uma psicologia dotada desta historicidade, que permita compreender a formação humana como processo situado no todo social, em vez de ser resumido à interação de indivíduos isolados com o ambiente ao seu redor e ao desenvolvimento compreendido como maturação biológica de estruturas mentais?

Entendemos que a Psicologia Histórico-Cultural é a teoria que surge como resposta a esta questão, e o restante do capítulo será dedicado a apresentá-la e a discutir suas interpretações.

\subsection{PSICOLOGIA HISTÓRICO-CULTURAL: TEORIA OBJETIVISTA, DIALÉTICA, CRÍTICA}

A Psicologia Histórico-Cultural - que se propaga sob diversas denominações, como "teoria histórico-cultural", "teoria sócio-histórica", "teoria sociocultural" ${ }^{31}$ - corresponde a um conjunto de estudos e conceitos originários da Rússia pós-revolucionária, e que encontra nos nomes de Aleksei Nikolaevitch Leontiev (1903-1979), Aleksandr Romanovitch Luria (1902-1977) e Lev Semionovitch Vigotski (1896-1934) ${ }^{32}$ seus principais representantes. Este último é considerado como o iniciador desta corrente psicológica e se tornou seu nome mais conhecido.

Para se compreender as características deste referencial, é necessário passar em revista, ainda que brevemente, a situação da psicologia no primeiro quartel do século XX. $\mathrm{O}$

\footnotetext{
${ }^{31}$ Preferimos chamá-la por "psicologia" em vez de "teoria" para ressaltar o pertencimento deste referencial a um determinado campo do saber (embora, de fato, ele avance em direção a outras ciências além da psicologia situação, aliás, que se aplica a qualquer ciência, pois o conhecimento não admite fronteiras rígidas), e também para afastar interpretações de que estes estudos não mantêm interlocuções com a prática. A verdade é que muitos dos principais conceitos da Psicologia Histórico-Cultural surgiram a partir de estudos empíricos e da refutação de hipóteses em julgamento. A denominação "histórico-cultural", por sua vez, é a preferida pelos principais nomes desta corrente, e iremos respeitar esta predileção.

${ }^{32}$ Como a língua russa utiliza o alfabeto cirílico, estes nomes constam no ocidente em grafias diversas (como "Vygotsky", "Vigotskí", "Leóntiev"), dependendo dos critérios utilizados na sua transliteração para o alfabeto romano. Adotaremos aqui as grafias sem o uso da letra "y" e sem acentuação, mas a referenciação de obras destes autores preservará o modo como seus nomes são grafados nestas fontes.
} 
próprio Vigotski escreveu um livro especialmente dedicado ao tema, traduzido para o português como $O$ significado histórico da crise da psicologia (VIGOTSKI, 2004, p. 201417). A referida "crise" se trata da oposição, à época, entre duas vertentes principais da psicologia, que a teria conduzido a uma espécie de "beco sem saída":

A tese de que existem duas psicologias (a científico-natural, materialista, e a espiritualista) expressa com mais precisão o significado da crise do que a tese da existência de muitas psicologias. Psicologias, sendo exato, existem duas: dois tipos distintos, inconciliáveis de ciência; duas construções do sistema de saber radicalmente diferentes. O restante são só diferenças nas perspectivas, escolas, hipóteses; combinações parciais, tão completas, tão confusas e entremeadas, cegas e caóticas, que com freqüência é muito difícil se orientar. Mas, na verdade, a luta só se dá entre duas tendências que subjazem e atuam em todas as correntes em litígio (ibidem, p. 335, grifos do autor).

Grande parte dos estudiosos denomina as tendências em disputa como "objetivismo" e "subjetivismo". Outro autor que examina o embate entre estas orientações é Valentin Nikolaevich Voloshinov (1895-1936), nome associado ao que se convencionou chamar de "Círculo de Bakhtin"33. Em sua análise crítica sobre o "freudismo", ele se refere à existência de uma orientação interna-subjetiva, contraposta à externa-objetiva. A primeira, que também é referida como psicologia experimental, toma como objeto de estudo "a vivência interior do experimentando; é para ela que se volta a diretriz do experimentador" (VOLOSHINOV, 2004, p. 15). Já a segunda orientação, identificada também como psicologia objetiva, importa-se apenas com os dados da experiência externa, com as grandezas puramente materiais, que seriam as "respostas do organismo vivo aos estímulos" (ibidem, p. 16). Pelo fato da corrente subjetiva explicar o fenômeno da consciência recorrendo a conceitos espiritualistas, encontrando nos métodos baseados na introspecção a chave para recolher manifestações do psiquismo humano, poderíamos identificá-la ainda como um subjetivismo idealista. A corrente objetiva, por outro lado, baseia-se principalmente no conceito de reflexo, que Vigotski considera, afinal, uma abstração vaga; não seria absurdo, então, chamarmos esta corrente de objetivismo abstrato ${ }^{34}$.

\footnotetext{
${ }^{33}$ Sugiro a leitura da análise empreendida por Jean-Paul Bronckart e Cristian Bota, e apresentada no livro Bakhtin desmascarado: história de um mentiroso, de uma fraude, de um delírio coletivo (BRONCKART; BOTA, 2012). Como leitor das obras de Bakhtin e de seu "Círculo", este livro convenceu-me de que os textos cuja autoria é atribuída a Bakhtin, embora tenham sido publicados originalmente sob a assinatura de Voloshinov e de Pavel Nikolaevich Medvedev (1892-1938), pertencem de fato a estes autores. Ainda segundo Bronckart e Bota, Bakhtin não teria passado de um escritor medíocre e de envergadura intelectual insignificante. A própria ideia de um círculo de estudos, por ele liderado, não passaria de uma ficção.

${ }^{34}$ É de se notar que Voloshinov, estudando o pensamento filosófico e linguístico da mesma época, também encontrará duas orientações em disputa, às quais atribuirá estes nomes - subjetivismo idealista e objetivismo abstrato (VOLOCHINOV, 2004).
} 
É verdade que este início de século já assistiria ao surgimento de outras correntes psicológicas que se esforçavam por resolver este impasse. Por exemplo, em 1926 Vigotski escreve e publica o texto "Sobre o artigo de K. Koffka 'A introspecção e o método da psicologia'. A título de introdução" (VIGOTSKI, 2004, p. 87-92) em que tece elogios à chamada psicologia da gestalt, reconhecendo o avanço que seu surgimento representava para a ciência psicológica como um todo, ao mesmo tempo em que identificava as dificuldades desta nova teoria, como "o vitalismo e o mecanicismo; a excessiva assimilação dos problemas da psique aos procedimentos teóricos e dados da física atual; a falta de um ponto de vista social; a teoria 'intuitiva' da consciência e muitas outras mais" (ibidem, p. 92). Já o livro sobre o freudismo, de Voloshinov, viria à luz no ano seguinte, e demonstraria que a psicanálise, apesar de se apresentar como teoria fundada em conceitos objetivos de ordem biológica, seria mesmo uma "variedade da psicologia subjetiva" - expressão que, inclusive, aparece no título de um de seus capítulos (VOLOSHINOV, 2004, p. 67-73). A própria teoria de Piaget buscou superar as orientações subjetivista e objetivista, rompendo a dicotomia entre sujeito do conhecimento e objeto cognoscível, e fundando uma espécie de interacionismo (SCALCON, 2002) com sua epistemologia genética. Mesmo atribuindo a este fato um caráter revolucionário, Vigotski também não poupou críticas à teoria do psicólogo suíço - por exemplo, nas dezenas de páginas de "A linguagem e o pensamento da criança na teoria de Piaget. Estudo crítico" (VIGOTSKI, 2001, p. 19-96), publicado apenas em 1934, texto sobre o qual voltaremos a falar mais adiante.

O entusiasmo em relação ao sucesso inicial da revolução russa gerou um clima de verdadeira efervescência entre os acadêmicos soviéticos, que se manifestou inicialmente na crítica implacável à orientação burguesa que era atribuída à ciência "tradicional". Ao mesmo tempo, buscou-se elaborar, a partir desta crítica, novos fundamentos para as ciências, tanto as naturais quanto as humanas, baseados no materialismo histórico e dialético de Marx e Engels. A saída para a crise da psicologia seria, portanto, a constituição de uma ciência do psiquismo humano comprometida com as teses mais fundamentais do marxismo, e foi a esta tarefa que Vigotski dedicou a maior parte de seu trabalho enquanto professor e pesquisador, especialmente no período de 1924 a 1934. Nos diversos artigos, prefácios de livros e ensaios que escreve durante este período, têm-se a impressão de que esta busca - por uma psicologia genuinamente dialética - teria se convertido numa verdadeira obsessão para o psicólogo russo. 
Primeiramente, Vigotski reconhece que uma teoria superadora do subjetivismo idealista e do objetivismo abstrato não poderia se resumir a uma simples adição dos métodos das duas orientações. Para ele, esta interpretação seria decorrente de um entendimento equivocado da preconizada união dialética entre o aspecto fisiológico, marca das orientações objetivistas, e a introspecção subjetivista. Mas

\begin{abstract}
Não se poderia conceber nada de mais antidialético.
A originalidade da psicologia dialética consiste justamente na tentativa de determinar de modo completamente novo seu objeto de estudo, que não é outro senão o processo integral do comportamento. Este se caracteriza por contar tanto com componentes psíquicos quanto fisiológicos, ainda que a psicologia deva estudálos como um processo único e integral, tentando, dessa maneira, encontrar uma saída para o beco em que se mete (VIGOTSKI, 2004, p. 146-147).
\end{abstract}

As tendências objetivistas - a reflexologia, a reatologia, o comportamentalismo estadunidense - haviam levado a uma "psicologia sem psique". Desprezando a investigação sobre a consciência, estas vertentes estariam incorrendo num erro metodológico da maior importância:

O comportamento do homem e o estabelecimento nele de novas reações condicionadas são determinados não pelas reações complexas, manifestas e totalmente explícitas, mas também pelas não reveladas externamente, que não podem ser vistas ao simples olhar. Por que podem ser estudados os reflexos complexos de linguagem e não podem ser levados em consideração os pensamentosreflexos, interrompidos em seus dois terços, embora se trate do mesmo tipo, real e inquestionável, de reação? (ibidem, p. 75).

O subjetivismo, por sua vez, dado seu caráter idealista, não poderia servir como ponto de partida para se erigir uma concepção materialista e dialética sobre a consciência. Tal concepção só poderia rejeitar, por exemplo, a redução sexualizante do psíquico operada pela psicanálise, em que um "princípio do prazer" antecederia ontogeneticamente o aparecimento de um "princípio da realidade", repercutindo na existência de uma etapa de pensamento "autístico" na infância, de busca desenfreada por satisfação de necessidades meramente biológicas. Da mesma forma, esta concepção dialética não poderia aceitar as soluções propostas pela epistemologia genética de Piaget que, incorporando estas noções da teoria de Freud, também cingiria a vida infantil em dois âmbitos, aquele da adaptação biológica e da satisfação de necessidades inconscientes ou pouco conscientes, nas etapas do pensamento autístico e, mais tarde, do pensamento egocêntrico; e aquele da vida socializada que é, no 
entanto, sempre circunscrita pelos limites de "substância psicológica" imanente ao psiquismo do sujeito ${ }^{35}$.

Haveria de se superar, portanto, os traços comuns ao objetivismo e ao subjetivismo: o empirismo, manifestado pela interpretação dos dados da realidade como se eles falassem por si (resumir o psiquismo às reações reflexas, no caso das tendências objetivistas, ou atribuir a certos traços do comportamento, por indução, raízes genéticas universais e metafísicas, característica das tendências subjetivistas); e o naturalismo, reduzindo a psicologia ao estudo das reações humanas frente a imperativos biológicos e, assim, anulando as diferenças entre a investigação das particularidades do psiquismo do homem e o comportamento animal.

Esta superação, no entanto, só poderia se dar a partir da orientação objetivista: nas palavras de Vigotski, ela deveria ser encarada como um "companheiro de viagem" na jornada pela constituição da psicologia dialética, a ser deixado para trás após certo avanço pelo caminho. Assim,

Os aliados de ontem na guerra comum contra o subjetivismo e o empirismo provavelmente se converterão amanhã em nossos inimigos na luta pela afirmação dos fundamentos básicos da psicologia social do homem social, pela libertação da psicologia do cativeiro biológico e por devolver a ela o significado de ciência independente, e deixar de ser um dos capítulos da psicologia comparada. Em outras palavras, quando passarmos a construir a psicologia como ciência do comportamento do homem social e não do mamífero superior, aparecerá claramente a linha de discrepância com nosso aliado do passado (ibidem, p. 90).

E quais seriam as diretrizes desta nova "psicologia social do homem social"? Como dissemos, tratar-se-ia de uma psicologia suficientemente sensível para captar a atuação, no psiquismo humano, das leis dialéticas (unidade dos contrários, conversão da quantidade em qualidade, negação da negação ou, o que é o mesmo, o processo de superação conforme o uso que Hegel faz da palavra aufheben). Nas palavras de Vigotski,

A psicologia dialética parte, antes de mais nada, da unidade dos processos psíquicos e fisiológicos. Para a psicologia dialética a psique não é, como expressa Spinoza, algo que jaz além da natureza, um Estado dentro de outro, mas uma parte da própria natureza, ligada diretamente às funções da matéria altamente organizada de nosso cérebro. Assim como o resto da natureza, não foi criada, mas surgiu num processo de desenvolvimento. [...] Em algum lugar, em um determinado nível de desenvolvimento dos animais, produziu-se uma mudança qualitativa no aperfeiçoamento dos processos cerebrais, que, por um lado, fora preparada por toda a marcha precedente do desenvolvimento e, por outro, constituía um salto em seu curso, já que representava o surgimento de uma nova qualidade, que não podia ser reduzida mecanicamente a fenômenos mais simples (ibidem, p. 144).

\footnotetext{
${ }^{35}$ Esta sentença resume - de modo precaríssimo, é verdade - a crítica de Vigotski à psicologia piagetiana em "A linguagem e o pensamento da criança na teoria de Piaget".
} 
A transcrição acima possui um conteúdo muito rico e traduz, em linhas gerais, as características desta nova psicologia: seu monismo materialista (daí a influência explícita de Spinoza), isto é, a concepção de que a consciência não se apresenta como uma entidade exterior à realidade objetiva, mas decorre justamente desta realidade; e sua preocupação com os aspectos distintivos do psiquismo humano em relação ao comportamento animal, decorrentes da evolução natural, a qual acumulou filogeneticamente uma série de mudanças qualitativas que, num determinado momento, viriam a produzir um salto inovador.

Até este salto, as leis biológicas haviam produzido o hominídeo com determinadas adaptações anatômico-fisiológicas que lhe garantiam novas capacidades para a satisfação de suas necessidades: o cérebro maior, a postura ereta, a manipulação de instrumentos. A partir daí, no entanto, o mecanismo evolutivo que veio a diferenciar este homem primitivo do homem atual passou a ser outro: não mais as leis naturais, mas as leis históricas.

Todas as investigações biológicas conduzem à idéia de que o homem mais primitivo que conhecemos merece biologicamente o título completo de homem. A evolução biológica do homem já tinha terminado antes que começasse seu desenvolvimento histórico. E a tentativa de explicar a diferença entre nossa forma de pensar e a do homem primitivo, considerando que este se encontre em outro nível de desenvolvimento biológico, constituiria uma confusão grosseira entre os conceitos de evolução biológica e desenvolvimento histórico (ibidem, p. 115).

O que diferencia o homem atual do homem primitivo não é sua anatomia; é exatamente este desenvolvimento histórico, traduzido nas inúmeras objetivações materializadas na cultura. Ao se objetivar, língua, costumes e conhecimentos passam a estar disponíveis para serem apropriados pelas novas gerações; a história da espécie humana, portanto, é uma contínua apropriação de experiências históricas de gerações passadas, que são então reproduzidas ou transformadas pelas gerações atuais, e assim sucessivamente.

O homem não se serve apenas da experiência herdada fisicamente. Toda nossa vida, o trabalho, o comportamento baseiam-se na utilização muito ampla da experiência das gerações anteriores, ou seja, de uma experiência que não se transmite de pais para filhos através do nascimento. Convencionaremos chamá-la de experiência histórica. [...] Se conheço o Saara e Marte, apesar de nunca ter saído de meu país e de nunca ter olhado pelo telescópio, isso se deve evidentemente ao fato de que essa experiência se origina na de outras pessoas que foram ao Saara e olharam pelo telescópio. É igualmente evidente que os animais não possuem esta experiência (ibidem, p. 65).

A consciência humana, assim, é entendida como resultado, primeiramente, do trabalho, que criou os instrumentos para a transformação da natureza, possibilitando a 
reprodução da existência dos homens. O trabalho, se organizando em um determinado modo de produção, leva, por sua vez, os homens a se relacionarem conforme determinadas normas; o modo de produção, em verdade, constrange as formas de organização dos homens, determina seu ser social, por assim dizer. Durante o processo de formação deste corpo social, além dos instrumentos para o trabalho, orientados para o exterior, para a transformação natureza, os homens elaboram também instrumentos orientados para seu interior: são os signos. Inicialmente assumindo uma função comunicativa, estes signos - gestos, articulações vocálicas, depois inscrições - passaram a fixar estas normas de organização social, objetivando-as: das primeiras palavras relacionadas à atividade de trabalho e às formações sociais primitivas (clãs, tribos, famílias), até códigos para a coesão do corpo social, religião, e então arte, ciência, filosofia. Tudo isto - que é cultura - se constitui de signos, mais ou menos elaborados, passíveis de serem apropriados pelos indivíduos singulares. Eis a matéria prima de sua consciência - e eis porque, reiteremos, a consciência é um produto da atividade laboral dos homens, visto que é o trabalho, organizado num modo de produção, que dá origem às objetivações em forma de cultura. É neste sentido que Vigotski se refere a um "caráter secundário" da consciência (ibidem, p. 80): ela não é primária, não existe independentemente dos homens e à margem do modo como estão organizados socialmente, mas se faz a partir de sua experiência, de sua atividade transformadora da realidade - de sua práxis.

Se o enfoque desta psicologia é dialético e materialista, trata-se, portanto, de uma ciência que adota a perspectiva realista-objetivista - "isto é, materialista em gnoseologia e dialética em lógica" (ibidem, p. 246) - e esse enfoque, além disso, indica que

a realidade determina nossa experiência; que a realidade determina o objeto da ciência e seu método, e que é totalmente impossível estudar os conceitos de qualquer ciência prescindindo das realidades representadas por esses conceitos (ibidem, loc. cit.).

Vigotski não viveu o suficiente para estudar profundamente a questão do método desta psicologia dialética e dar acabamento às questões que levantou quando examinava a crise da psicologia no início do século passado. O que restou de seus escritos são algumas indicações e formulações gerais, a serem desenvolvidas por seus seguidores. Mesmo assim, a produção de Vigotski ainda na década de 1920 determinou diretrizes sumamente importantes para a configuração da nova psicologia de caráter marxista. Uma delas se refere ao modo como a nova ciência do psiquismo deveria se relacionar com o pensamento dos autores do 
materialismo histórico e dialético. Vejamos algumas considerações suas a respeito das primeiras tentativas de se formular esta psicologia:

[A análise da psicologia marxista, ora em formação, é difícil] porque não dispõe ainda de sua metodologia e procura encontrá-la já terminada buscando-a em expressões casuais dos fundadores do marxismo. Mas querer encontrar em obras alheias uma fórmula já terminada da psique passaria a significar exigir "a ciência antes da própria ciência". Podemos dizer sobre essas tentativas que a heterogeneidade do material, sua incoerência, a variação que sofre o significado da frase fora do contexto, o caráter polêmico da maioria das opiniões - exatas somente na negação dos pensamentos falsos, mas vazias e genéricas no sentido da definição positiva das tarefas - não permitem de modo algum esperar desses trabalhos outra coisa além de um monte de citações mais ou menos casuais e sua interpretação escolástica (ibidem, p. 358).

A recusa em se formular uma psicologia "de citações" se justifica pela impossibilidade de que do materialismo dialético possam ser extraídas conclusões sobre as especificidades da mente humana. Da mesma maneira que o materialismo histórico se apresenta como uma teoria mediadora entre o materialismo dialético e a compreensão dos fenômenos da história dos homens, é preciso também formular-se esta teoria mediadora no âmbito especificamente psicológico para o avanço de uma psicologia que se pretenda marxista:

\begin{abstract}
A aplicação direta da teoria do materialismo dialético às questões das ciências naturais, e em particular ao grupo das ciências biológicas ou à psicologia, é impossível, como o é aplicá-la diretamente à história ou à sociologia. Existem entre nós aqueles que pensam que o problema da "psicologia e o marxismo" limita-se a criar uma psicologia que responda ao marxismo, mas o problema é, de fato, muito mais complexo. Da mesma maneira que a história, a sociologia necessária [necessita] de uma teoria especial intermediária, do materialismo histórico, que esclareça o valor concreto das leis abstratas do materialismo dialético para o grupo de fenômenos de que se ocupa. E igualmente necessária é a ainda não criada, mas inevitável, teoria do marxismo biológico e do materialismo psicológico, como ciência intermediária, que explique a aplicação concreta dos princípios abstratos do materialismo dialético ao grupo de fenômenos de que se ocupa (ibidem, p. 392-393, grifos do autor).
\end{abstract}

A nova psicologia deve eleger, assim, suas próprias unidades de análise: como Marx analisa em $O$ capital o valor da mercadoria enquanto "célula" da sociedade burguesa, deve ser encontrada também esta célula em psicologia - segundo Vigotski, o "mecanismo de uma reação" (ibidem, p. 374) - para a formulação de uma ciência que seja mais que um amontoado de citações dos clássicos do marxismo; uma psicologia que se respalde no método de Marx para se construir como ciência.

Em suma, pode-se dizer que Vigotski dedicou grande parte de seu trabalho teórico e prático à construção desta psicologia dialética. Observando que, à sua época, para cada novo 
fenômeno psíquico verificado na prática se construía uma nova teoria que o explicasse, o que levou à proliferação e fragmentação das correntes situadas num contínuo entre o subjetivismo idealista e o objetivismo abstrato, Vigotski pretendeu examinar e dar uma formulação inicial para as bases de uma teoria unificadora, de uma verdadeira psicologia geral. "Psicologia geral" é, aliás, o nome que aparece mais frequentemente associado a esta nova psicologia em seus escritos da década de 1920. Já a expressão "psicologia marxista" é, por vezes, explicitamente rejeitada. Para Vigotski, não faz sentido falar-se, por exemplo, em "biologia darwinista", já que o reconhecimento das ideias de Darwin estaria incluído na própria conceituação de ciência biológica; e assim,

\begin{abstract}
Um marxista-historiador nunca diria: "história marxista da Rússia". Consideraria que isto se depreende dos próprios fatos. "Marxista" para ele é sinônimo de "verdadeira, científica"; não reconhecemos outra história a não ser a marxista. E para nós a questão deve ser formulada assim: nossa ciência se tornará marxista na medida em que se tornar verdadeira, científica; e é precisamente à sua transformação em verdade, e não a coordená-la com a teoria de Marx, que nos dedicaremos. [...] A psicologia marxista não é uma escola entre outras, mas a única psicologia verdadeira como ciência; outra psicologia, afora dela, não pode existir. E, pelo contrário: tudo que já existiu e existe de verdadeiramente científico na psicologia faz parte da psicologia marxista [...] (ibidem, p. 414-415).
\end{abstract}

\title{
2.2.1 Conceitos principais para a educação escolar
}

Esboçada uma caracterização do desenvolvimento da Psicologia Histórico-Cultural no contexto filosófico e científico russo das primeiras décadas do século XX, passemos a analisar seu conteúdo conceitual propriamente dito. Nesta subseção, chamaremos a atenção do leitor para alguns dos principais conceitos desta psicologia, no nosso entender, que contribuem para a compreensão da educação escolar.

O desenvolvimento da Psicologia Histórico-Cultural, desde a época de Vigotski até o período de seu desaparecimento, quando Luria e Leontiev se firmaram como as duas maiores lideranças desta corrente, perpassou diversos âmbitos de interesse para os estudos psicológicos. Nos escritos do grupo que ficou conhecido como troika - o próprio trio Vigotski, Luria e Leontiev - registram-se investigações sobre domínios que se estendem da aprendizagem da escrita até o estudo sobre os reflexos sensoriais, passando pela pesquisa sobre as deficiências humanas congênitas ou adquiridas (“defectologia”), a análise das brincadeiras e, de modo geral, a pesquisa sobre o desenvolvimento da psique infantil. 
Em todos estes âmbitos houve a preocupação em considerar se as crianças, quando tomadas como sujeitos das pesquisas, estavam ou não em idade escolar e, quando fosse o caso, se estavam frequentando efetivamente as escolas. Numa conferência proferida em 1930, tratando do "método instrumental em psicologia" (isto é, o método de pesquisa que toma em consideração a existência de instrumentos psíquicos, que são os signos de que falamos há pouco), Vigotski afirma:

O método instrumental não estuda apenas a criança que se desenvolve, mas também aquela que se educa, fato este que qualifica como uma diferenciação crucial para a história do filhote humano. [...] O método instrumental estuda o processo de desenvolvimento natural e da educação como um processo único e considera que seu objetivo é descobrir como se reestruturam todas as funções naturais de uma determinada criança em um determinado nível de educação. O método instrumental procura oferecer uma interpretação acerca de como a criança realiza em seu processo educacional o que a humanidade realizou no transcurso da longa história do trabalho [...] (ibidem, p. 99, grifo nosso).

Dito isto é natural, portanto, que o primeiro livro que Vigotski publicou em vida, em 1926, seja Psicologia pedagógica (VIGOTSKI, 2010), escrito em 1924. Segundo Martins (2010), este livro compila uma série de conferências proferidas pelo autor entre 1917 e 1923 , época em que trabalhava numa espécie de escola normal. Pelo próprio conteúdo da obra, percebe-se mesmo um estilo didático, voltado para a formação de jovens professores.

Enquanto que certas ideias que seriam divulgadas nos textos do período entre 1924 e 1934 já se apresentavam quase plenamente desenvolvidas nesta obra inicial, algumas de suas considerações especificamente pedagógicas receberiam formulações mais precisas em textos futuros de Vigotski e seus colaboradores. Por exemplo, a crítica tanto à pedagogia tradicional quando à pedagogia nova é feita considerando-se a determinação social da educação, mas sem se definir precisamente o modo como esta determinação atua sobre indivíduos concretos:

Dando importância tão excepcional à experiência pessoal do aluno, podemos reduzir
a zero o papel do mestre? Podemos substituir a velha fórmula "o mestre é tudo, o
aluno, nada" pela fórmula inversa "O aluno é tudo, o mestre, nada?"36 De modo
algum. Se, do ponto de vista científico, devemos negar ao mestre a capacidade de
exercer influência educacional imediata, a capacidade mística de "esculpir a alma
alheia", então é precisamente porque reconhecemos para o mestre um valor
imensuravelmente mais importante. [...] Se o mestre é impotente para agir
diretamente sobre o aluno, é onipotente para exercer influência imediata sobre ele
através do meio social. O meio social é a verdadeira alavanca do processo
educacional, e todo o papel do mestre consiste em direcionar esta alavanca
(VIGOTSKI, 2010, p. 65).

${ }^{36}$ Há evidentes erros de digitação neste fragmento, que decidi manter nesta transcrição. 
Seriam as investigações de Leontiev, sobretudo a elaboração de sua teoria da atividade, cujos embriões já aparecem nos textos vigotskianos, que explicaria pormenorizadamente a ação do meio social no processo de formação humana.

Outro aspecto ligado à questão educacional que será mais bem desenvolvido em obras posteriores, também constando em Psicologia pedagógica, é a formação de conceitos $^{37}$. Tratase de um elemento essencial do processo de ensino e que é diretamente implicado nas formulações mais gerais da Psicologia Histórico-Cultural. O fragmento seguinte se tornou relativamente notório e transmite de modo conciso uma destas possíveis formulações:

Podemos formular a lei genética geral do desenvolvimento cultural do seguinte modo: toda função no desenvolvimento cultural da criança aparece em cena duas vezes, em dois planos; primeiro no plano social e depois no psicológico, inicialmente entre os homens como categoria interpsíquica e então no interior da criança como categoria intrapsíquica. $\mathrm{O}$ acima exposto se refere igualmente à atenção voluntária, à memória lógica, à formação de conceitos e ao desenvolvimento da vontade. [...] Por trás de todas as funções superiores e suas relações se encontram geneticamente as relações sociais, as autênticas relações humanas. [...] Assim, o resultado fundamental da história do desenvolvimento cultural da criança poderia ser denominado como a sociogênese das formas superiores do comportamento (idem, 1995, p. 150, grifos nossos, tradução nossa).

Esta fala de Vigotski demonstra claramente em que medida a Psicologia HistóricoCultural se diferencia de outras correntes objetivistas, como a reflexologia. O estudo dos reflexos, sendo os experimentos de Pavlov tomados como seu epítome, desconsidera que as chamadas funções psíquicas superiores - entre as quais Vigotski cita quatro exemplos, incluindo a formação de conceitos - se tratam de formas de comportamento muito mais complexas que as reações involuntárias e instintivas, sendo irredutíveis ao substrato biológico do sistema nervoso. Estas funções são, isto sim, fruto de um desenvolvimento histórico; surgem como produto das relações sociais e não se formam espontaneamente em cada indivíduo: cabe ao processo de educação possibilitar a apropriação destas formas de conduta.

\begin{abstract}
Modificando a conhecida tese de Marx, poderíamos dizer que a natureza psíquica do homem vem a ser um conjunto de relações sociais transladadas para seu interior e convertidas em funções da personalidade e em formas de sua estrutura. Não pretendemos dizer que este seja, precisamente, o significado da tese de Marx, mas vemos nela a expressão mais completa de todo o resultado da história do desenvolvimento cultural (ibidem, p. 151, tradução nossa).
\end{abstract}

\footnotetext{
${ }^{37}$ Tendo a preferir a expressão "elaboração de conceitos". A palavra "formação" pode levar a uma compreensão espontaneísta, como se os conceitos surgissem de modo natural. Já “elaboração" dá a entender que se trata de um processo ativo e trabalhoso, o que corresponde melhor à realidade. No entanto, empregarei nesta tese "formação de conceitos" com o fim de colaborar para a unidade terminológica, já que esta expressão está mais disseminada e é a que consta na maior parte dos textos da Psicologia Histórico-Cultural que a ela se referem.
} 
Assim, quanto à formação de conceitos, em Psicologia pedagógica Vigotski chama a atenção para a necessidade de se compreender seu mecanismo psicológico, avaliando o processo de conceituação em termos de seu "volume" e "conteúdo":

\begin{abstract}
Chama-se volume de um conceito o número de objetos e fenômenos que se enquadra nesse conceito. Chama-se conteúdo o número de indícios pensados nesse conceito. Quanto mais amplo é o volume de algum conceito tanto mais estreito é o seu conteúdo, e vice-versa. [...] Um psicólogo tem razão ao chamar isso de lei trágica da educação. De fato, o pedagogo está diante de dois extremos inconciliáveis: toda ampliação de um significado acarreta na mesma medida o empobrecimento de seu conteúdo e do seu sentido; todo enriquecimento de um conceito restringe o seu volume. Encontrar a correta correlação entre ambos é uma tarefa difícil para o pacto pedagógico e ela não poderá ser resolvida na forma geral enquanto a pedagogia não se tornar ciência exata (idem, 2010, p. 242-243).
\end{abstract}

O livro O significado histórico da crise da psicologia também tangencia esta questão e parece avançar um pouco mais para uma compreensão científica da formação de conceitos. Vigotski parte dos seguintes juízos: a todo conceito científico, por mais abstrato que seja, corresponde certo grau de realidade; e inversamente, todo fato científico, por mais empírico que seja, encerra em si uma abstração primária. A partir daí, o psicólogo agrega à questão da formação dos conceitos um fundamento sígnico, isto é, a importância da atribuição de palavras ao material sensorial que é conceituado:

O material da ciência não é constituído pelo material natural cru, mas pelo material logicamente elaborado que se destaca de acordo com um determinado signo. [...] Quando tropeçamos com o que denominamos vaca e dizemos: "isto é uma vaca", ao ato de perceber unimos o de pensar, incluindo a mencionada percepção num conceito geral; a criança, ao nomear pela primeira vez as coisas, realiza autênticos descobrimentos. O que se vê não é, na verdade, uma vaca. Não se vêem as vacas. O que se vê é algo grande, preto, que se move, muge etc.; e se compreende que é uma vaca e este ato é um ato de classificação, de inclusão de um fenômeno isolado dentro da categoria de fenômenos análogos, de sistematização da experiência etc. Assim, $a$ própria língua encerra os fundamentos e as possibilidades da cognição científica do fato. A palavra é o germe da ciência e nesse sentido cabe dizer que no começo da ciência estava a palavra (idem, 2004, p. 234-235, grifos nossos).

Na primeira obra póstuma de Vigotski publicada na Rússia, Michlenie $i$ retch (no Brasil, traduzida primeiro como Pensamento e linguagem, e numa nova edição, como $A$ construção do pensamento e da linguagem - comentaremos futuramente este fato), de 1934, são apresentados alguns dos estudos mais completos de Vigotski e seus colaboradores a respeito da formação de conceitos. Não vamos comentar detalhadamente estas investigações, mas encerraremos esta subseção apresentando algumas de suas conclusões gerais. 
De início, Vigotski aponta os defeitos dos métodos empregados até então para o estudo da formação de conceitos: segundo o autor, eles se caracterizam "pelo divórcio da palavra com a matéria objetiva; operam ou com palavras sem matéria objetiva, ou com matéria objetiva sem palavras" (idem, 2001, p. 153). Concebendo de modo dinâmico a formação do conceito, Vigotski afirma que o método de sua investigação deve espelhar igualmente este dinamismo; deve tomar o conceito em seu movimento, desenvolvimento:

o conceito não leva uma vida isolada, não é uma formação fossilizada e imutável mas sempre se encontra no processo mais ou menos vivo e mais ou menos complexo de pensamento, sempre exerce uma função de comunicar, assimilar, entender e resolver algum problema (ibidem, p. 154).

Como o conceito segue um caminho, se movimenta, parte de uma direção e alcança outra, ele possui uma história. É lógico que todo conceito científico possui também sua história, algo análogo a uma "filogênese" - sua sociogênese, para usar um termo já apresentado há pouco. No plano da ontogênese, no entanto, a história do conceito é outra: ela não precisa recapitular seu desenvolvimento sociogenético, do contrário, a apropriação de qualquer saber científico por parte das novas gerações seria impossível. Como reproduzir no decorrer de uma existência breve, singular, todo o caminho histórico de um conceito científico que exigiu séculos, às vezes milênios, para ser percorrido? Mas reproduzir este caminho milenar não é necessário, durante o processo de aprendizagem das atuais e novas gerações, justamente porque os conceitos se converteram em signos, se estabilizaram na língua através de palavras e suas combinações. E assim sendo, Vigotski insistirá na importância de se compreender o processo de apropriação de novas palavras e, usando uma expressão que aparece repetidamente nos textos de Michlenie $i$ retch, o "emprego funcional" destes instrumentos, pelo qual o sujeito consegue subordinar a seu poder, sua vontade, o uso de suas operações psicológicas.

Não existe conceito sem uma formulação linguística que o represente - "O conceito é impossível sem palavras, o pensamento em conceitos é impossível fora do pensamento verbal" (ibidem, p. 170) - e, portanto, a questão fulcral do ensino escolar passa a ser a transmissão de novos signos. $\mathrm{O}$ ensino, assim, deve proporcionar a cada aluno a experiência de, partindo da abstração representada pela palavra, chegar ao conteúdo real do conceito. $\mathrm{O}$ caminho da formação de conceitos científicos se faz, nesta perspectiva, do abstrato ao concreto. Trata-se do processo inverso ao da formação dos chamados conceitos espontâneos ou cotidianos: estes como que emanam da prática, são generalizações e vínculos precários, 
pouco sistematizados. Então, na ontogênese da formação dos conceitos, existiriam duas curvas: a que desce do abstrato em direção ao concreto, percorrida pelo conceito científico, curva esta que se inicia com o processo de ensino, de instrução; e a que ascende do material factual, empírico, ao abstrato, à generalização, que é a curva do conhecimento cotidiano. Não há dicotomia entre os processos, pois uma curva pode abrir o caminho para o desenvolvimento da outra:

O conceito espontâneo, que passou de baixo para cima por uma longa história em seu desenvolvimento, abriu caminho para que o conceito científico continuasse a crescer de cima para baixo, uma vez que criou uma série de estruturas indispensáveis ao surgimento de propriedades inferiores e elementares do conceito. De igual maneira, o conceito científico, que percorreu certo trecho do seu caminho de cima para baixo, abriu caminho para o desenvolvimento dos conceitos espontâneos, preparando de antemão uma série de formações estruturais indispensáveis à apreensão das propriedades superiores do conceito (ibidem, p. 349).

Vigotski então demonstra que ambos os tipos de conceitos, científicos e espontâneos, possuem forças e fraquezas, sendo a força de um exatamente a fraqueza do outro, e viceversa:

\begin{abstract}
Poderíamos dizer que a força dos conceitos científicos se manifesta naquele campo inteiramente determinado pelas propriedades superiores dos conceitos, como a tomada de consciência e a arbitrariedade; é justamente aí que revelam a sua fragilidade os conceitos espontâneos da criança, que são fortes no campo da aplicação espontânea circunstancialmente conscientizada e concreta, no campo da experiência e do empirismo. O desenvolvimento dos conceitos científicos começa no campo da consciência e da arbitrariedade e continua adiante, crescendo de cima para baixo no campo da experiência pessoal e da concretude. O desenvolvimento dos conceitos científicos [certamente há aqui um erro, trata-se dos conceitos espontâneos] começa no campo da concretude e do empirismo e se movimenta no sentido das propriedades superiores dos conceitos: da consciência e da arbitrariedade (ibidem, p. 350).
\end{abstract}

Estas conclusões, respaldadas pelo vasto material empírico apresentado nos estudos que compõem Michlenie $i$ retch, reafirmam o apreço da Psicologia Histórico-Cultural pela educação sistematizada mediante o ensino escolar. De acordo com Vigotski e os demais autores desta tendência, cabe à escola o papel social de orientar a formação das funções psicológicas superiores, dentre as quais a formação dos conceitos, mediante o ensino do material cultural sígnico registrado nas palavras científicas. Este é o núcleo principal das preocupações escolares.

Com estas considerações, Vigotski elaborará uma concepção sobre educação que entrará em franco conflito, por exemplo, com o construtivismo. Afinal, como dissemos, há 
uma verdadeira polêmica entre o psicólogo russo e o autor da epistemologia genética, como registra o texto "A linguagem e o pensamento da criança na teoria de Piaget", que também consta em Michlenie i retch. Neste trabalho, Vigotski detecta e atinge a pedra angular do edifício teórico piagetiano - o pensamento egocêntrico - e busca demonstrar, por vezes utilizando os dados empíricos coletados pelo próprio psicólogo suíço, o equívoco de sua interpretação sobre o desenvolvimento infantil. Segundo Piaget, a vida social começa a constranger o pensamento da criança a partir da idade escolar; o pensamento inteligente verdadeiramente deforma a substância psicológica infantil. Vigotski, realizando um estudo sobre a chamada "fala egocêntrica", refuta esta posição. Não é uma substância imanente ao psiquismo infantil que se socializa com o avanço etário; é o próprio psiquismo infantil imanentemente social.

Daí não fazer sentido uma periodização do desenvolvimento da criança como a que propõe Piaget, periodização esta que prescreve quais operações, habilidades, raciocínios etc. estão ou não estão ao alcance do sujeito em cada etapa de seu caminho da infância à vida adulta. De acordo com esta concepção, certos aprendizados estariam interditados às crianças, dependendo do nível de desenvolvimento em que elas se encontrem. Os conceitos de elevado grau de abstração só poderiam, por exemplo, ser ensinados a partir da consolidação das estruturas lógicas típicas do período das chamadas operações formais, a etapa derradeira do desenvolvimento psíquico: "na medida em que se interiorizam as operações lógicomatemáticas do sujeito graças às abstrações refletidoras que elaboram operações sobre outras operações" e "na medida em que é finalmente atingida esta extemporaneidade que caracteriza os conjuntos de transformações possíveis", é que o sujeito começa a tornar-se acessível "a uma observação objetiva de certas de suas leis [do mundo] e sobretudo a explicações causais que forçam o espírito a uma constante descentração na sua conquista dos objetos" (PIAGET, 1978, p. 30).

Já na concepção de Vigotski, ocorreria um processo completamente inverso. Piaget, como visto nos fragmentos transcritos acima, fala de abstrações refletidoras que levam à interiorização de operações lógico-matemáticas e, em outros momentos, se referirá, analogamente, à importância do processo conhecido como tomada de consciência para a formação dos conceitos científicos. Contrariamente, Vigotski afirma que "Os conceitos científicos são os portões através dos quais a tomada de consciência penetra no reino dos conceitos infantis" (2001, p. 295). Assim, não é a tomada de consciência que possibilita a formação do conceito, é o próprio conceito uma condição para a tomada de consciência. 
A principal consequência disto para o ensino é que o estágio de desenvolvimento atual do aluno não pode ser o critério definidor dos conteúdos escolares. A seleção destes conteúdos deve se basear num olhar mais prospectivo do que retrospectivo. Se na concepção construtivista é o desenvolvimento que determina a aprendizagem, na perspectiva históricocultural é a instrução que leva ao desenvolvimento. No capítulo "Estudo do desenvolvimento dos conceitos científicos na infância”, de Michlenie i retch, Vigotski apresenta quatro estudos sobre as relações entre instrução e desenvolvimento, cujas conclusões são assim resumidas:

\begin{abstract}
Vimos que a aprendizagem [leia-se sempre "instrução" - trata-se de uma questão relativa à tradução, que comentaremos mais adiante] e o desenvolvimento não coincidem imediatamente mas são dois processos que estão em complexas interrelações. A aprendizagem só é boa quando está à frente do desenvolvimento. Neste caso, ela motiva e desencadeia para a vida toda uma série de funções que se encontravam em fase de amadurecimento e na zona de desenvolvimento imediato [leia-se "zona de desenvolvimento iminente" - idem]. É nisto que consiste o papel principal da aprendizagem no desenvolvimento. É isto que distingue a educação da criança do adestramento dos animais. É isto que distingue a educação da criança, cujo objetivo é o desenvolvimento multilateral da educação especializada, das habilidades técnicas como escrever à máquina, andar de bicicleta, etc., que não revelam nenhuma influência substancial sobre o desenvolvimento. A disciplina formal de cada matéria escolar é o campo em que se realiza essa influência da aprendizagem sobre o desenvolvimento. $O$ ensino seria totalmente desnecessário se pudesse utilizar apenas o que já está maduro no desenvolvimento, se ele mesmo não fosse fonte de desenvolvimento e surgimento do novo (ibidem, p. 334, grifo nosso).
\end{abstract}

Novamente, observamos aqui uma apreciação essencialmente positiva da instituição escolar. Na próxima subseção mostraremos que não apenas os textos de Vigotski levam a esta apologia da escola: a produção de Leontiev, em especial, indicará a imprescindibilidade do ensino escolar, no atual estágio do desenvolvimento histórico do homem, para a apropriação das funções psicológicas superiores pelas novas gerações. Sua teoria da atividade revelará aproximações radicais e íntimas com a Pedagogia Histórico-Crítica, especialmente com os desenvolvimentos de Newton Duarte sobre as ideias iniciais de Dermeval Saviani.

\title{
2.2.2 Psicologia Histórico-Cultural e Pedagogia Histórico-Crítica: uma unidade psicopedagógica
}

Já em 1984 Libâneo, em um texto publicado primeiramente numa coletânea sobre psicologia social, e mais tarde em seu Democratização da escola pública, se queixava da 
hegemonia de um "individualismo" no campo da psicologia educacional, cuja orientação seria "considerar como fatores causadores do comportamento os processos psicológicos internos (emoções, sentimentos, ideias), sem levar em conta a natureza basicamente social do ser humano e de sua consciência" (1988, p. 87). Segundo o autor, tanto os fundamentos psicológicos das pedagogias renovadas (escolanovismo e humanismo), quanto as teorias cognitivas, que então começavam a monopolizar a atenção dos interessados em psicologia da educação, padeciam deste individualismo, não sem certos interesses políticos:

A idéia de uma essência humana pré-social concebe a personalidade humana individual como um caso particular da personalidade humana básica, o que pressupõe que cada indivíduo possui características que são universais e independentes de influência do meio social, cabendo à Psicologia conhecer esses traços universais. É evidente que tal idéia assume a sociedade de classes como o modelo social ideal na qual a realização individual resulta de uma perfeita harmonia entre indivíduo e sociedade. Daí a idéia corrente de ajustamento social aplicada à Psicologia da Educação. Os padrões de comportamento a serem ensinados ou modificados correspondem à perspectiva da classe dominante, que os torna universais e, portanto, compulsórios (ibidem, loc. cit., grifo do autor).

Ainda no mesmo texto, Libâneo apontará a necessidade de uma "psicologia das relações sociais" para a superação deste enfoque individualista e a-histórico. Para ele, tal psicologia "ainda está por ser feita, mas é possível estabelecer um caminho pelo qual se possa atender à experiência individual concreta, isto é, ao indivíduo no que concerne à sua existência material" (ibidem, p. 101). Fundamentando esta afirmação, o autor reproduz as seguintes passagens d'A ideologia alemã de Marx e Engels:

A produção de ideias, de representações, da consciência está em princípio diretamente entrelaçada com a atividade material e o intercâmbio material dos homens, linguagem da vida real. [...] Os homens são os produtores das suas representações, ideias etc., mas os homens reais, os homens que realizam [die wirklichen, wirkenden Menschen], tal como se encontram condicionados por um determinado desenvolvimento das suas forças produtivas e pelas relações [Verkehrs] que a estas corresponde até as suas formações mais avançadas $(2009, \text { p. } 31)^{38}$.

No ano seguinte (1985), Saviani realizou uma exposição no seminário promovido pela Associação Nacional de Educação em Niterói. Parte do debate que se seguiu a sua apresentação aparece transcrita em Pedagogia Histórico-Crítica: primeiras aproximações. $\mathrm{Na}$ resposta a uma das questões que plateia lhe dirigiu, Saviani tangencia alguns dos aspectos tratados por Libâneo, referentes à psicologia educacional:

\footnotetext{
${ }^{38}$ Os colchetes com as palavras originais em alemão constam na própria tradução consultada.
} 
Acho que uma das limitações da contribuição da psicologia à educação está no fato de que a psicologia tem tratado principalmente do indivíduo empírico, não do indivíduo concreto. Ora, o professor na sala de aula não se defronta com indivíduo empírico, descrito em todas as suas variáveis, a respeito do qual existem conclusões precisas, estatisticamente significativas. O professor está lidando com o indivíduo concreto; enquanto indivíduo concreto, ele é uma síntese de inúmeras relações sociais. Ele não se enquadra no modelo descrito pela psicologia, pois o indivíduo empírico é uma abstração, pressupõe um corte onde se definam determinadas variáveis que são objeto de estudo. O professor não pode fazer o corte; o aluno está diante dele, vivo, inteiro, concreto. Daí a necessidade de se desenvolver uma psicologia que leve em conta o indivíduo concreto e não apenas o indivíduo empírico (2008, p. 81-82).

No encontro Dermeval Saviani e a educação brasileira, conhecido como Simpósio de Marília (1994), os debates voltaram a tocar neste aspecto. Newton Duarte, neste evento, assim encerrou sua exposição sobre os fundamentos teóricos da obra de Saviani:

Há um acento de valor positivo nessa definição do trabalho educativo enquanto produção intencional ${ }^{39}$. Claramente Saviani assume considerar como um desenvolvimento do ser humano, que a formação dos indivíduos seja elevada ao plano de um processo intencionalmente dirigido. Esse aspecto por si só mereceria outra apresentação, pois toca na concepção de liberdade, tema fundamental para uma pedagogia fundamentada em Marx. Apenas deixarei assinalado que vejo nesse ponto uma decisiva confluência entre a Pedagogia histórico-crítica e uma das escolas da psicologia soviética, a escola de Vigotski, Leontiev e outros, que desenvolveu um grande trabalho teórico e prático dirigido justamente pelo princípio de que cabe ao processo educativo dirigir o desenvolvimento psíquico do indivíduo e não caminhar a reboque de um desenvolvimento espontâneo e natural (DUARTE, 1994, p. 147).

No encerramento do encontro, Duarte fez uma breve digressão a título de

esclarecimento sobre falas anteriores, inclusive sobre o conteúdo do fragmento acima:

se a gente discute Vigotsky, Leontiev, Piaget, ou se discutimos Freud ou qualquer outra contribuição da psicologia, nós não o estamos fazendo a partir desses autores, mas estamos fazendo a partir dos fundamentos da Pedagogia histórico-crítica. Portanto, o critério para nós analisarmos o quanto e até que ponto há coerência em incorporarmos os fundamentos da obra deste ou daquele autor, são justamente os fundamentos da Pedagogia histórico-crítica. E os fundamentos da Pedagogia histórico-crítica, a gente insistiu em falar aqui todos os dias, reside [sic] justamente na relação entre ser humano e história, tanto do ponto de vista do gênero humano como do ponto de vista do indivíduo [...]. Portanto, trata-se de uma base ontológica e epistemológica diferenciada em relação à base ontológica e epistemológica de Piaget e aí sim, então, cabe a referência de que, sendo a base epistemológica e ontológica de Vygotsky mais próxima aos pressupostos da Pedagogia históricocrítica, é evidente então que as contribuições da escola de Vigotsky têm uma possibilidade maior (SAVIANI, 1994, p. 274-275). ${ }^{40}$

\footnotetext{
${ }^{39}$ Duarte se refere à concepção de Saviani segundo a qual "o trabalho educativo é o processo de produzir, direta e intencionalmente, em cada indivíduo singular, a humanidade que é produzida histórica e coletivamente pelo conjunto dos homens" (SAVIANI, 2008, p. 7, grifo meu), fragmento que já reproduzi no capítulo 1.

${ }^{40}$ Há evidentes descuidos na transcrição em texto desta fala: além do erro de concordância verbal, o nome de Vigostki aparece redigido de duas maneiras, num mesmo parágrafo.
} 
A partir de então, tornou-se cada vez mais difícil ignorar as aproximações entre a teoria de Vigotski e seus colaboradores/seguidores e a pedagogia proposta por Saviani e desenvolvida com o auxílio de Duarte e outros autores.

Especificamente quanto a estas contribuições de Duarte, consideramos que elas ganham volume e sistematicidade na obra Educação escolar, teoria do cotidiano e a Escola de Vigotski (DUARTE, 2007), cuja primeira edição data de 1996. Este livro procura articular, visando a uma concepção histórico-crítica da educação (a própria Pedagogia HistóricoCrítica), uma teoria da formação da individualidade assente na concepção dialética da história e em teorias mediadoras cunhadas por outros autores além dos pais do marxismo. Nas palavras de Duarte, o livro busca mostrar que

a educação escolar, ao mediatizar a relação entre cotidiano e não-cotidiano na formação do indivíduo, forma nesse indivíduo necessidades cada vez mais elevadas, que ultrapassam a esfera da vida cotidiana (a esfera das objetivações genéricas emsi) e situam-se nas esferas não-cotidianas da prática social (as esferas das objetivações genéricas para-si) (ibidem, p. 2).

Procedendo de acordo com o método de Marx, Duarte parte de categorias mais abstratas e avança em direção a um entendimento do processo formativo dos indivíduos concretos. O ponto de partida são as categorias apropriação e objetivação; citando Marx, Duarte explica:

o homem, ao produzir as condições de sua existência, ao transformar a natureza, se apropria dela e se objetiva nela. Essa apropriação e essa objetivação geram no homem novas necessidades e conduzem a novas formas de ação, num constante movimento de superação por incorporação (ibidem, p. 23).

Apropriação e a objetivação se relacionam de modo dialético, e elas mesmas são categorias impregnadas de dialética; daí a referência, por parte de Duarte, ao caráter simultaneamente humanizador e alienador com que estes processos têm se efetivado na sociedade de classes:

A humanização avança na medida em que a atividade social e consciente dos homens produz objetivações que tornem possível uma existência humana cada vez mais livre e universal [...] O trabalho de milhões de seres humanos tem possibilitado que objetivações humanas como a ciência e a produção material gerassem, neste século, possibilidades de existência livre e universal sem precedentes na história humana, mas isso tem se realizado de forma contraditória pois essas possibilidades têm sido geradas às custas da miséria, da fome, da ignorância, da dominação e mesmo da morte de milhões de seres humanos (ibidem, p. 23-24). 
O ponto passa a ser o entendimento da contradição entre humanização e alienação. Entram em cena novas categorias: gênero e espécie humana, individualidade em-si e para-si. Conforme a definição do autor, reserva-se à categoria de espécie humana o conjunto de atributos biológicos que diferenciam o homem dos demais seres vivos. Já o gênero humano conserva o conjunto das objetivações humanas, sendo uma categoria, portanto, histórica. $\mathrm{O}$ intercâmbio material entre o corpo humano e seu ambiente, produto da fisiologia humana e regido por leis biológicas, transmitidas por hereditariedade, permite ao indivíduo seu desenvolvimento enquanto membro da espécie humana. Seu desenvolvimento enquanto membro do gênero humano, no entanto, só se faz pela apropriação das objetivações produzidas pelo trabalho dos indivíduos que o antecederam, durante o desenvolvimento histórico. Quando esta apropriação se dá de modo espontâneo, desprovido de reflexão, de relação consciente, estamos diante da formação da individualidade em-si. Já a individualidade para-si se caracteriza pela apropriação consciente das objetivações do gênero humano e, assim, condensa as máximas possibilidades para o desenvolvimento. O âmbito do em-si faz parte do desenvolvimento ontogenético de qualquer indivíduo e não é inerentemente negativo: é necessário, visto que não é possível que toda ação e toda apropriação sejam acompanhadas deste movimento reflexivo. O problema está na impossibilidade de que certos indivíduos ultrapassem este âmbito; que esteja negado, a eles, pelas condições objetivas da sociedade de classes, o desenvolvimento da individualidade para-si.

Vejamos o seguinte exemplo, proposto por Duarte, que parte da questão da linguagem:

\begin{abstract}
Não há nenhuma razão para que julguemos necessário que uma criança reflita sobre a linguagem da qual está se apropriando, assim como um adulto, em sua vida cotidiana, não reflete necessariamente sobre a linguagem que utiliza. Mas, usando um exemplo completamente oposto, a mesma atitude de utilização espontânea da linguagem não pode ocorrer quando não se tratar mais de uma atividade cotidiana, mas sim de uma atividade científica, artística, filosófica ou política. Pensemos no caso da atividade do professor, isto é, pensemos na utilização da linguagem numa aula. Nesse caso, é evidente que o professor não pode deixar de refletir sobre a linguagem que utiliza, não pode deixar de manter uma relação consciente com essa linguagem. No caso da individualidade, temos como um princípio básico de nossa teoria o de que o indivíduo só se desenvolve plenamente quando ele, a partir da individualidade em-si, forma sua individualidade para-si. Já não se trata mais, então, de uma individualidade assumida espontaneamente, mas sim de uma individualidade em constante e consciente processo de construção (ibidem, p. 28).
\end{abstract}

$\mathrm{O}$ autor prossegue examinando, então, as categorias de vida cotidiana e vida nãocotidiana, recorrendo à teoria de Agnes Heller: as atividades voltadas para a reprodução do indivíduo, mas que contribuem indiretamente para a reprodução da sociedade, são cotidianas; e de modo inverso, as atividades voltadas para a reprodução da sociedade, mas que 
contribuem indiretamente para a reprodução do indivíduo, são não-cotidianas. Segue-se que o indivíduo não pode se desenvolver completamente - desenvolver-se enquanto individualidade para-si - se suas atividades e necessidades permanecem restritas ao cotidiano. A categoria alienação passa a ser assim definida:

podemos falar em alienação quando as relações sociais não permitem que o indivíduo se aproprie das objetivações genéricas para-si, não permitem, portanto, que essas objetivações sejam utilizadas pelo indivíduo como mediações fundamentais no processo de direção consciente de sua própria vida. Quando o indivíduo não consegue dirigir conscientemente sua vida como um todo, incluída como parte desse todo a vida cotidiana, o que acontece é que sua vida como um todo passa a ser dirigida pela vida cotidiana (ibidem, p. 39).

E assim podemos falar de uma última categoria, para nosso interesse, abordada no estudo em questão: o carecimento. Lembrando Marx, o homem rico é o homem carente de uma totalidade de exteriorização da vida humana, expressão que pode ser entendida de duas maneiras: por um lado, o enriquecimento do indivíduo se traduz pelo "carecimento de situar suas atividades à altura do desenvolvimento historicamente já alcançado pelo gênero humano"; por outro, "o indivíduo não pode se objetivar [isto é, constituir sua individualidade] de forma cada vez mais humana sem apropriar-se das objetivações historicamente produzidas" (ibidem, p. 40). Assim,

defender que a prática pedagógica visa enriquecer o indivíduo significa defender que ela visa produzir no indivíduo carecimentos não-cotidianos, isto é, carecimentos voltados para a objetivação do indivíduo pela mediação das objetivações genéricas para-si, ou melhor, daquelas das quais ele se apropria, tornando-as "órgãos de sua individualidade" (Marx) (ibidem, loc. cit.).

A partir daí, Duarte procurará situar a educação entre estas categorias e irá recorrer a textos de Leontiev para fundamentar sua compreensão do trabalho educativo, mobilizando também as sínteses promovidas por Saviani nas obras Escola e democracia e Pedagogia Histórico-Crítica: primeiras aproximações. Gostaríamos de encerrar esta subseção apresentando alguns conceitos fundamentais da obra de Leontiev, buscando compreender o papel da educação no processo de apropriação das objetivações do gênero humano e o modo como se produzem novos carecimentos que impulsionam a formação da individualidade parasi. No entanto, não reproduziremos o caminho exato que Duarte percorre ao evocar a psicologia soviética em prol de sua teoria; seguiremos um percurso particular, mais conforme nossas próprias leituras da obra de Leontiev. 
Como mencionamos de passagem na subseção anterior, os embriões da teoria da atividade de Leontiev podem ser encontrados já nos textos de Vigotski. Entendemos que Leontiev dedicou grande parte de sua obra a elaborar estes rudimentos anunciados e esparramados pelo conjunto do corpus vigotskiano, já que a morte prematura do psicólogo impedira este desenvolvimento.

Se a unidade de análise enfocada pelos escritos de Vigotski é o signo, na produção de Leontiev trata-se da atividade. Que é a atividade? Segundo Tolman (1988), os equivalentes em inglês (e certamente em português) dos termos originais russos da teoria da atividade são, em geral, palavras típicas do cotidiano, sendo incapazes de expressar exatamente seus significados nos textos originais de Leontiev e outros. Deve-se ter isto em mente ao ler a definição de atividade abaixo reproduzida, que apresentará também outras categorias que cumprem papel relevante na teoria de Leontiev:

A atividade é um conceito que conota a função do indivíduo na sua interação com o ambiente. A atividade psíquica é uma relação específica de um organismo como meio ambiente, que medeia, regula e controla outras destas relações entre o organismo e o meio ambiente. A atividade psíquica é impelida por uma necessidade, que visa ao objeto que pode satisfazer essa necessidade, e é realizada pelo sistema de ações. [...] A forma elementar da atividade psíquica deve ser distinguida de sua forma mais elevada. A primeira é típica dos animais e consiste na adaptação instintiva do corpo ao meio. A última, que decorre da anterior e a transforma, é um atributo exclusivo do homem. A característica distintiva da forma mais elevada de atividade é o esforço deliberado do homem para transformar o seu ambiente. A atividade do homem tem um aspecto social e é determinada pelas condições sociais da vida. A atividade psíquica do homem pode ser externa ou interna. A primeira consiste em operações especificamente humanas com objetos existentes, realizadas pelo movimento de braços, mãos, dedos e pernas. A última se processa na mente por meio de "ações mentais", nas quais o homem não opera com objetos existentes através de movimentos físicos, mas com as imagens dinâmicas deles. A atividade interna planeja a externa e realiza-se através dela. A divisão do trabalho provoca uma diferenciação entre as formas teóricas e práticas de atividade do homem. De acordo com a variedade de necessidades do homem e da sociedade, surgem também variados tipos concretos de atividade, cada uma delas, geralmente, abrangendo elementos externos e internos, práticos e teóricos (FROLOV, 1984, p. 8 apud TOLMAN, 1988, p. 15, grifos nossos, tradução nossa). ${ }^{41}$

Analisemos o conteúdo deste longo fragmento.

Chama-se atividade uma relação específica do organismo com o ambiente. Ela responde a uma necessidade, que motiva, portanto, o organismo a se relacionar com seu meio. A categoria motivo, por sinal, é de grande importância para a compreensão da estrutura da atividade, apesar de não estar explicitada no fragmento acima. É a necessidade que fornece o

\footnotetext{
${ }^{41}$ Esta tradução foi cotejada com a realizada por Wellington Lima Cedro, à qual tive acesso durante a disciplina Princípios Teórico-Metodológicos de Psicologia Histórico-Cultural, ministrada na FFCLRP-USP pela Prof. Elaine Sampaio Araújo, em 2009.
} 
motivo para a realização de uma dada atividade. O motivo dirige a atividade a um determinado objeto, que irá satisfazer a necessidade. Toda atividade se orienta para um objeto; o motivo é o mediador entre estes elementos. Segundo Leontiev, o que diferencia uma atividade de outra é seu objeto, e não há atividade sem motivo.

A realização de uma atividade requer certas ações. Como a atividade se orienta para um objeto, a ação se orienta para um objetivo. As ações, por sua vez, se realizam mediante operações. O que determina quais operações irão compor uma ação serão as condições ambientais. Além disso, toda atividade possui um significado e um sentido; o significado é objetivo e reflete as propriedades do objeto a que a atividade se dirige; o sentido, por outro lado, tem caráter subjetivo.

Toda atividade interior, realizada no plano mental, foi um dia uma atividade exterior. O psiquismo é formado e se desenvolve pela interiorização das atividades, que possuem primeiro uma existência social, isto é, decorrem da atuação dos homens na prática, graças ao trabalho, contextualizado em determinadas relações de produção. Ou seja, a consciência nada mais é que o produto subjetivo da atividade objetiva do homem. Daí a importância metodológica de se tomar a atividade como objeto de estudo para a compreensão do processo de desenvolvimento humano.

Preenchamos de concretude estas categorias abstratas, aproveitando um exemplo proposto por Leontiev, no livro $O$ desenvolvimento do psiquismo (LEONTIEV, 1978): um estudante está lendo um livro, quando um colega lhe avisa que esta leitura não será necessária para nenhuma avaliação escolar. Diante disto, são possíveis dois desdobramentos: ou o estudante permanece lendo, mesmo diante do aviso do colega; ou detém sua leitura e não mais a retoma.

De acordo com as definições de Leontiev, a leitura, no primeiro caso, trata-se de uma atividade: o livro serve a uma necessidade objetivada nele, que é a necessidade de maior conhecimento. No segundo caso, a leitura seria apenas uma ação, e não uma atividade. $\mathrm{O}$ estudante não orienta sua leitura para o conteúdo objetivado no livro, mas para algo além, que é o sucesso na avaliação. A necessidade de ser bem avaliado é que motiva a atividade do estudante, sendo a leitura do livro apenas uma das ações que ele empreende para satisfazê-la. Por sua vez, a leitura é composta por operações: ler à mesa ou em um espaço aberto, dependendo das condições de iluminação, tomar notas numa folha à parte ou nas próprias margens do livro, e assim por diante. 
A coincidência do objeto com o motivo da necessidade é o que caracteriza a atividade. Se não há esta coincidência, trata-se de uma ação. Como o exemplo acima pode ter sugerido, uma das características destes processos - atividades, ações, operações - é sua possibilidade de se interconverterem. Se, mesmo advertido de que o livro não será requisitado nos exames, o estudante permanecer lendo-o, ocorreu que a ação (no interior da atividade de estudar para ser bem avaliado) transformou-se em uma atividade. Este é um aspecto de extrema importância, já que

É desta maneira, com efeito, que nascem novas actividades. É este processo que constitui a base psicológica concreta sobre a qual assentam as mudanças de actividade dominante e, por consequência, as passagens de um estádio de desenvolvimento a outro (ibidem, p. 293).

Infelizmente não dispomos de espaço para analisar mais profundamente o modo como todos estes conceitos se estruturam na teoria de Leontiev. Recorreremos novamente a ela no próximo capítulo. Por ora, voltemos a olhar para a teoria de Newton Duarte. Este estudioso nos falara de que cabe à prática pedagógica enriquecer os indivíduos com carecimentos nãocotidianos, isto é, incitar a que desenvolvam necessidades sempre mais elevadas, de modo a erigirem sua individualidade para-si. A teoria de Leontiev, que prevê o movimento de ações ascendendo a atividades, explica justamente o modo como estes carecimentos podem vir a se produzir. Por outro lado, Duarte se referira ao processo de alienação, que também encontra na teoria de Leontiev uma explicação em termos de seu mecanismo psicológico. De acordo com o psicólogo russo, quando o sentido de uma atividade não coincide com o significado objetivo cristalizado no objeto para o qual ela se orienta, ocorre efetivamente esta alienação.

Apesar desta exposição brevíssima e incompleta, a título de introdução, o leitor já deve estar convencido de que a teoria de Leontiev abrange muitos conceitos que vieram a encontrar ressonância nos textos brasileiros da Pedagogia Histórico-Crítica.

Desde a publicação do livro de Duarte de que tratamos, esta ressonância se intensificou. Em 2002 outra obra importante veio à luz: o livro de Suze Scalcon, intitulado À procura da unidade psicopedagógica: articulando a psicologia histórico-cultural com a pedagogia histórico-crítica (SCALCON, 2002). Segundo a autora,

a atenção dada pela psicologia à formação dos conceitos, justificada pelo fato de que os conteúdos histórico-culturais complexos ensejam um nível mais elevado de desenvolvimento psicológico, liga-se ao conhecimento sistematizado, o qual é o objeto específico do trabalho escolar para a pedagogia histórico-crítica, porque se trata de uma mesma preocupação. A psicologia, quando preocupada em explicar 
como o pensamento é formado diante de seu intercâmbio com a linguagem e em vista da construção do pensamento lógico, o qual é a base da compreensão dos sistemas científicos, tem no conhecimento sistematizado, na apreensão do conhecimento científico, por parte da criança, seu alvo principal (ibidem, p. 131).

Esta unidade psicopedagógica, atualmente, vem tornando difícil se falar em Pedagogia Histórico-Crítica sem qualquer menção à Psicologia Histórico-Cultural. No seminário Pedagogia Histórico-Crítica: 30 anos, realizado em Araraquara em 2009, a Prof. Lígia Márcia Martins, em sua fala sobre as relações entre as duas teorias, foi explícita e direta: o fundamento psicológico da Pedagogia Histórico-Crítica é a Psicologia Histórico-Cultural. Na publicação do texto que orientou sua exposição, àquela ocasião, constam também importantes considerações, e gostaríamos de reproduzir um longo fragmento seu:

Consideramos direito inalienável de todos os indivíduos o seu máximo desenvolvimento, cabendo à educação escolar trabalhar a serviço deste, promovendo a conquista das capacidades intelectuais das operações lógicas do pensamento, dos sentimentos éticos, enfim, de tudo que garanta, a cada indivíduo, a qualidade de ser humano. Porém, para a efetivação dessa conquista não podemos partir do princípio ingênuo de que quaisquer aprendizagens corroboram para sua realização e, nessa direção, urge superar os ideários que naturalizam a formação humana e preterem a inteligibilidade do real como necessariedade e direito de todos.

$\mathrm{Na}$ sociedade em que vivemos, universalizadora das relações de exploração do homem pelo homem, que usurpa da grande maioria das pessoas o direito a uma existência digna, a realidade, criada pelos próprios homens, não pode ser mero objeto de percepção, contemplação passiva e ação adaptativa. Preparar os indivíduos para seu controle e domínio demanda torná-la inteligível e objeto de ações transformadoras.

Tais ações exigem, necessariamente, um tipo de pensamento que promova a superação da empiria fetichizada, das aparências [...], instrumentalizando os indivíduos para a atividade consciente, para a transformação das circunstâncias e de si mesmos. É com essa tarefa que entendemos a educação escolar verdadeiramente emancipadora, e a serviço dela colocam-se tanto a pedagogia histórico-crítica quando a psicologia histórico-cultural (MARTINS, 2011, p. 56-57, grifos da autora).

Mas se já não é possível ignorar a Psicologia Histórico-Cultural quando se fala em Pedagogia Histórico-Crítica, será a recíproca verdadeira? Temos a impressão de que os autores soviéticos estão cada vez mais disseminados entre o meio de pesquisadores no campo da Educação, especialmente na especialidade da Educação em Ciências. Será que a apropriação da psicologia dialética russa, por estes autores, está acompanhada de referenciais pedagógicos igualmente dialéticos, e críticos?

Dedicaremos a próxima seção a investigar este aspecto, na primeira incursão desta tese no âmbito específico do ensino de Química. Tomando como objetos as publicações de um periódico da área, esboçaremos, com esta seção, uma espécie de "estado da arte", que avaliará as possibilidades de relacionamento entre a Psicologia Histórico-Cultural e a Educação em 
Química. Ao mesmo tempo, verificando o conteúdo das publicações em estudo, será possível abordarmos, ainda que superficialmente, alguns conceitos que nos escaparam à seção anterior.

\title{
2.3 APROPRIAÇÕES DA PSICOLOGIA HISTÓRICO-CULTURAL POR PESQUISAS DA EDUCAÇÃO EM QUÍMICA: UMA ANÁLISE42
}

Não é exagero afirmar que a própria identidade da Educação em Ciências, enquanto disciplina científica, deve sua constituição aos estudos de Jean Piaget. Afinal, da constatação da existência de concepções alternativas por parte dos aprendizes, até o desenvolvimento das chamadas estratégias de mudança conceitual, passando por propostas de atividades com a intenção de romper com o ensino tradicional, é explícita a influência de conceitos piagetianos como invariantes funcionais, períodos do desenvolvimento e tomada de consciência.

Nos últimos anos, no entanto, estas derivações ou aplicações práticas da epistemologia genética vêm sendo sistematicamente questionadas. Os educadores parecem ter encontrado na Psicologia Histórico-Cultural um referencial alternativo, supostamente capaz de explicar fenômenos de grande relevância no processo de ensino de ciências, mas para os quais as formulações de Piaget se mostrariam insuficientes. É o que se depreende da seguinte fala de Mortimer e Carvalho (1996, p. 6):

\begin{abstract}
A introdução do referencial teórico construído a partir dos escritos de Vygotsky permite perceber os limites de se trabalhar com a construção do conhecimento em sala de aula como resultado de construções individuais, ao introduzir elementos de análise que procuram revelar os aspectos sociais da sala de aula. Assim, a negociação dos significados entre professor e alunos e a forma como o professor se apropria dos conhecimentos dos alunos em seu sistema de explicação são aspectos fundamentais para entender a dinâmica de construção do conhecimento em sala de aula que ficariam ausentes numa abordagem puramente piagetiana.
\end{abstract}

Entretanto, buscaremos demonstrar, nesta seção, a tese de que a recorrência ao nome de Vigotski e de outros representantes da psicologia soviética, por parte destes pesquisadores da Educação em Ciências, não significa necessariamente que sua produção se apoia em uma compreensão aprofundada dos princípios teórico-metodológicos desta teoria, dos quais vimos falando ao longo da seção anterior.

\footnotetext{
${ }^{42}$ Parte desta seção foi apresentada no IX Encontro Nacional de Pesquisa em Educação em Ciências, realizado em 2013, em Águas de Lindóia (SP).
} 
A incompreensão ou a dissimulação destes princípios - radicados no materialismo histórico e no materialismo dialético - já foi sugerida por estudo anterior (SILVA; DAVIS, 2004), mas no caso de publicações do periódico Cadernos de Pesquisa, na área da Educação em geral. Esta reflexão ainda está por se iniciar quanto à Educação em Ciências no Brasil, e propomos aqui um ponto de partida.

Elegemos então, como um primeiro objeto de análise, os artigos de Química Nova na Escola (ou QNEsc, como costuma ser tratada pelo público e pelos editores), por ser a principal publicação brasileira voltada exclusivamente à subárea da Educação em Química.

\subsubsection{Artigos de Química Nova na Escola: características e critérios de seleção para este estudo}

O olhar retrospectivo de Eduardo F. Mortimer, membro do corpo editorial de QNESC desde seu primeiro número, relata que a revista surgiu do anseio dos educadores químicos do Brasil por um veículo que contemplasse "uma variada gama de interesses das pessoas ligadas profissionalmente ao ensino de Química" e que produzisse "uma revista inovadora, ousada, mas simples e direta" (MORTIMER, 2004, p. 3). O marco de seu nascimento foi o VII Encontro Nacional de Ensino de Química (Eneq), realizado em Belo Horizonte em 1994. Os dois números iniciais vieram à luz em 1995 e a periodicidade permaneceu semestral até 2007. Desde 2008 são lançados quatro volumes por ano.

Embora inspirada em outras publicações quanto a conteúdos admitidos e modo de arbitragem, QNESC se diferencia de revistas congêneres pelo layout e, principalmente, por seus públicos-alvo, pois a revista se dirige também a professores da educação básica.

As seções que compõem o periódico são: Química e sociedade, Educação em Química e multimídia, Espaço aberto, Conceitos científicos em destaque, História da Química, Atualidades em Química, Relatos de sala de aula, Pesquisa em ensino, O aluno em foco, Experimentação no ensino de Química e Elemento químico.

Até o momento, registram-se aproximadamente 11 artigos por volume de QNESC. Colen (2012), em outra retrospectiva (dos 17 anos da revista), demonstra que eles se concentram nas seções Experimentação no ensino de Química, Relatos de sala de aula, Pesquisa no ensino de Química e Química e sociedade, onde estão quase 60\% dos 439 textos 
publicados entre 1995 e 2011. E se aos dez anos de QNEsc afirmava Mortimer que as seções O aluno em foco e Pesquisa no ensino de Química não estavam contempladas em todos os volumes da revista, ao menos esta última vem recebendo um número crescente de submissões.

Para este estudo, selecionamos todos os artigos publicados em QNEsc, entre 1995 a 2012, que mencionassem em suas referências uma ou mais obras de autores da Psicologia Histórico-Cultural. No sítio da internet www.vigotski.net a listagem destes nomes compreende, além de Leontiev, Luria e Vigotski, também: Pavel Petrovitch Blonski (18841941), Lídia Ilinitchna Bojóvitch (1908-1981), Vasíli Valíl'evitch Davídov (1930-1998), Daniil Borisovitch Elkonin (1904-1984), Piotr Iakovlevitch Galperin (1902-1988), Serguei Leonidovitch Rubinshtein (1889-1960), Vladimir Aleksandrovitch Vagner (1849-1934) e Aleksandr Vladimirovitch Zaporójets (1905-1981).

O levantamento compilou 22 artigos, distribuídos entre as seções Relatos de sala de aula, Pesquisa em ensino de Química, O aluno em foco, Conceitos científicos em destaque, Espaço aberto e Experimentação no ensino de Química. Os textos selecionados foram lidos, registrando-se quais escritos da Psicologia Histórico-Cultural aparecem neles referenciados, quais são as palavras-chaves que eles indicam e em quais seções da revista foram publicados. As informações sobre os artigos selecionados estão sumarizadas no quadro da Figura 6.

A impressão de que os autores da Psicologia Histórico-Cultural vêm sendo mencionados mais frequentemente se confirma pelos indicadores quantitativos do levantamento: do primeiro número de QNEsc, em 1995, até o ano 2000, há 5 trabalhos que citam obras associadas à psicologia soviética; de 2001 a 2010, são 6; e de 2011 a 2012 (ano que encerra o levantamento), tratam-se de 11 artigos. De modo mais claro, são 11 trabalhos publicados até 2010, e a mesma quantidade publicada apenas nos dois anos seguintes.

Poder-se ia argumentar que a partir de 2008, com uma maior periodicidade da revista, naturalmente cresceria a quantidade de trabalhos com menções a Vigotski e seus colegas. Mas o fato é que durante os anos 1990 e 2000 os volumes contendo algum artigo com tais menções são exceção - apenas 12 em 38. A partir de 2011, a exceção se converte em regra, e somente 2 em 8 volumes do periódico não apresentam textos que mencionem os soviéticos.

Nestes 22 trabalhos levantados, 15 obras diferentes, de autores da psicologia soviética, foram referenciadas. Ao todo, trata-se de 36 referências bibliográficas a estas obras, o que perfaz uma média de 1,6 referência/trabalho. O quadro da Figura 7 apresenta quais obras foram referenciadas por quais trabalhos, e estes dados serão discutidos a seguir. 


\begin{tabular}{|c|c|c|}
\hline Autor(es) e ano & Título & Seção* \\
\hline $\begin{array}{l}\text { Maldaner e Piedade, } \\
1995\end{array}$ & $\begin{array}{l}\text { "Repensando a Química: a formação de equipes de professores/pesquisadores } \\
\text { como forma eficaz de mudança da sala de aula de Química" }\end{array}$ & RSA \\
\hline $\begin{array}{l}\text { Machado e Moura, } \\
1995\end{array}$ & $\begin{array}{l}\text { "Concepções sobre o papel da linguagem no processo de elaboração conceitual } \\
\text { em Química" }\end{array}$ & PEQ \\
\hline Echeverría, 1996 & "Como os estudantes concebem a formação de soluções" & $\mathrm{AF}$ \\
\hline Romanelli, 1996 & "O papel mediador do professor no ensino-aprendizagem do conceito átomo" & PEQ \\
\hline Machado, 2000 & "Pensando e falando sobre os fenômenos químicos" & $\mathrm{AF}$ \\
\hline Rosa e Rossi, 2002 & "Mediação interdisciplinar na construção de um projeto de ensino de Química" & PEQ \\
\hline $\begin{array}{l}\text { Martins, Santa Maria } \\
\text { e Aguiar, } 2003\end{array}$ & "As drogas no ensino de Química" & RSA \\
\hline Gauche et al., 2008 & "Formação de professores de Química: concepções e proposições" & (IA) \\
\hline $\begin{array}{l}\text { Oliveira, Gouveia e } \\
\text { Quadros, } 2009\end{array}$ & $\begin{array}{l}\text { "Uma reflexão sobre a aprendizagem escolar e o uso do conceito de } \\
\text { solubilidade/miscibilidade em situações do cotidiano: concepções dos } \\
\text { estudantes" }\end{array}$ & CCD \\
\hline \begin{tabular}{l|l} 
Nery e Maldaner, \\
2009
\end{tabular} & $\begin{array}{l}\text { "Ações interativo-reflexivas na formação continuada de professores: o Projeto } \\
\text { Folhas" }\end{array}$ & PEQ \\
\hline Santos e Michel, 2009 & "Vamos jogar uma SueQuímica?" & EA \\
\hline \begin{tabular}{l|l} 
Godoi, Oliveira e \\
Codognoto, 2010
\end{tabular} & $\begin{array}{l}\text { "Tabela periódica: um Super Trunfo para alunos do ensino fundamental e } \\
\text { médio" }\end{array}$ & EA \\
\hline $\begin{array}{l}\text { Benite, Benite e } \\
\text { Echeverría, } 2010\end{array}$ & $\begin{array}{l}\text { "A pesquisa na formação de formadores de professores: em foco, a educação } \\
\text { química" }\end{array}$ & PEQ \\
\hline $\begin{array}{l}\text { Pereira, Benite e } \\
\text { Benite, } 2011\end{array}$ & "Aula de Química e surdez: sobre interações pedagógicas mediadas pela visão" & $\mathrm{AF}$ \\
\hline Maceno et al., 2011 & $\begin{array}{l}\text { "A matriz de referência do ENEM } 2009 \text { e o desafio de recriar o currículo de } \\
\text { Química na educação básica" }\end{array}$ & EA \\
\hline $\begin{array}{l}\text { Santos e Aquino, } \\
2011\end{array}$ & $\begin{array}{l}\text { "Utilização do cinema na sala de aula: aplicação da Química dos perfumes no } \\
\text { ensino de funções orgânicas oxigenadas e bioquímica" }\end{array}$ & RSA \\
\hline $\begin{array}{l}\text { Sangiogo e Zanon, } \\
2012\end{array}$ & $\begin{array}{l}\text { "Reflexões sobre modelos e representações na formação de professores com } \\
\text { foco na compreensão conceitual da catálise enzimática" }\end{array}$ & CCD \\
\hline Cunha, 2012 & $\begin{array}{l}\text { "Jogos no ensino de Química: considerações teóricas para sua utilização em } \\
\text { sala de aula" }\end{array}$ & PEQ \\
\hline Silva e Abreu, 2012 & "Aulas coletivas na escola pública: interação entre universidade-escola" & RSA \\
\hline Vaz et al., 2012 & "Uma experiência didática sobre viscosidade e densidade" & EEQ \\
\hline Amaral, 2012 & $\begin{array}{l}\text { "Avaliando contribuições para a formação docente: uma análise de atividades } \\
\text { realizadas no PIBID-Química da UFRPE" }\end{array}$ & (PIBID) \\
\hline Focetola et al., 2012 & "Os jogos educacionais de cartas como estratégia de ensino em Química" & (PIBID) \\
\hline
\end{tabular}

Figura 6: quadro com os artigos que fazem referência a obras da Psicologia Histórico-Cultural publicados em QNEsc, dispondo autores e anos, títulos e seções em que foram incluídos. (* RSA: Relatos de sala de aula; PEQ:

Pesquisa em ensino de Química; AF: O aluno em foco; CCD: Conceitos científicos em destaque; EA: Espaço aberto; EEQ: Experimentação no ensino de Química; (IA) e (PIBID) se referem a seções não permanentes, veiculadas em números especiais, a primeira abarcando artigos em colaboração com pesquisadores iberoamericanos, e a segunda tratando do Programa Institucional de Bolsa de Iniciação à Docência-Pibid). 


\begin{tabular}{|c|c|c|c|c|}
\hline Autor(es) & Título & Tradutor(es) & Ano* & Trabalho(s) que referencia $(m)$ \\
\hline $\begin{array}{l}\text { Vygotsky, L. } \\
\text { S. }\end{array}$ & Pensamento e linguagem & Jefferson L. Camargo & $\begin{array}{l}1987(4) \\
1989(2) \\
1991(1) \\
1993(1) \\
2003(1)\end{array}$ & $\begin{array}{l}\text { Maldaner e Piedade, } 1995 \\
\text { Machado e Moura, } 1995 \\
\text { Romanelli, 1996 } \\
\text { Machado, 2000 } \\
\text { Rosa e Rossi, 2002 } \\
\text { Martins, Santa Ma e Aguiar, } 2003 \\
\text { Oliveira, Gouveia e Quadros, } 2009 \\
\text { Nery e Maldaner, } 2009 \\
\text { Silva e Abreu, 2012 } \\
\end{array}$ \\
\hline $\begin{array}{l}\text { Vygotsky, L. } \\
\text { S. }\end{array}$ & $\begin{array}{l}\text { A formação social da mente: } \\
\text { o desenvolvimento dos } \\
\text { processos psicológicos } \\
\text { superiores }\end{array}$ & $\begin{array}{l}\text { José Cipolla Neto, } \\
\text { Luís S. Menna } \\
\text { Barreto, } \\
\text { Solange Castro } \\
\text { Afeche }\end{array}$ & $\begin{array}{l}1984(1) \\
1988(4) \\
1989(2) \\
1991(1) \\
2010(1)\end{array}$ & $\begin{array}{l}\text { Maldaner e Piedade, } 1995 \\
\text { Machado e Moura, } 1995 \\
\text { Romanelli, } 1996 \\
\text { Santos e Michel, } 2009 \\
\text { Godoi, Oliveira e Codognoto, } 2010 \\
\text { Santos e Aquino, } 2011 \\
\text { Silva e Abreu, } 2012 \\
\text { Cunha, 2012 } \\
\text { Focetola } \text { et al., } 2012 \\
\end{array}$ \\
\hline $\begin{array}{l}\text { Vygotsky, L. } \\
\text { S. }\end{array}$ & $\begin{array}{l}\text { A construção do pensamento e } \\
\text { da linguagem }\end{array}$ & Paulo Bezerra & 2001 & $\begin{array}{l}\text { Gauche et al. } 2008 \\
\text { Nery e Maldaner, } 2009 \\
\text { Benite, Benite e Echeverría, } 2010 \\
\text { Maceno } \text { et al., } 2011 \\
\text { Sangiogo e Zanon, } 2012 \\
\text { Silva e Abreu, 2012 } \\
\text { Vaz, Acciari e Codaro, } 2012\end{array}$ \\
\hline $\begin{array}{l}\text { Vygotsky, L. } \\
\text { S.; Luria, A. } \\
\text { R.; Leontiev, } \\
\text { A. N. }\end{array}$ & $\begin{array}{l}\text { Linguagem, desenvolvimento e } \\
\text { aprendizagem }\end{array}$ & $\begin{array}{l}\text { Maria da P. } \\
\text { Villalobos }\end{array}$ & 1989 & Machado e Moura, 1995 \\
\hline $\begin{array}{l}\text { Vygotsky, L. } \\
\text { S. }\end{array}$ & $\begin{array}{l}\text { "Play and its role in the mental } \\
\text { development of the child" }\end{array}$ & $\begin{array}{l}\text { Catherine } \\
\text { Mulholland }\end{array}$ & 1967 & Focetola et al., 2012 \\
\hline $\begin{array}{l}\text { Vygotski, L. } \\
\text { S. }\end{array}$ & $\begin{array}{l}\text { Obras escogidas } V: \\
\text { fundamentos de defectología }\end{array}$ & $\begin{array}{l}\text { Julio Guillermo } \\
\text { Blank }\end{array}$ & 1997 & Pereira, Benite e Benite, 2011 \\
\hline Luria, A. R. & $\begin{array}{l}\text { Desenvolvimento } \\
\text { cognitivo: seus fundamentos } \\
\text { culturais } \\
\text { e sociais }\end{array}$ & $\begin{array}{l}\text { Fernando L. } \\
\text { Gurgueira }\end{array}$ & 1994 & Machado e Moura, 1995 \\
\hline Luria, A. R. & $\begin{array}{l}\text { Pensamento e linguagem: as } \\
\text { últimas conferências de Luria }\end{array}$ & $\begin{array}{l}\text { Diana M. } \\
\text { Lichtenstein, Mario } \\
\text { Corso }\end{array}$ & $\begin{array}{l}1986 \\
1987\end{array}$ & $\begin{array}{l}\text { Machado e Moura, } 1995 \\
\text { Pereira, Benite e Benite, } 2011\end{array}$ \\
\hline $\begin{array}{l}\text { Luria, A. R.; } \\
\text { Yudovich, F. } \\
\text { I. }\end{array}$ & $\begin{array}{l}\text { Linguagem e desenvolvimento } \\
\text { intelectual na criança }\end{array}$ & José C. de A. Abreu & 1985 & Machado e Moura, 1995 \\
\hline Leontiev, A. & $\begin{array}{l}\text { O desenvolvimento do } \\
\text { psiquismo }\end{array}$ & Manuel Dias Duarte & 1978 & $\begin{array}{l}\text { Machado e Moura, } 1995 \\
\text { Amaral, } 2012\end{array}$ \\
\hline Leontiev, A. & $\begin{array}{l}\text { "The problem of activity in } \\
\text { psychology" }\end{array}$ & James V. Wertsch & 1981 & Amaral, 2012 \\
\hline Leontiev, A. & $\begin{array}{l}\text { Atividade, consciência e } \\
\text { personalidade }\end{array}$ & $\begin{array}{l}\text { Maria Silvia Cintra } \\
\text { Martins }\end{array}$ & 1983 & Amaral, 2012 \\
\hline $\begin{array}{l}\text { Elkonin, D. } \\
\text { B. }\end{array}$ & Psicologia do jogo & A. Cabral & 1998 & Cunha, 2012 \\
\hline Davídov, V. & $\begin{array}{l}\text { La enseñanza escolar y el } \\
\text { desarrollo psíquico: } \\
\text { investigación psicológica } \\
\text { teórica y experimental }\end{array}$ & Martha Shuare & 1988 & Echeverría, 1996 \\
\hline
\end{tabular}

Figura 7: quadro com informações sobre as obras de autores da Psicologia Histórico-Cultural referenciadas pelos artigos de QNEsc. (* Entre parênteses, a quantidade de citações por edição). 


\subsubsection{Fontes e autores da Psicologia Histórico-Cultural referenciados}

Ao iniciarmos o levantamento, já imaginávamos que as obras A formação social da mente e Pensamento e linguagem seriam as mais referenciadas entre os artigos que constituiriam nosso corpus. Afinal, são estas as duas primeiras obras de Vigotski traduzidas e publicadas no Brasil, ambas pela editora Martins Fontes, em 1984 e 1987, respectivamente. Cada um destes livros foi referenciado por nove trabalhos, sendo quatro que referenciam ambos. Também são nove os trabalhos que referenciam apenas estes livros (somente um deles ou ambos).

A rigor, A formação social da mente trata-se de uma obra não "prevista" por Vigotski, publicada postumamente como uma coletânea de textos organizada por pesquisadores estadunidenses, que providenciaram não apenas sua tradução, mas atuaram verdadeira e assumidamente como editores:

O leitor não deve esperar encontrar uma tradução literal de Vigotski, mas, sim, uma tradução editada da qual omitimos as matérias aparentemente redundantes e à qual acrescentamos materiais que nos pareceram importantes no sentido de tornar mais claras as idéias de Vigotski. [...] ao mexer nos originais poderíamos estar distorcendo a história; entretanto, acreditamos também que, deixando claro nosso procedimento e atendo-nos o máximo possível aos princípios e conteúdos dos trabalhos, não distorceremos os conceitos originalmente expressos por Vigotski (COLE et al., 2007, p. xvi-xv).

Pensamento e linguagem foi o nome recebido pela primeira edição brasileira de Michlenie $i$ retch. Impressa pela Martins Fontes, trata-se de uma tradução da versão resumida da obra, publicada nos Estados Unidos em 1962. Vale a pena conhecermos também as palavras do prefácio dos editores:

Ao traduzir o livro, simplificamos e tornamos mais claro o estilo de Vigotski, ao mesmo tempo em que nos esforçamos para reproduzir com exatidão o seu sentido. A organização interna dos capítulos foi preservada, exceto no Capítulo 2, onde omissões externas resultaram em uma reestruturação do texto e em um número extremamente reduzido de subdivisões.

Embora nossa tradução mais compacta pudesse ser considerada uma versão simplificada do original, sentimos que a condensação aumentou a clareza e a legibilidade do texto, sem qualquer perda quanto ao conteúdo do pensamento ou à informação factual (HANFMANN; VAKAR, 2005, p. xvi).

O fato destas duas obras não serem, portanto, exatamente fiéis às palavras originais de Vigotski é objeto de crítica por parte de muitos pesquisadores. Já em 1996 Newton Duarte 
havia demonstrado sua preocupação em relação aos estudos apoiados apenas nestes dois livros, por vezes portando-se como representantes da "teoria sócio-histórica de Vigotski”, sem um aprofundamento em outras obras dos autores soviéticos já disponíveis no Brasil:

\begin{abstract}
Por incrível que pareça Vigotski vem tornando-se muito famoso no Brasil antes mesmo de ser conhecido "pessoalmente", através de seus próprios escritos, sem tradutores que procurem "aprimorar" seu estilo de escrita. Essa limitação do estudo de Vigotski a apenas duas obras reescritas torna preocupante a multiplicação de textos divulgadores, que apresentam como sendo o pensamento de Vigotski aquilo que, na verdade, deveria ser apresentado como algumas idéias parciais e provisórias de quem está estudando Vigotski (DUARTE, 1996, p. 20, grifo nosso).
\end{abstract}

Em 2001 foi editada uma nova versão brasileira de Michlenie $i$ retch, também pela Martins Fontes. Traduzida diretamente do russo pelo professor Paulo Bezerra, da USP, a obra foi intitulada desta vez A construção do pensamento e da linguagem, como já mencionado. Esta tradução apresentou a versão integral do texto de Vigotski, com cerca de 300 páginas a mais em relação à edição resumida, justificando o comentário de Zoia Prestes ${ }^{43}$ de que esta última não passa de "uma demonstração da ação de violência contra a produção científica de um pensador e, sem exageros, deve ser vista como uma das maiores agressões à obra de Vigotski [...]" (PRESTES, 2012, p. 61).

A primeira referência à tradução de Paulo Bezerra em QNEsc ocorrerá somente sete anos após sua publicação, como se observa na Figura 7, e até 2012 mais seis trabalhos o farão. Algo interessante a se observar é que, entre os autores destes sete trabalhos, há quase sempre nomes de prestígio e projeção nacional na área de Educação em Química. Ou seja, a presença de algum destes pesquisadores de maior reconhecimento entre os autores dos artigos parece ter repercutido numa seleção mais criteriosa das fontes da Psicologia Histórico-Cultural a serem referenciadas. Mas a maioria destes trabalhos apresenta somente A construção do pensamento e da linguagem entre as referências aos textos da Psicologia Histórico-Cultural. Curiosamente, os únicos dois artigos que não mencionam apenas a tradução de Paulo Bezerra fazem referência também à edição resumida Pensamento e linguagem - lembrando que a versão completa de Michlenie $i$ retch não apenas abrange como supera o texto editado pelos pesquisadores dos Estados Unidos.

De qualquer maneira, se tanto Prestes quanto Duarte saudaram a tradução de Paulo Bezerra como um evento importante e positivo na história da Psicologia Histórico-Cultural no Brasil, ambos também apresentaram críticas ao modo como termos e conceitos foram

\footnotetext{
${ }^{43}$ Educadora e tradutora, foi alfabetizada em russo e vem se dedicando, nos últimos anos, a novas traduções para o português de obras da Psicologia Histórico-Cultural, a partir das publicações soviéticas originais.
} 
reapresentados nesta edição. Duarte (2006) demonstra a inconsistência dos argumentos do tradutor pela escolha da expressão "zona de desenvolvimento imediato" em substituição a "zona de desenvolvimento proximal", termo pelo qual o conceito de zona blijaichego razvitia ficou conhecido no Brasil, além de aventar que o título escolhido para a nova edição poderia dar a entender que a psicologia soviética afilia-se ao construtivismo. Prestes (2012) reforçou a crítica de Duarte e propôs o termo “zona de desenvolvimento iminente”, demonstrando também que a palavra retch do título da obra deveria ser traduzida como "fala" e não "linguagem", e que o conceito de obutchenie, que Bezerra traduz como "aprendizagem", tem um sentido mais próximo de "instrução". (Daí as nossas advertências ao leitor, no decorrer da seção passada, quanto à leitura dos fragmentos que transcrevemos das obras de Vigotski).

Embora as referências em QNEsc a obras da Psicologia Histórico-Cultural raramente ultrapassem estes três livros - A formação social da mente, Pensamento e linguagem e A construção do pensamento e da linguagem -, podemos comentar algo sobre os outros títulos que aparecem na Figura 7.

Dois artigos citam o livro publicado no Brasil como Pensamento e linguagem: as últimas conferências de Luria. Prestes, que classifica tal título como uma "evidente jogada de marketing", afirma que

A irresponsabilidade dessa publicação é tamanha que, além de não dizer se foi traduzida do russo - pois indica somente que "a obra foi originalmente publicada em russo sob o titulo Iazik \& Sosnanie -, confunde, ao longo da tradução do texto do livro, linguagem e língua, linguagem e fala. Além do que, a palavra soznanie não quer dizer pensamento e sim consciência (ibidem, p. 146, grifos da autora).

No mesmo trabalho, Prestes acrescenta as seguintes informações sobre outras obras referenciadas nos artigos de QNEsc: na coletânea Linguagem, desenvolvimento $e$ aprendizagem, publicada pela Ícone em 1988, a tradução também confunde instrução com aprendizagem, e traduz o conceito de veduchaia deiatelnost ("atividade guia") de Leontiev como "atividade predominante" ou "atividade principal"; e o livro de Elkonin, Psirrologuia igri, deveria ter recebido o título em português de "Psicologia do brincar", em vez de Psicologia do jogo.

A propósito, há um ensaio importante de Vigotski, "Igra e ieio rol v psikhitcheskom razvitii rebionka", resumido na coletânea $A$ formação social da mente, e que é referenciado por dois artigos de QNEsc: em um trabalho, através desta coletânea; em outro, numa versão em inglês publicada em 1967 no periódico Soviet psychology. Este texto, que ficou conhecido no Brasil como "O papel do brinquedo no desenvolvimento", recebeu uma tradução 
diretamente do russo também por Zoia Prestes, com o título "A brincadeira e o seu papel no desenvolvimento psíquico da criança" (VIGOTSKI, 2008). Os dois artigos de QNESc que referenciam o texto foram publicados em 2012, mas parecem não conhecer esta tradução lançada quatro anos antes. Na próxima subseção voltaremos a falar deles.

E por que chamamos a atenção para estas substiuições, acima - de "atividade guia" por "atividade principal", de "o brincar" por "o jogo", de "a brincadeira" por "o brinquedo"? Ora, o conceito de atividade guia, de Leontiev, é fundamental para a Psicologia HistóricoCultural. Como apresentamos na seção anterior, a teoria da atividade permite explicar como os indivíduos se apropriam das objetivações históricas, vindo a participar da comunidade de seres humanos genéricos (isto é, pertencentes não apenas à espécie, mas ao gênero humano). Já a atividade guia elucida as etapas ou períodos do desenvolvimento humano sem a menção a aspectos idealistas, ou sem se recorrer à naturalização do desenvolvimento psíquico humano. De acordo com Leontiev (1978), a atividade guia possui três características: 1) ela se diferencia em novas atividades; 2) ela provoca a reorganização dos processos psíquicos; e 3) é aquela da qual dependem as mudanças psicológicas fundamentais da personalidade, numa dada etapa de seu desenvolvimento. Leontiev, então, determina a existência de quatro tipos de atividade guia na atualidade:

A apropriação da realidade material que circunda imediatamente a criança, o jogo [brincadeira] através do qual a criança toma posse de uma esfera mais larga de fenómenos e relações humanas, a formação sistemática na escola, finalmente a sua formação especializada ou a actividade de trabalho, tal é a sucessão das atividades dominantes [atividades guia], das relações dominantes que podemos constatar na nossa época e nas nossas condições (ibidem, p. 294).

Veja-se que esta sucessão de atividades oferece um modelo inteiramente distinto daquele proposto por Piaget para a periodização do desenvolvimento infantil, baseado essencialmente na maturação de estruturas lógicas - disparada pelo contato com a realidade, é verdade, mas ainda assim um processo universal e a-histórico. Leontiev, ao contrário, afirma:

Se bem que os estádios do desenvolvimento tenham um lugar determinado no tempo, os seus limites dependem, portanto, do seu conteúdo, o qual é por sua vez determinado pelas condições históricas concretas em que se desenrola o desenvolvimento da criança.

Assim, não é a idade da criança que determina, enquanto tal, o conteúdo do estádio de desenvolvimento, mas, pelo contrário, a idade de passagem de um estádio a outro que depende do seu conteúdo e que muda com as condições socio-históricas (ibidem, loc. cit). 
Se o ensino é a atividade guia da idade escolar, é porque ele aparece pela primeira vez na idade pré-escolar, participando da atividade guia da brincadeira - a criança começa a aprender brincando, diz Leontiev. Daí a importância de se compreender de modo mais exato possível as ideias de Vigotski e de Leontiev a respeito desta atividade guia, o que as traduções de seus textos disponíveis no Brasil nem sempre facilitam.

Zoia Prestes e Newton Duarte, nas obras citadas, reportam também a percepção de um movimento que busca distanciar os nomes de Leontiev e de Vigotski, como se entre um e outro a relação fosse antes de ruptura que de continuidade, talvez pelo fato dos textos mais acessíveis de Leontiev adotarem um estilo marcantemente militante em prol de uma sociedade socialista. Este movimento tem se valido de estratégias expressas sobretudo no mascaramento dos embriões do conceito de atividade na obra de Vigotski, fazendo parecer que Leontiev o teria elaborado de modo independente. Uma leitura mais cuidadosa de Vigotski, no entanto, demonstra que o conceito de atividade guia, por exemplo, já aparecia esboçado em suas ideias sobre a importância da brincadeira para o desenvolvimento psíquico infantil. O uso das palavras "jogo" e "brinquedo" para traduzir o termo russo igra (em inglês, play) dificulta seu entendimento enquanto processo do qual decorrem o desenvolvimento da abstração e da generalização, exigidas pela imaginação ativa; a apropriação de funções sociais e de normas de comportamento, graças ao jogo de papeis; e o surgimento da atividade guia da idade escolar, isto é, o ensino.

\subsubsection{Palavras-chaves}

Na Figura 8 apresentamos quais palavras-chaves são indicadas em cada um dos artigos levantados. Elas foram agrupadas no quadro da Figura 9, distribuídas entre cinco categorias (tendo sido excluídas aquelas relacionadas a conteúdos específicos de Química): âmbito, referente à localidade, nível ou modalidade de ensino, política ou projeto investigado pelos artigos; docência, abrangendo palavras relacionadas à formação e a prática de professores; métodos e recursos didáticos, cujo título é autoexplicativo; currículo e avaliação, que abarcou palavras historicamente relacionadas a estes elementos da educação; e psicologia, que abarcou palavras e expressões típicas dos referenciais psicológicos adotados pelos artigos. As células, neste quadro, se referem a subcategorias. 


\begin{tabular}{|c|c|}
\hline Autor(es) e ano & Palavras-chaves \\
\hline Maldaner e Piedade, 1995 & $\begin{array}{l}\text { ensino/aprendizagem em química; ensino médio; interação; mediação; linguagem } \\
\text { química; aprendizagem e desenvolvimento; ensino e pesquisa; educação química }\end{array}$ \\
\hline Machado e Moura, 1995 & linguagem; elaboração conceitual; ensino-aprendizagem \\
\hline Echeverría, 1996 & solução; dissolução; relação empírico-teórica \\
\hline Romanelli, 1996 & átomo; conceito de modelo; mediação do professor \\
\hline Machado, 2000 & ensino-aprendizagem; elaboração conceitual; equações químicas \\
\hline Rosa e Rossi, 2002 & formação docente; projeto de ensino; licenciatura \\
\hline $\begin{array}{l}\text { Martins, Santa } M^{\mathrm{a}} \text { e Aguiar, } \\
2003\end{array}$ & drogas; Química Orgânica; interdisciplinaridade \\
\hline Gauche et al., 2008 & formação de professores; ensino de química; Licenciatura em Química \\
\hline $\begin{array}{l}\text { Oliveira, Gouveia e } \\
\text { Quadros, } 2009\end{array}$ & concepções alternativas; ensino de química; aprendizagem \\
\hline Nery e Maldaner, 2009 & projeto folhas; formação continuada; professores de química da educação básica \\
\hline Santos e Michel, 2009 & força de ácidos orgânicos e inorgânicos; constante de ionização; jogo didático \\
\hline $\begin{array}{l}\text { Godoi, Oliveira e } \\
\text { Codognoto, } 2010\end{array}$ & jogos didáticos; Tabela Periódica; métodos de ensino \\
\hline $\begin{array}{l}\text { Benite, Benite e Echeverría, } \\
2010\end{array}$ & formação de formadores; educação química; prática docente; pesquisa-ação \\
\hline $\begin{array}{l}\text { Pereira, Benite e Benite, } \\
2011\end{array}$ & surdez; ensino de química; mediação pedagógica; recursos visuais \\
\hline Maceno et al., 2011 & ENEM; currículo; matriz de referência \\
\hline Santos e Aquino, 2011 & cinema; perfumes; química orgânica \\
\hline Sangiogo e Zanon, 2012 & modelos e representações; enzimas e catálise enzimática; formação de professores \\
\hline Cunha, 2012 & recurso; jogos; educação lúdica \\
\hline Silva e Abreu, 2012 & aula coletiva; escola; professores de química \\
\hline Vaz et al., 2012 & ensino de química; viscosidade; densidade \\
\hline Amaral, 2012 & PIBID; atividades; formação docente \\
\hline Focetolaet al., 2012 & jogos educacionais; ligação química; funções inorgânicas \\
\hline
\end{tabular}

Figura 8: quadro com autores e anos dos artigos que fazem referência a obras da Psicologia Histórico-Cultural publicados em QNESc, e as palavras-chaves que indicam.

\begin{tabular}{|c|c|c|c|c|}
\hline Âmbito & Docência & $\begin{array}{l}\text { Métodose } \\
\text { recursos didáticos }\end{array}$ & $\begin{array}{l}\text { Currículo e } \\
\text { avaliação }\end{array}$ & Psicologia \\
\hline $\begin{array}{l}\text { ensino médio; } \\
\text { escola; } \\
\text { professores de } \\
\text { química na } \\
\text { educação básica }\end{array}$ & $\begin{array}{l}\text { formação docente } \\
\text { (2); formação de } \\
\text { professores (2); } \\
\text { formação } \\
\text { continuada; } \\
\text { formação de } \\
\text { formadores }\end{array}$ & $\begin{array}{l}\text { jogo didático; } \\
\text { jogos didáticos; } \\
\text { jogos; educação } \\
\text { lúdica; jogos } \\
\text { educacionais }\end{array}$ & currículo & $\begin{array}{c}\text { ensino/aprendizagem em } \\
\text { química; ensino- } \\
\text { aprendizagem (2); } \\
\text { aprendizagem; aprendizagem } \\
\text { e desenvolvimento }\end{array}$ \\
\hline $\begin{array}{c}\text { licenciatura; } \\
\text { Licenciatura em } \\
\text { Química } \\
\end{array}$ & $\begin{array}{l}\text { professores de } \\
\text { química }\end{array}$ & $\begin{array}{l}\text { recursos visuais; } \\
\text { cinema }\end{array}$ & matriz de referência & $\begin{array}{c}\text { mediação; mediação do } \\
\text { professor; mediação } \\
\text { pedagógica; interação }\end{array}$ \\
\hline $\begin{array}{l}\text { projeto folhas; } \\
\text { ENEM; PIBID }\end{array}$ & prática docente & $\begin{array}{c}\text { recurso; } \\
\text { atividades; } \\
\text { métodos de ensino }\end{array}$ & interdisciplinaridade & $\begin{array}{l}\text { linguagem química; } \\
\text { linguagem }\end{array}$ \\
\hline surdez & ensino e pesquisa & projeto de ensino & & elaboração conceitual (2) \\
\hline \multirow[t]{3}{*}{$\begin{array}{l}\text { educação } \\
\text { química (2); } \\
\text { ensino de } \\
\text { química (4) }\end{array}$} & & pesquisa-ação & & relação empírico-teórica \\
\hline & & aula coletiva & & $\begin{array}{c}\text { conceito de modelo; modelos } \\
\text { e representações }\end{array}$ \\
\hline & & & & concepções alternativas \\
\hline
\end{tabular}

Figura 9: palavras-chaves dos artigos de QNEsc que fazem referência a obras da Psicologia Histórico-Cultural, distribuídas pelas categorias âmbito, docência, métodos e recursos didáticos, currículo e avaliação e psicologia.

Os parênteses indicam a quantidade de repetições de uma mesma palavra-chave. 
Chama a atenção na Figura 9, na categoria docência, a recorrência de termos relacionados à formação de professores, o que indica que os pesquisadores vêm buscando alternativas, na Psicologia Histórico-Cultural, aos autores consolidados neste campo. São seis artigos que trazem estas palavras-chaves, cinco deles citando apenas as obras Pensamento $e$ linguagem e/ou A construção do pensamento e da linguagem. $\mathrm{O}$ artigo que se diferencia é o de Amaral (2012), que se vale da teoria de Leontiev (referenciado por três textos diferentes) para analisar a atuação de licenciandos no âmbito do Pibid. Não iremos nos ater ao modo como tais trabalhos se apropriam dos termos e conceitos da Psicologia Histórico-Cultural, mas não podemos deixar de observar uma característica que se manifesta em alguns deles e em outros dos 21 artigos levantados por nós. Trata-se de uma espécie de ecletismo quanto à definição dos referenciais teóricos para a condução das pesquisas, em que autores e teorias de orientações filosóficas diversas, às vezes conflitantes, são utilizados para explicar diferentes fatos constatados nas realidades investigadas. Um exemplo dessa atitude seria a escolha dos autores soviéticos, para a interpretação do processo de aprendizagem dos conceitos químicos, ao mesmo tempo em que se recorre à chamada epistemologia da prática para explorar o campo da formação de professores. Para Mazzeu (2011), tal referencial se trata de uma concepção conveniente ao neoliberalismo e ao relativismo pós-moderno, já que subsume o processo formativo "à reprodução do cotidiano fragmentado e alienado", que permanece carente de uma "compreensão unitária, coerente, articulada e intencional" (p. 164). Deste ponto de vista, há uma flagrante contradição entre esse modo de analisar a formação docente e os pressupostos marxistas da Psicologia Histórico-Cultural. ${ }^{44}$

Também são notórios, entre as palavras-chaves, os termos referentes aos jogos enquanto métodos e recursos didáticos: "jogo(s) didático(s)", "jogos”, "educação lúdica”, “jogos educacionais". Os quatro artigos que apontam uma ou mais destas palavras-chaves citam A formação social da mente, em dois deles a única obra soviética referida, inferindo-se que o capítulo "O papel do brinquedo no desenvolvimento" tenha servido como base portanto não consideram, como já afirmamos, a tradução do mesmo texto por Zoia Prestes diretamente do russo. De um modo geral, os autores se valem desse trabalho para argumentar que jogos didáticos estimulam a curiosidade dos estudantes, aprimoram habilidades psíquicas, facilitam a aprendizagem de conceitos e, principalmente, incentivam e exercitam as interações aluno/professor e aluno/aluno. O trabalho de Cunha (2012) se destaca, lembrando que Vigotski “em seus trabalhos, procurou analisar o papel do desenvolvimento das crianças e das

\footnotetext{
${ }^{44}$ Quanto à questão da formação docente, a crítica à epistemologia da prática e as contribuições da Psicologia Histórico-Cultural (e da Pedagogia Histórico-Crítica) serão exploradas no capítulo 7 desta tese.
} 
experiências sociais e culturais por meio do estudo do jogo na criança", discriminando corretamente que ele investigou "o papel do brinquedo e, mais diretamente, da brincadeira de faz de conta no desenvolvimento da criança, pois esse desenvolvimento é fortemente influenciado por experiências concretas que elas vivenciam" (p. 94). Focetola e colaboradores (2012) também fazem um uso consequente do trabalho de Vigotski, aludindo à questão da imaginação e à importância das regras dos jogos, abordando assim aspectos específicos das contribuições do pesquisador soviético.

Por fim, notamos que na categoria psicologia há um conjunto de palavras relacionadas à mediação - "mediação", "mediação do professor", "mediação pedagógica", "interação" sugerindo que os autores dos artigos em questão encontram um "interacionismo" na Psicologia Histórico-Cultural que estaria ausente em outras teorias. Não vamos analisar o sentido atribuído à mediação nestes trabalhos, mas gostaríamos de chamar a atenção para um aspecto apontado por Duarte (2006): se há algum autor do campo da psicologia que mereceria a alcunha de "sócio interacionista", este estudioso é Piaget (que, contrariando o senso comum pedagógico, considera sim a importância das relações sociais para o desenvolvimento) e não Vigotski. Prestes (2012) acrescenta que as traduções da obra de Vigotski contribuíram para "atribuir-se à sua teoria o caráter de interacionista, não levando em conta a [sua] firme posição monista”, em que ambiente e personalidade formam um todo unitário.

Da mesma forma, a presença dos termos "linguagem" e "linguagem química", que alocamos na mesma categoria psicologia, sugere a ocorrência de interpretações de Vigotski e seus colegas como teóricos da mediação semiótica, operando assim uma "discursivização" de sua teoria. Também de acordo com Duarte (2006), “o objetivo de reduzir a teoria de Vigotski a uma ênfase nos signos é o de aproximá-lo das concepções pós-estruturalistas, que tudo reduzem ao embate de discursos", sendo que, pelo contrário, para os psicólogos soviéticos, “a linguagem só pode existir, na concepção de Marx, como um elemento integrante da prática social, produzido e reproduzido no interior dessa prática" (p. 164). De fato, o artigo de Machado e Moura (1995), que traz "linguagem" como palavra-chave, insiste na questão do discurso do professor em sala de aula e de seu papel na elaboração conceitual por parte dos estudantes. Com nada menos que sete referências de autores da Psicologia Histórico-Cultural (valor atípico entre os 22 artigos levantados, já que o segundo a apresentar mais referências traz apenas três), é preciso situar este artigo em seu contexto, antes de extrairmos conclusões apressadas: trata-se um trabalho dos primórdios de QNEsc, com o objetivo de apresentar aos leitores, de forma acessível e concisa, a importância de um olhar crítico para a questão da 
linguagem nas aulas de Química, assim como a existência de um referencial teórico sensível a tal aspecto. Daí tantas referências aos autores soviéticos. A bem da verdade, apenas o livro Pensamento e linguagem é utilizado para dar sustentação a algum aspecto investigado pelos autores; os outros seis livros constam apenas como uma espécie de bibliografia com obras de referência à perspectiva histórico-cultural.

Entre os artigos com palavras-chaves alocadas na categoria psicologia, há mais um que reúne elementos interessantes: o trabalho de Echeverría (1996). Com a palavra-chave "relação empírico-teórica", este é o único artigo de QNEsc que referencia uma obra de Davídov - a tradução em espanhol La enseñanza escolar y el desarollo psíquico -, além de chamar a atenção para aspectos da Psicologia Histórico-Cultural aparentemente relevados em muitos dos outros artigos levantados. Por exemplo, a imprescindibilidade da educação escolar para a formação dos conceitos científicos é devidamente destacada, assim como o fato da psicologia soviética, por fundamentar-se numa base materialista e dialética, não privilegiar nenhum dos polos entre o empírico e o teórico, mas a práxis que os integra em unidade:

Pensando no conhecimento químico, e considerando que processos químicos acontecem a todo momento em nossas vidas, é possível afirmar que aprendemos química constantemente, mas num nível fenomenológico de conhecimento: o conhecimento empírico, que desenvolve um vasto campo de capacidades intelectuais, mas expressa a existência das coisas nas categorias de quantidade, qualidade, propriedade, medida. O conhecimento empírico não conduz $\mathrm{o}$ pensamento à cognição da identidade, da essência, da causalidade. Isto só é feito pelo pensamento teórico. [...] Se o fenômeno mostra e ao mesmo tempo esconde a essência das coisas, se essa essência é mediada pelo pensamento humano, conclui-se que promover o pensamento teórico significa ir além das manifestações empíricas e questionar as causas, a origem, o desenvolvimento dos fatos, num esforço intelectual que dificilmente os alunos realizarão sozinhos. Esta é certamente uma função da escola e, principalmente, do professor (p. 17-18, grifos da autora).

\subsubsection{Algumas observações}

Ao distanciar os princípios do materialismo histórico-dialético da obra vigotskiana, corre-se o risco de banalizar alguns de seus conceitos fundamentais. Especialmente no campo educacional, isto implica a elaboração não só de estratégias pedagógicas, mas de um projeto político. Pensar e agir tendo como guia o materialismo histórico-dialético vai contra o que está posto em nosso momento histórico, exigindo do pesquisador a apropriação de um conhecimento que não é simples nem tampouco fácil de ser aplicado à realidade, exigindo, entre outras coisas, superar o aparentemente percebido, tentando alcançar a essência dos fatos. Para isso, cabe aprofundar a formação, estudando as obras de Marx, Leontiev e Luria (SILVA; DAVIS, 2004, p. 655, grifos nossos). 
Fazendo nossas estas palavras, podemos afirmar que a produção de QNEsc ainda não consumou um engajamento neste projeto político transformador encarnado na Psicologia Histórico-Cultural. Entre 489 artigos do periódico, encontramos 22 com referências a estes autores soviéticos, em geral concentradas em pouquíssimas obras, muitas vezes nas traduções mais questionadas pelos estudiosos, e sem expor aos leitores as particularidades da psicologia soviética e seus princípios teórico-metodológicos. Entendemos que isso contribui para alguns mal-entendidos sobre Vigotski e seus colegas, por exemplo, sua identificação com o construtivismo e com demais teorias que naturalizam a historicidade do desenvolvimento humano e das relações sociais.

Uma última observação se refere a um dos objetos de estudo desta tese. Como visto na Figura 6, apenas um artigo, dentre os 22 levantados, foi publicado na seção Experimentação no Ensino de Química. Mas esse trabalho pouco avança em direção a um entendimento das atividades experimentais conforme a Psicologia Histórico-Cultural, apenas baseando-se em $A$ construção do pensamento e da linguagem para exaltar o trabalho em grupo na sala de aula, apesar de Michlenie i retch não tratar especificamente do assunto.

Sendo essa a situação da experimentação no ensino de ciências perante o referencial da Psicologia Histórico-Cultural, dedicaremos o próximo capítulo inteiramente a discutir este aspecto da educação científica. Após isto, deveremos estar munidos de uma teoria que, fundamentada nas contribuições específicas da psicologia e da pedagogia dialéticas, providencie um entendimento igualmente dialético sobre o papel dos experimentos no ensino. 


\section{CAPÍTULO 3}

\section{EXPERIMENTAÇÃO NO ENSINO DE CIÊNCIAS: uma visão crítico-dialética ${ }^{45}$}

A experimentação, como estratégia para o ensino dos conteúdos de ciências, já serviu a diversos interesses pedagógicos, na história da educação científica e tecnológica ${ }^{46}$.

Até a renovação do ensino de ciências, a partir da década de 1950, pode-se afirmar que os experimentos eram recursos de caráter retórico, sendo sua função sustentar o discurso dos mestres. A verdade das afirmações teóricas era confirmada com demonstrações experimentais. Não era necessário que os estudantes realizassem eles mesmos os experimentos; quando isto acontecia, era numa perspectiva verificacionista, ou seja, seguidas instruções precisas, um resultado esperado, que confirmaria a teoria, seria obtido ao final.

Com esta renovação da educação científica e tecnológica, liderada pelos Estados Unidos e pela Inglaterra, os currículos sofreram grandes alterações, assim como as estratégias de ensino. A necessidade de formar mais quadros entre cientistas e engenheiros, palavra de ordem para estas nações em disputa científico-tecnológica contra os soviéticos (referimo-nos à Guerra Fria), ganhou terreno nas salas de aula, com o incentivo à opção por estas carreiras desde a tenra idade dos educandos. Apareceram então as atividades experimentais de

\footnotetext{
${ }^{45}$ Este capítulo se baseia no trabalho de mesmo título encaminhado ao VII Colóquio Internacional Marx e Engels, realizado em Campinas em 2012.

${ }^{46}$ Para tratar rapidamente desta história, apoio-me principalmente no livro da Prof. Myriam Krasilchik, $O$ professor e o currículo das ciências (KRASILCHIK, 1987) e na tese de doutorado de Pinho Alves (2000a). Este percurso histórico introdutório resume o segundo capítulo de minha dissertação de mestrado (MORI, 2009, p. 52-77). O capítulo como um todo, por sua vez, pode ser considerado como sua continuação, seu desdobramento.
} 
redescoberta, em que a coleta de dados em sala de aula levaria, por indução, a que os estudantes, eles mesmos, alcançassem as generalizações da ciência. O laboratório escolar estruturava-se então como espaço central do ensino e celeiro de novos talentos para o mundo da pesquisa e da tecnologia.

Com a aproximação dos anos 1970, crises econômicas e ambientais forçaram a uma revisão deste ideário. Até então, o desenvolvimento científico do século XX permitia se atribuir à ciência a capacidade de lidar com todas as consequências do desenvolvimento humano. Mas agora ela será cada vez mais analisada e/ou criticada em seus fundamentos filosóficos, e este movimento repercutirá na própria educação científica. Formar cientistas já não será prioridade, e as perspectivas mais empiristas da aprendizagem escolar (muito inspiradas no comportamentalismo) darão lugar às aplicações da psicologia cognitivista, em que se destacará o nome de Piaget.

Estamos nos anos 1980, firmando-se o "paradigma” construtivista na educação. O ensino de ciências, nesta perspectiva, procura rejeitar as visões positivistas do processo de ensino e aprendizagem e da história e natureza da ciência. O laboratório de ciências perde sua centralidade, visto que a experimentação passa a conviver com outras estratégias de ensino, como jogos e simulações.

No quadro da Figura 10, extraído de nossa dissertação de mestrado, sistematiza-se esta breve história da experimentação enquanto estratégia para o ensino das ciências. O quadro foi o produto de um estudo semântico quanto às palavras experimentar, experimentação, experiência e experimento. Este estudo, baseado na compilação dos significados atribuídos a estas palavras em dicionários de língua portuguesa, detectou serem três os domínios semânticos que concorrem para a produção do sentido destes termos. A cada momento histórico do ensino de ciências, estes domínios - domínio prático, domínio filosófico e domínio da atividade científica -, preenchidos por diferentes conteúdos objetivos, perfizeram concepções igualmente diferentes acerca do papel da experimentação didática.

Encerramos a confecção do quadro na linha referente ao período atual, que corresponderia à hegemonia do ideário pós-moderno no campo da educação. Os conteúdos desta última linha, portanto, nos três domínios semânticos, estão preenchidos por concepções que remetem ao relativismo e ao pluralismo metodológico no ensino e na natureza das ciências. Na verdade, estas concepções apenas aprofundam os conteúdos das duas linhas imediatamente anteriores, que assinalam a "virada cognitivista" na educação científica, quando o construtivismo começa a se estabelecer enquanto seu principal referencial. 


\begin{tabular}{|c|c|c|c|}
\hline \multirow{2}{*}{$\begin{array}{c}\text { Período elou } \\
\text { modalidade }\end{array}$} & \multicolumn{3}{|c|}{ Palavras experimentar, experimentação, experiência $e$ experimento } \\
\hline & Domínio prático & Domínio filosófico & $\begin{array}{c}\text { Domínio da atividade } \\
\text { científica }\end{array}$ \\
\hline "Pré-história" & $\begin{array}{l}\text { A experiência do senso } \\
\text { comum é desvalorizada, tida } \\
\text { como insuficiente ou } \\
\text { indesejável para a construção } \\
\text { de uma episteme. }\end{array}$ & $\begin{array}{l}\text { Bacon defende um método } \\
\text { empírico, baseado na indução; } \\
\text { Descartes e Galileu, } \\
\text { racionalistas, defendem uma } \\
\text { via matemático-dedutiva. }\end{array}$ & $\begin{array}{l}\text { Surge este domínio. } \\
\text { Defende-se a importância } \\
\text { de uma diferenciação entre } \\
\text { a experiência do senso } \\
\text { comum e a experiência } \\
\text { científica, vista como } \\
\text { diálogo matemático com os } \\
\text { fenômenos (Galileu) ou } \\
\text { como imposição à natureza } \\
\text { (Bacon). }\end{array}$ \\
\hline $\begin{array}{l}\text { Momentos } \\
\text { iniciais: } \\
\text { demonstrações }\end{array}$ & $\begin{array}{l}\text { Os fenômenos observáveis, } \\
\text { ou seja, "experimentáveis" } \\
\text { do ponto de vista do senso } \\
\text { comum, são importantes para } \\
\text { legitimar o conhecimento. }\end{array}$ & \multirow{2}{*}{$\begin{array}{l}\text { O conhecimento é adquirido } \\
\text { através de uma transmissão, do } \\
\text { mundo externo para o homem, } \\
\text { em uma concepção sensual- } \\
\text { empirista. }\end{array}$} & \multirow{2}{*}{$\begin{array}{l}\text { A ciência é um conjunto de } \\
\text { conhecimentos } \\
\text { sistemáticos, porque } \\
\text { provados por testes } \\
\text { empíricos. É sua tarefa } \\
\text { acumular descrições e } \\
\text { explicações, que devem ser } \\
\text { submetidas ao teste } \\
\text { experimental. }\end{array}$} \\
\hline $\begin{array}{l}\text { Momentos } \\
\text { iniciais: } \\
\text { verificações }\end{array}$ & $\begin{array}{l}\text { Idem ao anterior, acrescido } \\
\text { da importância da vivência } \\
\text { das situações correntes no } \\
\text { laboratório. }\end{array}$ & & \\
\hline $\begin{array}{l}\text { Era dos } \\
\text { projetos: } \\
\text { redescobertas }\end{array}$ & $\begin{array}{l}\text { A experiência do senso } \\
\text { comum não é desejável para } \\
\text { a formação do indivíduo. } \\
\text { Nas propostas mais } \\
\text { tecnicistas, busca-se uma } \\
\text { vivência do conhecimento } \\
\text { científico que leve ao treino, } \\
\text { ao adestramento de } \\
\text { habilidades. }\end{array}$ & $\begin{array}{l}\text { Uma adaptação/simplificação } \\
\text { do método científico de Bacon, } \\
\text { que parte da observação dos } \\
\text { fatos, se constitui em uma } \\
\text { garantia para o avanço do } \\
\text { conhecimento. }\end{array}$ & $\begin{array}{l}\text { A ciência é rigorosa porque } \\
\text { se realiza através de um } \\
\text { método científico, rígido, } \\
\text { linear, sequencial, do qual a } \\
\text { etapa da experimentação é } \\
\text { essencial, por ser capaz de } \\
\text { provar o valor de verdade } \\
\text { das teorias. }\end{array}$ \\
\hline $\begin{array}{l}\text { Virada } \\
\text { cognitivista: } \\
\text { modalidades } \\
\text { iniciais }\end{array}$ & $\begin{array}{l}\text { A experiência do senso } \\
\text { comum deve ser superada } \\
\text { para a construção do } \\
\text { conhecimento. A vivência, a } \\
\text { prática de habilidades e a } \\
\text { busca pelo comportamento } \\
\text { ideal numa situação de } \\
\text { aprendizagem não são suas } \\
\text { finalidades primordiais. }\end{array}$ & \multirow{2}{*}{$\begin{array}{l}\text { As visões empiristas devem } \\
\text { ser superadas, pois toda } \\
\text { observação e toda experiência } \\
\text { só podem ser interpretadas à } \\
\text { luz de formulações teóricas } \\
\text { prévias. }\end{array}$} & $\begin{array}{l}\text { Deve-se ter cautela quanto } \\
\text { à associação imediata entre } \\
\text { o empreendimento } \\
\text { científico e a etapa da } \\
\text { experimentação. Não existe } \\
\text { um único método para as } \\
\text { ciências. }\end{array}$ \\
\hline $\begin{array}{l}\text { Virada } \\
\text { cognitivista: } \\
\text { modalidades } \\
\text { oriundas do } \\
\text { modelo de } \\
\text { mudança } \\
\text { conceitual } \\
\end{array}$ & $\begin{array}{l}\text { Conhecimentos prévios, } \\
\text { decorrentes da experiência } \\
\text { do senso comum, podem se } \\
\text { constituir em obstáculos para } \\
\text { uma aproximação do } \\
\text { conhecimento científico. }\end{array}$ & & $\begin{array}{l}\text { Idem ao anterior, acrescido } \\
\text { pela possibilidade dos } \\
\text { experimentos, em situações } \\
\text { didáticas, serem capazes de } \\
\text { "destruir" concepções } \\
\text { alternativas. }\end{array}$ \\
\hline $\begin{array}{l}\text { Atualidade } \\
\text { (pós- } \\
\text { modernidade) }\end{array}$ & $\begin{array}{l}\text { A construção do } \\
\text { conhecimento é um processo } \\
\text { espontâneo e contínuo; a } \\
\text { mente é complexa, pois } \\
\text { abriga redes de conceitos e } \\
\text { esquemas que se inter- } \\
\text { relacionam. }\end{array}$ & $\begin{array}{l}\text { É possível abordar o problema } \\
\text { do conhecimento por diversas } \\
\text { vias. Em cada uma delas, a } \\
\text { relação entre teoria e } \\
\text { experiência pode assumir } \\
\text { formas e papéis diversos. }\end{array}$ & $\begin{array}{l}\text { A experimentação é apenas } \\
\text { uma etapa importante para } \\
\text { a evolução da ciência. } \\
\text { Também é considerada } \\
\text { importante para a } \\
\text { aprendizagem das ciências, } \\
\text { embora se reconheça que } \\
\text { outras estratégias também } \\
\text { possam servir a isto. }\end{array}$ \\
\hline
\end{tabular}

Figura 10: quadro sobre os períodos e/ou modalidades da experimentação no ensino de ciências e a importância dos domínios semânticos das palavras experimentar, experimentação, experiência e experimento (MORI, 2009, 
Desde então, o laboratório didático será encarado pelos educadores conforme posições nem sempre bem definidas, num discurso ambíguo, misto de entusiasmo e ceticismo. Entusiasmo, pois a pressão do construtivismo em direção a um ensino que relegue maior autonomia aos estudantes irá ao encontro da concepção de um laboratório aberto, pouco estruturado, sem o uso de roteiros fixos e experimentos do tipo "receita". Ceticismo, por outro lado, pela preocupação de que a experimentação apenas reforce visões positivistas empiristas, indutivistas - da natureza da ciência, pelos estudantes.

Neste capítulo, mostraremos que nenhuma destas visões é essencialmente correta, e que estas preocupações dos profissionais da educação não têm motivos para se somar aos problemas que estes trabalhadores já enfrentam.

A primeira seção examinará uma proposta para a experimentação no ensino apresentada ao público como fundamentada na "pedagogia sociocultural de Vigotski": a obra Experiências de ciências, de Alberto Gaspar. Será realizado, assim, um trabalho de análise crítica, tomando este livro como uma primeira tentativa (em termos de profundidade e alcance), no território brasileiro, de se buscar na Psicologia Histórico-Cultural os elementos para a compreensão e a elaboração de atividades experimentais para o ensino.

Prosseguiremos, na próxima seção, apresentando propostas e considerações de estudiosos da Educação em Ciências mais comprometidos com os pressupostos marxistas da psicologia de Vigotski e seus colegas. Alguns deles, inclusive, pertencem ao que poderíamos chamar de "corpo de colaboradores" da Pedagogia Histórico-Crítica.

Assim, cientes dos usos indevidos da teoria de Vigotski e dos caminhos apontados por pesquisadores mais próximos de nossas convicções em termos epistemológicos, a seção final do capítulo apresentará uma teoria sobre a experimentação vinculada às especificidades da Pedagogia Histórico-Crítica e da Psicologia Histórico-Cultural. Poderemos, assim, acrescentar mais uma linha ao quadro da Figura 10: a visão crítico-dialética.

\subsection{UMA ANÁLISE DE EXPERIÊNCIAS DE CIÊNCIAS}

O livro Experiências de ciências: para o ensino fundamental foi elaborado pelo Prof. Alberto Gaspar, docente da Faculdade de Engenharia de Guaratinguetá, da Universidade Estadual Paulista Júlio de Mesquita Filho (Unesp). Publicada em 2003 pela editora Ática, a 
obra possui cerca de 330 páginas e apresenta propostas de experimentos sobre o conhecimento físico para a educação básica. Os experimentos são em número de 80, distribuídos entre conteúdos sobre ar, água, sólidos e energia (sonora, luminosa, mecânica e eletromagnética). Os experimentos são propostos seguindo-se a ordem de sete tópicos: $o$ que se usa, como se faz, como funciona, o que observar, como se explica, o que pode dar errado e uma observação a mais.

O objeto de análise desta seção será o capítulo introdutório do livro, denominado "Experimentação em ciências - abordagem crítica e propostas" (GASPAR, 2003, p. 11-30). Vale a pena apresentar os títulos das seções e subseções que o compõem:

1) A experimentação no ensino tradicional

2) O método da redescoberta: um equívoco epistemológico

3) A teoria precede e orienta a experiência

4) Idéias piagetianas

Atividades experimentais de inspiração piagetiana

Dificuldade da teoria dos estágios cognitivos

Conceitos prévios

5) Panorama atual

6) Pedagogia sociocultural de Vigotski - fundamentação teórica de nossa proposta Uma síntese das idéias vigotskianas

7) Diferenças entre Piaget e Vigotski

8) A teoria de Vigotski e a atividade experimental

9) Objetivos da atividade experimental

Atividade experimental $\mathrm{X}$ atividade teórica

10) A pedagogia da atividade experimental

11) Os PCNs e as atividades experimentais

12) A seleção das atividades experimentais

Constam ainda, entremeados ao texto, três "boxes", cada um ocupando aproximadamente uma página: duas notas biográficas, uma de Jean Piaget e outra de L. S. Vigotski, e um comentário sobre o construtivismo.

Antes de iniciarmos nossa análise, é preciso justificar a escolha por este objeto de exame. O livro de Gaspar se tornou uma obra muito difundida pelo Brasil. Seu alcance entre um público amplo contribuiu consideravelmente para a divulgação do nome de Vigotski entre educadores de todos os níveis. Mesmo sendo dirigido à educação básica, Experiências de 
ciências é frequentemente referenciado em artigos publicados em periódicos científicos da área de Educação em Ciências, o que atesta o reconhecimento do livro e do seu autor por parte dos pesquisadores. Além destes motivos, o capítulo que iremos analisar expõe de modo bastante completo a maneira como autor pretende fundamentar, nos trabalhos de Vigotski, suas propostas pedagógicas. O espaço dedicado a isto, neste livro, é consideravelmente maior que em outras produções de Gaspar, como nos diversos artigos científicos de sua autoria também dedicados ao assunto.

Expostas estas razões, iniciemos nosso trabalho de análise com a nota biográfica de Vigotski apresentada no capítulo em questão. Interessam-nos, especialmente, quais considerações o autor prefere apresentar a respeito do trabalho teórico e prático do psicólogo russo (por isso desconsideraremos, na transcrição abaixo, os parágrafos iniciais que tratam de seu nascimento e de seu percurso formativo):

Em janeiro de 1924 Vigotski apresentou um trabalho num congresso de psiconeurologia realizado em São Petersburgo. Como resultado de sua apresentação foi convidado a integrar o corpo de pesquisadores do Instituto de Psicologia Experimental de Moscou. No verão de 1924 começou a trabalhar com crianças portadoras de necessidades especiais (físicas e mentais), no Departamento de Educação Popular desse instituto. Em 1925, numa viagem a Londres para participar de uma conferência internacional de educação para deficientes auditivos, pôde atualizar-se e conhecer o que se fazia na Europa em psicologia e educação especial. Ao retornar foi acometido seriamente de tuberculose, ficando entre a vida e a morte por alguns meses. Recuperou-se e passou a trabalhar intensamente em pesquisa e como professor de psicologia em instituições médicas e pedagógicas. Em 1926 publicou seu primeiro livro, Psicologia pedagógica, e começou a trabalhar em outros dois livros, Pensamento e linguagem e História do desenvolvimento das funções psicológicas superiores.

Durante todo esse tempo Vigotski nunca abandonou suas pesquisas psicológicas, especialmente no campo da psicologia infantil. Para melhor fundamentar suas pesquisas, ele ingressou numa escola de medicina, onde fez três anos de residência médica. Em 1926 criou um laboratório para estudar psicologia de crianças portadoras de necessidades especiais, que em 1929 se tornou Instituto Experimental de Educação Especial.

Vigotski trabalhou febrilmente durante seus últimos anos de vida. Ao final de seus 37 anos publicou cerca de 270 trabalhos científicos. Descuidando de sua saúde precária, faleceu de tuberculose no dia 10 de junho de 1934 (ibidem, p. 19-20).

Observa-se, nesta nota biográfica, que não foram feitas menções ao fato de Vigotski ter almejado, durante sua vida, elaborar uma psicologia de inspiração marxista que viesse a superar a crise da ciência psicológica no início do século XX. Seríamos exigentes demais se reivindicássemos que, no curto espaço de uma página, o autor expusesse o caráter desta crise e dos personagens em disputa, assim como as características da solução proposta por Vigotski e outros. No entanto, como quase a totalidade da produção do psicólogo russo, em seus dez 
últimos anos de vida, foi dedicada a este projeto, talvez coubesse ao menos uma breve referência ao fato.

Prossigamos com a análise. Nas seções 1 a 5 é narrada uma história da experimentação enquanto estratégia para o ensino de ciências, à semelhança do trabalho nosso que foi sumarizado na Figura 10. O autor conclui este percurso histórico assinalando também uma espécie de "crise" quanto ao panorama atual da experimentação no ensino de ciências:

Embora as atividades experimentais sejam uma necessidade incontestável para todo professor de disciplina da área de ciências, sua utilização em sala de aula é ainda inexpressiva no ensino fundamental e raríssima no ensino médio; quando aplicadas, os procedimentos quase sempre são tradicionais.

Pode-se supor que a causa dessa inconsistência entre a convicção do professor e sua prática pedagógica em relação à atividade experimental sejam os incipientes resultados das propostas inovadoras surgidas nas últimas décadas do século XX. Estariam os professores hesitantes em aplicá-las pela incerteza em relação aos objetivos e procedimentos pedagogicamente adequados? Essa hipótese não parece verdadeira, ou pelo menos, relevante. A prática dos professores das disciplinas científicas sempre padeceu dessa inconsistência - crer em algo que não pratica mesmo antes do movimento renovador.

Também não é correto julgar fracassadas as tentativas de renovação das atividades experimentais, já que a própria mobilização da comunidade acadêmica nesse sentido tem levado a uma intensa busca por novos referenciais teóricos, entre eles a psicologia sociocultural que fundamenta a proposta deste livro (ibidem, p. 18).

Considerando, então, que tanto a concepção de atividade experimental segundo a aprendizagem por redescoberta, quanto as propostas fundamentadas no modelo de mudança conceitual, se apoiavam em "errôneas compreensões" nos campos da epistemologia e da psicologia, Gaspar apresenta, à seção 6, uma síntese das ideias de Vigotski. Neste resumo, permeado por analogias diversas, redundando num estilo claro e didático, Gaspar introduz satisfatoriamente as diferenças entre a psicologia soviética e a teoria de Jean Piaget, dando destaque ao modo como a primeira entende a relação entre desenvolvimento e instrução:

no pensamento vigotskiano, [...] não é preciso esperar determinadas estruturas mentais se formarem para que a aprendizagem de um conceito seja possível. Ao contrário, é o ensino desse conceito que desencadeia a formação das estruturas mentais necessárias à sua aprendizagem. É preciso apenas não transpor a capacidade cerebral do aluno quando se busca criar novas estruturas mentais. Esse limite está contido numa zona de desenvolvimento imediato ou proximal, denominação dada por Vigotski a uma espécie de desnível cognitivo que cada pessoa tem para adquirir algo novo com a colaboração de um parceiro mais capaz, como é o caso do professor (ibidem, p. 20, grifo do autor).

Há três observações a se fazer a partir deste fragmento. Primeiramente, nota-se que Gaspar tende a fazer considerações de cunho psicológico empregando um linguajar 
essencialmente piagetiano, mesmo nos momentos em que trata da teoria de Vigotski. No fragmento acima, isto é evidente quando se afirma que, de acordo com o pensamento vigotskiano, não é preciso esperar a formação de estruturas mentais para que seja possível uma determinada aprendizagem. No entanto, os textos de Vigotski não tratam de estruturas mentais. Este é um termo recorrente nos escritos piagetianos, talvez devido à influência do estruturalismo sobre o psicólogo suíço. Além desta, há outras expressões que aparecem relacionadas a Vigotski, como "estrutura cognitiva", "desenvolvimento cognitivo", "processo cognitivo" (p. 21), "mudança cognitiva" (p. 22) e "estruturas de pensamento" (p. 26), mas que dificilmente são encontradas em seus textos. Por exemplo, em Michlenie i retch (VIGOTSKI, 2001) não se fala em "desenvolvimento cognitivo", mas de um desenvolvimento em geral da inteligência - cognitivo e afetivo -, que é pressuposto pela apropriação das funções psicológicas superiores, de constituição histórica. Segundo Martins (2011), a cisão entre funções cognitivas, de um lado, e afetivas, de outro, corresponde a uma artificialidade, visto que é umbilicalmente unidas que elas se põem a serviço da inteligibilidade do real:

sensação, percepção, atenção, memória, linguagem, pensamento e imaginação, a quem compete, fundamentalmente, a construção da imagem subjetiva da realidade concreta, isto é, a construção do conhecimento objetivo [...] são, via de regra, categorizadas como funções cognitivas.

Porém, a realidade concreta afeta o sujeito do conhecimento, isto é, suscita vivências ao mesmo tempo cognitivas e afetivas, ou seja, mobiliza emoções e sentimentos (p. 51, grifos da autora).

Uma segunda observação diz respeito ao modo como Gaspar se refere ao conceito de zona blijaichego razvitia, apresentando-o como "zona de desenvolvimento imediato ou proximal". O uso dos adjetivos imediato ou proximal permite-nos inferir que o autor estivesse tomando em consideração, ao redigir seu livro, os textos $A$ formação social da mente e $A$ construção do pensamento e da linguagem. De fato, são estas as únicas obras de Vigotski que aparecem em sua lista de referências bibliográficas, semelhantemente ao que observamos ao analisar como autores da Educação em Química se apropriam da Psicologia HistóricoCultural. Como afirmamos na seção final do capítulo anterior, tanto Zoia Prestes quanto Newton Duarte criticam o termo "zona de desenvolvimento imediato", que transmite a ideia de um desenvolvimento sem a mediação de um parceiro mais capaz.

A terceira e última observação sobre o fragmento de Gaspar transcrito há pouco se refere, justamente, ao modo como autor compreende a importância deste "parceiro": é positivo que sua figura seja associada à do professor. Como indicamos ao fim do capítulo 
anterior, há uma tendência a se atribuir à obra de Vigotski o caráter de uma teoria sobre a “interação grupal" ou sobre os "trabalhos escolares em grupo". Uma leitura atenta da versão completa de Michlenie $i$ retch - a que foi traduzida para o português, por Paulo Bezerra, como A construção do pensamento e da linguagem, nunca é demais lembrar - é suficiente para desfazer este engano. Conforme afirma Duarte (2006), é típico das apropriações neoliberais e pós-modernas da teoria vigotskiana esta associação equivocada, em que a importância do mestre e dos processos orientados de instrução é obnubilada.

Na seção 7 do texto, Gaspar estabelece, rapidamente, mais diferenças entre as teorias de Piaget e de Vigotski. A abordagem aqui é também satisfatória: destaca-se o papel da imitação para o desenvolvimento, um dos aspectos centrais da Psicologia Histórico-Cultural, e que é injustamente ignorado pela maioria das apropriações desta teoria por autores da Educação em Ciências; menciona-se que o entendimento de Vigotski sobre a relação entre os conceitos espontâneos e científicos é "contrário" ao de Piaget; e chama-se a atenção para uma espécie de aforismo que sintetiza bem o entendimento vigotskiano sobre os nexos entre desenvolvimento e instrução (embora confundida com aprendizagem, como ocorre com a maioria dos textos que referenciam A construção do pensamento e da linguagem): "não é o desenvolvimento cognitivo que viabiliza a aprendizagem, mas a aprendizagem que torna possível ou provoca o desenvolvimento cognitivo" (GASPAR, 2003, p. 21).

A partir da seção 8, no entanto, Gaspar volta a expor elementos semelhantes aos que analisamos criticamente, em nossa revisão de QNEsc. Depreende-se que, para ele, o elemento mais importante da teoria de Vigotski, a essência da Psicologia Histórico-Cultural, seria a valorização da "interação social”, expressão que aparecerá inúmeras vezes no decorrer deste capítulo de seu livro. Por exemplo, encerrando a seção 9, Gaspar afirma que "o objetivo fundamental das atividades experimentais" é "promover interações sociais que tornam as explicações mais acessíveis e eficientes” (ibidem, p. 24). No entanto, em Michlenie i retch, obra que teria fundamentado as posições do autor de Experiências de ciências, a expressão "interação social” consta pouco ou quase nunca, se bem nos lembramos. Como já afirmamos, o social aparece na teoria de Vigotski como o âmbito de origem das funções psicológicas superiores - são antes interpsicológicas, e depois intrapsicológicas. Estas funções são sociais porque emergem da atividade prática dos indivíduos, organizada coletivamente no contexto de um modo de produção. Mas esta determinação histórica da consciência humana nem sempre é lembrada pelos leitores de Vigotski no campo da Educação em Ciências, mal que 
vitima, além de trabalhos de educadores químicos que analisamos no capítulo anterior, também a obra de Gaspar.

Esta questão é tratada detidamente no livro Vigotski e o "aprender a aprender", de Newton Duarte:

\begin{abstract}
Consideramos externas e estranhas à teoria de Vigotski aquelas leituras que procuram caracterizar a psicologia vigotskiana como uma espécie de interacionismo, o sociointeracionismo. Visto por vezes como uma variante do construtivismo (nesse caso chamado de "socioconstrutivismo" ou "co-construtivismo") e noutras vezes como uma corrente que complementaria o construtivismo, o que caracterizaria o social nesse interacionismo seria o fato de que, além das relações sujeito-objeto, também as relações sujeito-sujeito seriam focalizadas pela psicologia da educação. Muitos educadores e psicólogos têm considerado Vigotski como representante desse sociointeracionismo e buscado na psicologia desse autor algo que faltaria na psicologia genética piagetiana, isto é, a valorização das interações intersubjetivas, das trocas mediadas pela linguagem, do trabalho em grupo, da construção coletiva do conhecimento (2006, p. 255-256, grifo nosso).
\end{abstract}

E após este comentário, Duarte inicia um capítulo desta sua obra - importante ressaltar, resultante de sua monografia de livre docência - inteiramente dedicado à tese de que $a$ psicologia de Piaget é sociointeracionista (ibidem, p. 257-280). Não temos espaço para apresentar os argumentos ali coligidos por Duarte. Vale notar, no entanto, que a aproximação de Vigotski ao construtivismo, operada pelos defensores da essência sociointeracionista de sua psicologia e mencionada no fragmento transcrito acima, aparece também no livro de Gaspar, não obstante as palavras que este autor enuncia na seção 7 (Diferenças entre Piaget e Vigotski) do capítulo que estamos analisando. Veja-se a seguinte passagem da seção 11, que recupera a visão dos PCN sobre as atividades experimentais no ensino:

Deve-se lembrar que os PCNs de ciências naturais fundamentam-se fortemente nas idéias de Piaget, enquanto o fundamento teórico deste livro está nas idéias de Vigotski. Mas, como já ressaltamos anteriormente, as implicações pedagógicas de ambas teorias não são obrigatoriamente contraditórias. A teoria de Vigotski admite práticas pedagógicas que a teoria de Piaget não recomenda, mas o oposto não ocorre, ou seja, toda prática de inspiração piagetiana pode ser adotada numa pedagogia de inspiração vigotskiana. Basta que a ela agregue a participação ativa e orientadora do professor ou de outro parceiro mais capaz (GASPAR, 2003, p. 27, grifos nossos).

Assim, o esforço prévio do autor por estabelecer as distinções entre o psicólogo suíço e o soviético parece ir por água abaixo. Mais decepcionante, no entanto, é que na busca por enaltecer o suposto sociointeracionismo de Vigotski, Gaspar acabe defendendo uma visão nitidamente relativista do ensino de ciências, aproximando-se mais uma vez do construtivismo. Por exemplo, ao enumerar as vantagens que a atividade experimental exibiria 
em relação à teórica, o autor recorre a um argumento que lida com a diferença de engajamento dos alunos em um tipo de atividade e em outro:

A terceira vantagem da atividade experimental se refere ao maior envolvimento do aluno, pois ele dificilmente arrisca previsões quanto ao resultado de atividades teóricas. Além de exigirem maior capacidade de abstração, as respostas - raramente observáveis - são dadas pelo livro ou pelo professor. Dúvidas ou contestações correm o risco de serem refutadas por argumentos de autoridade. Sabendo disso, o aluno se abstém de participar, fragilizando-se a interação social (ibidem, p. 24).

Além da presença de suposições frágeis, nota-se neste parágrafo uma apreciação negativa sobre o papel do professor, no exercício coercitivo de sua "autoridade" - autoridade esta, no entanto, legitimada pela sociedade e essencial para o cumprimento do trabalho que esta mesma sociedade lhe delega. E ao atacar este que seria um abuso por parte do docente, Gaspar emaranha-se involuntariamente em outra concepção já há tempos rejeitada pelos educadores, o indutivismo empirista, como se lê à continuação do fragmento acima:

Independentemente das razões que levam a uma determinada resposta, a quase unânime participação dos alunos nas atividades experimentais pode ser explicada principalmente por dois motivos: a possibilidade da observação direta e imediata da resposta, que envolve afetivamente o aluno com a atividade; [e] o aluno, livre de argumentos de autoridade, obtém uma resposta isenta, diretamente da natureza. Ambos os motivos garantem o desencadeamento de uma interação social mais rica, motivadora e, conseqüentemente, mais eficaz (ibidem, p. 25-26, grifo nosso).

$\mathrm{Na}$ busca por uma fundamentação vigotskiana da experimentação no ensino, Gaspar avança alguns passos, mas retrocede outros. O saldo, afinal, é positivo: diferentemente do ocorre na maioria dos artigos que levantamos na seção final do capítulo anterior, Gaspar se preocupa em apresentar alguns conceitos principais e específicos da Psicologia HistóricoCultural, como o papel da imitação e da instrução para o desenvolvimento.

Pausa para um pequeno esclarecimento. Sentimo-nos numa posição extremamente desconfortável ao elaborar estes apontamentos críticos, primeiramente dirigidos a nossos colegas da Educação em Química, depois ao respeitável Prof. Alberto Gaspar ${ }^{47}$. Seria injusto,

\footnotetext{
${ }^{47}$ Não posso deixar de reconhecer minha admiração por este educador. Foi através dele, inclusive, que vim a tomar conhecimento do nome de Vigotski, isto durante uma palestra no CDCC, em 2006. A honestidade intelectual do Prof. Gaspar é tamanha que, quando lhe solicitei por correio eletrônico uma cópia de sua tese de livre docência, com o objetivo de conhecer mais profundamente seu entendimento sobre as ideias de Vigotski, recebi o arquivo prontamente. Mesmo ciente de minha intenção em apresentar discordâncias em relação às suas ideias, o Prof. Gaspar endereçou-me também, em sua resposta, uma calorosa mensagem de saudação e incentivo. Deve-se observar, também, que em sua livre docência (GASPAR, 2006) consta uma visão sobre a teoria de Vigotski mais próxima àquela que buscamos recuperar neste trabalho. Poderíamos até pensar se tendência a ocultar as especificidades da teoria de Vigotki e sua fundamentação marxista, em Experiências de ciências, não decorreria de constrangimentos de ordem ideológica, impingidos a Gaspar pela editora que publicou o livro.
} 
de nossa parte, se aqui viéssemos para acusar nossos pares de estarem propositadamente distorcendo a teoria de Vigotski, afastando-a de seus pressupostos marxistas e, assim, contribuindo para uma leitura menos "ideológica" de seus escritos. Parece-nos indubitável que isto esteja acontecendo, mas poderíamos poupar ao menos os autores que publicaram seus textos anteriormente ou logo após a tradução para o português da versão integral de Michlenie $i$ retch - isto é, antes de 2001, e até 2003, 2004 -, dadas as condições limitadas que enfrentavam, à época, para acessarem textos que representassem fielmente as ideias de Vigotski. Assim, suas leituras "particulares" sobre a Psicologia Histórico-Cultural, sob um olhar crítico atual, tratam-se mais de um produto histórico da situação precária em que a psicologia soviética se apresentava em nosso país, do que de mostras de um pensamento reacionário. Podemos considerar que esse período representou uma fase primitiva da chegada das ideias da Psicologia Histórico-Cultural em nosso país. Com as traduções diretamente do idioma russo, elaboradas por Paulo Bezerra, chegamos a uma segunda fase. Felizmente, os acadêmicos permaneceram vigilantes e não se deixaram acomodar pelos inegáveis avanços daí decorrentes. Descortina-se hoje uma terceira fase, marcada por uma reverberação maior das leituras explicitamente marxistas de Newton Duarte, quanto aos textos dos psicólogos soviéticos, e pela propagação dos trabalhos de Zoia Prestes sobre estes mesmos textos, tanto no âmbito da tradução, quanto no âmbito conceitual.

Nossas críticas, portanto, se inserem junto a este movimento. Não nos causa deleite apresentá-las; não é com satisfação que nos voltamos contra nossos próprios companheiros de área, correndo ainda o risco de sermos mal interpretados e de virmos a colecionar desafetos futuramente.

Analisadas as contribuições do Prof. Gaspar para um entendimento da experimentação no ensino de ciências fundamentado em Vigotski, vejamos se outros educadores, desta vez mais próximos da Pedagogia Histórico-Crítica, conseguem caminhar mais alguns passos adiante em direção a uma visão crítico-dialética - portanto, mais afeita aos pressupostos da Psicologia Histórico-Cultural - dos experimentos didáticos. 


\subsection{CONTRIBUIÇÕES DE AUTORES PRÓXIMOS À PEDAGOGIA HISTÓRICO- CRÍTICA}

São poucos os autores, do âmbito da Educação em Ciências, que podem ser considerados como associados à Pedagogia Histórico-Crítica, orientando-se mais ou menos intensamente pelas ideias de Dermeval Saviani e/ou Newton Duarte. Sua produção encontrase registrada em suportes diversos, entre livros, artigos acadêmicos, relatórios de pesquisa e trabalhos apresentados em reuniões científicas. Nesta seção, falaremos sobre estas pequenas, mas significativas contribuições, atendo-nos à questão central deste capítulo, que é a experimentação para o ensino de ciências.

O primeiro autor a produzir uma obra que atende a estas características, e que se guia explicitamente pelas ideias de Dermeval Saviani, é César Sátiro dos Santos ${ }^{48}$, com o livro Ensino de ciências: abordagem histórico-crítica (SANTOS, 2005). Nele, Santos inicia uma seção dedicada à atividade experimental com as seguintes palavras:

O ensino por meio da experimentação é quase uma necessidade no âmbito das ciências naturais. Ocorre que podemos perder o sentido da construção científica se não relacionarmos experimentação, construção de teorias e realidade socioeconômica e se não valorizarmos a relação entre teoria e experimentação, pois ela é o próprio cerne do processo científico (ibidem, p. 61).

E entre uma e outra transcrição literal da obra Sobre a prática, de Mao Tsé-Tung, são apresentadas as sínteses:

A prática científica é parte da prática social global do homem. [...]

$\mathrm{O}$ conhecimento estabelecido pode ser testado. A ciência elabora teorias que respondem às demandas da prática. Não se pode falar de ciência essencialmente teórica ou prática. O saber científico é a relação dialética entre teoria e prática. [...]

O laboratório, sem teoria, é prática vazia e sem sentido. A teoria, sem prática que a confirme, é indiferenciável do conhecimento filosófico, religioso ou artístico. Não existe ciência sem ressonância prática, mas nem toda prática deriva para a ciência. Faz parte da especificidade científica sua natureza prática, bem como seu aspecto quantitativo. [...]

A prática confirma a teoria, mas também é o ponto de partida para sua superação (ibidem, p. 61-62).

\footnotetext{
${ }^{48}$ Em termos cronológicos, uma produção anterior à de Santos, e que mereceria figurar aqui, é a de Paulo M. M. Teixeira, com seus dois artigos que buscam aproximar as pedagogias críticas das ideias do movimento Ciência, Tecnologia e Sociedade (CTS). Deixaremos para falar destes trabalhos no capítulo 6, quando tratarmos do enfoque CTS.
} 
Portanto, Santos ressalta a unidade dialética entre teoria e prática, afirmando a necessidade do laboratório escolar contribuir para a explicitação desta relação. Ao mesmo tempo, convida o saber científico a se imiscuir na prática, tomando a inseparabilidade entre teoria e prática como qualidade específica deste saber.

Outro livro que se dedica a tomar algum aspecto da Educação em Ciências à luz da teoria de Saviani é a obra de Antonio C. H. Geraldo, intitulada Didática de ciências naturais na perspectiva histórico-crítica (GERALDO, 2009). Mais preocupado em sistematizar princípios para uma didática das ciências respaldada na Pedagogia Histórico-Crítica (e também na Psicologia Histórico-Cultural) do que em discorrer longamente sobre aspectos abrangidos pela área de Educação em Ciências como um todo, Geraldo pouco aborda a questão da experimentação. Quando o faz, é para reiterar a observação de Saviani, que transcrevemos à seção 1.2 do primeiro capítulo, de que "ensino não é pesquisa":

\begin{abstract}
Na organização do trabalho escolar, é necessário considerar as diferenças entre o conhecimento científico como linguagem para a compreensão do mundo (da natureza, da sociedade humana e do próprio homem) e como elemento mediador e auxiliar para várias atividades humanas (tais como: as práticas de saúde, de produção agrícola, de produção industrial etc.) e a pesquisa científica como atividade humana em sua especificidade e estrutura: organizada, sistematizada, planejada, institucionalizada. [...] Essa definição da especificidade do processo de conhecimento escolar não exclui a apropriação e o desenvolvimento das habilidades de investigação criadora de conhecimentos na escola por meio de técnicas didáticas específicas (projetos, pesquisa bibliográfica, seminários temáticos, aulas de laboratório e relatórios de procedimentos experimentais, relatórios de aulas de campo etc.); que possibilitem e estimulem o desenvolvimento dessas habilidades, nos moldes da pesquisa científica, pelo contrário, implica-as, como unidade na relação entre conteúdo e forma, entre a atividade sensorial e prática e a atividade de significação humana, e devem ser adequadamente e oportunamente desenvolvidas na educação escolar. Essa concepção da especificidade epistemológica da didática escolar apenas ressalta que as habilidades da investigação científica não se apresentam nem se estruturam como ponto de partida, nem como modelo e nem como estrutura lógica específica única, predominante ou determinante do processo de ensino-aprendizagem escolar. Vale ressaltar, também, o fato de que a escola não pode ser confundida com uma instituição de pesquisa científica, pois estas instituições (as escolas de formação básica e os institutos de pesquisa) têm especificidades estruturais, funcionais e de finalidades (ibidem, p. 79-81).
\end{abstract}

Algumas páginas adiante, quando elenca habilidades a serem estimuladas no ensino de ciências, Geraldo lista oito delas, constando "Aprender a planejar e realizar experimentos e a tirar deles conclusões válidas" e "Saber manusear instrumentos simples, como o termômetro, e realizar corretamente técnicas fundamentais, como a de pesar" (ibidem, p. 91).

Os próximos dois trabalhos que iremos comentar também não se atêm à questão da experimentação no ensino, embora forneçam "pistas" sobre como analisá-la a partir de um 
referencial materialista e dialético. O artigo de Pedrosa e Leite (2011), por exemplo, defende um ensino de ciências em que

\begin{abstract}
os alunos não só se apropriem de conceitos, de teorias, de princípios, de resultados consolidados nas diferentes disciplinas que compõem a Área das Ciências Naturais, mas também, dos recursos metodológicos utilizados na produção desses conhecimentos. Com efeito, é possível compreender que o ensino, por tratar de conhecimentos científicos e sócio-culturais, deve ter como ponto de partida a história que expressa a própria forma como os homens produzem conhecimentos (ibidem, p. 40).
\end{abstract}

Logo depois, os autores afirmam:

Como se pode perceber é na prática social humana que o patrimônio social, cultural e científico é produzido. Dessa forma, os conhecimentos científicos, os instrumentos de produção, a linguagem, as relações sociais, que constituem o patrimônio da humanidade, são históricos, contextualizados e determinados pelas intenções e necessidades humanas e trazem em si as marcas do tempo, do lugar e das intenções de quem os geraram (ibidem, loc. cit.).

Já o trabalho de Anunciação e Moradillo (2012) - um dos únicos trabalhos, do último Eneq, que tomou a Pedagogia Histórico-Crítica como referencial teórico ${ }^{49}-$, apresenta considerações semelhantes, embora sua pesquisa trate do contexto específico da educação voltada para o campo:

Visto que no dia a dia utilizamos coisas e objetos que possuem conhecimento científico a si incorporados, faz-se necessário um ensino de Ciência que relacione estes conhecimentos específicos à materialidade dos objetos, buscando fornecer uma razão de se estudar Ciência no nível médio (ibidem, não paginado).

O artigo de Boss e colaboradores (2012), colocando-se numa linha de continuidade em relação aos textos de Gaspar, como o examinado na seção anterior, dedica-se especificamente a analisar a experimentação para o ensino de conceitos físicos elementares a partir da Psicologia Histórico-Cultural, com contribuições também da Pedagogia Histórico-Crítica para as considerações de cunho estritamente pedagógico. Portanto, entre os trabalhos que comentamos durante esta seção, este é o que, até agora, mais se aproxima do objetivo que perseguimos neste capítulo. A psicologia soviética aparece, nesta pesquisa, principalmente através dos estudos sobre formação de conceitos expostos em Michlenie $i$ retch. Assim, os autores iniciam a discussão de seus resultados a partir de uma concepção de linguagem

\footnotetext{
${ }^{49}$ Há apenas mais um trabalho, apresentado neste evento, apoiado nas ideias de Saviani: um texto de nossa autoria, cujo conteúdo integrará também o próximo capítulo.
} 
enquanto "instrumento que possibilita aos homens se apropriarem das aquisições históricas da humanidade" (ibidem, p. 303-304). Pouco depois, entendem que

\begin{abstract}
a análise realizada no presente estudo reforça a importância, para a formação e alfabetização científica da criança, de se inserir, na educação, palavras mais específicas dos conteúdos de ciências, a partir dos anos iniciais do Ensino Fundamental. As atividades que desenvolvemos com os alunos propiciaram a aquisição de palavras específicas de conteúdos de Física. [...] Mesmo que algumas das palavras já fizessem parte do vocabulário das crianças, é possível que elas tenham sido ressignificadas pela experiência didática. (ibidem, p. 304)
\end{abstract}

Assim, esta investigação buscou aliar a realização de experimentos à transmissão de novas palavras, de modo a facilitar a formação de conceitos físicos verdadeiros em estágios mais avançados da escolarização (como afirmam ao final da p. 305). Dizemos "conceitos físicos verdadeiros" porque, como expõem os autores, os estudos sobre formação de conceitos em Michlenie $i$ retch se referem a diferentes estágios que este processo atravessa durante a educação infantil, partindo do chamado "pensamento por complexos", passando por uma etapa intermediária de "pseudoconceitos", e por fim culminando nos conceitos propriamente ditos, "conceitos verdadeiros" (VIGOTSKI, 2001).

Um último trabalho aqui comentado será a dissertação de mestrado de Juliano Camillo, intitulada Experiências em contexto: a experimentação numa perspectiva sóciocultural-histórica (CAMILLO, 2011). Da mesma forma que o artigo de Boss e colaboradores apresentado acima, trata-se, evidentemente, de mais uma produção dedicada inteiramente ao tema de interesse deste capítulo. Camillo elabora uma compreensão da atividade experimental para a educação científica tomando como base, principalmente, os textos de Leontiev. Seu entendimento do processo de formação humana, de modo mais amplo, se ampara em obras de Newton Duarte. Grande parte das análises do autor se refere ao caráter alienado da forma como as atividades experimentais são normalmente realizadas nos espaços escolares. Lembremos que, de acordo com Leontiev (1978), trata-se de um processo alienado aquele em que não há coincidência entre o motivo que orienta uma atividade e o objeto para o qual ela se dirige. Assim, no exemplo relatado no capítulo anterior (à subseção 2.2.2), diríamos que um estudante que lê um determinado livro, apenas com a finalidade de um bom aproveitamento na avaliação escolar, está engajado em uma ação alienada. Camillo, recorrendo a estas categorias da teoria da atividade, realiza uma análise semelhante. Nas palavras do autor, 
O sentido que queremos destacar, fundamental para nossa análise dos processos de ensino-aprendizagem de ciência - neste caso específico, por meio de atividades experimentais - é que a apropriação de instrumentos mediadores alienados (o que gera ações e atividades alienadas) está relacionada a não consciência de que tais instrumentos (conceitos cotidianos ou científicos, por exemplo) possuem um campo específico de aplicação, não sendo, portanto, universais e independentes do contexto nos quais o sujeito está imerso. Nem são, sobretudo, ontologicamente independentes do sujeito cognoscente, pois a característica instrumental das objetivações humanas apropriadas manifesta-se somente na atividade humana práxica (CAMILLO, 2011, p. 116).

Mais ao final de seu trabalho, Camillo defende a presença das atividades experimentais na sala de aula desde que elas não contribuam para a manutenção destas relações alienadas, pelo contrário, se ponham em prol da apropriação do conhecimento científico pelos educandos:

trata-se de atribuir a cada atividade experimental um sentido mais amplo dentro do conjunto das atividades educacionais como um todo; assim, mesmo o mais simples experimento ganha sua importância quando inserido em um sistema que possui objetivos maiores. O problema encontra-se quando tal objetivo maior não existe e a atividade experimental possui um fim nela mesma, não passando da simples repetição alienada de passos pré-definidos (ibidem, p. 159).

A análise de Camillo parte de um ponto inicial que é também aquele do qual partiremos - as contribuições de Leontiev para a compreensão do processo de humanização, a partir da apropriação, no nível ontogenético, das aquisições constituídas historicamente pelo gênero humano - mas toma outra direção. Interessar-nos-emos em aprofundar, tanto quanto possível no limitado espaço de um capítulo, um aspecto que Camillo utiliza apenas como elo entre suas hipóteses e a conclusão de sua análise, que é justamente o exame dos objetos da cultura humana, em especial os instrumentos de trabalho (inclusive o trabalho científico), enquanto mediadores da atividade prática dos indivíduos e o saber encarnado, materializado, cristalizado nestes mesmos objetos. Assim, teremos a oportunidade de retomar algumas passagens da dissertação de Camillo no momento em que desenvolvermos estas considerações, na próxima seção.

No momento, vale a pena sumarizar as contribuições que estes poucos autores nos legaram para um entendimento crítico-dialético da experimentação para o ensino de ciências:

- É preciso vincular a aprendizagem escolar aos acontecimentos do mundo; sendo assim, ensinar ciências por meio da experimentação se impõe como uma necessidade, pois contribui para explicitar a relação dialética entre teoria e prática; 
- Fazem parte da especificidade da ciência sua natureza prática e seu aspecto quantitativo, daí a importância destas características estarem presentes na educação científica escolar. Do contrário, o ensino de ciências se apresentará de modo incompleto;

- Apesar disso, não se deve confundir ensino com pesquisa. A experimentação para o ensino de ciências deve ser realizada de acordo com suas especificidades didáticas, sem que se espere que os alunos produzam novos conhecimentos, e sim que alcancem resultados da ciência já estabelecidos durante sua constituição histórica. Em outras palavras, qualquer função atribuída à experimentação, que não se refira à apropriação do conhecimento científico pelos estudantes, é estranha à especificidade de seu caráter didático;

- Os recursos metodológicos de que se vale a produção do conhecimento, bem como os objetos da cultura material humana, trazem em si as marcas do tempo, do lugar e das intenções de quem os geraram. É preciso que o ensino de ciências tome a relação entre a materialidade destes objetos e o conhecimento científico como um de seus motivos. Neste sentido, a atividade experimental assume grande importância no ensino, pois aproxima dos alunos um mundo de objetos e instrumentos nos quais estão cristalizados os conhecimentos científicos de que necessitam se apropriar - conforme exigência da prática social mais ampla. Esta apropriação, mediada pelos representantes das gerações anteriores, que no espaço escolar são os professores, pode se dar através do desenvolvimento de habilidades diversas, como as que estão implicadas em instrumentos e técnicas da ciência. Trabalhar com estes instrumentos e técnicas, no entanto, não deve ser fim em si; mais uma vez, trata-se de possibilitar o acesso ao conhecimento científico neles cristalizado, entendendo-se que teoria e prática, conteúdo e método, são pares que se condicionam reciprocamente.

A próxima seção buscará desenvolver o conteúdo dos quatro itens acima. Recorrendo desta vez a textos de autores marxistas, incluindo alguns clássicos do materialismo histórico, assim como às produções de Dermeval Saviani e de A. N. Leontiev, esperamos encerrar o capítulo com um entendimento mais bem embasado da atividade experimental didática a partir de uma visão crítico-dialética. 


\subsection{CONTRIBUIÇÕES DO PRESENTE TRABALHO}

A seção está dividida em três subseções. Na primeira, recuperamos alguns fundamentos da teoria do conhecimento na perspectiva do materialismo histórico e dialético. Tais considerações filosóficas são imprescindíveis para que prossigamos sem o risco de incorrer em posições racionalistas ou empiristas, há muito superadas pela gnosiologia marxista.

A seguir, apresentamos uma breve discussão que recorre novamente ao conteúdo do livro Escola e democracia, de Saviani, assentando algumas de suas posições no terreno concreto do ensino de ciências. Se a explicitação de aspectos de uma teoria do conhecimento marxista é comum em pesquisas congêneres à nossa - como se pode observar nos trabalhos citados na seção anterior -, uma análise do livro de Saviani direcionada ao ensino de ciências, salvo melhor juízo, é ainda algo inédito.

A subseção final apresenta outra contribuição nova. A partir das passagens de $O$ desenvolvimento do psiquismo, de Leontiev, que se referem aos instrumentos de trabalho, convocaremos outros textos e autores para entender como os experimentos para o ensino de ciências podem proporcionar a apropriação, por parte dos alunos, dos conhecimentos científicos associados aos instrumentos e aparatos experimentais.

\subsubsection{Teoria do conhecimento à luz do materialismo histórico e dialético}

Em momentos anteriores, analisamos concepções manifestadas no discurso e nas práticas de autores da Educação em Ciências, algumas delas se referindo ao campo epistemológico. Nesta subseção, poderemos estudar detidamente estas questões.

Lembremos que ao início do capítulo anterior elaboramos uma crítica ao construtivismo partindo de três frentes: a metodológica, a gnosiológica e a política. Quanto à frente gnosiológica, concentramos nossos argumentos na demonstração do equívoco do relativismo inerente a qualquer orientação construtivista. Deixamos de lado, naquela oportunidade, uma crítica também à posição do construtivismo frente a aspectos como a 
relação entre teoria e prática, na produção do conhecimento científico, e o papel da experiência.

Retomando a crítica ao construtivismo, portanto, a partir deste ponto, convém trazer novamente a voz de Michael Matthews para nosso texto. Para este autor, não há como negar que o construtivismo se insere junto à tradição filosófica do empirismo:

Qualquer teoria que formule o problema do conhecimento em termos de um sujeito observando um objeto, e questionando quão bem sua experiência ou suas sensações refletem a natureza ou essência deste objeto, é quintessencialmente aristotélica, ou de modo mais geral, empirista - mesmo se concluir que a experiência sensorial não reflete a natureza ou essência do objeto (MATTHEWS, 1994, p. 150, tradução nossa).

E o autor, então, narra um breve percurso histórico das ideias empiristas, dos aristotélicos aos construtivistas contemporâneos. Quando estes incorporam estas ideias, elas já estão coloridas pelo relativismo, cujos germens remontariam a Locke e Berkeley. Assim,

No interior desta tradição aristotélica-empirista a possibilidade do conhecimento se enfraqueceu, uma vez que, como assinalado, a mente é ativa na cognição. A possibilidade do conhecimento se evaporou já que, como afirmado, os objetos imediatos da faculdade intelectual eram impressões dos sentidos, em vez da própria natureza. A natureza, ou nos termos de Kant, a coisa-em-si, se tornou incognoscível, porque só podemos enxergar por lentes distorcidas, e não há posição privilegiada para, a partir dela, se checar a correspondência do pensamento à realidade.

Seguindo Kant, Piaget e o exército dos filósofos pós-positivistas tais como Toulmin, Kuhn, Feyerabend, Rorty e outros, o construtivismo moderno afirma que, porque os indivíduos são ativos na aquisição do conhecimento, o conhecimento de uma realidade exterior é impossível (ibidem, p. 151, tradução nossa).

Outro autor a que recorremos frequentemente naquela crítica ao construtivismo, e que convidamos novamente ao texto, é José S. Fonseca de Carvalho. Como que dando continuidade ao que foi transcrito acima, ele assim se refere à influência de Kant sobre Piaget:

Piaget é [...] não só um herdeiro do pensamento kantiano, mas de toda uma tradição moderna de investigações sobre o conhecimento, ainda que recorra a procedimentos inovadores, como os estudos empíricos em psicologia do desenvolvimento. Mas, não obstante essa inovação, sua concepção é solidária a essa perspectiva, muito característica da maior parte da epistemologia moderna clássica, na qual o problema do conhecimento é analisado a partir da formação - e dos problemas da adequação da representação - em uma mente individual e isolada. Descartes representa, em vários aspectos, o exemplo mais frisante - e mesmo paradigmático - dessa perspectiva na abordagem do desenvolvimento do conhecimento. Nele, a mente do sujeito, isolada em sua individualidade, obtém um conhecimento seguro a partir da primeira certeza interna - o cogito -, gradativamente ampliada por uma cadeia dedutiva de verdades. Assim concebido, o problema do conhecimento objetivo está ligado ao da confiabilidade das representações mentais de um indivíduo, e não à 
criação e ao uso coletivos de conceitos e procedimentos de linguagens públicas (CARVALHO, 2001, p. 107, grifos do autor).

Para Carvalho, tanto o empirismo quando o racionalismo estariam incorrendo no mesmo erro ao analisar a questão do conhecimento a partir de uma posição individualista. $\mathrm{O}$ primeiro acredita que o conhecimento provém das sensações, mas não encontra critérios para definir a objetividade da realidade conhecida. O segundo defende um isolamento introspectivo na busca pelo conhecimento verdadeiro, cercando-se de metafísica e apriorismo.

Trazer a relevo o individualismo destas tradições filosóficas é um bom mote para introduzirmos as características de uma teria do conhecimento apoiada em Marx, Engels e seus seguidores. Afinal, os pais do materialismo histórico já haviam se confrontado com tais posições. Já em sua primeira obra conjunta, A sagrada família (1845), afirmavam, na crítica ao entendimento precário dos jovens hegelianos sobre o materialismo francês, que

Se o homem é formado por circunstâncias, é preciso formar as circunstâncias humanamente. Se o homem é, por natureza, sociável, só desenvolverá sua verdadeira natureza na sociedade, e o poder da sua natureza deve medir-se não pela força do indivíduo singular, mas pela força da sociedade (MARX; ENGELS, 1974a, p. 196197).

Na famosa obra $O$ que é ciência, afinal?, Alan Chalmers caracteriza brevemente o modo como a filosofia de Marx redunda numa concepção sobre o conhecimento:

\begin{abstract}
o materialismo histórico, a teoria da sociedade e mudança social iniciada por Karl Marx é uma teoria objetivista na qual a abordagem objetivista [...] em relação ao conhecimento está aplicada à sociedade como um todo. O objetivismo de Marx está evidente em seu conhecido comentário "não é a consciência dos homens que determina o seu ser, mas, ao contrário, seu ser social é que determina a sua consciência." 50 Do ponto de vista materialista os indivíduos nascem em alguma parte de uma estrutura social preexistente que não escolhem e sua consciência é formada por aquilo que eles fazem e experimentam naquela estrutura. Embora os indivíduos possam vir a ter alguma compreensão da natureza da estrutura social em que vivem, haverá sempre uma "separação entre a estrutura e a operação da sociedade e seus reflexos distorcidos nas mentes individuais". [...] Da mesma forma que um físico que tenta contribuir para o desenvolvimento da física confronta-se com uma situação objetiva, que delimita as possibilidades de escolha e de ação e que influencia o resultado de tal ação, também, um indivíduo que espera contribuir para a mudança social se confronta com uma situação objetiva, que delimita as possibilidades de escolha e ação e que influencia o resultado de tal escolha e ação. Uma análise da situação objetiva é tão essencial para a compreensão da mudança social quanto o é para a mudança científica (CHALMERS, 1993, p. 161-162).
\end{abstract}

Busquemos, então, aprofundar estes entendimentos iniciais.

\footnotetext{
${ }^{50}$ Chalmers está reproduzindo as palavras de Marx no prefácio da Contribuição à crítica da economia política.
} 
Se o homem é formado por circunstâncias, nascendo em um mundo já préconfigurado, a teoria do conhecimento inspirada no marxismo deve necessariamente partir de pressupostos que deem vulto justamente ao primado destas circunstâncias. Tal teoria só poderia, portanto, se basear numa filosofia materialista. Transcrevemos uma conceituação de Lênin sobre esta posição filosófica:

O materialismo admite de uma maneira geral que o ser real objectivo (a matéria) é independente da consciência, das sensações, da experiência humana. O materialismo histórico admite que a existência social é independente da consciência social da humanidade. A consciência é só, aqui e ali, o reflexo do ser, no melhor dos casos um reflexo aproximadamente exacto (adequado, de uma precisão ideal). Não se pode suprimir nenhum princípio fundamental, nenhuma parte essencial desta filosofia do marxismo fundida num só bloco de aço, sem se afastar da verdade objectiva, sem cair na mentira burguesa reacionária (LÉNINE, 1975, p. 294).

Lênin, em outros momentos desta obra, se refere a esta concepção como uma ingenuidade, uma espécie de senso comum. Mas é justamente esta ideia "banal" que deve constituir a base das ciências naturais, que não poderão se desenvolver completamente se condicionadas a uma filosofia idealista, que tome o ser como decorrente da consciência. Do contrário, há o perigo de se cair na "absolutização de aspectos isolados do mundo objetivo" (KOPNIN, 1978, p. 56), ou no agnosticismo, a impossibilidade ontológica do conhecimento.

Mesmo assim, é preciso dar consistência teórica, elaborar em termos precisos e tornar frutífera esta concepção ingênua, o que levará a uma teoria do conhecimento coincidente com a lógica e a dialética. Kopnin recorre novamente a Lênin para caracterizar esta teoria:

Lênin formulou da seguinte maneira as exigências básicas da lógica dialética: "Para conhecer realmente o objeto, é preciso abrangê-lo, estudar todos os seus aspectos, todas as relações e 'mediações'. Nunca conseguiremos isto plenamente, mas a exigência de multilateralidade nos prevenirá contra erros e necrose. Isto em primeiro lugar. Em segundo, a lógica dialética exige que se tome o objeto em seu desenvolvimento, 'automovimento' (como Hegel às vezes dizia), em mudança... Em terceiro lugar, toda a prática humana deve incorporar-se à plena 'definição' do objeto quer como critério da verdade, quer como determinante prático da relação entre o objeto e aquilo de que o homem necessita. Em quarto lugar, a lógica dialética ensina que "não há verdade abstrata, que a verdade é sempre concreta'..." (ibidem, p. $82)$.

Estamos nos aproximando do assunto que interessa a este capítulo, que é o entendimento da função das experiências científicas para a evolução do conhecimento. Vale lembrar que, para o materialista dialético, as leis da natureza são perfeitamente cognoscíveis, embora nenhum conhecimento seja definitivo. 
Não conhecemos as leis necessárias da natureza nos fenómenos meteorológicos, e é por isso que somos inevitavelmente escravos do tempo que faz. Mas não conhecendo esta necessidade, sabemos que existe. De onde vem esse conhecimento? Vem justamente de onde nos vem o conhecimento das coisas existentes fora da nossa consciência e independentemente desta, por outras palavras: da evolução dos nossos conhecimentos, que mostrou milhões de vezes a qualquer homem que a ignorância dá lugar ao saber quando o objeto actua sobre os nossos órgãos dos sentidos, e inversamente: uma vez afastada a possibilidade desta ação, a ciência torna-se ignorância (LÉNINE, 1975, p. 169, grifos do autor).

Foi indispensável a transcrição do fragmento acima para explorarmos atentamente certa questão, que é a possibilidade de uma confusão do materialismo dialético com o empirismo sensualista. Lênin coloca como condição fundamental do conhecimento a ação da matéria sobre nossos órgãos dos sentidos. Entre os pesquisadores do ensino de ciências parece haver certa aversão a este tipo de pensamento, por associarem-no com o positivismo. Ora, isto é um engano. $\mathrm{O}$ materialismo dialético não afirma a identidade entre o conhecimento e o mundo sensível, que seria uma das consequências da filosofia de Comte. O mundo objetivo existe no pensamento - sendo, então conhecido - não como cópia, mas como reflexo (e como disse Lênin, um reflexo aproximadamente exato, no melhor dos casos). Mas se a relação entre a realidade e o pensamento, por um lado, não é de identidade, por outro, é de inseparabilidade:

O sensorial e o racional não são dois degraus do conhecimento mas dois momentos que o penetram em todas as formas e em todas as etapas de desenvolvimento. $\mathrm{O}$ próprio pensamento nunca pode carecer do sensorial quer na sua origem, quer na forma de existência; ele sempre se baseia no sistema de sinais sensorialmente perceptíveis (KOPNIN, 1978, p. 150).

E o fato do pensamento ser reflexo do mundo objetivo, e não cópia, necessariamente leva ao reconhecimento da importância da linguagem para o processo de conhecimento:

A unidade entre o sensorial e o racional no processo de conhecimento não significa que um sucede o outro mas que ambos participam necessariamente no nosso conhecimento. Mesmo quando apenas observamos os fenômenos da realidade, nós pensamos, traduzimos para a linguagem das idéias os resultados da nossa observação. Não podemos imaginar o conhecimento do homem sem a linguagem, pois a linguagem consubstancia nas palavras os resultados do pensamento (ibidem, loc. cit., grifo do autor).

A existência de um elemento mediador entre a sensação e o conhecimento é fundamental para se compreender a diferença entre o materialismo dialético e o positivismo, que é essencialmente a-histórico. A própria racionalidade deste mediador é uma prova de sua historicidade: se os primeiros conhecimentos elaborados pela humanidade deveriam coincidir 
com o conteúdo de suas sensações, no caminhar da história haveria de se interpor, entre a realidade empírica e a realidade conhecida, a linguagem, os conceitos e o próprio desenvolvimento histórico dos órgãos dos sentidos. Que a linguagem e os conceitos tenham sua historicidade, isto é ponto pacífico entre partidários de correntes filosóficas bastante diversas. Que os sentidos, no entanto, possuam também um caráter histórico, isto sim desafia o senso comum. Marx, nos Manuscritos econômico-filosóficos, já havia se referido a isto:

A superação da propriedade privada é por isso a emancipação total de todos os sentidos e qualidades humanos; mas é precisamente esta emancipação, porque todos estes sentidos e qualidades se fizeram humanos, tanto objetiva quanto subjetivamente. O olho fez-se olho humano, assim como seu objeto se tornou um objeto social, humano, vindo do homem para o homem. Os sentidos fizeram-se assim imediatamente teóricos em sua prática. Relacionam-se com a coisa por amor da coisa, mas a coisa mesma é uma relação humana e objetiva para si e para o homem $^{51}$ e inversamente. Carecimento e gozo perderam com isso sua natureza egoísta e a natureza perdeu sua mera utilidade, ao converter-se a utilidade em utilidade humana. Igualmente, os sentidos e o gozo dos outros homens converteramse em minha própria apropriação. Além destes órgãos imediatos constituem-se assim órgãos sociais, na forma da sociedade; assim, por exemplo, a atividade imediatamente na sociedade com outros, etc., converte-se em um órgão de minha exteriorização de vida e um modo de apropriação da vida humana (MARX, 1987, p. 177 , grifos do autor).

De modo mais concreto, diz ainda Marx:

É evidente que o olho humano goza de modo distinto que o olho bruto, não humano, que o ouvido humano goza de maneira distinta que o bruto, etc. [...] é primeiramente a música que desperta o sentido musical do homem; para o ouvido não musical a mais bela música não tem sentido algum, não é objeto, porque meu objeto só pode ser a confirmação de uma de minhas forças essenciais, isto é, só é para mim na medida em que minha força essencial é para si, como capacidade subjetiva, porque o sentido do objeto para mim (somente tem um sentido a ele correspondente) chega justamente até onde chega meu sentido: por isso também os sentidos do homem social são distintos do não social. É somente graças à riqueza objetivamente desenvolvida da essência humana que a riqueza da sensibilidade humana subjetiva é em parte cultivada, e é em parte criada, que o ouvido torna-se musical, que o olho percebe a beleza da forma, em resumo, que os sentidos tornam-se capazes de gozo humano, tornam-se sentidos que se confirmam como forças essenciais humanas. [...] A formação dos cinco sentidos é um trabalho de toda a história universal até nossos dias (ibidem, p. 177-178, grifos do autor).

Esta questão viria a ser investigada diligentemente pelos estudiosos da Psicologia Histórico-Cultural, como relata o livro $O$ desenvolvimento do psiquismo. $\mathrm{O}$ fragmento de Marx, transcrito acima, é também reproduzido e comentado por Leontiev nesta obra sua, após a seguinte colocação:

\footnotetext{
51 "Só posso relacionar-me na prática de um modo humano com a coisa, quando a coisa se relaciona humanamente com o homem" (nota de Marx).
} 
A actividade animal compreende actos de adaptação ao meio, mas nunca actos de apropriação das aquisições do desenvolvimento filogénico. Estas aquisições são dadas ao animal nas suas particularidades naturais hereditárias; ao homem, são propostas nos fenómenos objectivos do mundo que o rodeia. Para as realizar no seu próprio desenvolvimento ontogénico, o homem tem que apropriar-se delas; só na sequência deste processo - sempre activo - é que o indivíduo fica apto para exprimir em si a verdadeira natureza humana, estas propriedades e aptidões que constituem o produto do desenvolvimento socio-histórico do homem. O que só é possível porque estas propriedades e aptidões adquiriram uma forma material objectiva (LEONTIEV, 1978, p. 166, grifos do autor).

O homem se apropria da experiência histórica das gerações anteriores ao se relacionar praticamente com os produtos da objetivação desta experiência, ou seja, quando eles participam de sua atividade prática. Estes produtos sempre possuem uma forma material, objetiva, embora esta materialidade possa ser mais (caso dos instrumentos e objetos diversos) ou menos (caso da música e da linguagem) evidente. Todas as potencialidades do psiquismo animal já aparecem determinadas por sua hereditariedade. No caso do homem, tais potencialidades não obedecem a este determinismo biológico. Estão, isto sim, condicionadas pelo modo como se estabelecem as relações entre o homem e o ambiente que o cerca. São as formas de atividade prática, com os objetos que materializam o grau de desenvolvimento atingido pelas gerações anteriores, que garantem a apropriação das funções psicológicas surgidas no decurso do desenvolvimento histórico do gênero humano.

O caso específico do ouvido humano, comentado por Marx, é abrangido por estas investigações descritas no livro de Leontiev. No capítulo sobre "O biológico e o social no psiquismo do homem" (ibidem, p. 233-258), o pesquisador russo descreve os bem sucedidos experimentos que sua equipe empreendeu para formar certas faculdades auditivas em pacientes desprovidos delas. A formação do chamado "ouvido tonal" - habilidade de discriminar alturas musicais -, nestes sujeitos, fora observada após uma série de experiências, que não descreveremos em detalhe aqui, mas que levaram o grupo de Leontiev a conclusões importantíssimas no terreno da anato-fisiologia humana e do então emergente campo da neuropsicologia. Segundo estes estudos, da mesma maneira que a faculdade geral de ouvir é proporcionada pelo aparato anatômico do sistema auditivo, existem faculdades específicas associadas à audição, e aos demais sentidos, que são proporcionadas não por formações anatômicas, mas por formações fisiológicas, às quais Leontiev denomina "órgãos funcionais". É o estabelecimento de relações interfuncionais, possibilitado pela enorme plasticidade do aparato neurológico humano, que garante a emergência destas "neoformações", destes "órgãos fisiológicos", outros termos a que Leontiev recorre para denominar estes órgãos. O que forma, efetivamente, os órgãos funcionais não é nenhuma disposição interna individual, 
nenhum processo de maturação puramente psicológico, nenhuma vontade que emana dos recônditos da consciência humana. É a atuação prática dos indivíduos, com o mundo material produzido pelo trabalho das gerações anteriores, que garante o estabelecimento destes nexos interfuncionais, disparando um processo que, quando consolidado, desemboca na apropriação de funções psicológicas superiores formadas ao longo do desenvolvimento histórico humano. Nas palavras de Leontiev,

Se, portanto, distinguimos nos processos psíquicos superiores do homem, por um lado, a sua forma, isto é, as particularidades puramente dinâmicas que dependem da sua "factura" morfológica e, por outro, o seu conteúdo, isto é, a função que eles exercem e a sua estrutura, então podemos afirmar que o primeiro elemento é determinado biologicamente e o segundo, socialmente. Será preciso sublinhar que o aspecto decisivo é o conteúdo?

$\mathrm{O}$ processo de apropriação do mundo dos objetos e dos fenómenos criados pelos homens no decurso do desenvolvimento histórico da sociedade é o processo durante o qual teve lugar a formação, no indivíduo, de faculdades e de funções especificamente humanas. Seria profundamente erróneo todavia representar-se este processo como o resultado de uma actividade da consciência ou da acção da "intencionalidade" no sentido em que entendem Husserl e outros.

O processo de apropriação efectua-se no decurso do desenvolvimento de relações reais do sujeito com o mundo. Relações que não dependem nem do sujeito nem da sua consciência, mas são determinadas pelas condições históricas concretas, sociais, nas quais ele vive, e pela maneira como a sua vida se forma nestas condições.

É por isto que a questão das perspectivas de desenvolvimento psíquico do homem e da humanidade põe antes de mais o problema de uma organização equitativa e sensata da vida da sociedade humana - de uma organização que dê a cada um a possibilidade prática de se apropriar das realizações do progresso histórico e de participar enquanto criador no crescimento destas realizações (ibidem, p. 257-258, grifos do autor).

A doutrina empirista assevera, corretamente, que são as sensações o ponto de partida de todo conhecimento. No entanto, ignora que é o desenvolvimento histórico dos homens que determina as formas em que estas sensações serão apreendidas. A formação dos sentidos humanos não se resume ao desenvolvimento filogenético de nossa espécie: participa deste processo também o desenvolvimento histórico, que disponibiliza às novas gerações as conquistas das gerações anteriores, materializadas em objetos e signos. Um olhar que não tenha sido educado para apreender padrões geométricos dificilmente será capaz de fazer inferências a partir de um gráfico. O ouvido carente de educação musical é pouco competente para diferenciar duas sonatas de piano de autores diferentes, e totalmente incapaz de determinar objetivamente o que faz com que Chopin não seja Tchaikovski. Um episódio da história da ciência ilustra de modo convincente que a plena saúde das faculdades perceptivas visuais não é garantia de que algo esteja sendo visto ${ }^{52}$ : mesmo que Galileu levasse seus

\footnotetext{
${ }^{52}$ Não à toa, existe a máxima: "Enxerga, mas não $v e ̂ "$.
} 
inquisidores ao telescópio, eles não conseguiriam observar nada que atestasse as irregularidades da superfície lunar, o que seria, à época, um duro golpe à cosmologia aristotélico-ptolomaica. Faltava a eles a educação do olhar, que neste caso era mesmo uma educação artística, pela qual havia passado Galileu, vindo a se apropriar das noções de perspectiva e do contraste claro-escuro. Não fosse este olhar educado pela arte, Galileu teria chances mais limitadas de contribuir para a revolução científica que mais tarde o glorificaria (REIS; GUERRA; BRAGA, 2006).

Assim, o temor de que a atividade experimental redunde na aceitação do positivismo, caso se enfatize o caráter empírico dos fenômenos em estudo, é infundado. Insistimos nesta demonstração por acreditar que esta postura é que pode levar a prejuízos, na medida em que conduz muitos educadores a aderir ao extremo oposto do empirismo, que seria um racionalismo idealista. Como já dissemos anteriormente, no limite, este tipo de concepção pode resultar na própria negação da possibilidade do ato de conhecer.

Também não se trata de defender um meio-termo entre estas duas posições, mas sim advogar por uma postura superadora de ambas, no sentido dialético. Em outras palavras,

é estranho ao marxismo tanto o empirismo unilateral, rasteiro, que desdenha das abstrações como a teorização vazia, desvinculada dos fatos e fenômenos da realidade. As abstrações são boas quando têm a tarefa de desvendar as leis reais da natureza e da sociedade, quando armam o homem com o conhecimento dos processos profundos, inacessíveis à contemplação imediata, sensorial. Mas se o pensamento se encerra em abstrações, deixa de ser meio de conhecimento da realidade, transformando-se em instrumento para distanciar-se dela. Só a correta combinação do conhecimento experimental com o pensamento teórico assegura a obtenção da verdade objetiva (ibidem, p. 160).

O próprio Saviani, discorrendo sobre estas questões, apresenta-nos uma síntese clara e suficiente para encerrarmos as considerações desta subseção:

O movimento global do conhecimento compreende dois momentos. Parte-se do empírico, isto é, do objeto na forma como se apresenta à observação imediata, tal como é figurado na intuição. Nesse momento inicial, o objeto é captado numa visão sincrética, caótica, isto é, não se tem clareza do modo como ele está constituído. Aparece, pois, sob a forma de um todo confuso, portanto, como um problema que precisa ser resolvido. Partindo dessa representação primeira do objeto, chega-se por meio da análise aos conceitos, às abstrações, às determinações mais simples. Uma vez atingido esse ponto, faz-se necessário percorrer o caminho inverso (segundo momento) chegando, pela via da síntese, de novo ao objeto, agora entendido não mais como "a representação caótica de um todo", mas como "uma rica totalidade de determinações e de relações numerosas",53.

Assim compreendido, o processo de conhecimento é, ao mesmo tempo, indutivo e dedutivo, analítico-sintético, abstrato-concreto, lógico-histórico. [...]

\footnotetext{
${ }^{53}$ Passagem da introdução da Contribuição à crítica da economia política (MARX, 2013, p. 258).
} 
O empirismo e, portanto, o positivismo se limitam ao primeiro passo. Para essa tendência gnosiológica, conhecer, fazer ciência, é reduzir o complexo ao simples; é passar do particular ao geral; é chegar a conceitos gerais, por isso mesmo, simples e abstratos, dotados, exatamente por causa de seu caráter abstrato, de validade universal.

Inversamente, o racionalismo idealista limita-se ao segundo passo. Para essa tendência, em última instância, nada existe fora do pensamento. Assim é o pensamento que constitui o homem real, o que significa que também o mundo só é admitido como real enquanto concebido (SAVIANI, 2012, p. 61-62, grifos nossos).

\subsubsection{Uma análise de Escola e democracia}

Na seção 1.4 do capítulo 1, resumimos o conteúdo de "Onze teses sobre educação e política", o último texto do livro Escola e democracia de Dermeval Saviani. Nesta subseção, retornaremos a este escrito, buscando nele alguns elementos para a compreensão da atividade experimental para o ensino de ciências de acordo com a Pedagogia Histórico-Crítica.

“Onze teses sobre educação e política" (SAVIANI, 1983, p. 91-101), como já afirmamos, delineia as condições de elaboração da Pedagogia Histórico-Crítica na sociedade atual. Trata-se de um texto conciso, desenvolvido a partir de um único postulado: "De uns tempos para cá se tornou comum a afirmação de que a educação é sempre um ato político. Mas o que significa essa afirmação?” (ibidem, p. 91). Saviani, provavelmente, toma como referência a popularização das teorias educacionais com discurso renovador, sejam críticas (como a tendência libertadora, de Paulo Freire) ou acríticas (como a pedagogia escolanovista), ao se referir à fixação da educação enquanto ato político como um senso comum pedagógico.

O título do texto remete às famosas 11 Teses sobre Feuerbach (MARX; ENGELS, 2009, p. 119-126). Nestas formulações aforismáticas, que Marx teria redigido apenas para organizar suas ideias, o pai do materialismo histórico critica a concepção materialista do jovem hegeliano Ludwig Feuerbach (1804-1872). Seu pensamento é considerado por Marx como um avanço em relação ao idealismo de grande parte dos filósofos de seu tempo. Mas, como explicita Engels em Ludwig Feuerbach e o fim da filosofia clássica alemã (idem, 1974b), Feuerbach fica no meio do caminho entre o idealismo hegeliano e o materialismo dialético. As Teses sobre Feuerbach tratam de explicitar as insuficiências desta doutrina que, portanto, retêm seu avanço para uma concepção materialista e histórica. Por exemplo, a tese 6 assevera que Feuerbach, em sua crítica ao cristianismo, demonstra acertadamente a origem e a 
natureza humana dos sentimentos religiosos, mas ignora que tal natureza não foi dada aos homens de uma vez por todas, sendo um produto de sua atividade prática:

\footnotetext{
Feuerbach dissolve a essência religiosa na essência humana. Mas a essência humana não é uma abstração intrínseca ao indivíduo isolado. Em sua realidade, ela é o conjunto das relações sociais.

Feuerbach, que não penetra na crítica dessa essência real, é forçado, por isso:

1 - a fazer abstração do curso da história, fixando o sentimento religioso para si mesmo, e a pressupor um indivíduo humano abstrato - isolado;

2 - por isso, nele a essência pode ser compreendida apenas como "gênero", como generalidade interna, muda, que une muitos indivíduos de modo meramente natural (idem, 2009, p. 125, grifos dos autores).
}

Saviani parece fazer um trabalho análogo em Onze teses sobre educação e política. O escolanovismo e outras tendências renovadas haviam demonstrado que a pedagogia tradicional incorrera em um erro ao negar o caráter político da educação. Ao fazer esta crítica, no entanto, estas pedagogias acabaram por "santificar" o aspecto político da prática educativa, tornando-o absoluto e soberano. Importava, para Saviani, desfazer este reducionismo, explicitando a especificidade da prática educativa e suas distinções da prática política.

Partindo destas distinções, Saviani trata dos tipos de relações sociais engendradas por ambas as práticas. Neste aspecto, educação e política não são apenas diferentes, como opostas: a educação configura uma relação travada entre não-antagônicos, pois o educador está sempre a serviço dos interesses do educando; já a política é, em si, uma relação entre pares antagônicos, em que se defrontam interesses e perspectivas mutuamente excludentes. De modo resumido, "em educação o objetivo é convencer e não vencer" e "em política o objetivo é vencer e não convencer" (SAVIANI, 1983, p. 92). O autor nos previne do perigo de se confundir estas práticas, "o que redundaria em dissolver uma na outra (a dissolução da educação na política configuraria o politicismo pedagógico do mesmo modo que a dissolução da política na educação implicaria o viés do pedagogismo político)” (ibidem, p. 94).

Apesar desta oposição, educação e política são inseparáveis e mantém íntima relação, e é a desenvolver este aspecto que o texto de Saviani se dedica então. O autor busca demonstrar que toda prática educativa contém uma dimensão política e vice-versa, recorrendo novamente à questão das relações antagônicas/não-antagônicas:

A dimensão política da educação consiste em que, dirigindo-se aos não-antagônicos a educação os fortalece (ou enfraquece) por referência aos antagônicos e desse modo potencializa (ou despotencializa) a sua prática política. E a dimensão educativa da política consiste em que, tendo como alvo os antagônicos, a prática política se fortalece (ou enfraquece) na medida em que, pela sua capacidade de luta ela 
convence os não-antagônicos de sua validade (ou não-validade) levando-os a se engajarem (ou não) na mesma luta (ibidem, loc. cit.).

De modo mais claro,

A dimensão pedagógica da política envolve, pois, a articulação, a aliança entre os não-antagônicos visando à derrota dos antagônicos. E a dimensão política da educação envolve, por sua vez, a apropriação dos instrumentos culturais que serão acionados na luta contra os antagônicos (ibidem, loc. cit.).

Este seria o lado "interno" das relações entre educação e política, no sentido de uma prática manifestar características de outra, numa dialética unidade de contrários. Do lado "externo", educação e política também se relacionam: a primeira precisa de pressupostos materiais para acontecer, o que envolve políticas públicas, orçamentárias etc.; a última necessita de processos educativos para difundir propostas, formar quadros etc. De um ponto de vista ou de outro, portanto, educação e política são inseparáveis.

A seguir Saviani aborda a historicidade das práticas, considerando que ambas participam de um todo maior: "trata-se de práticas distintas, mas que ao mesmo tempo não são outra coisa senão modalidades específicas de uma mesma prática: a prática social. Integram, assim, um mesmo conjunto, uma mesma totalidade" (ibidem, p. 95). E que prática social é esta? "É a prática da sociedade de classes, que é uma sociedade cindida em interesses antagônicos". Como o antagonismo prevalece, é a política o aspecto da prática social que se sobressai nesta sociedade. Educação e política, portanto, possuem relativa autonomia uma em relação à outra, mas sua dependência recíproca não é simétrica: “é preciso levar em conta que o grau de dependência da educação em relação à política é maior do que o desta em relação àquela" (ibidem, loc. cit.). No entanto, dada a historicidade do caráter dominante da prática política no momento atual, ele pode ser subvertido:

superada a sociedade de classes, chegando o momento histórico em que prevalecem os interesses comuns, a dominação cede lugar à hegemonia, a coerção à persuasão, a repressão se desfaz, prevalecendo a compreensão. Aí, sim, estarão dadas historicamente as condições para o pleno exercício da prática educativa.

Falei antes em exercício pleno da prática educativa como algo só possível num tipo de sociedade que se delineia no horizonte de possibilidades das condições atuais mas que não chegou ainda a se concretizar. Isto porque a plenitude da educação como, no limite, a plenitude humana, está condicionada à superação dos antagonismos sociais. Ora, ser idealista em educação significa justamente agir como se esse tipo de sociedade já fosse realidade. Ser realista, inversamente, significa reconhecê-la com um ideal que buscamos atingir (ibidem, p. 96-97, grifos do autor). 
A prática educativa, no momento atual, confirma e ajuda a reproduzir o domínio da prática política, pois reproduz a própria sociedade de classes. Eis o caráter reprodutivista da educação. No entanto, ao reproduzir esta sociedade dividida em interesses antagônicos, a prática educativa reproduz também suas contradições. E eis então o caráter histórico e progressista da educação. Se a prática política se apoia na "verdade do poder", a prática educativa se apoia no "poder da verdade" (ibidem, p. 97). Ao transmitir esta verdade, representada pela cultura erudita, é que a escola assume um papel político na transformação da sociedade, pondo-se a favor do movimento da história. Nas palavras de Saviani,

É, pois, realizando-se na especificidade que lhe é própria que a educação cumpre sua função política. Daí eu ter afirmado que ao se dissolver a especificidade da contribuição pedagógica anula-se, em consequiência, a sua importância política (ibidem, p. 98).

Concluindo o texto, Saviani expõe suas 11 teses sobre educação e política, reproduzidas abaixo (ibidem, p. 98-101), e que sintetizam as considerações acima:

1. Não existe identidade entre educação e política.

Corolário: educação e política são fenômenos inseparáveis, porém efetivamente distintos entre si.

2. Toda prática educativa contém inevitavelmente uma dimensão política.

3. Toda prática política contém, por sua vez, inevitavelmente uma dimensão educativa.

4. A explicitação da dimensão política da prática educativa está condicionada à explicitação da especificidade da prática educativa.

5. A explicitação da dimensão educativa da prática política está, por sua vez, condicionada à explicitação da especificidade da prática política.

6. A especificidade da prática educativa se define pelo caráter de uma relação que se trava entre contrários não-antagônicos.

Corolário: a educação é, assim, uma relação de hegemonia alicerçada, pois, na persuasão (consenso, compreensão).

7. A especificidade da prática política se define pelo caráter de uma relação que se trava entre contrários antagônicos.

Corolário: a política é, então, uma relação de dominação alicerçada, pois, na dissuasão (dissenso, repressão). 
8. As relações entre educação e política se dão na forma de autonomia relativa e dependência recíproca.

9. As sociedades de classe se caracterizam pelo primado da política, o que determina a subordinação real da educação à prática política.

10. Superada a sociedade de classes, cessa o primado da política e, em consequência, a subordinação da educação.

11. A função política da educação se cumpre na medida em que ela se realiza enquanto prática especificamente pedagógica.

Voltemos a tratar do objeto de considerações deste capítulo, a experimentação para o ensino de ciências. De que modo esta análise do texto de Saviani pode auxiliar-nos a compreender melhor o papel desta estratégia na educação científica?

Para mediar as considerações de Saviani, no terreno propriamente pedagógico, e um olhar para nosso objeto de estudo através das lentes do materialismo histórico, chamemos um dos autores mais fundamentais do pensamento marxista latino-americano, Adolfo Sánchez Vázquez. Seu Filosofia da práxis (SÁNCHEZ VÁZQUEZ, 2011), cuja primeira edição data de 1967, é constantemente referenciado nas obras do formulador da Pedagogia HistóricoCrítica. Serão úteis ao nosso estudo, neste livro, suas breves menções à experimentação na ciência e no ensino de ciências enquanto modalidades da práxis.

Mas o que é práxis? Sánchez Vázquez identifica-a com a atividade prática, como a "que se manifesta no trabalho humano, na criação artística ou na práxis revolucionária" (ibidem, p. 227). Não se trata, portanto, de qualquer tipo de atividade dirigida à transformação mundo material. Os animais e outros seres vivos, e mesmo as coisas, também realizam atos que transformam o ambiente a seu redor, mas nem por isso participam ativamente da práxis. O que caracteriza a atividade prática é o que há de específico na humanidade que a realiza: a consciência. Com efeito, a atividade prática se dirige para um fim, sendo antecipada idealmente no pensamento antes de assumir uma forma objetiva. A atividade prática não apenas se diferencia da atividade teórica, puramente espiritual - já que seu resultado adquire uma "substantividade própria" (ibidem, loc. cit), persistindo independentemente do sujeito que a engendrou -, mas a pressupõe.

Assim, existem modalidades variadas de práxis:

A matéria-prima da atividade prática pode mudar, dando lugar a diversas formas de práxis. O objeto sobre o qual o sujeito exerce sua ação pode ser: a) o dado naturalmente, ou entes naturais; b) produtos de uma práxis anterior que se convertem, por sua vez, em matéria de uma nova práxis, como os materiais já 
preparados com os quais o operário trabalha ou o artista plástico cria; c) o próprio humano, trate-se da sociedade como matéria ou objeto da práxis política ou revolucionária, trate-se de indivíduos concretos (ibidem, p. 228).

Sánchez Vázquez, então, apresenta breves considerações sobre quatro modalidades principais de práxis, nesta ordem: produtiva, artística, experimental e política.

Interessa-nos aqui, obviamente, a práxis experimental, tratada como aquela que "satisfaz, primordialmente, as necessidades da investigação teórica e, em particular, as da comprovação de hipóteses" (ibidem, p. 231). Ainda,

Essa forma de práxis é a que se manifesta quando o investigador atua sobre um objeto material modificando à vontade as condições em que se opera um fenômeno. Tal é o sentido da experimentação como práxis científica. O investigador produz fenômenos que são uma reprodução dos que se dão em um meio natural, mas os produz justamente para poder estudá-los em um meio artificial - o do laboratório sem as impurezas e perturbações com que se apresentam no meio natural e que, por essa razão, dificultam seu estudo. Na medida em que se trata de produzir determinados fenômenos com a ajuda do instrumento físico adequado, a atividade científica experimental é, evidentemente, uma forma de práxis. Trata-se de uma atividade objetiva que dá lugar a um produto ou resultado real ou objetivo.

E é lembrando que o fim imediato desta forma de práxis é teórico, quer dizer, que ela se propõe a contribuir para o desenvolvimento de teorias, que Sánchez Vázquez encontra sua especificidade, o que possibilita diferenciar a experimentação no âmbito da ciência da experimentação no âmbito do ensino da ciência:

a experimentação não é privativa da ciência; cabe falar também de uma atividade experimental em outros campos: artístico, educativo, econômico ou social. Nesses casos, diferentemente da atividade experimental científica, o experimento não está a serviço direto e imediato de uma teoria, mas, sim, de uma forma específica de práxis; o experimento artístico ou educativo tem por fim o impulso da atividade prática correspondente, a arte ou a educação. Desse modo, vemos que enquanto na ciência o fim da atividade experimental é teórico - fortalecer ou impulsionar o desenvolvimento de uma teoria - e de um modo mediato, serve portanto a determinada atividade prática, em outros campos a experimentação contribui para o desenvolvimento da práxis correspondente, mas de uma maneira direta e imediata: enquanto seus resultados se aplicam na esfera prática adequada (ibidem, p. 232).

Entendida desta maneira, a experimentação, enquanto atividade que serve à práxis educativa mais ampla, é também uma práxis do tipo reiterativa ou imitativa:

Enquanto na práxis criadora o produto exige não só uma modificação da matéria, como também do ideal (projeto ou fim), aqui o ideal permanece imutável como um produto acabado já de antemão que não deve ser afetado pelas vicissitudes do processo prático. [...] 
$\mathrm{Na}$ prática imitativa, o campo do imprevisível estreita-se. O ideal permanece imutável, pois já se sabe de antemão, antes do próprio fazer, o que se quer fazer, e como fazê-lo. A lei que rege o processo prático já existe, de forma acabada, anteriormente a esse processo e ao produto em que culmina. [...] o resultado [da práxis imitativa] não tem nada de incerto; e o atuar, nada tem de aventura (ibidem, p. 277, grifo do autor).

A práxis imitativa, portanto,

É uma práxis de segunda mão que não produz uma nova realidade; não provoca uma mudança qualitativa na realidade presente, não transforma "criadoramente", ainda que contribua para ampliar a área do já criado e, portanto, para multiplicar quantitativamente uma mudança qualitativa já produzida (ibidem, loc. cit.).

Em suma, a experimentação, quando integrada à educação (isto é, enquanto estratégia para o ensino de ciências), não pode pretender ser criadora; limita-se a uma práxis de caráter imitativo, reiterativo. O experimento científico realizado na sala de aula, embora também sirva ao estudo de hipóteses e se oriente a partir de e em direção a um saber teórico, não se propõe, contudo, a contribuir direta e imediatamente para o desenvolvimento deste saber. Contribui indireta e mediatamente para isto somente na medida em que, proporcionando o acesso à cultura erudita, pode despertar a vocação pela carreira científica em certos estudantes. Retomando as palavras de Sánchez Vázquez, o experimento didático tem por fim impulsionar a práxis educativa, não a práxis experimental. Esta práxis dispõe de locais mais adequados para se realizar: os institutos de pesquisa, as universidades, as indústrias e empresas. À escola compete realizar a práxis educativa e apenas ela; outros tipos de práxis podem até se desenvolver no espaço escolar, mas apenas de modo incidental ou subordinado às finalidades educacionais mais amplas.

Podemos propor uma síntese entre as ideias de Sánchez Vázquez e de Saviani, a partir deste tema da experimentação no ensino de ciências, se identificarmos seus conceitos, respectivamente, de práxis e prática. Assim, quanto às práticas social e política, às quais Saviani se refere em Onze teses sobre educação e política, o filósofo espanhol diria que

a práxis social é a atividade de grupos ou classes sociais que leva a transformar a organização e a direção da sociedade, ou a realizar certas mudanças mediante a atividade do Estado. Essa forma de práxis é justamente a atividade política.

Nas condições da sociedade dividida em classes antagônicas, a política compreende a luta de classes pelo poder e a direção e estruturação da sociedade, de acordo com os interesses e fins correspondentes. A política é uma atividade prática na medida em que a luta travada pelos grupos ou classes sociais está vinculada a certo tipo de organização real de seus membros (instituições e organizações políticas, como são, por exemplo, os partidos); em segundo lugar, ainda que a atividade política seja acompanhada de um choque e contraposição de ideias, projetos, programas etc., e 
essa luta ideológica exerça uma influência indubitável nas ações políticas reais, concretas, o caráter prático da atividade política exige formas, meios e métodos reais, efetivos, de luta; assim, por exemplo, o proletariado em sua luta política valese de greves, manifestações, comícios e inclusive de métodos violentos. Em terceiro lugar, a atividade política gira em torno da conquista, conservação, direção ou controle de um organismo concreto como é o Estado. O poder é um instrumento de importância vital para a transformação da sociedade (ibidem, p. 233).

Equivalendo-se assim os conceitos de ambos os autores, a experimentação no ensino de ciências seria caracterizada, portanto, como um processo em que três tipos de práxis aparecem subordinados hierarquicamente:

- A práxis experimental servindo à práxis educativa, já que a primeira se apresenta, quando integrada à segunda, apenas em sua faceta imitativa ou reiterativa;

- E a práxis educativa servindo à práxis política, dado que na sociedade de classes há o primado do aspecto político, que só se dissolve com a extinção destas classes.

De modo esquemático, a situação seria representada pela ilustração da Figura 11.

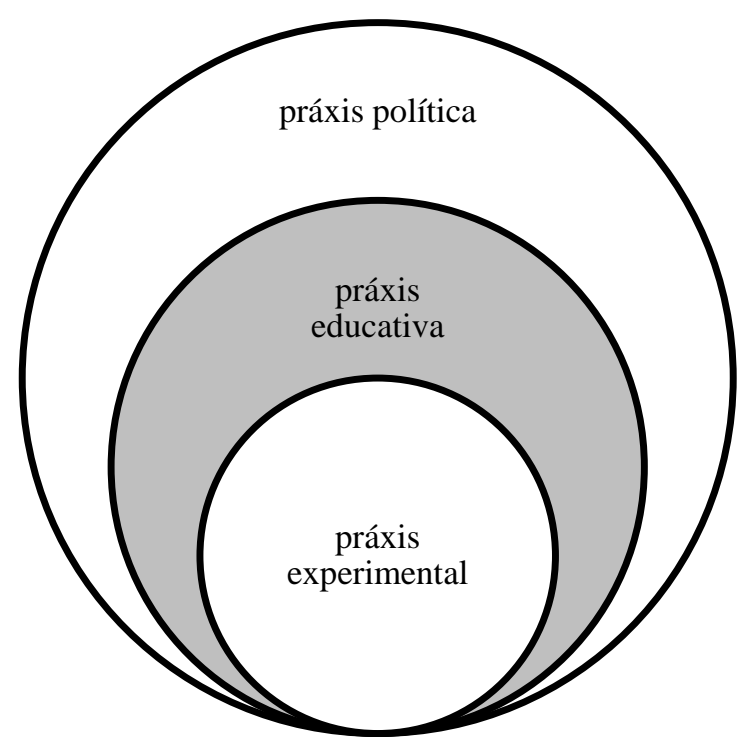

Figura 11: esquema que representa a articulação hierárquica das diferentes formas de práxis no âmbito do ensino: experimental, educativa e política.

Para Saviani, práxis "É um movimento prioritariamente prático, mas que se fundamenta teoricamente, alimenta-se da teoria para esclarecer o sentido, para dar direção à prática” (2008, p. 141-142). Diz ele ainda, fundamentado na Contribuição à crítica da economia política, que o movimento do conhecimento se faz pela "passagem do empírico ao concreto, pela mediação do abstrato [ou] da síncrese à síntese, pela mediação da análise” 
(MARX, 2013, p. 142). A partir destes pressupostos, Saviani propõe um método pedagógico que tomará, então, "a prática como ponto de partida e ponto de chegada" (ibidem, loc. cit.).

Se a experimentação no ensino de ciências serve a essa passagem do empírico ao concreto, então ela é um método admitido pela Pedagogia Histórico-Crítica. Mas não se pode perder de vista a especificidade da educação escolar, que é proporcionar a apropriação, pelos homens, da cultura elaborada coletiva e historicamente. E é a partir daí que retomamos a crítica ao construtivismo.

Conforme afirmamos no início deste capítulo, os educadores construtivistas se entusiasmam com a possibilidade do laboratório se converter num espaço para o exercício da autonomia dos estudantes. Veja que não estamos, de modo algum, destituindo a importância desta autonomia. Mas da forma como se apresenta, este discurso construtivista estaria propondo o primado do aspecto político da educação em detrimento de sua especificidade, que passa a ser encarada, assim, como algo secundário, de importância menor. Retomando as "Onze teses sobre educação e política" de Saviani, transcrevemos novamente o enunciado da última tese: A função política da educação se cumpre na medida em que se realiza enquanto prática especificamente pedagógica. E observa Saviani que

\footnotetext{
Esta tese afirma a autonomia relativa da educação em face da política como condição mesma da realização de sua contribuição política. Isto é óbvio uma vez que, se a educação for dissolvida na política, já não cabe mais falar de prática pedagógica restando apenas a prática política. Desaparecendo a educação, como falar de sua função política? (1993, p. 100).
}

Os educadores que acreditam que o ensino experimental - isto é, a educação científica realizada com ênfase na experimentação - deve servir para elevar o grau de autonomia dos estudantes, ao muni-los de um suposto método científico, ignoram o caráter mediador da práxis educativa no seio da práxis social global. (Na Figura 11, este nível mediador foi preenchido por uma cor diferente justamente para realçar este aspecto). Em outras palavras, se é facultado ao cientista interferir na práxis social ou política diretamente a partir da práxis experimental, com o estudante da educação básica isto só é válido através da mediação da práxis educativa, visto que a práxis experimental do espaço escolar é meramente reiterativa.

É interessante que ideias semelhantes são defendidas até por alguns representantes do construtivismo. Por exemplo, Pinho Alves apresenta as seguintes conclusões, analisando a questão do laboratório escolar a partir do referencial da transposição didática: 
- O laboratório didático para ser elemento do processo de ensinoaprendizagem de ciências, particularmente da Física, deve ser alvo de uma transposição didática diferente daquela que o introduziu no processo de ensino com o objetivo de ensinar o método experimental;

- A concepção construtivista da produção de Ciência deve ser adotada pelos personagens que farão parte da esfera responsável pela nova transposição didática, onde as atividades experimentais teriam função mediadora no ensino dos conteúdos de Ciência e não do método experimental;

- A nova transposição didática que delineará as atividades experimentais associadas diretamente com o processo de ensino-aprendizagem poderá estabelecer regras específicas para o laboratório didático (2000b, p. 186).

\subsubsection{A importância dos instrumentos e uma análise de $O$ desenvolvimento do psiquismo}

Registradas algumas contribuições da Pedagogia Histórico-Crítica para o entendimento da atividade experimental no ensino de ciências, vejamos como a Psicologia Histórico-Cultural também pode contribuir para isto. Nesta subseção, falaremos sobre a importância que esta teoria relega aos instrumentos de trabalho, observando com atenção as considerações de Leontiev em $O$ desenvolvimento do psiquismo a respeito desta categoria.

É bom lembrar que quando levantamos o entendimento sobre a experimentação no ensino de ciências, por parte de autores próximos à Pedagogia Histórico-Crítica, observamos que diversos deles haviam mencionado a importância dos instrumentos enquanto criações humanas dirigidas à transformação da natureza. Este fora o caso de Pedrosa e Leite (2011), Anunciação e Moradillo (2012) e Boss e colaboradores (2012). O leitor pode retornar à seção 3.2 deste capítulo para reler os fragmentos destes trabalhos em que a questão foi tangenciada.

O trabalho de Camillo (2011), com um objetivo próximo ao que tomamos neste capítulo, dispensou considerável atenção ao tema. Seu olhar sobre a experimentação no ensino, orientado quase sempre em função da categoria alienação, não teria sido possível sem que se mencionasse a concepção de Leontiev sobre os instrumentos e os saberes neles cristalizados. Por exemplo, após transcrever uma passagem de $O$ desenvolvimento do psiquismo, em que o psicólogo russo afirma que o mundo de objetos antecede o homem mas não lhe é fornecido imediatamente (sem mediações), Camillo diz:

O que Leontiev está apontando é que mesmo artefatos técnicos carregam marcas da cultura humana e da atividade da qual são originados. Uma chave de fenda, por exemplo, é um artefato carregado de significado cultural, desta maneira, aquele que queira utilizar desta ferramenta precisa conhecer, ao menos, algum detalhe da atividade para qual esta ferramenta foi concebida ou ela simplesmente servirá como 
um pedaço de metal e adquirirá uma função totalmente diversa daquela de apertar parafusos.

Outro aspecto importante dos instrumentos mediadores é que eles alteram por completo o fluxo ou a dinâmica da atividade, que antes era realizada sem mediação ou com outro instrumento mediador, seja técnico ou psicológico. Nas sociedades primitivas, por exemplo, a introdução da pedra lascada, como ferramenta, promove alterações significativas no mecanismo de caça e alimentação, modificando assim as condições de vida dos seres humanos, ocasionando, inclusive, outras necessidades, como a de buscar novas ferramentas, como a pedra polida (ibidem, p. 29).

A seguir, o autor ressalta que o instrumento mediador não possui sentido único de ação: "seu efeito não ocasiona modificações somente no objeto ou na estrutura da atividade, mas também no indivíduo" (ibidem, p. 30). Assim considerada a importância do instrumento, das ferramentas e, de modo geral, dos objetos que o homem utiliza para mediar suas relações com o ambiente, Camillo entende que os problemas da atividade experimental no ensino, isto é, seu fracasso, "estão associados ao não compartilhamento do objeto, pelos professores e alunos, na atividade educacional que se estabelece" (ibidem, p. 106). Para o autor, o que motiva este não compartilhamento é justamente a alienação - conforme a teoria de Leontiev interpreta este conceito de Marx - das atividades de que participam professores e alunos no ensino de ciências. Quanto ao objeto, categoria mais ampla que abarca os instrumentos, o autor expõe cuidadosamente sua concepção; vejamos a seguinte passagem, que vale a pena reproduzirmos, pois nela abundam conceitos de que já tratamos nesta tese:

Quando falamos em objeto não nos referimos ao objeto empírico, ao objeto físico, mas àquele cujos significados o transcendem e repousam sobre as complexas relações sócio-histórico-culturais que se estabelecem (ou se estabeleceram no passado da humanidade) entre os indivíduos na atividade práxica de transformação. Ao falar em práxis, nos referimos ao processo de conhecer-produzir o mundo por meio do contínuo movimento de redução do concreto sensório (inicial, primitivo) ao abstrato e a posterior (não em sentido causal, nem temporal, mas dialético) ascensão ao concreto real, no qual toda a complexidade e todas as contradições se fazem presentes [...]. É pelo contínuo movimento de redução ao abstrato e ascensão ao concreto real, visando a superação das contradições que se instauram, que o objeto real é alcançado-produzido. O objeto real não possui existência fora da atividade humana, pois é por meio da práxis que os objetos ganham realidade e são capazes de orientar a atividade a partir da coordenação de ações e operações (ibidem, p. 108, grifos do autor).

Mais adiante, falando dos "conceitos científicos acumulados no objeto experimental", Camillo esclarece: "Acumulado por meio das complexas relações sociais que determinam seus sentidos e que transcendem o objeto empírico" (p. 112, nota de rodapé). Lembrando também que a teoria de Leontiev prevê três classes de processos que se estruturam de modo hierárquico na relação do indivíduo com o ambiente - atividade, ação e operação -, e que eles 
podem se interconverter à medida que este indivíduo se apropria de novas objetivações do gênero humano, Camillo deixa-nos mais uma passagem de interesse:

\begin{abstract}
Em uma atividade em vias de se estabelecer, os diferentes indivíduos podem acabar realizando as suas ações/operações em níveis hierárquicos distintos - aquilo que para um é operação ao outro é ação. Por exemplo, para determinado sujeito uma ação pode ser executada no nível de operação, ou seja, é feita de maneira mais automática, sem consciência, permitindo que o sujeito direcione suas ações para outros aspectos da atividade [...]. Porém, para outro indivíduo, o 'acontecimento' compreende o objetivo da sua atividade, ou seja, é necessário que ele coordene operações e ações de maneira que consiga realizar o fenômeno (o 'acontecimento') todo o seu esforço está voltado para isto; o seu objeto é distinto do primeiro indivíduo, e assim, o engajamento na mesma atividade, por meio de um objeto comum, não é completamente possível (ibidem, p. 115).
\end{abstract}

No caso da experimentação no ensino de ciências, podemos considerar, seguindo o conteúdo do fragmento acima, que para um determinado aluno, operar uma bureta pode ser uma tarefa relativamente simples, uma mera ação, dirigida a uma atividade mais complexa (por exemplo, comparar os pHs de duas soluções); para outro colega, no entanto, o próprio ato de manipular a bureta pode se apresentar como uma atividade, para a qual será necessária uma coordenação complexa de todo um conjunto de ações e operações, antes que este instrumento de laboratório possa servir, futuramente, a um procedimento mais complexo.

O trabalho de Camillo, como dissemos, toma estas considerações como um meio para estudar o que seria o compartilhamento alienado de objetos pelos sujeitos que participam de uma atividade, especificamente, a experimentação no ensino. Nesta seção, em vez de prosseguirmos nesta direção, o que exigirá que retomemos o conceito de alienação, preferiremos dar algum aprofundamento à questão mesma dos objetos e instrumentos que participam da experimentação no ensino de ciências.

Primeiramente, deveríamos nos indagar sobre o porquê dos instrumentos se apresentarem como uma categoria tão cara aos psicólogos soviéticos. Ora, trata-se de um aspecto fundamental para o entendimento da atividade prática dos homens, e que não escapou aos pais do materialismo histórico. O livro de Engels Dialética da natureza, por exemplo, contém um esboço de manuscrito intitulado "O papel do trabalho na transformação do macaco em homem" (ENGELS, 1974, p. 171-186), de 1876. O texto, partindo de teses evolucionistas, defende que "o trabalho criou o próprio homem" (ibidem, p. 171), pois o uso de instrumentos se imprimiu na anatomia dos hominídeos, proporcionando a forma atual da mão humana, "altamente aperfeiçoada pelo trabalho de milhares de séculos" (ibidem, p. 173). Para Engels, “a mão não é apenas o órgão do trabalho, ela é também o produto do trabalho" (ibidem, p. 
174, grifo do autor). Mas não foi apenas a mão humana que ficou marcada pela história da atividade de nossos primeiros antepassados:

O domínio da natureza que começa com o desenvolvimento da mão, como trabalho, foi alargando, a cada progresso, o horizonte do homem. Este descobria constantemente nos objectos naturais propriedades novas até então ignoradas. Por outro lado, o desenvolvimento do trabalho contribuiu para aprofundar os laços entre os membros da sociedade, multiplicando os casos de assistência múltipla, de cooperação comum e tornando mais clara em cada indivíduo a consciência da utilidade de tal cooperação. Numa palavra, os homens em formação chegaram a um ponto em que tinham algo a dizer uns aos outros. A necessidade criou o órgão; a laringe não desenvolvida do macaco foi-se transformando, lentamente, mas com segurança, mediante a modulação, até adquirir a capacidade de emitir sons cada vez mais modulados e os órgãos da boca aprenderam a pouco e pouco a pronunciar uma sílaba após outra. [...] Primeiro o trabalho; e depois dele e em seguida a par dele, a linguagem: tais são os incentivos mais importantes sob cuja influência o cérebro de um macaco se foi a pouco e pouco transformando num cérebro de homem que, embora lhe seja semelhante, o ultrapassa de longe em caminho e perfeição. Mas, a par com o desenvolvimento do cérebro houve também o dos seus utensílios imediatos, os órgãos dos sentidos (ibidem, p. 175-176, grifo do autor).

Todas estas conquistas - formação da mão humana, da laringe apropriada para a vocalização, dos órgãos dos sentidos - têm sua origem no processo de trabalho, na modificação da natureza, pelo homem, em busca da satisfação de suas necessidades. Mas o trabalho não é trabalho humano propriamente dito sem os instrumentos; em realidade, "O trabalho começa com o fabrico de ferramentas" (ibidem, p. 178).

Décadas mais tarde, a revista Scientific American publicaria uma série de artigos referentes à origem da espécie humana, destacando-se o texto de Sherwood Washburn, "Tools and human evolution" (WASHBURN, 1960). Afirma o autor que "a estrutura do homem moderno deve ser o resultado da mudança, em termos de seleção natural, fornecida pelo modo de vida baseado no uso de instrumentos", tendo sido "o sucesso dos instrumentos mais simples que iniciou toda a trajetória da evolução humana e levou às civilizações de hoje" ( $p$. 63, tradução nossa $\left.{ }^{54}\right)$. A partir do domínio dos instrumentos, outros fatores vieram a se somar (e se relacionar) para a formação de nossa espécie:

Do ponto de vista evolucionário, comportamento e estrutura compõem uma interação complexa, cada mudança em um afetando o outro. [...] Instrumentos, caça, fogo, vida social complexa, fala, o percurso humano e o cérebro evoluíram conjuntamente para produzir o antigo homem do gênero Homo há aproximadamente meio milhão de anos (ibidem, loc. cit.).

\footnotetext{
${ }^{54}$ A tradução de todas as demais transcrições, desta referência, é de nossa autoria.
} 
Para Washburn, "os instrumentos alteraram as pressões da seleção natural e assim modificaram a estrutura do homem" (ibidem, p. 65). A interação complexa, que o fragmento acima menciona, se refere à reciprocidade das alterações anatômica e comportamental, exemplificadas ao longo do artigo: "Os registros fósseis fundamentam a ideia, proposta primeiramente por Charles Darwin, de que o uso de instrumentos é tanto a causa quanto o efeito da locomoção bipedal", já que "na seleção natural, causa e efeito estão interrelacionados" (ibidem, p. 69); “O motivo pelo qual o cérebro humano torna possível o modo de vida humano é que ele é resultado deste modo de vida" (ibidem, p. 73); "Cada estágio comportamental [da trajetória humana] foi tanto causa quanto efeito das modificações biológicas nos ossos e no cérebro" (ibidem, p. 75).

A questão é recorrente também no âmbito da teoria marxista do conhecimento. Lefebvre, por exemplo, tratando da penetração do pensamento no mundo real, afirma:

Este martelo é um objeto que isolo provisoriamente por meio de contornos definidos; ele vai me permitir separar da totalidade natural outros objetos (essas pedras que quero cortar), vai me permitir impor a tais objetos, por seu turno, contornos também definidos. A noção de quantidade ou de espaço geométrico é um "objeto de pensamento" de contornos igualmente definidos; e essas noções me permitem isolar, graças a tais contornos, outros objetos imersos na totalidade do universo. A diferença é que o espaço geométrico me permite ir mais longe que minha experiência sensível imediata. Nesse sentido, é um "objeto do pensamento" propriamente dito: um instrumento de conhecimento e, ao mesmo tempo, um conhecimento, não um instrumento prático e uma constatação imediata (1983, p 112, grifo nosso).

Já Sánchez Vázquez, ao explicar o que seria a práxis produtiva, declara:

Quando Marx reduz o instrumento de trabalho - condição material e objetiva do processo de trabalho - ao trabalho humano, o instrumento aparece, assim, humanizado também - tanto por seu uso como por sua fabricação. O certo é que essa humanização não pode ser concebida em um sentido abstrato, antropológico, mas, sim, como expressão tanto de uma determinada relação entre o homem e a natureza como das relações sociais em que os homens produzem (relações de produção). [...] Graças aos instrumentos, a relação entre o homem e a natureza deixa de ser direta e imediata. $\mathrm{O}$ aparecimento de instrumentos mais aperfeiçoados modifica o tipo de relação entre o homem e a natureza e, nesse sentido, é um índice revelador do desenvolvimento de sua força de trabalho e de seu domínio sobre a natureza. O poder de mediação do instrumento estendeu-se e elevou-se com a introdução da máquina até chegar à automatização com a qual o homem fica separado radicalmente do processo de produção. Mas quaisquer que sejam os instrumentos de que se valha para transformar a matéria conforme seus fins, é sem dúvida o homem quem os usa e fabrica; e é ele, em última instância, que, ao se valer deles, atua sobre as matérias e as transforma de acordo com as suas necessidades (2011, p. 229).

Kopnin, quase à mesma época, afirma coisas semelhantes: 
Entre o machado de pedra do homem primitivo e o complexo computador eletrônico moderno há uma enorme distância. No entanto há certa afinidade entre eles: ambos são instrumentos de trabalho humano, em qualquer parte o homem usa as propriedades físicas e mecânicas dos objetos como instrumentos de sua atividade. (1978, p. 137).

O emprego das máquinas no processo de pensamento se constitui em mais uma prova a favor da natureza social deste. A própria máquina é medida pelo pensamento e a prática social, porquanto é resultado do progresso da ciência e da técnica dos homens; na máquina materializam-se os resultados do pensamento humano. [...] A máquina pode ajudar ao homem até no conhecimento do próprio processo de pensamento. Sendo cópia material de um aspecto qualquer do pensamento, ela contribui para que o homem tenha mais clareza dessa ou daquela função do pensamento. Assim, por exemplo, a prática atual de construção de máquinas cibernéticas contribui para o progresso no desenvolvimento da lógica matemática (ibidem, p. 139, grifos nossos).

Entre autores a que já recorremos para fundamentar considerações pedagógicas na teoria marxista, os instrumentos também são referidos de modo mais ou menos destacado. Em Educação, saber e produção em Marx e Engels Nogueira, falando sobre a concepção de Marx sobre o ensino tecnológico, refere-se a seu entendimento da chamada "cultura técnica":

esta última deveria compreender tanto as bases científicas dos procedimentos de produção ("os princípios gerais e científicos de todos os processos de produção"), quanto a aplicação prática desses conhecimentos (o "manejo dos instrumentos elementares de todos os ramos industriais"). Isto implica, por um lado, a aquisição de um mínimo de conhecimentos científicos, se se admite que o objeto técnico representa o momento de coagulação de leis científicas. E, por outro lado, a aquisição de um saber-fazer, dado que esse objeto técnico é também um sujeito suscetível de ser manipulado. Processo esse cuja finalidade (que já se conhece bem) seria a apropriação pelos trabalhadores das condições de organização e de controle do processo de trabalho. Entretanto, isso não é o bastante. Há que se observar ainda que o acesso à cultura técnica é posto, por Marx, como uma condição necessária mas não suficiente para o controle das bases sócio-técnicas da produção: este último supõe, outrossim, uma transformação mais profunda das relações sociais (1993, p. 173, grifo nosso).

\section{À continuação, afirma a autora que}

Conforme se lê em $O$ Capital, o ensino da tecnologia deve ser, ao mesmo tempo, teórico e prático. Este ponto é importante porque significa a recusa da idéia de um adestramento gestual, visando apenas habilitar o trabalhador a executar uma operação precisa no seio do sistema produtivo. Muito diferentemente, o que Marx pretende é dotar o trabalhador de meios para que ele compreenda e avalie a sua atividade produtiva ou, em outras palavras, fazer com que os princípios científicos e tecnológicos subjacentes ao funcionamento das técnicas não escapem à compreensão dos seus utilizadores. Desde modo seria facultado aos operários aproveitar da experiência prática obtida no trabalho para adquirir uma formação teórica profunda (ibidem, p. 173-174). 
Newton Duarte, em Vigotski e o "aprender a aprender", tece as seguintes considerações sobre o instrumento, após lembrar que a atividade prática promove a objetivação do homem na natureza, humanizando-a:

\begin{abstract}
A diferença entre a produção animal e a produção humana se evidencia claramente quando se analisa, por exemplo, a atividade de produção de instrumentos. Essa produção é tanto um processo de apropriação da natureza pelo homem, como um processo de sua objetivação. [...]

Um instrumento não é apenas algo que o homem utiliza em sua ação, mas algo que passa a ter uma função que não possuía como objeto estritamente natural, uma função cuja significação é dada pela atividade social. O instrumento é, portanto, de início, um conjunto de elementos puramente naturais, resultantes de forças da natureza, que, ao passar pela transformação da atividade humana, adquire o significado objetivo de constituir-se em meio para o alcance de determinadas finalidades no interior da prática social. $O$ homem cria novo significado para o objeto. Mas essa criação não se realiza de forma arbitrária. Em primeiro lugar porque o homem precisa conhecer a natureza do objeto para poder adequá-lo às suas finalidades. [...]. Em segundo lugar, a transformação de um objeto em instrumento não pode ser arbitrária porque um objeto só pode ser considerado um instrumento quando possui uma função no interior da prática social (2006, p. 118-119, grifo nosso).
\end{abstract}

ao sofrer a ação humana, o objeto passa a ter novas funções, passa a ser uma síntese da atividade social, síntese essa que deverá ser objeto de apropriação por todos os seres humanos que venham a incorporar aquela objetivação à sua atividade individual (ibidem, p. 120).

Há outros momentos do livro de Newton Duarte que fazem referência à questão dos instrumentos. Muitos deles são comentários sobre passagens de algumas das obras dos autores da Psicologia Histórico-Cultural, em especial, de Leontiev. Antes de trazermos aqui as contribuições de seu $O$ desenvolvimento do psiquismo, obra particularmente rica em tais considerações, vejamos como a produção de Vigotski, que lhe é anterior, abordou o tema.

Já em seu primeiro livro, Psicologia pedagógica, o capítulo "Leis fundamentais da atividade nervosa superior (do comportamento) do homem" (VIGOTSKI, 2010, p. 35-61) menciona que

Segundo definiu um estudioso, toda a diferença entre o homem e o animal consiste em que o homem é um animal que faz ferramentas. Desde que se tornou possível o trabalho na acepção humana da palavra, ou seja, a intervenção planejada e racional do homem nos processos naturais com o fim de reagir e controlar os processos vitais entre o homem e natureza, desde então a humanidade se projetou a um novo degrau biológico e à sua experiência incorporou-se algo que fora estranho aos antepassados e parentes animais (ibidem, p. 43).

A seguir, Vigotski recita a famosa passagem de $O$ capital, em que Marx e Engels lembram que a feitura da teia por uma aranha não supera o trabalho do arquiteto, pois neste último caso 
estão envolvidas as componentes de intencionalidade e consciência. Considerações semelhantes serão retomadas em Michlenie $i$ retch, quando Vigotski estudará as raízes genéticas do pensamento e da fala humanos, encontrando-as já nos primatas próximos ao homem: "Para nós está claro que, independentemente da classificação que se lhe dê, o tipo superior de comportamento do chimpanzé é [...] a raiz do comportamento humano, que se caracteriza pelo emprego de instrumentos" (idem, 2001, p. 141). Em outro momento desta obra, Vigotski retoma a analogia entre os instrumentos técnicos, dirigidos para o mundo exterior, e os instrumentos psíquicos, como os signos, lembrando que ambos têm origem na práxis do homem:

\begin{abstract}
não podemos explicar satisfatoriamente o trabalho como atividade humana voltada para um fim, afirmando que ele é desencadeado por objetivos, por tarefas que se encontram diante do homem; devemos explicá-lo com o auxílio do emprego de ferramentas, da aplicação de meios originais sem os quais o trabalho não poderia surgir; de igual maneira, para a explicação de todas as formas superiores de comportamento humano, a questão central é a dos meios através dos quais o homem domina o processo do próprio comportamento.

Como mostram investigações que aqui não vamos abordar, todas as funções psíquicas superiores têm como traço comum o fato de serem processos mediatos, melhor dizendo, de incorporarem à sua estrutura, como parte central de todo o processo, o emprego de signos como meio fundamental de orientação e domínio nos processos psíquicos (ibidem, p. 161).
\end{abstract}

Na conferência sobre o "método instrumental em psicologia", referida à subseção 2.2.1 do capítulo passado, Vigotski também discorre sobre esta analogia:

Ao inserir-se no processo de comportamento, o instrumento psicológico modifica de forma global a evolução e a estrutura das funções psíquicas, e suas propriedades determinam a configuração do novo ato instrumental do mesmo modo que o instrumento técnico modifica o processo de adaptação natural e determina a forma das operações laborais (idem, 2004, p. 94).

Nota-se, no entanto, que Vigotski tende a enfatizar, em seus escritos, a importância dos instrumentos psicológicos, como no seguinte fragmento: "O emprego de um instrumento psicológico eleva e amplia infinitamente as possibilidades do comportamento, pois põe ao alcance de todos o resultado do trabalho dos gênios [...]" (ibidem, p. 98). A abordagem de Leontiev se equilibrará um pouco melhor entre destacar as contribuições dos instrumentos técnicos (“objetuais") e psíquicos para o desenvolvimento das funções psicológicas superiores dos homens. Mesmo assim, já é possível encontrar em Vigotski algumas considerações que seguem nesta linha, posteriormente desenvolvidas por seu colega e sucessor. Por exemplo, em 
O significado histórico da crise da psicologia consta a seguinte passagem, que merece ser transcrita na íntegra por tratar especificamente sobre a questão dos instrumentos científicos:

\begin{abstract}
Muitos dizem: “a história interpreta os vestígios do passado, mas a física observa o invisível com a ajuda de instrumentos de forma tão direta como se o visse com os olhos. Os instrumentos são a prolongação dos órgãos sensoriais do cientista: o microscópio, o telescópio, o telefone etc. convertem o invisível em visível e em objeto da experiência direta; a física não interpreta o invisível, ela o vê".

Mas essa opinião é falsa. A análise metodológica da significação dos aparelhos científicos evidenciou, já faz tempo, que estes desempenham um papel novo e fundamental e que não se limitam a prolongar os órgãos sensoriais. O próprio termômetro pode servir de exemplo desse novo componente que os instrumentos introduzem nos métodos científicos: no termômetro lemos a temperatura; esse aparelho não reforça nem prolonga a sensação de calor da maneira como o microscópio continua olho, mas nos emancipa plenamente da sensação no estudo do calor; o termômetro pode ser utilizado por alguém que careça dessa sensação, ao passo que um cego não pode fazer uso do microscópio. A termometria constitui um modelo puro do método indireto: porque, diferente do que acontece com o microscópio, não estudamos aquilo que vimos - a elevação do mercúrio, a dilatação do álcool -, mas o calor e suas mudanças, indicados pelo mercúrio ou pelo álcool, interpretamos as indicações do termômetro, reconstruímos o fenômeno a estudar por suas marcas, por sua influência na dilatação do corpo. É assim que são feitos todos os instrumentos a que se refere Planck como meios para estudar o invisível. Por conseguinte, interpretar significa reconstruir o fenômeno segundo suas marcas e influências, baseando-se em regularidades estabelecidas anteriormente (neste caso, na lei da dilatação dos corpos em conseqüência do calor) (ibidem, p. 281).
\end{abstract}

Verillon (1995) afirma que as investigações sobre a cognição humana sempre privilegiaram o conhecimento das funções psíquicas de indivíduos isolados, "estudados quase que exclusivamente dentro dos laboratórios universitários" (p. 79, tradução nossa ${ }^{55}$ ). Para este autor, interessado nas relações entre os artefatos e a cognição, os estudos que buscaram esclarecer estes elos vêm sendo obscurecidos por paradigmas psicológicos alicerçados na biologia e/ou na cibernética, como a reflexologia, o interacionismo, o comportamentalismo e a inteligência artificial. Assim,

Dentro dos paradigmas correntemente dominantes no campo da psicologia, a oposição entre objetos naturais e objetos artificiais ou manufaturados não é relevante. Por exemplo, o objeto submetido ao sujeito piagetiano é fundamentalmente a-histórico e a-social: sua principal propriedade é ser estruturado por leis físicas. [...] na epistemologia piagetiana, assim como naquela de inspiração comportamentalista, afigura-se que não há ruptura fundamental entre os processos adaptativos observados nos níveis mais elementares do reino animal e o desenvolvimento cognitivo do ser humano (ibidem, p. 80).

\footnotetext{
${ }^{55}$ A tradução de todas as demais transcrições, desta referência, é de nossa autoria.
} 
Pelo contrário, para autores como Leontiev, "esta ruptura é óbvia e fundamental" (ibidem, loc. cit.). Verillon então explica rapidamente o modo como Leontiev concebe a relação entre desenvolvimento psíquico e apropriação das realizações da cultura material humana:

Para ele, o desenvolvimento resulta da progressiva apropriação destas realizações socialmente formadas, no lugar de um processo de equilibração que seria mais característico de uma relação biológica com o ambiente [em referência, claramente, a Piaget].

Sob tal modelo, o conceito de artefato é pertinente. Ele se refere a todos os objetos da cultura material aos quais a criança tem acesso durante seu desenvolvimento, e primeiro de tudo, ao instrumento. Além das propriedades físicas do instrumento, o que é importante é "seu modo de emprego, elaborado socialmente no decurso do trabalho colectivo e atribuído a ele" (p. 74) [p. 82 $]^{56}$. Portanto, seu processo de apropriação implica tanto a transmissão do instrumento quanto a reprodução do uso da "actividade prática ou cognitiva que responda de maneira adequada [...] à actividade humana que eles encarnam" (p. 263) [p. 167].

Ele [Leontiev] nega que estas ações e operações podem "formar-se [...] na criança sob a influência do próprio objeto" (p. 313) [p. 321] no interior de um processo solipsista: elas são transmitidas à criança e, portanto, implicam a mediação social (ibidem, p. 81, grifos nossos).

Contrariamente a nós, Verillon acredita que o autor que mais avança na compreesão da importância do instrumento para o desenvolvimento psicológico é Vigotski, e não Leontiev, (cuja teorização estaria enraizada mais na antropologia que na psicologia):

Com efeito, para Vygotsky, o instrumento, seja ele material ou "psicológico" (isto é, a linguagem, os meios computacionais ou mnemônicos, símbolos, diagramas, mapas etc.) não podem ser reduzidos a meros estímulos, mas constituem, "entre o objeto e a operação psicológica a ele dirigida, [...] um novo componente intermediário" (p. 42) $[\text { p. 96] }]^{57}$.

A introdução e o uso de instrumentos, sejam eles materiais ou psicológicos, acarreta profundas alterações, tanto estruturais quanto funcionais, na cognição do sujeito: "provoca [...] a atividade [ativação] de toda uma série de funções novas, relacionadas com a utilização do mencionado instrumento e de seu manejo"; ela "suprime e torna desnecessária toda uma série de processos naturais, cujo trabalho passa a ser efetuado pelo instrumento"; e ela "modifica também o curso e as diferentes características (intensidade, duração, sequiência etc.) de todos os processos psíquicos que fazem parte do ato instrumental [...]" (p. 42) [p. 96-97] (ibidem, p. $82)$.

\footnotetext{
${ }^{56}$ Verillon está citando palavras de Leontiev em $O$ desenvolvimento do psiquismo, na tradução francesa. Reproduzimos, neste fragmento, as traduções dos mesmos trechos registradas na edição portuguesa (LEONTIEV, 1978), indicando-se entre colchetes as respectivas páginas.

${ }^{57}$ Aqui, cita-se o texto Vigotski "O método instrumental em psicologia", também na tradução francesa. Como no caso anterior, reproduzimos aqui as traduções em português da coletânea brasileira Teoria e método em psicologia (VIGOTSKI, 2004), indicando-se entre colchetes as respectivas páginas.
} 
Verillon prossegue reproduzindo mais alguns fragmentos de Vigotski, que ressaltam, da mesma forma que Leontiev, a importância da instrução orientada e intencional para a apropriação do instrumento por parte das crianças em desenvolvimento:

o desenvolvimento das funções superiores resulta de um processo de "instrumentação" [tooling] das funções psíquicas naturais: "O domínio de um instrumento psicológico e, por seu intermédio, da correspondente função psíquica natural, eleva esta última a um nível superior, aumenta e amplia sua atividade e recria sua estrutura e seu mecanismo. Os processos psíquicos naturais não são eliminados com isso, mas entram em combinação com o ato instrumental e dependem funcionalmente, em sua estrutura, do instrumento utilizado" (p. 46) [p. $100]$.

Neste referencial teórico, a educação logicamente aparece como um fator determinante no desenvolvimento: "A educação é o domínio artificial dos processos naturais de desenvolvimento. A educação não apenas influi em alguns processos de desenvolvimento, mas reestrutura as funções do comportamento em toda sua amplitude. [...] Qualquer tipo de desenvolvimento infantil é determinado, em grande medida, pela incapacidade da criança de utilizar por si mesma suas próprias funções naturais e de dominar os instrumentos psicológicos" (p. 45) [p. 99-100].

$O$ desenvolvimento é, portanto, visto como resultado de um processo amplamente artificial, no qual a aquisição de instrumentos exerce um papel preponderante (ibidem, loc. cit., grifos nossos).

Vistas as considerações de autores diversos, daqui em diante concentrar-nos-emos no que Leontiev tem a dizer sobre a produção e utilização de instrumentos numa atividade de trabalho, em $O$ desenvolvimento do psiquismo (LEONTIEV, 1978).

Concebendo que "Todo reflexo psíquico resulta de uma relação, de uma interacção real entre um sujeito material vivo, altamente organizado, e a realidade material que o cerca" (ibidem, p. 93), Leontiev assim caracteriza o fabrico e o uso de instrumentos pelos homens:

[isto] só é possível em ligação com a consciência do fim da acção de trabalho. Mas a utilização de um instrumento acarreta que se tenha consciência do objeto da acção nas suas propriedades objectivas. $\mathrm{O}$ uso do machado, por exemplo, não responde ao único fim de uma acção concreta; ele reflete objectivamente as propriedades do objecto de trabalho para o qual se orienta a acção. O golpe do machado submete as propriedades do material de que é feito este objecto a uma prova infalível; assim se realiza uma análise prática e uma generalização das propriedades objectivas dos objectos segundo um índice determinado, objectivado no próprio instrumento. Assim é o instrumento que é de certa maneira portador da primeira verdadeira abstracção consciente e racional, da primeira generalização consciente e racional (p. 82, grifo nosso).

O fragmento em destaque na transcrição acima, a nosso entender, representa uma contribuição original e importantíssima para a análise do papel dos instrumentos no desenvolvimento, tanto filogenético quando do ontogenético. $\mathrm{O}$ instrumento se origina de um material puramente empírico, da matéria-prima mais bruta que o compõe; a seguir, entra em relação com outras 
matérias, que especificam sua forma. Para quais materiais se dirigirá um dado instrumento, isto se determina pela função social a que corresponde o seu uso. Na matéria empírica do instrumento, portanto, agrega-se uma generalização, uma abstração primitiva exigida pelas relações sociais que determinam a forma e a função deste objeto: o machado serve especificamente para cortar certas madeiras, tendo sua forma (tipo de lâmina, tamanho do cabo, peso da peça como um todo) determinada pela resistência material dos caules, dado generalizado a partir da experiência dos homens. Ao material empírico acumula-se, portanto, uma abstração, perfazendo o instrumento concreto, que possui uma função definida pela necessidade dos homens produzirem sua própria existência (desmatar áreas para o plantio, conseguir lenha para se aquecer, obter materiais para a construção de casas e abrigos etc.). Neste caminho de ascensão do empírico ao concreto, pela mediação do abstrato, o instrumento adquire uma significação, que é "o reflexo generalizado da realidade elaborado pela humanidade e fixado sob a forma de conceitos, de um saber ou mesmo um saber-fazer ('modo de acção' generalizado, norma de comportamento, etc.)" (ibidem, p. 96). Estamos acostumados a associar o termo "significação" à constituição de palavras e demais signos; Leontiev trata de expandir o uso dele também para o âmbito da atividade prática dos homens, fazendo do instrumento "um precursor material da significação" (ibidem, loc. cit.).

O psicólogo russo assinala que o instrumento exerceu um papel fundamental para o aparecimento e a evolução da consciência humana:

A necessidade de uma tomada de consciência das operações tem a sua causa na passagem à fabricação de utensílios diferenciados, em particular de instrumentos compostos. Os instrumentos mais antigos, como testemunham as descobertas arqueológicas, podiam ainda resultar de uma simples "adaptação" dos objectos naturais às condições da acção de trabalho [...]. O fabrico de instrumentos especializados é diferente. A sua produção exige a distinção e a consciência das operações. A produção de um instrumento desse tipo tem com efeito como fim uma operação de trabalho, materializado no instrumento (ibidem, p. 105, grifo nosso).

O mesmo processo, porém, não é observado no reino dos animais:

Nos animais, o "instrumento" não cria nova operação, está submetido aos seus movimentos naturais no sistema dos quais se inclui. No homem, é o contrário que se verifica: a sua própria mão está incluída num sistema de operações elaborado socialmente e fixado no próprio instrumento e está submetida a ele. As investigações actuais demonstram com bastante precisão estes dois factos. Razão porque, se podemos dizer, a propósito do símio, que o desenvolvimento natural da sua mão determina nele o uso do pau enquanto "instrumento", temos as nossas razões para afirmar que no homem foi a sua actividade instrumental que criou as particularidades específicas da mão. 
Assim, o instrumento é um objecto social, o produto de uma prática social, de uma experiência social de trabalho. Por consequência, o reflexo generalizado das propriedades objectivas dos objectos de trabalho, que ele cristaliza em si, é igualmente o produto de uma prática individual. Por este facto, o conhecimento humano mais simples, que se realiza directamente numa acção concreta de trabalho com a ajuda de um instrumento, não se limita à experiência pessoal de um indivíduo, antes se realiza na base da aquisição por ele da experiência da prática social (ibidem, p. 83).

Para os animais, o instrumento possui apenas um sentido pragmático, respondendo a necessidades puramente biológicas, determinadas pela herança genética e manifestadas na forma de instinto. $\mathrm{O}$ homem, ao contrário, faz do instrumento uma alavanca para a aquisição de novas aptidões, inscreve nele um significado que é social e lhe atribui, assim, um caráter psicológico:

O instrumento [...] não é de modo algum em si um objecto "psicológico"; todavia, a estrutura interna da actividade intelectual ligada ao instrumento e ao processo de domínio do instrumento tem indubitavelmente um conteúdo psicológico. Mediatizando a actividade do homem, o instrumento reorganiza-a de tal maneira que mesmo os processos mais elementares que a constituem se transformam (ibidem, $\mathrm{p}$. 136).

Mais adiante, Leontiev irá se ater à necessidade da mediação, a que tantas vezes já nos referimos, para a apropriação dos instrumentos pelas novas gerações, já que o "mundo real, imediato, do homem, que mais do que tudo determina a sua vida", "não é dado imediatamente ao indivíduo, enquanto mundo de objectos sociais, de objectos encarnando aptidões humanas formadas no decurso do desenvolvimento da prática socio-histórica” (ibidem, p. 166). Para o pesquisador russo, a criança necessita realizar uma atividade prática com estes objetos para se apropriar dos saberes neles encarnados, atividade esta que só pode ser orientada por alguém mais experiente. Em outras palavras, "Para que a criança reflicta os fenómenos na sua qualidade específica - na sua significação - deve efectuar em relação a ela uma actividade conforme à actividade humana que eles concretizam, que eles 'objectivam'” (ibidem, p. 185).

É isto que explica que quando se colocam objectos da cultura material humana na gaiola de um animal, se bem que eles não percam evidentemente qualquer das suas propriedades físicas, torna-se impossível a manifestação das propriedades específicas que estes têm para o homem; eles aparecem como simples objectos de adaptação ou de equilíbrio, isto é, como elemento do meio natural do animal (ibidem, p. 167).

Numa passagem próxima a este último fragmento, há mais uma menção ao fato dos instrumentos encarnarem aptidões humanas: 
O instrumento não é para o homem um simples objecto de forma exterior determinada e possuindo propriedades mecânicas definidas; ele manifesta-se-lhe como um objecto no qual se gravam modos de acção, operações de trabalho socialmente elaboradas. Por tal motivo, a relação adequada do homem ao instrumento traduz-se, antes do mais, no facto de o homem se aproximar, na prática ou em teoria (isto é, apenas, na sua significação), das operações fixadas no instrumento, desenvolvendo assim as suas capacidades humanas (ibidem, p. 168169).

Este processo de "encarnação" é passado em revista em outro momento (ibidem, p. 265-266), que resumiremos para dispensar uma transcrição muito longa do texto de Leontiev. Partindo da pergunta “como é que a evolução dos homens se produziu?", o autor da teoria da atividade lembra que os humanos, diferentemente dos animais, não só se adaptam à natureza, mas a adaptam também, modificando-a através do trabalho. $\mathrm{O}$ fenômeno do trabalho não pode ser transmitido mediante herança genética, mas pode ser passado adiante, às novas gerações, pelo fato de se fixar na cultura material e intelectual. Sendo os homens criadores e produtivos, suas realizações se tornam objetivas, adquirindo perenidade. $\mathrm{O}$ trabalho, respondendo às necessidades destes homens, promove a criação de todo um mundo de artefatos e instrumentos, progresso material este que é acompanhado também de um desenvolvimento da cultura, cujo enriquecimento leva à formação da ciência e da arte.

Ao mesmo tempo, no decurso da actividade dos homens, as suas aptidões, os seus conhecimentos e o seu saber-fazer cristalizam-se de certa maneira nos seus produtos (materiais, intelectuais, ideais). Razão por que todo o progresso no aperfeiçoamento, por exemplo, dos instrumentos de trabalho pode considerar-se, deste ponto de vista, como marcando um novo degrau do desenvolvimento histórico nas aptidões motoras do homem: também a complexificação da fonética das línguas encarna os progressos realizados na articulação dos sons e do ouvido verbal, os progressos das obras de arte, um desenvolvimento estético, etc. (ibidem, p. 265).

Prossegue, Leontiev, lembrando mais uma vez que as novas gerações começam suas vidas em um mundo já produzido pela atividade das gerações anteriores. Ingressando nesta produção, nestas atividades, é que elas vêm a se apropriar destas aptidões humanas cristalizadas na cultura material e intelectual existente. Somente a vida em sociedade proporciona esta apropriação; o indivíduo isolado é incapaz de participar desta humanidade:

Está fora de questão que a experiência individual de um homem, por mais rica que seja, baste para produzir a formação de um pensamento lógico ou matemático abstracto e sistemas conceptuais correspondentes. Seria preciso não uma vida, mas mil. [...] Está hoje estabelecido com toda a certeza que se as crianças se desenvolverem desde a mais tenra idade, fora da sociedade e dos fenómenos por ela 
criados, o seu nível é o dos animais (Zingg) ${ }^{58}$. Não possuem nem linguagem nem pensamento e os seus próprios movimentos em nada se assemelham aos dos humanos; não adquirem mesmo a posição vertical. Conhecem-se, pelo contrário, casos inversos em que crianças, oriundas de povos que se encontram num nível de desenvolvimento económico e cultural muito baixo, são colocadas muito cedo em condições culturais elevadas; forma-se então nelas todas as aptidões necessárias para a sua plena integração nesta cultura (ibidem, p. 266).

Adiante, há diversas passagens relevantes para o tema desta subseção, algumas repetindo considerações anteriores, mas que merecem a transcrição:

A questão do desenvolvimento do homem, considerado em ligação com o desenvolvimento da cultura e da sociedade [...] leva a perguntar-se em que consiste e como se desenrola o processo [...] de apropriação pelos indivíduos das aquisições do desenvolvimento histórico da sociedade [...], que é ao mesmo tempo o processo de formação de suas faculdades específicas do homem? [...]

$\mathrm{O}$ instrumento é o produto da cultura material que leva em si, da maneira mais evidente e mais material, os traços característicos da criação humana. [...] $O$ instrumento é ao mesmo tempo um objecto social no qual estão incorporadas e fixadas as operações de trabalho historicamente elaboradas. [...]

A apropriação dos instrumentos implica, portanto, uma reorganização dos movimentos naturais instintivos do homem e a formação de faculdades motoras superiores.

A aquisição do instrumento consiste, portanto, para o homem, em se apropriar das operações motoras que nele estão incorporadas. É ao mesmo tempo um processo de formação activa de aptidões novas, de funções superiores, "psicomotoras", que "hominizam" a sua esfera motriz (p. 268-270, grifos nossos).

Encerraremos esta análise de $O$ desenvolvimento do psiquismo com três exemplos, da obra, sobre a relação entre as funções psíquicas superiores e o uso orientado de instrumentos.

A primeira se refere à apropriação, pela criança, "de uma coisa tão simples como uma colher" (ibidem, p. 321). Leontiev parte da seguinte situação imaginária:

A criança nunca viu uma colher, e põe-se-lhe uma nas mãos. Que vai fazer com ela? Começará por a manipular, deslocá-la, martelar com ela, tentar metê-la na boca, etc. Por outras palavras, não a verá do ponto de vista dos modos de utilização elaborados pela sociedade, concretizados nas suas características exteriores, mas do ponto de vista das suas propriedades físicas, "naturais", não específicas (ibidem, loc. cit.).

Da situação imaginária, Leontiev nos guia para uma possibilidade mais concreta:

A mãe ou a ama alimenta a criança à colher; depois põe-lhe a colher na mão e ela tenta comer sozinha. A princípio, observamos que os seus gestos seguem o processo natural pelo qual "se leva à boca o que se tem na mão". A colher não se mantém horizontal na mão e o alimento cai. Mas a mãe ajuda a criança, intervém nas suas acções; na ação comum que daqui resulta, forma-se na criança o hábito de utilizar a

\footnotetext{
${ }^{58}$ Leontiev faz referência ao trabalho "Feral man and extreme cases of isolation", de R. Zingg, publicado no American Journal of Psychology em 1940.
} 
colher. Ela sabe doravante manejar a colher como um objecto humano (ibidem, p. 322 , grifos do autor).

O fato aludido nestas situações evoca prontamente o conceito de zona de desenvolvimento iminente de Vigotski, e o papel da imitação, processo que gozava de reconhecimento já nos escritos do autor de Michlenie $i$ retch, e que Leontiev continuará a levar em consideração. A importância da educação - do parceiro mais capaz - é igualmente ressaltada por ele:

\begin{abstract}
Este exemplo leva-se a pôr outra questão. Pode-se supor que o hábito de se servir de uma colher se possa formar numa criança fora de toda a comunicação, fora da acção comum com os adultos, à maneira como e formam as práticas nos animais? Teoricamente, é evidente que podemos supô-lo. E na prática pode-se mesmo colocar uma criança em condições tais que esta via seja a única via possível. Mas é uma suposição perfeitamente abstracta. Como efeito, a criança não pode viver $e$ desenvolver-se fora da comunicação prática e verbal com os adultos.

Suponhamos, todavia, que a criança se vê forçada a elaborar sozinha tal ou tal prática, tal ou tal aptidão, pela razão, por exemplo, de que os métodos aplicados por aqueles que a ajudam, os adultos que a rodeiam, não são suficientemente acessíveis. Pode-se esperar um resultado, mas após quanto tempo, e qual será o seu atraso em relação a uma criança mais feliz a quem "inteligentemente se guiou a mão"!... (ibidem, loc. cit., grifo nosso).
\end{abstract}

O segundo exemplo envolve a ação de uma criança em beber através de um copo. Leontiev busca, aqui, explicar como o processo de apropriação se constitui como um "mecanismo de formação de mecanismos" (ibidem, p. 178):

Quando um adulto procura que uma criança beba pela primeira vez por um copo, o contacto do líquido provoca nela movimentos reflexos incondicionais, estritamente conformes às condições naturais do acto de beber (a concha da mão forma um recipiente natural). Os lábios da criança esticam-se em forma se tubo, a língua avança, as narinas contraem-se e produzem-se movimentos de sucção. $O$ copo não é percebido ainda como objecto que determina o modo de realização do acto de beber. Todavia a criança aprende rapidamente a beber com correcção pelo copo, quer isto dizer que os movimentos se reorganizam e que ela utiliza o copo de conformidade com a função deste. $\mathrm{O}$ bordo é pressionado em tal posição que a ponta toca a face interna da mandíbula inferior, as narinas dilatam-se e o líquido escorre do copo inclinado para a boca. Há, portanto, verdadeiramente, o aparecimento de um sistema motor funcional absolutamente novo que realiza o acto de beber integrando novos elementos [...] (ibidem, p. 179).

Gostaríamos de reafirmar uma consideração de Vigotski, transcrita há pouco, sobre a relação entre o substrato natural e a aquisição instrumental mediante o processo de ensino: "Os processos psíquicos naturais não são eliminados com isso, mas entram em combinação com o ato instrumental e dependem funcionalmente, em sua estrutura, do instrumento utilizado" (2004, p. 100). Para compreender a situação exemplificada por Leontiev, a partir desta 
passagem de Vigotski, bastaria que substituíssemos a expressão "processos psíquicos” por "processos psicomotores". Leontiev acrescenta:

\begin{abstract}
A formação deste novo sistema funcional [o sistema motor de adaptação ao uso de um copo] depende das propriedades objectivas do próprio objecto que o copo é, que se distingue de todo o "recipiente natural" não só porque pode ser deslocado, mas também devido ao seu bordo fino; a utilização pela criança destas propriedades não é determinada pela sua própria existência, mas pelas acções do adulto que a obriga a beber: o adulto leva correctamente o copo aos lábios e inclina-o progressivamente; em seguida, depois de the ensinar a segurar sozinha o copo, dirige e rectifica activamente os movimentos da criança. Assim, o adulto constrói na criança um novo sistema motor funcional, em parte inculcando-lhe directamente movimentos (segurar o copo entre os lábios e incliná-lo progressivamente), em parte despertando nela com isso reflexos existentes, mas pertencentes a outros "conjuntos reflexos" naturais (1978, p. 179, grifo do autor).
\end{abstract}

O mecanismo descrito é análogo ao que já expusemos na subseção 3.3.1, sobre a formação dos sentidos humanos através da atividade prática dos homens. Da mesma forma que o ouvido tonal se constitui a partir da coordenação interfuncional de diversos sistemas fisiológicos relacionados à audição, tornando-se assim um “órgão funcional sensorial”, um amplo conjunto de partes do corpo da criança se coordena para que ela se aproprie do uso do copo enquanto instrumento. Esta aptidão em se servir de um objeto da cultura material, conquistada pela criança, é também uma espécie de órgão funcional, um “órgão funcional motor”. E Leontiev completa:

O processo de apropriação pela criança de acções especificamente humanas, como o uso da colher, da pá, etc., desenrola-se de maneira idêntica. No princípio, o objecto que a criança agarra entra no seu sistema de movimentos naturais; ele leva uma colher à boca contendo alimento como se se tratasse de um objecto natural "não instrumental" qualquer, isto é, não leva em conta, por exemplo, a necessidade de manter a colher em posição horizontal. Posteriormente, pela intervenção directa do adulto, os movimentos da mão reorganizam-se: começam a obedecer à lógica objectiva da utilização da colher. O carácter geral da aferentação destes movimentos muda; estes últimos atingem um nível superior, nível "objectal”; forma-se na criança um sistema motor funcional, o sistema das acções de tipo instrumental (ibidem, p. 179-180).

O último exemplo que extraímos da obra de Leontiev, de modo bastante feliz, se articula perfeitamente ao assunto deste capítulo: o laboratório científico e as atividades que ele sedia. Partindo do dado de que a "actividade interior teórica possui a mesma estrutura que a actividade prática", e que portanto devemos, "também no pensamento, distinguir entre actividade propriamente dita, as acções e operações e as funções cerebrais que as possibilitam" (ibidem, p. 119), Leontiev fala sobre a interconvertibilidade entre os elementos internos e externos da atividade: 
É precisamente a comunidade [ou comunhão] de estrutura da actividade interior teórica e da actividade exterior prática que permite aos seus diferentes elementos estruturais passar - e eles passam realmente - de uns para os outros; assim, a actividade interior inclui sempre acções e operações exteriores, ao passo que a actividade exterior inclui acções e operações interiores de pensamento (ibidem, loc. cit.).

É no exame deste aspecto que se apresenta o exemplo da atuação prática laboratorial:

Quando efectuo um trabalho científico, a minha actividade é evidentemente mental, teórica. Todavia, no decurso do meu trabalho apresenta-se-me uma série de fins cuja realização necessita de acções exteriores práticas. Suponhamos que tenho que montar (montar e não imaginar ou projectar) uma instalação laboratorial; começo a estender fios, a aparafusar, serrar, soldar, etc.; ao montar esta instalação, efectuo operações que, se bem que práticas, não entram menos no conteúdo da minha actividade teórica e que fora dela estariam desligadas de sentido.

Suponhamos agora que, para pôr em circuito um dos aparelhos da instalação, devo ter em conta a grandeza da resistência eléctrica do conjunto do circuito eléctrico; ao colocar o fio no borne, calculo mentalmente esta grandeza; neste caso é a minha acção prática que inclui uma operação intelectual (ibidem, loc. cit.).

Tais considerações retomam, sob uma forma rica em conceitos psicológicos, afirmações de outros autores a que recorremos, e que insistiam na importância do trabalho em laboratório ser uma verdadeira práxis, isto é, servir à unidade entre teoria e prática. Nas palavras de Leontiev,

O que há de comum entre a actividade prática exterior e a actividade interior teórica não se limita unicamente à sua comunidade de estrutura. É psicologicamente essencial, igualmente: que elas religuem, as duas, se bem que de maneira diferente, o homem ao seu meio circundante, o qual, por este facto, se reflecte no cérebro humano; que uma e a outra formas de actividade sejam mediatizadas pelo reflexo psíquico da realidade; que sejam a título igual processos dotados de sentido e formadores de sentido. Os seus pontos comuns testemunham a unidade da vida humana (ibidem, loc. cit.).

$\mathrm{Na}$ busca por esta unidade, fazemos nossas as palavras de Ingold (1994). O autor assim se pronuncia sobre as dicotomias, típicas da tradição ocidental de pensamento, entre as esferas das relações técnicas e sociais e, mais fundamentalmente, entre natureza e sociedade:

esta mesma tradição de pensamento, cuja inclinação para construir dicotomias é uma de suas principais características, nos ofereceu uma distinção entre intelecto (como uma propriedade da mente) e comportamento (uma execução corporal), junto com a ideia de que toda ação propositada ou intencional é precedida por um ato intelectual de cognição, envolvendo a construção de representações, a consideração de alternativas e a formulação de planos (ibidem, p. 431, grifos nossos, tradução nossa ${ }^{59}$ ).

\footnotetext{
${ }^{59}$ A tradução de todas as demais transcrições, desta referência, é de nossa autoria.
} 
Certamente Ingold não está se opondo ao que tecemos em diversas ocasiões nesta tese, quando afirmamos que os atos humanos, especialmente o trabalho, se caracterizam pela intencionalidade. Entendemos que sua crítica se dirige ao ponto de vista solipsista de que o homem primeiro é "informado" pela mente - esta entidade primeva, superior, ideal - e então canaliza esta informação, mediante seu aparato corporal, para atuar na realidade.

\begin{abstract}
Nós podemos, é claro, descrever como "inteligente" um animal cujas ações manifestam certa sensibilidade ou responsividade [ou então "respondibilidade", pois se usa aqui a palavra responsiveness] às nuances de suas relações com os componentes do ambiente. Mas é algo bem diferente atribuir esta qualidade à operação de um equipamento cognitivo, uma "inteligência", a qual estaria, de alguma forma, dentro do animal e que, desta localização privilegiada, processa os dados da percepção e toma o controle da ação. De fato, não faz mais sentido falar de cognição como o funcionamento de tal equipamento do que falar da locomoção como o produto de um mecanismo motor interno análogo ao motor de um carro. Como a locomoção, cognição é uma execução do animal como um todo, não é realizada por um mecanismo interior ao animal e à qual serve como veículo. Não há, portanto, algo como uma "inteligência" dissociada do próprio animal (ibidem, loc. cit., grifos do autor).
\end{abstract}

Como já afirmamos à exaustão, a consciência humana não é uma entidade à parte do mundo, não o precede, pelo contrário, é constituída pelo reflexo psíquico desta realidade material. Consequentemente, nenhum de seus planos ou antecipações ocorre em um vácuo; não brotam espontaneamente de uma suposta essência humana, que dirigiria a ação corporal. Pelo contrário, tais antecipações ideais respondem a necessidades impostas pela prática social. $\mathrm{O}$ que Ingold está dizendo, e com o que concordamos, é que nenhum ato técnico, instrumental, é puramente prático. Não há uma exterioridade corporal que executa ideias ou planos interiores; há, isto sim, uma unidade entre psiquismo e corpo, já que a própria consciência é fruto da atividade prática do homem sobre o mundo material que o rodeia. Assim, sobre o "poder da imaginação", Ingold diz:

As pessoas constroem sim planos e representações, e consideram sim cenários alternativos. Tais construções e considerações, no entanto, são gerados por meio da atividade inteligente - neste caso, o tipo de atividade que nós costumamos chamar de "pensamento", da mesma maneira que artefatos materiais são gerados pela atividade inteligente que nós chamamos de "produção". Eles não são, então, prelúdios necessários à ação, mas seus produtos. Mesmo quando ações são precedidas por planos (e isto provavelmente se aplica senão a uma pequena parte de todo o que fazemos), os últimos servem como padrões ou diretrizes em nossas relações com o mundo, em vez de programas que "convocam" a ação como um resultado [output] comportamental automático (ibidem, loc. cit., grifos do autor).

Estas palavras de Ingold lembram o que Sánchez Vázquez (2011) afirma sobre a práxis, que é sempre uma atividade orientada pelo pensamento, embora quase nunca o 
reproduza fielmente, exceto no caso da práxis imitativa. Ingold, longe de menosprezar a importância dos processos neurais para a consumação de atos como a fala e o uso de instrumentos, na verdade ressalta que eles estão sempre "imersos em um contexto de atividade corporal em um ambiente" (1994, p. 432).

O texto de Ingold, por diversas vezes, ressalta os nexos íntimos entre as habilidades práticas e o conhecimento. Comentando a suposição comum de que uma dada habilidade jaz na efetiva aplicação de um conhecimento, pressupondo portanto a existência de um conhecimento aplicável, ele afirma:

Eu acredito que esta visão é equivocada. Pois agir no mundo é o modo de que o praticante habilidoso [skilled practitioner] se utiliza para conhecê-lo. É no contato direto com os materiais - estando ou não mediado por ferramentas -, em ações atentas de tocar, sentir, manusear, olhar e ouvir, implicadas no processo de trabalho criativo, que o conhecimento técnico é obtido, assim como aplicado. [...] a habilidade é, simultaneamente, uma forma de conhecimento e uma forma de prática, ou - como queira - é tanto conhecimento prático quanto prática cognoscitiva (ibidem, p. 434, grifos nossos).

Podemos então retomar as considerações de Verillon (1995) a respeito do uso de instrumentos. Ao final de sua investigação, ele afirma:

\begin{abstract}
os instrumentos, por sua natureza, sejam eles semióticos ou materiais [...] justificam uma abordagem dupla. Como artefatos, eles são apropriados para um olhar objetivista, que pode legitimamente considerá-los como independentes tanto das condições reais e situadas de sua implementação, quanto das intenções individuais e das estratégias de seus usuários. Anulando-se estas dimensões situacionais e procedimentais, é possível então trazer à tona certas regularidades objetivas dos artefatos: estruturas, sistemas relacionais, leis de evolução etc. No estudo da linguagem, por exemplo, esta tem sido a abordagem da linguística geral. No estudo dos objetos manufaturados, tal abordagem seria aquela da tecnologia geral (ibidem, p. 97).
\end{abstract}

No entanto, uma tal abordagem, que abstrai as condições concretas de uso dos instrumentos, ainda que possível e legítima, é incompleta:

Mas da mesma maneira que Saussure salientou o fato de que "a fala é a condição da língua", no sentido de ser o lócus de seu real funcionamento e de sua evolução, nós igualmente sustentamos que a relação instrumental é a condição dos artefatos, seu modo de existência. Com efeito, apesar da ruptura epistêmica entre artefato e instrumento (ou entre língua e fala) ser legítima e produtiva, cuidados devem ser tomados para evitar que se considere o comportamento dos usuários em termos de uma aplicação do modelo dos tecnologistas (ou dos gramáticos). Portanto, é necessário conceber uma nova abordagem, sem desconsiderar a abordagem anterior centrada nos objetos, mas capaz de tomar em consideração a dimensão instrumental, que é a condição dos artefatos incorporados na práxis real (ibidem, loc. cit.). 
Vale a pena explorar esta analogia entre artefatos/instrumentos e língua/fala. Verillon menciona as diferenças que o célebre linguista Saussure considerou haver entre langue e parole. Epistemologicamente mais próximo de nós, Voloshinov fez afirmações parecidas:

De fato, a forma lingüística [...] sempre se apresenta aos locutores no contexto de enunciações precisas, o que implica sempre um contexto ideológico preciso. $\mathrm{Na}$ realidade, não são palavras o que pronunciamos ou escutamos, mas verdades ou mentiras, coisas boas ou más, importantes ou triviais, agradáveis ou desagradáveis, etc. A palavra está sempre carregada de um conteúdo ou de um sentido ideológico vivencial (VOLOCHÍNOV, 2004, p. 95, grifo do autor).

Em sua filosofia da linguagem, Voloshinov afirma que os interlocutores não trocam palavras e orações. Estas são unidades abstratas, meramente convencionais, da língua, sendo estudadas pela Linguística. O que se intercambia em um diálogo são enunciados, unidades concretas da fala. Ingold, fazendo referência a tais considerações de Voloshinov em Marxismo e filosofia da linguagem, estabelece novamente a analogia entre fala e uso de instrumentos:

Divorciado de seu contexto de produção, o instrumento é revertido a sua condição inicial de objeto inerte [...]. [Paralelamente,] Em si mesmas, as palavras não possuem significado, elas meramente se dispõem à possibilidade de significar. Apenas sendo aproveitadas pela intenção de um falante, em um contexto de troca verbal, é que elas vêm a exercer um impacto significativo sobre o ouvinte. Procurar o significado na palavra isolada é - para adotar uma metáfora vívida sugerida por Vološinov (1986: 103) - querer acender uma lâmpada depois de se ter cortado a corrente $^{60}$. Da mesma forma que o significado das palavras emerge do contexto situacional declarativo, que gera a corrente que ilumina a lâmpada, também o valor de uso de instrumentos-objetos emerge da situação do agente [ou usuário, nas palavras de Verillon] em um contexto de ação prática (1994, p. 440, grifo nosso).

Verillon (1995) propõe um modelo, para o estudo da atividade "instrumentada", que leva em consideração outras interações, além da estabelecida entre o sujeito e o objeto para o qual seu ato se dirige: as interações recíprocas entre o sujeito e o instrumento; entre o instrumento e seu objeto; e as relações mediadas entre sujeito e objeto. O exemplo que o autor sugere envolve também o uso da colher por uma criança:

Considere um exemplo [...]: um bebê aprendendo a usar uma colher. Não só ele tem que elaborar sistemas eficientes para agarrar e manipular a colher (interação sujeitoinstrumento), como também precisa aprender a manter um pouco do leite na colher no caminho para sua boca (interação instrumento-objeto). Neste processo, ele

\footnotetext{
${ }^{60} \mathrm{Na}$ edição que consultamos, o trecho referido é: "A significação não está na palavra nem na alma do falante, assim como também não está na alma do interlocutor. Ela é o efeito da interação do locutor e do receptor produzido através do material de um determinado complexo sonoro. É como uma faísca elétrica que só se produz quando há contato entre dois pólos opostos. [...]. Só a corrente da comunicação verbal fornece à palavra a luz da sua significação" (VOLOCHÍNOV, 2004, p. 132, grifo do autor).
} 
adquire também algum conhecimento sobre o comportamento de líquidos, em oposição, por exemplo, ao de um purê de batatas (interação sujeito-objeto mediada pelo instrumento) (ibidem, p. 96).

Na Figura 12 há uma representação esquemática deste processo, da autoria de Verillon.

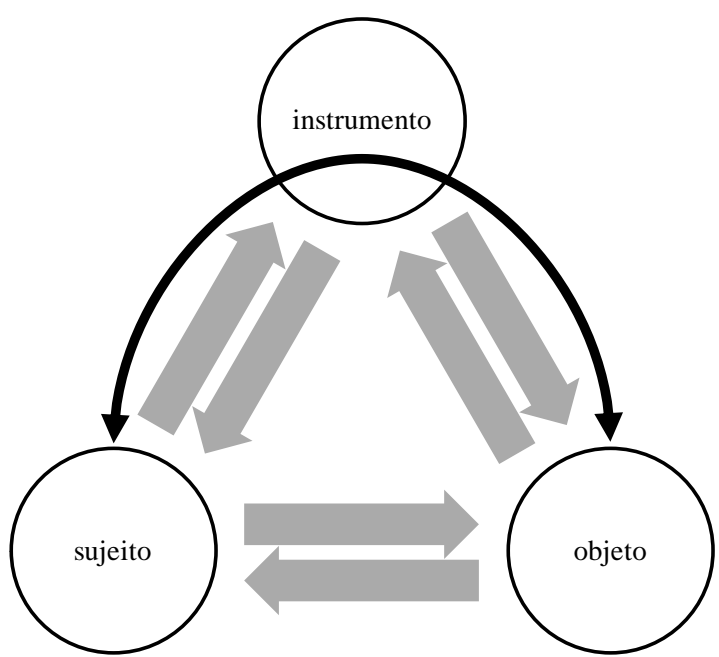

Figura 12: esquema das interações recíprocas entre sujeito, objeto e instrumento, na atividade instrumentada (VERILLON, 1995, p. 85).

Considerando que os instrumentos cristalizam ou materializam determinadas operações motoras de trabalho historicamente elaboradas, reside aí a importância de estarem disponíveis aos estudantes em seu processo formal de aprendizagem, quando estas operações aparecem vinculadas com os conteúdos curriculares. Possibilitados de um contato com estes instrumentos, os educandos poderão se apropriar das atividades encarnadas neles que, posteriormente, se interiorizarão em sua estrutura psíquica. Por exemplo, a bureta encarna em si determinadas operações químicas, sendo a principal a de titulação. O manuseio correto e orientado desta ferramenta de laboratório deverá permitir a interiorização não apenas da operação motora de titular uma amostra, mas também de todos os conceitos que esta operação carrega consigo em sua significação social, por exemplo, os conceitos químicos de ácido e base e do mecanismo de funcionamento dos indicadores químicos. $\mathrm{O}$ ato de titular - uma atividade, ação ou operação instrumentada, de acordo com o significado que assume para o sujeito que o realiza - não representa apenas uma relação entre o sujeito que titula e o instrumento da titulação. Representa também uma relação entre o sujeito e o objeto para o qual o instrumento se dirige, uma dada solução. O conhecimento de determinados aspectos desta solução - como atua nela um indicador ácido-base, qual o seu $\mathrm{pH}$, qual a força do ácido que ela contém - não pode se apresentar ao sujeito de forma pura, imediata; mas é pela mediação de instrumentos (tanto o instrumento técnico que é a bureta, quando os instrumentos 
psíquicos na forma de signos - conceitos, equações, fórmulas químicas) que o sujeito pode se apropriar deles. Tal apropriação, além de tudo, se apresenta rica em significados, pois se estabelece no decorrer de uma relação entre teoria e prática sediando, portanto, uma práxis.

Chegamos ao final deste capítulo. Com base no que registramos até aqui, podemos nos considerar de posse de uma teoria que extrai, da Pedagogia Histórico-Crítica e da Psicologia Histórico-Cultural, elementos específicos que permitem uma compreensão da importância do laboratório de ciências na educação formal. Apresentamos esta teoria tomando como referência os instrumentos de laboratório, mas consideramos que ela seja válida também para o laboratório como um todo. Este espaço, em sua singularidade e especificidade para a educação científica, traz objetivado em sua materialidade todo um conjunto de atividades, ações e operações práticas, desenvolvidas historicamente, e acessíveis para a incorporação na estrutura psíquica dos indivíduos que ali desenvolvam novas atividades.

Antes de partirmos para os próximos capítulos, em que finalmente poderemos nos dedicar ao estudo do objeto que motivou a elaboração da presente tese - a Experimentoteca -, completemos o quadro da Figura 10 com uma linha final, aquela referente à visão críticodialética experimentação no ensino de ciências (Figura 13).

\begin{tabular}{|c|c|c|c|}
\hline \multirow{2}{*}{$\begin{array}{c}\text { Período } \\
\text { elou } \\
\text { modalidade }\end{array}$} & \multicolumn{3}{|c|}{ Palavras experimentar, experimentação, experiência $e$ experimento } \\
\hline & Domínio prático & Domínio filosófico & Domínio da atividade científica \\
\hline $\begin{array}{l}\text { Atualidade } \\
\text { e sua } \\
\text { superação } \\
\text { histórica } \\
\text { (visão } \\
\text { crítico- } \\
\text { dialética) }\end{array}$ & $\begin{array}{l}\text { A prática com objetos } \\
\text { empíricos, típica do senso } \\
\text { comum, não pode levar a } \\
\text { uma episteme, pois se } \\
\text { restringe ao cotidiano } \\
\text { alienado, fragmentado, } \\
\text { assistemático. A prática } \\
\text { com objetos concretos, } \\
\text { isto é, tomados enquanto } \\
\text { síntese de relações } \\
\text { sociais, pelo contrário, é } \\
\text { uma prática intencional e } \\
\text { consciente. Considerada } \\
\text { deste modo, trata-se de } \\
\text { uma prática em unidade } \\
\text { com a teoria: uma } \\
\text { verdadeira práxis. }\end{array}$ & $\begin{array}{l}\text { A práxis, enquanto } \\
\text { movimento que ascende do } \\
\text { empírico ao concreto pela } \\
\text { mediação do abstrato, ou } \\
\text { da síncrese à síntese pela } \\
\text { mediação da análise, é o } \\
\text { processo que aproxima os } \\
\text { homens da verdade } \\
\text { objetiva. Não sendo nem } \\
\text { puramente indutivo (como } \\
\text { é o empirismo inglês e o } \\
\text { método positivista), nem } \\
\text { puramente dedutivo (como } \\
\text { no cogito cartesiano), o } \\
\text { método é, } \\
\text { simultaneamente, indutivo } \\
\text { e dedutivo, analítico- } \\
\text { sintético, abstrato-concreto, } \\
\text { lógico-histórico. }\end{array}$ & $\begin{array}{l}\text { A práxis experimental modifica a } \\
\text { natureza, através de instrumentos } \\
\text { especializados (semióticos e } \\
\text { técnicos), criativamente, buscando } \\
\text { novos conhecimentos. Trata-se de } \\
\text { uma práxis, portanto, produtiva. A } \\
\text { práxis educativa pode assimilar a } \\
\text { experimental, colocando os } \\
\text { educandos em contato com a } \\
\text { cultura material e sígnica da } \\
\text { ciência, para que se apropriem das } \\
\text { aptidões humanas representadas } \\
\text { pelas conquistas científicas. No } \\
\text { entanto, neste caso, trata-se de uma } \\
\text { práxis reiterativa ou imitativa, que } \\
\text { não pretende a produção do } \\
\text { conhecimento, mas a sua } \\
\text { reprodução. }\end{array}$ \\
\hline
\end{tabular}

Figura 13: quadro com as contribuições dos domínios semânticos das palavras experimentar, experimentação, experiência e experimento para se entender a visão crítico-dialética da experimentação no ensino de ciências. 


\title{
CAPÍTULO 4
}

\section{O LABORATÓRIO DIDÁTICO E A MATERIALIDADE DO ENSINO DE CIÊNCIAS: \\ o caso de São Carlos ${ }^{61}$}

\begin{abstract}
Até aqui, preocupamo-nos somente em articular uma teoria para a análise da experimentação enquanto estratégia para a educação científica, valendo-se da unidade psicopedagógica da Pedagogia Histórico-Crítica e da Psicologia Histórico-Cultural. Esta busca, ao final do capítulo passado, culminou na "visão crítico-dialética sobre a experimentação no ensino de ciências". De agora em diante, nos aproximaremos cada vez mais de nosso objeto de investigação, a Experimentoteca do CDCC. Assim, do âmbito da teoria, nos encaminharemos ao da prática, tratada efetivamente nos capítulos seguintes a este.
\end{abstract}

\footnotetext{
${ }^{61}$ Este capítulo é uma adaptação do texto O laboratório didático e a materialidade do ensino de ciências em São Carlos, encaminhado ao Concurso Anual de Monografias da Fundação Pró-Memória de São Carlos 2011/2012, cujo tema foi "Professores, alunos, escolas: a educação em São Carlos". O trabalho, submetido sob o pseudônimo de Samir Nakayama, foi contemplado com o $2^{\circ}$ lugar na classificação final do concurso. A monografia incluiu, ainda, uma versão modificada do trabalho que originou o capítulo anterior desta tese, "Experimentação no ensino de ciências: uma visão crítico-dialética". A comissão avaliadora do concurso foi composta pelos professores Paolo Nosella, Manoel Nelito Matheus Nascimento (ambos da UFSCar) e Rosa Fátima de Souza (da Faculdade de Ciências e Letras da Unesp, campus Araraquara). O Prof. Nosella atribuiu a nota 80 pontos (de 100 possíveis), não deixando comentários em seu parecer. O Prof. Nelito atribuiu a nota 75, comentando que "Esta monografia sobre os laboratórios de ensino de ciências em escolas públicas de São Carlos trata de um item específico da escola, sem a abrangência que o tema do concurso proporciona". Já a Prof. Rosa, que atribuiu a nota 67, apresentou um comentário mais completo: "O texto compreende um estudo monográfico interessante sobre a situação material dos laboratórios didáticos, para o ensino de ciências, nas escolas públicas do ensino médio da cidade de São Carlos. O tema é pertinente e o texto apresenta consistência teóricometodológica e clareza. No entanto, a monografia apresenta fragilidades em relação ao aprofundamento da análise e ao diálogo com a bibliografia atualizada sobre ensino de ciências". Considerando estes pareceres, busquei mitigar os defeitos do estudo original ao reapresentá-lo nesta tese. A propósito, o texto original e os pareceres podem ser consultados na sede da Fundação Pró-Memória de São Carlos.
} 
Mas antes de imergirmos na prática, achamos imprescindível examinar a situação em que ela se desenvolve, isto é, a configuração de sua materialidade - o conjunto de potências materiais que lhe serve de fundamento, e sobre o qual ela atua desejando modificar. Afinal, nossos referenciais se baseiam em uma filosofia materialista, para a qual não é a consciência que determina o ser, é o ser que determina a consciência dos homens. Assim, compreender a materialidade da existência e das práticas sociais se converte num imperativo para a compreensão dos fenômenos que tomam lugar no seio destas mesmas práticas. Ora, a educação, conforme Saviani, não é mais que uma entre tantas práticas sociais, o que implica que sua plena compreensão somente possa se dar a partir de seu aspecto material.

Portanto, vemos como natural que a caracterização do laboratório científico escolar, considerado como espaço específico para o ensino e a aprendizagem dos conteúdos curriculares científicos, se interponha como requisito para a investigação da prática da educação científica, e por extensão, da prática educativa de modo geral numa determinada totalidade, que é aqui o município de São Carlos. Tal caracterização será o objeto deste capítulo, sendo apresentada na forma de uma investigação: convém esclarecer, uma investigação bastante diferente de suas congêneres que buscam como primeira fonte de dados as ideias, as concepções de diversos sujeitos do processo educacional. Entendemos que estas ideias e concepções - ou em uma palavra, esta consciência -, sendo historicamente determinadas, só podem ser interpretadas de modo fidedigno à realidade quando confrontadas com os dados desta mesma realidade, tomada em sua existência objetiva.

Adotar este ponto de vista, no entanto, não pode significar uma imobilização da realidade material no pensamento. Alerta-nos Karel Kosik que "O reconhecimento do caráter histórico da realidade social não equivale à redução historicizante à situação dada" (KOSÍK, 1989, p. 127). O filósofo tcheco afirma ainda:

\footnotetext{
Dizer que a realidade está "acima" das situações dadas e das suas formas históricas de existência, significa: a realidade não é um caos de eventos ou de situações fixadas; é unidade dos eventos com os sujeitos dos eventos, é unidade das situações e, portanto, é capacidade prático-espiritual de transcender a situação - na qual se fundamenta a possibilidade de passar da opinião à ciência, da doxa ao episteme, do mito à verdade, do casual ao necessário, do relativo ao absoluto - não significa sair da história, é a expressão da especificidade do homem como ser capaz de ação e de história: o homem não é prisioneiro da animalidade e da barbárie da espécie, dos preconceitos, das circunstâncias, mas com o seu caráter ontocriador (como práxis) possui a capacidade de transcendê-los para se elevar à verdade e à universalidade (ibidem, p. 134, grifo do autor).
}

A pesquisa é apresentada em quatro seções. 
A primeira trata da categoria materialidade conforme os textos de Dermeval Saviani a compreendem, no âmbito especificamente educativo.

A segunda seção apresenta os fundamentos metodológicos da pesquisa, caracterizada como um empreendimento tão crítico-dialético quanto a teoria que o orienta. São apresentados também todos os procedimentos realizados para a coleta de dados, que se tratou, adiantemos, de um levantamento da situação material dos laboratórios científicos das escolas da educação básica em São Carlos.

$\mathrm{Na}$ seção seguinte são expostos e discutidos os resultados alcançados, à luz das categorias analíticas extraídas do estudo sobre a materialidade da ação educativa e de nosso referencial sobre a experimentação no ensino de ciências.

Por fim, apresentamos considerações a título de conclusão sobre a pesquisa realizada.

\subsection{A MATERIALIDADE DE UMA AÇÃO EDUCATIVA}

Já afirmamos, à seção 1.4 do capítulo 1 desta tese, que nas páginas iniciais de Pedagogia Histórico-Crítica: primeiras aproximações (SAVIANI, 2008) são expostas as bases desta pedagogia. Entre elas, está a consideração da natureza da educação enquanto trabalho do tipo "não-material", cujo produto não se separa do ato de produção.

Concentremo-nos neste aspecto da prática educativa. Conforme se depreende de um trabalho de Newton Duarte e colaboradores (2012), esta questão ainda confunde muitos educadores. Afinal, o que significa que a educação se constitua como "trabalho do tipo nãomaterial?” Responde-nos o próprio formulador da Pedagogia Histórico-Crítica:

o processo de produção da existência humana implica, primeiramente, a garantia da sua subsistência material com a conseqüente produção, em escalas cada vez mais amplas e complexas, de bens materiais; tal processo nós podemos traduzir na rubrica de "trabalho material". Entretanto, para produzir materialmente, o homem necessita antecipar em idéias os objetivos da ação, o que significa que ele representa mentalmente os objetivos reais. Essa representação inclui o aspecto de conhecimento das propriedades do mundo real (ciência), de valorização (ética) e de simbolização (arte). Tais aspectos, na medida em que são objetos de preocupação explícita e direta, abrem a perspectiva de uma outra categoria de produção que pode ser traduzida pela rubrica "trabalho não-material". Trata-se aqui da produção de idéias, conceitos, valores, símbolos, hábitos, atitudes, habilidades (SAVIANI, 2008, p. 12). 
Assim, a educação se inscreve como uma das feições da produção do saber, no caso, a reprodução do saber sobre a cultura humana, que necessita ser realizada em cada indivíduo singular para que ele venha a participar da humanidade. Saviani distingue ainda entre duas modalidades de trabalho não-material, de modo a demarcar mais inequivocamente a natureza da educação, donde emerge a seu comentário sobre a inseparabilidade entre produto e ato de produção:

A primeira [modalidade] se refere àquelas atividades em que o produto se separa do ato de produção, como no caso dos livros e dos objetos artísticos. Há, pois, nesse caso, um intervalo entre a produção e o consumo, possibilitado pela autonomia entre $\mathrm{o}$ produto e o ato de produção. A segunda diz respeito às atividades em que o produto não se separa do ato de produção. Nesse caso, não ocorre o intervalo antes observado; o ato de produção e o ato de consumo imbricam-se. É nessa segunda modalidade do trabalho não-material que se situa a educação (ibidem, loc. cit.).

O fato da educação se tratar de um trabalho do tipo não-material não implica que ela careça de objetividade. Com efeito, materialidade e objetividade não são sinônimos: "Em termos dialéticos, o polo oposto ao da materialidade é o da idealidade. Já a objetividade tem como polo oposto a subjetividade" (DUARTE et al., 2012, p. 96). Assim, o processo de educar se apresenta como um trabalho objetivo e não-material, e esta não-materialidade se revela quando a educação é analisada pelos produtos ou resultados que gera. É um trabalho não-material porque seu resultado, a formação humana através da transmissão/assimilação dos conteúdos culturais produzidos historicamente, tem um caráter espiritual, simbólico.

Não obstante, reconhecer isto não significa negar que a educação tenha uma materialidade, já que a "a produção não material não existe sem as determinações materiais, a começar da própria materialidade do corpo humano e dos recursos materiais empregados, por exemplo, numa aula" (ibidem, p. 99). Nas palavras de Saviani,

A ação educativa [...] desenvolve-se $a$ partir de condições materiais e $e m$ condições também materiais.

Essas condições materiais configuram o âmbito da prática. Esta exerce-se no âmbito da materialidade e é um dos fundamentos da [...] pedagogia histórico-crítica, a qual [...] considera que a teoria tem o seu fundamento, o seu critério de verdade e sua finalidade na prática. Então o primado da prática sobre a teoria é posto aí de forma clara. $[\ldots]$

Quando entendemos que a prática será tanto mais coerente e consistente, será tanto mais qualitativa, será tanto mais desenvolvida quanto consistente e desenvolvida for a teoria que a embasa, e que uma prática será transformada à medida que exista uma elaboração teórica que justifique a necessidade da sua transformação e que proponha as formas da transformação, estamos pensando a prática a partir da teoria (2008, p. 107, grifos nossos). 
Esta referência à materialidade como configurando o âmbito da prática leva Saviani a tecer considerações de caráter filosófico-gnosiológico, tomando como primordial a questão da dependência recíproca entre teoria e prática. Nesse aspecto, se as condições de desenvolvimento da prática são precárias, também se criam desafios ao desenvolvimento da teoria:

num primeiro sentido, na medida em que, se a prática que fundamenta a teoria e que opera como seu critério de verdade e sua finalidade tem um desenvolvimento precário, enfrentando no âmbito de sua materialidade entraves complexos, ela coloca limites à teoria, dificultando o seu avanço; num segundo sentido, na medida em que as condições precárias da prática provocam a teoria a encontrar as formas de compreender esse entraves e, ao compreendê-los, buscar os mecanismos efetivos e, portanto, também práticos, formulando-os com a clareza que a teoria exige, tendo em vista a sua mobilização para a transformação efetiva dessas mesmas condições (ibidem, p. 108).

E a partir destas considerações, Saviani se propõe a analisar a questão da materialidade da ação pedagógica a partir de três grandes problemas: o problema da ausência de um sistema de educação em nosso país; o problema da estrutura organizacional da educação; e o problema da descontinuidade.

A questão do sistema educacional foi desenvolvida detalhadamente por Saviani na obra Educação brasileira: estrutura e sistema (idem, 1975) ${ }^{62}$. A certa altura do livro o autor busca estabelecer qual o sentido da palavra "sistema" no âmbito educacional. Antes, faz-se sua distinção da palavra "estrutura", visto que ambas, na história da legislação educacional brasileira, aparecem diversas vezes como sinônimas ou envoltas em grandes imprecisões terminológicas:

A estrutura implica [...] a própria textura da realidade; indica a forma como as coisas se entrelaçam entre si, independentemente do homem e, às vezes, envolvendo o homem (como no caso das estruturas sociais, políticas, econômicas, educacionais, etc.). O sistema implica uma ordem que o homem impõe à realidade. Entenda-se, porém: não se trata de criar a realidade. O homem sofre a ação das estruturas, mas, na medida em que toma consciência dessa ação, ele é capaz de manipular a sua força, agindo sobre a estrutura de modo a lhe atribuir um sentido (ibidem, p. 76, grifos nossos).

\footnotetext{
${ }^{62}$ Conforme se lê nesta obra, resultante da tese de doutoramento de Saviani na PUC-SP, a investigação nela relatada vale-se de um método que o autor denominava, à época, fenomenológico-dialético. Mais tarde, no entanto, ele reconheceria: "Eu, em certa época, pensei o método fenomenológico-dialético como uma superação dos limites tanto da fenomenologia quanto da dialética. Depois, reconsiderei isso. Como? Percebi que o que eu denominava 'método fenomenológico-dialético' era o próprio método dialético. E mais. O que eu denominava 'limites do método dialético’ eram limitações impostas pela leitura mecanicista” (SAVIANI, 2010, p. 12).
} 
Em um texto da mesma época (1974), intitulado "Estruturalismo e educação brasileira" (idem, 2009, p. 141-154), Saviani dedica grande espaço à questão, partindo de um estudo etimológico da palavra "estrutura" e chegando aos seguintes resultados (p. 149-150): primeiramente, que a estrutura é constituída por dois níveis, a infraestrutura ("a realidade concreta no seu sentido mais próprio e imediato") e a supraestrutura (“esquemas construídos pelos homens por exigência do processo de produção de sua existência", sendo "produtos objetivos, caracterizando-se como componentes da cultura"); que estes dois níveis compartilham de um atributo comum, que é a inintencionalidade, pois não são produzidos de modo intencional e refletido; que a estrutura se apresenta como um conceito, quanto a este aspecto, oposto ao conceito de sistema, pelo fato deste implicar a ação intencional; e, finalmente, como consequência, o sistema implica práxis, tomada como unidade entre teoria e prática. Assim,

\begin{abstract}
"Sistema" é uma organização objetiva resultante da atividade sistematizadora que se dirige à realização de objetivos comuns. É, pois, um produto da práxis intencional comum. [...] "a teoria não faz o sistema; ela é apenas uma condição necessária para que ele se faça. Quem faz o sistema são os homens quando assumem a teoria na sua práxis. E quem faz o sistema educacional são os educadores quando assumem a teoria na sua práxis educativa",63 [...] (ibidem, loc. cit.).
\end{abstract}

O raciocínio é complementado com o seguinte jogo de palavras:

enquanto a estrutura se apresenta como um "sistema" que o homem não fez (ou fez sem o saber), o sistema pode ser comparado a uma "estrutura" que o homem faz e sabe que o faz. Note-se que no segundo caso o verbo foi utilizado no presente e não foi por acaso; é preciso atuar de modo sistematizado no sistema educacional; caso contrário, ele tenderá a distanciar-se dos objetivos humanos, caracterizando-se, agora sim, especificamente como estrutura (resultado comum inintencional de práxis intencionais individuais) (ibidem, loc. cit.).

Voltando a Educação brasileira: estrutura e sistema, Saviani lembra que, para Jean-Paul Sartre,

O essencial não é o que foi feito do homem, mas o que ele faz daquilo que fizeram dele. $\mathrm{O}$ que foi feito dele são as estruturas, os conjuntos significantes estudados pelas ciências humanas. O que ele faz é a própria história, a superação real dessas estruturas numa práxis totalizadora (SARTRE, 1968, p. 110 apud SAVIANI, 1975, p. 77, grifo do autor $\left.{ }^{64}\right)$.

\footnotetext{
${ }^{63} \mathrm{O}$ fragmento está em aspas porque, aqui, Saviani está transcrevendo suas próprias palavras, registradas em Educação brasileira: estrutura e sistema.

${ }^{64}$ Não está discriminado, na referência, se o grifo é do próprio Sartre ou de Saviani.
} 
E parafraseando o existencialista francês, ele define: "o que foi feito do homem são as estruturas; o que ele faz (daquilo que fizeram dele) é o sistema” (ibidem, loc. cit.). Na mesma obra, encontramos também a seguinte definição, bastante simples: "Sistema é a unidade de vários elementos intencionalmente reunidos, de modo a formar um conjunto coerente e operante" (ibidem, p. 75, grifo do autor). Pouco antes, Saviani explica:

$\mathrm{O}$ ato de sistematizar, uma vez que pressupõe a consciência refletida, é um ato intencional. Isto significa que, ao realizá-lo, o homem mantém em sua consciência um objetivo que lhe dá sentido: em outros termos, trata-se de um ato que concretiza um projeto prévio. Este caráter intencional não basta, entretanto, para definir a sistematização. Esta implica também uma multiplicidade de elementos que precisam ser ordenados, unificados (veja-se a origem grega do significado da palavra sistema: reunir, ordenar, coligir). Sistematizar é, pois, dar, intencionalmente, unidade à multiplicidade. E o resultado obtido, eis o que se chama sistema. Este é, então, produzido pelo homem a partir de elementos que não são produzidos por ele, mas que se-lhe oferecem na sua situação existencial. E como esses elementos, ao serem reunidos, não perdem a sua especificidade, o que garante a unidade é a relação de coerência que se estabelece entre os mesmos. Além disso, o fato de serem reunidos num conjunto não implica em que os elementos deixem de pertencer à situação objetiva em que o próprio homem está envolvido; por isso, o conjunto, como um todo, deve manter também uma relação de coerência com a situação objetiva referida (ibidem, p. 72).

Se o sistema, portanto, engloba as categorias "intencionalidade", "unidade", "variedade", "coerência interna" e "coerência externa" (ibidem, p. 72), o que seria, então, educar de modo sistematizado? Para Saviani, o homem é capaz disto quando (ibidem, p. 78):

a) Toma consciência da situação (estrutura educacional);

b) Capta os seus problemas;

c) Reflete sobre eles;

d) Formula-os em termos de objetivos realizáveis;

e) Organiza os meios para alcançar os objetivos;

f) Instaura um processo concreto que os realiza; e

g) Mantém ininterrupto o movimento dialético ação-reflexão-ação.

Três páginas adiante, o autor determina as condições básicas para a construção de um sistema educacional em uma dada situação histórico-geográfica, sendo elas:

a) Consciência dos problemas da situação;

b) Conhecimento da realidade (as estruturas);

c) Formulação de uma pedagogia. 
Retomaremos estes enunciados na seção sobre os resultados da pesquisa apresentada neste capítulo. Neste momento, importa demonstrar como a inexistência de um sistema educacional em nosso país coloca óbices a todo o conjunto da prática educativa e, por conseguinte, cria gravíssimos problemas sociais, por exemplo, o analfabetismo.

Saviani concentra esforços, ao tratar do problema da ausência de um sistema educacional, nas dificuldades de caráter econômico, visto que os "recursos para a educação, isto é, o orçamento [...] é o pressuposto das condições materiais da organização do ensino" (idem, 2008, p. 112). As principais dificuldades, quanto a isto, são duas. Uma é a escassez de verbas destinadas à educação, já que o Estado direciona recursos que poderiam até ser suficientes para a manutenção e desenvolvimento de um sistema, mas que não o são devido a um déficit histórico. O Brasil, desde sua tardia preocupação com a educação, mesmo em comparação com outras colônias de metrópoles da Europa, acumula uma dívida que repercute, inevitavelmente, na própria organização física das escolas:

temos um sistema dimensionado a partir das perdas. Se nós imaginássemos uma situação em que as oito séries fossem implantadas efetivamente, de tal modo que, em cada escola, todas as crianças que entrassem na $1^{\mathrm{a}}$ série passassem para a $2^{\mathrm{a}}$, a $3^{\mathrm{a}}$, chegando, sem repetir, até a $8^{\mathrm{a}}$ série, só isso já implicaria que nós teríamos que ter mais salas de aula, mais carteiras e, portanto, mais investimentos na rede física, que na verdade são necessários porque o sistema não está ainda implantado. Então, é claro que para se implantar o sistema o percentual definido na Constituição não é suficiente (ibidem, p. 114).

A outra dificuldade, indissociável da primeira, é a necessidade de mecanismos que assegurem a correta destinação das verbas educacionais para, especificamente, as atividades fins da escola, e não para lidar com questões que poderiam ser resolvidas em outros âmbitos. Por exemplo, a desnutrição infantil pode ser encarada como um desajuste no âmbito da saúde pública; portanto, as verbas educacionais não deveriam ser destinadas a esta questão.

O segundo problema concernente à materialidade da ação educativa, aquele que se refere à estrutura organizacional da educação, se revela a partir da constatação de dois fatos. Veremos que, assim caracterizado, este aspecto da materialidade da educação se apresenta em estreita vinculação com o problema anterior, a ausência de um sistema educacional no Brasil.

O primeiro fato diz respeito ao ensino em sua organização física, pois “o próprio aspecto físico das salas de aula se modifica à medida que a concepção de educação se altera e vice-versa" (ibidem, p. 118). Saviani, antes de apresentar esta passagem, leva o leitor ao exame das salas de aula comparando o contexto das escolas da pedagogia tradicional com o contexto dos estabelecimentos escolanovistas. No primeiro caso, há o aluno numa sala 
isolada, silenciosa, prevenindo o contato com estímulos externos, porque se pressupunha que a aprendizagem seria tanto melhor quanto maior fosse a concentração no discurso do professor. No outro, o pressuposto é que as crianças devem aprender em interação mútua, processando todos os estímulos ambientais, apenas sob a orientação do professor, daí as paredes serem coloridas e cheias de cartazes e o ambiente ser barulhento. Dito de outra forma, é possível afirmar que a pedagogia instituída - o que ocorre por meio da legislação de ensino - não apenas busca orientar a prática desenvolvida em sala de aula, mas aparece mesmo cristalizada na materialidade da ação educacional.

As redes escolares são organizadas segundo determinada concepção [...] embora contenham, às vezes de forma contraditória, elementos implícitos derivados de concepções que penetraram no cotidiano das escolas, constituindo aquilo que poderíamos chamar de "senso comum educacional" (ibidem, p. 119).

Este raciocínio explica de maneira precisa alguns aspectos da atual realidade do ensino em nosso país, por exemplo, a "rejeição", dos educadores, aos documentos curriculares brasileiros - Parâmetros Curriculares Nacionais, Diretrizes Curriculares Nacionais, propostas curriculares das unidades federativas. Especificamente, vejamos o caso dos PCN (BRASIL, 1997). Um rápido exame de seu texto revela um compromisso com a concepção construtivista do ensino ${ }^{65}$. No entanto, é óbvio que o construtivismo nunca se identificou plenamente com a realidade de grande parte de nossas escolas, ou pelo menos não vem se apresentando como a concepção hegemônica a orientar o trabalho docente. O fato da edição destes documentos oficiais ter interferido pouco na rotina das salas de aula se explicaria, ao menos em parte, pela própria questão material das escolas, no tocante aos aspectos físicos. Pois

Se considerarmos a rede escolar de educação básica no Brasil, veremos que sua organização atual ainda se pauta, fundamentalmente, pelas características que assumiu em decorrência da reforma do ensino estatuída pela Lei n. 5.692, promulgada em 11 de agosto de 1971 (SAVIANI, 2008, p. 119).

Como já afirmamos, a referida lei é conhecida por incorporar concepções da pedagogia tecnicista. Já o construtivismo se alinha a uma filosofia educacional do tipo liberal renovada, estando em consonância com a pedagogia nova. Apesar destas duas pedagogias - tecnicista e nova - serem liberais e acríticas, as maneiras como ambas orientam a configuração do espaço da sala de aula são inegavelmente diversas, para não dizer incompatíveis.

\footnotetext{
${ }^{65}$ Para uma crítica ao modo como o construtivismo aparece incorporado aos PCN, veja Duarte (2006, p. 56-69).
} 
as escolas estão organizadas de determinada maneira que corresponde a determinada concepção, ou seja, determinada orientação teórica. Assim, quando se quer mudar o ensino, guiando-se por uma outra teoria, não basta formular o projeto pedagógico e difundi-lo para o corpo docente, os alunos e, mesmo, para toda a comunidade [...]. É preciso levar em conta a prática das escolas que, organizadas de acordo com a teoria anterior, operam como um determinante da própria consciência dos agentes, opondo, portanto, uma resistência material à tentativa de transformação alimentada por uma nova teoria (ibidem, p. 121, grifo nosso).

O segundo fato, relativo à contribuição do problema da estrutura organizacional para a materialidade da educação, se refere à organização administrativa e ao modo como os processos ganham corpo no interior desta estrutura. O contexto da legislação educacional brasileira recente fornece material também para o exame desta questão. Saviani traz como exemplo o modo de gestão educacional instituído com a Lei n. 5.692/1971, que foi ao mesmo tempo transformado e preservado pelos governos da Nova República, até a promulgação da nova Lei de Diretrizes e Bases da Educação Nacional (Lei n. 9.394/1996). Diz o autor que este processo desorganizou a rede escolar ainda mais,

passando da gestão tecnocrática, própria do período autoritário do regime militar, para o extremo oposto, da fragmentação e do descontrole, em nome da descentralização, mantendo-se, porém, os mecanismos autoritários pelos quais se impunha a nova situação (ibidem, p. 122).

Em suma, as questões organizacionais, como demonstra nossa própria história educacional recente, são um elo fundamental para a transformação do ensino. Ao mesmo tempo, elas colocam para a Pedagogia Histórico-Crítica um duplo desafio:

de um lado, elas dificultam o avanço da teoria, dados os limites que esse tipo de organização institucional impõe; de outro lado, colocam também o desafio de nós mexermos nisso, de modificarmos essas formas, e ao apresentarmos propostas não apenas pensarmos nas concepções, mas também nas alterações organizacionais exigidas pela nova proposta teórica (ibidem, p. 125).

A descontinuidade é último problema, relacionado à materialidade da ação educacional, exposto por Saviani, que enfatiza inicialmente a importância de seu antônimo, a continuidade, no processo da educação:

O trabalho educativo tem que se desenvolver num tempo suficiente para que as habilidades, os conceitos que se pretende sejam assimilados pelos alunos, de fato, se convertam numa espécie de segunda natureza. Ora, isso exige tempo. A continuidade é, pois, uma característica própria da educação (ibidem, p. 126-127). 
A necessidade dos processos educacionais serem contínuos e prolongados no tempo é explicada recorrendo-se aos chamados automatismos: "é preciso fixar certos automatismos, incorporá-los, isto é, torná-los parte de nosso corpo, de nosso organismo, integrá-los em nosso próprio ser" (ibidem, p. 20). Por exemplo, mesmo a alfabetização envolve esta "automatização", no sentido de que o alfabetizando "vai se libertando dos aspectos mecânicos, [e] progressivamente, [vai] concentrando cada vez mais sua atenção no conteúdo, isto é, no significado daquilo que é lido ou escrito" (ibidem, loc. cit.). Assim

me parece essencial considerar que esse elemento de continuidade, de um tempo necessário para se fixar as habilidades básicas, é algo que deve ser inscrito como condição preliminar indispensável na organização dos sistemas de ensino e na forma como o trabalho pedagógico deve ser conduzido no interior da escola (ibidem, p. 128).

Saviani aborda ainda a questão da continuidade/descontinuidade quanto às políticas públicas educacionais, algo que não está distante do aspecto acima mencionado, já que há uma série de políticas cujos reflexos sobre os acontecimentos em sala de aula são imediatos:

O problema apresenta-se aí com um grau tal que inviabiliza qualquer avanço no campo da educação. Parece que cada governo, cada secretário de educação ou cada ministro quer imprimir sua própria marca, deixando de lado os programas implementados nas gestões anteriores. Com esse grau de descontinuidade, não há como fazer frente às questões especificamente educacionais, dado que, como se mostrou, trata-se de um tipo de atividade que requer continuidade. Portanto, a política educacional precisa levar em conta essa peculiaridade e formular metas não apenas a curto mas a médio e longo prazo e instituir propostas que possam, de fato, ser implementadas e avaliadas no seu processo e nos seus resultados, sendo corrigidas, se for o caso, mas que tenham sequiência, e que permitam criar situações irreversíveis de tal modo que as mudanças de governo não desmantelem aquilo que está sendo construído (ibidem, p. 128-129).

Exposto o entendimento do que seria a materialidade da ação educacional por parte da Pedagogia Histórico-Crítica, cabe situar o laboratório escolar neste contexto. Isto é, buscaremos demonstrar como este referencial proporciona as categorias através das quais iremos examinar a realidade do município de São Carlos, considerando a presença (ou a ausência) de laboratórios didáticos nas instituições públicas para o ensino médio.

A materialidade da ação educacional, como vimos, é atravessada por três problemas.

O primeiro diz respeito à questão da educação se apresentar como uma estrutura ou um sistema. O próprio ato de investigar os espaços escolares, a nosso entender, se coloca como uma contribuição para o desfecho deste problema. Afinal, o primeiro dos requisitos para a formação de um sistema educacional é a tomada de consciência da situação (estrutura) 
educacional. Então, levantar a situação dos laboratórios, nos parece, é um esforço somado neste sentido. Com relação às três condições básicas para a construção de um sistema educacional - consciência dos problemas da situação, conhecimento da realidade (as estruturas) e formulação de uma pedagogia -, este empreendimento de pesquisa está em explícita sinergia com elas. Esperamos que o leitor capte cada vez mais claramente esta relação à medida que prosseguir pelo texto.

O segundo problema se relaciona à estrutura organizacional da educação. Lembremos que, quanto a isto, tomamos como verdadeiro que as pedagogias imprimem marcas materiais sobre o aspecto físico das escolas. Acontece que, historicamente, as reformas educacionais vêm sendo realizadas sem um adequado conhecimento da realidade educacional em sua concretude. Quando a legislação educacional incorpora um novo ideário pedagógico, não há e não pode haver uma imediata transformação da prática pedagógica sem que tenha havido alterações estruturais, isto é, mudanças nas condições concretas, objetivas desta prática. Não foi por acaso que, em uma fala de Saviani, que transcrevemos, grifamos a expressão "resistência material"; estamos falando, aqui, exatamente desta espécie de "inércia". Assim, buscaremos investigar de que forma as marcas materiais cristalizam certos ideários pedagógicos, no espaço dos laboratórios escolares. Onde estarão estas marcas? A própria presença ou a ausência de um laboratório científico, em um dado estabelecimento, se constitui como um destes indicadores. Havendo o laboratório, sua organização e seu funcionamento fornecerão dados a respeito de outros destes sinais, donde poderemos fazer novas inferências.

Num outro sentido, argumentaremos que o aspecto material relacionado à gestão da instituição escolar também exercerá uma notável influência sobre o modo como se apresenta o laboratório de ciências. O modelo de gestão escolar atualmente adotado no Brasil é baseado em determinadas obrigações e em disposições hierárquicas. Mostraremos que estes elementos podem exercer uma forte pressão para o estabelecimento de certas práticas educacionais, e o laboratório não escapará a esta determinação.

Finalmente, há o problema da descontinuidade. Aqui, será possível discorrer sobre os mecanismos através dos quais a ocorrência contínua, prolongada de certas práticas de sala de aula pode gerar alterações irreversíveis na prática educacional de um modo geral, tomando como exemplos alguns fatos em nosso município. Também será possível analisar políticas e iniciativas, dirigidas ao laboratório escolar de ciências, em termos dos conceitos de continuidade/descontinuidade, e os fatores intervenientes em seu sucesso, quando for o caso. 


\subsection{METODOLOGIA DA PESQUISA}

Nesta seção descrevemos o "mergulho na materialidade" realizado por esta pesquisa. Primeiramente, apresentamos os pressupostos teórico-metodológicos que orientaram a coleta de dados e, a seguir, descrevemos os procedimentos empregados nesta coleta.

Antes de tudo, lembremos que nosso referencial teórico foi intitulado como "críticodialético", cabendo-lhe também outros adjetivos, como objetivista, histórico e materialista. Poderíamos estruturar a metodologia de nossa investigação também de acordo com estas qualidades?

Para Gamboa (2004), a resposta é sim. Numa análise epistemológica das teses e dissertações produzidas em cursos de pós-graduação em Educação no Estado de São Paulo, realizada nas décadas finais do século passado, o autor identificou, inclusive, este viés críticodialético em crescimento, diante de outras duas abordagens mais recorrentes, a empíricoanalítica (hegemônica) e a fenomenológico-hermenêutica. Segundo o pesquisador,

As pesquisas dialéticas se fundamentam na lógica interna do processo e nos métodos que explicitam a dinâmica e as contradições internas dos fenômenos e explicam as relações entre homem-natureza, entre reflexão-ação e entre teoria-prática (ibidem, p. 98).

A “ação" é concebida como uma categoria epistemológica fundamental, assim como a "concreticidade", que reflete a ascensão da síncrese à síntese pela mediação da análise, quando o concreto pensado é confrontado com seu ponto de partida, o empírico, através da prática. "Nas pesquisas dialéticas, o homem é tido como ser social e histórico; embora determinado por contextos econômicos, políticos e culturais, é o criador da realidade social e o transformador desses contextos" (ibidem, p. 103).

Frigotto (2004) concorda:

No processo dialético de conhecimento da realidade, o que importa fundamentalmente não é a crítica pela crítica, o conhecimento pelo conhecimento, mas a crítica e o conhecimento crítico para uma prática que altere e transforme a realidade anterior no plano do conhecimento e no plano histórico-social. [...] A reflexão teórica sobre a realidade não é uma reflexão diletante, mas uma reflexão em função da ação para transformar (ibidem, p. 81).

Ao contrário das abordagens metafísicas - sejam elas "empiricistas, positivistas, idealistas, ecléticas e estruturalistas" (ibidem, p. 74), vieses que abrangem aquelas pesquisas empírico- 
analíticas e fenomenológico-hermenêuticas que mencionamos há pouco - , a abordagem dialética, sabendo que sua busca é pela "coisa em si", pela essência dos fenômenos que toma como objeto de estudo, busca realizar a distinção entre o fundamental e o secundário, o necessário e o fortuito. No entanto, concebendo que a consciência é reflexo da realidade material que lhe antecede ontologicamente, esta abordagem precisa se atentar para não "confundir o movimento do real com suas contradições, conflitos, antagonismos, com o movimento do pensamento no esforço de apreender esse movimento da forma mais completa possível" (ibidem, p. 80). Este reflexo, esta "apreensão subjetiva da realidade objetiva" (ibidem, p. 75), é mobilizado, numa investigação dialética, a compreender as leis e forças reais e históricas que determinam os fenômenos sociais; busca atingir o caráter histórico dos objetos investigados, seu processo de modificação, desenvolvimento, de "transição de uma forma a outra, de uma ordem de relações a outra" (MARX, 1983 apud FRIGOTTO, 2004, p. 79). Mais categorias fundamentais, para a pesquisa dialética, podem ser então elencadas: “totalidade, contradição, mediação, ideologia, práxis etc.” (ibidem, p. 76).

Sanfelice (2008), falando sobre o mesmo assunto, lembra que, para Lênin, a dialética é "um processo de complexos nos quais as coisas e os seus reflexos intelectuais em nossos cérebros, os conceitos, estão em mudanças contínuas e ininterruptas de devir. E é essa a razão pela qual a dialética marxista não está reduzida à lógica e nem a um método de investigação" (p. 76). O autor cita também Lefebvre, em Lógica formal/lógica dialética (obra a que já recorremos nesta tese), para quem só há dialética se houver movimento, e só há movimento se existir processo histórico. Sanfelice acrescenta, ainda, que

\begin{abstract}
pesquisas orientadas pela dialética, em seu sentido amplo, buscam contemplar o melhor possível uma análise objetiva da realidade estudada, após explorá-la exaustivamente. Tenta-se apreender o conjunto das conexões internas da coisa e isso é possível com o auxílio de muitos procedimentos científicos disponíveis. Não menos importante é a apreensão dos aspectos e dos momentos contraditórios internos, pois o objeto é tomado como totalidade e como unidade de contrários. Torna-se um desafio captar o conflito, o movimento, a tendência predominante da sua transformação (ibidem, p. 85).
\end{abstract}

Tanto para Sanfelice quanto para Frigotto, a dialética materialista, assim concebida, se apresenta simultaneamente como postura, método e práxis.

Geraldo (2009, p. 51-54) apresenta uma pequena listagem de "regras gerais" para a investigação dialética, que toma em consideração estes aspectos e, portanto, merece ser apresentada por nós, ainda que de forma resumida/adaptada: 
a) Apreender o real em sua historicidade, em sua evolução;

b) Apreender a realidade como totalidade;

c) Apreender as relações do real (interações das partes entre si e das partes com o todo contextual);

d) Apreender as contradições da realidade em estudo;

e) Determinar as condições próximas e longínquas de um fato, discernindo entre as mais e menos essenciais, sem descurar dos acasos e de suas somas;

f) Não se esquecer que o processo de conhecimento nunca se dá por satisfeito, é infinito;

g) Tomar o empírico como ponto de partida, torná-lo abstrato mediante a análise, e elevá-lo ao concreto mediante a síntese;

h) Delimitar e elucidar as relações reiterativas, ou seja, as repetições e regularidades que podem estruturar leis de conservação/transformação dos fenômenos.

Estes autores, também, nos autorizam a eleger a materialidade como ponto de partida para qualquer investigação que se pretenda dialética. Frigotto fala em um "levantamento do material da realidade que se está investigando" (2004, p. 88) e Sanfelice cita Mao Tsé-Tung, que afirmou "que sempre que se faz alguma coisa, é impossível conhecer as leis que a regem, saber como realizá-la e levá-la a bom fim, se não se lhe compreendem as condições, o caráter e os laços com as outras coisas", sob o risco de se "cair no idealismo e na metafísica" (TSÉTUNG, 1972 apud SANFELICE, 2008, p. 83).

Se o laboratório é, no espaço escolar, a localidade mais específica para o ensino das disciplinas científicas - argumento que o capítulo anterior tratou de desenvolver, especialmente no momento em que trouxe em relevo a importância da atividade com instrumentos científicos para a aprendizagem dos conteúdos associados a eles -, então é a materialidade deste espaço que nos será interessante para a compreensão do processo de educação em ciências. E é assim que fomos atirados ao estudo das condições materiais dos laboratórios didáticos de ciências das escolas públicas de São Carlos.

Falemos, portanto, do modo como realizamos este estudo, considerando especificamente o processo de coleta de dados.

Como adeptos de um referencial teórico materialista, obviamente nosso referencial metodológico deveria se mostrar igualmente seguro do primado do mundo material sobre a consciência. Assim, o motivo da escolha pela modalidade qualitativa, para investigar o 
presente objeto de estudo, partiu das próprias imposições deste objeto. Expliquemos: de antemão, o número reduzido de escolas em nosso município (ao todo, 17 estabelecimentos públicos com o oferecimento do ensino médio) já seria um obstáculo a generalizações de cunho quantitativo. Por outro lado, optando pela modalidade qualitativa, o caminho estaria aberto para o estudo em profundidade, o que julgamos necessário para a consolidação de um corpus de dados maior e mais fidedigno à realidade.

Portanto, consciente e explicitamente, subordinamos a abordagem às questões e ao objeto de pesquisa, o que é defendido, por exemplo, por Laville e Dionne (1999):

A partir do momento em que a pesquisa centra-se em um problema específico, é em virtude desse problema específico que o pesquisador escolherá o procedimento mais apto, segundo ele, para chegar à compreensão visada. Poderá ser um procedimento quantitativo, qualitativo, ou uma mistura de ambos. O essencial permanecerá: que a escolha da abordagem esteja a serviço do objeto de pesquisa, e não o contrário, com o objetivo de daí tirar, o melhor possível, os saberes desejados (p. 43).

Bogdan e Biklen (1994) resumem as características da pesquisa qualitativa:

1. Na investigação qualitativa a fonte direta de dados é o ambiente natural, constituindo o investigador o instrumento principal.

2. A investigação qualitativa é descritiva.

3. Os investigadores qualitativos interessam-se mais pelo processo do que simplesmente pelos resultados ou produtos.

4. Os investigadores qualitativos tendem a analisar os dados de forma indutiva.

5. O significado é de importância vital na abordagem qualitativa.

Enquanto pesquisa educacional, de modalidade qualitativa, consideramos ainda que esta investigação se trata de um estudo de caso. De acordo com Lüdke e André (1988),

1. O estudo de caso visa à descoberta;

2. Enfatiza a interpretação em contexto;

3. Busca retratar a realidade de forma completa e profunda;

4. Utiliza várias fontes de informação;

5. Revela experiência vicária e permite generalizações naturalísticas;

6. Procura representar diferentes e às vezes conflitantes pontos de vista presentes na situação em estudo.

Citando Bassey (2003), André (2005) apresenta uma pequena listagem de características dos estudos de caso educacionais, a qual será útil para esclarecermos em que sentido a presente investigação empírica se insere nesta modalidade: 
- São conduzidos dentro de limites localizados no tempo e no espaço (singularidades): este estudo tratou das escolas situadas no município de São Carlos, no tempo presente. A pesquisa abrangeu a totalidade das escolas públicas que oferecem o ensino médio em nosso município, ao todo 17 escolas. Suas conclusões, portanto, poderão ser confrontadas, através das "experiências vicárias e generalizações naturalísticas”, com o contexto de outros municípios, no todo mais amplo do Estado de São Paulo e, porque não, do Brasil.

- Versam sobre aspectos interessantes de uma atividade educacional, programa, instituição ou sistema: a atividade educacional "interessante" será a prática da educação científica no ensino escolar. Ao mesmo tempo, espera-se que o caso ilumine aspectos das instituições analisadas e do próprio sistema educacional que engendra estas instituições, se é que ele se constitui como sistema.

- Realiza-se num contexto natural e dentro de uma ética de respeito às pessoas: o trabalho busca retratar um contexto sem julgamento de valores quanto às posturas de indivíduos específicos (como professores e gestores educacionais), e respeitando suas vontades quanto ao desenvolvimento da pesquisa, principalmente nas etapas de coleta de dados e divulgação dos resultados ${ }^{66}$.

- Pode subsidiar julgamento e decisões de práticos ou de gestores de políticas: conclusões desta investigação podem orientar olhares e ações de outros sujeitos, como os participantes do fenômeno educacional nas escolas deste e de outros municípios; gestores de políticas nas esferas municipal, estadual e federal; e investigadores que desejem aprofundar questões aqui tangenciadas.

- Pode subsidiar o trabalho de teóricos: o momento prático desta investigação possibilita o avanço das teorias que lhe dão suporte. Em outras palavras, esta investigação dá partida ao movimento dialético que considera a prática como fundamento, critério de verdade e finalidade da teoria.

- Proporciona a coleta de dados suficientes para: a) explorar aspectos significativos do caso; b) criar interpretações plausíveis do foi obtido; c) testar a confiabilidade das interpretações; d) construir uma narrativa que tenha valor; e) relacionar a narrativa às pesquisas relevantes na literatura; f) comunicar, de forma convincente, esta narrativa; g) fornecer pistas para que

\footnotetext{
${ }^{66}$ Os sujeitos, representando as instituições a que estão vinculados, concordaram em participar da pesquisa assinando um termo de consentimento. $\mathrm{O}$ termo e os materiais relativos à coleta de dados (cartas aos diretores de escolas, guia de observações, questionário e transcrição de entrevistas), seguem nos “Anexos” desta tese.
} 
outros pesquisadores possam validar ou contestar os resultados aqui obtidos, ou interpretá-los alternativamente. Estes aspectos serão desenvolvidos conforme se apresentem os resultados.

Quanto à coleta de dados, foram empregados os seguintes procedimentos:

a) Contato prévio com as escolas por telefone: telefonamos à Diretoria de Ensino - Região São Carlos, solicitando uma listagem das escolas públicas localizadas no município, com informações sobre os níveis de ensino oferecidos, os nomes dos respectivos diretores e os números de telefone e endereços dos estabelecimentos. Obtida a listagem, para cada uma das 17 escolas públicas que oferecem o ensino médio em São Carlos encaminhamos uma carta a seu diretor ou diretora, apresentando e justificando a investigação e solicitando colaboração para a coleta de dados. Um dos diretores retornou, poucos dias depois, informando que sua escola não dispunha de laboratório escolar. Telefonamos às 16 escolas restantes, conversando com o diretor ou vice-diretor de cada uma. Mais oito gestores informaram que suas escolas não dispunham de laboratório de ciências; com os oito gestores restantes, agendamos visitas, que ocorreram durante o mês de fevereiro de 2012.

b) Observações estruturadas: com um guia de observações, realizamos um pequeno inventário dos itens que compunham os laboratórios visitados.

c) Fotografias: em seis das oito escolas visitadas obtivemos autorização para fotografar e divulgar as fotografias dos laboratórios. Em uma das escolas obtivemos autorização apenas para fotografar. Foram tiradas, em média, cerca de dez fotografias de cada laboratório. A quantidade variava em função das condições dos espaços. Por exemplo, naqueles em que os armários estavam destrancados, acrescentamos fotos de seus conteúdos.

d) Notas de campo: imediatamente à visita a cada um dos oito estabelecimentos, redigimos notas de campo, com descrições e impressões sobre as realidades examinadas. Aproveitamos para registrar também os conteúdos dos diálogos travados com os gestores e funcionários que nos conduziram aos laboratórios. Em uma das escolas a diretora sugeriu que conversássemos também com uma das professoras efetivas de ciências. Consideramos esta conversa, realizada ainda durante a visita à escola, como uma "entrevista improvisada". As notas tomadas durante este diálogo foram incorporadas às notas de campo. 
e) Entrevistas semi-estruturadas: três das oito escolas visitadas haviam desenvolvido projetos relacionados a seus laboratórios, no passado, em parcerias com as universidades públicas de São Carlos (USP e UFSCar). Para melhor compreender estas iniciativas, e assim dispor de um conhecimento mais aprofundado sobre o laboratório didático de ciências em São Carlos, entramos em contato com os coordenadores dos dois projetos desenvolvidos com as três escolas. Agendamos a realização de uma entrevista com cada um dos pesquisadores; elas ocorreram nos dias finais de fevereiro de 2012, em locais escolhidos pelos sujeitos. As entrevistas seguiram um guia de questões, complementadas por perguntas de esclarecimento e aprofundamento. O áudio, em cada situação, foi gravado e transcrito.

f) Análise documental: obtivemos acesso a documentos referentes a um dos projetos supracitados, aquele que envolveu duas escolas. Estes documentos complementaram as informações fornecidas na entrevista com seu coordenador. Um dos laboratórios visitados, devido a seu caráter histórico, fora mencionado em alguns documentos historiográficos disponíveis nos acervos municipais. Consideramos um destes documentos, na forma de um livro sobre a escola em questão, como fonte complementar de dados. Não faremos referência à obra para não expor o nome do estabelecimento, pois como fora acordado, com os gestores das escolas visitadas, elas não seriam identificadas na divulgação dos resultados.

Sistematizamos no quadro da Figura 14 os materiais que foram obtidos nesta coleta de dados, apresentando as unidades de codificação a que recorreremos para fazer referência a eles, na próxima seção.

\begin{tabular}{|c|c|c|c|c|c|c|c|c|}
\hline \multirow{2}{*}{ Item } & \multicolumn{8}{|c|}{ Escolas* } \\
\hline & $\mathrm{A}$ & $\mathrm{B}$ & $\mathrm{C}$ & $\mathrm{D}$ & $\mathrm{E}$ & $\mathrm{F}$ & $\mathrm{G}$ & $\mathrm{H}$ \\
\hline Guia de obs. & g-A & g-B & g-C & g-D & g-E & $\mathrm{g}-\mathrm{F}$ & g-G & g-H \\
\hline Fotografias & $\begin{array}{c}\text { f-A1 a f- } \\
\text { A12 }\end{array}$ & $\begin{array}{c}\text { f-B1 a f- } \\
\text { B10 }\end{array}$ & $\begin{array}{c}\mathrm{f}-\mathrm{C} 1 \mathrm{a} f- \\
\mathrm{C} 12\end{array}$ & $\begin{array}{c}\text { f-D1 a f- } \\
\text { D24 }\end{array}$ & $\begin{array}{c}\text { f-E1 a f- } \\
\text { E5 }\end{array}$ & $\begin{array}{c}\text { f-F1 e f- } \\
\text { F2 }\end{array}$ & N/D & $\mathrm{N} / \mathrm{R}$ \\
\hline Notas de campo & nc-A & nc-B & nc-C & nc-D & nc-E & nc-F & nc-G & nc-H \\
\hline $\begin{array}{c}\text { Entrevistas - } \\
\text { coord. de } \\
\text { projetos }\end{array}$ & \multicolumn{2}{|c|}{ e1 } & e2 & - & - & - & - & - \\
\hline Documentos & \multicolumn{2}{|c|}{ projetos/relatórios } & - & $\begin{array}{l}\text { registro } \\
\text { histórico }\end{array}$ & - & - & - & - \\
\hline
\end{tabular}

Figura 14: quadro-síntese dos materiais obtidos com a coleta de dados, com exposição dos códigos adotados para identificá-los. (* Apenas as oito escolas que dispunham de laboratório receberam codificação com letras de

A a H; N/D: unidade cuja divulgação não foi autorizada; N/R: unidade cujo registro não foi autorizado). 


\subsection{RESULTADOS E DISCUSSÕES}

Nesta seção, expomos os resultados da investigação realizada, analisando-os conforme as categorias decorrentes da exposição teórica nas seções anteriores.

Antes, apresentamos uma caracterização geral dos laboratórios, conforme a análise dos guias de observação. Os dados estão sumarizados nos quadros das Figuras 15 e 16.

\begin{tabular}{|c|c|c|c|c|c|c|c|c|}
\hline \multirow{2}{*}{ Itens } & \multicolumn{7}{|c|}{ Escolas } \\
\hline & $\mathrm{A}$ & $\mathrm{B}$ & $\mathrm{C}$ & $\mathrm{D}$ & $\mathrm{E}$ & $\mathrm{F}$ & $\mathrm{G}$ & $\mathrm{H}$ \\
\hline bancadas & & & & & & & & \\
\hline torneiras & & & & & & & & \\
\hline armários & & & & & & & & \\
\hline instrumentos de medida & & & & & & & & \\
\hline vidrarias & & & & & & & & \\
\hline reagentes & & & & & & & & \\
\hline materiais em exposição & & & & & & & & \\
\hline microscópio óptico & & & & & & $\mathrm{X}$ & & \\
\hline eletricidade & & & & & & $\mathrm{X}$ & & \\
\hline balança & & & & & & & $\mathrm{X}$ & \\
\hline gás & & & & & $\mathrm{X}$ & & $\mathrm{X}$ & \\
\hline material para higiene & & $\mathrm{X}$ & $\mathrm{X}$ & & $\mathrm{X}$ & & & \\
\hline itens de segurança & & $\mathrm{X}$ & $\mathrm{X}$ & & $\mathrm{X}$ & & $\mathrm{X}$ & \\
\hline pôsteres & $\mathrm{X}$ & & $\mathrm{X}$ & $\mathrm{X}$ & & & & $\mathrm{X}$ \\
\hline refrigerador & & & $\mathrm{X}$ & $\mathrm{X}$ & $\mathrm{X}$ & $\mathrm{X}$ & $\mathrm{X}$ & $\mathrm{X}$ \\
\hline relógio & $\mathrm{X}$ & $\mathrm{X}$ & $\mathrm{X}$ & $\mathrm{X}$ & $\mathrm{X}$ & $\mathrm{X}$ & $\mathrm{X}$ & $\mathrm{X}$ \\
\hline outros itens & & & & & & & & \\
\hline total de itens presentes & 15 & 14 & 12 & 14 & 12 & 13 & 12 & 14 \\
\hline itens inferidos & - & 1 & 2 & - & - & 1 & 3 & 1 \\
\hline
\end{tabular}

Figura 15: quadro-síntese dos guias de observação dos laboratórios escolares de São Carlos, apresentando os itens presentes (células hachuradas) e ausentes (x) em cada escola visitada.

\begin{tabular}{|l|c|}
\hline Observações sobre os itens & Quantidade de escolas \\
\hline Principais itens ausentes \\
\hline itens de segurança & 4 (B, F, E e G) \\
\hline pôsteres & $4(\mathrm{~A}, \mathrm{C}, \mathrm{D}$ e H) \\
\hline refrigerador & $6(\mathrm{C}, \mathrm{D}, \mathrm{E}, \mathrm{F}, \mathrm{G}$ e H) \\
\hline relógio & 8 (todas) \\
\hline Outros itens observados (ausentes no guia) \\
\hline quadro negro & 7 (exceto $\mathrm{H})$ \\
\hline multimídia & 7 (exceto $\mathrm{G})$ \\
\hline estufa & $4(\mathrm{~A}, \mathrm{~B}, \mathrm{C}$ e D) \\
\hline capela & $4(\mathrm{~A}, \mathrm{~B}, \mathrm{C}$ e D) \\
\hline
\end{tabular}

Figura 16: detalhamento de itens ausentes e de outros itens presentes nos laboratórios escolares de São Carlos, mas não contemplados no guia de observações. 
Dos 17 itens presentes no guia de observações, todas as escolas contemplaram a maioria deles. Mesmo as que registraram maior número de ausências conseguiram ainda apresentar 12 itens.

$\mathrm{O}$ item instrumentos de medida (que incluía pequenos instrumentos portáteis, como termômetros e cronômetros) não foi observado em cinco escolas, mas sua presença foi inferida, pois poderiam estar guardados nos armários trancados. Os servidores que nos guiaram até os laboratórios e acompanharam as observações, nestas situações, eram também consultados e dirimiram algumas dúvidas. Outros itens cuja presença foi assim inferida, em alguns dos laboratórios, foram vidrarias, reagentes e balança.

Os itens menos contemplados foram itens de segurança (extintores, lava-olhos, kit de primeiros socorros, alocação de botijões de gás em local à parte do laboratório etc.) e pôsteres (tabelas periódicas, diagramas, tabela de conversão de unidades etc.), cada um ausente em quatro escolas. O refrigerador esteve presente em apenas dois laboratórios. Nenhum deles dispunha de um relógio de parede.

Alguns itens foram recorrentes nos laboratórios, mas não estavam previstos no guia de observações. Os itens quadro negro e multimídia (abrangendo televisão, videocassete, DVD, projetor, computador etc.) estiveram presentes em sete dos oito laboratórios visitados. Quatro escolas possuíam estufa e capela em seus laboratórios.

Não foi possível observar, no entanto, o estado de todos os itens constantes no guia, pela curta duração das visitas, já que não desejávamos interferir negativamente nas atividades escolares. Mesmo assim, algumas observações gerais podem ser feitas:

- A maior parte dos laboratórios dispõe de microscópio óptico, mas não há exemplares suficientes para a realização de aulas práticas em duplas de alunos, supondo classes com cerca de 30 estudantes. Os grupos teriam que ser maiores. A escola com maior quantidade de microscópios (Escola D) possui sete deles. $\mathrm{Na}$ Escola B, há pelo menos seis exemplares, mas eles aguardam manutenção.

- Também em muitos dos laboratórios, as vidrarias e os materiais para exposição pareciam não ser usados há muito tempo (como no exemplo da Figura 17). De fato, em apenas três laboratórios houve o relato de uso constante no ano de 2011, sediando uma aula por semana ou mais. Nos outros, a média de uso permaneceu entre uma vez por bimestre e uma vez por mês, para cada turma de cursos de ciências. Dois laboratórios, à época da pesquisa, aguardavam reformas e por isso não vinham sendo utilizados. Especificamente quanto aos 
materiais para exposição, em grande parte dos laboratórios eles não estavam expostos, mas guardados em armários, como medida de segurança contra furtos e danos (Figura 18).

- Embora todos os laboratórios dispusessem de reagentes químicos, nenhum apresentou estrutura adequada para o descarte dos materiais. Em três escolas visitadas, inclusive, fomos perguntados pelos gestores sobre nosso conhecimento a respeito de possibilidades de destinação correta dos materiais com prazo de validade esgotado.

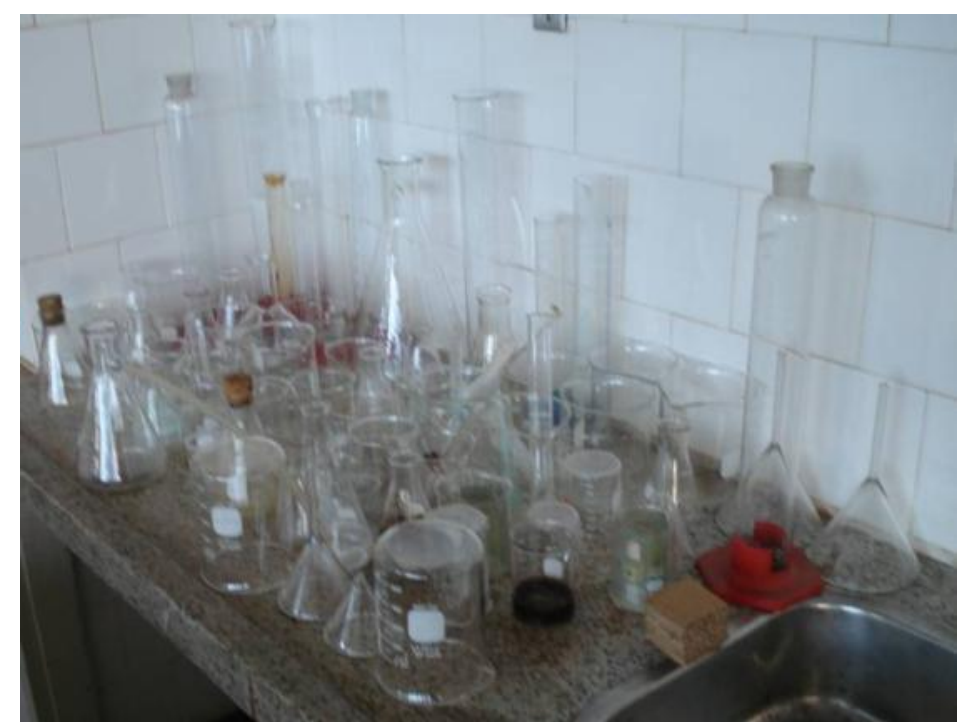

Figura 17: vidrarias com indicações de uso infrequente, fora dos armários e contendo restos de reagentes (fA12).

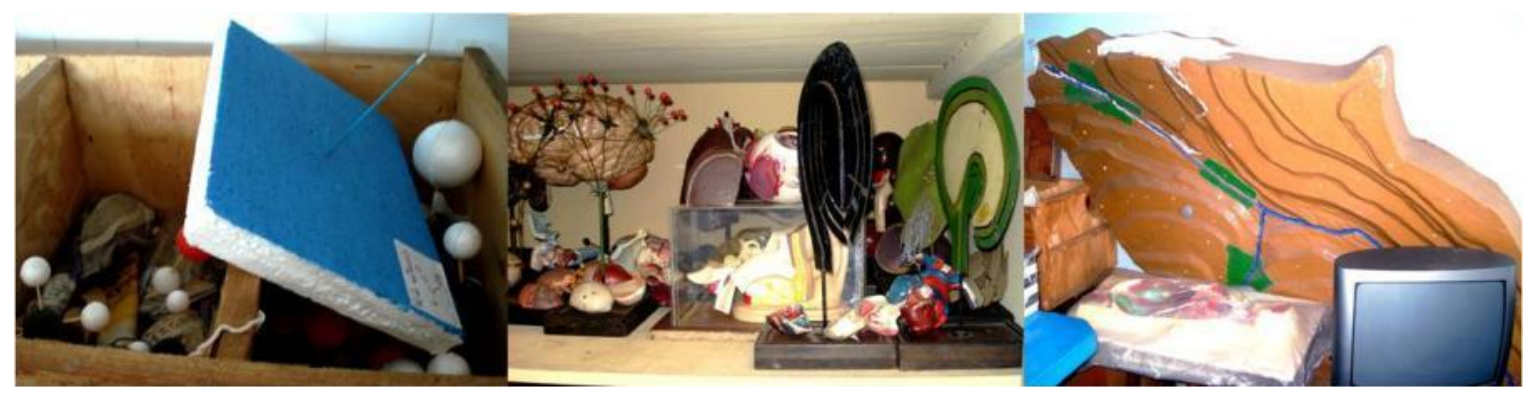

Figura 18: mosaico com fotos de materiais para exposição de diversas disciplinas, mas não expostos (f-A8, $\mathrm{f}$ D1, f-B4).

Daqui em diante, adotaremos um tom mais crítico e menos descritivo para lidar com os dados. Isso ocorrerá no interior de três subseções: “O laboratório entre especificidades”, “A questão da (des)continuidade e da estrutura organizacional da educação" e "A necessidade de um sistema de ensino", desenvolvidas nesta ordem. 


\subsubsection{O laboratório entre especificidades}

No decurso de nossa exposição sobre a Pedagogia Histórico-Crítica, uma das categorias enfatizadas foi a especificidade da educação enquanto transmissora dos conteúdos culturais. O cumprimento desta função especificamente formativa é que garantiria o exercício de sua função política, isto é, prover as classes dominadas com instrumentos que ajudariam a implodir a relação de dominação que as classes proprietárias do capital e, portanto, do poder político, estabelecem com elas. Permitindo a apropriação, pela massa proletária, da cultura elaborada, a educação estaria posta a serviço da revolução que destituiria a propriedade dos meios de produção por parte daquela classe minoritária, os capitalistas.

Apesar da investigação sobre os laboratórios científicos escolares de São Carlos ter se concentrado no ensino público, cuja função deveria ser justamente a elevação do nível cultural das classes menos favorecidas, este aspecto quase não pôde ser observado em suas manifestações objetivas. Esta não realização da especificidade educativa dos laboratórios escolares levou a que considerássemos a categoria "especificidade" de modo mais amplo, recorrendo à sua mediação para a análise do problema em questão.

Num primeiro momento, entendemos haver uma especificidade do laboratório de ciências enquanto espaço para o desenvolvimento dos conteúdos curriculares científicos: neste lugar, com sua determinada configuração em bancadas, sua necessidade de canalização de água e gás combustível, seu arsenal de equipamentos, seria possível desenvolver o estudo da ciência com a íntima associação entre teoria e prática. Leontiev afirma ser característico da sociedade de classes, e resultado da divisão social do trabalho, a dissociação entre atividade prática e atividade intelectual, e diz ainda que

A penetração na consciência destas relações traduz-se psicologicamente pela "desintegração" da sua estrutura geral que caracteriza o aparecimento de uma relação de alienação entre os sentidos e as significações, nas quais o seu mundo e a sua própria vida se refractam para o homem (1978, p. 126).

Assim, estabelecemos como hipótese que o laboratório cumpre esta função integrativa, superficialmente apenas psicológica, mas essencialmente política, na medida em que o exercício de sua função pedagógica é garantido, primeiramente, na forma material. A materialidade do laboratório é representada, entre outros aspectos, pelos itens e instrumentos que ele abriga, daí a importância da caracterização dos espaços visitados nesta pesquisa 
através do guia de observações. Essa materialidade do instrumento, por sua vez, encarna um saber historicamente acumulado, como fizemos questão de ressaltar na parte final do capítulo passado.

Se em 17 escolas públicas de São Carlos apenas 8 possuem laboratório de ciências, sendo que nestas a metade não possui estufa e capela, 6 não possuem refrigerador, só 2 certamente abrigam mais de meia dúzia de microscópios; então consideramos que diversas operações práticas fixadas nestes instrumentos, e seus conceitos científicos correspondentes, têm sua apropriação pelos estudantes um tanto dificultada, senão impossibilitada. A existência física dos itens, por outro lado, também não é suficiente, pois exibimos nas Figuras 17 e 18 alguns materiais que não estão em condições plenas de operação.

A "corrupção" da especificidade do laboratório escolar de ciências aparece manifesta também em outros aspectos. Um fenômeno muito verificado em nossas visitas foi a constituição dos laboratórios em espaços que muito forçosamente poderiam ser considerados apropriados para este tipo de função. Em outras palavras, estes laboratórios estavam montados em salas de aulas comuns, "adaptadas" ou "improvisadas" para o trabalho prático em aulas de ciências. Os coordenadores de projetos que entrevistamos, ao tratarem da estrutura física dos laboratórios de ciências, mencionaram este aspecto:

a primeira coisa que eu quis fazer lá na Escola $C^{67}$ foi colocar a sala que era chamada de laboratório em condições operacionais (e2).

Se você perguntar nas escolas se elas têm laboratório, a maior parte fala que tem. Isso no Brasil todo. "Não, tem laboratório". Só que você vai ver o laboratório, o que eles estão chamando de laboratório não é laboratório. Quando muito tem uma bancadinha, meia dúzia de vidro jogado num canto e muita carteira quebrada, mesa quebrada, caixa de papelão que você não sabe pra quê que serve, enfim. É um depósito, né. Eles falam "aqui é o laboratório". É... Então essas duas escolas [que sediaram um dos projetos desenvolvidos com as universidades] tinham coisa parecida e chamavam de laboratório. Na verdade, não era laboratório. Aí eu senti a necessidade de fazer a reforma completa de tudo, inclusive mudanças do espaço físico para um espaço adequado, enfim. Nas duas, era uma pequena sala, muito pequena, que eles chamavam de laboratório. Então nós organizamos um amplo local, que era um ambiente maior, fazendo toda a reforma, construção de bancadas... equipamos. Então... é... eu comprei na época todo o equipamento pra Química, vidraria, tinha reagente, geladeira, enfim... agitador e manta de aquecimento, eu já nem lembro mais, mas enfim... muito e muito tempo faz... E material pra aula de Física e Biologia. Então pra Biologia também tinha microscópio, um monte de coisa... (e1).

\footnotetext{
${ }^{67}$ Nas transcrições das entrevistas e dos outros materiais, substituí as marcas que poderiam identificar as escolas mencionadas pela codificação que adotei e que expus na Figura 14. Ainda, todo e qualquer depoimento registrado em entrevista ou nota de campo, ao longo de toda a tese, será identificado por fonte em itálico.
} 
As visitas nos permitiram atribuir a qualidade de laboratório "de fato" apenas aos espaços das escolas A, B e D, embora as escolas F e $\mathrm{G}$ dispusessem de ambientes com potencial (não por acaso, são as escolas com reformas dos laboratórios previstas à época da pesquisa). As escolas A e B são aquelas que sediaram um mesmo projeto de parceria com a universidade, e a Escola D se trata de um prédio histórico, que inclusive possui um laboratório para cada disciplina de ciências do currículo do ensino médio (Física, Química e Biologia). No entanto, mesmo a Escola A, com um espaço devidamente disposto para o exercício do ensino de ciências, pareceu contradizer este aspecto, conforme relatamos nas notas de campo:

De acordo com o diretor, o laboratório é pouco usado, e quando o é, é apenas como sala de aula (nc-A).

Outra questão relacionada à especificidade do espaço do laboratório de ciências foi amplamente mencionada pelos sujeitos participantes da pesquisa: a exigência de um saber especializado para realizar a manutenção do espaço e permitir seu uso contínuo.

Segundo ele [o diretor da escola], os professores "não se arriscam”, embora ele entenda que não há tempo para o planejamento e desenvolvimento de tais atividades [em laboratório] e que falta a figura do técnico laboratorista (nc-A).

"Infelizmente", lamentou a professora que me acompanhava, "falta um profissional que faça a correta manutenção destes itens" (nc-D).

"Devia haver um técnico laboratorista” (nc-H).

Preparar uma aula prática não é uma coisa que se faz com uma varinha mágica. Você tem que ter tempo. Às vezes você tem que ter uma tarde inteira juntando equipamento, vendo o que tá faltando, vendo se tem algum equipamento danificado, e isso daí gasta muito tempo. [...] Quer dizer: o que precisava ter é, pelo menos, eram os ajudantes de professores. Precisa ter dois professores na sala de aula. Inclusive, da hora do laboratório, você não pode ter 1 professor lá, com 20 alunos dentro do laboratório. [...] Até pra segurança. Então o fato de ter mais uma ou duas pessoas, lá dentro, ajudando, contribui para o bom resultado da aula prática (e2).

O reconhecimento deste problema por parte dos professores, principalmente, é já bastante antigo, tendo sido relatado nos anos 1980 na pesquisa de Myriam Krasilchik:

[os docentes] não dispõem de tempo para fazer compras, lavar e guardar material usado, preparar experimentos, cuidar de animais e plantas mantidos nos laboratórios, atender alunos fora de aula. Uma das antigas reivindicações, muitas vezes reiterada pelos professores, é a de contarem com um funcionário para auxiliá-los nestas tarefas, ou ainda conseguir uma remuneração adequada para que possam responsabilizar-se por elas (KRASILCHIK, 1987, p. 51). 
Por fim, consideramos ainda a influência de outra especificidade perdida ou desvirtuada, no tocante às condições dos laboratórios escolares: qual seria fonte de recursos apropriada para a manutenção destes espaços. Saviani (2008) fala sobre a "necessidade de se dispor de mecanismos que impeçam os desvios de recursos [educacionais], muito comuns na nossa cultura política" (p. 114). Ora, em relação aos laboratórios visitados, o afluxo destes recursos quase não pôde ser observado. Veremos, adiante, que se observou no máximo a chegada de recursos materiais, às escolas, sem que tivessem sido requisitados, ou sem que as escolas tivessem sido consultadas a respeito de suas reais necessidades. Por outro lado, foi possível verificar, quando do aprofundamento das questões sobre as parcerias entre escolas e universidades, que as verbas para as reformas dos laboratórios só puderam ser viabilizadas graças à Fundação de Amparo à Pesquisa do Estado de São Paulo (Fapesp):

\begin{abstract}
não existe verba pra gente investir em laboratório escolar. Se a gente quiser fazer algum projeto de laboratório escolar, qualquer que seja, tenha a escola ou não um laboratório, seja ou não equipado, se a gente quiser tocar nesse ponto, nós temos que fazer um projeto pra Fapesp ou pra $\mathrm{CNPq}$ [Conselho Nacional de Desenvolvimento Científico e Tecnológico] ou pra não sei quem, envolvendo apenas essa escola, com recurso apenas praquela pesquisa, enfim, então tem uma limitação grande. Agora: nós temos alguma coisa em torno de 50 milhões de estudantes no Brasil entre o ensino fundamental e o médio. Os projetos de um de desses órgãos jamais vão conseguir atender 50 milhões. Jamais. Mesmo que todas as universidades se envolvessem, não dá pra trabalhar com todos (e1).
\end{abstract}

Então fizemos desde a reforma física da sala, até a aquisição de equipamentos com o recurso generoso que a Fapesp forneceu (e2).

Conferindo o material documental referente ao projeto que abrangeu duas escolas públicas, vê-se que as quantias envolvidas na manutenção dos laboratórios escolares são consideráveis:

Total de investimentos em cada escola pública participante[:]

Recursos Humanos: $R \$ 16.000,00$

Implantação dos Laboratórios (capital+custeio): $R \$ 51.0000,00$

Total: $R \$ 67.000,00$

Total de alunos beneficiados: 3.000 - custo por aluno: $R \$ 480,00$

Total de experimentos desenvolvidos: 170 experimentos - custo médio por experimento: $R \$ 850,00$

Os custos acima incluem gastos com a implantação elou aquisição do instrumental do experimento e agrega também o valor referente à recursos humanos empregados no desenvolvimento da metodologia.

Um estudo feito pela equipe após a implantação do laboratório mostra que cada atividade experimental custa em média $R \$ 60,00$ tomando como base uma turma de 35 alunos. Com este valor é possível manter um certo nível de qualidade no material adquirido, bem como manter uma manutenção adequada nos equipamentos instalados. 
Este valor ainda é muito elevado para a realidade da escola pública. Com algumas adaptações no material (conjunto de atividades) desenvolvido é possivel chegar a um custo limite por aluno de $R \$ 1,00 /$ experimento.

Um laboratório completo de Ciências Naturais adquirido no mercado custa hoje por volta de $R \$ 250.000,00$ e muitos dos equipamentos são provenientes do mercado internacional, o que encarece muito a sua manutenção (relatório).

O exame deste aspecto coloca-nos algumas questões, que consideramos que não foram refletidas suficientemente pelos pesquisadores e pelos especialistas em educação: de fato o Estado não dispõe de recursos para investir nos laboratórios escolares? Então as escolas deverão ficar à mercê da disposição de pesquisadores em angariar fundos junto às agências de fomento à pesquisa, mesmo sabendo que é impossível que estes projetos possam atingir a totalidade dos estudantes da educação básica brasileira (vide o depoimento e1 acima)? É papel das agências de fomento contribuir desta maneira para a melhoria do ensino público?

A título de ilustração, transcrevemos outro fragmento da entrevista e1, bastante elucidativo sobre as situações que alguns agentes educacionais precisam enfrentar para adquirir recursos financeiros que viabilizem certos projetos:

É... até tem uma coisa que eu tô lembrando agora: depois que acabou a vigência do projeto Fapesp a direção de uma escola bem na periferia de São Carlos [...] me procurou, eu fui até a escola conversar com ele [o diretor da escola] e ele tava super interessado em a gente fazer isto lá também. Na época eu esclareci pra ele o seguinte: "Eu não tenho mais recurso da Fapesp". Mas mesmo assim ele se mobilizou, junto à Secretaria de Educação, conseguiu um dinheiro e nós fizemos o projeto sem o financiamento da Fapesp. E ele chegou a usar até dinheiro de festa, de quermesse, de coisa do tipo que ele fez na escola, mas nós construímos lá também um laboratório e também enquanto esse diretor tava lá funcionou. Depois o diretor saiu, o laboratório tá lá - não sei se ainda tá em uso (e1).

\subsubsection{A questão da (des)continuidade e da estrutura organizacional da educação}

Como mostramos na seção 4.1, lembrando que a continuidade é uma característica do próprio processo de educação, Saviani (2008) elencou este aspecto entre aqueles de relevância para a análise da materialidade da ação educativa.

De fato, este foi um dos pontos mais enfatizados nas entrevistas com os coordenadores dos projetos de parceria entre escolas e universidades, até porque ambos os projetos foram interrompidos, em períodos diferentes, e permanecem desativados até hoje. 
É... Gerou resultados interessantes [o projeto de parceria]. Gerou inclusive artigo na época, teve coisa interessante aí. Mas não teve continuidade. [...] A ideia era trabalhar com o professor por um longo período. E no começo eles tinham pressa de resultados assim. Eles queriam ver... então a gente publicava como um roteiro de um experimento que eles... que a gente desenvolveu junto e eles aplicavam nas escolas. Então acabava sendo assim. [...] essa etapa, que a gente tava caminhando acho que rapidamente em direção a ela, foi interrompida (e1).

Nós talvez pudéssemos ter alguma ação, nas escolas. E... algo... e... e realmente isso acontece. Acontece mas... é... a maioria são eventos transitórios. E eu acho que a educação não se faz só com coisas transitórias. Você precisa ter uma coisa focada mesmo. Por isso que eu entrei numa escola só. Porque você faz uma... um curso de um mês numa escola, depois numa outra mais 30 dias... Não é... nós precisávamos ter uma mudança radical, né. [...] em educação nada dá resultado de um ano pro outro. Você não pode usar esse argumento como argumento eleitoral, digamos assim. A coisa tem que ser uma coisa muito mais sólida, feito um plano nacional, $e$ que isso daí precisa um investimento constante de recursos, tanto na formação dos professores, como na manutenção das escolas (e2).

Analisando o depoimento do coordenador do projeto que abrangeu as escolas A e B, fica até mesmo claro que esta iniciativa foi motivada pela necessidade de maior continuidade em um projeto já corrente: trata-se exatamente da Experimentoteca. Pela primeira vez, podemos falar de modo mais objetivo ${ }^{68}$ sobre esta iniciativa desenvolvida pelo CDCC-USP, que possibilita o empréstimo de kits com material didático, aos professores, para a realização de experimentos em sala de aula ou mesmo nos laboratórios escolares.

O Projeto Experimentoteca acabou. Não a Experimentoteca, ela continua, com aportes cada vez mais fortes, mas o Projeto, aquele né, que tinha a equipe inteira trabalhando no desenvolvimento, no teste nas escolas, esse projeto acabou, não existe mais. Então quando eu digo que foge ao controle é porque hoje o professor vai até o $C D C C$, retira a caixa [kit com material para a realização do experimento] mas eu não sei o que ele tá fazendo com ela. Né... Bom. Isso começou a ficar claro pra gente nessa ocasião do desenvolvimento da Experimentoteca. Então, o que começou a me incomodar é o seguinte: a gente tem que ter alguma coisa que sirva de piloto pra nós, mas que seja mais permanente. Que seja desvinculado com o desenvolvimento da Experimentoteca (e1).

O outro projeto, que envolveu a Escola C, parece ter partido de observação semelhante:

Então foi assim: "Eu vou fazer uma coisa pequena, local, mas eu quero ter contato com os alunos da escola pública. Os professores serão meus parceiros. Mas nós vamos tentar fazer uma atividade em que nós entramos dentro da escola pública, e fazermos uma atividade em parceria com eles". E uma coisa continuada. Quer dizer, não é ir lá, fazer um curso de uma semana. É como eu te disse, nós ficamos lá na Escola $C$ durante vários anos. Inclusive a ponto de ter a turma de primeiro, segundo e o terceiro anos científicos simultaneamente sendo atendidas (e2).

\footnotetext{
${ }^{68} \mathrm{Na}$ “Apresentação" desta tese, meu depoimento sobre a Experimentoteca foi mais "subjetivo", digamos.
} 
Ironicamente, a situação se desenvolveu de tal maneira que os projetos de parcerias entre universidades e escolas foram encerrados, e a Experimentoteca, embora não enquanto Projeto, permanece em execução pelo CDCC, parecendo ter atingido o "ponto da irreversibilidade" de que fala Saviani (2008), a partir do qual já não é possível prosseguir sem a existência da iniciativa em questão.

Os motivos para a descontinuidade das parcerias, conforme apontado pelos dois pesquisadores, nos levam de volta à questão da estrutura organizacional da educação:

[A parceria] começou a funcionar legal por um tempo e aí a primeira escola que deu um problema foi a Escola A porque a diretora aposentou, mudou a direção, a direção não apoiava mais o projeto, porque não gostava do trânsito de alunos entre sala de aula e laboratório, então o projeto ficou prejudicado, mas a gente ainda conseguia tocar. Não do mesmo jeito, mas conseguia tocar. Na Escola B tava indo bem. Aí depois, na mesma época, com diferença muito pequena de tempo aí, aconteceu duas coisas. Eu fui pra USP de Ribeirão... e o projeto não era da USP de Ribeirão, o projeto era do CDCC. Porque aquela validade perante a Fapesp, de implantação dos laboratórios e etc. e tal, aquilo já tinha expirado. Então com a Fapesp já tinha acabado o assunto. Só que a ideia de fazer esse acompanhamento permanente é com o CDCC, até pela proximidade né. [...] Aí depois, diretor da Escola B, ele aposentou e esse projeto começou aos poucos... ele foi sendo desativado. É uma pena, porque era uma oportunidade da gente trabalhar $-e$ trabalhar muito forte - metodologia. Já não era problema aquilo que era problema pra toda escola, que é assim: ou não tem laboratório, ou não tem vidraria, não tem reagente, não tem equipamento. Tinha tudo: toda a vidraria, estoque de reagente, $e$ etc. Podia concentrar e gastar energia apenas na pesquisa, apenas na metodologia e tal, porque o resto não era problema. Só que eu sei que praticamente foi desativado. Até onde eu sei, nas duas escolas o uso do laboratório depende da boa vontade do professor. Dependendo do professor - que tem uma rotatividade muito grande, né [...] (e1).

Na primeira vez que foi feito o Enem [Exame Nacional do Ensino Médio], sete alunos nossos [que participavam do curso experimental de ciências desenvolvido na escola, em horário alternativo às aulas] conseguiram bolsa integral [no Programa Universidade Para Todos, Prouni]. Então eu achei que foi bom. Mas, a partir daquilo, houve um desinteresse. Era uma coisa gozada... Era uns... era... não tinha mais aquela frequência nas aulas de tarde. E eu não aguentei mais dois anos tentando. Depois eu resolvi que eu não ia mais fazer isso. Eu tava jogando dinheiro fora e o tempo de meus bolsistas fora. Porque eles iam lá, preparavam as aulas e não tinha aluno pra assistir. A própria direção da escola não fazia muita coisa, muita ênfase, né. Mudou a direção da escola, inclusive, nesse período. E os professores, eles são... eles mudam muito de escola. Então alguns professores eram, digamos assim, os que carregavam o piano lá, eles saíram, foram pra outra escola, e entrou gente muito desinteressada, que não queria fazer nada. Tem... teve um ano que não tinha professor de fato nem de Física nem de Química! Eram substitutos, daqueles temporários, que podem ser qualquer coisa! Então, era muito... foi muito desestimulante quando chegou esse pedaço (e2).

Para os pesquisadores, grande parte das dificuldades na manutenção dos projetos se devia à alta rotatividade dos corpos gestor e docente. No depoimento e1, o entrevistado se detém mais longamente sobre esta questão: 
[...] has escolas a gente teve problemas com mudança de direção... Mudança de professor não era tanto problema, embora também tinha um processo. Porque você tá com um professor há um tempo, preparando esse professor, passando material pra leitura e fazendo discussão e etc. Quando você perde um professor e entra um outro, você tem que começar tudo de novo, então é um problema. Mas o pior problema é mudança de diretor. Porque se o diretor não veste a camisa, não apoia o projeto, aí... aí não tem jeito, né. Porque dentro da escola tem uma hierarquia, o professor é subordinado à direção, e dá pra complicar de trocar... Ele é difícil, por natureza ele é difícil de ser mantido. [...]

Eu acho que é assim... Eu vou falar de direção, mas também da Secretaria de Educação, a parte da estrutura: ela tem uma estrutura bastante complexa, né. Primeiro porque o dirigente mesmo fica em São Paulo. Depois, lá dentro já tem: departamento, e etc... vinculado à Secretaria de Educação. Depois tem outra distribuição que é por diretorias regionais. Em São Carlos, por exemplo, tem uma; nós temos uma diretoria regional. E depois tem o diretor da escola, depois tem os professores, então, é assim, tem uma fila enorme. O começo desta fila (que começa lá pela Secretaria de Educação, lá em São Paulo e vem parar na diretoria regional)... essas pessoas muitas vezes nem querem tomar conhecimento desses projetos ou quando tomam conhecimento não oferecem apoio e etc. Então, o diretor, ele é a penúltima etapa, né, desse processo todo [...].

E é... pra você ver como é complicado: quando esse diretor da Escola B aposentou... pouco antes dele aposentar ele mudou de escola. Na verdade eles não decidem isso, né. Direção não; professor até tem um pouco mais de poder de decisão em transferências. Professor, na atribuição de aulas, ele ainda consegue fazer as manobras, ir pra uma outra escola (ou às vezes até contra a vontade dele né, porque depende de pontos na carreira e tal. Às vezes ele perde a escola em que ele tava, contra a vontade dele)... mas enfim, ele tem mais poder de decisão - o professor. O diretor não, quase sempre é ordem superior. Então é assim: "Hoje você está na direção da escola A". E de repente chega uma ordem assim "Vá para a escola B". Não é porque você decidiu. É porque lá em cima alguém decidiu e você tem que ir praquela escola $(\mathrm{e} 1)$.

$\mathrm{Na}$ Escola B, a questão também foi tangenciada durante a entrevista improvisada com a professora de ciências, conforme relatamos na respectiva nota de campo:

a diretora chamou a professora de ciências para conversarmos. Ela explicou que costuma levar as turmas uma vez por bimestre para fazer práticas, mas que o espaço do laboratório não está totalmente adequado. Entendi que por falta de manutenção. Segundo ela, a rotatividade dos professores dificulta a integração das áreas - Ciências, Física, Química e Biologia - para a elaboração de um projeto conjunto para o espaço (nc-B).

Estes depoimentos demonstram claramente a existência daquela "resistência material" a que nos referimos na primeira seção deste capítulo. Neste caso, ela se manifesta em duas formas.

A primeira é a estrutura hierárquica em que se distribui o poder decisório pelas instâncias educacionais, da Secretaria de Educação, passando pelas Diretorias Regionais, até as escolas propriamente ditas, em cujo seio se estabelece outra hierarquia própria (gestores, docentes, servidores e discentes, nesta ordem). A dificuldade em comunicar tantos níveis e colocá-los em sintonia acaba por impedir ou dificultar as iniciativas, por parte de outros agentes (no caso, os pesquisadores universitários), que possam redundar em incrementos na 
qualidade da educação escolar. É como se o poder centralizador da Secretaria de Educação erguesse, desta maneira, um "cinturão protetor", de natureza essencialmente burocrática, blindando a rede estadual da educação escolar de iniciativas alternativas ou resistentes a este poder. O problema do "burocratismo", a propósito, não escapou a Saviani:

\begin{abstract}
é preciso atuar de modo sistematizado no sistema educacional para que ele continue sendo "sistema"; do contrário, ele irá se degenerar em "estrutura". A formalização da prática conduz a esse risco que na época atual está caracterizado no burocratismo. Este consiste em que, a um novo processo, se apliquem mecanicamente formas extraídas de um processo anterior. A atividade educacional é particularmente vulnerável a esse tipo de desvio (1975, p. 85, grifo do autor).
\end{abstract}

A outra forma de resistência material, inseparável da enunciada acima, se concretiza no modo como se estrutura a atribuição de cargos para a gestão e a docência escolar. Não deixa de ser, também, de ordem burocrática. Parecem atuar, neste ponto, três questões problemáticas: os critérios para a permanência dos trabalhadores em seus estabelecimentos, que na tentativa de valorizar o mérito pessoal e a conquista de pontos para a progressão na carreira, incentivam a elevada rotatividade de pessoal; a escassez de corpo qualificado para assumir a atividade docente nas disciplinas científicas, resultante do desprestígio social dos profissionais da educação, das baixas remunerações e dos preocupantes índices de conclusão de curso nas licenciaturas plenas, entre outros fatos; e a ausência de políticas públicas sólidas e compromissadas com a elevação da qualidade da educação, atuando de forma direta na melhor qualificação do corpo docente e na garantia de condições de trabalho dignas.

A próxima subseção irá explorar mais a fundo as relações entre estrutura e sistema educacional, considerando o material concreto fornecido pelos dados coletados na realização desta pesquisa sobre os laboratórios escolares de São Carlos.

\title{
4.3.3 A necessidade de um sistema de ensino ${ }^{69}$
}

Retomemos o que Saviani estabelece como característico do "educar de modo sistematizado", conforme expusemos na seção inicial deste capítulo: a) tomar consciência da

\footnotetext{
${ }^{69}$ Esta subseção gerou o trabalho "O laboratório científico escolar e a questão do sistema educacional", apresentado no XVI Eneq. Como afirmei na seção 3.2 do capítulo anterior, o trabalho de Anunciação e Moradillo foi um dos únicos, a integrar este evento, que se referenciou na Pedagogia Histórico-Crítica; somente o texto gerado por esta subseção lhe fez companhia. Quanto à análise do nosso trabalho, o avaliador único afirmou, em seu parecer, apenas: "Fundamentação teórica interessante e relevante".
} 
situação educacional, isto é, de sua estrutura; b) captar os problemas; c) refletir sobre eles; d) formular objetivos realizáveis para sua resolução; e) organizar os meios para alcançar estes objetivos; f) instaurar um processo concreto para realizá-los; e g) manter um movimento ininterrupto de ação-reflexão-ação. Lembremos também que as condições básicas para a construção de um sistema educacional em uma dada situação são três: a) consciência dos problemas; b) conhecimento da realidade (estruturas); e c) formulação de uma pedagogia. Sobre estas condições, comenta o autor:

\begin{abstract}
A consciência dos problemas é um ponto de partida necessário para se passar da atividade assistemática à sistematização; do contrário, aquela satisfaz, não havendo razão para ultrapassá-la. Contudo, captados os problemas, eles exigem soluções; e como os mesmos resultaram das estruturas que envolvem o homem, surge a necessidade de conhecê-las do modo mais preciso possível, a fim de mudá-las; para esta análise das estruturas, as ciências serão um instrumento indispensável. A formulação de uma pedagogia (teoria educacional) integrará tanto os problemas como os conhecimentos (ultrapassando-os) na totalidade da praxis histórica onde receberão o seu pleno significado humano. A teoria referida deverá, pois, indicar os objetivos e meios que tornem possível a atividade comum intencional (ibidem, p. $81)$.
\end{abstract}

Ao buscar compreender como as parcerias entre escola e universidade se propuseram a incidir prioritariamente na organização dos laboratórios científicos escolares, pudemos observar claramente esta tensão entre os conceitos de estrutura e sistema. De fato, estivemos diante de ações sistematizadoras que partiram de iniciativas individuais, atuantes sobre a estrutura da educação. E se bem que "a atividade sistematizadora pode ser reduzida a uma tarefa individual" (ibidem, p. 79),

O sistema, porém, ultrapassa o indivíduo. Com efeito, os indivíduos podem agir de modo intencional visando, contudo, objetivos diferentes e até opostos. Estas ações diferentes ou divergentes levarão, é verdade, a um resultado comum; este, não terá, contudo, um caráter de sistema, mas de estrutura (ibidem, loc. cit., grifos do autor).

A contradição entre estas iniciativas que partiram da universidade e a atuação do Estado pelos seus órgãos foi mencionada nos depoimentos dos coordenadores de projetos:

essas pessoas [da Secretaria de Educação] muitas vezes nem querem tomar conhecimento desses projetos ou quando tomam conhecimento não oferecem apoio e etc. Então, o diretor, ele é a penúltima etapa, né, desse processo todo. Por isso que muitas vezes ele não apoia. Ele é cobrado por outras coisas - que não essas então ele acaba não se envolvendo nessas. "Nessas eu não sou cobrado". Porque o interessante de projetos da universidade com a escola é que (eu sempre chamo isso, então eu faço muita questão de enfatizar) isso é parceria: não existe hierarquia. A universidade nunca tá acima da escola. A escola pode falar "não" à hora que bem entender pra um projeto da universidade. Ele pode ou não aceitar um aluno nosso 
ou nós mesmos como pesquisadores, ela pode fechar as portas pra universidade. Então é interessante olhar pra esse lado: ou você estabelece parceria (e daí isso requer envolvimento, boa vontade, etc. e tal) ou então não funciona (e1).

Neste depoimento em especial, ao tratar deste assunto, o coordenador entrevistado retomou os comentários sobre a importância da continuidade das iniciativas, e da influência da estrutura organizacional da Secretaria de Educação:

Eventualmente - e muito eventualmente - a gente consegue algum projeto direto com a Secretaria, e aí é diferente, porque a coisa chega na escola, porque tem uma ordem superior, aquilo foi mandado e etc. Mas também não é um caminho muito interessante ter a escola envolvida "porque o chefe mandou". Então é difícil ter um projeto de médio e longo prazo com escola por isso. Porque ou você vai à escola e daí muitas vezes a escola não quer participar, ou você vai direto à escola e tem o envolvimento mas a rotatividade é muito grande: daí a pouco você perde o diretor, daí a pouco muda o professor, então é complicado. Projeto de médio a longo prazo é difícil de manter (e1).

Já o depoimento da coordenadora da parceria entre a universidade e a Escola $\mathrm{C}$ se deteve mais sobre a necessidade de sintonia entre os diversos sujeitos que agem na estrutura educacional:

Não adianta nem ter bom professor lá no segundo grau. Ele não tem tempo material pra fazer nada com os alunos. Ele tem muito poucas aulas. E aqui, ainda por cima, somos utópicos, né: "Vamos introduzir Espanhol. Vamos introduzir Filosofia. Vamos introduzir Sociologia." E o pessoal acha que isso daí se faz com varinha mágica. Onde tá o professor de Filosofia treinado pra dar Filosofia pro aluno de segundo grau? Não existe! E mesmo Espanhol. Nós temos aí uma comunidade de língua hispânica que poderia se... se mascarar de professor. Mas não é professor, né! Então nós temos essa falta de visão integrada do que é que a gente quer com a educação. Nós queremos ir pra que lado? Pra que coisa? Qual é o objetivo? Formar gente pra quê? (e2).

Portanto, parece-nos que a estrutura educacional do Estado de São Paulo ainda não veio a se integrar a um sistema, pois já as primeiras características do "educar de forma sistematizada", que seriam tomar consciência desta estrutura e captar seus problemas essenciais, não são verificadas. Mais uma vez, recorremos ao depoimento do coordenador do projeto que envolveu as escolas A e B:

Se a Secretaria de Educação valorizasse mais o desenvolvimento dessas parcerias, desses projetos... porque muitas vezes ela quer implantar na escola projetos que estão fadados ao insucesso. Você vê projeto e você fala que isso não vai levar a nada, mas o professor tem que estar envolvido com aquilo, o diretor tem que estar envolvido com aquilo, eles são cobrados por aquilo, eles têm que apresentar relatório, eles têm que participar de reunião... E coisas que você fala "Pô, mas isso não leva a nada!’. (Eu não tô dizendo de todos os projetos não). Tem projetos que são assim: que absorvem um tempo enorme e não levam a nada. E daí não cabe à universidade fazer parceria porque o projeto é deles e etc... (e1). 
Um exemplo de ação da Secretaria de Educação, relacionada aos laboratórios escolares, mas que se mostra "inconsciente" da estrutura educacional em suas manifestações materiais, é o envio de kits com material experimental para as instituições. Tais kits, pelo que apuramos, são constituídos de caixas - "módulos" - expedidos diretamente às escolas e portando materiais como instrumentos, vidrarias e reagentes (ver Figura 19). Verificamos a presença dos kits nas escolas A, E e F, e inferimos serem eles os materiais referidos pela coordenadora da Escola $\mathrm{H}$, com quem conversamos:

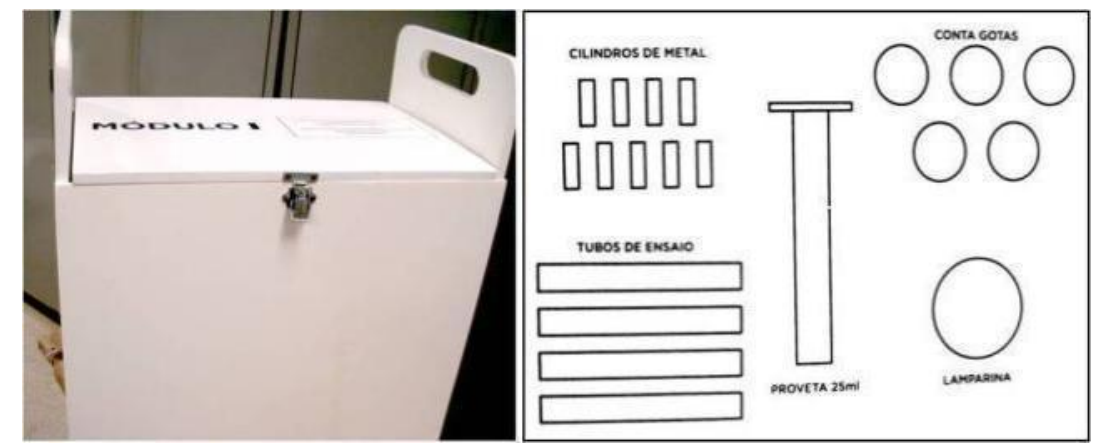

Figura 19: mosaico exibindo um dos kits com material para laboratório enviado pela Secretaria de Estado, e uma caracterização do conteúdo da mesma caixa, conforme impresso em uma de suas faces (f-E3 e f-E4).

Então ela [a diretora] me apresentou ao laboratório, no $1^{o}$ andar. Uma sala bem iluminada e com "cara" de laboratório. Havia amplas bancadas de azulejo branco. Sobre uma delas, grandes caixas de madeira contendo reagentes químicos aguardando descarte. [...] Mostrou-me que alguns destes reagentes estão em vias de ter sua validade vencida, como o ácido sulfúrico, enquanto outros chegaram já vencidos $[\ldots]$ (nc-H).

Os reagentes sequer foram solicitados pela escola, criando o problema do descarte do material com prazo de validade expirado. Nas notas referentes à Escola F, um relato semelhante:

A vice-diretora contou que a escola recebeu kits com materiais laboratoriais do Estado. Perguntei se havia sido feito um levantamento prévio das condições dos laboratórios por técnicos do Estado, para saber das reais necessidades da escola quanto a isso, e ela respondeu negativamente (nc-F).

A diretora de uma escola situada em outro município, com quem conversamos informalmente, confirmou-nos ter recebido estes kits mesmo não dispondo de laboratório para alocá-los. Bastaria que a escola oferecesse o ensino médio para que a Secretaria de Educação enviasse o material, sem qualquer tipo de consulta prévia. Demonstra-se novamente a ausência de sintonia - palavra sinônima de "coerência interna", conforme entendemos - entre os diversos níveis da estrutura organizacional da educação no âmbito estudado, o que sugere que ela não integre um sistema. 


\title{
4.4 A TÍTULO DE CONCLUSÃO
}

O município de São Carlos conta com 17 escolas estaduais que oferecem o nível médio da educação básica.

A pesquisa realizada mostrou que oito destes estabelecimentos possuem um espaço constituído como laboratório escolar. Destes oito, apenas três poderiam ser considerados como laboratórios no sentido restrito do termo, dispondo da maioria dos recursos característicos destes espaços e estando em condições operacionais mais ou menos adequadas.

Uma destas escolas é um prédio histórico, construído no início do século XX. Segundo os documentos historiográficos referentes a este estabelecimento, visava-se, com a construção deste prédio, à criação de uma instituição educacional de nível elevadíssimo, rivalizando com as nascentes universidades brasileiras tanto em estrutura como em funcionamento. Daí a necessidade de haver um laboratório separado para cada disciplina - Física, Química, Biologia -, e os respectivos técnicos laboratoristas ou preparadores. Por exemplo, lê-se, no registro histórico consultado, que o laboratório de Química

\begin{abstract}
possuía toda a vidraria clássica de laboratório vinda da França, bem como os reagentes imprescindíveis, fabricados pela firma Poulenc Fréres. Havía um forno para aquecimento de retortas à base de carvão incandescente e canaletas para aquecimento de tubos de combustão com o mesmo sistema de aquecimento. Lothario Novaes e depois José Bentim foram os primeiros preparadores e finalmente Elvirinha Leite Martins cujo cargo também foi extinto com sua aposentadoria em 1965 (registro histórico).
\end{abstract}

Assim, com exceção deste espaço histórico, idealizado sob a influência de uma mentalidade de vanguarda, restam apenas dois verdadeiros laboratórios escolares nas escolas estaduais do ensino médio de São Carlos. Estas são justamente duas das três escolas que sediaram parcerias, com as universidades públicas locais, especialmente focadas na construção e no equipamento dos laboratórios de ciências, e também no trabalho conjunto entre pesquisadores e professores para a melhoria da educação científica na cidade. Nas outras escolas há espaços chamados de laboratórios, mas que a rigor não o são, nas palavras de um dos pesquisadores entrevistados; no máximo, há planos de se realizar reformas em espaços já constituídos, para adequá-los e colocá-los em funcionamento.

Recentemente, o título de Capital Nacional da Tecnologia foi conferido a São Carlos por meio de uma Lei Federal (BRASIL, 2011). Mas então, há um cenário contraditório. Como 
uma cidade assim nomeada sequer dispõe de condições materiais favoráveis ao ensino escolar dos conteúdos sobre ciência e tecnologia?

a mídia fala, explora bastante isso... "São Carlos é a cidade que tem o maior número de doutores... a relação número de doutores por habitante..." É... Essa meninada sabe disso. Essa criançada de ensino fundamental, de ensino médio ouve o tempo todo falar das universidades, de USP, de UFSCar, dos projetos, da pesquisa, da tecnologia, do conhecimento, etc. (e1).

Ao longo deste capítulo, procuramos mostrar que não é possível responder de modo simples e direto à questão posta por esta contradição, e que diversos fatores interferem na constituição dos laboratórios escolares deste município como espaços capazes de sediar uma educação científica de qualidade. Estes fatores, aqui tratados, foram aqueles relacionados especificamente ao que chamamos, citando Saviani, de resistências materiais. Elas se manifestam na estrutura organizacional da educação, dificultando a continuidade de iniciativas (e impossibilitando sua fixação como processos irreversíveis, como habitus) e o estabelecimento de um sistema de educação sobre esta estrutura. Aliás, no ciclo vicioso em que se inserem as ações educativas emanadas do poder político, estas resistências materiais se mostram não apenas fruto da inexistência de um sistema educacional, mas também como entraves à constituição futura deste sistema.

Poder-se-ia objetar que não se trata, efetivamente, da inexistência de um sistema educacional; que apenas não foi possível observar, dado o recorte analítico de nossa investigação, o sistema em pleno funcionamento. Ou então, que a existência de graves problemas em sua configuração, a precariedade do sistema, implicaria um desenvolvimento apenas incipiente da unidade por ele engendrada, não significando, no entanto, que ele não esteja estabelecido. Mas lembremos que, para Saviani, a unidade proporcionada pela reunião intencional de vários elementos de uma dada estrutura deve formar um conjunto "coerente e operante" (1975, p. 75). E explica o educador brasileiro:

Foi necessário acrescentar o termo "operante" [nesta definição] para se evitar que a coerência fosse reduzida apenas à coerência interna. $\mathrm{Na}$ verdade, um sistema se insere sempre num conjunto mais amplo do que ele próprio; e a sua coerência em relação à situação de que ele faz parte (coerência externa), se exprime precisamente pelo fato de operar intencionalmente transformações sobre ela. Com efeito, se o sistema nasce da tomada de consciência da problematicidade de uma situação dada, ele surge como forma de superação dos problemas que o engendraram. E se ele não contribuir para essa superação, ele terá sido ineficaz, inoperante, ou seja, incoerente do ponto de vista externo. E tendo faltado um dos requisitos necessários (a coerência externa), isso significa que, rigorosamente, ele não terá sido um sistema (ibidem, loc. cit.). 
Se a compreensão da totalidade mais desenvolvida é a chave para a compreensão da menos desenvolvida, o estudo da situação dos laboratórios didáticos em São Carlos convertese num importante momento para a compreensão da mesma situação em uma totalidade maior, que poderia ser o conjunto dos municípios do Estado de São Paulo, ou mesmo de todo o país. Se São Carlos, Capital Nacional da Tecnologia e sede de duas universidades públicas com importantes projetos na área de Educação em Ciências, ainda abriga escolas desprovidas de espaços adequados para o ensino das disciplinas científicas em sua especificidade, é razoável supor que na maioria dos demais municípios brasileiros a situação não seja melhor. Assim, as conclusões aqui elencadas poderiam ser generalizadas e orientar outros trabalhos.

No caso desta tese, estas conclusões serão fundamentais para se dimensionar corretamente a importância e a abrangência da Experimentoteca enquanto ação educativa emanada de um centro de ciências como é o CDCC. A investigação demonstrou também que a Experimentoteca exerceu um papel importante para equipar de algumas escolas de São Carlos com instalações laboratoriais, o que a torna um objeto de pesquisa contraditório e, portanto, interessantíssimo a um empreendimento epistemológico de caráter crítico-dialético, como é o nosso.

Tentemos desenvolver melhor estas questões nos capítulos vindouros. 


\section{CAPÍTULO 5}

A EXPERIMENTOTECA, I:

uma ação educativa de um centro de ciências à luz da Pedagogia Histórico-Crítica

A partir daqui, finalmente poderemos dar atenção ao principal objeto que motivou a elaboração desta tese, a Experimentoteca. Ainda que já tenhamos nos referido a ela, possibilitando ao leitor ao menos uma noção do que seria, afinal, esta iniciativa do Centro de Divulgação Científica e Cultural, buscaremos caracterizá-la de modo mais apurado neste capítulo, que se divide em três seções.

$\mathrm{Na}$ primeira, trataremos da Experimentoteca, de sua gênese a seu estado atual, enquanto uma ação educativa promovida por um centro de ciências. Para isso, será necessário narrar, ainda que brevemente, a inserção do CDCC em um movimento mais amplo de proliferação de centros e museus de ciências pelo Brasil e pelo mundo. Este percurso narrativo será amparado por autores diversos, e que não haviam sido convocados ainda a este trabalho, militantes de áreas como a Museologia e os estudos sobre divulgação e popularização da ciência.

A segunda seção realiza um estado da arte dos estudos acadêmicos sobre a Experimentoteca. Veremos que, a despeito da ampla difusão deste projeto pelas diversas regiões do Brasil, estes trabalhos compõem um corpus ainda diminuto. Apesar disso, será imprescindível retomar as conclusões destes autores pioneiros, já que sua produção aparece dispersa e relativamente pouco acessível. Ainda, aproveitaremos este momento para demarcarmos as linhas de continuidade entre estes trabalhos e as perspectivas desta tese. 
Encerrando o capítulo, voltaremos a chamar autores da Pedagogia Histórico-Crítica para propormos novas contribuições teóricas às áreas da Educação, da Educação em Ciências e da Museologia. Delimitando e discutindo a abrangência de termos como "educação formal”/“escolar", "educação não formal” e "educação informal”, caminharemos em direção a um entendimento das ações educativas de centros e museus de ciências à luz da Pedagogia Histórico-Crítica. Estas considerações, a bem da verdade, já haviam sido anunciadas no capítulo anterior, quando, de modo até inesperado, a Experimentoteca acabou se revelando um objeto importante para a configuração da realidade ali investigada (a situação dos laboratórios escolares de São Carlos). Nesta seção final, iremos aprofundar tais considerações, iniciando a série de conclusões inéditas abrangidas por estes três capítulos finais.

\subsection{SITUANDO A EXPERIMENTOTECA}

Esta seção está dividida em três subseções.

A primeira é dedicada a caracterizar o CDCC enquanto instituição dedicada a difundir o conhecimento científico e, consequentemente, elevar o nível cultural da comunidade de São Carlos e região. Isto implicará que revisemos, brevemente, o desenvolvimento histórico dos centros e museus de ciências no Brasil e no mundo, explicitando as finalidades a que estas instituições vêm servindo desde que surgiram.

Caracterizado o CDCC, falaremos especificamente sobre a gênese e a concepção da Experimentoteca. Nossas principais referências serão depoimentos dos seus criadores, constituindo a visão institucional - isto é, da USP, do CDCC - sobre esta iniciativa.

Finalmente, exporemos a situação atual da Experimentoteca, com atenção especial para os materiais destinados ao ensino de Química, nos ensinos fundamental e médio.

\subsubsection{O CDCC enquanto centro de ciências}

Qualquer ponto de partida, na busca pelas raízes históricas dos atuais centros e museus de ciências, é no mínimo arbitrário. 
O Prof. Alberto Gaspar, em sua tese de doutorado (GASPAR, 1993), lembra que o hábito de colecionar objetos remonta à pré-história, tendo sobrevivido também nas antigas sociedades greco-romanas. Aristóteles é reconhecido como um dos maiores nomes da filosofia ocidental, mas muitos se esquecem de sua importância no campo do que seriam hoje as ciências naturais, e algumas das primeiras taxonomias de seres vivos, de sua autoria, poderiam não ter sido possíveis sem a formação de suas coleções de espécimes. Provavelmente, foi a partir de tais repositórios particulares, com fins de pesquisa, que vieram a se constituir as primeiras instituições dedicadas a compartilhar estes acervos com o grande público, em séculos seguintes.

Localiza-se também na cultura helenística a origem do próprio termo "museu": templo ou santuário das musas, local de inspiração, meditação, erudição. O Museu de Alexandria (século III a.C.), talvez a primeira instituição a receber esta denominação, era, ainda segundo o trabalho de Gaspar, uma entidade de ensino e pesquisa, semelhante às atuais universidades.

Observa-se, portanto, que desde suas origens, a principal finalidade dos museus foi a produção de conhecimento. A preservação - e, posteriormente, a exposição - de artefatos naturais ou artificiais se dispunha em função, prioritariamente, do empreendimento investigativo.

Com o passar do tempo, a formação de coleções, de atividade-meio, se tornou ela mesma uma atividade-fim dos museus. Este processo tem início na Idade Média, com a constituição de coleções pessoais de riquezas por parte da nobreza, e perdura até a Renascença, quando a efervescência cultural da época eleva os acervos particulares à condição de objetos de apreço estético. Mais do que isso: ostentar riquezas e obras de arte se torna uma mostra de domínio da cultura erudita, o que contribui para a acelerada publicização das coleções. Cria-se o objeto expositivo. Para Gaspar, a palavra “museu” é redescoberta, para designar os locais de exposição das coleções, em analogia com o ambiente literário e reflexivo do museu helenístico.

Uma outra historiografia dos museus e centros de ciências observaria que, em diferentes períodos, estas instituições desenvolveram características também peculiares, podendo-se falar no aparecimento de sucessivas "gerações" de museus. É nestes termos que a pesquisadora inglesa Paulette McManus trata a questão, apresentando então três gerações que demarcam períodos específicos da história dos museus, refletindo o desenvolvimento histórico mais geral das ciências e de seu ensino (McMANUS, 1992). 
Assim, uma primeira geração seria aquela iniciada com os chamados "gabinetes de curiosidades" - os próprios acervos da nobreza, de que falamos acima. De meros almoxarifados e amontoados de objetos, os gabinetes vão progressivamente adotando critérios de organização: as pinturas separadas dos animais empalhados; estes, por sinal, separados conforme o porte e, posteriormente, de acordo com os recentes conhecimentos em Sistemática e Taxonomia. Mas é a heterogeneidade de seus objetos o que melhor caracteriza estas coleções, típicas do século XVII, fazendo com que a palavra "museu", já usada para se referir a elas, possa ser sinônimo de "almoxarifado", como já afirmamos, ou mesmo de "santuário". É a partir do século seguinte que estes acervos, já mais bem organizados, se convertem em repositórios para a investigação científica, recuperando o sentido tradicional do termo "museu”. Surgem os museus de história natural e a visitação pública, antes indesejável, vai timidamente - se impondo como uma necessidade. No século XIX, o museu de história natural já é uma instituição tida como essencial para a investigação científica. O Iluminismo retoma o apreço renascentista pela ciência, e por toda a Europa proliferam os acervos de objetos naturais, de origem biológica ou geológica, organizados para facilitar a pesquisa. A própria história natural adquire o status de disciplina científica, congregando os campos da Botânica, da Zoologia, da Geologia e da Mineralogia.

A segunda geração de museus, que se inicia no século XIX, reflete o entusiasmo para com os progressos da Revolução Industrial. Sendo verdadeiras "vitrines de avanços", estes espaços procuravam retratar e expor os objetos associados à vanguarda da ciência e da tecnologia de então. A literatura é unânime em apontar a descontinuidade deste momento em relação àquele da primeira geração: o museu é agora um local aberto para a visitação, entendendo-se que os objetos em exposição podem servir não apenas ao trabalho dos especialistas em ciência, mas também para a educação científica do público. Valente e Marandino (2003) afirmam que estes museus viriam a atender à crescente necessidade de informar a população sobre os emergentes conceitos em ciência de então - o evolucionismo, por exemplo -, ao mesmo tempo em que contribuíam para atenuar o isolamento da comunidade científica em relação à sociedade como um todo. Cazelli, Marandino e Studart (2003) notam que este é o momento em que a questão da educação científica é reconhecida como pertencente não apenas ao âmbito escolar, deslocando-se para esferas mais amplas, o que atribuiu uma nova responsabilidade ao museu. Gaspar afirma que, a partir de então, 
pode-se dizer que a educação passou a ser a principal função dos museus públicos. O papel dessas instituições na divulgação científica teve grande destaque nos Estados Unidos, onde associações e academias de ciências foram criadas para que, entre outras coisas, fundassem museus com essa finalidade, uma mobilização tão forte que chegou a provocar reações contrárias. [...]. Quando criados, os primeiros museus de história natural eram centros de pesquisas. [...] Entretanto, o desenvolvimento e a diversidade das ciências naturais, a partir do final do século XIX, trouxeram a necessidade da utilização de laboratórios mais avançados, exclusivos para a pesquisa, sobretudo no trabalho com organismos vivos, o que reduziu a importância dessas instituições como centros de pesquisas em favor de uma função voltada predominantemente à educação (2006, p. 29-30).

É então que surgem os primeiros museus interativos, isto é, aqueles que previam a possibilidade do visitante tocar ou manipular os objetos expositivos. Será esta a característica marcante dos museus da terceira geração. A tendência à interatividade se firma em meados do século XX, acompanhando o movimento pedagógico que redundaria no escolanovismo. Da mesma maneira que no âmbito educacional se questionava a pedagogia tradicional, com sua ênfase no professor e no ensino, propondo-se a centralidade do aluno e da aprendizagem, a filosofia orientadora das exposições buscava reduzir a ênfase no objeto, fazendo do visitante um "protagonista". A presença mais acentuada de aparatos e exposições baseados no pushbutton faz desta geração uma radicalização da anterior, de acordo com Gaspar (ibidem). Mas esta não é a única característica distintiva dos novos museus. Junto da interatividade, promove-se certa "dessacralização" dos objetos e das coleções, nas palavras de Ruiz (2003), conforme citado também por Gaspar. O objeto expositivo já não é um valor em si: serve a uma ideia. Valente e Marandino (2003), apresentando as conclusões de Lourenço (2000), que citam, falam de diferentes categorias de objetos expositivos: os científicos, produzidos no âmbito da investigação; os pedagógicos, concebidos especificamente para o ensino de conceitos; e os objetos para a popularização da ciência, que buscam difundir a ciência para amplas audiências. Ora, na terceira geração será esta última categoria a privilegiada para a concepção das exposições. Há ainda outra inovação trazida por estes museus: como já não se trata apenas de exibir objetos para o público, mas de criar situações educativas e o contato da plateia com ideias e conceitos da ciência, se faz necessária alguma espécie de mediação entre o visitante e a exposição. Surgem aí os mediadores/monitores da "experiência museal" termo introduzido pelo jargão da Museologia, setor do conhecimento já bem consolidado a esta altura.

A tipologia de McManus não determina rigidamente um padrão linear de sucessão de museus de ciências do século XVI ao XX; pelo contrário, entende que nenhuma geração deixou de ser representada por novas instituições ao longo desta história, sendo que 
atualmente um mesmo museu pode apresentar características das três gerações. Ainda, este modelo concebe que as gerações teriam apresentado "estágios" de desenvolvimento. Por exemplo, um segundo estágio dos museus da primeira geração teria se iniciado a partir dos anos 1960, com uma maior preocupação com a atratividade das exposições não interativas. Gaspar (2006), no entanto, critica esta forma de se classificar os museus, por sua ênfase no critério da interatividade:

A meu ver, as relações entre visitante e museu que caracterizam a sua classificação por gerações decorrem muito mais das atribuições dadas à interação visitante-museu em razão dos pressupostos teóricos dos pesquisadores que fazem essa classificação do que algo que se possa efetivamente ser detectado (p. 34).

Citando Saunier (1988), Gaspar prefere classificar os museus de ciências de acordo com sua semelhança a um de três exemplares da América do Norte, tomados como modelos:

- O modelo do Exploratorium, museu de São Francisco, fundado em 1969 e fortemente baseado em experimentos interativos, sem instruções de operação;

- O modelo do Ontario Science Centre, em Toronto, inaugurado também em 1969, que combina os experimentos interativos com o apoio à educação escolar, mediante convênios e estímulos à frequência regular dos estudantes a suas instalações; e

- O modelo Epcot, acrônimo para Experimental Prototype of the Community of Tomorrow, centro da Flórida precursor dos parques de diversão voltados à ciência e à tecnologia, direcionado mais ao espetáculo e, nos termos de Gaspar, a uma visão hollywoodiana da ciência.

Caberia falarmos algo sobre os museus de ciências no Brasil. Este capítulo da história das ciências brasileiras conserva fatos interessantes (sobre os quais não haverá espaço, aqui, para tratarmos com atenção) e revela até certo pioneirismo em comparação com as iniciativas dos outros países. Assim, conforme Gaspar (1993), um dos museus de ciências mais antigos do mundo é o nosso Museu Nacional, criado em 1818, por D. João VI, como Museu Real. Seguiram-se a ele o Museu Paraense (1866) e o Museu Paulista (1894). Todos eles voltavamse prioritariamente para a atividade científica, até por haver à época poucas instituições, no território brasileiro, com algum caráter acadêmico. No século XX, destaca-se a criação do Museu Biológico do Instituto Butantan, em 1957, espaço reconhecido mundialmente por sua coleção permanente e viva de animais peçonhentos. 
Enquanto o mundo, polarizado pela Guerra Fria, assistia ao início do embate científico-tecnológico entre União Soviética e Estados Unidos, o Brasil criava, em 1950, o Instituto Brasileiro de Educação, Ciência e Cultura (IBECC). Esta instituição, vinculada à USP e à Unesco, orientou os diversos setores preocupados com a educação científica brasileira, incluindo os museus, a repensar suas atividades e desenvolver novas iniciativas. Graças ao IBECC, o Brasil antecipou-se às grandes potências do ocidente, que só viriam a criar instituições e projetos semelhantes ao final desta década de 1950 (KRASILCHIK, 1987).

Neste momento, no contexto mundial, a denominação "museu de ciências" começava a perder em popularidade para o termo "centro de ciências", talvez em decorrência de um preconceito que associou a palavra "museu" a "passado", "antiguidade", "velharia". O Brasil passa a contar também com seus "centros de ciências", emanados diretamente do IBECC. São instituídos seis deles, entre 1963 e 1965, em Minas Gerais, Bahia, Pernambuco, Rio Grande do Sul, Rio de Janeiro e São Paulo.

Embora essas instituições, eventualmente, tenham desenvolvido muitas atividades na área da difusão científica, não era esse o foco principal de sua atuação. Mas é inegável que elas e o IBECC tiveram um papel importante como pólos geradores de pesquisadores e de material para o ensino e para a divulgação da ciência e direta ou indiretamente estão ligados a todos os museus e centros de ciências criados no Brasil, desde então (GASPAR, 2006, p. 41-42).

Como veremos na próxima subseção, a produção de material instrucional para a educação básica, objetivo que remonta aos primórdios do IBECC e que se manteve vivo naqueles seis centros de ciências espalhados pelo país, exerceu uma influência inegável nas atividades do CDCC, especialmente em relação ao desenvolvimento da Experimentoteca.

A propósito, o CDCC é um dos tantos centros e museus de ciências criados no Brasil nos anos 1980, década "marcante", no dizer de Cazelli, Marandino e Studart (2003). Conforme lembram estes autores, surgem neste momento o Espaço Ciência Viva, no Rio de Janeiro; o Museu de Astronomia e Ciências Afins, também no Rio; a Estação Ciência, em São Paulo; e o Museu Dinâmico de Ciências de Campinas.

Podemos falar, a partir de agora, exclusivamente do CDCC.

Criado em 1980 como uma Coordenadoria de Divulgação Científica e Cultural da USP, surgiu respondendo aos educadores de São Carlos que, reunidos no I Simpósio de Integração Universidade-Escolas de $1^{\circ}$ e $2^{\circ}$ Graus em novembro de 1979 , ansiavam por uma maior colaboração entre universidades e profissionais da educação básica para a melhoria do ensino. Especificamente, educadores das áreas de ciências físicas e naturais requeriam apoio, 
por parte dos docentes universitários das áreas de Física, Química e Biologia - reunidos no então Instituto de Física e Química de São Carlos, da USP, e no Departamento de Ciências Biológicas, da UFSCar - para a instrumentação de seu ensino, tanto através do oferecimento de cursos de formação continuada na universidade, quanto pelo desenvolvimento de materiais e roteiros para atividades práticas (GASPAR, 1993, 2006; SCHIEL, 1998).

Inicialmente, $a \mathrm{CDCC}$ dispunha de um único funcionário e habitava apenas uma sala do prédio histórico da Società Dante Alighieri, alugado para as atividades iniciais da USP em São Carlos a partir de 1953. Em 1985, o prédio foi adquirido pela universidade (contando com recursos também da CAPES, do CNPq, da Finep e da Secretaria de Educação do Estado de São Paulo) com a finalidade de sediar um centro de ciências, já estando quase totalmente ocupado pela CDCC desde 1983 (SCHIEL, 1998; FERREIRA; SCHIEL, 2001) ${ }^{70}$.

Atualmente, a Coordenadoria, que se tornou Centro em 1995, abrange também um observatório astronômico (no atualmente chamado Centro de Divulgação da Astronomia Dietrich Schiel, localizado na área 1 do campus da USP de São Carlos) e mantém diversos espaços para a visitação na mesma sede, à Rua Nove de Julho, 1227, bem no centro do município (Figura 20). A Figura 21, por exemplo, mostra o Jardim da Percepção, a mais recente área expositiva do CDCC (inaugurada em 2006), que ocupa praticamente toda a parte externa do prédio. Há mais espaços para visitação no interior (o Espaço Vivo de Biologia e o Espaço de Física), que conta ainda como uma biblioteca pública, sala de informática, laboratórios científicos, salas de aula, auditório e as seções de estrutura e manutenção do CDCC.

\footnotetext{
${ }^{70}$ Informações sobre o prédio do CDCC, segundo a publicação Percursos, produzida pela Fundação PróMemória de São Carlos (2013): "Construído em 1908 por imigrantes italianos do norte da península para ser sede da Societá Dante Alighieri (fundada em 1902), sua arquitetura segue as linhas predominantes naquele período, bastante influenciadas pela imigração italiana. Originalmente o prédio tinha apenas um pavimento, sendo o segundo construído em 1921.

A Societá Dante Alighieri deixou de funcionar a partir da Segunda Guerra Mundial devido a retaliações à Itália, aliada da Alemanha nazista. Na década de 1950, o prédio foi cedido para a Escola de Engenharia de São Carlos, tendo abrigado seus cursos durante alguns anos. Em 1980, a USP instalou em suas dependências o CDCC."
} 


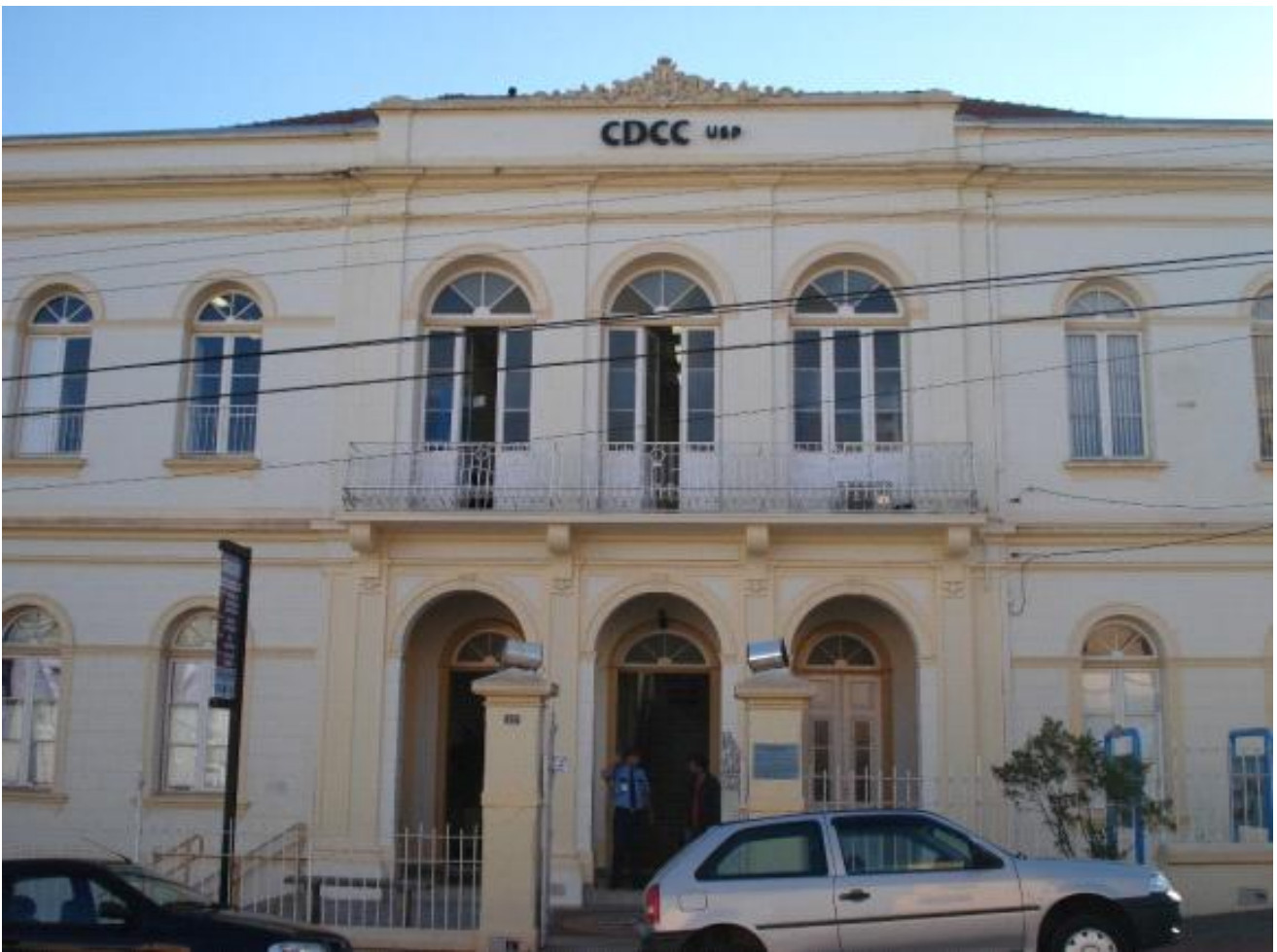

Figura 20: fachada do CDCC, à Rua Nove de Julho.

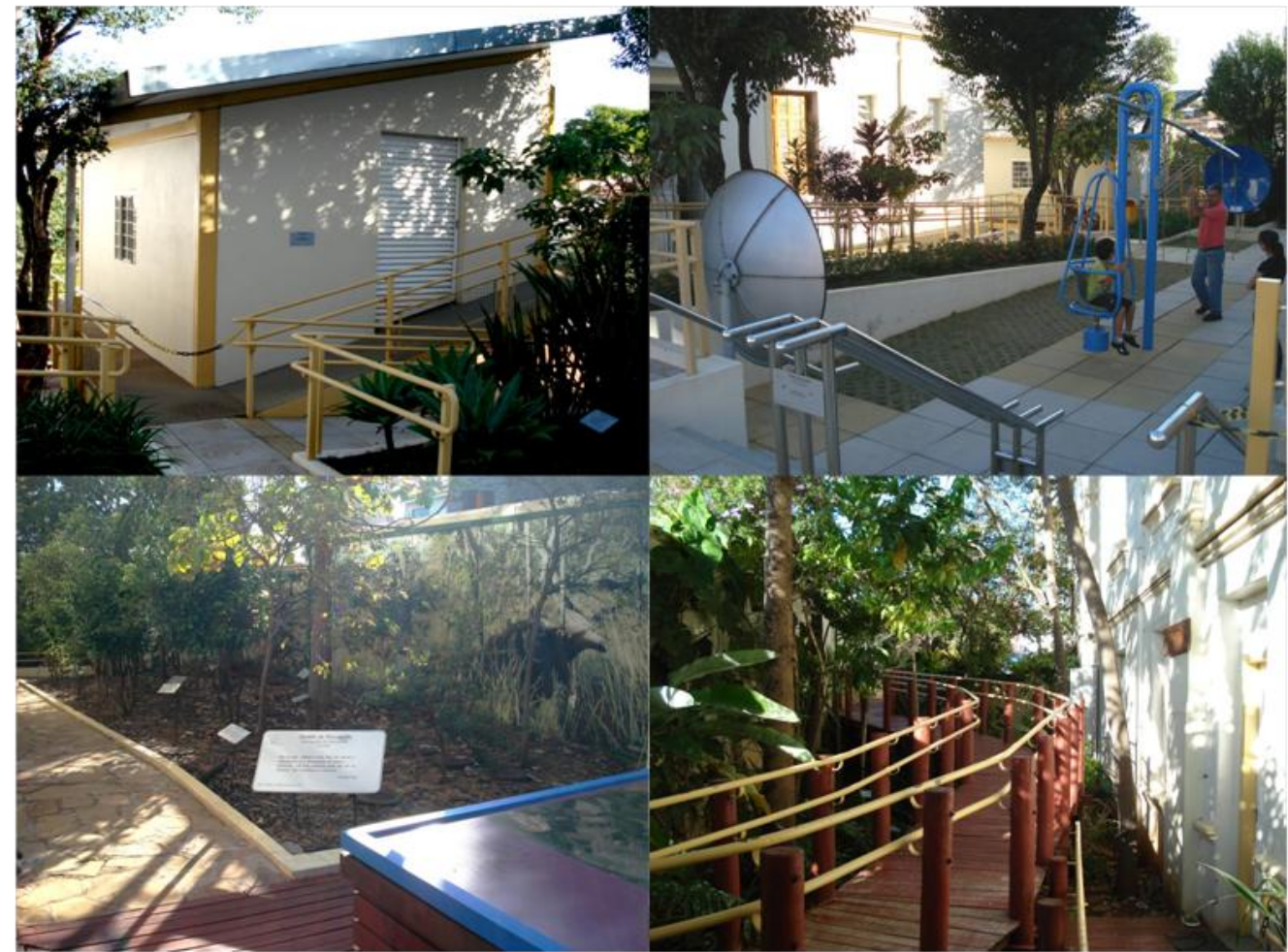

Figura 21: mosaico de fotos do Jardim da Percepção, na parte externa do prédio do CDCC. Em sentido horário, a Casa Maluca (percepção da vertical), visitantes utilizando o equipamento da alavanca (percepção da força) e os ambientes de imersão do cerrado e da mata de galeria (percepção do ambiente).

Além das exposições, o CDCC mantém uma série de atividades de apoio à educação básica. Na verdade, a atuação deste centro de ciências é, em sua maior parte, voltada para as 
ações educativas. De fato, no texto de descrição do CDCC (FERREIRA; SCHIEL, 2001) presente na coletânea Educação para a ciência: curso de treinamento em centros e museus de ciência, ao lado de 12 atividades elencadas como as de maior destaque do centro (excursões e projetos envolvendo educação ambiental; orientação, plantões de dúvidas e minicursos para alunos da educação básica; orientação técnico-científica e cursos para professores da educação básica; palestras e debates sobre Astronomia; cineclube; biblioteca e videoteca; atendimentos à distância), apenas um item trata da realização de exposições permanentes e itinerantes. Assim, justifica-se o seguinte comentário de Gaspar (2006, p. 46-47):

De acordo com a abordagem de Saunier, o CDCC é um centro de ciências que se aproxima do modelo do Centro de Ciências de Ontário, sobretudo por sua preocupação com o ensino formal. Aliás, essa é a sua preocupação básica, o que o distingue ligeiramente desse modelo, no qual o maior destaque é o museu, embora entendido também como elemento de apoio à educação formal. No CDCC, apesar de o museu ter sido continuamente incrementado e ampliado, ainda vale a opinião inicial do seu primeiro coordenador [...].

A opinião a que Gaspar faz referência se trata de uma declaração do Prof. Dietrich Schiel, registrada nas gravações de vídeo de um seminário proferido em 1991: “o museu [do CDCC] não é essencial, o museu é um chamariz". ${ }^{71}$

A exata dimensão da importância das ações educativas do CDCC, mais até do que a manutenção de seus espaços expositivos, pode ser apreendida pela análise de seu projeto de maior reconhecimento, impacto e difusão - a Experimentoteca.

\subsubsection{A gênese da Experimentoteca ${ }^{72}$}

Assim como a história dos museus e centros de ciências pode ser contada remontando a épocas em que estas instituições sequer existiam, a origem da Experimentoteca situa-se antes mesmo do próprio CDCC ser criado.

Lembremos que uma das missões do IBECC e dos centros de ciências originados a partir dele era o desenvolvimento de material instrucional em apoio à educação científica

\footnotetext{
${ }^{71}$ Manterei o uso de itálico para identificar depoimentos transcritos mesmo quando eles integrarem materiais consultados da literatura, e a despeito dos autores nem sempre realizarem tal identificação.

${ }^{72} \mathrm{O}$ leitor poderá encontrar muito material que caberia a esta subseção nos trabalhos revisados na próxima seção. Para não repetir as conclusões destas pesquisas, enfatizarei nesta subseção aspectos não ressaltados nelas, valendo-me também de parte do material que orientou a investigação apresentada no capítulo anterior.
} 
escolar básica. Gaspar (2006) fala sobre as iniciativas, em prol desta finalidade, desenvolvidas pelo IBECC em três décadas de atuação, que iremos apenas resumir neste parágrafo. Primeiramente, ainda na década de 1950, o IBECC criou o projeto Iniciação às Ciências, produzindo kits de experimentos para alunos da educação básica, contemplando assuntos de Física, Química e Biologia. Os kits continham todo o material para a execução dos experimentos, um manual com orientações e um folheto com leituras suplementares. Uma segunda etapa destas iniciativas pode ser identificada no engajamento do IBECC em traduzir e adaptar os projetos curriculares estadunidenses e ingleses, produzidos na transição da década de 1950 para a de 1960. Estes materiais, orientados de início pela pedagogia tecnicista, propugnavam o método da aprendizagem por redescoberta, através de atividades que pudessem levar à apreensão do método científico, geralmente baseadas na experimentação. A grande demanda pela produção de material experimental, por parte do IBECC, foi uma das razões que levou à criação da Fundação Brasileira para o Desenvolvimento do Ensino de Ciências (Funbec) em 1966. Gaspar afirma que, até o final da década de 1960, a parceria IBECC-Funbec originaria 15 projetos, alguns envolvendo a produção de kits experimentais, como a Coleção Mirim (30 kits) e a Coleção Cientistas de Amanhã (21 kits). Já na década seguinte, após a promulgação da Lei n. 5.692/1971, foram produzidas novas coleções de kits, um Laboratório Portátil de Física, Biologia e Química (projetado para a realização de experimentos em sala de aula) e o projeto Os Cientistas. Esta ação, datada de 1972, compreendeu a elaboração de 50 kits de material experimental vendidos em bancas de jornal, e é considerada por Gaspar "a mais importante iniciativa voltada à divulgação científica desenvolvida no Brasil até nossos dias” (ibidem, p. 43). Segundo ele, o primeiro volume da coleção vendeu cerca de 200.000 cópias, e as vendagens se estabilizaram, em volumes futuros, em cerca de 50.000 exemplares.

Impossível não se associar, portanto, a criação da Experimentoteca com a iniciativa pioneira e bem sucedida do IBECC em produzir massivamente materiais para a realização de experimentos didáticos, visando à universalização do método experimental. Certamente o projeto do IBECC exerceu enorme influência no que o CDCC viria a realizar anos mais tarde, justificando o comentário de Gaspar de que este centro é "Uma das instituições que podem ser consideradas como sucessoras ou continuadoras do IBECC [...]” (ibidem, p. 44).

Apesar disso, pode-se dizer que o embrião da Experimentoteca nasceu de reivindicações bastante concretas dos educadores de São Carlos, como demonstra o seguinte fragmento das atas do I Simpósio de Integração Universidade-Escolas de $1^{\circ}$ e $2^{\circ}$ Graus: 
Propõe-se a criação de um grupo de trabalho envolvendo físicos, químicos e biólogos para a elaboração de material para os cursos de ciências do primeiro grau [...] Propõe-se que o Instituto de Física e Química de São Carlos ofereça cursos de Instrumentação [...] cuja finalidade seja a preparação de um conjunto de protótipos e roteiros para os laboratórios nas escolas. Solicita-se que o Instituto de Física e Química de São Carlos estude a viabilidade da construção deste equipamento, devendo o mesmo ficar guardado em um almoxarifado central na cidade, a ser requisitado pelas escolas, quando necessário (SCHIEL, 1998, p. 189) ${ }^{73}$.

Esta "preparação de um conjunto de protótipos e roteiros para os laboratórios nas escolas" teve início, efetivamente, em 1984 (SCHIEL, 1998, 2001; SCHIEL; CURVELO; FERREIRA, 2004). O tempo de quatro anos passado entre a criação do CDCC e o início da principal atividade que motivou sua instalação, provavelmente, decorreu da necessidade primordial de se formar toda a estrutura física, organizacional e administrativa, da então Coordenadoria, antes de se partir para a realização de seus grandes projetos. Também, Schiel relata que o ano de 1984 assistiu ao crescimento das atividades do centro como um todo, o que foi motivado pelo surgimento do Programa de Aperfeiçoamento do Desenvolvimento Científico e Tecnológico (PADCT), apoiado pelo Banco Mundial:

\begin{abstract}
Graças à intercedência de Sérgio Mascarenhas, foi possível incluir nesse programa um Subprojeto de Educação para a Ciência (SPEC), base necessária para qualquer desenvolvimento científico e tecnológico. Isso fez com que pela primeira vez surgissem recursos institucionais para projetos auxiliares às Secretarias de Educação que não fossem meros trabalhos de pesquisa educacional, isto é, que aliassem à dimensão da pesquisa uma conotação de extensão universitária, com o propósito explícito de poder influenciar o ensino regular destinado a grandes populações estudantis (1998, p. 190).
\end{abstract}

Garantidos os recursos financeiros, a gênese da Experimentoteca, para finalmente se consumar, precisou ainda que a equipe do CDCC atacasse três ordens diferentes de problemas ou desafios: a questão operacional, a questão do design e a questão propriamente didáticopedagógica. São três questões que se imbricam profundamente e a ordem em que as apresentaremos, aqui, é meramente convencional: nenhuma se sucedeu cronologicamente a outra, pelo contrário, elas precisaram ser abordadas de modo concomitante.

A questão operacional diz respeito à própria filosofia orientadora da Experimentoteca. Se a ideia inicial do projeto foi instrumentalizar a prática dos professores de ciências de São Carlos, deveria ser concebida uma forma de se abastecer a educação científica do município com materiais didáticos de fácil acesso e utilização. A maneira como operacionalizar isto foi criar um sistema de empréstimo dos materiais desenvolvidos no CDCC, por sua equipe

\footnotetext{
${ }^{73}$ As supressões indicadas por “[...]” são do próprio Prof. Schiel.
} 
interdisciplinar de pesquisadores e técnicos. Assim, o CDCC deveria fornecer estes materiais aos professores da mesma maneira que uma biblioteca é capaz de prover de livros uma dada população, e vem daí o nome "Experimentoteca". Ao longo dos anos, esta questão operacional foi acrescida de outras saídas práticas que vieram a potencializar a viabilidade do projeto em São Carlos. Podemos mencionar, entre estas saídas, a alocação do setor responsável pela Experimentoteca, num primeiro momento, em uma das salas do subsolo do prédio do $\mathrm{CDCC}$, muito próxima à garagem da instituição, facilitando o carregamento de veículos com os kits para seu transporte até as escolas; e posteriormente, a transferência deste setor para uma casa vizinha ao CDCC, alugada pela USP, permitindo a centralização do trabalho relacionado à Experimentoteca em um único local, sem prejuízos para a mencionada facilidade de acesso aos transportes (Figura 22). Ainda, isto possibilitou melhores condições para a manutenção constante dos kits, exigida pela elevada quantidade de usuários, e por haver muitos materiais de consumo que necessitam ser repostos a cada uso (por exemplo, os reagentes, no caso dos kits de Química).

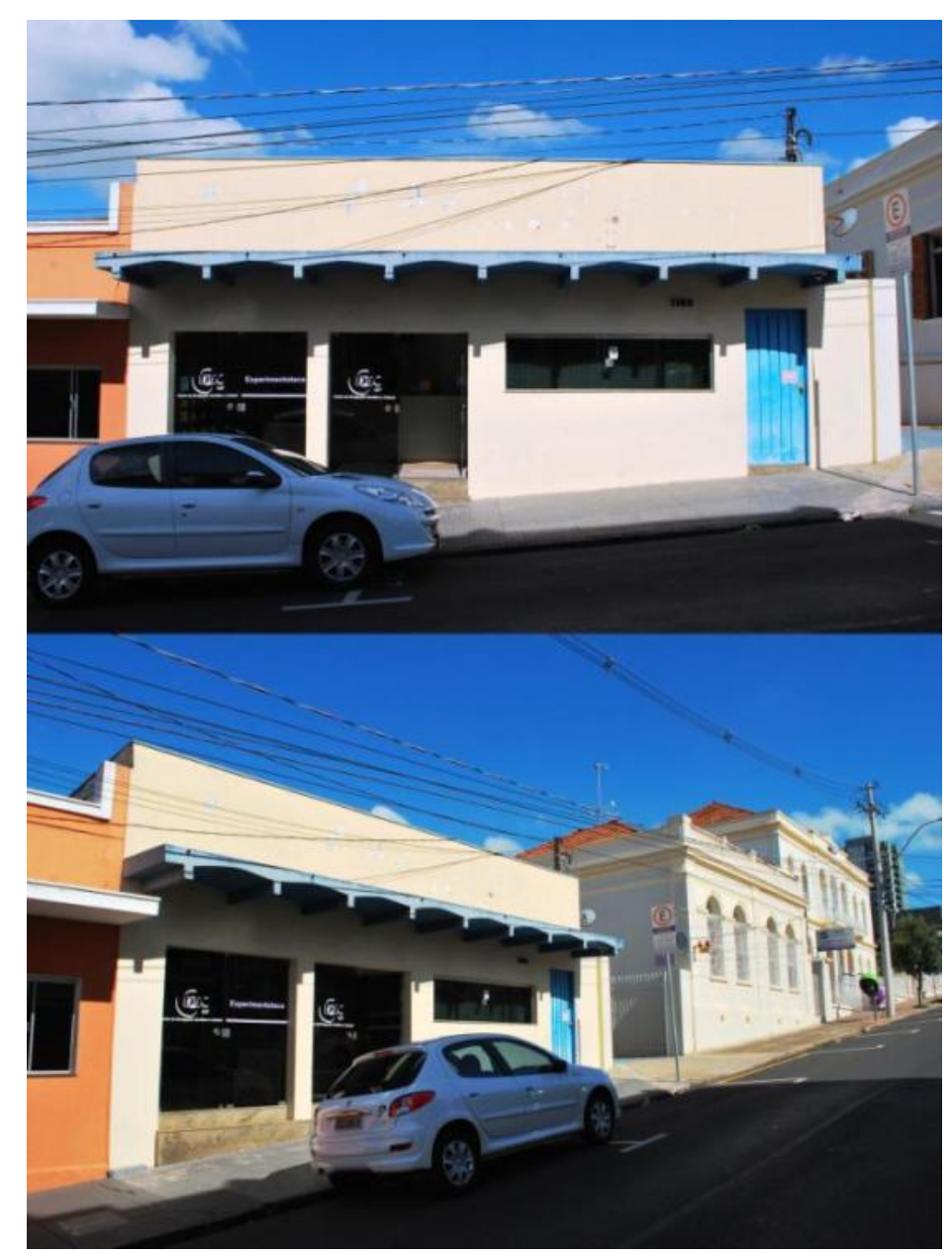

Figura 22: mosaico com fotos da fachada da casa onde funciona o setor do CDCC responsável pela Experimentoteca (Fonte: José Braz Mania). 
A questão do design é aquela cuja resolução levou a resultados mais imediatamente apreensíveis pelos usuários da Experimentoteca. A necessidade de produzir um material didático para uso não apenas de professores em demonstrações, mas pelos próprios alunos em acordo com uma concepção pedagógica crítica ao ensino tradicional - levou a Experimentoteca a se constituir como um conjunto de kits para o trabalho experimental de equipes ou grupos de alunos. Para isso, além de cada kit necessariamente conter material suficiente para cerca de 10 grupos de quatro estudantes utilizarem simultaneamente (considerando um máximo de 40 estudantes por sala de aula, nas salas das escolas públicas da educação básica), deveriam ser encontradas maneiras de dispô-lo de modo otimizado em seus "recipientes". As primeiras tentativas de se viabilizar a ideia, como relata Schiel, entrevistado por Luisa Massarani e Fabio Gouveia em novembro de $2002^{74}$, foram marcadas pela modéstia e pelo improviso:

Começamos pela $5^{a}$ série. Tínhamos dois professores bolsistas do PADCT, além da nossa equipe e monitores. O kit era um material improvisado, colocado em uma caixa de sapato. Ali havia experimentos de biologia, física e química. Colocávamos, como fazemos até hoje, mais exemplares de cada experimento para os alunos terem acesso (SCHIEL, [200-], não paginado).

Com o passar do tempo, o projeto foi se sofisticando. Como relata Schiel na mesma entrevista, no início da década de 1990 o design dos kits foi repensado, de modo a se tornar menos amador, a partir de uma parceria com Christian Folz, engenheiro da Faber Castell (indústria que possui sede em São Carlos). No trabalho "Projeto Experimentoteca: a contribuição do design" (SCHIEL; CURVELO; FERREIRA, 2004), os autores relatam as soluções adotadas para a armazenagem dos materiais experimentais em caixas de madeira facilmente transportáveis por apenas uma pessoa - o que se tornou uma das "marcas registradas" da Experimentoteca -, baseadas em preceitos do campo do design industrial. Entre estes preceitos estão a subordinação da relação forma/conteúdo à qualidade estética, à satisfação do usuário, à possibilidade de produção em série, aos custos e, obviamente, ao perfeito atendimento às finalidades a que o produto se propõe. Assim,

A produção em série foi sempre uma necessidade tendo em vista o público alvo da Experimentoteca (alunos do Ensino Fundamental). O custo foi outro fator preponderante, visto a extensão da Escola Pública em nosso país e a própria necessidade de atingir o maior número de usuários. A concepção da Experimentoteca, como um equipamento a ser disponibilizado para diferentes

\footnotetext{
${ }^{74}$ A entrevista integra a iniciativa do Brasiliana, o sítio da internet dedicado a mapear a história da divulgação científica no Brasil, mantido pelo Museu da Vida da Fundação Oswaldo Cruz.
} 
usuários por meio de Centros de Ciências (como uma biblioteca) exigiu esforços na escolha de materiais que assegurassem qualidade, resistência e segurança para o estudante usuário. $\mathrm{O}$ atrativo visual e estético foi igualmente considerado, de forma a cativar o estudante e seus professores. Ainda que o estudante usuário não seja um comprador da Experimentoteca, sua satisfação como cliente-usuário foi um compromisso constante na elaboração dos experimentos e do produto final. Considerando-se ainda o ponto de vista educacional, a Experimentoteca foi concebida com ênfase aos fenômenos objetos do projeto instrucional, onde o equipamento e os materiais devem garantir uma montagem fácil e não ocupar, além do necessário, o tempo dos usuários, o qual dever [sic] ser dedicado à realização e análise dos experimentos propostos (ibidem, p. 151).

Na Figura 23, apresentamos algumas fotos do design da Experimentoteca em seus primeiros anos de existência. Repare no uso de isopor para acondicionar os componentes dos kits no interior das caixas.

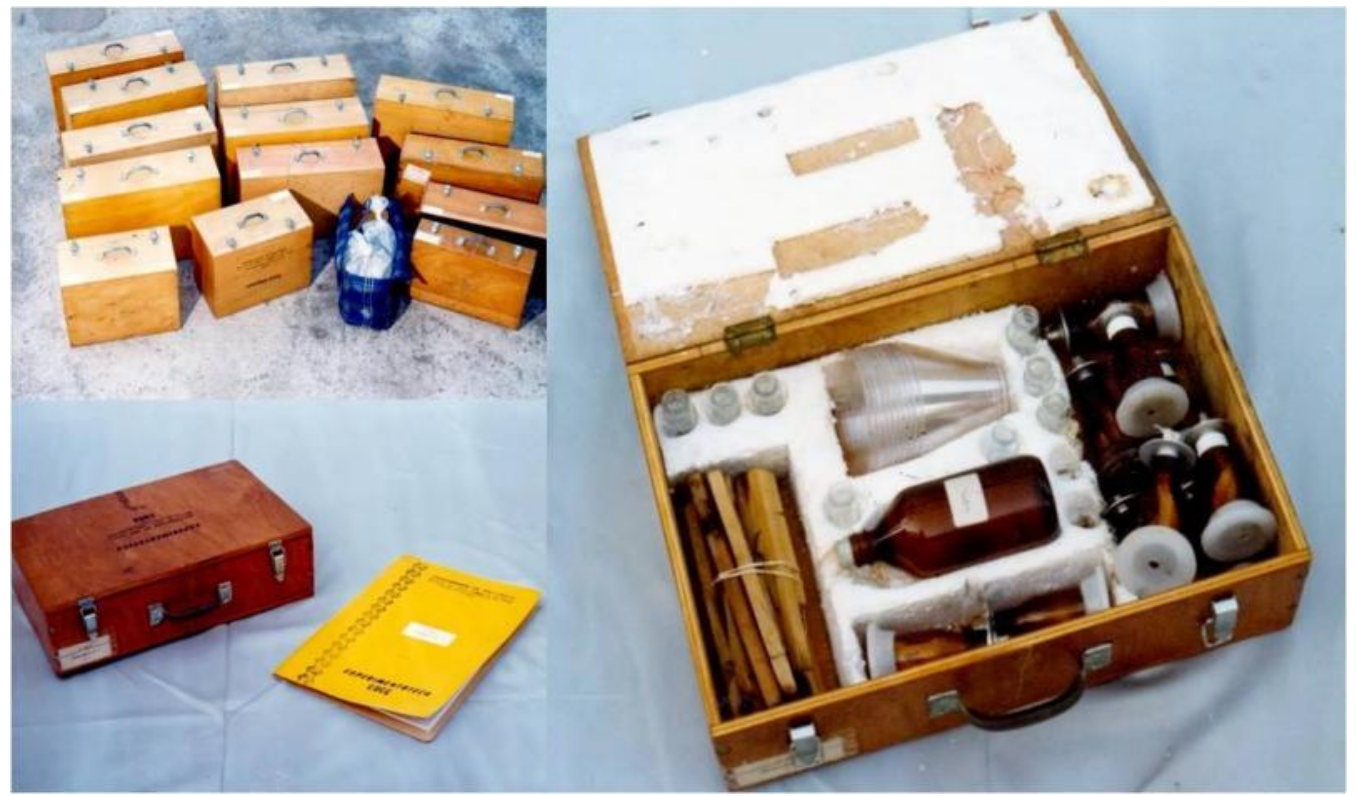

Figura 23: mosaico com fotos da Experimentoteca em uma de suas primeiras versões (SCHIEL, 1991).

Já na Figura 24, são exibidos os aspectos interno e externo da Experimentoteca, conforme seu design atual. As divisórias internas já não são feitas de isopor, garantindo não somente a organização dos materiais, como também a segurança dos mesmos durante o transporte e armazenamento", e "as tampas das caixas são também empregadas para condicionar, em sua parte interna, os roteiros impressos das experiências que podem ser realizadas a partir dos materiais contidos nas caixas" (ibidem, p. 152). Na Figura 25, há fotos do interior de alguns kits destinados ao ensino fundamental. 

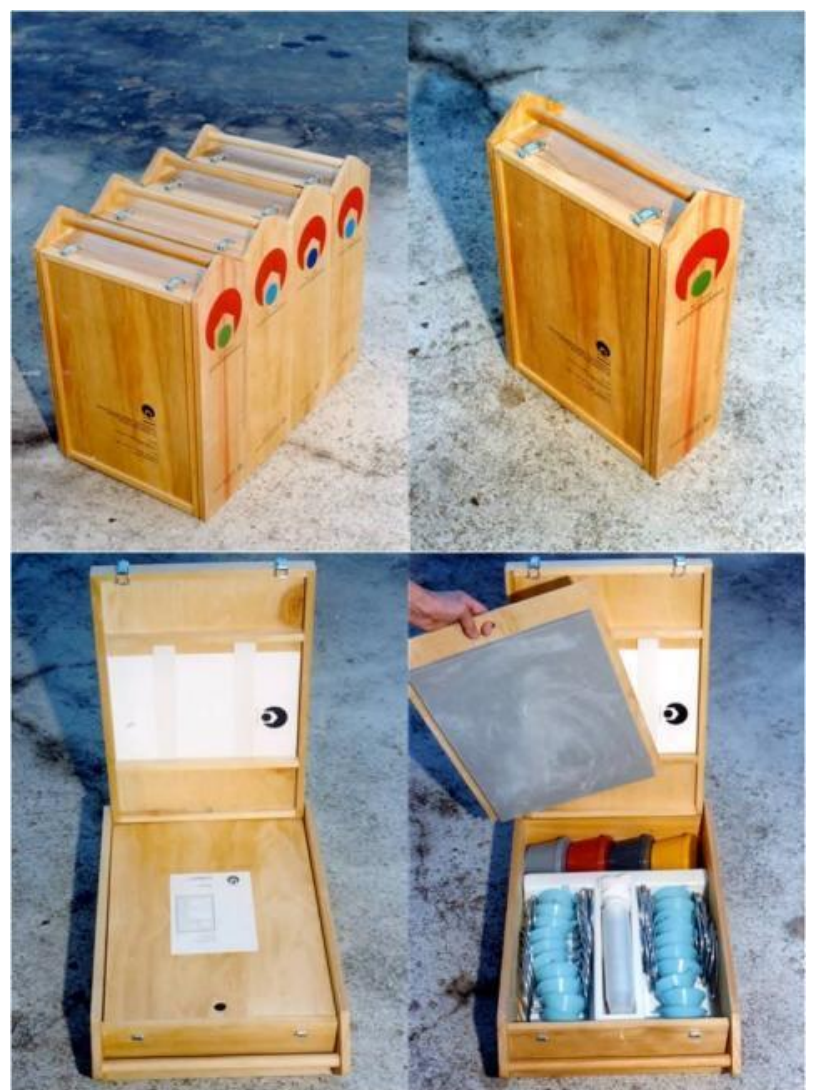

Figura 24: mosaico com fotos do interior e do exterior do design atual da Experimentoteca (SCHIEL, 1991).

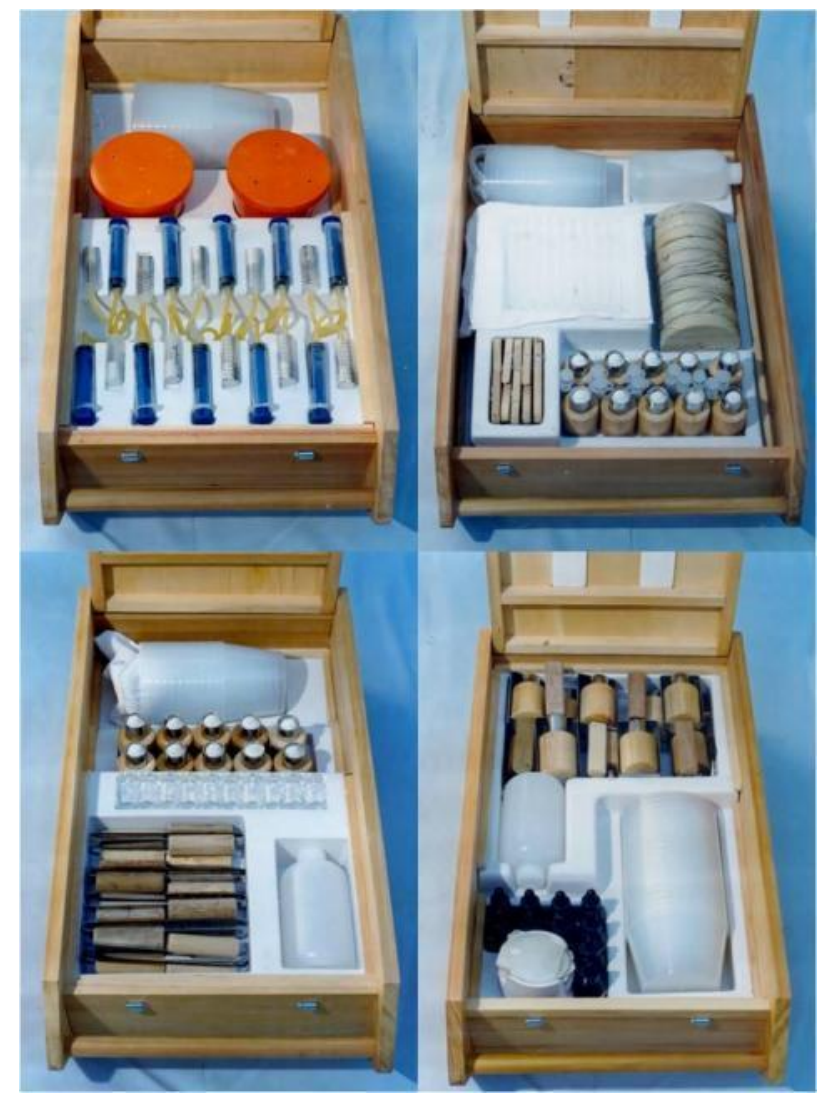

Figura 25: mosaico com fotos da disposição dos materiais em kits para o ensino fundamental (SCHIEL, 1991). 
Finalmente, há a questão didático-pedagógica propriamente dita, que se impôs mais fortemente nos momentos iniciais da concepção do projeto: desde a própria ideia que motivou a criação da Experimentoteca, discutida pelos professores reunidos no I Simpósio de Integração Universidade-Escolas de $1^{\circ}$ e $2^{\circ}$ Graus, até os primeiros anos de sua existência, em que foram produzidos e testados os primeiros protótipos de materiais. Schiel, falando sobre o modo como a equipe do CDCC se confrontou pela primeira vez com este desafio, argumenta:

A Experimentoteca foi concebida como um meio auxiliar para o ensino de ciências, aliada a leitura, discussões, visitas e a própria aula expositiva. Isso significa que o programa em si não constitui um programa didático mas, como qualquer meio auxiliar, possibilita a criação de maneiras adequadas utilizadas pelo professor (2001, p. 261).

É evidente que material de laboratório não dá aula, assim como filmes didáticos e software também não o fazem. Para que material colocado à disposição do professor seja realmente útil no processo educativo do aluno há necessidade de uma proposta pedagógica clara, além de uma proposta para a operacionalidade do uso. Parece incrível que, por mais triviais que sejam essas colocações, elas sejam tão pouco levadas em conta no projeto de material instrucional comercial (1998, p. 192).

Para elaborar esta proposta pedagógica, lidando ao mesmo tempo com as outras duas questões que necessitavam ser equacionadas - como dissemos, a questão operacional e a questão do design - Os idealizadores da Experimentoteca investiram cerca de cinco anos em ciclos de desenvolvimento/aplicação/investigação/novo desenvolvimento dos materiais, até a finalização dos kits para o ensino fundamental. Um dos membros da equipe original que planejou a Experimentoteca, e que entrevistamos durante a coleta dos dados apresentados no capítulo anterior, fala sobre este momento:

Eu participei disso [da Experimentoteca] de todas as etapas, desde a criação, a definição de temas, a elaboração do material, testes, né... Nós fizemos a testagem em escolas, aqui em São Carlos, deste material. Na verdade tem uma pesquisa, em paralelo, no desenvolvimento da Experimentoteca, que é pra ver aspectos didáticos mesmo. Então é assim: não adianta você pensar num kit, pensar num experimento se não sabe como isso vai funcionar em sala de aula, se de fato o aluno aprende, se o professor tem dificuldade, etc. Isso tudo caminhava em paralelo, né, dentro de um projeto grande que é a Experimentoteca (e1).

No entender deste pesquisador, o projeto Experimentoteca - ou melhor, o Projeto, com " $p$ " maiúscula - se restringiu apenas a este momento; daí suas declarações, que já reproduzimos no capítulo anterior, de que "O Projeto Experimentoteca acabou. Não a Experimentoteca, ela continua, com aportes cada vez mais fortes, mas o Projeto [...] que tinha a equipe inteira trabalhando no desenvolvimento, no teste nas escolas, esse projeto acabou, não existe mais." 
Schiel, Curvelo e Ferreira (2004) explicam a importância desta fase de testes para a constituição dos kits:

A participação dos professores exerce um papel importante não somente na utilização do material didático, mas também na concepção desse mesmo material. A metodologia do projeto Experimentoteca prioriza ações de intervenção na escola que estejam baseadas na aprendizagem ativa/participativa por meio de atividades cooperativas/interdisciplinares, pois os resultados de pesquisa na área de educação têm mostrado que a simples introdução de inovações tecnológicas, sem a fundamentação teórica/metodológica inerente, é infrutífera e ineficiente. [...] Uma maneira de minimizar esse fator de resistência para a adoção e difusão de propostas inovadoras na educação é envolver os professores na fase de concepção do projeto e, posteriormente, na difusão dos mesmos, dando ao material produzido uma feição articulada com o cotidiano escolar (p. 150-151).

De qualquer forma, quando o CDCC decidiu expandir a Experimentoteca, que até os anos 1990 era proposta apenas para as séries finais do ensino fundamental, de modo a cobrir tópicos do currículo do ensino médio, o Projeto foi retomado. Outra característica do trabalho de concepção e teste dos kits é que a equipe responsável necessariamente teria de envolver profissionais de diversas áreas:

eu participava, não só na Química - eu coordenava toda a parte da Química -, mas também nas outras áreas. Isso era legal, que a equipe era bem interdisciplinar. Então é assim, eu trabalhava também os kits de Física, de Biologia e etc., e eu me dedicava muito ao de Química, aí eu tinha a equipe própria que trabalhava... [...] o CDCC é muito legal porque, principalmente quando eu tava lá, eu não via muita separação nas atividades por área. Você tem liberdade de atuar de maneira multidisciplinar mesmo. É assim... multi e interdisciplinar. Que é assim, os projetos normalmente eles pegam mais de uma área. Então tem projeto que ele próprio pega Física, Química, Biologia, Matemática e tal. É... então ele é multidisciplinar. Mas a equipe trabalha interdisciplinarmente. Você, mesmo sendo químico, você tem participação lá na Biologia e entra nisso, desenvolve alguma coisa, e é algo que também ajuda na Química e por aí vai (e1).

Especificamente, Schiel, Curvelo e Ferreira (2004) resumem os resultados dos esforços coletivos de uma gama ampla e diversificada de profissionais para a constituição da Experimentoteca do ensino médio, ressaltando pontos já levantados nas outras declarações que vimos reproduzindo:

O programa Experimentoteca para o Ensino Médio foi desenvolvido durante 10 anos e passou por diferentes fases de aprimoramento. As soluções e propostas apresentadas foram ensaiadas na prática antes das definiçõos finais de projeto. $\mathrm{O}$ uso por professores e alunos, usuários finais do produto, levou a alterações tanto no conteúdo como no design de diferentes peças e materiais. Paralelamente ao andamento das operações-piloto, foram desenvolvidos os ensaios visando a produção dos materiais aprovados em grande escala. 
Essa dinâmica levou à participação de mais de uma centena de profissionais, incluindo não somente a equipe do CDCC, mas também professores dos Ensinos Fundamental e Médio e colaboradores especialistas em diferentes áreas técnicas. A multidisciplinaridade foi vivenciada na prática, e o perfeito entrosamento entre diferentes profissionais foi uma das razões para o sucesso do Projeto Experimentoteca (p. 153).

O conjunto dos depoimentos acima demonstra inequivocamente, portanto, que a Experimentoteca não se trata apenas de um projeto de provimento de materiais didáticos para a educação científica escolar. Por ter envolvido em sua concepção o empenho de profissionais vindos de diversos setores do conhecimento, com destaque para a participação de professores e alunos da educação básica como avaliadores dos protótipos, a Experimentoteca se apresenta como uma iniciativa que condensa anos de práxis educacional, materializando as vivências de um grande conjunto de educadores brasileiros dedicados ao ensino das ciências.

\title{
5.1.3 A Experimentoteca hoje
}

Nas palavras de Schiel, atualmente "A Experimentoteca é um laboratório para uso em sala de aula projetado e aplicado por um Centro de Ciência” (2001, p. 261). Ou, mais precisamente,

\begin{abstract}
A Experimentoteca é um laboratório de ciências que pretende racionalizar o uso de material experimental, da mesma maneira que uma biblioteca pública facilita o acesso de um público extenso a um grande número de publicações. Nos locais onde a Experimentoteca entrou em uso ela é sediada em centros de ciências, prefeituras municipais, institutos universitários que mantém convênio com autoridades educacionais. Um mesmo acervo circulante atende simultaneamente de vinte a trinta escolas, e mais de 4.000 alunos por ano podem usá-lo (idem, 1998, p. 193).
\end{abstract}

Segundo informações no sítio na internet do CDCC, a Experimentoteca para o ensino fundamental se encontra disseminada para 31 universidades, centros e museus de ciências em diversos estados do Brasil (CENTRO DE DIVULGAÇÃO CIENTÍFICA E CULTURAL, [200-]). Schiel fornece alguns detalhes sobre o processo que levou à difusão da iniciativa:

Na primeira fase da Experimentoteca, atingíamos a comunidade de São Carlos. Mas logo surgiu uma demanda grande em outras cidades. Professores das cidades vizinhas e grupos nacionais que trabalhavam na renovação da educação pediam que déssemos oficinas e palestras. Então tentamos montar um projeto nacional de disseminação. Isso foi em 1990. A gente conseguiu apoio do governo, do novo 
PADCT, mas o dinheiro não saía. Conseguimos finalmente apoio da Vitae, que nos possibilitou desenvolver um projeto nacional, atingindo mais de 20 cidades ([200-], não paginado).

De 1984 a 1989 foram colocados à disposição dos professores de São Carlos sessenta kits para a experimentação em sala de aula. $\mathrm{O}$ sucesso foi considerável não só os professores de São Carlos passaram a usar sistematicamente o sistema, como começamos a receber convites de todos os cantos do país para treinar professores com o nosso material. A partir disso surgiu a idéia do projeto de disseminação para outros centros. Esse projeto teve apoio não só do PADCT quanto decisivamente da Vitae - apoio considerável numa época (1991) em que todos e quaisquer recursos de fomento no país estiveram congelados e inacessíveis (1998, p. 192).

$\mathrm{Na}$ entrevista a Massarani e Gouveia em 2002, Schiel fornece mais detalhes sobre a colaboração da Fundação Vitae (que encerrou suas atividades no Brasil em 2005) e sua importância para a disseminação da Experimentoteca:

A Vitae surgiu em 1985, com três linhas de fomento: educação, cultura e promoção social. Eles começaram financiando projetos na área de cultura. Quando conversaram comigo, estavam iniciando a linha de educação. Na época, os recursos permitiram a implantação da Experimentoteca em 20 cidades do país, do Pará a Santa Catarina. Foi um sucesso! Apareceu nos jornais. [...] Escolhemos centros que já haviam nos convidado para dar oficinas. Ficamos em contato com esses espaços. Quando recebemos os recursos da Vitae, mandamos os nossos kits para eles. Usamos também um critério pessoal. Mandamos para alguns lugares onde achávamos que havia uma liderança legal para desenvolver o projeto (idem, [200-], não paginado).

Conforme explicam Schiel, Curvelo e Ferreira (2004), a propriedade intelectual da Experimentoteca se encontra resguardada por patente ${ }^{75}$. No mesmo trabalho, os autores explicam e ilustram as diferenças existentes entre as versões comercializável e não comercializável do projeto. Novamente, na entrevista acima referida, Schiel explica os motivos que levaram à decisão de criar a patente, respondendo à pergunta "O projeto da Experimentoteca tem retorno financeiro?":

Teve um tempo em que a gente vendia bem, mas percebemos que estávamos extrapolando os limites da proposta da universidade. Ela não deve produzir industrialmente. No início, produzíamos apenas para responder a uma pequena demanda. Depois que o negócio cresceu, enfrentamos até mal pagador. E não é nosso papel ficar cobrando. A indústria sim tem esse perfil. Resolvemos então patentear a Experimentoteca, seguindo o procedimento legal. Fizemos uma licitação pública e uma empresa de Curitiba, Brinkmobil, ganhou (SCHIEL, [200-], não paginado).

\footnotetext{
${ }^{75}$ À época do relato destes autores, a patente estava licenciada para a empresa privada Brink Mobil (como registrará o depoimento de Schiel), que comercializava os kits e transferia os royalties à USP. Expirado este contrato, um novo foi celebrado em 2013 com outra empresa, a Central do Saber.
} 
Além de sua difusão para outros territórios, é possível afirmar que a Experimentoteca, em termos de sua proposta e seu modelo de funcionamento, se alastrou para ao menos outro programa desenvolvido no próprio CDCC: trata-se do ABC da Educação Científica - Mão na Massa. O projeto iniciou-se na década de 1990 com o programa estadunidense "Hands On" proposto por Leon Lederman (Prêmio Nobel de Física), estendendo-se à França em 1995 com o apoio de Georges Charpak (outro Prêmio Nobel de Física), onde adotou a denominação "La Main à la Pâte”. Aportou ao Brasil em 2001 como atividade de cooperação entre as academias de ciências brasileira e francesa, conduzida inicialmente em escala piloto por três centros, a Estação Ciência, a Fundação Oswaldo Cruz e o CDCC. O Mão na Massa apresenta uma metodologia para o ensino de ciências baseada na investigação, com grande ênfase na educação infantil e nas séries iniciais do ensino fundamental. O programa preconiza a realização de atividades diferenciadas em sala de aula, priorizando a discussão, o planejamento, a experimentação e a observação, articulando a aprendizagem do conhecimento científico com o desenvolvimento das expressões oral e escrita. Em São Carlos, as atividades do programa envolvem "cursos de formação continuada [de professores], mostras de trabalhos, produção de material didático e adaptação de material de apoio" (SCHIEL; ORLANDI, 2009, p. 9). Especificamente quanto a este trabalho de produção de material didático, incorporou-se ao Mão na Massa o desenvolvimento de kits semelhantes àqueles da Experimentoteca, estando hoje disponíveis aos professores, também por um sistema de empréstimo, seis deles. Os temas dos kits são apropriados ao ensino de noções elementares das ciências para os anos iniciais da escolarização: "Diagnóstico ambiental”, "Estados físicos da água", "Flutua ou afunda", "O céu e a terra", "Órgãos dos sentidos" e "Resíduos sólidos". Na Figura 26 apresentamos fotos dos kits "Flutua ou afunda" e "Estados físicos da água".

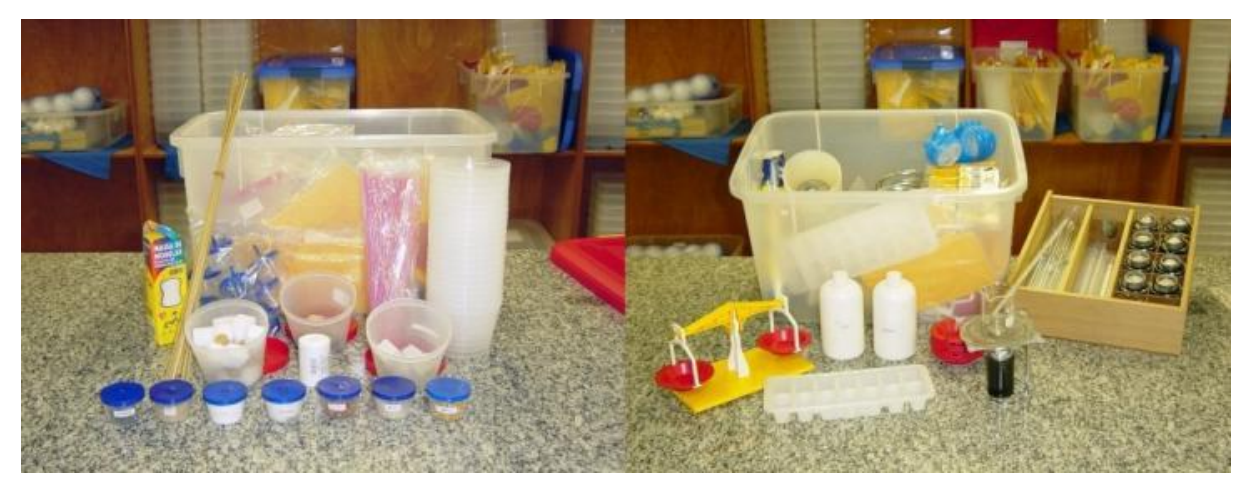

Figura 26: fotos de dois kits de material desenvolvidos pelo CDCC para o Mão na Massa (CENTRO DE DIVULGAÇÃO CIENTÍFICA E CULTURAL, [200-]). 
A propósito, a Experimentoteca é composta atualmente por 102 conjuntos temáticos, 64 para o ensino fundamental e 38 para o médio. Os kits de ciências para o ensino fundamental estão agrupados em quatro eixos, que remetem à sequência em que os conteúdos são tradicionalmente ensinados na disciplina de Ciências do $6^{\circ}$ ao $9^{\circ}$ ano: Ar, Água e Solo; Seres Vivos; Corpo Humano; e Física e Química. Há ainda um eixo que abarca filmes a serem exibidos em sala de aula, todos com temas de Biologia, e eixo recente de Matemática. Já os kits para o ensino médio estão agrupados conforme as disciplinas Biologia, Física e Química, também havendo um conjunto mais recente de Matemática. No quadro da Figura 27 apresentamos a relação completa dos kits para o ensino de Química, nos níveis fundamental e médio. Nos materiais para o ensino médio os conteúdos abrangidos pelos temas aparecem discriminados na forma de subtemas, também expostos no quadro.

\begin{tabular}{|c|c|c|}
\hline Nivel de ensino & Tema do kit & Subtema \\
\hline \multirow{7}{*}{$\begin{array}{l}\text { Ensino } \\
\text { fundamental }\end{array}$} & 1. Dimensão do átomo & \multirow{7}{*}{ - } \\
\hline & $\begin{array}{l}\text { 2. Processos físicos/processos } \\
\text { químicos }\end{array}$ & \\
\hline & 3. Separação de misturas & \\
\hline & 4. Eletrólise da água & \\
\hline & 5. Ácidos e bases & \\
\hline & 6. Noções de concentração & \\
\hline & 7. Estequiometria & \\
\hline \multirow{9}{*}{ Ensino médio } & $\begin{array}{l}\text { 1. Compostos iônicos e compostos } \\
\text { moleculares }\end{array}$ & $\begin{array}{l}\text { 1.1. Polaridade } \\
\text { 1.2. Ponto de fusão } \\
\text { 1.3. Condução de corrente elétrica }\end{array}$ \\
\hline & 2. Reações químicas I & 2.1. Reação de síntese e Reação de decomposição \\
\hline & 3. Reações químicas II & 3.1. Reação de simples troca e Reação de dupla troca \\
\hline & 4. Soluções & $\begin{array}{l}\text { 4.1. Solubilidade } \\
\text { 4.2. Solubilidade e temperatura } \\
\text { 4.3. Soluções saturadas, insaturadas e supersaturadas }\end{array}$ \\
\hline & 5. Cinética química & $\begin{array}{l}\text { 5.1. Temperatura } \\
\text { 5.2. Superfície de contato } \\
\text { 5.3. Concentração } \\
\text { 5.4. Catalisador } \\
\text { 5.5. Inibidor }\end{array}$ \\
\hline & 6. Eletroquímica & $\begin{array}{l}\text { 6.1. Reatividade de metais } \\
\text { 6.2. Pilha de Daniell } \\
\text { 6.3. Galvanização }\end{array}$ \\
\hline & 7. Bioquímica - Proteínas & $\begin{array}{l}\text { 7.1. Coagulação de uma proteína } \\
\text { 7.2. Albumina e Caseína } \\
\text { 7.3. Desnaturação de proteína com solvente orgânico }\end{array}$ \\
\hline & $\begin{array}{l}\text { 8. Química orgânica - Reação de } \\
\text { oxidação }\end{array}$ & $\begin{array}{l}\text { 8.1. Obtenção e oxidação de acetileno } \\
\text { 8.2. Oxidação de materiais orgânicos } \\
\text { 8.3. Identificando o gás produzido na combustão de } \\
\text { materiais orgânicos } \\
\text { 8.4. Bafômetro }\end{array}$ \\
\hline & 9. Polímeros & 9.1. Identificação de polímero \\
\hline
\end{tabular}

Figura 27: quadro com a relação dos temas e subtemas dos kits da Experimentoteca para o ensino de Química. 
As possibilidades de trabalho com os kits não estão restritas àquelas indicadas nos roteiros experimentais que acompanham as caixas de madeira. Além de adaptações que os próprios professores podem vir a desenvolver no momento de utilizar a Experimentoteca, existem as propostas e variações apresentadas n'O livro da Experimentoteca (TOMAZELLO; SCHIEL, 2000). Esta obra, publicada em dois volumes, se apresenta como mais um material de apoio ao professor, e busca complementar e embasar teoricamente o rol de atividades passíveis de serem instrumentalizadas com o projeto do CDCC. O próximo capítulo desta tese, inclusive, será dedicado a, entre outras discussões, comentar e analisar o conteúdo desta publicação.

Iniciemos agora mais uma seção, dedicada a revisar o que a literatura tem registrado sobre a Experimentoteca.

\subsection{O QUE SABEMOS SOBRE A EXPERIMENTOTECA}

Apesar de estar completando, neste ano de 2014, já 30 anos de existência, muito pouco se produziu a respeito da Experimentoteca em termos de pesquisas acadêmicas.

Uma busca na literatura pelos verbetes "Experimentoteca" e "CDCC" gera como resultados praticamente apenas pesquisas educacionais sobre situações em que, por comodidade ou familiaridade, tais kits foram empregados sem, contudo, terem se constituído como objeto de investigação. Já a busca apenas pelo termo "Experimentoteca" revela que esta palavra pode ter se "dicionarizado". São encontrados trabalhos diversos em que se utilizou ou se desenvolveu algum tipo de acervo itinerante de materiais experimentais, sem menções à iniciativa do CDCC e sem vínculos com as atividades da USP.

Genuinamente, há apenas três pesquisadores que desenvolveram trabalhos, em nível de pós-graduação, em que a Experimentoteca é tomada como objeto central. Os autores, que produziram dissertações de mestrado na área de Educação - mais especificamente, no Programa de Pós-Graduação em Educação da UFSCar -, são Renato Eugênio da Silva Diniz, Célia Lusia Martinelli Joaquim e Renata Pereira Canales. Descrevamos e analisemos seus trabalhos, seguindo esta ordem.

A dissertação de Renato Diniz se intitula A experimentação no ensino de ciências no $1^{o}$ grau: analisando a Experimentoteca de $7^{a}$ série. Orientado pela Prof. Maria da Graça 
Nicoletti Mizukami, sob co-orientação da Prof. Maria Lúcia Vital dos Santos Abib, o trabalho foi entregue em 1992 e divide-se em quatro capítulos.

No primeiro capítulo Diniz faz um apanhado da história do ensino de ciências no Brasil, sob o recorte das concepções e práticas envolvendo atividades experimentais. Realiza um olhar para a legislação vigente nos diferentes momentos históricos da educação brasileira, com especial atenção para as Leis de Diretrizes e Bases n. 4.024/1961 e n. 5.692/1971, e para as propostas curriculares oficiais decorrentes delas. A seguir, analisa as diferentes perspectivas e concepções sobre a experimentação expressas tanto nestes documentos oficiais, quanto na literatura sobre a educação científica. As muitas menções a nomes brasileiros, entre os autores citados, provam que o campo da Educação em Ciências já se apresentava bem estabelecido no início da década de 1990, sendo destacados por Diniz os nomes de sua coorientadora Maria Lúcia Abib, de Myriam Krasilchik e de Hilário Fracalanza. A partir desta revisão o autor explicita um posicionamento construtivista, em nítida contraposição à pedagogia tecnicista e à aprendizagem por redescoberta. Lembremos que, no caso da experimentação no ensino de ciências, estas concepções haviam redundado em certa "glorificação" de um pretenso método científico e no predomínio de uma visão empiristaindutivista sobre o fazer científico, conforme resumimos no quadro da Figura 10.

O capítulo seguinte se inicia remetendo o leitor a resultados reportados pela Prof. Myriam Krasilchik em sua obra $O$ professor e o currículo das ciências (KRASILCHIK, 1987). Ali, docentes da educação básica listam, como entraves a um bom ensino de ciências, diversas questões que alguma maneira se relacionam à inexistência ou à precariedade dos laboratórios escolares. Diniz lembra, então, que estas questões não deverão ser um problema na realidade que irá investigar, pois sua pesquisa se estruturará como um estudo de caso envolvendo uma classe e um professor que estão habituados ao uso da Experimentoteca. $\mathrm{O}$ autor afirma que versará sobre o ensino prático e sobre o material do CDCC a partir do acompanhamento de aulas de uma $7^{\mathrm{a}}$ série do $1^{\mathrm{o}}$ grau (atual $8^{\circ}$ ano do ensino fundamental), em uma escola pública de São Carlos. Os registros em áudio das aulas observadas serão complementados por entrevistas com alunos e com o docente responsável.

O terceiro capítulo é dedicado a expor os resultados, o que Diniz realiza a partir de três frentes: a análise da situação investigada, mediante a comparação entre as aulas teóricas e práticas desenvolvidas pelo professor que acompanhou; os depoimentos concedidos pelos alunos, já ao final do ano letivo, após um semestre de convivência com o pesquisador; e o depoimento do professor. As falas dos discentes indicam uma preferência unânime em favor 
da experimentação como estratégia de ensino. Já a entrevista com o professor, apresentada conforme o critério do "afunilamento" (primeiro, considerações gerais sobre o ensino de ciências; depois, sobre o ensino prático; e então sobre a própria Experimentoteca), aponta um grau de satisfação elevado em relação ao material do CDCC, com o qual já trabalhava havia sete anos. Nas palavras dele, tratando das possíveis e desejáveis melhorias no ensino de ciências, "você não poderia mudar a Experimentoteca, você tem que mudar a estrutura da escola, porque a Experimentoteca não tem o que mudar" (DINIZ, 1992, p. 146). Destaca ainda, o docente, algumas características que tornam o emprego dos kits vantajoso para os professores: é possível adaptar seu uso para diversas finalidades, seja para demonstrações ou para proporcionar formas de trabalho experimental com maior ou menor grau de estruturação; há materiais suficientes para todos os alunos, desde que reunidos em grupos; os aparatos experimentais já vêm praticamente prontos para o trabalho, necessitando de poucas montagens; e se trata de um material específico para o ensino de ciências, sem improvisações. Então Diniz traça algumas conclusões gerais, partindo do estabelecimento de elos entre as possibilidades e a importância do trabalho experimental em sala de aula e a teoria de Jean Piaget. Aparecem aqui algumas críticas às aulas acompanhadas durante sua pesquisa. Por exemplo, o autor considera negativas as experiências em que os alunos teriam realizado os procedimentos de modo mecânico:

O que se verificou, foi que os alunos "recebem" a questão a ser tratada pelo kit experimental através da leitura feita pelo professor do Roteiro de instruções para a realização do trabalho. Não houve de fato uma situação prévia em que o tema, a ser abordado durante a aula prática de laboratório, tenha sido discutido entre os alunos de modo que anteriormente passasse a se configurar para os mesmos como um problema a ser solucionado, no sentido de se buscar um entendimento mais completo do fenômeno, a partir da experimentação, e não apenas a comprovação ou prova de que este realmente ocorre (ibidem, p. 155-156).

De fato, a maioria das aulas experimentais acompanhadas pela pesquisa teria servido apenas à comprovação de teorias - com exceção de uma única experiência que foi além do previsto pelo respectivo roteiro da Experimentoteca graças à curiosidade dos alunos, episódio que Diniz menciona repetidas vezes. Esta crítica é bastante típica das posturas construtivistas, especialmente no tempo histórico em que esse trabalho foi realizado, quando o construtivismo ainda necessitava demarcar fortemente sua contraposição à pedagogia tecnicista. Daí o verdadeiro dilema a que recai essa pesquisa e outras congêneres, em que se defende maior autonomia e maior protagonismo dos alunos nas atividades, mas com todo o cuidado para evitar a ênfase no aprendizado de um método científico - desejando-se, isto sim, "a 
aproximação destes alunos de procedimentos e posturas da metodologia científica [... ] que se constituam em momentos importantes para a formação dos estudantes” (ibidem, p. 178).

O capítulo IV, finalmente, apresenta algumas reflexões gerais, sob o critério do afunilamento também: primeiro sobre a experimentação didática, depois sobre a Experimentoteca e, por último, sobre a Experimentoteca para a $7^{\mathrm{a}}$ série (que corresponde atualmente a todo o conjunto abarcado pelo eixo temático Corpo Humano). Especificamente quanto ao projeto do CDCC, Diniz compila as seguintes ressalvas, em contrariedade com o depoimento do professor que afirmava não haver o que se mudar nos kits: há um uso dos materiais com pouca criticidade, por parte dos docentes; o projeto deveria possibilitar atividades mais abertas, menos direcionadas; os kits deveriam incentivar um trabalho mais contínuo, abrangente e integrado, em que a experimentação fosse apenas uma etapa, no lugar de servir como mero acessório para a comprovação das teorias; e os professores e alunos não deveriam quedar tão dependentes dos roteiros experimentais que acompanham os kits. Em resumo, a Experimentoteca seria "sem dúvida, um facilitador em termos operacionais, mas não necessariamente em termos de aprendizagem dos alunos” (ibidem, p. 185).

Há outras conclusões que Diniz extrai de sua investigação, mas gostaríamos aqui de expor apenas mais um fragmento de seu trabalho:

\footnotetext{
Entende-se que o tempo necessário para a realização e finalização de uma experiência seja um fator de relevância para o professor nas condições atuais da escola pública, principalmente referentes à sobrecarga de trabalho docente. Considera-se, porém, que a superação desta problemática do tempo disponível para o uso da experimentação no ensino passa necessariamente por uma reflexão sobre o planejamento da prática docente, preocupando-se com as potencialidades e o encadeamento das modalidades didáticas a serem utilizadas, o domínio do professor sobre as mesmas e os conteúdos curriculares, e a situação conjuntural na qual se dará esta prática (ibidem, p. 190-191).
}

Esta consideração ilustra muito claramente o modo como a perspectiva construtivista de Diniz difere daquela que adotamos nesta tese. No trecho acima se observa a responsabilização do professor, individualmente, em tornar as condições materiais de seu trabalho mais favoráveis a uma educação de melhor qualidade. Do nosso ponto de vista, trata-se exatamente do contrário: é a partir de melhores condições de trabalho que podemos esperar do professor uma atuação mais responsável. Não é a consciência dos homens que determina o seu ser...

O segundo trabalho que comentaremos, o de Célia Joaquim, também foi publicado em 1992, com o título Estudando a experimentação no ensino de ciências. A orientação coube à Prof. Rosália Maria Ribeiro de Aragão e a dissertação apresentada divide-se em seis capítulos. 
No capítulo inicial argumenta-se pela importância da experimentação para o ensino de ciências, à luz de uma crítica - dada como consensual - tanto à pedagogia tradicional quanto ao tecnicismo. Aproveita-se para já introduzir o objeto central da pesquisa, a Experimentoteca, narrando-se os eventos que levaram a sua criação. Neste momento a autora se apresenta como uma professora da educação básica membro da equipe original que desenvolveu e testou os primeiros kits do CDCC, aqueles previstos para a então $5^{\mathrm{a}}$ série do $1^{\mathrm{o}}$ grau (que correspondem hoje aos kits do eixo temático Ar, Água e Solo).

No capítulo II traça-se um histórico das concepções e práticas sobre a experimentação didática, à semelhança do que fez Diniz no primeiro capítulo de sua dissertação. Seu percurso histórico toma como ponto de partida a década de 1930, dando mais atenção ao contexto brasileiro. Também como fez Diniz, Joaquim compara as práticas correntes em cada momento histórico do ensino de ciências brasileiro com as legislações em vigência, como as reformas de ensino e as Leis de Diretrizes e Bases n. 4.024/1961, n. 5.692/1971 e n. 7.024/1982.

O capítulo a seguir explora mais detidamente as diferentes abordagens da experimentação, considerando três delas:

- O "laboratório estruturado ou programado";

- O "laboratório não estruturado com ênfase na estrutura do experimento"; e

- O "laboratório sob enfoque epistemológico".

O laboratório estruturado seria aquele conformado por instruções detalhadas; o não estruturado só especificaria objetivos do experimento, permitindo que o aluno decidisse que procedimentos adotar; e a abordagem epistemológica analisaria a natureza do conhecimento, tomando como orientação o modelo heurístico conhecido como "V de Gowin". Joaquim fala, aqui, sobre os âmbitos mais adequados para a aplicação de cada abordagem, considerando resultados de pesquisas que os investigaram.

No capítulo IV é feita a descrição da metodologia da pesquisa apresentada, caracterizando-se os sujeitos que dela participaram e a situação investigada. O estudo foi realizado a partir de entrevistas com 21 docentes da disciplina Ciências para a $5^{\mathrm{a}}$ série, das 22 escolas públicas de São Carlos que ofertavam o $1^{\text {o }}$ grau à época. (Partira-se inicialmente de uma amostra composta de um docente de cada escola, mas um dos sujeitos precisou se ausentar da pesquisa a certa altura de seu transcorrer. Ao todo, havia 33 professores que lecionavam na $5^{\text {a }}$ série em São Carlos no período). Dos 21 professores, 15 se apresentam como usuários da Experimentoteca. Já surgem aqui dados interessantes, respaldando algumas 
conclusões de relevância para se compreender o uso ou o não uso dos kits do CDCC. Por exemplo, comparando as jornadas de trabalho dos professores usuários e não usuários,

parece haver evidência de que a quantidade de aulas semanais interfere na realização da prática experimental. O professor com jornada de mais de 20 horas aula até 40 horas aula, pode estar mais comprometido com a educação na medida em que equilibra ausência e presença na escola.

As condições extremas, isto é, ter poucas ou muitas aulas, sugerem, segundo as conclusões de análise desses dados, efeitos negativos quer pelo não comprometimento docente com a educação, quer pela sobrecarga de trabalho à qual o docente está submetido (JOAQUIM, 1992, p. 86).

Outros dados, a respeito das concepções dos professores sobre a experimentação, revelam que a maioria deles aprova a Experimentoteca, dizendo sobre o projeto que ele "É importante" e "Acredito nele". Os dados mostram ainda que os docentes usuários da Experimentoteca são aqueles que fazem da experimentação um recurso mais frequente entre os empregados nas aulas. Sua condução destas aulas experimentais seria mais planejada, quase nunca recorrendo ao improviso, ao contrário do que parece ocorrer com as aulas práticas dos não usuários. A maior parte dos usuários utiliza os kits de forma a ilustrar o conteúdo, depois das aulas teóricas, "coerentemente com a característica tendendo a laboratório estruturado apresentada pelos kits", que se "prestam mais à natureza ilustrativa/demonstrativa que à natureza investigativa/redescoberta da experimentação" (ibidem, p. 110). São apresentadas também colocações interessantes sobre o papel do roteiro dos kits, evidenciando que os sujeitos da pesquisa manifestam opiniões divididas quanto ao assunto:

Nas opiniões de 04 professores, todos usuários, a inibição da criatividade acontece quando se usa exclusivamente o roteiro, atribuindo ao roteiro a condição de inibidor, o que é contestado por $36,8 \%$ dos sujeitos entre usuários e não usuários, na declaração "o kit (implícito o roteiro) não inibe de jeito nenhum” (ibidem, p. 112).

Após a apresentação de todo este conjunto de dados, vem o capítulo $\mathrm{V}$, que realiza um “estudo das condições reais de atuação experimental". Na procura pelos dificultadores do uso da Experimentoteca, a pesquisa observa a menção a fatores conjunturais pela maioria dos entrevistados, no nível de entraves administrativos e técnicos: sobrecarga de trabalho, excesso de alunos e inadequação da estrutura física escolar. Já quanto aos facilitadores são mencionadas as "contribuições ao aluno" (que, na visão dos professores, gosta das atividades experimentais, se interessa mais por elas e aprende melhor) e o fato do projeto ser reconhecido como uma "inovação do ensino". Entre fatores determinantes do não uso do projeto, 
as causas citadas pelas duas categorias coincidem em relação à necessidade de alguém para ajudar; ao cansaço e desgaste no desempenho; à dependência do interesse; comodismo e hábito do professor. Todas essas considerações mais o fator de consumo de tempo extra; o da responsabilidade e do tumulto da classe; citados só pelo usuário podem estar de alguma forma relacionados ao desabafo de dois professores não usuários que categoricamente afirmam "o professor descontente só faz a obrigação" (ibidem, p. 133).

Encerrando o capítulo, Joaquim lista algumas perspectivas de enriquecimento e melhoria da Experimentoteca. Os professores usuários sugerem a diversificação de kits para um mesmo conteúdo (embora, contraditoriamente, alguns também sugiram a diminuição da quantidade de kits), a realização de reuniões para a crítica e o aperfeiçoamento do projeto, e um trabalho de revisão e atualização dos roteiros.

Finalmente, o capítulo VI, que se apresenta "à guisa de conclusão", difere do que normalmente se observa neste tipo de trabalho acadêmico: em vez de breve, trata-se de uma reflexão final de quase 40 páginas. $\mathrm{Na}$ primeira seção, “Avaliando o Projeto Experimentoteca", a autora afirma que os kits possibilitaram mudar "o vivido em direção ao concebido" (ibidem, p. 153), o que foi visado e atendido, desde a idealização e construção da proposta, até sua realização.

A Experimentoteca pareceu respeitar o que o professor sabia; aproveitou as peculiaridades próprias de cada professor e estabeleceu múltiplas e até impensadas relações. Encarou o desafio de auxiliar o professor dentro da sala de aula, muitas vezes o único espaço físico que lhe é garantido na atual estruturação escolar. Não pareceu minimizar nem se desviar dos problemas diários como o reagrupamento das carteiras; os cuidados com a limpeza e a guarda do material; a condição geral da sala em seus aspectos físico ou disciplinar no momento de entrada do professor da aula a seguir, e outros tantos problemas, que aos olhos de um observador menos atento podem parecer irrelevantes ou de menor importância, mas que no mínimo desestimulam a empreitada (ibidem, p. 154).

Depois, parte para uma espécie de defesa dos roteiros experimentais pelas páginas seguintes, resumida no parágrafo abaixo:

A preocupação em cercear o aluno mostrou-se desnecessária pois o roteiro que a princípio é fator de segurança e acomodação, parece incapaz de conter as inúmeras interações e representações mentais que ocorrem no aluno quando interage com o material, com as novas situações, avançando em suas interpretações (ibidem, p. 157).

A seção é encerrada com mais uma defesa da Experimentoteca, a partir dos aspectos "a construção", "a divulgação" e o "o uso". A próxima seção, "Idéias e expressões sobre experimentação", é apresentada apenas na forma de quadros contendo justamente essas ideias 
e expressões, às vezes sobre a experimentação em geral, às vezes sobre a Experimentoteca e o CDCC, conforme manifestadas nas entrevistas, separando-se as declarações dos professores usuários dos não usuários. Por fim, a seção final é constituída por um depoimento do Prof. Dietrich Schiel, apresentado como o Coordenador do Projeto Experimentoteca, com falas que lembram aquelas que vimos reproduzindo na seção anterior deste capítulo. Entre estas asserções, destacamos um fragmento cujas ideias se mostram assaz afins à nossa perspectiva neste trabalho, tratando de aspectos da materialidade da ação educativa:

Quem está dando 40 aulas por semana não consegue... você querer que ele dê as 40 aulas de uma forma extremamente dinâmica e agitada, mobilizando todos os alunos... ele não vai passar de 02 meses e vai “empacotar". Então, infelizmente, os professores limitam o uso [da Experimentoteca] por causa de uma questão de resistência física dele. Isso só se resolveria baixando a carga horária do professor. Um absurdo! Na Universidade dou 06 horas de aula por semana. Essa carga da rede não há como justificá-la!

Quero dizer que a Experimentoteca não existe sozinha, ela está inserida numa realidade social e a gente sabe que está dando uma pequena contribuição, mas outras coisas têm também que contribuir simultaneamente (ibidem, p. 176).

De fato, tem-se a impressão que o texto integral do trabalho de Joaquim, talvez por estar menos comprometido com o construtivismo em comparação com a dissertação de Diniz, mantém certa proximidade com o nosso ponto de vista pedagógico e epistemológico. Joaquim chega mesmo a fazer referência a autores das pedagogias progressistas, como Freinet, Libâneo e até Vigotski, nome que apenas começava a ser notado pelo campo da Educação em Ciências. Em particular, gostaríamos de transcrever um fragmento, apesar de extenso, que situa este estudo de Joaquim numa perspectiva muito próxima à nossa:

Nos desdobramentos deste estudo, percebo o desvelar de uma estrutura injusta que ao invés de proteger iniciativas, mutila no professor o despertar da consciência de seu valor profissional. E enquanto não adquire essa consciência, não se torna cidadão responsável e capaz de tomar iniciativas que solucionem os problemas que no cotidiano afetam a própria atuação.

Aceita ingenuamente a condição da ideologia dominante que coloca a culpa das dificuldades ora nos alunos (incapacidade de aprender), ora nos pais (condição social), ora nos professores (incompetência), desconsiderando as limitações colocadas pelo Sistema.

O que deveria ser combatido coletivamente, passa a ser cobrado de modo individual. Enquanto os órgãos representativos negociam, os professores, para sobreviver adaptam-se às condições reais, à espera de dias melhores e alertas ao menor sinal, a exemplo do Projeto Experimentoteca que alterou a atuação docente do professor de Ciências na cidade de São Carlos, principalmente pela melhoria das condições reais de atuação experimental do docente, dentro ou fora do Projeto aqui estudado (ibidem, p. 121). 
Infelizmente, nem o trabalho de Diniz, nem o de Joaquim, parecem ter repercutido na literatura sobre a Educação em Ciências no Brasil. Salvo melhor juízo, a única publicação de relevância a fazer menção a estas duas dissertações foi a pesquisa de estado da arte do Prof. Jorge Megid Neto. Em sua tese de doutorado, intitulada Tendências da pesquisa acadêmica sobre o ensino de ciências no nível fundamental, publicada em 1999, Megid Neto se depara com as pesquisas de Diniz e Joaquim e tece a seguinte avaliação sobre a Experimentoteca:

\begin{abstract}
Notamos, por intermédio da leitura desses dois trabalhos, que o Projeto Experimentoteca tem características bastante semelhantes aos projetos de ensino norte-americanos (PSSC, BSCS, CBA, Chem Study, IPS, ESCP) que se difundiram pelo Brasil nos anos 60, ou aos projetos de ensino nacionais da década de 70: Projeto de Ensino de Física (PEF), Física Auto-Instrutivo (FAI), Projeto de Ensino de Ciências para o $1^{\circ}$ Grau - CECIRS, Laboratório Básico Polivalente de Ciências FUNBEC, Projeto de Ciência Mobral/FUNBEC, entre outros (MEGID NETO, 1999, p. 172-173).
\end{abstract}

Propostas metodológicas como as contidas no Projeto Experimentoteca tentam reeditar as principais características destes projetos de ensino de trinta anos atrás, desconsiderando especialmente o avanço do pensamento educacional e das pesquisas na área, nos anos 80. Avanços que incorporam o movimento construtivista no ensino escolar, as abordagens histórico-críticas, o resgate aos conhecimentos e experiências prévias dos educandos, as relações entre ciência, tecnológica e sociedade, a busca pela formação de um cidadão crítico, participativo, potencial agente de transformação social. Avanços que não são assimilados no Projeto Experimentoteca (ibidem, p. 174).

Sem dúvidas, trata-se de um comentário infeliz, nada condizente com o conhecido espírito inquiridor e crítico do Prof. Megid. Provavelmente, no afã de se posicionar a respeito do Projeto do CDCC, a despeito da impossibilidade de melhor conhecê-lo à época em que escrevia sua tese - certamente um dos mais completos e exaustivos trabalhos de revisão da literatura produzidos pelos pesquisadores brasileiros em Educação em Ciências -, o referido professor tenha realizado esta avaliação apressada, e que não faz justiça às conclusões dos trabalhos de Diniz e Joaquim. São gritantes também as diferenças entre o tom assumido por Megid Neto e as considerações de Alberto Gaspar em suas teses de doutorado e livre docência, que vimos citando na seção anterior (GASPAR, 1993, 2006). Veja-se o que afirma explicitamente o Prof. Gaspar - vale lembrar, profundo conhecedor dos centros e museus de ciências brasileiros, e pesquisador especializado em seu estudo - a respeito da Experimentoteca:

É, sem dúvida, uma inovação didático-pedagógica com possibilidade de dar condições efetivas para que a experimentação seja utilizada de forma corriqueira e continua em sala de aula. Os experimentos, concebidos com material de boa 
qualidade, são projetados para serem utilizados em salas de aula comuns, dispensando instalações especiais; e nesse sentido lembram o Laboratório Portátil criado pela FUNBEC em 1976. A avaliação desse projeto por uma equipe da Universidade Federal de São Carlos, está em andamento, entretanto, pode-se adiantar que a ampliação constante do número de usuários desse material ao longo destes anos mostra que ele tem atingido seus objetivos (1993, p. 28).

Passaram os anos e a literatura permaneceu carente de mais estudos sistemáticos sobre a Experimentoteca. Apenas em 2006 - quase 15 anos após a divulgação dos relatórios de Diniz e Joaquim - seria publicada uma nova dissertação de mestrado contemplando o tema. $\mathrm{O}$ trabalho de Renata Canales, O Centro de Divulgação Científica e Cultural da Universidade de São Paulo, campus de São Carlos: um projeto de extensão universitária, foi orientado pela Prof. Ester Buffa e apresenta notáveis diferenças em relação aos seus dois antecessores.

Enquanto os outros trabalhos partiam de uma preocupação imediatamente relacionada com a educação básica, neste o interesse imediato é com a educação superior. Não se fala do nível básico senão com referência à universidade, ao encaminhamento de suas ações e aos resultados delas. Se as pesquisas de Diniz e Joaquim se realizaram no interior de uma área de concentração que poderia receber o nome de "Metodologia do Ensino", a de Canales é desenvolvida na área de "Fundamentos da Educação". Saem as preocupações com a didática, entram os interesses voltados para a historiografia da educação brasileira e para as políticas públicas educacionais.

O texto divide-se em cinco partes.

A primeira se trata de uma introdução, em que a autora apresenta brevemente alguns conceitos e o objeto central de sua investigação, a Experimentoteca, a partir de um ponto de vista histórico. Assim, é narrada, apenas em linhas gerais neste momento, a constituição do CDCC e seus primeiros passos rumo à concretização da Experimentoteca. O conceito de extensão universitária é apresentado conforme a visão de autores progressistas do campo da filosofia da educação brasileira: Paulo Freire e, mais enfaticamente, Dermeval Saviani. Seu principal texto referenciado neste trabalho será "Extensão universitária: uma abordagem nãoextensionista", encontrado na coletânea Ensino público e algumas falas sobre universidade (SAVIANI, 1991). Neste escrito, Saviani busca se contrapor ao entendimento da extensão universitária que a reduz a uma forma de assistencialismo. No lugar disso, defende:

[a extensão] significaria a articulação da universidade com a sociedade, de tal modo que aquilo que ela produz em termos de novos conhecimentos e aquilo que ela difunde através do ensino não ficasse restrito apenas àqueles elementos que conseguem ser aprovados no vestibular, e que integram determinado curso objetivando se formar numa determinada profissão. Ao contrário, cabe à 
universidade socializar seus conhecimentos, difundindo-os à comunidade e se convertendo, assim, numa força viva capaz de elevar o nível cultural geral da sociedade (ibidem, p. 48).

Se nos trabalhos de Diniz e Joaquim a historicidade do conceito principal - a experimentação no ensino de ciências - conduzira os autores a abordarem as Leis n. 4.024/1961 e n. 5.692/1971, aqui será enfocada a Lei n. 5.540/1968, primeiro dispositivo legal a institucionalizar a extensão universitária no país. (Lembramos o leitor que comentamos rapidamente a referida lei, que promulgou a Reforma Universitária, na seção 1.1 do primeiro capítulo desta tese).

A próxima divisão do trabalho é o capítulo I, "Histórico do CDCC". A origem desta unidade da USP, como já apresentamos, remonta ao encontro entre docentes dos ensinos básico e superior no Simpósio de Integração Universidade-Escolas de $1^{\circ}$ e $2^{\circ}$ Graus, em 1979. Canales situa este acontecimento no ambiente político e ideológico de então, quando a educação brasileira fora emparelhada pela ditadura civil-militar que governava o país desde o golpe de 1964. Especificamente sobre o Simpósio, a autora detalha aspectos como a dinâmica de funcionamento de suas atividades e as origens institucionais e geográficas dos participantes (já que houve a adesão de educadores externos a São Carlos). Sobre o CDCC, são esclarecidas a origem e a construção dos seus primeiros elementos expositivos, influenciados pela característica interatividade de centros como Deutsches Museum de Munique e o Centro de Ciências de Ontário (como corretamente induzira o Prof. Gaspar). A Experimentoteca tem sua história narrada de forma também detalhada, num registro complementar àquele que fizera Joaquim em sua dissertação. Finalizando o capítulo, Canales dedica uma seção para falar sobre o prédio do CDCC, à luz de uma literatura sobre as relações entre arquitetura e educação. Também são contados os eventos históricos que levaram a que a USP, e posteriormente o CDCC, ocupasse e adquirisse o prédio pertencente à Società Dante Alighieri.

O capítulo II discorre sobre o funcionamento do $\mathrm{CDCC}$, do ponto de vista administrativo. São apresentados os nomes dos responsáveis, funcionários, bolsistas e colaboradores de cada setor do centro, e descrevem-se suas atividades.

O capítulo seguinte aborda exclusivamente a Experimentoteca, definida como um "laboratório de ciências ambulante". As primeiras duas seções apenas fornecem alguns detalhes sobre o processo de criação, disponibilização e difusão da Experimentoteca, e descrevem de forma geral o conteúdo dos kits. As duas próximas seções são mais interessantes, pois já trazem resultados de pesquisa, utilizando como dados os relatórios 
anuais de empréstimos dos kits, preparados pelo próprio CDCC; depoimentos da educadora Vanilde de Fátima Bongiorno, responsável pelo setor da Experimentoteca e envolvida com o projeto desde 1981; falas de estudantes usuários dos kits, de escolas públicas de São Carlos; e a fala da docente de Biologia de uma das escolas estaduais do município. Segundo números dos relatórios, a participação proporcional das escolas públicas, entre o total de empréstimos de kits, vem caindo: como o CDCC também realiza empréstimos para escolas privadas (apenas não disponibilizando seus veículos para entregá-los, como o faz gratuitamente para as escolas públicas do município ${ }^{76}$ ), a participação deste setor saltou de menos de $5 \%$ dos empréstimos em 1986 para mais de 50\% em 2006. Quanto aos estudantes, foram propostas cinco questões com possibilidade de resposta afirmativa ou negativa:

1) O trabalho prático com material da Experimentoteca fez com que você entendesse melhor a teoria aprendida em sala de aula?

2) O seu interesse pelas disciplinas química, física e biologia aumentou depois do uso do material da Experimentoteca?

3) Você acha fácil fazer os experimentos da Experimentoteca?

4) Pretende fazer curso superior ligado às ciências exatas?

5) Se na questão anterior, a resposta foi afirmativa, responda se o interesse em curso superior na área de exatas foi despertado a partir do contato com o material da Experimentoteca.

Nas duas escolas, apesar da maioria dos estudantes responderem afirmativamente às questões 1 a 3 (ainda que as respostas da questão 2 apareçam divididas em uma das turmas), apenas 2 estudantes, em um universo de 72, o fazem quanto à questão 4. As ciências exatas e naturais não são avaliadas como carreiras de interesse por parte desta população. Canales ilustra a situação com o seguinte relato do momento de coleta dos dados:

Um dos alunos entrevistados ao ser questionado se o material da Experimentoteca tinha lhe despertado interesse pelas ciências, revelou: "A aula foi legal. A gente fez uma mistura e depois, com o fogo que a gente colocou, cada coisa se separou da outra".

O aluno não foi capaz de responder que nome tinha a experiência e afirmou que não lembrava se na aula seguinte continuaram as discussões sobre os resultados do experimento. Ainda revelou que pretende ter uma oficina mecânica e que já sabe acertar algumas falhas que o carro do pai apresenta (CANALES, 2006, p. 108).

Também vale a pena conferirmos o que diz a professora entrevistada. Segundo ela,

\footnotetext{
${ }^{76}$ Professores de escolas em municípios adjacentes a São Carlos, como Ibaté, podem também realizar empréstimos de kits da Experimentoteca, desde que os educadores responsáveis se dirijam ao CDCC para retirar e devolver o material requisitado.
} 
quando aplica o material da Experimentoteca, a maioria [dos alunos] reclama e não consegue tirar proveito. A professora ainda afirmou que o problema é que a aluno não está acostumado à observação de experimentos desde os primeiros anos do ensino fundamental e, portanto, tem dificuldade em enxergar a teoria aplicada se o professor não auxiliá-lo. Mesmo assim, ela confirma que o material da Experimentoteca é valioso para que os estudantes visualizem a teoria (ibidem, loc. cit.).

A autora parte, então, para a última divisão do trabalho, as "Considerações finais". Segundo ela, há duas conclusões principais a se firmarem:

A primeira é que este trabalho de extensão [a Experimentoteca do CDCC] não é assistencialista. Ele surgiu com o intuito de despertar o interesse da população, principalmente dos alunos do ensino básico, pelas ciências. Para tanto, em sua proposta original, percebia-se a necessidade de aproximar a universidade da comunidade para que houvesse a comunicação entre os dois sujeitos da ação. Estabeleceu-se, dessa maneira, um trabalho de extensão que foge do padrão da grande maioria existente, que traz uma visão assistencial e impõe o saber acadêmico, desprezando o saber popular (ibidem, p. 110, grifo da autora).

Mas apesar do CDCC realizar um trabalho de importância social e ter a Experimentoteca munida de boa intenção, faz-se necessária uma segunda consideração, a qual aponta que o projeto acaba por ser uma gota limpa em oceano sujo. Os alunos da rede pública, que eram o principal alvo da Experimentoteca, utilizam cada vez menos o material, que, por sua vez, é retirado com mais frequência pela rede privada (ibidem, p. 115).

A partir deste quadro contraditório, Canales conclui de forma forte:

Consideramos que chega a ser inócuo o trabalho da Experimentoteca dentro de uma realidade em que o cidadão é desprezado e na qual não há investimento educacional e cultural. $\mathrm{O}$ aumento da retirada da Experimentoteca pelas escolas particulares comprova que o ensino na rede privada busca uma melhor qualidade para seus alunos. Na análise de retiradas pelas séries, notamos que houve um aumento significativo dos materiais de física e química voltados à $8^{\mathrm{a}}$ série e utilizados também pelo ensino médio. Concluímos que há a possibilidade de este aumento de retiradas estar relacionado à visão propedêutica das escolas particulares, preocupadas em preparar bem os estudantes para competir por uma vaga em universidade (ibidem, p. 116).

Também como ocorrera com os trabalhos de Diniz e de Joaquim, esta dissertação de Canales não repercutiu na literatura, embora tenham decorrido dela até algumas publicações em periódicos. De qualquer forma, todos estes resultados estão sendo compilados aqui por nós, e podemos admitir que eles continuam atuais. Recordemos que, nos anos de 2008 e 2010, realizamos alguns estudos de caráter exploratório, em escolas públicas e privadas de São Carlos - vide a Apresentação desta tese - que atestam esta atualidade. Resumamos, então, os achados desta pequena, mas valiosa, literatura. 
Quanto à concepção pedagógica que orientaria os kits, Diniz conclui que seja ela qual for - pois não havia nenhum material do CDCC que a pudesse explicitar, à época em que seu estudo se realizou -, não há compatibilidades dela com o construtivismo. Joaquim, em outros termos, afirma algo parecido: a Experimentoteca, pelo próprio caráter dos materiais que a constituem, se aproxima mais do modelo de laboratório estruturado. Segundo o depoimento da professora entrevistada por Canales, de fato, não há como os alunos utilizarem autonomamente o material, pois não estão familiarizados com o ensino experimental.

Sendo assim, Diniz acredita ser um ponto negativo da Experimentoteca sua proposta de trabalho com roteiros experimentais bem detalhados, o que tolheria a criatividade dos alunos, tornando sua prática mecânica, automática, irrefletida. Joaquim, que enuncia suas posições de um ponto de vista mais próximo da Pedagogia Histórico-Crítica, coerentemente com a avaliação de Saviani de que o automatismo não necessariamente prejudica a autonomia do indivíduo - pelo contrário -, rebate esta crítica: há a necessidade do roteiro para que as atividades possam ocorrer sem imprevistos que impliquem em desorganização do trabalho escolar. Além disso, não será a existência de um roteiro experimental que conseguirá conter o dinamismo e o espírito criativo e "experimentador" dos jovens.

Na mesma linha de raciocínio, Diniz argumenta que a Experimentoteca pode até ser um facilitador para o trabalho do professor, quanto ao aspecto operacional, não significando, no entanto, que seu uso efetivamente melhore a aprendizagem em ciências. Joaquim, em sua defesa do projeto do CDCC, se desvia um pouco da questão e discorda de seu colega. De modo mais equilibrado, Canales conclui que a Experimentoteca até auxilia na aprendizagem e ajuda a despertar o interesse científico dos alunos, mas em uma intensidade decepcionante. Segundo sua pesquisa, os alunos expostos aos kits não se interessam por carreiras científicas, nem mesmo demonstram a aquisição de um vocabulário mínimo para se comunicar em termos do linguajar das ciências.

Apesar de críticas parciais, detectadas no trabalho de Diniz, sobre a quantidade dos kits e sobre possibilidades de aprimoramento do material, os três trabalhos trazem dados que respaldam fortemente a qualidade da Experimentoteca e sua facilidade de acesso e uso por parte dos docentes.

Os trabalhos concordam também que, apesar destas contribuições, a Experimentoteca não é capaz de resolver todas as questões envolvidas na qualidade do ensino de ciências. Existiriam outras mediações, a serem atacadas com a mesma diligência com que o CDCC fez com a questão da experimentação no ensino em São Carlos, cuja resolução deveria ocorrer 
simultaneamente com o desenvolvimento, a aplicação e a avaliação da Experimentoteca. Estas mediações vão além da iniciativa individual dos docentes e do seu âmbito mais imediato de ação, e esbarram nas questões implicadas na materialidade da educação - o sistema de ensino, a estrutura organizacional e a continuidade das políticas e iniciativas.

Iremos retomar muitas destas conclusões nos capítulos vindouros. Por ora, esta síntese inicial será suficiente para darmos continuidade ao propósito do presente capítulo, que é compreender o papel de instituições como o CDCC no desenvolvimento da educação formal, função específica de instituições - as escolas - com características inteiramente diferentes dos museus e centros de ciências.

Para dar continuidade a este intuito, voltemos a lidar com textos e autores da Pedagogia Histórico-Crítica, para vermos se e como eles contribuiriam para iluminar estes aspectos.

\subsection{A EXPERIMENTOTECA E A PEDAGOGIA HISTÓRICO-CRÍTICA}

Um ponto de partida óbvio para a procura de considerações sobre centros e museus de ciências, em obras de autores associados à Pedagogia Histórico-Crítica, seriam os dois livros dedicados à teorização do ensino de ciências já comentados na seção 3.2 do terceiro capítulo desta tese. Mas em Ensino de ciências: abordagem histórico-crítica (SANTOS, 2005) há apenas uma brevíssima menção ao assunto à p. 62: “Tendências como o ensino com o auxílio de visitas a museus podem ser mais abrangentes no aspecto das relações entre ciência e sociedade". Já em Didática das ciências naturais na perspectiva histórico-crítica (GERALDO, 2009) consta somente um comentário por parte do autor que, partindo da concepção de Vigotski sobre a relação entre ensino e desenvolvimento psíquico, afirma:

crianças, adolescentes, jovens ou adultos poderão visitar vários zoológicos e museus de zoologia, mas as atividades e experiências sensoriais espontâneas vividas nesses locais não irão substituir a importância da assimilação-apropriação das bases gerais da zoologia contemporânea como sistema conceitual para o desenvolvimento da compreensão dos animais: de suas interações, de seus graus de parentesco, das suas relações ecológicas, do seu desenvolvimento evolutivo, contribuindo para o desenvolvimento, no sujeito, da percepção, da memorização, da imaginação, em novos níveis de generalização e de generalidade conceitual, tanto para o caso específico dos seres vivos como para a sensibilidade e a compreensão do mundo como um todo (ibidem, p. 103). 
Será necessário, portanto, recorrer aos clássicos da Pedagogia Histórico-Crítica, mesmo sabendo que não encontraremos em nenhum deles um tratamento explícito do tema. De fato, a teoria proposta por Saviani, e desenvolvida por Duarte e outros, toma a educação sistematizada como preocupação central, elaborando uma defesa intransigente do direito ao ensino escolar. A especificidade da escola, lembremos, é a transmissão do saber elaborado para que as novas gerações se apropriem das conquistas históricas da humanidade, sendo que os centros e museus de ciências possuem suas próprias especificidades.

Assim, se desejamos acessar o pensamento de Saviani a respeito da educação que se processa em outros espaços que não a escola, teremos de fazê-lo através da mediação de suas considerações sobre a própria educação escolar. No texto "A pedagogia histórico-crítica e a educação escolar" (SAVIANI, 2008, p. 87-103), coerentemente com o método de Marx anunciado na Contribuição à crítica da economia política, é o próprio Saviani quem afirma:

na sociedade atual, pode-se perceber que já não é possível compreender a educação sem a escola, porque a escola é a forma dominante e principal da educação. Assim, para compreender-se as diferentes modalidades de educação, exige-se a compreensão da escola. Em contrapartida, a escola pode ser compreendida independentemente das demais modalidades de educação (ibidem, p. 102-103).

Começando por Educação brasileira: do senso comum à consciência filosófica (idem, 2009), cuja primeira edição data de 1980, Saviani fala sobre a presença de uma "educação difusa e indiferenciada em todos os setores da sociedade":

as pessoas comunicam-se tendo em vista objetivos que não o de educar e, no entanto, educam e educam-se. Trata-se, aí, da educação assistemática (fundada na "filosofia da vida"); ocorre uma atividade educacional, mas ao nível da consciência irrefletida, portanto, não intencional, ou seja, concomitantemente a uma outra atividade, esta sim desenvolvida de modo intencional. Quando educar passa a ser objeto explícito da atenção, desenvolvendo-se uma ação educativa intencional, então se tem a educação sistematizada (ibidem, p. 60).

Num capítulo mais adiante, serão distinguidas três formas de educação desenvolvidas na sociedade contemporânea: a "educação escolar", a "educação difusa” e a "educação popular”:

A educação escolar corresponde à cultura erudita. Rege-se pelos padrões eruditos, sua finalidade é formar o homem "culto" no sentido erudito da palavra, seu conteúdo e sua forma são eruditos; é, enfim, o principal meio de difusão da "cultura erudita". Aquilo que chamamos, na falta de uma expressão mais adequada, de "educação difusa" corresponde à "cultura de massa". Participa praticamente de todas as características da referida "cultura" de tal modo que se pode mesmo dizer que se identifica com ela. Seu principal instrumento de difusão são os meios de 
comunicação de massa. Enfim, a educação popular corresponde à "cultura popular" (ibidem, p. 101).

Saviani, no entanto, faz uma ressalva importante ao estabelecimento desse paralelismo entre educação e cultura:

Com efeito, ele só seria plenamente válido ao nível da educação assistemática; mas aí educação e cultura se identificam. No plano da educação sistematizada (a educação propriamente dita, já que é aí que a educação adquire especificidade), a situação é mais complexa, as mediações multiplicam-se, as diferentes "culturas" cruzam-se. Com efeito, a educação sistematizada, via de regra, é uma atividade que se dirige ao outro: a outra geração, a outra classe social, a outra cultura. Supõe, portanto, uma heterogeneidade real e uma homogeneidade possível; uma desigualdade no ponto de partida e uma igualdade no ponto de chegada (ibidem, loc. cit.).

Encontraremos novas menções a estas outras modalidades de educação em Pedagogia Histórico-Crítica: primeiras aproximações (idem, 2008), especificamente no próprio texto que mencionamos há pouco, “A pedagogia histórico-crítica e a educação escolar”. Após narrar o aparecimento de diferentes concepções educacionais ao longo da história, até o momento em que elabora sua própria pedagogia, Saviani apresenta o seguinte paradoxo da atualidade: de um lado, exige-se a ampliação da educação escolar, tanto no sentido "vertical" (em termos de anos passados na escola), quanto no "horizontal" (em termos da jornada diária dos estudantes); de outro, advoga-se pela não exclusividade da escola enquanto instituição responsável por educar. Estas duas reivindicações, se podemos chamá-las assim, se chocam como resultado de uma contradição mais fundamental, aquela inerente ao modo de produção capitalista - em que o desenvolvimento cada vez maior das forças produtivas, visando-se à acumulação privada do capital, acaba exigindo a própria socialização dos meios de produção e, por conseguinte, do saber. Neste embate, Saviani se coloca a favor da valorização da escola, desde que respeitada sua função específica, isto é, a transmissão dos conteúdos culturais clássicos. A tendência a secundarizar a escola é rejeitada explicitamente, até pelo modo perigoso a que esta concepção pode redundar na própria negação da instituição escolar, se tomada de modo extremo:

afirma-se que não é só através dela que se educa; educa-se através de múltiplas formas, através de outras instituições, como os partidos, os sindicatos, associações de bairro, associações religiosas, através de relações informais, da convivência, dos meios de comunicação de massa - isto é, do cinema, do rádio, da televisão. Portanto, há múltiplas formas de educação, entre as quais se situa a escolar. Segundo essa tendência, a escola não é a única nem mesmo a principal forma de educar; há, até mesmo, aqueles que consideram a escola negativa, do ponto de vista educacional, o 
que foi formulado explicitamente pela proposta de desescolarização, cujo principal mentor foi Ivan Illich (ibidem, p. 97).

Entendendo que esta concepção se mostra conveniente aos interesses do capital, e portanto, inconveniente àqueles que lutam pela transformação das estruturas sociais, Saviani reitera a defesa da escola, ressaltando a atual subordinação de todas as modalidades da educação ao próprio ensino escolar:

A educação escolar é simplesmente a educação; já as outras modalidades são sempre definidas pela via negativa. Referimo-nos a elas através de denominações como educação não-escolar, não-formal, informal, extra-escolar. Portanto, a referência de análise, isto é, o parâmetro para se considerarem as outras modalidades de educação, é a própria educação escolar. Esta é a situação com a qual nos defrontamos hoje. É nesse quadro e a partir dessas bases que o que chamamos de pedagogia históricocrítica se empenha na defesa da especificidade da escola. Em outros termos, a escola tem uma função especificamente educativa, propriamente pedagógica, ligada à questão do conhecimento; é preciso, pois, resgatar a importância da escola e reorganizar o trabalho educativo, levando em conta o problema do saber sistematizado, a partir do qual se define a especificidade da educação escolar (ibidem, p. 98).

Outra passagem em que Saviani se refere a modalidades não escolares de educação pode ser encontrada na sua fala durante o Simpósio de Marília (SAVIANI, 1994). Diante da seguinte questão da plateia,

Professor, de que forma a educação informal pode contribuir para a elevação cultural das massas, principalmente aquelas marginalizadas do processo de produção material e que afluem aos grandes centros urbanos, invadindo áreas periféricas e que não oferecem o mínimo de condições de vida? (ibidem, p. 274)

Saviani - que além da "educação informal", se refere outras expressões, como "educação extra-escolar", “não-escolar", “assistemática”, "não-formal”, "não institucionalizada" responde:

[a] educação informal é uma manifestação do fenômeno educativo que, embora tenha sido suplantada pela educação formal, pela educação escolarizada, nem por isso desapareceu. Ela está presente no nosso contexto, e, nesse sentido, ela pode ser acionada, ela pode ser utilizada como um instrumento em função dos objetivos mais amplos da educação. Mas eu entendo que isso irá ocorrer em articulação com a escola e, via de regra, de maneira subordinada à forma escolar, a tal ponto que se as duas modalidades entrarem em conflito, então é preciso decidir-se pela principal (ibidem, p. 286).

Com estas indicações - sumárias, é verdade - já é possível que consolidemos um olhar para a Experimentoteca a partir da Pedagogia Histórico-Crítica. No entanto, antes de 
prosseguirmos, queremos sistematizar nosso entendimento de todos estes termos que apareceram no decorrer desta seção - educação formal, não formal, informal, assistemática, sistematizada. Há autores (em sua maioria, como nós, interessados também na questão dos centros e museus de ciências) que se pronunciaram a respeito destas terminologias, e convém consultá-los a fim de refinarmos nossos conceitos, para então acrescentarmos nossas contribuições a este tópico.

\subsubsection{Uma digressão: educação formal, não formal ou informal}

Analisando-se a literatura sobre centros e museus de ciências, observa-se não haver consensos quanto ao emprego dos termos "educação não formal" e "educação informal" para se referir ao aspecto educativo destas instituições.

Marandino e colaboradores (2003), realizando uma revisão destes trabalhos, além de uma pesquisa com profissionais ligados a projetos de divulgação científica, chegaram às seguintes conclusões: tanto na literatura quanto na produção dos profissionais, há certa confusão terminológica, levando até mesmo a se chamar de "educação não formal" algumas iniciativas de educação popular; em língua inglesa, todas formas de educação não escolar costumam ser tratadas simplesmente como "educação informal”; já em língua portuguesa, especialmente na produção de autores brasileiros, as modalidades não escolares de educação são normalmente divididas entre uma "educação informal" (aquela que se dá de forma incidental a partir da convivência ou da exposição a determinadas mídias) e uma "educação não formal" (a que é resultante, por exemplo, da visita a um museu); em todo caso, há uma tendência a se tomarem como sinônimos os termos "não formal" e “ informal", e sujeitos participantes da pesquisa chegam mesmo a considerar a questão puramente "acadêmica", não auxiliando em sua prática profissional.

Jacobucci (2008) sugere o seguinte raciocínio: quando tratamos de um "espaço formal", estamos falando de um "espaço escolar", onde se pratica a "educação escolar"; analogamente, um "espaço não formal" se trata de um "espaço não escolar". Este pode ser tanto "institucional" (como é o caso dos museus e centros de ciências), como "não institucional" (caso das ruas, praças, praias etc.). Em síntese, 
pode-se dizer que os espaços formais de Educação referem-se a Instituições Educacionais, enquanto que os espaços não-formais relacionam-se com Instituições cuja função básica não é a Educação formal e com lugares não-institucionalizados (ibidem, p. 57).

Gaspar (1993) também tenta resolver, pautando-se por analogias, a questão terminológica. Por adotar como referencial teórico a psicologia de Vigotski, baseando-se fortemente em Pensamento e linguagem, o pesquisador assim considera a questão: da mesma maneira que o psicólogo russo discrimina os conceitos científicos dos conceitos espontâneos, podemos determinar os locais mais apropriados para a aprendizagem de cada tipo de conceito. Ora, se cabe à escola - e somente a ela - promover os conceitos científicos, os centros e museus de ciências contentar-se-iam, portanto, em ao menos fazer seu público avançar no caminho que parte dos conceitos espontâneos, passa pelos pseudoconceitos e atinge os conceitos verdadeiros. Assim, se cabe à educação formal ensinar propriamente os conceitos científicos, cabe à "educação informal”, no máximo, contribuir para este fim. Gaspar acaba sendo, desta maneira, um dos únicos autores brasileiros a não utilizar a expressão "educação não formal" para tratar dos centros e museus de ciências.

Outra referência a que Gaspar recorre é um artigo de Dib (1988). Aqui, distingue-se entre "educação formal", "educação não formal" e "educação informal" recorrendo-se ao critério do diretivismo das atividades educativas. As atividades mais centradas no professor, proporcionando um maior grau de direcionamento às práticas estudantis, seriam a principal característica da educação formal. A educação através de cursos à distância, com estrutura curricular, certificação e avaliações, corresponderia ao tipo não formal. A educação informal, por fim, seria aquela marcada pelo total "voluntarismo" do estudante, que regularia completamente sua aprendizagem - como aconteceria durante as visitas a centros e museus de ciências. Assim, haveria um contínuo entre as três formas de educação: da formal à informal, passando pela não formal, a aprendizagem se torna menos rígida e menos centrada no professor, com o desaparecimento de características como a existência de um local específico para o ensino, a obrigatoriedade da presença estudantil, as avaliações e o próprio currículo. Dib, entendendo que a educação formal não mais atende às necessidades dos estudantes contemporâneos, defende uma maior flexibilidade por parte das instituições escolares através da incorporação de características das modalidades informal e não formal.

A tipologia de Dib parece interessante e simples, mas apresenta uma série de pontos passíveis de questionamento. Sua conclusão de que a educação escolar deveria se tornar menos formal não aparece apoiada em fatos, e recorre ao erro comum de se sobrevalorizar as 
necessidades do aluno empírico para a defesa de uma pedagogia que, em todos os aspectos, se assemelha às pedagogias do "aprender a aprender", tão criticadas por Newton Duarte. Além disso, o critério do diretivismo leva a uma verdadeira confusão entre modalidades de educação e teorias pedagógicas. Por exemplo, ao descrever o que entende por educação formal, Dib elenca uma série de características típicas das "caricaturas" do ensino tradicional: possui caráter punitivo, obedece a uma metodologia "unidirecional", atribui o fracasso da aprendizagem aos próprios alunos, desconsidera seus conhecimentos prévios, apresenta os tópicos do currículo de forma fragmentada, baseia-se na tática do fingimento recíproco (docentes fingem que ensinam, discentes fingem que aprendem). Já a educação não formal é associada ao ensino autoinstrutivo, estratégia emblemática da pedagogia tecnicista. Por fim, a modalidade informal seria a forma mais "escolanovista"/“construtivista", garantindo ao estudante a escolha de onde, como e por quanto tempo irá aprender determinado conteúdo.

De qualquer forma, a existência de um contínuo que vai da educação formal à informal é praticamente tomada como ponto pacífico entre os pesquisadores brasileiros. Seguindo a orientação do grupo de pesquisa liderado por Martha Marandino na Faculdade de Educação da USP (Grupo de Estudo e Pesquisa em Educação Não Formal e Divulgação em Ciência), a maior parte das publicações em território nacional entende que os museus e centros de ciências sejam caracterizados como "espaços não formais", diferentemente do que propõem Gaspar e Dib. Em uma publicação do seu grupo, Marandino (2008) organiza na forma de um quadro o entendimento conceitual sobre estas modalidades educacionais, que adaptamos na Figura 28.

\begin{tabular}{|c|c|c|}
\hline Característica & \multicolumn{2}{|c|}{ Modalidade } \\
\hline propósitos & geral, com certificação & específico, sem necessidade de certificação \\
\hline $\begin{array}{l}\text { organização do } \\
\text { conhecimento }\end{array}$ & padronizada, acadêmica & individualizada, prática \\
\hline tempo & longo prazo, contínuo, sequencial & curto prazo, tempo parcial \\
\hline estrutura & $\begin{array}{c}\text { altamente estruturada, currículo definido, } \\
\text { atividade determina perfil do aprendiz, } \\
\text { baseada na instituição, avaliativa }\end{array}$ & $\begin{array}{c}\text { flexível, ausência de currículo, aprendiz } \\
\text { determina o perfil da atividade, relacionada } \\
\text { à comunidade, não avaliativa }\end{array}$ \\
\hline controle & externo, hierárquico & interno, democrático \\
\hline intencionalidade & centrada no educador & centrada no aprendiz \\
\hline
\end{tabular}

Figura 28: características das modalidades educacionais que se situam no contínuo do "formal" ao "informal", passando pelo "não formal" (MARANDINO, 2008, p. 15). 
Ressaltando a complexidade do assunto, observa ainda a pesquisadora:

Por meio desse continuum, podemos analisar nossas instituições, e as atividades que nela desenvolvemos, de forma integrada ou separadamente. Podemos ainda realizar essa análise pelo ponto de vista do aprendiz. Dessa forma, um museu, por exemplo, poderia ser nomeado como um espaço de educação não-formal quando o pensamos como instituição, com um projeto de alguma forma estruturado e com um determinado conteúdo programático. Mas, ao pensarmos sob o olhar do público, poderíamos considerá-lo como educação formal, quando alunos o visitam com uma atividade totalmente estruturada por sua escola, buscando aprofundamento em um determinado conteúdo conceitual (ou, como muitos professores dizem, tentando "ver na prática o que têm em teoria na sala de aula"). E podemos, ainda sob o olhar do público, imaginá-lo como educação informal, ao pensarmos em um visitante que procura um museu para se divertir em um final de semana com seus amigos ou familiares (ibidem, p. 15).

Entre as tendências a se adotar um tipo de terminologia ou outro, gostaríamos ainda de comentar uma última, a proposta por Falk e Dierking (2000). Estes estudiosos sugerem o termo "aprendizagem por livre escolha" (free-choice learning) para se referir àquela passível de ocorrer em centros e museus de ciências. Segundo os pesquisadores, os museus são locais onde as pessoas podem satisfazer, de forma livre, suas necessidades de aprender, engajandose em um processo descrito como não linear e intrinsecamente motivado. Trata-se de uma aprendizagem semelhante à envolvida durante as conversas e a convivência, quando se assiste à televisão, quando se lê jornal ou quando se usa a internet - em resumo, é uma aprendizagem relacionada ao que se costuma chamar de educação informal. Falk e Dierking propõem, além da terminologia, um modelo que explicaria este tipo de aprendizagem, baseado na interação entre fatores de três ordens: pessoal, sociocultural e física.

Apesar da interpretação de Marandino e colaboradores (2003) de que "Na aprendizagem por livre escolha, o interesse e a intenção do aprendizado têm origem no indivíduo, logo, não são impostas por elementos externos, como ocorre na escola” (p. 14), Falk e Dierking são bastante explícitos em atribuir à motivação intrínseca do indivíduo uma origem que seria, afinal de contas, externa:

toda aprendizagem se apoia em uma aprendizagem prévia, não somente aquela do próprio indivíduo, nas da sociedade como um todo, na qual este indivíduo vive. As palavras e conceitos que nós usamos em nosso dia-a-dia, assim como os artefatos concretos com que lidamos [...], são legados históricos da nossa cultura/sociedade; estas são as ferramentas que nos foram dadas para fazermos nossas vidas (FALK; DIERKING, 2000, p. 43-44, tradução nossa). 
Mas apesar dos próprios proponentes do termo "aprendizagem por livre escolha" negarem qualquer idealismo nele implicado, entendemos que o termo em si, utilizado sem a devida contextualização, pode levar a esta confusão ${ }^{77}$.

Não parecemos ter avançado muito para uma melhor compreensão da terminologia, ao fazermos esta pequena revisão nas últimas páginas. Afinal, o que definiria os processos educativos proporcionados por centros e museus de ciências? Poderíamos falar que eles se caracterizam como uma forma de educação "não formal", mesmo sabendo que tais instituições, da mesma forma que a escola, geralmente estão vinculadas ao Estado, ou pelo menos aparecem respondendo a interesses tão públicos e "formais" quanto os interesses a que se dirige a educação escolar? Ou deveríamos considerar os centros e museus de ciências como as sedes por excelência da educação "informal" - termo com conotação um tanto negativa, que remete ao que é "oculto", “furtivo", "clandestino", "ilegal”? (Aqui, temos que reconhecer que "aprendizagem por livre escolha" realmente soa melhor!). E lembremos que, de passagem, encontramos também menções pontuais às formas de "educação popular", que alguns autores consideram equivalente a "educação não formal".

A propósito, vejamos como um autor associado à Pedagogia Histórico-Crítica conceberia esta última modalidade:

\begin{abstract}
$\mathrm{Na}$ atualidade, há um debate polêmico entre os educadores em relação ao lugar do conhecimento científico e da escola na formação humana e nas lutas dos movimentos sociais populares. Alguns entendem que a escola não contribui na luta revolucionária por ser reprodutora das relações sociais dominantes, outros avaliam que a centralidade das atividades educativas se encontra nos saberes locais e intersubjetividades existentes num mundo diverso e complexo modulado pelas incontáveis realidades étnicas, campesinas, urbanas, cujas racionalidades e culturas são variadas. Outros ainda advogam uma pedagogia da prática, sendo os movimentos sociais os portadores da nova e verdadeira educação. A forma escolar e a defesa da apropriação do conhecimento sistematizado seriam nocivas para as organizações populares. [...] Na ótica da pedagogia histórico-crítica, em vez de invasão e contaminação da educação não escolar pelas práticas escolares ou de negação/minimização da educação escolar em relação à educação nos movimentos sociais populares, o que há, de fato, são reciprocidades entre ambas as práticas com ricas possibilidades de enriquecimento delas.

Se considerarmos que a fonte de produção do conhecimento e do processo educativo é a prática social, a qual se apresenta como elo articulador das práticas educativas em geral, tanto os movimentos sociais populares como a educação escolar têm um mesmo ponto de partida e de chegada. Contudo, para cada espaço educativo (escola, família, sindicato etc.) existem práticas, métodos, atividades diferentes que, embora se relacionem, não se identificam (SANTOS, 2012, p. 198-199).
\end{abstract}

\footnotetext{
${ }^{77}$ O capítulo 3 deste livro de Falk e Dierking, "The sociocultural context" (p. 37-52), onde são feitos estes esclarecimentos, baseia-se fortemente em Vigotski, ainda que apenas através da coletânea Mind in society (o texto que, traduzido para o português, gerou A formação social da mente). Em apoio à leitura dos autores sobre as ideias deste livro, eles fazem referência também às palavras de Luria em sua obra Language and cognition, o que leva a uma interpretação mais próxima às ideias de Vigotski presentes nos textos publicados na Rússia.
} 
No capítulo 4 desta tese, nos esforçamos por demarcar as diferenças entre o que seria uma "educação sistematizada" e uma "educação assistemática". Veja-se que no primeiro caso a adjetivação do substantivo "educação" se dá através do particípio do verbo "sistematizar". No segundo caso, por outro lado, jamais caberia se falar em "educação assistematizada". Com efeito, como vimos, sistematizar implica uma ação intencional e refletida - uma práxis sobre uma estrutura que carece deste tipo de diligência.

Com as palavras que iniciaram a presente seção, mais os esclarecimentos realizados há pouco, estamos em condição de propor mais uma tipologia que tente demarcar o que seriam diferentes modalidades do ato educativo, e quais instituições seriam de sua competência em cada caso. Baseando-nos em autores da Pedagogia Histórico-Crítica, entendemos que as formas de educação podem ser definidas em termos de seu grau de sistematicidade, no contínuo entre as formas assistemáticas e as sistematizadas; e se elas são ou não escolares, o que se considerará como qualidades discretas, não contínuas. Teríamos, assim, o diagrama exposto na Figura 29.

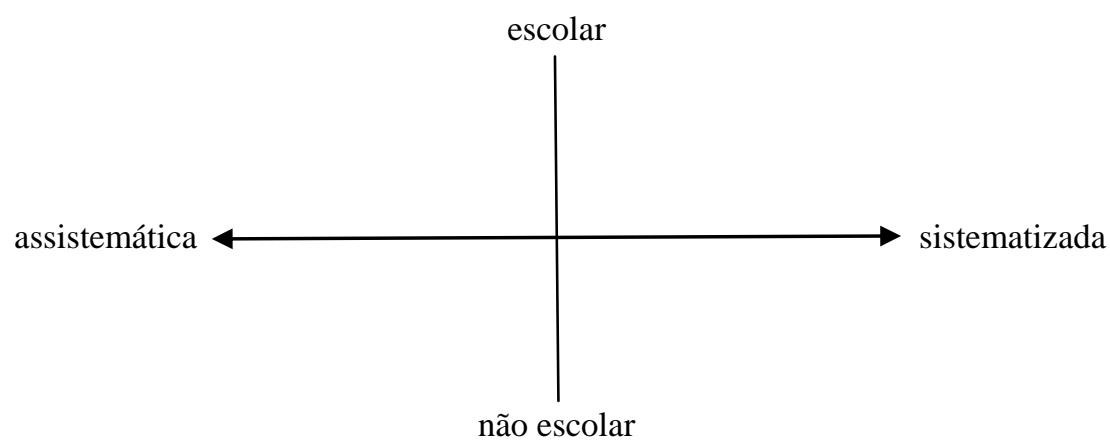

Figura 29: diagrama das modalidades de educação entre as dimensões escolar/não escolar e assistemática/sistematizada.

Haveria, portanto, quatro modalidades de educação concebíveis de acordo com a Pedagogia Histórico-Crítica: a "educação escolar assistemática"; a "educação escolar sistematizada"; "a educação não escolar assistemática"; e a "educação não escolar sistematizada".

A educação escolar sistemática é a forma institucional, oficial, formalizada da educação escolar; é, em verdade, sua essência. A literatura a identifica como "educação formal", embora tenhamos demonstrado a imprecisão deste termo.

Esta forma principal de educação escolar convive com outra, que lhe é inerente e inevitável: é a educação escolar assistemática. Entre os estudiosos do "campo do currículo", costuma-se identificá-la como "currículo oculto": são as aprendizagens que ocorrem à revelia 
do trabalho educativo intencional do professor. Poderia ser considerada como uma espécie de "educação escolar informal". Os alunos a vivenciam durante suas conversas e na convivência uns com os outros; quando visitam a biblioteca escolar para fazer leituras que não dizem respeito à matéria ensinada; ao tomar os docentes e demais profissionais do ambiente escolar como referência comportamental; quando se organizam em coletivos com fins reivindicatórios e políticos; entre outros e outros.

A educação não escolar assistemática lhe é análoga. Estaria implicada em atividades semelhantes às enumeradas acima, alterando-se simplesmente o contexto. Assim, abrangeria as aprendizagens que ocorrem nos espaços tradicionais de convivência (lar, rua, praça etc.), nas associações civis, no contato com artefatos e produtos culturais, enfim, tratar-se-ia de uma modalidade semelhante ao que tradicionalmente se concebe como "educação informal" ou como a "aprendizagem por livre escolha" de Falk e Dierking.

Finalmente, a educação não escolar sistemática seria aquela realizada por diversas instituições, entidades e empresas que oferecem cursos de frequência facultativa, mas com organização semelhante àquela praticada no ensino escolar. Estamos falando das academias de futebol, de artes marciais, das escolas de música, de idiomas, de certos cursos técnicos e profissionalizantes com maior ou menor duração, dos antigos cursos por correspondência e dos atuais cursos à distância. Identifica-se, portanto, com as formas enumeradas por Dib para se referir à "educação não formal”.

Mas a questão permanece sem resposta: e os centros e museus de ciências, como entendê-los a partir das formas de educação escolar/não escolar e sistemática/assistematizada?

\subsubsection{Experimentoteca: do não escolar para o escolar}

No primeiro capítulo desta tese, tivemos de recuperar o caráter histórico da instituição escolar para compreender sua especificidade, e somente a partir daí, falar em uma pedagogia. Algo análogo terá de ser feito neste capítulo, se quisermos concluí-lo compreendendo adequadamente de que formas os centros e museus de ciências podem interagir com o ensino formal, isto é, escolar.

Muito já fizemos neste sentido. Precisaremos, agora, apenas sistematizar todo o conteúdo exposto nas seções anteriores. 
Os museus surgem na Antiguidade como locais dedicados à inspiração, à cultura e ao trabalho intelectual criador, identificando-se assim como instituições voltadas para a produção do conhecimento. Muitos séculos mais tarde, com o advento do Renascimento, eles ressurgem dando nova forma a um hábito pré-histórico da humanidade - colecionar objetos -, de início apenas com fins contemplativos ou estéticos, mais tarde servindo novamente ao empreendimento investigativo. Após as luzes do século XVIII, e valendo-se do culto à razão que redundara na Revolução Industrial, os museus se modernizam e, paulatinamente, vão se apropriando de uma nova finalidade: a transmissão do conhecimento. A partir daí, passam a ser considerados como espaços para a instrução que atuam paralelamente à rede escolar, daí se identificarem como promotores de uma educação "informal" ou "não formal". No século XX, compreende-se que a antiga noção de museu, como local para a guarda ou para a preservação de um dado legado histórico, já seria insuficiente para abarcar a diversidade de abordagens e objetivos que se apresentam nos novos espaços. Assim, no âmbito das ciências surge a designação "centro de ciências". A formação de equipes multidisciplinares para a organização destes centros - cientistas das áreas específicas, museólogos, educadores, comunicadores, arquitetos, designers - impossibilita que se resumam suas atividades a fins de ensino e pesquisa. Agora é preciso considerá-los também como comunicadores do conhecimento, se esforçando para difundir os avanços da pesquisa científica a audiências cada vez maiores.

Neste percurso histórico, observa-se que a emergência da função comunicativa dos centros e museus de ciências é acompanhada de uma atrofia de sua função investigativa. Com a especialização cada vez maior das ciências, a exigência de equipamentos especializados e de equipes especificamente treinadas em cada ramo do saber levou a que o museu perdesse terreno, enquanto instituição produtora de conhecimento, para os laboratórios universitários e centros de pesquisa.

Por outro lado, sua função educativa, transmissora de conhecimento, nunca foi tão valorizada. Entende-se que os museus possuem elevada responsabilidade, enquanto instituições educacionais, por caberem a eles grande parte das aprendizagens que não são possíveis durante a (curta) vida escolar dos indivíduos. Parece pouco controverso que os centros e museus de ciências atuem de modo complementar à educação científica escolar. Algumas vozes, no entanto, defendem que os espaços ditos não formais se tornem progressivamente mais protagonistas da educação científica, dado o baixíssimo desempenho dos alunos em avaliações oficiais. 
Atendendo a estes clamores, temos visto os centros e museus de ciências se preocuparem cada vez mais com sua função educativa: treinam-se mais e melhor os monitores/mediadores, pedagogos passam a se tornar profissionais indispensáveis em seu quadro de profissionais, elaboram-se programas de visitas para o recebimento da população escolar, oferecem-se cursos a professores da rede oficial de ensino, e mesmo parte da formação inicial destes docentes passa a ocorrer nestes espaços.

As instituições que atendem a estas demandas, de acordo com a terminologia que acabamos de propor, promovem uma educação não escolar cada vez mais sistematizada. $\mathrm{Ou}$ seja, o lugar dos centros e museus de ciências, no diagrama da Figura 29, são os dois quadrantes abaixo do eixo horizontal, com uma tendência, na atualidade, para a ocupação do quadrante da direita.

De acordo com seu processo histórico de formação, a escola é uma instituição que transmite o conhecimento às novas gerações para que a cultura humana sobreviva à passagem do tempo, e assim continue a orientar a atuação prática dos indivíduos no mundo. Em outras palavras, a escola reproduz o conhecimento para preservar a cultura. Nestes mesmos termos, assistimos a uma completa reconfiguração das finalidades dos museus também ao longo de sua formação histórica. Na primeira geração de museus, conforme a tipologia de McManus, o "lema" destas instituições seria preservar a cultura para produzir o conhecimento. À geração seguinte podemos atribuir o lema preservar a cultura para reproduzir o conhecimento, em uma atuação "inversa" àquela das escolas, portanto. Na terceira geração, que predomina na atualidade, observa-se uma busca, por parte destas instituições, em se apropriar do lema escolar - reproduzir o conhecimento para preservar a cultura.

Este lema convive com outro: comunicar o conhecimento para (re)produzi-lo. Analisemos os dois sentidos sintetizados neste único aforismo, que nos fornecerão quatro justificativas para esta função comunicativa. Comunicar o saber científico é necessário para "reproduzi-lo" na medida em que o museu ou centro de ciências é capaz de contribuir para a aprendizagem escolar: 1) tanto quando serve como elemento motivador para o corpo discente; 2) quanto ao facilitar o contato dos estudantes com as aplicações e os artefatos da cultura material associados ao conhecimento científico. E comunicar este saber é necessário para "produzi-lo": 3) primeiramente, por existir uma relação dialética entre conhecimento científico e cultura popular, sendo necessário que a ciência se comunique - ou seja, estabeleça uma relação bidirecional, de diálogo, de reciprocidade - com os saberes de um público mais amplo para que ela mesma se nutra destes conhecimentos ainda não sistematizados, e 
sistematizando-os, faça-os ascenderem ao nível da cultura erudita; e 4) porque os museus e centros de ciências podem fomentar o interesse de sua plateia para se encaminhar às carreiras científicas, o que pode contribuir para minimizar a carência de quadros no mundo do trabalho com as ciências.

Nestes termos, é fácil identificar os museus e centros de ciências como entidades assemelhadas às universidades, ou pelo menos ao atual conceito de universidade no Brasil, se considerarmos que os museus da atualidade, mesmo os de terceira geração, ainda mantém características das gerações anteriores. Assim como as instituições de educação superior obedecem ao princípio constitucional da indissociabilidade entre ensino, pesquisa e extensão, os ditos espaços "não formais" também adquiriram tais missões ao longo de sua constituição histórica, primeiramente a pesquisa (preservar a cultura para produzir o conhecimento), depois o ensino (preservar a cultura para reproduzir o conhecimento) e, por fim, a extensão (comunicar o conhecimento para (re)produzi-lo).

Vejamos como o CDCC pode ser analisado a partir deste ponto de vista, e segundo também o referencial teórico da Pedagogia Histórico-Crítica.

Conforme os depoimentos dos sujeitos envolvidos na concepção e na organização da então Coordenadoria de Divulgação Científica e Cultural, desde seu início esta entidade esteve voltada para a melhoria do ensino de ciências em São Carlos e, posteriormente, em outros municípios. Uma visita ao CDCC confirma que as coleções de objetos, neste centro, são apenas um entre diversos outros elementos. Sua vocação é mesmo o fomento ao ensino escolar, em detrimento da ênfase sobre o aspecto expositivo. Assim, as finalidades deste centro não se alicerçam sobre o "preservar": os lemas preservar a cultura para produzir o conhecimento e preservar a cultura para reproduzir o conhecimento não são os lemas principais do CDCC.

As ações educativas do CDCC, se não aparecem estritamente relacionadas com a organização de seus espaços expositivos, também não se propõem a substituir a educação escolar. Portanto, a incorporação do lema escolar - reproduzir o conhecimento para preservar a cultura - não é uma aspiração deste centro de ciências. Quanto a isto, o CDCC se apresenta como uma entidade que incentiva a educação escolar e, de certa maneira, se subordina a ela. Sua atuação é, assim, consistente com o preceito de valorização da educação escolar, defendido pela Pedagogia Histórico-Crítica.

As atividades de pesquisa e ensino realizadas pelo CDCC, portanto, se processam em grande medida mediadas pela extensão, representada pelo lema comunicar o conhecimento 
para (re)produzi-lo. Como observamos, este lema compreende quatro justificativas principais para a função comunicativa dos centros e museus de ciências. Notadamente, as quatro foram contempladas pelo estudo de Canales sobre a Experimentoteca. Não à toa, seu trabalho considerou este projeto como uma iniciativa de extensão universitária, tomando como referência o modo como autores de pedagogias progressistas a conceituam: Paulo Freire, que a concebe exatamente como processo de comunicação ${ }^{78}$; e Dermeval Saviani, que a analisa a partir das relações entre saber popular e saber científico.

Canales observou que a Experimentoteca é capaz de motivar os estudantes para o aprendizado das ciências, auxiliando também na apreensão dos conceitos teóricos, na medida em que proporciona a "visualização" dos fenômenos em estudo. Tanto este aspecto motivacional, quanto o fato da Experimentoteca poder servir à verificação dos conteúdos científicos escolares, foram constatados nos estudos de Diniz e de Joaquim. Entretanto, cada um destes autores realiza sua própria apreciação valorativa sobre estes resultados: Diniz entende ser negativo que os kits do CDCC sirvam à perspectiva verificacionista, pois isto os aproximaria da pedagogia tecnicista e do empirismo-indutivismo; Joaquim, por outro lado, considera importante que o saber teórico escolar possa dialogar de alguma maneira com a prática, ainda que por uma via criticada pelos autores construtivistas.

Estas (o elemento motivador e o elemento de verificação do saber teórico) são as duas justificativas para o sentido comunicar o conhecimento para reproduzi-lo do lema da extensão. Como afirmamos, há mais duas justificativas, referentes ao sentido comunicar $o$ conhecimento para produzi-lo, do mesmo lema.

A dissertação de Canales abordou uma destas justificativas ao estudar o modo como a Experimentoteca se apresenta enquanto projeto de extensão universitária. Como seu estudo historiográfico apontou - e como a revisão que realizamos na subseção 5.1.2, de modo alternativo, o corrobora -, a constituição dos kits de materiais didáticos envolveu ampla participação de docentes das escolas públicas de São Carlos, e demandou um período prolongado de testes. As sucessivas reformulações pelas quais os materiais dos kits passaram, durante este momento, terminaram por garantir que o produto final materializasse diversos tipos de saber - o saber conceitual das disciplinas científicas, o saber didático-pedagógico, o

\footnotetext{
${ }^{78} \mathrm{Na}$ verdade, Paulo Freire denuncia os equívocos de ordens semântica e gnosiológica implicados no uso da palavra "extensão", e entende que "comunicação" sirva melhor à designação de um processo que é transformador, humanizador e emancipador. Deve-se ter em mente que a obra Extensão ou comunicação? (FREIRE, 1977), em que estas ideias são expostas, trata do conceito de extensão relativo ao processo de educação popular em que são apresentados saberes agrícolas a comunidades de camponeses (a chamada “extensão agrícola”).
} 
saber sobre o design - e, portanto, pudesse atender satisfatoriamente às exigências da práxis educativa neste município e em outras localidades. Portanto, o sucesso da Experimentoteca pode ser atribuído ao fato deste projeto ser o resultado de um abrangente e perene processo de comunicação, em que os saberes científicos do mundo acadêmico dialogaram com os saberes experienciais dos professores da educação básica. Nem um saber, nem o outro, poderiam sozinhos levar à concretização de um empreendimento como a Experimentoteca. É neste sentido que Canales afirma que o CDCC realiza um trabalho de extensão que não é assistencialista:

\begin{abstract}
A extensão assistencialista realiza ação caritativa e submete a população à passividade tratando-a apenas como objeto e utilizando-a para complementar, de forma prática, o ensino universitário. São muitos os trabalhos de extensão que oferecem atendimento semiprofissional médico odontológico e mesmo educacional, sem estabelecer uma relação de circularidade de informação com a comunidade. Agindo assim, impõe uma via de mão única na qual a universidade presta assistência à população e despreza o saber desta, retirando-lhe a reflexão e a responsabilidade tão fundamentais para o crescimento e independência (CANALES, 2006, p. 110111).
\end{abstract}

No fragmento acima, queremos destacar um ponto em que se insere nossa própria contribuição para o estudo acadêmico da Experimentoteca, e que não foi detectado pelas pesquisas de Diniz, de Joaquim e de Canales. Trata-se da questão da independência. Em seu texto sobre a extensão universitária, Saviani ressalta a importância de se "partir dos conhecimentos da própria comunidade, elaborar esses conhecimentos, em lugar de justapor conhecimentos extraídos de um outro contexto", mas com a ressalva de que "é preciso que a população, organizando-se, vá crescendo nesta articulação, na coesão, na elaboração de sua forma de entender a realidade" (SAVIANI, 1991, p. 63). Ao falar especificamente sobre o caso concreto do Projeto Rondon, Saviani assim ilustra suas ideias: tais projetos de extensão não podem se limitar à visão de curto prazo, apenas resolvendo as dificuldades de certas comunidades sem se preocupar com a continuidade das ações. Mais do que lidar com os problemas imediatos que incidem em dada localidade, as iniciativas de extensão precisam garantir condições para que as populações afetadas possam reivindicar, de forma organizada, a solução das questões crônicas, o que exige um trabalho que ultrapasse a vigência dos projetos. Para Saviani, “se a população não se organizar, ela não poderá se libertar e crescer" (ibidem, p. 62); e em resumo, as iniciativas de extensão precisam estar 
imbuídas deste espírito de pensar a médio e longo prazo. Neste esforço, o que caberia trabalhar é justamente o potencial de organização dessas populações. Qual, por exemplo, a capacidade de reivindicação existente, a percepção política que essas populações têm da sua situação? Nesse nível, o trabalho pode adquirir mais consistência (ibidem, p. 64).

Como demonstrou nossa pesquisa sobre os laboratórios didáticos de São Carlos, apresentada no capítulo 4, a iniciativa do CDCC se estendeu para além do domínio imediato do provimento de material didático às escolas. Contrariando o senso comum, a disponibilização dos kits da Experimentoteca, no lugar de acomodar a comunidade escolar e desmobilizar suas reivindicações pela melhoria da estrutura física para um melhor ensino de ciências, levou a que duas escolas tivessem esta estrutura incrementada justamente para possibilitar o contínuo desenvolvimento das atividades do CDCC. De fato, a montagem de laboratórios escolares adequados foi possível graças à iniciativa de lideranças do próprio CDCC. No entanto, a comunidade atendida pelo projeto de extensão precisou também se engajar neste processo para o enfrentamento de um problema crônico das escolas públicas, no tocante à educação científica. A reforma dos laboratórios das escolas A e B, como observamos em nossa pesquisa, seria uma condição necessária para que as mesmas desenvolvessem uma crescente independência em relação às iniciativas de extensão emanadas das universidades. Uma condição necessária, mas não suficiente. Vimos que os desafios relacionados à materialidade da ação educativa (não existência de um sistema educacional, problemas na estrutura organizacional da educação e descontinuidade das iniciativas) se constituíram como entraves para o prosseguimento do projeto de extensão do CDCC.

Faltou falarmos da segunda justificativa para o sentido comunicar o conhecimento para produzi-lo, do lema que formulamos e associamos à extensão universitária. Relembrando, trata-se de compreender que instituições como museus e centros de ciências podem ser importantes para despertar um interesse, em sua plateia, em fazer da ciência uma escolha profissional no futuro, próximo ou distante. Quanto a isto, a pesquisa de Canales apresentou resultados que nos levam a relativizar o sucesso da Experimentoteca. Conforme os depoimentos dos estudantes que entrevistou, a pesquisadora demonstrou que, pelo menos em sua amostragem, a interesse pelas carreiras científicas praticamente não foi despertado.

$\mathrm{O}$ insucesso da Experimentoteca quanto a este objetivo vem convivendo com outro desafio recente: o recuo na participação proporcional das escolas públicas em relação às instituições privadas, quanto ao empréstimo dos kits. Como observa Canales, este fato abala o poderio da Experimentoteca de mitigar a desigualdade entre o ensino público e o privado. Proibir o empréstimo dos kits ao setor privado, entretanto, seria uma saída irresponsável e 
ingênua. Considerando que as verbas que sustentam a manutenção da Experimentoteca provêm do imposto sobre circulação de mercadorias (a fonte do orçamento das universidades estaduais de São Paulo é a alíquota de 9,57\% da arrecadação do ICMS), as classes econômicas mais e menos elevadas são ambas mantenedoras da iniciativa do CDCC. Ainda que, como demonstra Saviani (ibidem, p. 50-53), o mencionado imposto seja do tipo regressivo (os mais despossuídos são os que mais contribuem, em termos absolutos), nem por isso as classes mais abastadas deixam de ter seu direito ao usufruto de um produto como a Experimentoteca. A solução para o desafio de incrementar a participação do setor público quanto ao uso dos kits, portanto, não está no desestímulo ao setor privado, pelo contrário, está no encorajamento à maior participação das escolas estaduais no projeto.

Para enfrentar este desafio, Canales sugere que seja direcionada uma maior atenção à Experimentoteca no processo de formação inicial de professores de ciências. A formação docente é também objeto de considerações nos trabalhos de Diniz e Joaquim. É justo que dediquemos nossa atenção também a este aspecto, nas páginas que estão por vir.

Assim, a formação de professores será o tema do capítulo 7 desta tese. O próximo capítulo será dedicado a uma questão que também se insinuou nos trabalhos pioneiros de Diniz e Joaquim, e por isso a consideramos mais premente: trata-se da fundamentação pedagógica da Experimentoteca. 


\title{
CAPÍTULO 6
}

\author{
A EXPERIMENTOTECA, II: \\ por uma fundamentação pedagógica
}

Este capítulo e o próximo partem da mesma constatação: vive-se atualmente uma crise no teorizar. Uma fobia teórica, conforme resume acertadamente um dos autores com quem dialogaremos nas próximas páginas.

A teoria nunca foi tão menosprezada, tão reduzida a falatório sem rumo, tão identificada como abstração estéril. À prática, pelo contrário, cabem todas as glórias: só ela transforma, só ela é ação, só ela realiza - como se o aspecto teórico fosse algo irreal...

As mais de 150 páginas que passamos "teorizando" nesta tese - nos três primeiros capítulos - devem bastar ao leitor para convencê-lo do quanto nos opomos a esta visão. Para nós, é inadmissível que o postulante a um título de mestre ou doutor renuncie a este movimento de mergulho na teoria. E se mesmo no nível da pós-graduação a carência de um suficiente aprofundamento teórico se apresenta como um problema crônico, que dirá no exercício profissional de quem, por exiguidade de tempo ou de estímulos, não está tão familiarizado com o estudo das teorias relativas a seu campo de trabalho. Estamos falando, especificamente, do trabalho nas salas de aula da educação básica.

No próximo capítulo, trataremos destas questões no âmbito particular da formação docente. Daremos mostras, inclusive, do quanto este discurso de depreciação da teoria é propagado pelos meios de comunicação e assumido acriticamente pelos educadores, a partir de suas leituras segmentárias e "monológicas" de determinados referenciais teóricos. 
Neste capítulo, o tom deverá ser menos polêmico (será?). O assunto a que ele se dedicará é a possibilidade de uma fundamentação teórica para a Experimentoteca, ou seja, uma pedagogia que lhe dê suporte. "Oficialmente", este fundamento pedagógico já está estabelecido n'O livro da Experimentoteca, e por isso a análise desta obra será o principal procedimento que adotaremos aqui. No entanto, não só as teorias ali expostas se referem a objetos diferentes - a experimentação no ensino de ciências, os conteúdos curriculares, a questão da aprendizagem - como podem ser cooptadas por perspectivas até divergentes. Em termos mais claros, O livro da Experimentoteca pode servir facilmente à propagação dos ecletismos que mencionamos no capítulo 2 desta tese, ao analisarmos as apropriações que os educadores químicos brasileiros fazem da Psicologia Histórico-Cultural.

Visando a um tratamento mais integrado dos diversos assuntos que aqui nos interessarão, fracionaremos o capítulo em cinco seções “maciças”, sem divisões. Em verdade, somente este capítulo já poderia ser o assunto de uma tese inteira. Portanto, as discussões aqui propostas não serão tão aprofundadas, reservando-se a possibilidade de que novos estudos as desenvolvam melhor.

A primeira seção revisa rapidamente a importância conferida ao fazer teórico, e sua integração com a prática na práxis, de acordo com o materialismo dialético. Dentre os incontáveis teóricos marxistas que se dedicaram à questão, recorreremos novamente à voz de Sánchez Vázquez. Para a mediação entre estas considerações filosóficas e o campo da educação, poderemos contar mais uma vez com Dermeval Saviani.

A seção seguinte apresenta, descreve e comenta $O$ livro da Experimentoteca. Os conteúdos desta obra que nos interessarão, e que iremos analisar nas seções seguintes, são aqueles relacionados à atuação pedagógica de educadores químicos. Assim, as considerações deste livro sobre outras disciplinas não serão abordadas.

Esta análise d'O livro da Experimentoteca revelará três tendências para a educação em Química que merecerão um olhar mais detido, o que será realizado nas três seções seguintes.

Assim, a terceira seção trata da tendência ao ensino com enfoque CTS.

A quarta, da tendência ao ensino por investigação.

E a quinta, por fim, da tendência à teoria dos perfis conceituais.

Estas três tendências serão dissecadas a partir da Pedagogia Histórico-Crítica e da Psicologia Histórico-Cultural, prezando-se mais, neste momento, pelos pontos de convergência do que em uma "via negativa". Muitas das críticas que dirigiríamos a estas tendências já foram enunciadas nos capítulos anteriores, dispensando-nos deste trabalho aqui. 


\title{
6.1 A NECESSIDADE DE FUNDAMENTOS TEÓRICOS NA PRÁTICA EDUCATIVA
}

O que é teoria?

Pereira (1985), procurando responder esta pergunta, começa listando os significados atribuídos à palavra nos dicionários, chegando às seguintes possibilidades: contemplação ou ato contemplativo, beatitude, atividade desinteressada, doutrina, sistema de ideias, ideologia, abstração. Todas expressões que reforçam a dicotomia entre teoria e prática, corroborando uma visão reducionista, simplista... e errada. Caberia, então, buscar a origem desta confusão:

\begin{abstract}
Onde está o mal-entendido que nos leva a confundir teoria com abstração, com conhecimento desarticulado da realidade? Por que este verbete nos dicionários pode atrapalhar-nos mais que nos ajudar? Como entender a teoria em seu verdadeiro significado e extensão e com muito menos blá-blá-blá? Em que e onde reside mesmo o verdadeiro fundamento do ato da teoria? (ibidem, p. 12, grifos do autor).
\end{abstract}

E durante o percurso por esta investigação, Pereira encontra a práxis, unidade entre teoria e prática. Não será possível avançar no entendimento da teoria sem que se considere sua indissociabilidade em relação à prática, convence-nos o autor.

Mas então, o que é práxis?

Não sendo prática pura é a prática objetivada (individual e socialmente) pela teoria. É a prática aprofundada por esta "meditação" ou reflexão que não deve ser solta, mesmo na consciência da relativa autonomia da teoria, na capacidade do ato teórico em antecipar idealmente a prática como objeto da mesma. A práxis, enfim, é a ação com sentido humano. É a ação projetada, refletida, consciente, transformadora do natural, do humano e do social (ibidem, p. 77).

Entre a bibliografia indicada por Pereira, para o estudo da práxis, consta um título que já nos serviu nesta tese, mais especificamente no capítulo 3. Trata-se de A filosofia da práxis de Adolfo Sánchez Vázquez, cujo capítulo "Unidade da teoria e da prática" (SÁNCHEZ VÁZQUEZ, 2011, p. 241-266) pode nos fornecer bons subsídios para a presente discussão.

O marxista mexicano começa por distinguir teoria de prática, e em que sentido caberia falar de uma oposição entre estes conceitos:

enquanto a atividade prática pressupõe uma ação efetiva sobre o mundo, que tem como resultado uma transformação real deste, a atividade teórica apenas transforma nossa consciência dos fatos, nossas ideias sobre as coisas, mas não as próprias coisas. Nesse sentido, cabe falar de uma oposição entre o teórico e prático (ibidem, p. 241). 
Mas se trata de uma visão estreita do problema, superável por um olhar mais totalizante; teoria e prática não se opõem, apenas se diferenciam.

Sánchez Vázquez falará, então, sobre o senso comum que atribui um papel nocivo à teoria, e que acaba legitimando todos os tipos de preconceitos, de estereótipos e de visões irracionais sobre o mundo. Recebendo um acabamento filosófico, depurando-se de seu aspecto rudimentar, esta visão redunda no chamado pragmatismo. Teremos oportunidade de discutir este ponto de vista ao final do capítulo.

Prosseguindo, em uma visão baseada no plano histórico-social todo conhecimento está submetido ao primado da prática, o que de modo algum anula a importância da teoria. Nas palavras do filósofo mexicano, “a prática é fundamento da teoria, já que determina o horizonte de desenvolvimento e progresso do conhecimento" (ibidem, p. 245). O senso comum atribui grande autonomia da teoria em relação à prática, mas trata-se novamente de um engano. Sánchez Vázquez, traçando as "origens do conhecimento das forças naturais", afirma que é a partir da divisão social do trabalho, na sociedade escravista, que se pode falar de certa "autonomização" do aspecto teórico em relação ao prático. Mesmo assim, se trata de uma autonomia apenas relativa: o que é teórico está sempre subsumido à prática.

Mas a teoria não responde apenas às exigências e necessidades da prática já existente. "Fosse assim, não poderia adiantar-se a ela e, portanto, influir - inclusive decisivamente - em seu desenvolvimento" (ibidem, p. 258). Há um outro plano de análise, além daquele em que a teoria não existente persegue a prática já estabelecida: é o plano em que estas relações são inversas, ou seja, quando uma teoria já elaborada se orienta para uma prática que ainda não existe (ou que ainda se encontra em forma embrionária).

\footnotetext{
Com efeito, o homem pode sentir a necessidade de novas atividades práticas transformadoras para as quais carece ainda do necessário instrumental teórico. A teoria é determinada, nesse caso, por uma prática da qual ainda não se pode nutrir efetivamente. Assim, o que significa essa determinação por algo que ainda não existe, ou que só existe de um modo ideal? $E$ a determinação pelo que anteriormente chamamos fim, antecipação ideal do que, não existindo ainda, queremos que exista. A prática é aqui o fim que determina a teoria. E como todo fim, esta prática - ou, mais exatamente, esse projeto ou antecipação ideal - só será efetiva com o concurso da teoria (ibidem, p. 258-259, grifo nosso).
}

Outra observação importante: as relações entre prática e teoria nem sempre são diretas e imediatas; às vezes, "uma teoria pode surgir - e isso é bastante frequente na história da ciência - para satisfazer direta e imediatamente exigências teóricas, isto é, para resolver as dificuldades ou contradições de outra teoria" (ibidem, p. 259). 
Cumpre destacar, considerando nosso contexto, o papel revolucionário das teorias:

Certamente, com base no conhecimento do objeto ou do fenômeno que se trate, pode-se modelá-lo idealmente e arrancá-lo de seu presente para situá-lo em uma futura situação possível. O conhecimento de certa legalidade do objeto permite, desse modo, antecipar com um modelo ideal uma fase de seu desenvolvimento não alcançada ainda (ibidem. p. 263).

Sánchez Vázquez apresenta alguns exemplos da história da ciência e da matemática para ilustrar este poder de antecipação das teorias, como no caso da relação entre as geometrias não euclidianas e a física de Einstein. Contudo, como já alertara previamente o autor, "O que é válido no terreno das relações entre a prática material produtiva e a atividade científica se evidencia com não menor clareza no campo da vida social” (ibidem, p. 252). Da mesma forma que a necessidade de tecnologias impulsiona o fazer científico, as contradições impulsionam as "teorias da revolução". Assim,

Em todos esses casos, a teoria mostra sua autonomia com relação à prática, adiantase a ela e acaba por influir na prática; e é precisamente sua capacidade de modelar idealmente um processo futuro que lhe permite ser um instrumento - às vezes decisivo - na práxis produtiva ou social. É claro que, como já mostramos anteriormente, essa influência implica uma disponibilidade da teoria, isto é, sua abertura ao mundo da prática, pois, como enfatizamos mais de uma vez, a teoria por si mesma - como produção de fins ou de conhecimento - não transforma nada real; ou seja, não é práxis (ibidem, p. 263).

Há de se destacar também o papel da consciência nesta práxis, se ela se deseja de fato revolucionária. Segundo Sánchez Vázquez, “a consciência não pode bater em retirada no processo prático", devendo "estar alerta às exigências imprevistas do processo objetivo de realização" (ibidem, p. 265). Em outras palavras,

\begin{abstract}
a consciência não pode limitar-se a traçar um fim ou modelo ideal imutável. O dinamismo e a imprevisibilidade do processo exigem também um dinamismo da consciência. [...] O resultado real só é alcançado ao cabo de um processo prático, objetivo, que ultrapassa a cada momento o resultado ideal. Por conseguinte, a consciência tem de permanecer ativa ao longo de todo esse processo, não só buscando impor o fim original, mas também modificando-o em prol de sua realização (p. 265-266).
\end{abstract}

Bastando-nos, por ora, as considerações de Sánchez Vázquez, voltemos a recorrer a Pereira (1985). Um aspecto tratado por ele merece atenção: a práxis é exclusividade do gênero humano - "O animal absolutamente não pode ser o ser da práxis" (ibidem, p. 70). Melhor dizendo, 
na sua ação, [o animal] não pode elaborar a teoria. Sua ação é uma espécie de "prática pura", não é interiorizada, não é "contemplada". Porque não é ação da consciência. Há uma diferença antropológica fundamental que separa o homem do animal. É que o animal não possui a capacidade de distanciar-se da natureza para refletir sobre sua ação. Distanciar-se em termos de tempo e espaço para poder articular a significação ou o sentido de seu ato. $\mathrm{O}$ animal está mergulhado no dado imediato que é a natureza presente em tempo e espaço diante de si mesmo, no momento de sua ação. É por isso que não cria nem a relação social (para se fazer e crescer nela) e tampouco faz história (nem a de si mesmo, nem a de seu tempo). Mesmo mergulhado na natureza, conhecendo-a de forma espetacular, é dramático o fato de o animal não poder criar cultura (ibidem, p. 70).

As ações dos animais são orientadas pelos imperativos da sobrevivência, estabelecendo relações quase sempre imediatas com a natureza. Nas pouquíssimas exceções a este comportamento, como no uso de instrumentos por alguns primatas, por exemplo, trata-se de uma ordem de relações ainda marcantemente primitivas em comparação com a capacidade criativa dos humanos:

A ação da natureza ou do animal são apenas ação de mudança. A ação do homem é duplamente transformadora. Transforma a natureza e, ao transformá-la, transforma a si mesmo. Em maior ou menor medida é a práxis. Ainda, em nível superior esta ação transformadora (práxis) é que chega ao estágio de ação revolucionária (ibidem, p. 72).

Pode-se falar, assim, em diferentes graus ou estágios das ações ou atuações práticas: num grau mais primitivo, estão as ações aleatórias ou contingentes associadas aos fenômenos naturais, e as ações instintivas dos animais; a seguir, aparecem as ações humanas ainda carentes de suficiente elaboração teórica; e por fim, a ação revolucionária, que é práxis legítima. E ainda que não seja possível identificar completamente o comportamento humano com o comportamento animal, é neste segundo estágio das atividades práticas (aquelas que ainda carecem de teorização) que se podem traçar semelhanças entre a práxis humana e as ações animais. Com efeito, “o que é dramático é que o animal não pode meditar o que faz e muito menos fazer-se a partir do que faz (porque o resultado de sua ação não recai sobre si mesmo)" (ibidem, loc. cit.). Ora, se o ser humano se vê privado de, exatamente, meditar sobre o que faz e fazer-se a partir do que faz, sua práxis compartilha dos atributos das ações animais. Trata-se de uma práxis cujo sentido foi subtraído, realizada com um mínimo de consciência, apegada e acostumada com o cotidiano. Uma práxis alienada. Neste aspecto, pode-se dizer que o indivíduo submetido a tais condições está "animalizado".

Segundo este raciocínio, portanto, a teoria cumpre o papel capital de "humanizar" a práxis carente de sentido e de fundamento. Se a práxis, em seu estágio inferior, anda a 
reboque da prática, é o aspecto teleológico da teoria que pode elevá-la a uma práxis revolucionária.

E quando falamos em caráter teleológico da teoria (ou do aspecto teórico da prática), isto é, no fato de o homem poder projetar ou idealizar uma prática antes de acontecer, é aí que a teoria deve servir de instrumento da práxis social. Aqui entra também o aspecto da utopia, do projeto humano (individual e social), tanto do ponto de vista do pensamento como da ação (ibidem, p. 76, grifo do autor).

E comentando uma famosa passagem de Lênin - "Só uma teoria revolucionária cria uma ação revolucionária" -, Pereira conclui:

Essa frase simplesmente nucleia toda nossa discussão em torno da relação teoria/prática. O que acontece é que em nosso conhecimento diário e ordinário estamos de tal forma imbuídos do senso-comum que nem percebemos a profundidade das coisas simples. A simplificação demasiada das coisas pode levarnos ao estado de certa inconsciência ou de "inocência teórica" e representar sério entrave à articulação crítica de nossa visão de mundo e de nosso ascenso à práxis (ibidem, p. 82).

Um resumo de nossas discussões filosóficas sobre a relação entre teoria e prática pode ser encontrado no livro de P. V. Kopnin que também temos citado nesta tese, A dialética como lógica e teoria do conhecimento:

O pensamento como relação teórica do sujeito com o objeto surge e se desenvolve à base da interação prática entre eles e se caracteriza pelas seguintes peculiaridades:

1. Essa interação tem caráter material. A prática não é uma relação lógica mas concreta-sensorial, material. Os resultados da interação prática são direta ou indiretamente acessíveis à contemplação empírica, pois surtem efeito a mudança do objeto e, simultaneamente, do próprio sujeito.

2. A prática é uma forma especificamente humana de atividade, de interação entre o homem e os fenômenos da natureza. Neste sentido o homem atua não como indivíduo mas como membro da sociedade, da humanidade.

3. O prático é a atividade racional do homem. A prática une realmente o sujeito com o objetivo e cria os objetos, as coisas existentes independentemente da consciência do homem; o pensamento os une apenas teoricamente, criando imagens, medidas de possíveis coisas e processos da realidade. [...]

Tanto a contraposição da teoria à prática quanto a identificação de ambas surgem como resultado da compreensão da prática apenas como atividade subjetiva, sem que se saiba ao certo que atividade é essa, qual o seu objeto concreto. A prática é a unidade do sujeito com o objeto, é ativa por forma porém concreto-sensorial por conteúdo e resultados (KOPNIN, 1978, p. 168-169, grifos do autor).

Dotemos estas considerações gerais, a partir de agora, de concreticidade. Vejamos, por intermédio de Saviani, como estes conteúdos abstratos do materialismo dialético podem ser articulados para a compreensão das relações concretas que se estabelecem no âmbito educacional. 
Em Educação brasileira: estrutura e sistema (SAVIANI, 1975) o pai da Pedagogia Histórico-Crítica já alertara sobre a importância do ato de refletir:

E o que significa reflexão? Re-flexão significa desdobramento (flexão = dobramento, ato de dobrar). Sua origem está no verbo latino "reflectere",79 que quer dizer "voltar atrás". Assim como o espelho tem a propriedade de captar a luz e projetá-la numa determinada direção (reflexão da luz), assim também o homem tem a capacidade de captar (através da consciência) os dados da realidade e imprimirlhes determinado sentido. Refletir é o ato de retomar, reconsiderar os dados disponíveis, revistar, vasculhar numa busca constante o significado (p. 67).

A partir da defesa de que a reflexão filosófica não deva ser qualquer tipo de reflexão - "para ser tal, deve ser radical, rigorosa e de conjunto" (ibidem, p. 68) - Saviani defenderá a necessidade desta filosofia como um requisito para a ação sistematizada. Assim, se podemos falar, abstratamente, que o filosofar é necessário para se agir de modo sistematizado, educar de modo sistematizado exige uma reflexão filosófica no âmbito educacional. Por isso, mais adiante, Saviani considerará que a formação de um sistema educacional exige a formulação de uma pedagogia. Em suas palavras, "Sem uma teoria educacional será impossível uma atividade educativa intencional comum" (ibidem, p. 80). E, ainda, retomando um fragmento já citado no capítulo 4 desta tese, "A formulação de uma pedagogia (teoria educacional) integrará tanto os problemas como os conhecimentos (ultrapassando-os) na totalidade da praxis histórica onde receberão o seu pleno significado humano" (ibidem, p. 81).

Também já havíamos citado, naquele capítulo, outro fragmento importante, desta vez da obra Pedagogia Histórico-Crítica: primeiras aproximações (idem, 2008), falando da necessidade de elaboração teórica para se justificar a transformação da prática, propondo também as formas desta transformação. Neste livro, Saviani afirma adotar o conceito de práxis conforme o entendimento de Sánchez Vázquez a respeito dele, como "um conceito sintético que articula teoria e prática", ou como "uma prática fundamentada teoricamente" (ibidem, p. 141). Para o educador brasileiro,

\footnotetext{
Se a teoria desvinculada da prática se configura como contemplação, a prática desvinculada da teoria é puro espontaneísmo. É o fazer pelo fazer. Se o idealismo é aquela concepção que estabelece o primado da teoria sobre a prática, de tal modo que ela se dissolve na teoria, o pragmatismo fará o contrário, estabelecendo o primado da prática. Já a filosofia da práxis, tal como Gramsci chamava o marxismo, é justamente a teoria que está empenhada em articular a teoria e a prática, unificando-as na práxis. É um movimento prioritariamente prático, mas que se fundamenta teoricamente, alimenta-se da teoria para esclarecer o sentido, para dar direção à prática (ibidem, p. 142).
}

\footnotetext{
${ }^{79}$ Saviani indica como referência a obra Iniciação ao filosofar de Joel Serrão.
} 
No texto base para uma "aula síntese" da cadeira de Introdução à Educação da PUCSP em 1971, intitulado "Para uma pedagogia coerente e eficaz" (idem, 2009, p. 59-63), Saviani traz esta discussão para o terreno educacional propriamente dito. Considerando a educação como ato intencional, ele assim introduz a questão:

agir de modo intencional significa agir em função de objetivos previamente definidos. Por isso, a reflexão sobre os problemas educacionais leva-nos à questão dos valores e objetivos na educação. Partindo de uma compreensão do homem no contexto situação-liberdade-consciência, referindo-o à realidade existencial concreta do homem brasileiro, pode-se enunciar esquematicamente objetivos gerais para a educação brasileira: educação para a subsistência, para a libertação, para a comunicação e para a transformação (ibidem, p. 61).

Considerados estes quatro objetivos educacionais, coloca-se a questão dos meios que podem ser empregados para assegurar sua consecução:

\begin{abstract}
Mas nós não estamos interessados em quaisquer meios e sim nos meios adequados à realização dos objetivos propostos. A posse de tais meios está na razão direta do conhecimento que temos da realidade. Ou seja: quanto mais adequado for o nosso conhecimento da realidade, tanto mais adequados serão os meios de que dispomos para agir sobre ela. Com efeito, já dissemos que promover o homem significa tornálo cada vez mais capaz de conhecer os elementos de sua situação a fim de poder intervir nela transformando-a no sentido da ampliação da liberdade, comunicação e colaboração entre os homens. E, para o conhecimento da situação, nós contamos hoje com um instrumento valioso: a ciência. $\mathrm{O}$ educador não pode dispensar-se desse instrumento, sob risco de se tornar impotente diante da situação com que se defronta (ibidem, loc. cit., grifo do autor).
\end{abstract}

O autor irá, então, detalhar três motivos pelos quais a ciência interessa aos educadores. Sem discutirmos o segundo e o terceiro motivos elencados por Saviani (e que são bastante óbvios: as ciências são conteúdos do ensino, e precisam ser dominadas pelos professores para serem transmitidas; e as ciências interessam aos educadores porque a própria educação pode vir a formar cientistas), analisemos detidamente o primeiro motivo, que já foi antecipado no fragmento acima: o conhecimento científico permite a adequada apreensão dos aspectos da realidade em que o educador atua. É aí que entra o papel da técnica, ressaltada na seguinte passagem:

a técnica pode ser definida, de modo simples, como a maneira julgada correta de se executar uma tarefa. E quando a técnica é derivada do conhecimento científico, ou seja, quando ela se fundamenta em princípios cientificamente estabelecidos, ela denomina-se tecnologia. Assim, a engenharia é uma tecnologia derivada das ciências físico-matemáticas, do mesmo modo que a medicina é uma tecnologia derivada das ciências biológicas. Portanto, quando a ação educativa se fundamenta em princípios científicos, pode-se falar também em tecnologia (ibidem, p. 63). 
Talvez a contribuição mais importante deste texto de Saviani, além do exposto acima diga-se de passagem, considerações até óbvias - consta no parágrafo de encerramento, que transcrevemos na íntegra:

\begin{abstract}
No que diz respeito às relações entre fins e meios no processo educacional, é preciso observar ainda o seguinte: se geralmente está a nosso alcance definir novos objetivos para a nossa ação no campo da educação, frequentemente não está a nosso favor a escolha dos meios adequados aos novos objetivos. Defrontamo-nos, pois, com o problema de usar meios velhos em função de objetivos novos. Com efeito, educar tendo em vista os objetivos propostos (subsistência, libertação, comunicação e transformação) exigiria instituições educacionais diferentes daquelas que possuímos, com uma organização curricular também diferente. No entanto, não nos é dado criar as novas instituições, independentemente das atuais. Nós temos que atuar nas instituições existentes, impulsionando-as dialeticamente na direção dos novos objetivos. Do contrário, ficaremos inutilmente sonhando com instituições ideais. Problemas desse tipo fazem com que, a par de uma sólida fundamentação científica, o educador necessite também se aprofundar na linha da reflexão filosófica. É isso que justifica a existência de cursos de educação em nível superior. Com efeito, a passagem de uma educação assistemática (guiada pelo senso comum) para uma educação sistematizada (alçada ao nível da consciência filosófica) é condição indispensável para se desenvolver uma ação pedagógica coerente e eficaz (ibidem, loc. cit.).
\end{abstract}

Esse parágrafo sintetiza perfeitamente o que desejamos ter transmitido nas páginas anteriores. $\mathrm{O}$ educador necessita estar armado de uma pedagogia - e podemos considerar que ela unifica um pensamento que é ao mesmo tempo ciência e filosofia - para desenvolver uma ação consciente e intencional, sua práxis. $\mathrm{O}$ aspecto científico da pedagogia determina de modo adequado as técnicas de que se valerá para alcançar os objetivos educacionais, que provêm, por sua vez, da reflexão filosófica sobre a educação. A teoria não pode deixar de se referir à prática, o que não significa que deva ser sempre sua caudatária. $\mathrm{O}$ aspecto teleológico da teoria - que dirige a finalidade da ação, antecipando os resultados ainda não existentes na prática - sugere um matiz utópico à práxis assim concebida. Mas, como a realidade objetiva é constituída de múltiplas relações e determinações, nem sempre o que resulta destas ações é exatamente aquilo que delas se concebeu. Daí a necessidade de a consciência acompanhar todo o processo em que o ato prático é orientado pela teoria visando à transformação da realidade.

Uma educação transformadora, assim, deve estar iluminada por uma teoria que lhe dê suporte, possibilitando ao educador a clareza de objetivos e de métodos de que dispor em sua prática - prática esta que, por sua vez, será o fundamento, a finalidade e o critério de verdade desta teoria educacional. 


\title{
6.2 O LIVRO DA EXPERIMENTOTECA E AS TENDÊNCIAS DA EDUCAÇÃO EM QUÍMICA
}

À luz da seção anterior, e da história narrada no capítulo 5, surge uma questão: como o CDCC e os idealizadores da Experimentoteca concebem a relação entre a prática pedagógica dos professores de ciências, o uso deste material didático em sala de aula e a fundamentação em teorias educacionais?

Nos depoimentos transcritos na dissertação de mestrado de Joaquim, o Prof. Dietrich Schiel nos fornece algumas pistas sobre esta questão:

\begin{abstract}
Acho que a proposta da Experimentoteca como nós a fazemos, é uma busca de solução para os problemas. Não devemos dar receitas rígidas nem ter a ilusão de que a Experimentoteca é proposta curricular. Ela é um meio. Mesmo assim não se pode abrir mão de outros meios.

A Experimentoteca em momento nenhum foi "proposta de gabinete" encaminhada à rede. É uma proposta de criação conjunta, nossa com os professores da rede, e enquanto nós mantivermos essa porta aberta, ela será sempre funcional porque o professor não vai criar um instrumento que não sirva para si mesmo. Então, a esperança que se tem é que, mantendo essa forma de trabalho, na Experimentoteca se farão todas as modificações curriculares e metodológicas. Se se mantiver essa porta aberta não se vai correr o risco de, de ela se tornar obsoleta porque o material é dado físico, mas a forma como se trabalha pode sempre se adaptar às novidades que vão surgindo.

No Projeto Experimentoteca você pode trabalhar todo o conteúdo de todas as maneiras possíveis (JOAQUIM, 1992, p. 173, grifos nossos).
\end{abstract}

Esta primeira fala do idealizador da Experimentoteca já sugere que, na verdade, a discussão de uma pedagogia que fundamentasse o projeto não foi uma preocupação inicial da equipe que criou os kits. $\mathrm{O}$ objetivo do projeto seria equipar ou instrumentalizar a prática dos professores de ciências do município de São Carlos. O material deveria caracterizar-se, assim, por certa "universalidade", sendo adaptável às (presumivelmente) diversas concepções pedagógicas de seus usuários:

A Experimentoteca cresceu quantitativamente e qualitativamente. O ensino em geral se tornou mais amplo hoje do que quando começamos, então esse instrumento tem que ser mais aberto para se adaptar às novas propostas e esse é o grande desafio. Em parte, se o professor quiser usá-la como ele usava há dez anos, ele pode. Se quiser usá-la de outras formas, ele também pode (ibidem, p. 174, grifo nosso).

A preocupação com os fundamentos pedagógicos da Experimentoteca só teria assumido maior importância para a equipe responsável pelo projeto, no CDCC, após 
equacionada a questão material propriamente dita. Schiel, comentando a ideia de elaborar kits também para as séries iniciais do ensino fundamental, chega a dizer que, no momento (início da década de 1990), "podemos nos dar ao luxo de usar o que temos de mais recente em termos de proposta metodológica" (ibidem, p. 175). Naturalmente, o que havia de mais atual à época, em termos de teorias pedagógicas, era o entusiasmo para com as ideias construtivistas. A questão do diretivismo - muito cara ao construtivismo - é tratada também neste depoimento de Schiel:

A diferença entre esse [a Experimentoteca] e outros projetos está na construção, no processo de desenvolvimento, de aplicação. Como se baseia estritamente na experiência do professor, qualquer professor, que a use, vê, percebe isso. É aquilo que nós discutimos muito na fase de formulação: o professor vai estar fazendo as experiências "sozinho", mas com 40 alunos, muitas vezes indisciplinados. Isso não é nada trivial. Na universidade eu tenho um técnico ao meu lado, me dando assistência.

A consequência disso é que, para garantir o funcionamento, a gente acabou criando experiências bem direcionadas. Isso porque se você deixar a experiência muito aberta o professor perde o controle. Contudo, a gente não deve esquecer que por mais que se direcione, o aluno sempre tem a chance de criar em cima. Não se conseguiria brecar, nem que quisesse... (ibidem, p. 178, grifo nosso).

O tom assumido pela fala, neste momento, é quase como se o entrevistado estivesse se desculpando. No contexto desta época o construtivismo aparecia em franca ascensão, e a não adoção de alguns de seus preceitos poderia ser interpretada como um retorno às ideias das pedagogias tradicional e tecnicista. Assim, é compreensível que o Prof. Schiel pareça estar "pisando em ovos" ao defender que a Experimentoteca se apresentasse com atividades mais estruturadas e diretivistas:

A gente queria deixar a proposta aberta mas, assim como está, tem funcionado bem. Claro que eu sou a favor da liberdade "ampla e total" do aluno, desde que isso seja funcional.

$[\ldots]$

Nunca se sabe exatamente, sem uma investigação muito a fundo, se a orientação foi diretiva, se você tolheu a liberdade. Vamos ter que perguntar ao aluno (ibidem, p. 178-179).

Já em uma época posterior à publicação d'O livro da Experimentoteca, Schiel explicitaria a relação entre os kits e uma possível fundamentação construtivista, em um texto sintomaticamente intitulado "A construção do conhecimento pelo aluno no programa Experimentoteca" (SCHIEL, 2001): 
Foi recentemente lançado o Livro da Experimentoteca - educação para as ciências da natureza através de práticas experimentais, em que, além da coleção completa dos roteiros, são feitas sugestões baseadas na prática de professores de ciências, usuários do sistema. Com isso, procura-se produzir um auxílio importante para professores que queiram usar a experimentação de maneira apropriada para permitir a construção adequada do conhecimento pelos seus alunos.

$\mathrm{O}$ uso em sala de aula fez com que diversos professores usuários criassem recursos didáticos adicionais, tais como introduções apropriadas, discussões, apresentação de conceitos de acordo com avanços mais recentes da teoria construtivista. Há a necessidade ainda de atualização de informações de conteúdo científico vinculado ao cotidiano do professor (p. 261-262).

Assim, pode-se dizer que a Experimentoteca foi planejada e concebida como um material universal e passível de ser empregado em qualquer sala de aula, por qualquer professor, não importando suas concepções teóricas sobre o ato de educar. A associação dos kits do CDCC ao ideário construtivista aconteceu por iniciativa dos próprios criadores destes materiais, como um produto histórico da situação educacional no Brasil numa época em que aportavam no país, com firmeza, valores como o não diretivismo, o recurso às ideias prévias dos alunos e o estímulo a sua criação livre e espontânea.

Já apresentamos, no capítulo passado, algumas das diversas passagens do trabalho de Diniz (1992) que explicitam a filiação deste autor às ideias construtivistas. Nesta primeira dissertação de mestrado sobre a Experimentoteca, pode-se considerar que o referencial teórico adotado bebe na fonte dos trabalhos de Jean Piaget direta e indiretamente (mediante a didática de Hans Aebli). Transcreveremos dois fragmentos, abaixo, para trazer mais exemplos destas “declarações de princípios” por parte de Diniz:

Por estar o presente trabalho voltado para o ensino de ciências de $5^{\mathrm{a}}$ a $8^{\mathrm{a}}$ série, englobando indivíduos na faixa etária de 10 aos 15 anos, na qual se entrecruzam os estágios das operações concretas e das operações formais, é que se considera que a atividade experimental possa desempenhar um papel importante no desenvolvimento de tal ensino, desde que pensada como uma alternativa para envolver os alunos em situações onde possam desenvolver, conjuntamente, ações concretas e mentais (ibidem, p. 60).

[A] atividade do aluno durante o processo de aprendizagem é entendida aqui, numa perspectiva construtivista, como sendo fundamental para que a aprendizagem se estruture a partir de operações deste aluno sobre os objetos de conhecimento com os quais se depara. Já a atuação do professor nesta mesma perspectiva, é compreendida como sendo fundamentalmente de mediador, de propiciador de situações pedagógicas, nas quais os alunos possam efetivamente interagir com o conteúdo estudado (ibidem, p. 105).

Como afirmamos, entre os três autores que produziram dissertações de mestrado sobre a Experimentoteca, Diniz é o único que demonstra certa desaprovação em relação a esta 
iniciativa do CDCC. Isto porque de sua posição construtivista, só poderia ser negativo que, durante um ano inteiro de pesquisa em sala de aula, o autor conseguisse observar apenas uma situação em que os alunos puderam externar sua criatividade a ponto de definir o conteúdo que seria abordado em sala de aula. Mas, como observa Diniz, a Experimentoteca foi planejada para um uso mais direcionado das atividades, o que só poderia criar óbices a uma atuação verdadeiramente construtivista por parte de seus usuários.

Já o trabalho de Joaquim (1992) parte de uma perspectiva diferente. Por ter participado do processo de teste dos primeiros protótipos da Experimentoteca, a autora apresenta informações interessantes sobre a questão dos possíveis fundamentos pedagógicos da proposta do CDCC:

\footnotetext{
Como professor integrante do grupo de estudos [que testava os kits], pude testemunhar a preocupação constante de todos para que o desenvolvimento da atividade prática levasse o aluno a pensar com acerto, a colher informações por si mesmo e a resolver problemas de modo ativo e orientado.

Era consenso entre os professores que compunham o grupo de estudo, que no experimento o aluno só se dispõe a pensar quando o assunto se apresenta como um problema a ser resolvido, quando recebe orientações teóricas ou técnicas na quantidade necessária para enfrentar por si pequenas dificuldades, quando sem saber o resultado do experimento, perguntas orais ou escritas conduzem seu raciocínio para aspectos importantes (ibidem, p. 36).
}

Joaquim conta também o motivo da não explicitação destes fundamentos nos materiais da Experimentoteca (ou da inexistência de um material específico para explicitá-los, como passou a acontecer a partir da publicação d'O livro da Experimentoteca):

Essa metodologia nunca foi explicitada como a que deveria ser desenvolvida na aplicação do kit, até porque a metodologia impregnada no professor é quem determina a postura a ser considerada frente a qualquer recurso didático (ibidem, $\mathrm{p}$. 36-37).

E em apoio a esta fala, a autora transcreve a seguinte passagem de Rodrigues (1987, p. 19): "Não se pode transferir para o instrumento a razão operacional de seu uso. A direção do ato não é determinada pelo instrumento, mas por aqueles que o usam”. No entanto, não podemos concordar inteiramente com esta citação dado que, como desenvolvemos no capítulo 3 , se é a intenção do homem que direciona o uso do instrumento, também é verdade que nele próprio estão fixadas determinadas operações que constrangem seus modos de emprego efetivo.

É justamente considerando este papel instrumental dos kits da Experimentoteca que Joaquim avança consideravelmente, em relação às declarações de Schiel e Diniz, para um entendimento dos fundamentos pedagógicos deste material numa visão mais além do 
construtivismo. Ainda que de modo incipiente e tentativo, a autora agrega contribuições de Vigotski para elaborar uma avaliação do projeto Experimentoteca, apesar de partir de uma das obras que não reproduzem fielmente as palavras do pesquisador russo:

\begin{abstract}
Os kits funcionam para o professor como instrumento de ampliação de atividades com função mediadora externa de orientação de comportamento, onde novas funções psicológicas podem operar, tornando mais eficazes os esforços de adaptação e solução de problemas.

Vygotsky, (1988, p. 8) [referência a A formação social da mente - mais especificamente, ao prefácio dos organizadores da obra], ao estabelecer que mudanças históricas na sociedade produzem mudanças na consciência e no comportamento, observou no trabalho humano: "o uso de instrumentos como meios pelos quais o homem transforma a natureza e, ao fazê-la, transforma a si mesmo". Para ele, "o mecanismo de mudança individual ao longo do desenvolvimento tem sua raiz na sociedade e na cultura" (JOAQUIM, 1992, p. 152).
\end{abstract}

Mas apesar desta e de outras tentativas de articular a Experimentoteca a fundamentos pedagógicos das tendências educacionais progressistas, Joaquim mantém uma posição ainda cautelosa e evita tais compromissos:

[A Experimentoteca] partiu de das expectativas e do trabalho de uma comunidade docente, abrindo um canal de comunicação e interação entre elementos dos diferentes níveis de ensino. Embora concebida e estruturada com o embasamento teórico dos Guias Curriculares e Programas de Saúde de 1973 e as percepções da realidade educacional do período, manteve-se aberta a reestruturações e adaptações decorrentes dos avanços teóricos (ibidem, p. 153, grifo nosso).

Curiosamente, em um texto mais recente, Schiel e outros coordenadores da Experimentoteca iriam se referir ao projeto utilizando um discurso crítico ao ensino tradicional, geralmente de teor construtivista, mas se apropriando também da terminologia típica dos escritos vigotskianos, como "mediação", "instrumento", "sentido" e "significado":

Os materiais instrucionais não devem ser concebidos numa perspectiva de transmissão de um conhecimento pronto, organizado a partir de uma lógica cujo sentido encontra-se apenas no interior da própria ciência que se procura ensinar. [...] O material didático deve ser entendido como um instrumento mediador entre o aluno e o conhecimento para que ele possa apreender o sentido e o significado do conteúdo de ensino (SCHIEL; CURVELO; FERREIRA, 2004, p. 150).

Evidentemente, o fato de a Experimentoteca ter se constituído, inicialmente, apenas como um conjunto de materiais, sem comprometimentos com qualquer concepção pedagógica, levou a esta situação de "disputa": cada sujeito que discorre sobre este projeto do CDCC, involuntariamente ou não, acaba por analisá-lo a partir de seus pressupostos teóricos; e mais do que "analisá-lo", busca mobilizá-lo para a confirmação ou a propagação destes 
pressupostos. Na Figura 30 organizamos, como quadro, o modo como estes diferentes sujeitos se referem à Experimentoteca a partir de seus referenciais teóricos particulares ${ }^{80}$ :

\begin{tabular}{|l|l|l|}
\hline \multicolumn{1}{|c|}{ Autor } & \multicolumn{1}{|c|}{ Referência(s) } & \multicolumn{1}{c|}{ Considerações } \\
\hline $\begin{array}{l}\text { Schiel, em } \\
\text { publicações e } \\
\text { depoimentos }\end{array}$ & $\begin{array}{l}\text { construtivismo, sem citar } \\
\text { autor específico }\end{array}$ & $\begin{array}{l}\text { busca articular a Experimentoteca para um ensino de ciências } \\
\text { menos influenciado pela pedagogia tradicional }\end{array}$ \\
\hline Diniz (1992) & $\begin{array}{l}\text { construtivismo (Piaget, } \\
\text { Aebli) }\end{array}$ & $\begin{array}{l}\text { analisa a Experimentoteca a partir do ideário construtivista, } \\
\text { chegando a resultados que colocam em questão as } \\
\text { contribuições deste projeto para um ensino conforme esta } \\
\text { posição pedagógica }\end{array}$ \\
\hline Joaquim (1992) & $\begin{array}{l}\text { tendências educacionais } \\
\text { progressistas (Freinet, } \\
\text { Libâneo, Vigotski) }\end{array}$ & $\begin{array}{l}\text { analisa a Experimentoteca a partir de tendências progressistas, } \\
\text { dando relevo a aspectos da materialidade do ensino de } \\
\text { ciências (realidade objetiva precede consciência; relação entre } \\
\text { uso de instrumentos e desenvolvimento humano) }\end{array}$ \\
\hline $\begin{array}{l}\text { Schiel, Curvelo e } \\
\text { Ferreira (2004) }\end{array}$ & $\begin{array}{l}\text { construtivismo, sem citar } \\
\text { autor específico; } \\
\text { terminologia vigotskiana }\end{array}$ & $\begin{array}{l}\text { buscam articular a Experimentoteca para um ensino de } \\
\text { ciências menos influenciado pela pedagogia tradicional }\end{array}$ \\
\hline
\end{tabular}

Figura 30: quadro que expõe o modo como diferentes autores elaboram considerações sobre a Experimentoteca, a partir de suas próprias referências no campo da educação

Neste sentido, a publicação d'O livro da Experimentoteca serviu ao menos para guiar estas discussões e propor um ponto de partida para este debate, como que "padronizando" um rol de referências admissíveis para se trabalhar com os kits elaborados pelo CDCC. Apresentemos esta obra, antes de partir para sua análise nas seções vindouras.

O livro da Experimentoteca: educação para as Ciências da Natureza através de práticas experimentais é uma publicação em dois volumes, impressa no ano 2000. O primeiro volume possui 207 páginas; o segundo não é paginado e contém apenas a totalidade de roteiros experimentais que acompanham os kits para o ensino fundamental. Portanto, nosso objeto de considerações, aqui, será apenas o volume 1 do livro, cuja capa é reproduzida na Figura 31. A obra se divide da seguinte maneira:

\section{Prefácio}

1) A experimentação em sala de aula e a construção do conhecimento pelo aluno

2) A dimensão ambiental no ensino de ciências

3) Como a matéria se apresenta no ambiente

4) Fenômenos cíclicos na natureza relacionados com o ciclo energético

\footnotetext{
${ }^{80}$ Não mencionamos o trabalho de Canales (2006) já que a autora não aborda a Experimentoteca do ponto de vista pedagógico, analisando a iniciativa do CDCC enquanto projeto de extensão universitária, como visto. Deve-se lembrar, também, que tanto Gaspar $(1993,2006)$ quanto Megid Neto (1999) se referem à Experimentoteca como sucessora dos materiais didáticos resultantes da parceria IBECC-Funbec. Gaspar, no entanto, considera positivo que o CDCC possa ser tido como uma instituição herdeira dos ideais do IBECC, enquanto Megid Neto, como demonstramos, faz um comentário depreciativo da Experimentoteca, avaliando-a como continuadora da pedagogia tecnicista e alheia às inovações pedagógicas trazidas pelo construtivismo ou pelas pedagogias críticas.
} 
5) Os habitantes da terra

6) A ação do homem no ambiente

7) O mundo visto por meio da Física

8) O mundo visto por meio da Química

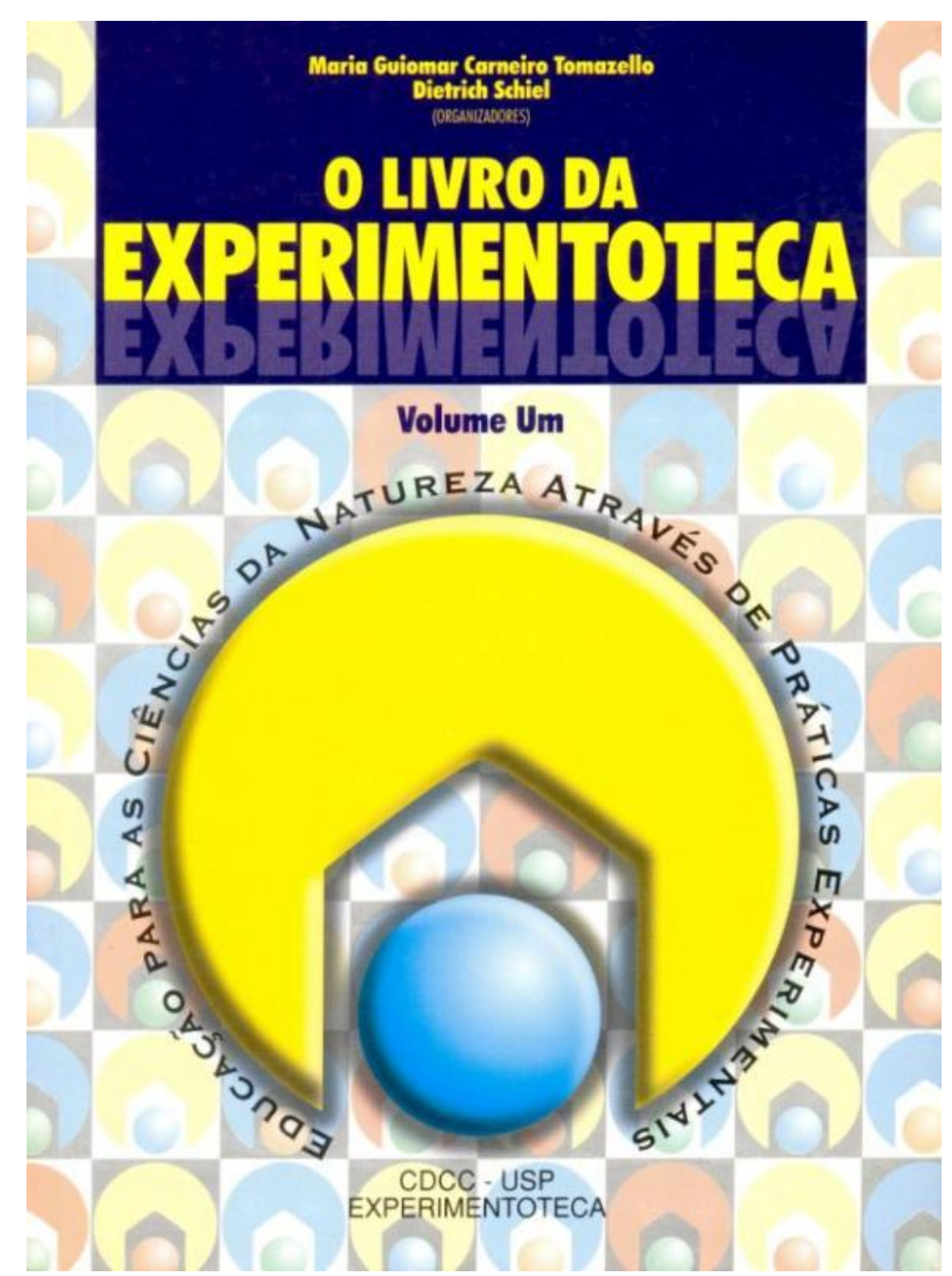

Figura 31: capa do volume 1 d'O livro da Experimentoteca

$\mathrm{Na}$ "Apresentação" da obra, o Prof. Schiel resume a história da Experimentoteca e explica o processo que levou à publicação do livro:

O programa Experimentoteca vem se desenvolvendo em três fases. A primeira ocorreu em São Carlos, entre 1984 e 1989, quando foram produzidos kits para o uso nesta cidade. O processo ocorreu de forma contínua e cada experimento foi produzido e aplicado com a participação de professores da rede pública, cuja avaliação crítica contribuiu para dar ao conjunto uma conotação prática. De 1990 a 1995, o programa foi disseminado para mais de 30 centros de Ciência em todo o território nacional, com revisão completa do conteúdo e design. A partir de 1998, tornou-se um produto industrial com o objetivo de constituir uma opção nacional de equipamento didático para a sala de aula. Além disso, o programa prevê a capacitação dos professores usuários do sistema em cursos específicos. 
A Experimentoteca é projetada de acordo com modernas técnicas de design, permitindo a reprodução em série. Foram solicitadas patentes para o sistema. $\mathrm{O}$ critério para escolha e produção de tópicos (kits, filmes ou jogos) sempre foi o aspecto prático da conveniência do uso em sala de aula. Faltou assim, ao final do projeto, um texto que reunisse informações metodológicas para a aplicação em classe.

Ele é agora apresentado neste livro, com um apêndice reunindo o acervo completo de roteiros, que foram produzidos, em grande parte, com a colaboração de professores em serviço, que trouxeram e discutiram as possibilidades metodológicas de sua aplicação em sala de aula (TOMAZELLO; SCHIEL, 2000, v. 1, p. 6-7).

Neste capítulo vamos observar apenas os momentos em que a obra traz considerações sobre aspectos que interessem especificamente à Educação em Química, que aparecem concentrados no prefácio do livro e nos capítulos 1 e 8 . Existem materiais de interesse também nas demais divisões (especialmente nos capítulos 3, 4 e 6), mas sua análise implicaria que o presente capítulo desta tese se estendesse demais. Como já afirmamos, nossa esperança é que outros trabalhos se dediquem integralmente à tarefa de analisar $O$ livro da Experimentoteca, e o que faremos aqui é apenas uma primeira avaliação da obra e de seus compromissos com referenciais teóricos contemporâneos sobre a Educação em Ciências.

No quadro da Figura 32 descrevemos brevemente as características das divisões que serão analisadas aqui. As divisões do livro foram compostas por diferentes autores ou equipes de autores, e possuem extensões variáveis. Os capítulos 3 a 8 apresentam em papel branco considerações sobre conteúdos específicos de ciências, entremeadas com referências à literatura do campo da Educação em Ciências; e em papel azul algumas orientações (sob o título "Desenvolvimento das aulas") sobre como utilizar os kits da Experimentoteca relacionados a estes conteúdos, propondo também atividades alternativas, não veiculadas nos roteiros que acompanham os kits.

\begin{tabular}{|l|l|l|l|}
\hline \multicolumn{1}{|c|}{ Título } & \multicolumn{1}{|c|}{ Páginas } & \multicolumn{1}{|c|}{ Autor $($ a $)$} & \multicolumn{1}{c|}{ Tendência adotada } \\
\hline "Prefácio" & $\begin{array}{l}\text { p. } 8-11 \\
(4 \text { p. })\end{array}$ & $\begin{array}{l}\text { Célia Margutti do Amaral } \\
\text { Gurgel }\end{array}$ & $\begin{array}{l}\text { ensino com } \\
\text { enfoque CTS }\end{array}$ \\
\hline $\begin{array}{l}\text { 1) "A experimentação em sala de aula e a } \\
\text { construção do conhecimento pelo aluno" }\end{array}$ & $\begin{array}{l}\text { p. } 15-18 \\
(4 \text { p. })\end{array}$ & $\begin{array}{l}\text { Célia Margutti do Amaral } \\
\text { Gurgel }\end{array}$ & $\begin{array}{l}\text { ensino por } \\
\text { investigação }\end{array}$ \\
\hline 8) "O mundo visto por meio da Química" & $\begin{array}{l}\text { p. } 177-207 \\
(31 \text { p. })\end{array}$ & $\begin{array}{l}\text { Maria Inês de Freitas } \\
\text { Petrucci dos Santos Rosa }\end{array}$ & $\begin{array}{l}\text { teoria dos perfis } \\
\text { conceituais }\end{array}$ \\
\hline
\end{tabular}

Figura 32: quadro com características das divisões d'O livro da Experimentoteca analisadas neste trabalho.

Conforme a Figura 32, há três tendências da Educação em Ciências, particularmente interessantes aos educadores químicos, adotadas nas divisões que iremos analisar d'O livro da Experimentoteca. As próximas seções serão dedicadas a explorá-las conforme nosso entendimento crítico-dialético sobre o papel da experimentação no ensino de ciências. 


\subsection{TENDÊNCIA 1: ENSINO COM ENFOQUE CTS}

Após a "Apresentação" do livro por Dietrich Schiel, da qual reproduzimos um fragmento há pouco, segue-se o prefácio, de autoria de Célia Margutti do Amaral Gurgel, a ser analisado. Esta divisão possui apenas quatro páginas e se inicia com o seguinte parágrafo:

Este livro surgiu do esforço coletivo de professores e alunos comprometidos com o ensino das Ciências Naturais, nos níveis fundamental, médio e superior, preocupados com a prática pedagógica das atividades experimentais em sala de aula. Esse grupo de pesquisadores entendeu que tais atividades não têm levado em conta, ao longo do tempo, o processo ensino/aprendizagem como promotor da articulação contínua entre os conceitos científicos e as ações do cotidiano social dos aprendizes e que a experimentação, no âmbito das aulas de Ciências, apesar de constituir uma representação dos fenômenos ocorridos na natureza e/ou no ambiente, requer uma análise menos superficial e mecanicista na sua abordagem. Em resposta, propôs-se a redimensionar o foco desse ensino, de maneira a possibilitar uma interpretação e ação mais crítica e problematizadora de tal temática (TOMAZELLO; SCHIEL, 2000, v. 1, p. 8).

A partir de então, a autora introduz o referencial que, presume-se, deverá orientar todas as considerações dos capítulos apresentados n'O livro da Experimentoteca (já que seu texto é um prefácio): tratar-se-ia de um modo integrado de se abordar as relações entre fatos científicos, a criação e o uso de tecnologias e as ressonâncias sociais destes dois elementos. No terceiro parágrafo de seu texto, prossegue:

O pensamento educativo na última década tem destacado uma série de idéias relacionadas entre si, oferecendo um ensino construtivo juntamente a uma aprendizagem eficaz. Essa tendência procura enfatizar temas importantes para os interesses e preocupações dos estudantes, relações significativas e claras entre o assunto e as formas de conhecimento aplicadas e/ou utilizadas pela comunidade em geral, e a investigação do problema a partir de projetos, com questões propostas pelos estudantes e avaliação das informações precedentes de várias fontes. Por outro lado, muitos países estão introduzindo em seus currículos escolares uma educação científica apoiada em uma disciplina transversal denominada Ciência-TecnologiaSociedade (C-T-S), cuja ênfase seria de extrema relevância social (ibidem, v. 1, p. 9).

E após apresentar o esquema da Figura 33, ela detalha o que seria tal "disciplina transversal":

Essa proposta inspira-se no movimento Ciência, Tecnologia e Sociedade (CTS), originado no início dos anos 70 como conseqüência do impacto da Ciência e da Tecnologia na sociedade moderna e que tem por objetivo envolver o ensino de Ciências com aspectos ligados à formação da Cidadania (ibidem, loc. cit., grifos da autora). 


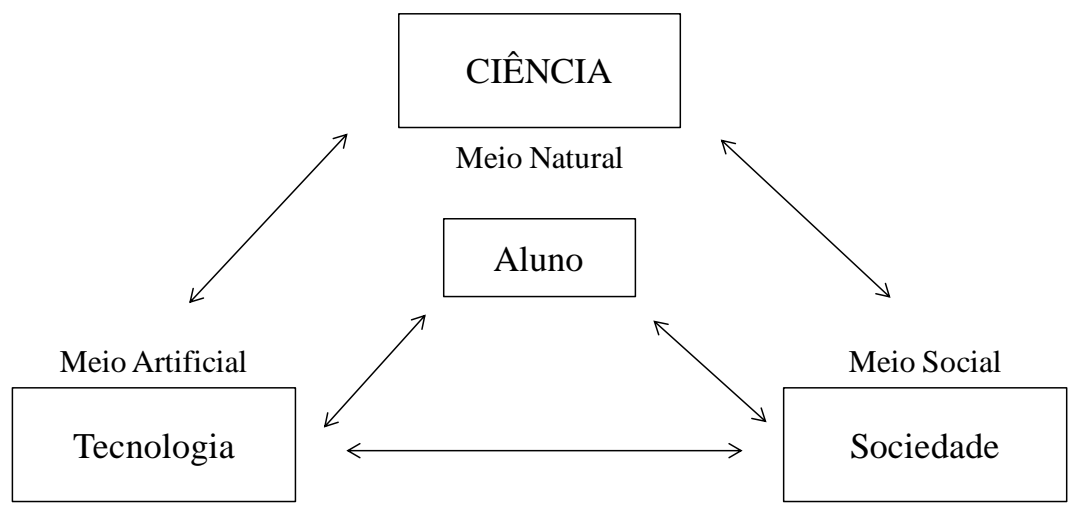

Figura 33: esquema das inter-relações entre ciência, tecnologia e sociedade, apresentado em $O$ livro da Experimentoteca (TOMAZELLO; SCHIEL, 2000, v. 1, p. 9).

No Brasil, a principal obra a discutir as implicações deste movimento - ou enfoque, como preferimos tratar - para o ensino de Química é o livro Educação em Química: compromisso com a cidadania, de Wildson L. P. dos Santos e Roseli P. Schnetzler. Nele, os autores explicam o significado que a cidadania, mencionada na transcrição de Gurgel acima, assume para o enfoque CTS:

educar para a cidadania é preparar o indivíduo para participar em uma sociedade democrática, por meio da garantia de seus direitos e do compromisso de seus deveres. Isso quer dizer que educar para a cidadania é educar para a democracia (SANTOS; SCHNETZLER, 2003, p. 29).

Para o caso específico da educação em Química, a perspectiva CTS critica o ensino voltado para a classificação das substâncias e elementos em categorias sem significado para os alunos, para o exercício exaustivo de nomeação dos compostos, para a aplicação mecânica de algoritmos na solução de "problemas" e para a ênfase da teoria sobre a prática. Assim, os educadores químicos deveriam perseguir o objetivo de

preparar o indivíduo para que ele compreenda e faça uso das informações químicas básicas necessárias para a sua participação efetiva na sociedade tecnológica em que vive. Neste sentido, o ensino levaria o aluno a compreender os fenômenos químicos mais diretamente ligados a sua vida cotidiana; a saber manipular as substâncias com as devidas precauções; a interpretar as informações básicas químicas transmitidas pelos meios de comunicação; a compreender e avaliar as aplicações e implicações tecnológicas; a tomar decisões frente aos problemas sociais relativos à química (ibidem, p. 93-94).

A referida tomada de decisões, segundo este trabalho de Santos e Schnetzler, é o principal objetivo do ensino com enfoque CTS. Este objetivo convive com outro, que lhe é secundário, embora esteja longe de ser desimportante, que é o ensino de aspectos da natureza da ciência: 
[A tomada de decisões] relaciona-se à solução de problemas da vida real que envolvem aspectos sociais, tecnológicos, econômicos e políticos, o que significa preparar o indivíduo para participar ativamente na sociedade democrática. [...] um segundo propósito dos cursos de CTS refere-se à compreensão da natureza da ciência e de seu papel na sociedade, o que implica a necessidade de o aluno adquirir conhecimentos básicos sobre filosofia e história da ciência, para compreender as potencialidades e limitações do conhecimento científico (ibidem, p. 68-69).

Estes objetivos são reconhecidos pelo prefácio de Gurgel; continuemos transcrevendo suas passagens mais importantes:

A proposição [do enfoque CTS] visa, sobretudo, humanizar o ensino, colocando-o no contexto social e tecnológico, sob uma abordagem interdisciplinar e multidisciplinar fazendo-o lidar com problemas reais. Ao contrário do ensino tradicional, a nova ênfase busca principalmente as implicações sociais dos problemas tecnológicos, ou seja, a tecnologia para a ação social. Isto por entender que o desenvolvimento de teorias científicas pode influenciar o pensamento e a solução de problemas reais.

A sociedade é uma instituição humana, na qual ocorrem mudanças científicas e tecnológicas. E o ensino por meio da Ciência, sob a perspectiva CTS, pretende preparar os cidadãos a partir do conhecimento mais amplo da Ciência e de suas implicações com a vida. Seu objetivo é desenvolver no indivíduo a capacidade de tomar decisões frente aos problemas sociais, tecnológicos, econômicos e políticos, o que significa prepará-lo para participar ativamente da sociedade contemporânea (TOMAZELLO; SCHIEL, 2000, v. 1, p. 10).

Por outro lado, a tomada de decisão é entendida como fundamental também à docência:

As sugestões de estudiosos e educadores para que se aborde os conceitos científicos a partir de temas sociais têm encontrando apoio em todo mundo, dada a evidência de que os problemas das Ciências Naturais têm implicações com as Ciências Sociais, como a História, a Geografia, a Economia e a Política. Contudo, isso requer uma nova postura do professor, enquanto mediador do processo ensino/aprendizagem. Do mesmo modo que os alunos precisam participar das questões sociais relacionadas à Ciência e à Tecnologia, assim também os professores devem estar envolvidos na tomada de decisões pedagógicas sobre o ensino de Ciências (ibidem, loc. cit.).

É positivo que, neste prefácio, a dimensão ambiental não esteja isolada em relação à ciência, à tecnologia e à sociedade, como o fazem os autores que preferem a terminologia "CTSA" (Ciência, Tecnologia, Sociedade e Ambiente) a CTS. Gurgel ressalta que

A proposição de uma prática pedagógica das atividades experimentais sob a perspectiva ambiental tem justamente essa finalidade: permitir a professores e alunos um redimensionamento de suas concepções sobre o ensino e aprendizagem das Ciências, proporcionando, dessa forma, condições efetivas para a superação do modelo de ensino fragmentado e a-histórico, hoje predominante em nossas escolas, além de contribuir para a formação de indivíduos capazes de questionar e interferir nos caminhos da sociedade em que vivem (ibidem, loc. cit.). 
Assim, a Figura 33 aponta adequadamente que, no âmbito do enfoque CTS, a ciência diz respeito ao ambiente natural, a tecnologia ao ambiente artificial e a sociedade ao ambiente social. No entanto, o esquema ali apresentado possui diferenças em relação à fonte de onde foi adaptado, o artigo de Hofstein, Aikenhead e Riquarts (1988). Uma reprodução do esquema original aparece na Figura 34.

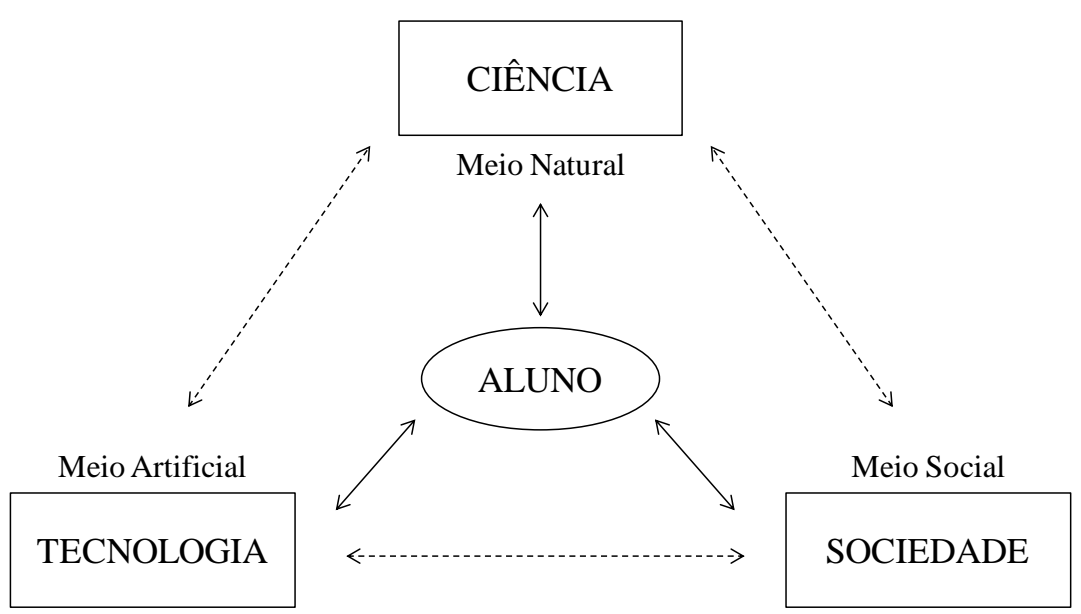

Figura 34: esquema das inter-relações entre ciência, tecnologia e sociedade, sem as adaptações apresentadas em O livro da Experimentoteca (HOFSTEIN; AIKENHEAD; RIQUARTS, 1988, p. 358).

Os autores explicam este esquema da seguinte maneira (conforme a tradução do fragmento reproduzida no livro Educação em Química: compromisso com a cidadania):

CTS, significa o ensino do conteúdo de ciência no contexto autêntico do seu meio tecnológico e social. Os estudantes tendem a integrar a sua compreensão pessoal do mundo natural (conteúdo da ciência) com o mundo construído pelo homem (tecnologia) e o seu mundo social do dia-a-dia (sociedade). Essas inter-relações de ciência-tecnologia-sociedade são sugeridas pelas setas da figura 1 [Figura 34]. As setas contínuas representam o aluno fazendo uso lógico do conteúdo da ciência. As setas pontilhadas representam as conexões feitas pelos materiais de ensino de CTS que fornecem o conteúdo de ciência neste contexto integrativo (HOFTEIN; AIKENHEAD; RIQUARTS, 1988, p. 358 apud SANTOS; SCHNETZLER, 2003, p. 60 , grifos dos autores originais).

O material passível de análise, neste prefácio escrito por Gurgel, se resume aos poucos parágrafos resumidos acima. Mesmo assim, dada a importância do enfoque CTS como referencial para o campo da Educação em Química, teceremos mais alguns comentários.

Primeiramente, queremos destacar que o referido enfoque é frequentemente associado com as teses construtivistas, talvez pela imediata equiparação entre o processo de tomada de decisão, almejado pelo ensino CTS, e a preconizada postura ativa por parte dos estudantes, enfatizada pelo construtivismo (ou ainda, o paralelo entre o estudo sobre a natureza da 
ciência, o segundo objetivo CTS mais importante, e o relativismo inerente à posição construtivista, que tenta se ancorar em leituras - por vezes, equivocadas - de historiadores e filósofos da ciência, como Thomas Kuhn e Paul Feyerabend). Em Educação em Química: compromisso com a cidadania, a relação entre os dois referenciais é assumida como ponto pacífico, como se observa nas seguintes passagens:

Pode-se verificar que as estratégias de ensino freqüentemente utilizadas nos cursos de CTS pressupõem e implicam a participação ativa dos alunos mediada pela ação docente, significando a adoção de uma concepção construtivista para o processo de ensino-aprendizagem [...] (SANTOS; SCHNETZLER, 2003, p. 86).

Outra orientação metodológica para esse ensino está nos princípios construtivistas, já que eles constituem a base de desenvolvimento da capacidade de tomada de decisão, pois o cidadão participará efetivamente da sociedade à medida em que se sentir em condições de efetivamente construir proposições visando à solução de problemas e, ao mesmo tempo, tenha uma participação ativa, condições essas que são centrais na concepção construtivista de ensino (ibidem, p. 113, grifo dos autores).

Os procedimentos metodológicos recomendados [no ensino CTS] são aqueles que se enquadram em uma perspectiva construtivista de ensino-aprendizagem, o que significa levar em conta os interesses e os conhecimentos prévios dos alunos e que o processo de ensino seja desenvolvido de forma a possibilitar que o aluno construa e reconstrua o conhecimento (ibidem, p. 121).

Em diversos outros momentos desta obra, os autores indicam que, de fato, estão se guiando por esta concepção construtivista. Merece ser comentado também o parágrafo central da página 49, em que, depois de reconhecer que "para o cidadão viver melhor na sociedade, não precisa ter conhecimento tão específicos de química, como classificar e nomear as substâncias utilizadas no dia-a-dia", os autores elaboram uma lista exagerada de fatos químicos ("o nylon, uma das fibras sintéticas de nossas roupas, é uma poliamida; [...] os antibióticos, conhecidos como sulfas, são compostos chamados de sulfamidas; [...] a alizarina, a mauveína e índigo são exemplos de corantes [...]") para então concluir:

Obviamente que essa não é a química que temos de ensinar ao cidadão [...]. Acreditamos até que esses conhecimentos contribuem tanto para a formação do cidadão, quanto os conceitos de isótono, isóbaro e números quânticos. Todos eles servem apenas como ornamento cultural, para que sejamos chamados de letrados em ciências, detentores do ócio da cultura ornamental, para assim nos aproximarmos da classe dos senhores que tudo sabem (ibidem, p. 49-50, grifo dos autores). 
Não concordamos inteiramente com esta posição. Nossos estudos sobre a Pedagogia Histórico-Crítica, especialmente aqueles desenvolvidos no primeiro capítulo desta tese, apontam para as consequências nefastas da diluição dos conteúdos de ensino e do aligeiramento do processo de educação escolar. Por outro lado, a Psicologia HistóricoCultural, que estudamos de modo mais aprofundado no capítulo 2, aponta a estreita relação entre o aprendizado de novas palavras, o aprendizado de novos conceitos (afinal, todo conceito é palavra) e a formação de novas visões de mundo.

Apesar destas ressalvas, e da adoção explícita destes autores de uma posição liberal, há tentativas (tímidas, é verdade) de se mobilizar o enfoque CTS para posturas próximas às que temos defendido aqui, como no questionamento abaixo:

Como pensar em educar o cidadão num país de miséria, de chacinas, de marginalizados, em que a maioria não tem garantido o direito básico à vida, sendo excluída do direito à educação, à saúde, à moradia? Em um país em que a maioria paga para sustentar a minoria? Será possível educar o cidadão num país neoliberal? (ibidem, p. 36).

Ou na seguinte passagem, que lembra nossas críticas aos educadores pós-estruturalistas:

Podemos caracterizar, ainda, que tem grande importância a seleção de temas sociais que estejam relacionados a problemas locais da comunidade em que o aluno vive. Isso porque eles propiciam uma maior contextualização do problema a ser posto em discussão, o que envolverá muito mais o aluno no processo de busca de solução. Por outro lado, sabe-se que a abordagem de apenas temas regionais tem o aspecto negativo de não ampliar o leque de conhecimento do aluno, além de ter um caráter de perpetuação da situação cotidiana da comunidade em que o aluno está inserido (ibidem, p. 101).

Estamos insistindo nestas discussões - e propositadamente, desviando-nos da análise d'O livro da Experimentoteca, para fazermos uma breve leitura de Educação em química: compromisso com a cidadania - para esclarecermos que os pressupostos do enfoque CTS não se coadunam, necessariamente, com as tendências educacionais liberais.

Ao contrário: como Santos explica, "o movimento CTS foi defendido inicialmente por educadores de esquerda" (2008, p. 118), embora algumas de suas teses tenham sido apoderadas por concepções que apenas se pretendem críticas, mas que afinal se mostram descomprometidas com a transformação da sociedade e com o questionamento da ideologia dominante. Neste trabalho, inclusive, Santos mostra a viabilidade de uma aproximação do enfoque CTS com a teoria de Paulo Freire, reconhecidamente contrária às pedagogias liberais: 
Ao pensar em uma proposta de CTS na perspectiva humanística freireana, busca-se uma educação que não se restrinja ao uso e não uso de aparatos tecnológicos ou ao seu bom e mau uso. Além disso, propõe-se uma educação capaz de pensar nas possibilidades humanas e nos seus valores, em fim em uma educação centrada na condição existencial. Isso significa levar em conta a situação de opressão em que vivemos, a qual é marcada por um desenvolvimento em que valores da dominação, do poder, da exploração estão acima das condições humanas.

Nesse sentido, uma educação com enfoque CTS na perspectiva freireana buscaria incorporar ao currículo discussões de valores e reflexões críticas que possibilitem desvelar a condição humana. Não se trata de uma educação contra o uso da tecnologia e nem uma educação para o uso, mas uma educação em que os alunos possam refletir sobre a sua condição no mundo frente aos desafios postos pela ciência e tecnologia (ibidem, p. 122).

Outro autor que vem investigando as convergências entre as pedagogias críticas e o enfoque CTS é Paulo M. M. Teixeira. Listando, entre os principais autores associados a tais pedagogias, os nomes de Saviani, Vale, Demo, Palma Filho, Libâneo e Paulo Freire, Teixeira deixa transparecer sua preferência pela Pedagogia Histórico-Crítica, que é objeto de consideração de um artigo seu publicado no periódico Ciência \& Educação (TEIXEIRA, 2003). Neste texto, ele elenca cinco principais pontos de intersecção entre a obra de Saviani e o movimento $\mathrm{CTS}^{81}$, considerando as categorias:

1. Prática social: da mesma forma que a Pedagogia Histórico-Crítica estabelece a prática social como ponto de partida e ponto de chegada da instrução, o movimento CTS propõe que os temas de ensino sejam extraídos da realidade social dos alunos, que a ela retornam instrumentalizados com o conhecimento científico de modo embasar racionalmente suas decisões;

2. Objetivos educacionais: para ambas as correntes, a escola é considerada um instrumento para a formação da cidadania, pressupondo que a adequada formação dos indivíduos levará a uma atuação social mais responsável;

3. Metodologias de ensino: tanto a obra de Saviani quanto os teóricos do movimento CTS propõem a diversificação dos métodos de ensino, atendendo aos ritmos de aprendizagem e às necessidades dos estudantes (no caso da Pedagogia Histórico-Crítica, faz-se a ressalva de que se trata de necessidades concretas, isto é, aquelas que são postas pelo condicionamento social);

4. Conteúdos: a escola é uma instituição socializadora de conhecimentos, conforme a visão da Pedagogia Histórico-Crítica, e deve transmitir conteúdos vivos e relacionados à prática social dos estudantes. O movimento $\mathrm{CTS}$, de

\footnotetext{
${ }^{81}$ Teixeira afirma haver divergências entre a Pedagogia Histórico-Crítica e o enfoque CTS, mas considera que elas não são suficientes para instalar um quadro de completo antagonismo entre as duas correntes.
} 
modo semelhante, propõe a centralidade dos conteúdos científicos e a explicitação de seus nexos com as tecnologias e o todo social;

5. O papel dos professores: o professor, conforme explica Saviani, deve possuir competência técnica e compromisso político, características que não se excluem, pois não se pode confundir objetividade com neutralidade (a primeira é uma questão gnosiológica; a segunda, ideológica). Aqui talvez apareçam mais nitidamente as divergências entre a Pedagogia Histórico-Crítica e o enfoque CTS, já que a literatura desta última corrente tende a considerar as funções dos docentes de modo semelhante ao que fazem os autores construtivistas, isto é, considerando os mestres como mediadores, gerenciadores, organizadores.

Já num artigo em que busca situar a educação científica e o movimento CTS no quadro das tendências pedagógicas brasileiras, Teixeira afirma que

as concepções que nas últimas décadas influenciaram a prática da educação em ciências não conseguiram contribuir para superação dessa realidade [a realidade de uma educação neutra, sem conexão com o contexto social]. O Movimento CTS parece ser a primeira corrente que procura sistematizar idéias nesse sentido, porém [...] falta radicalidade em suas posições. Radicalidade que poderia ser alcançada com a contribuição dos princípios contidos nas teses formuladas pelas correntes progressistas em educação, incluindo categorias como "transformação"; "totalidade"; "compromisso social"; "crítica social"; "conscientização" etc. [...] (TEIXEIRA, 2005, p. 101).

Realmente, tanto o prefácio d'O livro da Experimentoteca quanto a obra Educação em química: compromisso com a cidadania não demonstram esta radicalidade. As discussões desta seção, assim, se propõem a dirigir a leitura destes materiais a partir de um ponto de vista mais comprometido com a crítica ao capitalismo. E se o livro de Santos e Schnetzler se apresenta ainda bastante influenciado pelo construtivismo, também é verdade que sua leitura pode ser o ponto de partida para um posicionamento mais próximo às pedagogias progressistas, em especial a Pedagogia Histórico-Crítica. Para Teixeira, o próprio enfoque CTS tende a se beneficiar deste contato, que pode levar a que ele se situe melhor entre as questões postas pelo contexto brasileiro:

A contribuição das idéias oriundas das pedagogias progressistas [para o movimento CTS] poderá estar na radicalidade de suas posições em relação ao papel da educação numa sociedade injusta como é característica da sociedade brasileira. Os interlocutores do Movimento CTS, reiteradas vezes, mencionam a questão da formação para cidadania, apontando a dimensão da formação para tomada de decisão, a questão da educação tecnológica, e a importância da transmissão de uma 
visão mais coerente da ciência e de seu papel na sociedade. Porém, em função do movimento ter origem fora do Brasil, muitas vezes em países que não presenciam os problemas sociais pelos quais o Brasil está submetido, essas posições ganham uma dimensão mais sutil, já que o contexto lá é outro, bastante diferenciado em relação à realidade brasileira (ibidem, p. 100).

Futuramente, quem sabe, possa $O$ livro da Experimentoteca receber uma nova edição, passando a comportar estas ideias. É neste sentido que defendemos a preservação do enfoque CTS como orientação curricular e metodológica dos materiais da Experimentoteca, considerando, especialmente, a possibilidade de novos kits de experimentos serem desenvolvidos pelo CDCC.

Inclusive, a pesquisa de Zuin e colaboradores (2008), apesar de não fazer referência ao nome da Experimentoteca, analisou quatro de seus kits destinados ao ensino médio (concebidos, portanto, após a publicação de O livro da Experimentoteca), dois de Biologia e dois de Química, quanto ao atendimento de cinco aspectos do enfoque CTS (promoção da responsabilidade sócio-ambiental dos cidadãos, abordagem das influências mútuas entre C-T$\mathrm{S}$, relacionamento com questões sociais, incentivo à ação responsável e estímulo à tomada de decisões e resolução de problemas). Os kits de Química escolhidos foram os dos temas “Compostos Iônicos e Moleculares" e "Eletroquímica”. Segundo as autoras, estes materiais atendem aos cinco critérios CTS:

os kits experimentais mais empregados em Química, "Compostos Iônicos e Moleculares" e "Eletroquímica" também propiciam aos agentes educacionais a possibilidade de estabelecerem conexões CTS, além de proporcionarem aos mesmos explorar aspectos relacionados com a sociologia e história da Ciência. [...] É possível verificar que em alguns kits a visão de ciência e as facetas tecnológicas apresentadas nos roteiros dos experimentos estudados demonstram a natureza evolutiva destas [...]. Outro aspecto importante da escolha desses experimentos diz respeito à indicação de diversas fontes de informação e referências exteriores à escola sem, contudo, desvalorizá-las. Como exemplo, podemos citar o kit de "Eletroquímica" que por tratar de galvanização, aborda a proteção de metais, e inicia o debate sobre processos de revestimento para evitar a corrosão. Como esperado, este tema pode remeter o professor à discussão de outros textos que, por exemplo, tratam da proteção de cascos de navios ou mesmo de estacas de plataforma de petróleo contra a corrosão em ambiente marítimo [...] (ibidem, p. 62).

No próprio livro Educação em química: compromisso com a cidadania, encontramos palavras adequadas para expressar este nosso entendimento a respeito de um ensino de Química mais crítico e transformador. Palavras que, em suma, propõem a substituição de um ensino da "Química em-si” por uma "Química para-si”, se podemos falar em tais termos: 
O que queremos dizer é que a química no ensino médio não pode ser ensinada como um fim em si mesma, senão estaremos fugindo do fim maior da educação básica, que é assegurar ao indivíduo a formação que o habilitará a participar como cidadão na vida em sociedade. Isso implica um ensino contextualizado, no qual o foco não pode ser o conhecimento químico, mas o preparo para o exercício consciente da cidadania (SANTOS; SCHNETZLER, 2003, p. 50).

\subsection{TENDÊNCIA 2: ENSINO POR INVESTIGAÇÃO}

Existe uma tendência muito valorizada na atualidade, e referente à experimentação para o ensino de ciências, com bastante apelo também entre os autores preocupados com o enfoque CTS: trata-se do ensino por investigação. A pesquisa reproduzida no livro de Santos e Schnetzler, que sondaram as opiniões de diversos pesquisadores brasileiros da Educação em Química a respeito de aspectos do ensino CTS, demonstra haver certo consenso sobre esta proposta:

Quanto à inclusão da experimentação na proposta de ensino de química para a cidadania, os educadores justificaram sua importância em função de seu papel investigativo e pedagógico de auxiliar o aluno na compreensão dos fenômenos químicos, propósito este que não demanda condições sofisticadas na escola.

Ficou evidenciado, também, que o papel da experimentação não seria no sentido da formação de cientistas, como foi concebido pelos projetos inovadores de ensino de ciências da década de sessenta (ibidem, p. 107, grifo dos autores).

O livro da Experimentoteca dedica quatro páginas ao tema, que é exposto no capítulo 1, “A experimentação em sala de aula e a construção do conhecimento pelo aluno". A autora do texto é também Célia Margutti do Amaral Gurgel, que como descobrimos observando a (pequena) lista de referências do capítulo, doutorara-se na Universidade Estadual de Campinas (Unicamp) com a tese Em busca da melhoria da qualidade do ensino de ciências e matemática: ações e revoluções.

O início de suas considerações traça um pequeno histórico sobre o papel pedagógico da experimentação no ensino de ciências, apresentando uma crítica à "era dos projetos" (vide nossa Figura 10, no capítulo 3):

Nos últimos anos, docentes e pesquisadores vêm chamando atenção para os limites da utilização dos métodos de descoberta/redescoberta, observando que o ensino apoiado nessas práticas parte da convicção de que os alunos aprendem qualquer conteúdo científico, por conta própria, a partir da observação. Tais práticas fazem crer que os trabalhos experimentais, radicados no sensorial e no imediato, induzem à 
descoberta de fatos novos, levando a pressupor que as idéias constroem-se com base em acontecimentos, e não que exista no indivíduo um pré-sistema de significações. Com base nos mesmos princípios, esses métodos aproximam-se da atividade científica e exigem uma visão pedagógica empirista, indutiva e positivista da Ciência e do cientista, evidenciando o conhecimento não como processo, mas como resultado e instrumento para a ação. $\mathrm{Na}$ condição de produto, o conhecimento científico apresenta-se neutro, objetivo, impessoal e a-histórico, estático, acabado e cumulativo sobre o real elaborado e sistematizado. Além disso, a experimentação, sob essa perspectiva, pode sugerir a existência de um método único de investigação da realidade, fazendo prevalecê-lo sobre o sujeito e mascarando o caráter revolucionário do conhecimento processo/produto (TOMAZELLO; SCHIEL, 2000, v. 1, p. 16).

Alguns apartes até aqui: como já discutimos no capítulo 3, ao contrário do que Gurgel afirma, um trabalho radicado no "sensorial" não necessariamente se radica também no "imediato", pois os sentidos humanos possuem não apenas uma filogênese, mas também uma sociogênese, e o indivíduo educado está provido da historicidade dos conceitos humanos como mediação entre seus sentidos e a realidade objetiva. Considerada devidamente esta historicidade, a atividade experimental perde seu caráter empirista-indutivista/positivista, e é somente neste sentido histórico que caberia falar em um "pré-sistema de significações" - e não como propriedades imanentes e apriorísticas do psiquismo humano, como esta expressão pode dar a entender.

Prosseguindo, a autora propõe ser necessário que os trabalhos práticos se transformem em situações problemas que estimulem a investigação:

Isso significa criar novas possibilidades de forma a permitir aos alunos criar novas hipóteses, relacionar e comparar dados, alcançando, com o auxílio do professor mediador desse processo - resultados que possam cotejar com os obtidos pela comunidade científica. Restringir-se a contar a história de como as investigações foram realizadas não torna os alunos sujeitos da operação realizada e, conseqüentemente, não avança na metodologia científica. [...]

Assim, o ensino de Ciências desprovido de preocupação problematizadora e/ou crítica e de articulação entre teoria e prática, baseado apenas em roteiros assépticos, acaba por reduzir a associação do trabalho científico com a prática experimental, fragilizando as pesquisas nas escolas e contribuindo para um vazio de significado em suas transmissões. Tal procedimento torna o saber ilusório, fragmentado e desatualizado em sua base teórica e alheio à realidade dos alunos (ibidem, loc. cit.).

Este discurso aparecerá novamente em outros momentos do texto que estamos analisando:

Para que o estudante compreenda os conhecimentos como respostas a questões, há que se planejar a aprendizagem a partir de situações-problema de seu interesse. É preciso inclusive considerar que o conhecimento científico não se constrói a partir do nada: ele apresenta um caráter social e histórico a ser respeitado no processo ensino/aprendizagem (ibidem, p. 17). 
A metodologia de trabalho sugerida a seguir para as atividades práticas em sala de aula tem como pressuposto que a solução de problemas deve ser contemplada como tarefa básica no ensino de Ciências. Estratégica na busca de mudança ou de evolução nos conceitos dos alunos, essa metodologia orienta-se pelos princípios de inovação/ação, permitindo, ao final do processo, que estudantes e professores percebam diferenças significativas nas idéias previamente apresentadas. Por serem de natureza aberta, os procedimentos científicos utilizados neste processo também possibilitam aos alunos, a partir de situações-problema, desenvolver formas de resolução mais ricas e complexas em relação aos exercícios fechados. Tal tarefa fomenta a criatividade, característica fundamental do trabalho científico (ibidem, loc. cit.).

A ênfase na experimentação formulada de modo a gerar situações problemas tornou-se característica de propostas construtivistas para o ensino, e no Brasil aparece bem representada pela produção da Prof. Anna Maria Pessoa de Carvalho e de seu grupo de pesquisa. Por sinal, uma das obras da autora, embora não especificamente dedicada à experimentação no ensino de ciências, é citada por Gurgel (trata-se do livro Formação de professores de ciências: tendências e inovações, em coautoria com Daniel Gil-Pérez). Orientando-se por tais pressupostos, assim, o texto d'O livro da Experimentoteca irá propor as seguintes "fases fundamentais do processo investigativo":

Fase preliminar: planejamento de uma situação-problema com enunciado aberto, para que os alunos resolvam em equipe. O professor os orienta a levantar material bibliográfico sobre o assunto e a registrar/documentar as leituras mais importantes. As fontes podem ser livros, revistas, jornais, etc.

Fase de enfoque: com um plano de ação, apresentado pelo professor, evidencia os objetivos da pesquisa e explicita as hipóteses ou questões norteadoras do trabalho. É necessário que os alunos coloquem suas idéias acerca das variáveis e da natureza das influências sobre o processo.

Fase de aplicação e análise: os alunos já devem estar preparados para buscar soluções ao problema proposto. O professor estimula os grupos, apresentando diferentes questões problematizadoras para reflexão e debate, levantando novas hipóteses, estabelecendo inter-relações e comparando-as com outras situações. O confronto ou a criação de conflitos cognitivos entre as hipóteses levantadas e os resultados obtidos pelos alunos exigem do professor análise teórica e revisão crítica do trabalho. Caso os resultados não se mostrem satisfatórios, serão retomados passo a passo, para que o processo não se perca em tratamentos puramente operativos e difíceis de analisar (ibidem, loc. cit.).

Sendo estas as etapas propostas para o trabalho experimental, assim como a orientação geral de aliar a experimentação à resolução de situações problemas, gostaríamos de retomar algumas considerações ${ }^{82}$ sobre o grau de direcionamento das atividades solicitadas aos alunos na educação escolar. No âmbito específico da experimentação no ensino de ciências, encontramos um instrumento para a classificação das atividades conforme sejam mais ou menos diretivas, apresentado na forma de um quadro na Figura 35.

\footnotetext{
${ }^{82}$ Que expus pela primeira vez em minha dissertação de mestrado (MORI, 2009).
} 


\begin{tabular}{|l|c|c|c|c|c|c|}
\hline \multirow{2}{*}{ Etapas do procedimento } & \multicolumn{7}{|c|}{ Categoria da atividade } \\
\cline { 2 - 7 } & $\mathrm{I}$ & $\mathrm{II}$ & $\mathrm{III}$ & $\mathrm{IV}$ & $\mathrm{V}$ & $\mathrm{VI}$ \\
\hline Elaboração do problema & $\mathrm{P}$ & $\mathrm{P}$ & $\mathrm{P}$ & $\mathrm{P}$ & $\mathrm{P}$ & $\mathrm{A}$ \\
\hline Hipótese & $\mathrm{P}$ & $\mathrm{P}$ & $\mathrm{P}$ & $\mathrm{P}$ & $\mathrm{A}$ & $\mathrm{A}$ \\
\hline Plano de trabalho & $\mathrm{P}$ & $\mathrm{P}$ & $\mathrm{P}$ & $\mathrm{A}$ & $\mathrm{A}$ & $\mathrm{A}$ \\
\hline Montagem dos instrumentos & $\mathrm{P}$ & $\mathrm{A}$ & $\mathrm{A}$ & $\mathrm{A}$ & $\mathrm{A}$ & $\mathrm{A}$ \\
\hline Observações/coleta de dados & $\mathrm{P} / \mathrm{A}$ & $\mathrm{A}$ & $\mathrm{A}$ & $\mathrm{A}$ & $\mathrm{A}$ & $\mathrm{A}$ \\
\hline Conclusões & $\mathrm{P} / \mathrm{A}$ & $\mathrm{P}$ & $\mathrm{A}$ & $\mathrm{A}$ & $\mathrm{A}$ & $\mathrm{A}$ \\
\hline
\end{tabular}

Figura 35: instrumento para classificação de atividades experimentais de acordo com o grau de participação do estudante em sua condução (adaptado de Pella (1961)). P: professor; A: aluno.

Remetemos o leitor a nosso trabalho anterior, para um detalhamento sobre o significado e a aplicação do instrumento proposto (MORI, 2009, p. 112-114). Por ora, bastanos observar apenas a Figura 35 para compreendermos que as atividades defendidas n'O livro da Experimentoteca são aquelas da categoria VI, isto é, aquelas em que o professor exerceria participação mínima, atribuindo-se aos alunos a elaboração do problema a ser investigado, a formulação de hipóteses, o desenho de um plano de trabalho, a montagem dos instrumentos/aparatos experimentais, as observações e coletas e dados e a tomada de conclusões.

Temos entendido que, grosso modo, o rótulo de "atividades experimentais com caráter investigativo" pode ser aplicado, além de às atividades da categoria VI, também àquelas da categoria $\mathrm{V}$ e, por que não, da categoria IV. A categoria III referir-se-ia ao chamado "laboratório estruturado"; a categoria II, ao laboratório de verificações, em que os resultados do trabalho experimental já foram antecipados pelo professor; e a categoria I, finalmente, às demonstrações experimentais (e que, em alguns casos, podem se apresentar de forma mais aberta, como prevê o quadro da Figura 35).

Ao contrário do que parece advogar o texto de Gurgel, no entanto, nossa produção considera que as atividades abertas demais não devem ser a regra, e sim a exceção do ensino de ciências. Os depoimentos colhidos pelos autores que estudaram a Experimentoteca - Diniz (1992), Joaquim (1992) e Canales (2006), como visto no capítulo anterior - confirmam as dificuldades que os professores de ciências enfrentam para conduzir a experimentação em modalidades que releguem maior participação aos alunos em todas as etapas do trabalho. $\mathrm{O}$ depoimento da professora de Biologia entrevistada por Canales (2006, p. 108) sugere que uma das razões para esta dificuldade é que os estudantes não estão habituados ao trabalho experimental desde os anos iniciais do ensino fundamental, o que é bastante razoável. Nesta linha de raciocínio, vimos enfatizando, em trabalhos anteriores, a necessidade de que o menor diretivismo imposto ao trabalho discente surja de modo progressivo. Isto é, ao longo das séries, as atividades experimentais deveriam partir - desde os anos iniciais do ensino 
fundamental - das demonstrações (categoria I), das verificações (categoria II) e do laboratório estruturado (categoria III), para lenta e paulatinamente passarem a abranger as modalidades com algum caráter investigativo (categorias IV e V). As atividades da categoria VI, de acordo com esta perspectiva, só seriam propostas após a aquisição de uma maior maturidade e familiaridade com os procedimentos experimentais por parte dos alunos. Seriam, por assim dizer, não um meio para se ensinar ciências, mas um fim deste ensino.

Coerentemente com as considerações que desenvolvemos nos capítulos iniciais desta tese, a proposta acima concebe que a valorização da autonomia estudantil não pode ocorrer em detrimento dos conteúdos a serem transmitidos no processo de ensino. Não existiria uma "autonomia em geral", que pudesse ser desenvolvida durante o trabalho experimental no ensino de ciências, e que fosse transferível para a atuação do sujeito em outros âmbitos, notadamente o âmbito da prática social. Não há desvinculação entre forma e conteúdo: o progresso do estudante no domínio de formas mais ativas de se relacionar com os conteúdos tem de, necessariamente, ser acompanhado por um domínio maior dos próprios conteúdos.

Estas conclusões colocam-nos outras interrogações e novas perspectivas para a pesquisa sobre os materiais desenvolvidos e difundidos pelo CDCC. Como visto, um dos projetos mais recentes do CDCC, o ABC da Educação Científica - Mão na Massa, propõe um ensino de ciências prático e investigativo da educação infantil até as séries iniciais do ensino fundamental. Caberia investigar se os estudantes egressos da metodologia do Mão na Massa, ao adentrarem em níveis mais avançados de ensino, de fato se apresentam mais bem preparados para a condução de atividades experimentais, especialmente as modalidades mais investigativas. Mais ainda: seria interessante saber que tipo de papel a Experimentoteca poderia exercer na formação destes estudantes. Considerando que Diniz (1992) e Joaquim (1992) avaliaram os kits experimentais do CDCC como orientados para uma forma de laboratório estruturado (categoria III), o uso da Experimentoteca ofereceria obstáculos à aprendizagem de tais estudantes, promovendo uma solução de continuidade em sua sequência de desenvolvimento iniciada na educação infantil?

Em todo caso, seriam necessários novos subsídios aos kits já existentes da Experimentoteca para aliá-la a outras possibilidades de trabalho experimental, mais coerentes com a fundamentação proposta n'O livro da Experimentoteca. Neste sentido, outro projeto interessante seria o desenvolvimento de novos roteiros experimentais, a serem adicionados ao conjunto de roteiros anteriores, possibilitando que os professores dispusessem de um material de qualidade e que facilitasse sua escolha por atividades mais ou menos estruturadas, 
conforme as exigências de sua prática. Assim, cada caixa da Experimentoteca viria acompanhada de cinco ou seis roteiros diferentes, indicando aos professores formas para se trabalhar os conteúdos referentes aos kits conforme as diversas modalidades ou categorias de atividades experimentais. A formação docente, em nível contínuo, também se beneficiaria da disponibilização de um material que expusesse claramente as diferentes formas de trabalho experimental no ensino - algo que nem sempre é bem compreendido pelos professores, desde seu egresso dos cursos de formação inicial.

As propostas elencadas nos parágrafos anteriores, portanto, não questionam as vantagens de uma experimentação didática menos engessada por instruções de roteiros do tipo "receitas", mas relativizam sua adequação a todos os momentos da educação científica, como parecem defender os educadores construtivistas. E dado que já apresentamos um conjunto amplo de críticas ao construtivismo e às pedagogias do "aprender a aprender", gostaríamos que as seguintes passagens do texto de Célia Gurgel sejam lidas muito criticamente:

\footnotetext{
Nesse processo educativo [viabilizado pelas atividades investigativas], é importante que os conhecimentos prévios dos alunos - suas concepções sobre as Ciências e os fenômenos científicos - sejam enfatizados, pois eles interagem diariamente com seus contextos sociais e constroem suas próprias idéias.

Ao invés de insistir em receitas e prescrições determinadas, a abordagem do ensino deve estar comprometida com uma visão mais complexa da escola e da sala de aula. É nelas que se estabelecem as relações sociais, através da socialização dos estudantes, a produção do conhecimento e outras formas de interação entre professor, alunos e comunidade. Ao se criar condições para que o aluno aprenda a aprender, está se levando em conta que este aluno é um ser cognoscente - ele pensa, interpreta, critica e cria (TOMAZELLO; SCHIEL, 2000, v. 1, p. 16-17).
}

Nesta tese foram expostos repetidas vezes os argumentos contrários a tal posição que “enfatiza” as concepções prévias dos alunos e que propõe o aprender a aprender, já que estes elementos são próprios de uma concepção pedagógica liberal, que ignora a natureza e a especificidade da educação e contribui para o esvaziamento da instituição escolar enquanto socializadora dos conteúdos culturais construídos historicamente.

Vale observar também que as atividades experimentais do tipo investigativo, no ensino de ciências, não são em si uma novidade. Como demonstra Andrade (2011), o entusiasmo para com o ensino por investigação, em fins do século XX, é na verdade uma retomada de ideários de décadas anteriores, como aqueles que orientaram as reformas do ensino de ciências nas décadas de 1950/60, e até mais antigamente, os ideários da pedagogia escolanovista: 
Apesar de não referir especificamente sobre o ensino de Ciências, Dewey propõe a perspectiva investigativa no contexto escolar no início do século XX. A investigação para Dewey se constituía na execução do método científico em busca de uma sociedade mais democrática e do desenvolvimento social. As ideias de Dewey se constituem em um modelo de desenvolvimento muito comum no século XX em que os conhecimentos científicos proporcionariam o progresso, o desenvolvimento social, por isso ele propõe que a atividade científica fosse trabalhada na Educação Básica. Essa proposta se constituía na realização das etapas do método científico: definição do problema, elaboração de hipóteses, sugestão de verificação da hipótese, desenvolvimento e aplicação de testes experimentais e obtenção de resultados e conclusão (ibidem, p. 133).

De fato, como tomamos ciência participando de um dos projetos desenvolvidos em nosso grupo de pesquisa entre 2008 e $2012^{83}$, os fundamentos pedagógicos do programa Mão na Massa, bastante representativo das iniciativas voltadas ao ensino de ciências por investigação, se adéquam perfeitamente à tendência liberal renovada progressivista, esteja ela representada pelas ideias de Dewey ou de Piaget (SOUZA et al., 2011).

Assim, seria necessário um trabalho muito cuidadoso para articularmos a tendência ao ensino por investigação à visão crítico-dialética da experimentação no ensino de ciências. $\mathrm{O}$ conteúdo desta seção, esperamos, pode ser encarado como uma tentativa incipiente de, a partir da Pedagogia Histórico-Crítica e da Psicologia Histórico-Cultural, indicar aqueles elementos desta tendência que poderiam ser afinados com uma teoria menos liberal e mais progressista.

Há ainda os esforços de pesquisadores da Educação em Química em prol de uma "experimentação problematizadora", a qual assentaria os fundamentos das atividades investigativas na pedagogia de Paulo Freire (FRANCISCO JUNIOR; FERREIRA; HARTWIG, 2008). Trata-se de uma proposta interessante e promissora, sem dúvidas. No entanto, seu desenvolvimento deve pautar-se pelo mesmo zelo e cuidado que defendemos no caso dos estudos que desejam se fundamentar na Psicologia Histórico-Cultural. Os investigadores que pretendam continuar elaborando-a devem estar conscientes de que uma proposta de ensino "freireana" não pode ser inspirada na leitura de apenas algumas das obras do educador pernambucano. O mínimo que se pode exigir, destes estudiosos, é que compreendam as motivações que levaram ao surgimento do "método Paulo Freire"; os perigos de uma transposição mecânica, da proposta inicial de Freire voltada para a educação popular de adultos, para as salas de aula da educação escolar; e a complexa síntese que o renomado educador promoveu entre correntes filosóficas tão diversas (fenomenologia, marxismo, personalismo, existencialismo, teologia da libertação).

\footnotetext{
${ }^{83}$ Cujo trabalho principal era o doutorado de Renata Faria de Souza, Pedagogia do Projeto ABC da Educação Científica-Mão na Massa.
} 


\subsection{TENDÊNCIA 3: TEORIA DOS PERFIS CONCEITUAIS}

Sem dúvidas, o momento mais importante deste capítulo é compreendido por esta seção. Aqui, teremos a oportunidade de conhecer e analisar as considerações especificamente direcionadas ao ensino de Química, difundidas n'O livro da Experimentoteca, além de entrar em contato com a complexa teoria que lhe dá suporte, a teoria dos perfis conceituais.

Estas contribuições estão reunidas no capítulo 8 da obra, intitulado "O mundo visto por meio da Química", mais extenso que os textos analisados nas seções anteriores, com 31 páginas e várias divisões internas. A autora do capítulo é desta vez a Prof. Maria Inês Petrucci dos Santos Rosa, uma das mais renomadas pesquisadoras brasileiras da Educação em Química na atualidade. A escolha pelo nome da Prof. Inês como participante deste momento d'O livro da Experimentoteca parece-nos bastante feliz: além de possuir uma sólida formação teórica e prática, e uma produção profícua, pouquíssimos educadores químicos no Brasil poderiam se gabar de deter uma compreensão tão profunda quanto a dela sobre o conceito de transformação química. Os estudos reunidos em sua dissertação de mestrado ( $A$ evolução de idéias de alunos do ensino médio sobre transformação química numa abordagem construtivista, de 1996, orientada pela Prof. Roseli P. Schnetzler) são ainda hoje uma referência indispensável a quem deseja pesquisar sobre o ensino e a aprendizagem de um conceito tão central para a ciência química.

O texto inicia com considerações gerais sobre o estado em que a Química se apresentava em fins do século passado, e que continuam atuais:

A palavra Química carrega uma série de significados, muitas vezes ambíguos ou confusos. Basicamente parece que ela pode ser entendida de três formas: como um repertório imenso de técnicas, como uma ciência ou como um setor da economia. Essas concepções têm origens históricas, pois, se examinarmos a história dessa ciência nos últimos trezentos anos, poderemos perceber vários movimentos surgidos dentro dela e que levaram a caminhos diferentes nas relações com outras ciências e com a evolução da qualidade de vida da espécie humana.

No seu período pré-científico, quando ainda era chamada de alquimia, o seu modo de agir e de pensar se encerrava em discursos herméticos cercados por uma aura de magia e mistério. Ao se firmar como ciência, já no final do século XVIII, a Química passou a recusar o pensamento pré-científico, contudo muitos dos seus métodos ainda se baseavam nas técnicas e pesquisas desenvolvidas pelos alquimistas.

Foi com a Revolução Industrial, no século XIX que a Química viveu seu grande "boom", passando a desempenhar um papel relevante na economia. É claro que hoje a indústria química explora as possibilidades de novas tecnologias e idéias geradas no meio acadêmico, porém o seu campo de ação tem predominantemente implicações sociais e econômicas (TOMAZELLO; SCHIEL, 2000, v. 1, p. 178). 
Esta abordagem historiográfica do tipo externalista, por sinal, será uma das marcas do texto da Prof. Inês, constando em todas as suas divisões. Prossegue a autora, então, apresentando os dilemas e desafios que se apresentam à Química, diante do desprestígio que assolou as ciências em geral desde as crises ambientais deflagradas em fins do século XX:

Por outro lado, desde duas ou três décadas atrás vivemos num mundo onde a Química tem sido encarada numa perspectiva diferente, numa visão mais negativa. Vem crescendo um sentimento de "anticiência" e "antitecnologia" nas populações de vários países desenvolvidos e, conseqüentemente, entre políticos. A tecnologia tornou-se uma espécie de bode expiatório para as campanhas sociais. E, dentro desse pensamento, parece que as necessidades humanas estariam se tornando fúteis, artificiais, e satisfazê-las implicaria acumular esforços geradores de perigos para a humanidade: riscos permanentes, câncer, guerra nuclear, etc. (ibidem, loc. cit.).

Se foi o desenvolvimento histórico - da própria ciência e da sociedade em que ela se insere - que dirigiu a Química para este estado de descrédito perante a população, o reestabelecimento de sua reputação passa necessariamente pela mobilização de seus praticantes em prol destas mesmas forças históricas. Ou seja, como bem resume a Prof. Inês, a "renovação" da Química exige que esta ciência não se comprometa tanto com os interesses postos contra o movimento da história, sob a pena de permanecer contribuindo para o esgotamento dos recursos naturais e, consequentemente, continuar sendo vista com desconfiança por parte do público mais amplo:

Essa ciência precisa caminhar gradativamente nesse fỉm de milênio para uma postura mais próxima à restauração do equilíbrio, ao invés de continuar se associando a processos capitalistas de produção que só visam lucro, em detrimento da preservação das espécies presentes no planeta (inclusive a humana).

Repensar os processos de produção científico-tecnológicos e industriais, buscando saídas para a crise ambiental que vivemos, parece ser o caminho para a Química nesse momento histórico (ibidem, p. 179).

A seguir, o texto se dedicará aos aspectos do ensino da Química propriamente dito, mantendo a abordagem ancorada no desenvolvimento histórico de seus principais conceitos, e acrescentando os então recentes resultados da pesquisa brasileira e estrangeira sobre a Educação em Ciências.

Assim, começando por uma seção intitulada "Fenômeno químico/fenômeno físico", a Prof. Inês irá narrar a conquista dos conhecimentos químicos pela humanidade, partindo do domínio do fogo na pré-história e enfatizando o rico período compreendido entre os séculos XVIII e XIX, que assistiu ao florescimento de nomes como Lavoisier, Cavendish, Galvani, Volta, Proust e Dalton - todos eles lembrados pelo texto por suas contribuições ao 
estabelecimento do caráter científico da Química, como que livrando-a dos resquícios do pensamento mágico-vitalista herdado das práticas alquímicas. Relata-se, então, uma progressiva "teorização" desta ciência, marcada pela distância cada vez maior entre seus modelos explicativos e as manifestações mais empiristas ou sensorialistas de seus fenômenos:

Por trás dos "porquês" vem, então, a construção de modelos teóricos que tentam explicar e prever os fenômenos químicos. Por isso os químicos procuram discutir o conceito dentro de parâmetros microscópicos, afirmando que os fenômenos químicos são processos que envolvem a formação e a quebra de ligações entre partículas atômicas [...] (ibidem, p. 180).

Se os critérios para se definir o que são processos químicos radicam não no mundo fenomenológico, mas no microscópico (inatingível pela contemplação sensorial imediata), de que forma ensinar a Química - ressaltando seu caráter específico, isto é, suas diferenças em relação às demais ciências, especialmente a Física - em níveis elementares, para os quais a apreensão de conceitos como átomo e elétron é ainda um grande obstáculo? Os autores clássicos de livros textos teriam encontrado uma resposta, mas que não seria a mais apropriada:

Pode-se constatar que muitos livros didáticos de Ciências e de Química apenas distinguem os fenômenos reversíveis (físicos) dos irreversíveis (químicos). De fato, percebemos muitas vezes que, ao saírem do nível fundamental de ensino, os alunos se limitam a conceituar um fenômeno químico simplesmente através da contraposição com um fenômeno físico, distinguindo-o pelo critério da irreversibilidade (ibidem, p. 180-181) ${ }^{84}$.

Fornecendo exemplos tanto de transformações físicas irreversíveis, quanto de transformações químicas reversíveis, o texto d'O livro da Experimentoteca lembrará que "Existem outros atributos mais importantes do conceito de fenômeno químico possíveis de serem desenvolvidos durante o ensino" (ibidem, p. 181), e é a partir disto que serão introduzidas algumas ideias principais da noção de perfil conceitual. A propósito, "noção de perfil conceitual" ou "modelo de mudança dos perfis conceituais" são expressões bastante comuns nos textos do Prof. Eduardo F. Mortimer, educador químico brasileiro criador da teoria. Sem prejuízos a estes termos, falaremos aqui simplesmente da "teoria dos perfis conceituais".

\footnotetext{
${ }^{84}$ A pesquisa com livros didáticos de Ciências para as séries iniciais do ensino fundamental, em meu mestrado (MORI, 2009), notou que a associação entre fenômeno químico e irreversibilidade permanecia sendo explorada em obras que adentraram as escolas brasileiras entre 2007 e 2010. A conexão Química/irreversibilidade em livros didáticos, aliás, foi objeto do trabalho de Lopes (1993), que demonstrara ser esta identidade infundada uma herança dos compêndios escolares da época da Reforma Francisco Campos (1931).
} 
Vejamos, antes de tudo, como a Prof. Inês traz a teoria para seu texto. Primeiramente, ela afirma acreditar que "todo conceito científico possa ser construído de maneira correta dentro de diferentes campos ou zonas de pensamento" (ibidem, loc. cit.). Este, que é o cerne da teoria, deriva das considerações de um dos mais interessantes pensadores no campo da História e Filosofia da Ciência (e também do campo que hoje é chamado de Filosofia da Química), o francês Gaston Bachelard (1884-1962). Falando sobre o chamado "perfil epistemológico", que seria a forma global como um dado indivíduo apresenta estes campos ou zonas de pensamento sobre um dado conceito, Bachelard propôs que a apreensão total do mundo e de seus fenômenos nunca seria possível se levada a cabo por meio de um único ponto de vista; neste processo de relacionamento entre o sujeito e a realidade, formas de pensamento até mesmo discrepantes - sendo o exemplo típico a contraposição entre senso comum e conhecimento científico - seriam válidas em seus respectivos contextos.

Mortimer adotou esta visão para criar um novo modelo que explicasse o processo de ensino e aprendizagem das ciências, e que superasse o modelo de mudança conceitual, uma concepção paradigmática no campo da Educação em Ciências desde sua proposição em um (agora clássico) artigo de pesquisadores da Universidade de Cornell (George J. Posner, Kenneth A. Strike, Peter W. Hewson e William A. Gertzog), intitulado “Accommodation of a scientific conception: toward a theory of conceptual change" e publicado na revista Science Education em 1982. De acordo com estes estudiosos (POSNER et al., 1982), o processo de ensino, para lograr êxito, além de aceitar a existência de concepções alternativas por parte dos estudantes, deveria reconhecer a natureza "altamente robusta" delas, que implicaria na grande resistência - detectada pelas pesquisas - dos pupilos em aceitarem as ideias científicas transmitidas na escola. Segundo o artigo, as pesquisas não haviam ainda elucidado exatamente a maneira como ocorreria a interferência das ideias prévias sobre o saber a ser apreendido, tendo sido enunciados, por Piaget, apenas princípios formais (abstratos, gerais) do desenvolvimento do pensamento lógico. Então, apesar de incorporarem até mesmo parte da terminologia piagetiana - em especial, os termos "assimilação" e "acomodação", com um significado próximo, embora não idêntico, daquele usado pelo psicólogo suíço em seus escritos -, Posner e seus colaboradores buscarão na nova filosofia da ciência os subsídios para se compreender a substituição das ideias alternativas pelo saber científico na mente dos aprendizes. Sua referência primeira serão os conceitos de Thomas Kuhn ${ }^{85}$ de paradigma,

\footnotetext{
${ }^{85}$ Também aparecerão menções à teoria de Imre Lakatos; por exemplo, os pesquisadores considerarão que a assimilação é análoga ao desenvolvimento do conceito lakatosiano de "programa de pesquisa", sendo a acomodação a "mudança de programa de pesquisa".
} 
revolução científica e crise, sobre os quais serão elaboradas analogias em relação, respectivamente, a assimilação, acomodação e conflito cognitivo. Se a assimilação corresponde à pura adaptação de uma nova ideia à chamada "ecologia conceitual” do aprendiz (seu conjunto de concepções prévias e compromissos epistemológicos), o ensino de ciências deveria enfatizar o processo de acomodação, isto é, uma alteração substancial nesta ecologia, a forma mais radical da mudança conceitual propriamente dita. Duas preocupações emergiriam daí: 1) as condições em que ocorre a troca de um conceito por outro; e 2) quais características de uma ecologia conceitual governariam a seleção de novos conceitos. Da resposta a estas questões, os pesquisadores estabeleceram quatro condições para a ocorrência bem sucedida de uma mudança conceitual: 1) insatisfação perante as concepções prévias; 2) inteligibilidade da nova concepção; 3) plausibilidade da nova concepção; e 4) caráter frutífero da nova concepção. O ensino deveria ser dirigido, assim, para a criação de conflitos cognitivos que colocassem em xeque os conceitos prévios dos estudantes, diminuindo seu status e, ao mesmo tempo, apresentando as vantagens da adoção dos novos conceitos, operando uma verdadeira revolução científica - a troca de um antigo paradigma por um novo - nas mentes dos discípulos.

Acontece que, passados anos de pesquisa com propostas de ensino baseadas no modelo de Posner e colaboradores, consolidou-se a certeza de que, mesmo quando conceitos científicos pareciam ter sido adequadamente incorporados às explicações dos estudantes, em contextos não acadêmicos (por exemplo, no cotidiano ou em qualquer situação em que não estivessem submetidos a algum tipo de avaliação escolar) estas explicações frequentemente regrediam ao nível dos conceitos prévios, como que ignorando o aprendizado do saber científico. A noção de que na mente dos aprendizes podem conviver as mais diversas e até discrepantes explicações para um mesmo fenômeno - e de modo geral, as mais diversas e discrepantes visões de mundo - consolidou-se e não tardaria a impor empecilhos ao próprio modelo de mudança conceitual.

Foi na tentativa de incorporar estes novos resultados que Mortimer propôs sua teoria dos perfis conceituais, adaptando o conceito de perfil epistemológico de Bachelard. Embora o marco da proposta do educador químico brasileiro seja a publicação do artigo "Conceptual change or conceptual profile change?" na revista Science \& Education em 1995, é no livro Linguagem e formação de conceitos no ensino de ciências (2000) que a teoria é apresentada de forma mais completa e aprofundada. Portanto, apesar da ampla produção de Mortimer, representada por seus incontáveis artigos em periódicos do campo da Educação em Ciências, 
reportar-nos-emos principalmente a este livro, no estudo desta seção. É nele que encontraremos, também, uma boa definição do que seria ensinar ciências de acordo com a teoria dos perfis conceituais:

\begin{abstract}
O ensino-aprendizagem de ciências ganha um novo enfoque se pensado como uma mudança de perfil conceitual. Primeiramente, seria possível ensinar um conceito num certo nível de seu perfil sem fazer referência a seus níveis menos complexos, desde que eles sejam epistemológica e ontologicamente diferentes. Neste sentido, o processo de ensino-aprendizagem pode ser pensado como a construção de um corpo de noções baseado em novos fatos e experimentos apresentados ao estudante no processo de ensino. O novo conceito não depende, necessariamente, das concepções prévias, já que pode ser aplicado a um novo e diferente domínio. Apenas quando as concepções prévias constituem-se em obstáculos ao desenvolvimento do novo conceito será necessário lidar com essa contradição, o que pode ocorrer em qualquer momento do processo de ensino e não apenas no início. Ultrapassar essa contradição significa encontrar um meio de explicá-la, o que é possível no nível mais complexo do conceito que está sendo ensinado, mas não significa o abandono dessa velha maneira de ver o mundo, que continua a fazer parte do perfil do indivíduo (MORTIMER, 2000, p. 142).
\end{abstract}

O estudo relatado neste livro apresenta-se como fundamentado em teorias provenientes de três eixos: no "eixo do desenvolvimento cognitivo", recorre-se à teoria de Piaget sobre a equilibração, bem como suas investigações sobre o processo de generalização, além da revisão crítica do modelo de mudança conceitual; no "eixo da História e Filosofia da Ciência", aparece o já mencionado conceito bachelardiano de perfil epistemológico, e também contribuições de diversos autores da nova filosofia da ciência; e por fim, no eixo do "desenvolvimento social de ideias em sala de aula", despontam os russos "Vygotsky" (mediante as traduções em língua inglesa), Bakhtin e Voloshinov.

Estes três eixos serão mobilizados para o entendimento de perfis conceituais do atomismo e dos estados físicos da matéria, tendo sido investigada uma sequência didática apresentada a alunos do último ano do ensino fundamental. Não nos interessa, aqui, descrever minuciosamente as aulas e os procedimentos utilizados na investigação, importando-nos apenas citar alguns dos resultados a que Mortimer chegou. Assim, com relação às categorias estruturantes do perfil conceitual sobre átomo, ou seja, suas "zonas", foram detectadas as seguintes:

- $1^{a}$ zona - concepção contínua da matéria: negação do conceito de átomo e da existência de vácuo;

- $2^{a}$ zona - atomismo substancialista: atribuição de propriedades do mundo macroscópico aos próprios átomos (possibilidade deles se dilatarem, se aquecerem, possuírem coloração própria, entre outros e outros); 
- $\quad 3^{a}$ zona - racionalismo clássico: átomo como unidade básica de constituição da matéria, conservado durante suas transformações.

Mortimer descreve também uma quarta zona, referente à visão mecânico quântica do átomo, mas reconhece a dificuldade em promover sua construção através do ensino nos níveis fundamental e médio. No entanto, a lógica que subjaz à teoria dos perfis conceituais não propõe a mera substituição de noções mais antigas por outras novas; antes, procura reconhecer em que medida uma determinada zona pode dificultar ou facilitar o aparecimento de uma nova. Assim, a zona do racionalismo clássico é vista como importante para a construção deste atomismo contemporâneo em níveis mais avançados:

\begin{abstract}
Poderíamos não estar interessados em outras áreas mais avançadas do perfil conceitual do átomo, já que nossa preocupação, neste trabalho, é como ensiná-lo em um nível elementar. No entanto, é importante identificar a direção geral da evolução no conceito, a fim de evitar que no ensino elementar sejam reforçados alguns obstáculos ao seu entendimento num nível mais avançado. Esse problema não pode ser evitado completamente, uma vez que a visão clássica do átomo possui algumas características intrínsecas que são obstáculos à construção de uma visão quântica [...] O que hoje é uma nova idéia está fadado a ser, no futuro, um obstáculo para a resolução de um problema novo. Essa provisoriedade do conhecimento nos obriga a pensar o ensino como a mudança de perfis conceituais e não como a substituição de noções cotidianas por conceitos científicos, pois estes terão que ser substituídos por conceitos mais avançados no futuro. Na lógica da substituição de conceitos seria inútil ensinar conceitos clássicos, já que eles não são científicos à luz da ciência moderna e contemporânea (ibidem, p. 137-138).
\end{abstract}

E além disso, o atomismo clássico possui um valor intrínseco:

Para os químicos, a visão clássica, atômica e descontínua é, sem dúvida, fundamental. Todo nosso universo molecular é representado desse modo. Isso não significa que um químico não possa imaginar uma molécula como um agrupamento de singularidades matemáticas em campos de força. Contudo, ao planejar uma síntese, por exemplo, ele representará agrupamentos moleculares como um conjunto de partículas materiais, que podem ser adicionados ou removidos numa seqüência de reações, de modo a obter um composto final (ibidem, p. 140).

Voltemos a $O$ livro da Experimentoteca. O texto da Prof. Inês também propõe três zonas para um perfil conceitual, desta vez quanto ao conceito de fenômeno químico:

Zona realista: nela estão situadas as concepções prévias dos alunos sobre fenômeno químico, ligadas ao aspecto fenomenológico e às evidências visuais, como mudança de cor e forma. [...]

Zona empirista: nesse nível estão as idéias marcadas pela observação experimental, pelo mensurável, pelas técnicas empregadas em laboratório. Ao perceber que num fenômeno químico o que ocorre é a formação de novas substâncias, o aluno está usando idéias pertencentes a essa zona do pensamento. Essa idéia de formação de novos materiais pode ser construída a partir de dados experimentais, envolvendo, 
por exemplo, a comparação de propriedades físicas das substâncias iniciais e finais no processo.

Zona racionalista: nessa zona estão as concepções associadas ao nível microscópico do conhecimento químico, que envolvem noções de particular e seu rearranjo, ou seja, ao apresentar essas idéias, os alunos se expressam utilizando palavras como átomo, molécula e ligação [química] de maneira correta (TOMAZELLO; SCHIEL, 2000 , v. 1 , p. 181).

Assim categorizado o perfil conceitual para fenômeno químico, conclui a autora:

\begin{abstract}
Seria adequado desenvolver a zona racionalista desse conceito ainda nesse nível de ensino [fundamental]? Será que os alunos precisam saber explicar os fenômenos químicos em termos de rupturas e formações de ligações no nível fundamental?

Um enfoque centrado na zona racionalista envolveria a apresentação de modelos atômicos e de interações químicas, que exige um nível de abstração mais sofisticado por parte dos estudantes. Assim, pode ser suficiente e adequado facilitar a construção do conceito de fenômeno químico dentro da zona empirista para os alunos no nível em que se encontram, ou seja, buscar como atributo criterial para esse conceito a ocorrência da formação de novas substâncias, possível de ser levantado com o auxílio de atividades experimentais.

Nesse sentido, a Prática Pedagógica de Ciências da CENP $^{86}$ e o kit da Experimentoteca desenvolvem atividades que abordam esse tema sob essa perspectiva, envolvendo conceitos como substância, propriedade, fenômeno físico e fenômeno químico. Trabalhando tais conceitos de forma adequada, o aluno estará preparado para adquirir noções microscópicas atreladas à zona racionalista, em um momento posterior (ibidem, p. 182).
\end{abstract}

A seguir, surgirão três novas divisões no texto da Prof. Inês, em que as discussões serão dirigidas aos temas de três dos sete kits da Experimentoteca para o ensino de Química no nível fundamental, nesta ordem: 1. "Dimensão do átomo"; 5. "Ácidos e bases"; 4. "Eletrólise de água". Como apenas as duas primeiras divisões contemplam aspectos implicados na teoria dos perfis conceituais, não analisaremos o texto sobre eletrólise, que, além disso, é bastante breve (sendo desenvolvido em pouco mais de uma página).

A primeira divisão (“A dimensão do átomo”, quatro páginas) relata aspectos históricos do atomismo, como que resumindo o conjunto de considerações históricas desenvolvidas no livro de Mortimer. As principais escolas de pensamento que meditaram sobre a existência de átomos, ao longo da história, são revistas brevemente. A noção bachelardiana de perfil epistemológico é exposta para o conceito de átomo, apresentando três zonas: a realista, a empirista e a racionalista (esta, dividida entre o atomismo clássico e o moderno). Enquanto a segunda zona é definida de modo vago - "[como] o conceito de átomo é originalmente racional, somos levados assim a dispensar a parte empírica desse conceito, já que ela é completamente subordinada à zona racional" (TOMAZELLO; SCHIEL, v. 1, p. 185) -, a

\footnotetext{
${ }^{86}$ Referência à proposta curricular do Estado de São Paulo, organizada pela Coordenadoria de Ensino e Normas Pedagógicas (CENP).
} 
zona realista aparece como uma mescla entre a primeira e a segunda zona do perfil conceitual de Mortimer (visão descontínua da matéria e substancialismo), sendo as duas zonas racionalistas definidas de modo quase idêntico. Salvo isto, a abordagem da Prof. Inês é essencialmente a mesma que se defende no livro Linguagem e formação de conceitos no ensino de ciências:

No nível fundamental de ensino, podemos nos preocupar em levar o aluno a construir o conceito de átomo na zona racionalista clássica, o que será adequado para que ele tenha condições de explicar os fenômenos químicos no nível microscópico. Ainda nessa zona do pensamento, nos atemos ao modelo atômico de Dalton, suficiente para o espectro de explicações que pretendemos nesse estágio de ensino (ibidem, loc. cit.).

Também concordando com o livro de Mortimer, o texto defenderá que o atomismo seja ensinado lembrando-se de seu papel enquanto modelo científico:

Para que os alunos depreendam o significado da expressão modelo atômico, torna-se necessário trabalhar com eles os conceitos de analogia e modelo. Vários autores apontam a importância do uso das analogias na construção de modelos, contudo devemos ter em mente também os "riscos" que elas podem representar para a aprendizagem (ibidem, loc. cit.).

Especificamente sobre modelos, estão expostas as seguintes considerações:

É importante notar que a matematização das teorias levou também a um avanço, em termos filosóficos, do significado da expressão modelo atômico. O que podemos dizer hoje em relação a isso?

- Um modelo é uma construção mental, produto do trabalho da razão humana;

- um modelo; não é uma reprodução real de um sistema (não é uma fotografia dele);

- um modelo é passível de sofrer modificações, já que ele significa exclusivamente a tentativa de se explicar algo que não é visível simplesmente.

O que isso significa, então? Que parece ser necessário sempre levar em conta esse aspecto filosófico da idéia de modelo quando estamos em sala de aula com nossos alunos. Em outras palavras: a visão histórica da construção da idéia de átomo permite a nossos alunos a percepção de que a Ciência é dinâmica culturalmente e evolutiva em termos ideacionais. A Ciência não deve ser apresentada numa perspectiva dogmática, de verdades intocáveis (ibidem, p. 184).

seria desejável que os alunos pensassem nos modelos como construções que servem para desenvolver e testar idéias sobre a realidade. Aquele que constrói um modelo faz com que seus objetivos determinem a forma como ele será construído. Os modelos podem ser manipulados e testados para controlar diferentes idéias.

Para auxiliar na construção desta noção de modelo, podemos enfatizar os seguintes pontos no ensino:

- fornecer aos alunos várias oportunidades para usar modelos, assim como para a reflexão da natureza dos modelos; 
- fornecer aos alunos experiências onde eles possam usar os modelos como instrumentos de inquisição, não como pacotes de fatos a serem memorizados;

- fornecer-lhes modelos que não sejam só físicos ou espaciais, mas também modelos abstratos;

- encorajar os alunos a construir modelos que reflitam seus próprios conceitos sobre os fenômenos e que possibilitem a confrontação com modelos criados por seus colegas e pelos cientistas;

- enfatizar a importância dos modelos para a previsão de novos fatos (ibidem, p. 186).

A ênfase no caráter de modelo das concepções atomistas se relaciona às características do respectivo kit da Experimentoteca, "Dimensão do átomo". Na atividade proposta pelo material, os alunos precisam descobrir a quantidade e o tipo de objetos (lápis sextavado, parafuso, bola de gude, borracha, arruela) existentes dentro de uma pequena "caixa preta" (Figura 36). Para isso, dispõem de outra caixa igual, vazia, que podem preencher com os mesmos objetos. Comparando as duas - por exemplo, através dos sons produzidos no deslocamento dos objetos pelos interiores - eles podem chegar à solução do problema. $\mathrm{O}$ objetivo é compreender o processo de construção de modelos, especialmente nas situações em que não é possível visualizar os fenômenos em estudo, como ocorre na Química.

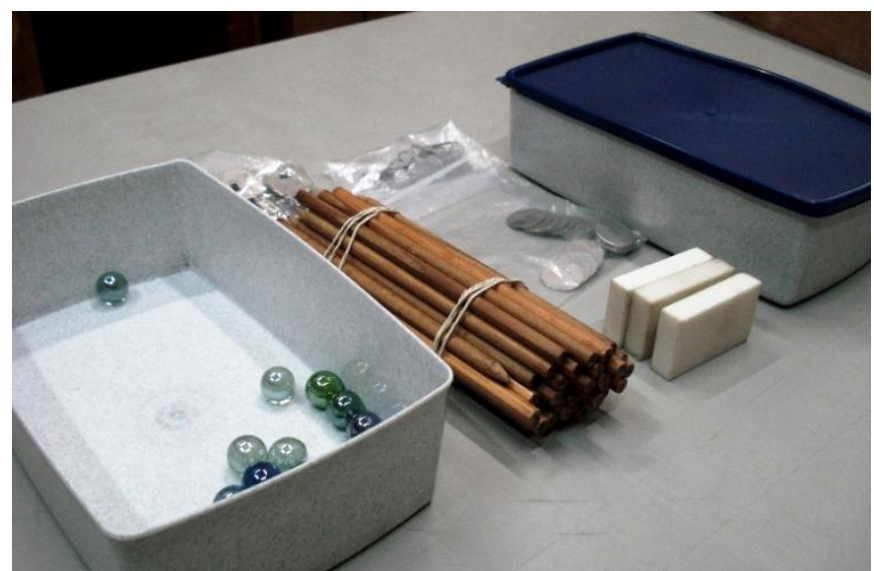

Figura 36: foto dos materiais que compõem o kit "A dimensão do átomo", da Experimentoteca para o ensino fundamental.

Já tivemos a oportunidade de estudar empiricamente o uso deste kit, embora não no âmbito da educação básica, mas como atividade integrante da formação de professores de ciências, em São Carlos $^{87}$. Este estudo, que integrou um projeto mais amplo abrangendo a pesquisa com atividades do tipo investigativo na formação inicial docente, fundamentou-se em Talanquer (2011), num trabalho que analisa criticamente usos e interpretações do famoso

\footnotetext{
${ }^{87}$ Isto aconteceu entre os anos de 2008 e 2011, participando da pesquisa $A$ investigação científica na formação inicial do professor de ciências, cujo principal trabalho foi o relatório de iniciação científica de Jonathan Francisco de Freitas, no âmbito do projeto Ensinar com Pesquisa, desenvolvido pela Pró-Reitoria de Graduação da USP.
} 
“tripé” em que repousaria o conhecimento químico, proposto por Johnstone em 1982. O tripé se refere a três níveis de interpretação dos fenômenos químicos: descritivo e funcional (macroquímica), relacionado ao que é tangível/visível; representacional (simbólico), que abrange signos químicos, matemáticos e suas relações (equações); e explanatório ((sub)microquímica), que lida com a natureza corpuscular/descontínua da matéria. Verificando que os educadores químicos vêm utilizando o tripé muitas vezes sem delimitar claramente os domínios a que se referem os três níveis, Talanquer, neste artigo, sugere que "o conhecimento químico relevante para o ensino pode ser caracterizado como constituído de três 'tipos' principais” (p. 187, tradução nossa):

- Experiências, que incluem conhecimento descritivo de substâncias e processos, adquirido tanto por via sensorial quanto por vias indiretas (instrumentais);

- Modelos, que incluem os construtos descritivos, explanatórios e preditivos que os químicos elaboram para dar significado ao mundo; e

- Visualizações, tratando de signos visuais desenvolvidos para facilitar o pensamento quantitativo e qualitativo acerca das experiências e modelos.

De acordo com esta visão, importa aos alunos saberem diferenciar experiências de modelos e visualizações, construindo conexões entre estes elementos em diferentes escalas, e reconhecendo as diversas dimensões (energia, tempo, estrutura etc.) em que os fenômenos podem ser explorados/modelados/visualizados.

Nossa pesquisa, dimensionada de acordo com esta perspectiva, evidenciou algumas das dificuldades possíveis de ocorrerem em uma situação didática de utilização do kit "Dimensão do átomo". A primeira delas é de caráter técnico: como é preciso acompanhar os sons produzidos pelas caixas, na tentativa de se adivinhar qual o conteúdo da caixa que se deseja "modelar", o ambiente da sala de aula pode ficar barulhento se todos os alunos - em 10 grupos, suponhamos - manipularem os materiais simultaneamente. O desejável, acreditamos, é que os estudantes possam usar outros espaços, como o pátio da escola, para desenvolver a atividade sem que os grupos se atrapalhem mutuamente. Outra dificuldade se refere à própria atuação dos educandos - e lembremos, a situação que investigamos envolveu licenciandos em ciências -, que nem sempre parecem compreender o papel da atividade proposta pelo CDCC. Por exemplo, um dos vieses de nossa pesquisa envolveu o aspecto da quantificação, isto é, a importância de se atribuir e/ou investigar valores quantitativos, numéricos para as grandezas 
envolvidas em um trabalho prático do tipo investigativo ${ }^{88}$. Os dados revelaram que os professores em formação têm dificuldades em determinar quais parâmetros desta atividade são quantificáveis, e de como poderiam realizar estas medidas. De modo geral, pareceram não compreender a importância dos modelos para o ensino de diversos conteúdos de ciências, em especial o atomismo. Sem dúvidas, tal incompreensão coloca em risco a efetividade do uso do kit da Experimentoteca na educação básica, e elimina suas possibilidades de um proveitoso engajamento tanto no ensino CTS, quanto no ensino por investigação. Mais que isso, como demonstra o livro de Mortimer, a incompreensão do que é um modelo e de seu papel na ciência pode ser um obstáculo crucial para a elaboração das zonas mais avançadas do perfil conceitual de átomo, notadamente as zonas racionais clássica e moderna.

Na tentativa de contribuir para eliminar estas dificuldades, a pesquisa que realizamos voltou-se também para a construção de materiais didáticos complementares ao kit "Dimensão do átomo". Foram desenvolvidos então dois protótipos:

- Caixa furada: um cubo de madeira com arestas de cerca de $30 \mathrm{~cm}$, sendo duas faces opostas inteiramente furadas, com orifícios alinhados vertical e horizontalmente, a uma distância de aproximadamente $1 \mathrm{~cm}$. No interior do cubo são colocadas bolas de borracha de diferentes tamanhos. $\mathrm{O}$ objetivo da atividade é estimar o diâmetro das bolas sem observá-las ou manipulá-las, apenas utilizando varetas que são trespassadas no cubo pelas faces (Figura 37).

- Caixa de gavetas: três gavetas totalmente perfuradas (furos com diâmetros de 1,0, 1,3 e 2,0 cm) podem ser introduzidas livremente em um cubo de madeira, funcionando como peneiras, para que se estime a quantidade e o diâmetro de bolas de metal ali encerradas. As bolas maiores ficam retidas nas "peneiras", e as menores caem ao fundo da caixa (Figura 38).

Estes materiais foram elaborados pensando-se em reproduzir, na sala de aula, algumas das dificuldades envolvidas na investigação da dimensão do átomo e de seus constituintes. A referência óbvia, nos dois casos, foi o famoso "experimento de Rutherford". Mais informações sobre os materiais e sobre a investigação de seu uso pelos licenciandos podem ser encontradas na respectiva publicação de nosso grupo (FREITAS; MORI; CURVELO, 2011a).

\footnotetext{
${ }^{88}$ Mais precisamente, desejávamos investigar em que medida a necessidade desta quantificação (identificando-se corretamente quais parâmetros poderiam ser quantificados, e se os valores das grandezas físicas correspondentes poderiam ser de valia para a resolução dos problemas propostos) contribuiria para tornar a atividade mais investigativa, ou seja, demandando mais consciência das ações efetuadas e maior planejamento do trabalho como um todo, por parte dos alunos.
} 


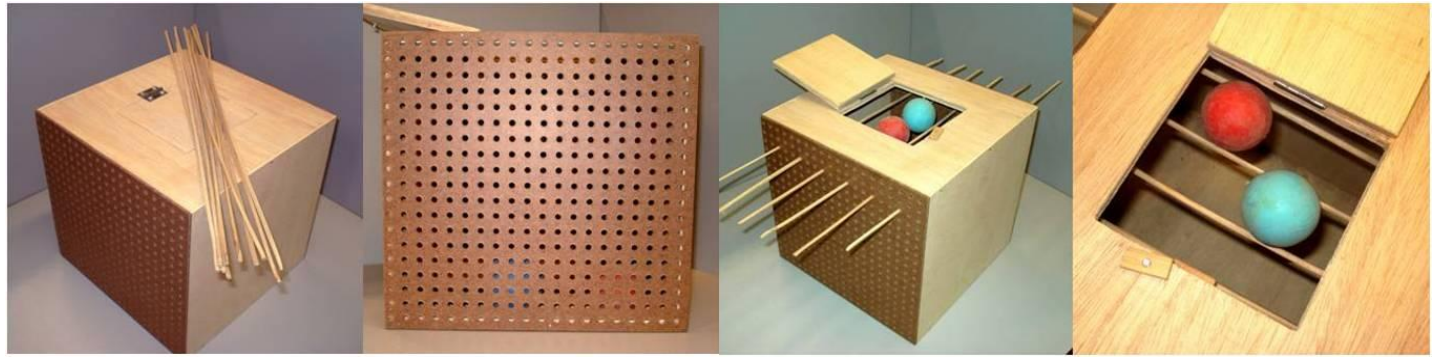

Figura 37: caixa furada. Na situação registrada, as varetas foram introduzidas a distâncias de cerca de $4 \mathrm{~cm}$. As bolas não conseguiram atravessar a "malha"; portanto, seu diâmetro é maior do que esta distância.

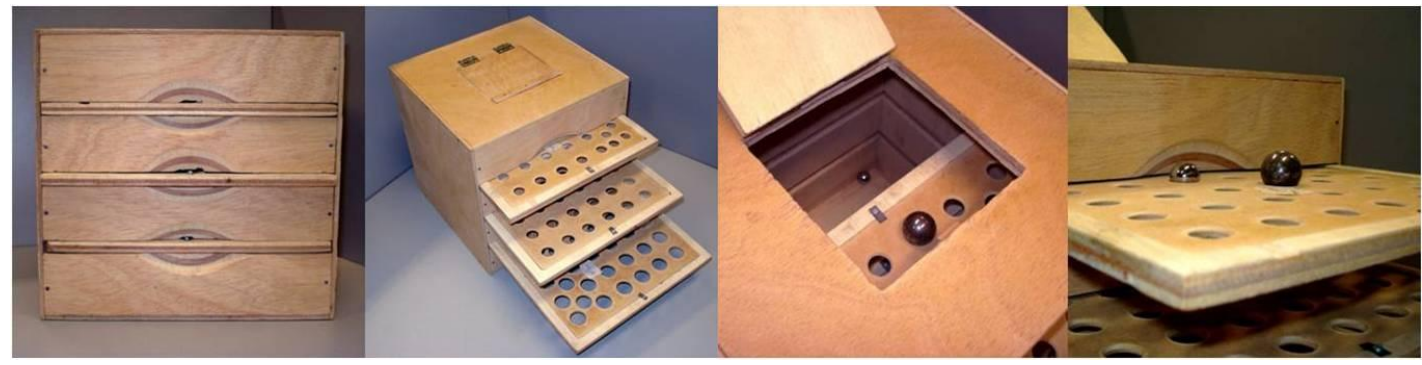

Figura 38: caixa de gavetas, que funcionam como peneiras, seus orifícios apresentando diferentes diâmetros. Na situação da terceira foto (da esquerda para a direita), uma das bolas ficou retida na peneira com furos de $2,0 \mathrm{~cm}$ de diâmetro.

Não estamos aqui defendendo os materiais que propusemos, mas apenas assinalando que a contínua investigação sobre o kit em questão da Experimentoteca pode se beneficiar da pesquisa por novos materiais didáticos que venham a lhe complementar (sendo incorporados futuramente ao material do CDCC, quem sabe). Abrem-se, nesta linha, possibilidades interessantes de se conjugar ensino com pesquisa, produção com teste de material didático, e a tendência ao ensino por investigação com a tendência à teoria dos perfis conceituais. Parecenos, sobretudo, que os resultados positivos relatados em Linguagem e formação de conceitos, atestando a apropriação de novas zonas do perfil conceitual de átomo por parte dos aprendizes (que, submetidos ao ensino do atomismo com ênfase na noção de modelo, evoluíram de ingênuas explicações realistas e empiristas para noções substancialistas mais refinadas e, principalmente, para um domínio da zona racionalista clássica), devem ser levados em consideração na formulação de novas propostas e materiais didáticos por parte do CDCC ou de outros pesquisadores que possam tomar a Experimentoteca como objeto.

Retornando à análise do texto d'O livro da Experimentoteca, vejamos as considerações da Prof. Inês sobre o kit "Ácidos e bases”, na divisão homônima de seu texto (quatro páginas). Novamente, temos a exposição de aspectos históricos dos conceitos de ácido e base, enfatizando-se as conquistas, para o estado do conhecimento, representadas pela adoção de uma nomenclatura mais criteriosa para estes materiais (a partir da proposta de 
Lavoisier) e pelo domínio do uso de indicadores, e não mais da aferição de propriedades organolépticas, para a apreensão do caráter ácido ou alcalino das substâncias. O texto também explora a importância ambiental do tema, ressaltando os malefícios causados pela acidificação das chuvas e dos rios. De modo um pouco superficial, retomam-se aqui as tendências ao ensino CTS e ao ensino por investigação:

Dentro de tal perspectiva crítica, o(a) professor(a) pode discutir com seus alunos os efeitos nocivos da poluição industrial que promove o aparecimento das chuvas ácidas. Os alunos devem ser estimulados a fazer investigações sobre a qualidade das águas dos rios que banham a cidade onde moram e tentar verificar se a acidez delas está acima dos limites aceitáveis. Para investigar isso, eles podem valer-se também de fontes como jornais e revistas, em textos que tratem o assunto (TOMAZELLO; SCHIEL, v. 1, p. 189).

Mais significativa, a nosso ver, é a contribuição do texto para uma proposta de perfil para os conceitos de ácido e base, também constituído pelas zonas realista, empirista e racionalista:

\footnotetext{
Zona realista: apareceriam todas as noções sobre ácidos e bases que envolvem aspectos da realidade imediata dos alunos; ou seja, eles costumam pensar que ácidos são sempre substâncias tóxicas, corrosivas e venenosas e que bases têm características opostas. [...]

Zona empirista: o conceito ácido-base pode ser construído através da caracterização de substâncias pelo emprego de indicadores. Assim, a elaboração de registros das observações empíricas acerca das mudanças de coloração dos indicadores em meios ácido e básico ajuda os alunos a construírem o conceito.

Zona racionalista: as noções sobre ácidos e bases que envolvem partículas e suas representações estariam de acordo com teorias, como a do sueco Arrhenius, no século XIX. Assim, em termos racionalistas, esse conceito seria construído com base na definição de ácido considerado como toda substância que libera $\mathrm{H}^{+}$e base, como toda substância que libera $\mathrm{OH}^{-}$quando dissolvidas em água (ibidem, p. 189-190).
}

Novamente, a Prof. Inês defende que não se avance em direção à zona racionalista no ensino fundamental, dirigindo-se o ensino para a consolidação da zona empirista.

Infelizmente o texto d'O livro da Experimentoteca não se arrisca a propor perfis para outros conceitos abordados pelos cinco outros temas dos kits para o ensino elementar de Química. Assim, uma revisão dos diversos perfis conceituais já propostos na literatura (por exemplo, o perfil para o conceito de molécula, proposto pelo próprio Mortimer (1997)), alinhando-os conforme a abordagem dos temas do material do CDCC, bem como a elaboração de perfis para os conceitos que eventualmente não tenham sido estudados conforme esta perspectiva, surgem como uma necessidade a ser encarada por futuros projetos que tomem a Experimentoteca como objeto. 
No entanto, gostaríamos de apresentar nossas ressalvas, senão à teoria em si do Prof. Mortimer, pelo menos ao modo como seu livro se refere a determinados assuntos.

Vejamos, primeiramente, o seguinte comentário de El-Hani e Bizzo (2002, p.19):

\begin{abstract}
No modelo de mudança de perfis conceituais, a evolução conceitual não é entendida como uma substituição das concepções prévias do aprendiz por idéias científicas, mas como um enriquecimento do espectro de idéias de que ele dispõe para a compreensão de um dado assunto. Na evolução de um perfil conceitual, o domínio de aplicabilidade de cada concepção pode ser delimitado. Nesses termos, pode-se dizer que o Ensino de Ciências deve, sobretudo, mostrar aos alunos como um conjunto de problemas é resolvido da perspectiva científica, ampliando o espectro de possibilidades disponíveis para eles. Agora, a questão de se o aluno acreditará ou não nas concepções científicas, em vez de somente compreendê-las, pode ser apropriadamente entendida como um problema de foro íntimo do aluno, a ser examinado por ele no contexto de sua visão de mundo, à luz das idéias que têm força e alcance para ele. [...] O modelo de mudança de perfis conceituais admite a possibilidade de que diferentes formas de pensar, mesmo sendo contraditórias convivam de modo estável na ecologia conceitual de uma única pessoa. Estes aspectos do modelo de Mortimer sugerem a possibilidade de relacioná-lo com proveito com o construtivismo contextual de Cobern.
\end{abstract}

Para os autores acima, a noção de perfil conceitual permite reconciliar dois aspectos conflitantes do construtivismo: a necessidade de se ensinar um corpo consensual de conhecimentos, e a natureza pessoal do conhecimento de cada indivíduo. Vendo-se desta maneira, "Cada aluno continuará, ao longo de todos os episódios de ensino, na posse de seu próprio perfil de concepções, mas este perfil não será mais o mesmo após ele ter aprendido um dado corpo de conhecimentos científicos" (ibidem, loc. cit.).

Já no livro Linguagem e formação de conceitos, parece haver um comprometimento, por parte do autor, em afastar sua teoria do construtivismo, em qualquer de suas vertentes. Mortimer realiza isto por duas vias. Pela via negativa, ele demonstra a incapacidade da teoria de Piaget sobre a equilibração em explicar os acontecimentos em sala de aula. Sua pesquisa mostra, por exemplo, que a proposta de situações "perturbadoras" (no jargão piagetiano) aos estudantes não fora capaz de alterar suas concepções, sendo, em vez disso, neutralizada, "absorvida e compensada nos modelos rivais, que tendem a se estabilizar" (MORTIMER, 2000, p. 291). Pela via positiva, o pesquisador demonstrou que, conforme o ensino progride, as falas docentes vão adquirindo cada vez mais o caráter de discurso de autoridade, como que se impondo como "a" voz científica, num processo de coerção social; mas, mais do que isso, Mortimer demonstra a imprescindibilidade da aula expositiva e seu caráter benéfico para a aprendizagem: 
[As exposições orais] nos parecem uma parte importante do processo de construção do conhecimento em sala de aula, principalmente se considerarmos o ensino como um processo social em que se busca desenvolver um conhecimento intersubjetivo que seja o mais próximo possível do conhecimento aceito pela comunidade científica. O professor tem o discurso científico e usa-o para responder as perguntas dos estudantes. Evidentemente que a construção do conhecimento em sala de aula pressupõe que o professor dê aos estudantes a oportunidade de falarem por si mesmos, dando-lhes o suporte necessário nesta tentativa de construírem seu próprio discurso (ibidem, p. 315-316).

Desta maneira, não há como se sustentar uma posição relativista, como reflete Mortimer após narrar uma das sequências de ensino desenvolvidas em sua pesquisa, em que o docente precisou direcionar mais firmemente os trabalhos em sala de aula:

Apesar de no momento do processo de ensino termos tido muitas dúvidas sobre a validade de se precipitar essa decisão por um dos modelos, hoje ela nos parece uma decisão inevitável, pois impediu que o processo de ensino se degenere num construtivismo relativista, no qual qualquer idéia é válida desde que faça sentido para o aluno e se relacione com a experiência. Se temos a preocupação de que nossos alunos aprendam uma idéia científica, essa idéia e não outras alternativas devem ser reforçadas no processo de ensino. Esperar que essa idéia brote espontaneamente da discussão parece ser ilusório (ibidem, p. 294).

Apesar deste posicionamento, com que concordamos, e da ênfase que Mortimer atribui à chamada "tomada de consciência do perfil conceitual" (processo que leva o sujeito a identificar, crítica e corretamente, os contextos de aplicação de cada zona de seu próprio perfil), há alguns de seus pressupostos que não podemos aceitar, até por sua evidente contradição com passagens como as transcritas acima. Por exemplo, logo no início de seu livro, o pesquisador brasileiro supõe que uma pessoa com formação científica até poderia "rir da ingenuidade do pensamento infantil", capaz de inventar as entidades opostas "frio" e "calor"; e

No entanto, no seu cotidiano, essa pessoa continuará a usar esses conceitos de uma forma muito natural. Mesmo porque soaria pedante alguém afirmar que "vestiu uma blusa de lã porque ela é um bom isolante térmico, impedindo que o corpo ceda calor ao ambiente". Ora, nós vestimos lã porque ela é quente e nós estamos com frio. Não há aí nenhum vestígio de concepções ingênuas, mas o uso da palavra calor num sentido de senso comum que a nossa cultura consagrou. Essa maneira de ver o mundo está largamente incorporada como uma característica da cultura. Uma pessoa poderia adquirir a capacidade de distinguir essa maneira cotidiana de ver o mundo de maneiras mais sofisticadas. Suprimir essas "concepções alternativas", no entanto, significaria suprimir o pensamento de senso comum e seu modo de expressão, a linguagem cotidiana. Uma expectativa irreal e inútil. A linguagem cotidiana é o modo mais abrangente de se compartilhar significados e permite a comunicação entre os vários grupos especializados dentro de uma mesma língua. Suprimi-la seria instaurar uma babel, impedindo que diferentes grupos pudessem compartilhar de significados numa mesma cultura (ibidem, p. 60-61). 
Ora, um alegado pedantismo, atribuído à pessoa que se referiria a fatos cotidianos utilizandose de uma linguagem mais científica, não pode ser utilizado como argumento para se defender a perpetuação do senso comum. Até porque, no desenvolvimento histórico da civilização, o próprio senso comum tende a se desenvolver, e o que era explicado magicamente ontem, hoje o é por vias mais próximas do conhecimento científico ${ }^{89}$. Amanhã, quiçá este conhecimento científico - o senso comum de seu tempo - possa ser superado por uma visão ainda mais racional e mais próxima da verdade objetiva. Acreditar que a superação do senso comum e de seu modo expressão é um objetivo "irreal e inútil” é cultuar a estagnação cultural da humanidade. É inadmissível que nós, educadores, vangloriemos tanto assim a "linguagem cotidiana", se o processo da educação busca justamente o despertar de carecimentos nãocotidianos, que promovam o nível cultural dos indivíduos em direção a um usufruto mais consciente e criterioso das artes, da filosofia, da ciência e da própria linguagem.

Também nos causa estranheza o fato de, apesar de propor um modelo superador da mudança conceitual - comprometida até as raízes com o construtivismo -, Mortimer continuar se valendo de jargões e termos típicos dos educadores construtivistas. É lógico que não podemos reprovar ou censurar a forma com que outro pesquisador prefere expressar suas posições. A bem da verdade, nossa advertência se dirige menos ao texto do renomado educador químico que a seus leitores: é preciso que eles assimilem criticamente as passagens em que Mortimer fala sobre os professores como "condutores das discussões" ou "gerenciadores dos discursos", por exemplo. Apesar de falar por estas expressões que, de certa forma, obscurecem o papel do professor enquanto instrutor (membro da sociedade autorizado - portador de autoridade - a transmitir a cultura elaborada), e ajudam a enevoar a natureza e a especificidade da educação escolar, o trabalho de Mortimer revela a imprescindibilidade do docente e de seu papel de representante da voz científica na sala de aula. Em nenhum momento a obra Lingiuagem e formação de conceitos no ensino de ciências deslegitima ou desmerece a educação escolar; pelo contrário, reconhece seu papel insubstituível - ao menos nas nossas atuais condições histórico-econômicas - durante o processo de formação dos indivíduos, e em suas jornadas rumo à apropriação de formas mais racionais de perceber e lidar com os fenômenos do mundo a sua volta.

\footnotetext{
${ }^{89}$ O próprio Mortimer reconhecerá isto numa passagem mais ao final de seu livro: "A ciência poderia ser vista [...] como um aperfeiçoamento do senso comum que admite a construção de teorias contra-intuitivas. À medida que essas contra-intuições são aceitas pela comunidade científica como verdades, elas tendem a se incorporar à cultura, primeiro a científica e depois a mais geral, tendendo a perder, paulatinamente, seu caráter contraintuitivo" (2000, p. 351).
} 
Há movimentos recentes, quanto ao desenvolvimento da teoria dos perfis conceituais, que devem garantir a continuidade dos debates em torno da produção de Mortimer. No último Encontro Nacional de Pesquisa em Educação em Ciências, realizado em Águas de Lindóia (SP) em 2013, o Prof. Charbel Niño El-Hani fez uma notável apresentação sobre um trabalho, elaborado em conjunto com Mortimer e o Prof. Waldomiro José da Silva Filho, que buscou "mostrar que a teoria dos perfis conceituais não é relativista, oferecendo uma base filosófica alternativa para ela", sendo esta base "o pragmatismo objetivo, como formulado por Peirce, Dewey e outros pensadores, e não o pragmatismo jamesiano, mais subjetivista, que influenciou o argumento de Wertsch [um dos autores que inspirou a teoria]" (EL-HANI; MORTIMER; SILVA-FILHO, 2013, não paginado). O objetivo dos pesquisadores é, assim,

\begin{abstract}
formular uma via média entre racionalismo e relativismo como base epistemológica para a teoria dos perfis conceituais, tomando o pragmatismo como fundamento. Nesta posição, nós nos distanciamos do relativismo ao demandar que escolhas entre modos de pensar, falar e agir sejam criticamente apreciadas e discutidas, considerando suas consequências para problemas concretamente colocados. Na sala de aula, este compromisso aparece num dos objetivos de aprendizagem da teoria dos perfis, a tomada de consciência sobre os vários modos de pensar disponíveis numa circunstância sociocultural e os domínios em que sua aplicação mostra valor pragmático. O pragmatismo objetivo não tem qualquer problema com esforços de comparação entre diferentes modos de pensar, ideias, formas de conhecer etc., desde que essas comparações não sejam feitas em abstrato, mas sempre numa clara conexão com situações concretas nas quais devemos tomar decisões e agir (ibidem, não paginado, grifos dos autores).
\end{abstract}

Afastar a teoria dos perfis conceituais de qualquer forma de relativismo parece-nos um empreendimento relevante e promissor. No entanto, é preciso verificar em que medida a associação do modelo proposto por Mortimer com uma filosofia pragmática pode contribuir para uma maior compreensão dos problemas da educação científica. Não temos conhecimento suficiente sobre este pragmatismo objetivo, a que os pesquisadores se referem, e baseado principalmente em Peirce, para tecermos qualquer tipo de crítica a esta noção. No entanto, se para esta doutrina "a eficácia na aplicação prática propicia um padrão para a determinação da verdade dos enunciados", sendo que o "o conhecimento deve ser julgado, ao menos em parte, em termos de sua utilidade" (ibidem, não paginado), como afirmam El-Hani, Mortimer e Silva-Filho em relação ao pragmatismo em geral, então os pesquisadores precisarão encarar as abundantes críticas a tal concepção, a partir das filosofias mais diversas, e datadas de já bastante tempo.

Por exemplo, do ponto de vista do materialismo histórico e dialético, a ênfase no valor utilitário do conhecimento é assim criticada por Sánchez Vázquez (2011, p. 244): 
É evidente que quando o marxismo fala da utilidade ou da função prático-social da ciência, coloca-se em um plano muito diferente, pois não se trata da utilidade num sentido estritamente egoísta, mas, sim, da utilidade social. O conhecimento verdadeiro é útil na medida em que, com base nele, o homem pode transformar a realidade. $\mathrm{O}$ verdadeiro implica uma reprodução espiritual da realidade, reprodução que não é um reflexo inerte, mas, sim, um processo ativo que Marx definiu como ascensão do abstrato ao concreto $\mathrm{em}$ e pelo pensamento, e em estreita vinculação com a prática social. O conhecimento é útil na medida em que é verdadeiro, e não é verdadeiro porque é útil, como sustenta o pragmatismo. Enquanto para o marxismo a utilidade é consequência da verdade, e não seu fundamento ou essência, para o pragmatismo a verdade fica subordinada à utilidade, entendida como eficácia ou êxito da ação do homem, concebida essa última, por sua vez, como ação subjetiva, individual, e não atividade material, objetiva, transformadora (p. 244, grifos do autor).

Acrescentamos também, aos desafios com que a noção de perfil poderá se deparar num futuro próximo, a necessidade de uma reconsideração para com os escritos de Vigotski, com base numa leitura marxista de sua obra (como temos defendido, a exemplo de Newton Duarte e Zoia Prestes); e a reviravolta causada pelo livro Bakhtin desmascarado (BRONCKART; BOTA, 2012), que volta a atribuir a seus autores originais - Voloshinov e Medvedev - os textos "disputados", que no Brasil foram publicados sob o nome de M. M. Bakhtin.

É verdade que a pesquisa de Mortimer relatada em Linguagem e formação de conceitos no ensino de ciências já levava em consideração os conceitos de Voloshinov, não se envolvendo com a polêmica disputa em torno do nome de Bakhtin, nem com suas obras controversas (e contraditórias, se examinadas ao lado dos textos disputados), como $O$ autor $e$ o personagem na atividade estética. Assim, o impacto de Bakhtin desmascarado sobre a teoria dos perfis conceituais deve ser mínimo.

No entanto, a noção de perfil conceitual se apresenta imbricada com muitos dos conceitos e resultados a que chegaram Vigotski e seus colaboradores. A apropriação da Psicologia Histórico-Cultural, por parte de Mortimer, é bastante razoável e responsável inclusive, a explicação de zona de desenvolvimento iminente, que o pesquisador ainda chama de "zona de desenvolvimento proximal” (MORTIMER, 2000, p. 155-160), é interessantíssima e coerente com os trabalhos originais de Vigotski, acrescentando-lhe também elementos originais de grande importância -, mas nada se fala sobre os interesses do psicólogo russo em promover um "novo homem", o homem da sociedade socialista. Com a maior disseminação dos trabalhos de Duarte (2006) e Prestes (2012), talvez haja uma maior pressão, por parte dos educadores progressistas, para que as menções a nomes como Vigotski e Leontiev, daqui por diante, se façam acompanhadas da lembrança do contexto em que suas produções 
floresceram, e dos interesses que animaram sua militância em prol de uma psicologia dialética.

Estas ressalvas, de modo algum, anulam nossa admiração para com a teoria de Eduardo F. Mortimer, e hoje defendida também pelo Prof. Charbel El-Hani. Igualmente, o fato de o texto d'O livro da Experimentoteca, escrito pela Prof. Inês, propor um respaldo nesta teoria para o trabalho com os kits desenvolvidos pelo CDCC, só pode ser auspicioso. Trata-se de uma teoria poderosa e ricamente embasada, tanto em termos filosóficos quanto práticos, e que pode ser facilmente incorporada a uma visão transformadora e emancipadora sobre o processo educacional.

E por falar em vida, cultura e sobretudo em escola, aproveito para uma ressalva: notadamente após as reformas de 1971 e a conseqüente profissionalização do ensino, a nossa vida escolar parece padecer de um mal ao mesmo tempo drástico e curioso. Vale dizer, se a escola é o lugar onde se deve cultivar a teoria (justamente com a prática) no ensino, na pesquisa... ela curiosamente parece refletir hoje uma "neurose" ou fobia teórica.

Explico o porquê. Após o movimento da Escola Nova [...] e, principalmente, após o golpe de 64 que esvaziou por completo não só o conteúdo como também o lado crítico das disciplinas, nossas práticas de ensino foram reduzidas a certo "malabarismo pedagógico". Além do mais, percebe-se de modo crescente em nossa geração jovem certa "política do prazer" interferindo negativamente no processo educacional. Interessante notar aí que tudo o que exige um pouco mais de sacrifício é simplesmente encarado como antididático, antiprodutivo, cansativo [...].

Aí passamos a endossar um processo didático-pedagógico em que professores exercem a função de "camelôs do ensino" ou então meros repetidores de apostilas com respostas prontas, bem buriladas [...].

Por outro lado a clientela, isto é, os alunos, parecem cada vez mais dispostos ao circo, ao que agrada e não ao pensamento, à crítica. E para estes, o conceito de professor eficiente passa a ser o que dá aulas leves e não cansa, vale dizer, o que não exige labor, pesquisa, articulação teórica. O trabalho teórico da leitura, da pesquisa, da discussão e crítica passa a ser substituído pela "camelagem pedagógica” desse professor-padrão das reformas e endossado pelo comportamento consumista de sua clientela (PEREIRA, 1985, p. 9-11, grifos nossos).

Este capítulo buscou ressaltar a importância da teorização enquanto momento de "pensar a prática". Não se trata de um teorizar solitário, de uma introspecção autista, de um isolamento monástico em busca da apreensão da essência da prática, como se costuma conceber. Teorizar é envolver-se com construções coletivas que nos fornecem os apoios para a caminhada, nem sempre tranquila, no terreno da prática - um terreno às vezes imprevisível e evasivo, mas, por isto mesmo, sempre desafiador e instigante.

O trabalho que engendramos, nas cinco últimas seções, buscou analisar criticamente as teorias "incorporadas" à proposta da Experimentoteca, enfatizando-se seus pontos de contato 
com a nossa própria visão teórica sobre a atividade experimental no ensino de ciências. Buscou-se, assim, iluminar perspectivas para a continuidade deste estudo, e também para o necessário trabalho de se permanecer repensando a Experimentoteca, aprimorando-a e agregando os novos resultados da pesquisa em Educação em Ciências no seu desenvolvimento.

O próximo capítulo - o último desta tese - trata essencialmente do mesmo assunto: o teorizar. Dirige-se, entretanto, a um âmbito ainda pouco explorado por nós, até o momento: o âmbito da formação docente.

O tom polêmico, que abandonamos ou atenuamos em algumas das seções passadas, novamente será a tônica destas linhas, e munidos dele, encerraremos nosso percurso. 


\section{CAPÍTULO 7}

\section{A EXPERIMENTOTECA E A FORMAÇÃO DE PROFESSORES DE QUÍMICA}

Chegamos, enfim, a um dos assuntos anunciados no título desta tese, mas que passou ao largo de todos os capítulos anteriores. Sem dúvidas, os estudos sobre formação de professores vêm crescendo em termos quantitativos, sobretudo na área de Educação em Ciências, e este trabalho não estaria completo sem que se pudesse dedicar ao menos um capítulo à questão.

De qualquer forma, entendemos também que as mencionadas "contribuições da Experimentoteca para a formação docente", conforme o título de nosso trabalho, já se consubstanciaram em grande parte no conjunto dos capítulos anteriores. Quer dizer, todos os estudos que realizamos até a chegada do capítulo 7 - a comparação entre diferentes tipologias educacionais a partir das categorias "pedagogia da essência" e "pedagogia da existência" (capítulo 1), a análise da Psicologia Histórico-Cultural enquanto referencial teórico para a Educação em Química (capítulo 2), a elaboração de uma teoria sobre a experimentação no ensino de ciências a partir da unidade psicopedagógica entre a Pedagogia Histórico-Crítica e a Psicologia Histórico-Cultural (capítulo 3), o levantamento das condições materiais dos laboratórios científicos escolares da rede pública de ensino (capítulo 4), a análise do papel dos museus de ciência e de seus projetos sob o olhar da Pedagogia Histórico-Crítica (capítulo 5) e a crítica de tendências atuais da Educação em Química e sua apropriação por um projeto emanado de um centro de ciências (capítulo 6) - são, eles mesmos, contribuições em 
potencial para a formação docente. Eles tratam de questões relevantes à formação de professores de Química, e que podem se constituir em material de apoio a diversas disciplinas típicas dos cursos de licenciatura, como Fundamentos da Educação ou Introdução aos Estudos da Educação (capítulo 1), Psicologia da Educação (capítulos 2 e 3), Metodologia do Ensino de Química (capítulos 4 e 6) e Estágio Supervisionado em Ensino de Química (capítulos 4 e 5). Oxalá possam esses capítulos auxiliar os licenciandos a compreender a situação da educação em Química no Brasil - e a situação da educação brasileira como um todo -, a estruturar suas atividades de pesquisa e de estágio curricular, e a refletir sobre este seu percurso formativo.

Este capítulo final divide-se em três seções.

A primeira retoma nossa crítica à fobia teórica no campo educacional, em continuidade com o caráter geral do capítulo 6. Aqui, no entanto, esta crítica será contextualizada no âmbito específico dos estudos sobre formação de professores.

Considerando que a desvalorização da teoria é uma característica em comum entre as ideias defendidas por diversos autores destes estudos, com ampla aceitação entre os círculos profissionais e intelectuais brasileiros, a segunda seção apresentará alternativas a esta concepção. Entendendo-se que ela se insere junto às "pedagogias do aprender a aprender", conforme Newton Duarte, recorreremos à Pedagogia Histórico-Crítica e à Psicologia Histórico-Cultural para alcançar uma síntese que fundamente no materialismo histórico e dialético um entendimento sobre a formação docente.

Com base nestes encadeamentos, a seção final volta a examinar a Experimentoteca, tratando de entender por quais vias esta iniciativa do CDCC contribui (ou pode contribuir) para a formação inicial e continuada de professores de ciências e de Química.

\subsection{A FOBIA TEÓRICA NO CAMPO DA FORMAÇÃO DE PROFESSORES}

(Sugerimos, antes de tudo, que o leitor retorne à seção 6.1 do capítulo anterior, pois já estão registradas ali muitas das discussões relevantes ao desenvolvimento deste capítulo).

Em fevereiro de 2008, a revista $V e j a^{90}$ publicou uma entrevista com a então Secretária da Educação do Estado de São Paulo, a cientista social Maria Helena Guimarães de Castro. Perguntada sobre qual seria o caminho para elevar o nível dos professores da rede que

\footnotetext{
${ }^{90}$ VEJA. São Paulo: Abril, n. 2047, 13 fev. 2008.
} 
administrava, a Secretária emitiu uma declaração que, a muitos, soou impactante: a de que faculdades de educação como as da USP e da Unicamp deveriam ser fechadas e recomeçadas "do zero". Segundo a administradora, tais instituições estariam realizando um desserviço à formação dos professores ao receitar cursos voltados para assuntos demasiadamente teóricos e desconectados das reais demandas das escolas públicas. Os professores em formação, proclamou Castro, estariam perdendo-se em discussões estéreis sobre grandes questões do universo e do pensamento humano, em detrimento de absorverem conhecimentos básicos de didática.

Calorosos debates se estabeleceram nos meses e anos seguintes. Enquanto que muitas vozes se insurgiram em defesa da formação pedagógica oferecida pelas universidades públicas do Estado, sucessivas publicações na própria Veja e em outros veículos da grande mídia viriam a insistir nas posições defendidas pela Secretária da Educação.

Assim, no mesmo ano (novembro de 2008) a antropóloga Eunice Durham, anunciada como "uma das maiores especialistas em ensino superior brasileiro", declarava à Veja que as faculdades de educação estariam formando professores incapazes, sobrevalorizando a teoria em detrimento da prática em sala de aula, estando a bibliografia de seus cursos supostamente circunscrita a autores de esquerda. Perguntada se defenderia o fechamento das faculdades de educação, Durham repetiu a fala de Maria Helena Guimarães de Castro.

Em agosto do ano seguinte, o jornal Folha de S. Paulo entrevistou o pesquisador estadunidense Martin Carnoy ${ }^{92}$. Economista de formação e professor da Universidade de Stanford, Carnoy estava no Brasil, à época, para lançar seu livro A vantagem acadêmica de Cuba, obra que apresenta um estudo baseado em observações em sala de aula e na comparação de indicadores macroeconômicos. Apesar deste não ter sido o foco da entrevista, em certo momento Carnoy precisou comentar que os professores brasileiros, de modo geral, não sabem como transmitir o conhecimento a seus alunos. $O$ pesquisador até reconheceu que a leitura de clássicos da educação, como as obras de Paulo Freire (de quem foi amigo pessoal) poderia servir como um exercício intelectual para os docentes em formação. Mas o que eles precisariam, de fato, é "aprender a ensinar", disse o estudioso.

Poucas semanas depois, a $V e j a^{93}$ entrevistou o mesmo pesquisador - e como seria de se esperar, ocultando o motivo de sua passagem pelo Brasil. Já esta entrevista pareceu mais

\footnotetext{
${ }^{91}$ VEJA. São Paulo: Abril, n. 2088, 26 nov. 2008.

${ }^{92}$ FRIAS, M. C.; BENCINA, R. Professores brasileiros precisam aprender a ensinar. Folha de S. Paulo, São Paulo, 10 ago. 2009. Entrevista da 2a Caderno 1, p. 16.

${ }^{93}$ VEJA. São Paulo: Abril, n. 2132, 30 set. 2009.
} 
direcionada a aspectos polêmicos em comparação com aquela fornecida à Folha, ressoando o discurso de que os professores precisariam de "menos teoria e mais prática" em sua formação inicial, ou mesmo defendendo o fim do ensino superior público.

A mesma revista entrevistou, em outubro de $2009^{94}$, o então novo Secretário de Educação do Estado de São Paulo, o também economista Paulo Renato Souza, ex-ministro da Educação do governo de Fernando Henrique Cardoso. As falas do Secretário foram quase idênticas às opiniões dos entrevistados anteriores: faltava aos professores brasileiros um melhor aprendizado de "didática", já que sua formação universitária estaria centrada em debates improdutivos sobre o sistema capitalista, propagando o ideário de um "marxismo de segunda ou terceira categoria”. Também como afirmaram os diversos entrevistados anteriores, Souza manifestou-se favoravelmente à cobrança de mensalidades nas universidades públicas, acusou os sindicados de professores de corporativismo e descompromisso para com a educação, atribuiu exclusivamente aos docentes a responsabilidade pelos péssimos indicadores educacionais brasileiros e defendeu a implantação de um sistema meritocrático de avaliação docente, seguindo o modelo de culturas "mais individualistas e competitivas".

Nos anos seguintes, a Folha de S. Paulo continuou entrevistando autores estrangeiros de livros e de estudos sobre educação, como Doug Lemov (Teach like a champion ou, no Brasil, Aula nota 10) em agosto de $2010^{95}$, e o Prêmio Nobel de Economia James Heckman, em outubro de $2011^{96}$. Se nestas entrevistas o tema da oposição entre uma formação docente mais "teórica" ou mais "prática" não alcançou o nível polêmico das publicações anteriores, em agosto de 2013 o jornal produziria um caderno especial inteiramente dedicado a aspectos da formação de professores no Brasil ${ }^{97}$, voltando a advogar que os cursos superiores proporcionariam um contato muito grande com teóricos da educação, mas formando docentes “despreparados para enfrentar salas de aula". É sintomático o título da análise realizada pelo colunista Hélio Schwartsman, com base nos diversos dados expostos neste caderno: "Curso de pedagogia segue preso a referências [sic] teóricas que não evoluíram, apesar de a escola ter mudado" (grifos do original) ${ }^{98}$.

\footnotetext{
${ }^{94}$ VEJA. São Paulo: Abril, n. 2136, 28 out. 2009.

${ }^{95}$ GOIS, A. Só conhecimento teórico não forma bom professor. Folha de S. Paulo, São Paulo, 16 ago. 2010. Entrevista da $2^{\text {a }}$, Caderno 1, p. 17.

${ }^{96}$ GOIS, A. Ênfase em testes empobrece a qualidade da educação, diz Nobel. Folha de S. Paulo, São Paulo, 17 out. 2011. Entrevista da 2a, Caderno 1, p. 12.

${ }^{97}$ QUEM EDUCA OS EDUCADORES?. Folha de S. Paulo, São Paulo, 4 ago. 2013. Caderno especial, 8 p.

${ }^{98}$ A ombudsman do jornal, Suzana Singer, faria o seguinte comentário sobre o caderno, uma semana após sua publicação: "O título principal do caderno especial que circulou no domingo passado - 'Formação de professor fica longe da realidade da escola'- poderia ser adaptado para uma autocrítica: 'Suplemento fica longe da realidade da escola'. Com a proposta de discutir 'quem educa os educadores', o caderno era um amontoado de
} 
Como foi possível observar, a repulsa a uma formação teórica mais consistente, do corpo docente brasileiro, permanece ampla e fortemente propalada pela mídia. No lugar desta formação "filosófica", propõe-se um modelo cuja ênfase recairia nos aspectos didáticos de cada disciplina, e na presença mais acentuada de estágios supervisionados nas escolas. Além de manifestar esta fobia teórica - lembremos, já detectada pelo texto de Pereira (1985) há mais de três décadas -, os proponentes desta visão acabam defendendo também o aligeiramento da formação inicial docente, o recurso à educação à distância e, de modo nem sempre sutil, a extinção da formação universitária como a conhecemos.

Se a defesa de tais posicionamentos estivesse restrita ao ambiente midiático, não teríamos muito com o que nos preocupar. Ainda que os veículos com maior penetração entre as camadas menos esclarecidas difundam uma visão ideologicamente conservadora, a progressiva massificação de mídias alternativas vem possibilitando que os questionamentos a tais pontos de vista disponham também de algum espaço. Assim, a hegemonia desta posição oposta àquilo que defendemos como um ideal para a formação docente - parece cada vez mais ameaçada, pelo menos no que tange à cobertura jornalística do assunto.

Perturbador mesmo é constatar que este senso comum pedagógico é a tendência dominante também no ambiente que, em tese, seria justamente o mais avesso a qualquer tipo de senso comum: a academia. A partir dos anos 1980, difundiu-se no Brasil um conjunto de ideias que buscou fornecer sustentação científica a um "novo" modelo de formação docente, em que o recurso às teorias educacionais seria mínimo, em prol de um aprendizado mais situado na prática. Este modelo, a que se costuma referir como baseado numa "epistemologia da prática", está para a formação docente assim como construtivismo está para a educação escolar: encontra-se amplamente difundido na academia, apresenta-se como portador de um ideal progressista (e crítico a um modelo anterior, que considera "tradicional") e vem orientando políticas e a elaboração de documentos oficiais.

A consolidação da epistemologia da prática enquanto paradigma para a formação docente remonta à propagação das ideias do filósofo estadunidense Donald Schön (19301997), o que ocorreu no Brasil na transição da década de 1980 para a de 1990. Suas principais obras são relativamente pouco conhecidas por aqui - seu livro mais importante sobre o assunto, The reflective practitioner: how professionals think in action (1983), sequer recebeu edição brasileira -, mas seus conceitos foram popularizados graças à edição da coletânea $O s$

estatísticas e conversas de especialistas. Pouquíssimos professores entrevistados e apenas um curso visitado. A Folha precisa se convencer de que não dá para discutir educação sem sujar a roupa de giz" (SINGER, S. Dois tipos de coragem. Folha de S. Paulo, São Paulo, 11 ago. 2013. Ombudsman, Caderno 1, p. 8). 
professores e sua formação (1992), organizada pelo português António Nóvoa. Schön parte da constatação de que a formação profissional, desde as décadas finais do século XX, vive uma crise, que associa à vigência de uma "racionalidade técnica" como pressuposto orientador dos currículos dos cursos superiores. Tratar-se-ia de uma postura essencialmente positivista, justificando uma organização curricular que parte dos fundamentos teóricos das disciplinas para só depois permitir sua vivência, pelos graduandos, enquanto ciências aplicadas. Segundo Schön, tais currículos não permitiriam o desenvolvimento de um "talento artístico" necessário para que os profissionais, no futuro, possam resolver dilemas que não seriam previstos em sua formação teórica. Influenciado por Dewey, o filósofo irá propor sua epistemologia da prática a partir de três conceitos, associados a um "aprender fazendo": $o$ conhecimento-na-ação, a reflexão-na-ação e a reflexão-sobre-a-reflexão-na-ação. Daí a proposta de Schön também ser conhecida como "modelo do professor reflexivo".

Eis algumas de suas palavras, conforme a obra Educando o profissional reflexivo: um novo design para o ensino e a aprendizagem:

\begin{abstract}
Os educadores [professores universitários], observei, estão cada vez mais cientes das zonas de indeterminação na prática que demandam um talento artístico, mas estão limitadas por compromissos institucionais com um currículo profissional normativo e uma separação entre pesquisa e prática que não deixa qualquer espaço para esse talento. A partir daí, argumentamos em favor da necessidade de levar a sério o talento artístico. Propus uma epistemologia da prática que lhe abra espaço, baseada no conhecimento-na-ação e na reflexão-na-ação, e examinei algumas das tradições divergentes na educação, a maioria das artes, das quais podemos aprender sobre educação para o talento artístico. Desses estudos vem a idéia de um ensino prático reflexivo. Suas principais características são o aprender fazendo, a instrução ao invés de ensino e um diálogo de reflexão-na-ação recíproca entre instrutor e estudante. Ilustrei essa idéia primeiramente no design arquitetônico, que tomei como protótipo de um ensino prático reflexivo, e depois em outros campos cada vez mais distantes do ateliê de arquitetura (SCHÖN, 2000, p. 121).
\end{abstract}

Além de Nóvoa, diversos outros educadores se apropriaram das ideias de Schön, dedicando-se a desenvolvê-las e a contextualizá-las no campo da formação de professores, tomando-as de modo mais ou menos crítico. Podemos citar, por exemplo, Maurice Tardif, Philippe Perrenoud, Thomas S. Popkewitz, Angel Pérez Gómez e Isabel Alarcão.

Um dos mais importantes documentos oficiais brasileiros sobre formação de professores, atualmente, é ainda o caderno Referenciais para formação de professores, publicado em 1999. Dissemos que a epistemologia da prática está para a formação docente como o construtivismo está para a educação escolar. Pois bem, de modo análogo, os Referenciais estão para os currículos dos cursos de formação inicial de professores assim como os PCN estão para os ensinos fundamental e médio. E vale a pena analisarmos alguns 
fragmentos desta publicação, para entendermos como as ideias de Schön, Perrenoud e Nóvoa, entre outros, viriam a desembocar numa visão alegadamente crítica do processo de formação de professores, mas comprometida, em verdade, com o ideário contemporâneo pós-moderno e neoliberal.

O documento parte do pressuposto de que é necessário organizar um movimento pela "profissionalização do professor", pautado na "concepção de competência profissional”. Este profissionalismo exigiria

compreensão das questões envolvidas no trabalho, competência para identificá-las e resolvê-las, autonomia para tomar decisões, responsabilidade pelas opções feitas. Requer também que o professor saiba avaliar criticamente a própria atuação e o contexto em que atua e interagir cooperativamente com a comunidade profissional a que pertence. Além disso, ele precisa ter competência para elaborar coletivamente o projeto educativo e curricular para a escola, identificar diferentes opções e adotar as que considere melhor do ponto de vista pedagógico. Essa perspectiva traz para a formação a concepção de competência profissional, segundo a qual a referência principal, o ponto de partida e de chegada da formação é a atuação profissional do professor (BRASIL, 1999, p. 61).

Competência, por outro lado, referir-se-ia

à capacidade de mobilizar múltiplos recursos, entre os quais os conhecimentos teóricos e experienciais da vida profissional e pessoal, para responder às diversas demandas das situações de trabalho. Apoia-se, portanto, no domínio de saberes, mas não apenas dos saberes teóricos, e refere-se à atuação em situações complexas (ibidem, loc. cit.).

Assim, os Referenciais propõem um novo modelo para a formação de professores enfatizando o caso dos docentes para a educação infantil e para as séries iniciais do ensino fundamental - que estaria ciente de diversos defeitos ou falhas do modelo tradicional, entre eles:

- $\quad$ ignoram-se as condições reais e os pontos de partida dos professores - seus interesses, motivações, necessidades, conhecimentos prévios, experiências e opiniões - quando esses deveriam servir como ingredientes do planejamento das ações de formação;

- as práticas inspiram-se numa perspectiva homogeneizadora: são destinadas a "professores em geral", e não ajustáveis a diferentes tipos de professores e suas respectivas necessidades de formação;

- a concepção é autoritária, cabendo ao professor um papel passivo de receptor de informações e executor de propostas, e não de co-participante do planejamento e discussão do próprio processo de formação;

- o enfoque é instrumental: as práticas de formação destinam-se a preparar o professor para ser um aplicador e um técnico, e não um profissional com domínio de sua prática e autonomia para a tomada de decisões; [...] 
- a educação é tratada como uma atividade formal, rígida, desconsiderando-se a importância que têm a informalidade, o vínculo afetivo, a comunicação, o jogo, o riso, o entretenimento;

- o foco é a perspectiva do ensino, e não da aprendizagem;

- a concepção de base é acadêmica e teórica, centrada no texto escrito, desprezando-se a prática como importante fonte de conteúdos da formação;

- a transmissão de informação é o centro do processo de ensino e aprendizagem, como se ensino pudesse ser confundido com transmissão e aprendizagem com assimilação passiva de informações; [...] (ibidem, p. 42-43).

O leitor talvez já tenha percebido nossa intenção ao transcrever estes 8 itens (entre 15 listados no documento): demonstrar como o modelo do professor reflexivo ou da epistemologia da prática, defendido pelos Referenciais, se vale de uma estratégia idêntica à empregada pelo construtivismo para se erigir enquanto paradigma para a educação, com a diferença que estamos tratando, agora, do processo de formação de professores. Veja-se como o documento critica a concepção tradicional, taxando-a de cega para "concepções prévias", "interesses", "necessidades", “experiências" e "opiniões” dos professores em formação; chama o modelo tradicional de "autoritário", porque considera os sujeitos da aprendizagem como "assimiladores passivos de informações"; defende a presença do "riso", do "jogo", do "entretenimento", do "vínculo afetivo", contra um processo de formação excessivamente "formal" e "rígido"; a propósito, defende a importância da "informalidade" e da "prática", em contraposição a uma formação "centrada no texto", "acadêmica", "teórica"; e defende que se coloque o professor em formação no "centro" do processo, valorizando sua "autonomia" e seu papel de "co-participante" do processo.

Ora, todas as críticas que direcionamos ao construtivismo, no capítulo 2 desta tese, aplicam-se igualmente ao modelo da epistemologia da prática para a formação docente, conforme assumido pelos Referenciais. Assim, o modelo do professor reflexivo também assume apressadamente que todo processo de ensino deve fazer do aprendiz um personagem central, pois a psicologia do desenvolvimento teria demonstrado inequivocamente que as aprendizagens que o sujeito realiza de modo autônomo e independente são sempre de melhor qualidade. Da mesma forma que o construtivismo, este modelo defende um relativismo cultural - daí as menções à situação contextual dos aprendizes, a sua história de vida e a seus interesses imediatos - sem se dar conta das contradições lógicas inerentes a tal posicionamento. Finalmente, este modelo foi exposto nos Referenciais como um conhecimento de vanguarda; no entanto, assim como o construtivismo reedita teses antigas do escolanovismo, a epistemologia da prática apenas incorpora pressupostos do construtivismo e da escola nova ao âmbito da formação profissional. Em realidade, não há novidade alguma: a 
alegada "crise da profissionalização", que tanto preocupou Donald Schön, não passa do reflexo da assimilação dos ideários pós-modernos por certa elite intelectual. A fobia teórica "assepsia teórica", "recuo da teoria", todas expressões de uma suposta crise da racionalidade - é um movimento dos mais previsíveis na história da humanidade, e sua adoção como slogan da pós-modernidade fora antecipada por diversos pensadores marxistas. Por exemplo, Kosík, na Dialética do concreto (1963), já havia dito que

Como as coisas não se mostram ao homem diretamente tal qual são e como o homem não tem a faculdade de ver as coisas diretamente na sua essência, a humanidade faz um détour para conhecer as coisas e a sua estrutura. Justamente porque tal détour é o único caminho acessível ao homem para chegar à verdade, periòdicamente a humanidade tenta poupar-se do trabalho desse desvio e procura observar diretamente a essência das coisas (o misticismo é justamente a impaciência do homem em conhecer a verdade). Com isso corre o perigo de perder-se ou de ficar no meio do caminho, enquanto percorre tal desvio (KOSÍK, 1989, p. 21, grifos do autor).

Para não sermos acusados de estar exagerando quanto às implicações da epistemologia da prática como pressuposto dos Referenciais, vejamos mais alguns fragmentos deste documento, em que é nítido o quanto tal posição retrocede a concepções filosóficas já fartamente criticadas, especialmente no âmbito educacional. Por exemplo, é impossível não se associar os dois fragmentos abaixo a uma apologia do empirismo (doutrina repelida, especialmente, pelos pesquisadores do campo da Educação em Ciências):

O trabalho do professor - e, portanto, sua formação - inclui competências de um profissional intelectual que atua em situações singulares. Para tanto, o domínio teórico do conhecimento profissional é essencial, mas não é suficiente. É preciso saber mobilizá-lo em situações concretas, qualquer que seja sua natureza. A produção de conhecimento pedagógico exige a competência para construir um discurso sobre a prática: de sistematizar e comunicar os saberes construídos para poder compartilhá-los. É isso que possibilitará, inclusive, confrontar os limites do conhecimento na explicação e solução das questões da realidade. Tudo isso se aprende a fazer, fazendo (BRASIL, 1999, p. 62).

O conhecimento profissional do professor deve se construir no curso de formação inicial, ampliando-se, depois, nas ações de formação continuada. O professor se desenvolve à medida que vai estudando, refletindo sobre a prática e construindo conhecimentos experienciais por meio da observação e das situações didáticas reais ou de simulação de que participa. Entretanto, o início dessa construção não se dá no momento em que ele ingressa num curso de formação inicial. A condição de aluno, pela qual todo professor passa durante muitos anos de sua vida antes da formação profissional, faz com que ele aprenda muito sobre a profissão no convívio diário com seus professores e colegas. [...] Além disso, também desempenham um papel importante na formação do professor outras experiências de vida, conhecimento de mundo e formas de se relacionar com os outros, uma vez que a educação é uma relação entre pessoas. Ou seja, inevitavelmente, a história de vida se mistura muito com a atuação profissional (ibidem, p. 85). 
Apesar das concessões ao teorizar, que aparecem aqui e ali nos Referenciais, a essência do documento é uma visão depreciativa das teorias, em consonância com o discurso dos autores referenciados no texto, e com o próprio ceticismo pós-moderno:

\begin{abstract}
é preciso superar a visão aplicacionista das teorias, segundo a qual são ministrados cursos de teorias prescritivas e analíticas, deixando para os estágios o momento de colocar esses conhecimentos em prática, como se a escola antecipasse questões e respondesse a elas antes que os alunos as tivessem formulado. Ao contrário, organizar a formação em função do desenvolvimento de competências e na perspectiva da resolução de problemas exige que os formadores explicitem a contribuição de suas disciplinas a partir das questões da realidade educativa e das que são postas pelos professores (ibidem, p. 111-112).
\end{abstract}

Mazzeu (2011) também analisou os Referenciais, assim como as Diretrizes Curriculares Nacionais para a Formação de Professores da Educação Básica, baseadas no documento de 1999. A autora, recuperando a historicidade destes textos oficiais, demonstra o quanto eles se mostram comprometidos com os interesses de organismos multilaterais internacionais e regionais, como o Banco Mundial. As políticas educacionais do governo Fernando Henrique Cardoso, lembra Mazzeu, inserem-se em um conjunto mais amplo de medidas que visavam, ao atender às recomendações destes organismos, adequar a formação dos trabalhadores brasileiros às demandas da reestruturação produtiva. Assumindo os modelos da acumulação flexível, cujos conceitos-chaves seriam flexibilidade, autonomia e polivalência dos trabalhadores, o Brasil estaria contemplando em seu sistema produtivo as características das economias mais eficientes quanto à reprodução do capitalismo - ou seja, promovendo a máxima acumulação de capital com a mínima socialização dos meios de produção (e, por conseguinte, do conhecimento).

Nesse sentido, os Referenciais e os demais documentos oficiais sobre formação docente, emanados deste contexto,

Pautados pela formação de competências e pela prática reflexiva, promovem a redução do trabalho educativo a um saber-fazer circunstancial, os saberes e os conhecimentos àqueles construídos na e pela prática e a formação de competências no lugar da formação teórica e acadêmica (ibidem, p. 162).

E assim, "o conhecimento como um dado subjetivo e a secundarização do saber científico são fortes componentes dessa perspectiva, com importantes consequências para a formação do professor" (ibidem, p. 163). Sabemos muito bem a quem interessa este menosprezo ao saber científico e teórico, até porque já estudamos, no capítulo passado, a importância das teorias para o avanço do movimento histórico. Se não é qualquer prática que transforma efetivamente 
a realidade, mas sim a práxis, unidade teórico-prática - e lembremos que "Só uma teoria revolucionária cria uma ação revolucionária" -, então

\begin{abstract}
A proposição de uma formação estruturada em torno da reflexão sobre a prática considera apenas a atuação eficiente do professor no contexto particular no qual, circunstancialmente, o trabalho educativo se desenvolve. Nessa epistemologia da prática, parece não haver espaço para um conhecimento efetivo e verdadeiro sobre a realidade, o que compromete as possibilidades de compreensão, por parte do professor, das múltiplas determinações que interferem no desenvolvimento do trabalho educativo, e no próprio sentido dessa atividade para uma formação humana emancipatória (ibidem, p 165, grifo nosso).
\end{abstract}

\title{
7.2 ALTERNATIVAS CRÍTICAS À FORMAÇÃO DOCENTE COMO “APRENDER A
} APRENDER”

Do exposto na seção anterior, fica claro o quanto o modelo do professor reflexivo, ou da epistemologia da prática (aparecendo também, conforme alguns autores, como modelo do "professor pesquisador" ou "professor investigador") se assemelha ao construtivismo, podendo ser considerado também como uma das pedagogias do "aprender a aprender" (DUARTE, 2006, 2010a; FACCI, 2004, 2011; MAZZEU, 2011). Isto não apenas é demonstrado pelo trabalho de Facci (2004), que analisa as convergências do construtivismo com três diferentes perspectivas da epistemologia da prática - a perspectiva "narrativa" de Schön, centrada no subjetivismo e na história de vida dos professores; a perspectiva "crítica" de Kenneth Zeichner, que acrescentou uma dimensão social, coletivista e política ao processo reflexivo proposto por Schön; e a perspectiva "cognitivista" de Lee Shulman, que discrimina diferentes tipos de conhecimento que compõem a prática docente, e estuda suas influências sobre a formação do educador -, como é assumido pelos próprios Referenciais:

\footnotetext{
a formação é aqui entendida como processo contínuo e permanente de desenvolvimento, o que pede do professor disponibilidade para a aprendizagem; da formação, que o ensine a aprender; e do sistema escolar no qual ele se insere como profissional, condições para continuar aprendendo. Ser profissional implica ser capaz de aprender sempre (BRASIL, 1999, p. 63).
}

Inclusive, ao levantar as "tendências atuais" sobre a formação de professores, o documento reconhece (e parece legitimar, considerando com um consenso) as conclusões do texto conhecido como “Relatório Jacques Delors”. Esta publicação, como demonstra Duarte (2006), 
apresenta os pilares do "aprender a aprender" - aprender a conhecer, aprender a fazer, aprender a viver junto e aprender a ser - e orientou grande parte das políticas educacionais de caráter neoliberal que foram assumidas pelo Brasil durante os anos 1990.

A epistemologia da prática, a nosso entender, não passa de mais um modismo acatado acriticamente pela comunidade educacional, como o construtivismo e, no momento, a própria Psicologia Histórico-Cultural. Talvez se os educadores não se deixassem seduzir tão facilmente por estas ideias, e as problematizassem devidamente, não teria sido necessário dispendermos as páginas anteriores explicitando seus pressupostos e criticando-as. Lembremos que, para Saviani (2009), problematizar é se dispor a uma análise radical, rigorosa e de conjunto. Escapando a tal exame detido - a este refletir -, só podemos considerar as apropriações, destas ideias, como sendo alienadas.

Mas, se não há esta reflexão, não há como perceber que a epistemologia da prática se baseia: em um ceticismo que recusa a existência de uma verdade objetiva e promove a desqualificação do conhecimento; na negação da historicidade das práticas docentes, e de seu condicionamento pela prática social mais ampla; e na contraposição meramente maniqueísta e caricatural a um modelo anterior, como se a questão se resolvesse simplesmente por um embate tradição versus atualidade.

Se não há esta reflexão, permanece a cegueira diante dos sutis laços desta e de outras pedagogias do "aprender a aprender" com a agenda neoliberal, à qual estes educadores dizem se opor. Por trás do subjetivismo epistemológico defendido por Schön e seus seguidores, repousa uma concepção pragmatista que, nas palavras de Mazzeu (2011), em vez de uma pretendida articulação entre prática e teoria, realiza mesmo é a subsunção desta àquela. Justifica-se, de acordo com esta visão, um "esvaziamento da formação docente, bem como sua limitação à contingência da prática" (ibidem, p. 161). Como defender a formação universitária e a constituição dos docentes enquanto intelectuais, a partir de uma visão relega a segundo plano uma formação teórica consistente, entendendo-a como perda de tempo? Seria mais honesto e coerente, da parte dos entusiastas destas concepções, que a defesa por uma formação docente aligeirada e superficial fosse exposta sem meias palavras, a exemplo dos depoimentos à mídia relatados na seção anterior.

Antes de dar continuidade a esta seção, lembremos uma das discussões que introduzimos no capítulo 5, em que discernimos entre as diferentes modalidades da educação, considerando que o fenômeno educativo pode ter caráter escolar ou não escolar, e ser sistematizado ou assistemático (Figura 29). Poderíamos afirmar que, de modo análogo, a 
formação de professores também se desenvolveria por meio de quatro diferentes modalidades, considerando que ela ocorra de modo institucional/acadêmico ou não, e apresentando-se em um contínuo entre formas assistemáticas e sistematizadas. Isto pode ser representado através do diagrama da Figura 39.

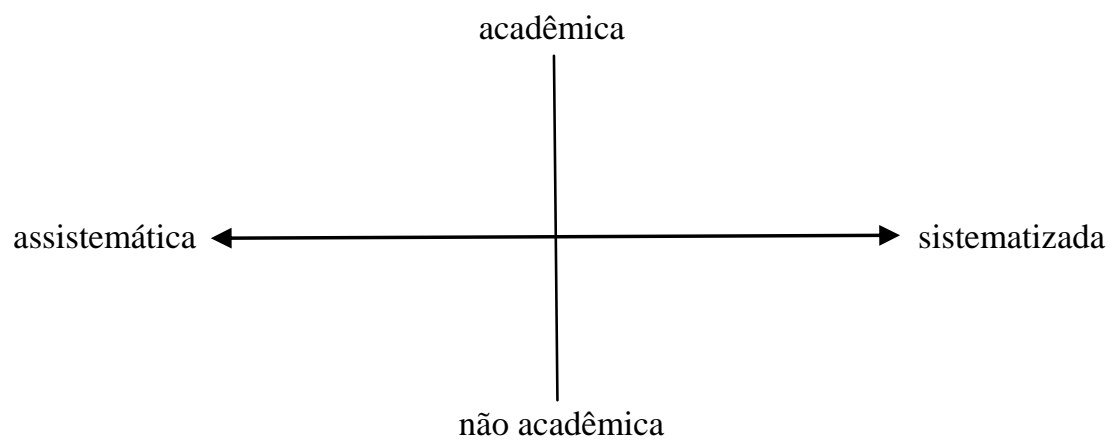

Figura 39: diagrama das modalidades de formação docente entre as dimensões acadêmica/não acadêmica e assistemática/sistematizada.

Os quadrantes da Figura 39 corresponderiam às seguintes modalidades: a "formação docente acadêmica assistemática"; a "formação docente acadêmica sistematizada"; a "formação docente não acadêmica assistemática"; e a "formação docente não acadêmica sistematizada". Como fizemos no capítulo 5, expliquemos a que tipo de formação cada um dos quadrantes corresponderia.

A formação docente acadêmica sistematizada é, assim como a educação escolar sistemática, uma forma institucional, oficial e formalizada. Desenvolve-se nas instituições de ensino superior, nos cursos de licenciatura plena e de Pedagogia, e está mais fortemente associada à formação inicial dos professores. Nada impede, contudo, que certos momentos da formação continuada se processem por esta modalidade institucional e sistemática. Podemos incluir aqui, também, os estudos em nível de pós-graduação, tanto aqueles a que professores se dirigem para complementar sua formação, na forma de especializações ou em programas lato sensu nas áreas de Ensino ou Educação; quanto a formação pedagógica voltada para a atuação no nível superior, como aquela apregoada pela CAPES.

Inevitavelmente, a formação docente acadêmica sistematizada convive com a formação docente acadêmica assistemática. Trata-se da educação decorrente das vivências específicas do ambiente universitário, como a participação em representações e órgãos de classe, as atividades extracurriculares, a convivência com os pares etc. É uma modalidade de formação informal, desarticulada do projeto político pedagógico dos cursos de licenciatura ou 
Pedagogia, mas impossível de ser vetada, especialmente nos tempos mais democráticos de hoje.

A formação docente não acadêmica sistematizada, tomando-se o termo "acadêmico" em sentido restrito (ou seja, identificando-o exclusivamente com a riqueza da vida universitária, a vivência do ambiente do campus, o estar exposto à diversidade indelével da universidade enquanto instituição, seja pública ou privada), referir-se-á aos cursos a distância, ainda que eles abarquem componentes presenciais. Não se trata, entretanto, da formação universitária clássica. Grande parte das oportunidades de formação continuada tende a ocorrer por esta modalidade. Poderíamos incluir aqui a antiga Habilitação Específica para o Magistério, que ofertava uma formação inicial docente em nível médio, preparando normalistas para a educação infantil e as séries iniciais do ensino fundamental. Ainda, a formação em "institutos superiores de educação", de que falam os Artigos 62 e 63 da Lei n. 9.394/1996 (BRASIL, 1996), poderia ser associada a esta modalidade, se concebermos que tais institutos não perfazem universidades propriamente ditas (pois não desenvolvem atividades apoiadas no tripé ensino-pesquisa-extensão, dedicando-se apenas ao ensino).

Por fim, a formação docente não acadêmica assistemática seria, essencialmente, o domínio da epistemologia da prática. Abarca tudo aquilo que é contingente à prática docente e que, oferecendo desafios à atuação do professor, acaba por conduzi-lo a adquirir um saber de experiência, fruto de uma "reflexão", que pode ser individual ou coletiva. Tal reflexão, contudo, não se trata da reflexão filosófica em sentido restrito. Isto é, não necessita ser radical, rigorosa e de conjunto. Serve apenas aos dilemas da prática, o que a torna imbuída de um caráter pragmático. Trata-se, efetivamente, de um conhecimento tácito, nos termos de Duarte (2010a).

Observa-se, portanto, que a adoção do modelo proposto por Schön, e suas variações, enfatizaria apenas um dos quadrantes do diagrama da Figura 39, justamente aquele marcado por duas negações: a formação não acadêmica/assistemática. Não à toa, Duarte (2006) considera a epistemologia da prática e as demais pedagogias do "aprender a aprender" como concepções negativas sobre o ato de ensinar. Além das evidentes implicações pedagógicas deletérias à escolarização - desvalorização do saber erudito, questionamento da possibilidade de sua transmissão, confusão entre o curricular e o extracurricular, entre outras e outras -, estas concepções negativizam a própria constituição da docência. No limite, levam a que se duvide da necessidade de formação profissional especializada para os docentes, e promovam a perda da identidade dos professores - uma identidade constituída, com muito custo, pelo 
trabalho das gerações anteriores de professores, que não se furtavam à tarefa de transmitir o conhecimento, cumprindo a função de socializadora da cultura que se atribui à escola.

Desvalorizando a formação teórica, característica da formação acadêmica sistematizada, cria-se um expediente para que a educação dos professores, especialmente aquela em nível inicial, seja deslocada para o quadrante da formação não acadêmica sistematizada. Assim, o modelo da epistemologia da prática legitima a formação aligeirada em instituições que de "superiores" só possuem o nome. A educação a distância também se aproveitou e continua se aproveitando deste aval. A este respeito, tornamos nossas as palavras da Prof. Lígia Márcia Martins:

a "flexibilização" representada pela modalidade EaD [educação a distância] nos convida a um apelo por coerência no próprio discurso educacional hegemônico. Ora, se a "prática" é critério de referência para a formação do professor, como pensá-la externa à escola e à própria sala de aula? Nessa direção, nem mesmo os adeptos das teorias do "aprender a aprender" deveriam advogar a seu favor, dado que, lamentavelmente, não vem ocorrendo (MARTINS, 2010, p. 29)..$^{99}$

Para melhor explicitar, sob o ponto de vista dos autores em que temos nos baseado, os paralelos entre a presente discussão e os assuntos tratados em capítulos anteriores, a adoção de pedagogias do "aprender a aprender" no campo da formação de professores se equivale à inversão operada na função educativa dos museus. Lembremos que há propostas contemporâneas, certamente influenciadas pela literatura construtivista, que propõem que os centros e museus de ciências, em vez de preservar a cultura para reproduzir o conhecimento, ocupem cada vez mais os espaços gerados pela precária educação escolar, passando a reproduzir o conhecimento para preservar a cultura, função precípua da escola. Argumentase que não se pode limitar os indivíduos da sociedade contemporânea a aprenderem conteúdos científicos apenas nas escolas, já que a escolarização se restringe a apenas uma fração de suas vidas. Ainda, uma vertiginosa sucessão de conhecimentos, na chamada "sociedade da informação", estaria fazendo com que a participação na vida social exigisse atualização constante, justificando que instituições mais flexíveis e menos formais passem a assumir a tarefa de educar as novas gerações.

\footnotetext{
${ }^{99}$ Lembro-me também da participação da Prof. Lígia na mesa redonda "Formação de professores na perspectiva da psicologia histórico-cultural", em 10 de maio de 2012, durante a X Semana da Educação - UFSCar. Disse a pesquisadora, a certa altura, que “A formação de professores é a primeira que vai à leilão para a EaD!", referindo-se a projetos como a Universidade Virutal do Estado de São Paulo. A seguir, provocou: como se pode admitir que o exercício profissional dos docentes seja confiado a esta modalidade? Será que a sociedade endossaria que, igualmente, a formação de médicos e engenheiros em instituições públicas também se realizasse através de cursos semipresenciais?
} 
Se no campo da educação escolar elege-se uma suposta "crise da razão" para se justificar o esvaziamento dos conteúdos e a dissolução dos currículos (perdendo-se de vista os conteúdos clássicos, os saberes essenciais que precisam ser transmitidos), no campo da formação de professores recorre-se à "crise da profissionalização", vulgarizada por Schön. Em igual medida, as duas "crises" acabam por destituir de importância, de um lado, a escola, e de outro, a universidade.

Como escola e universidade são instituições cujos elos se explicitam no processo de formação de professores, decorre das premissas acima que a luta por uma melhor educação (básica e superior) e pela valorização do magistério passa, necessariamente, bem longe das pedagogias do "aprender a aprender", seja o construtivismo, a epistemologia da prática, a pedagogia dos projetos, a pedagogia multiculturalista etc. Trata-se de modelos salientam o que é circunstancial em detrimento do que é necessário; a forma em detrimento do conteúdo; o determinado em detrimento do determinante; o imediato em detrimento do mediado. Assim resume Martins:

\begin{abstract}
Concebendo a formação como um processo que a pessoa, em formação, realiza sobre si mesma e o conhecimento, como instrumento para a resolução de problemas práticos imediatos, esse modelo visa à elaboração de ações adequadas aos contextos e às próprias possibilidades nele existentes, o que, em última instância, significa preparar os indivíduos para a plena adaptação às circunstâncias sem debruçar-se sobre a real compreensão de seus determinantes. Por essa via, ratifica-se a cotidianidade, o "recuo da teoria" e a empiria no âmbito da educação escolar, dados que ampliam sobremaneira os limites a uma formação escolar verdadeiramente emancipatória (ibidem, p. 27).
\end{abstract}

E que alternativas teríamos, portanto, ao irracionalismo que acompanha o "descarte da teoria, da objetividade e da racionalidade" (ibidem, p. 20) no campo da formação dos professores?

Novamente, a Pedagogia Histórico-Crítica e a Psicologia Histórico-Cultural poderão nos fornecer os fundamentos para se devolver ao processo de formação docente a historicidade e o compromisso com a prática social mais ampla. Assim, dedicaremos as duas próximas subseções para analisar as propostas emanadas de partidários destas teorias. Seria preferível que nos valêssemos da unidade psicopedagógica, estabelecida por elas, para fornecermos um tratamento mais integrado do tema. No entanto, acreditamos ser mais conveniente, a esta altura (em que os esforços por uma formação docente fundamentada em pressupostos marxistas são ainda incipientes em comparação com a difusão da epistemologia da prática), demonstrar nitidamente qual o âmbito de aplicação de cada uma das correntes. 


\subsubsection{A formação de professores e a Pedagogia Histórico-Crítica}

Existem autores brasileiros que têm se esforçado para discutir criticamente o modelo da epistemologia da prática para a formação de professores. Por exempo, a Prof. Selma Garrido Pimenta (Faculdade de Educação da USP), tendo elaborado uma produção digna de respeito sobre o tema, busca analisar a questão dos nexos entre teoria e prática a partir de sua articulação enquanto práxis - como temos insistido desde a seção 6.1 do capítulo passado.

Em relação a autores associados à Pedagogia Histórico-Crítica, existem alguns textos específicos sobre o tema, como aqueles que vimos citando ao longo deste capítulo. Estes escritos - Duarte (2010a, 2011), Facci (2004, 2011), Martins (2010), Mazzeu (2011) -, em geral, se propõem a demonstrar os limites das visões ora hegemônicas que vêm orientando o processo de formação docente. A partir desta via negativa é possível inferir quais seriam suas propostas, que apontam de modo unânime para uma formação docente consistente em termos científico-filosóficos, ou seja, superando o "aprender a aprender” da epistemologia da prática.

Entre esta produção, tem destaque o livro de Facci (2004) - Valorização ou esvaziamento do trabalho do professor?: um estudo crítico-comparativo da teoria do professor reflexivo, do construtivismo e da psicologia vigotskiana -, que reúne em um texto abrangente análises profundas e alguns rumos para uma formação docente que supere os modelos que dicotomizam teoria e prática e esvaziam o papel profissional dos professores. Teremos oportunidade de falar mais sobe esta obra na próxima subseção.

Excetuando-se estes textos, não há propriamente uma obra que exprima a concepção da Pedagogia Histórico-Crítica sobre a formação de professores. O próprio Dermeval Saviani, no entanto, tem exposto algumas falas em uma produção ainda difusa sobre o tema, registrada especialmente na forma de entrevistas. Deste modo, será interessante dedicar esta subseção a recuperarmos estes depoimentos, buscando apreender o pensamento do formulador da Pedagogia Histórico-Crítica sobre o tópico da formação docente. Os materiais base desta subseção, assim, serão os dois livros que coligem as falas de Saviani fornecidas a veículos diversos, Interlocuções pedagógicas (2010) e Educação em diálogo (2011).

Realizando-se uma análise de conteúdo (ainda que tentativa e superficial) destes materiais, podemos identificar três categorias através das quais Saviani aborda o tema da formação de professores, intituladas aqui na forma de prescrições: 
- Formação que supere a sofia em direção à episteme (ou o pré-conceito em direção ao conceito, ou o senso comum em direção à consciência filosófica);

- Formação que articule teoria e prática em unidade dialética;

- Formação universitária seguindo o modelo da formação médica.

Algumas falas do educador brasileiro conseguem expor de modo sintético estas três ordens de prescrições, como a seguinte:

os cursos de formação de professores devem garantir uma sólida cultura que lhes permita atingir uma aguda consciência da realidade em que vão atuar associada a um consistente preparo teórico-científico que os capacite à realização de uma prática pedagógica coerente e eficaz. Vê-se que esse tipo de formação só poderá acontecer em cursos de longa duração impregnados de espírito universitário, isto é, realizados no interior de instituições organizadas na forma de universidades (SAVIANI, 2010, p. 209).

Alertamos o leitor de que a sugestão destas categorias atende a fins exclusivamente didáticos, de modo a tornar nosso texto mais compreensível. Como a passagem acima confirma, estas prescrições estão imbricadas, sendo indissociáveis. Mesmo assim, vejamos detalhadamente quais pronunciamentos de Saviani podemos alocar em cada uma delas.

$\mathrm{Na}$ primeira categoria, que trata da formação enquanto processo que dirige os professores de um estado ancorado apenas na experiência de vida (sofia) para uma condição erudita e respaldada por conhecimentos científico-filosóficos (episteme), há uma fala bastante interessante, e que parte da consideração de que seriam cinco os saberes implicados na formação do professor (conhecimentos específicos, conhecimento didático-curricular, saber pedagógico, saber crítico-contextual e saber atitudinal ${ }^{100}$ ):

é possível constatar que a forma "sofia" e também a forma "episteme" atravessam indistintamente os diferentes tipos de saber, ainda que com ênfases diferenciadas. Assim, se no caso do "saber atitudinal" tende a predominar a experiência prática e nos casos dos "saberes específicos" e do "saber pedagógico" prevalecem os processos sistemáticos, ficando em posição intermediária os saberes "críticocontextual" e "didático-curricular", é certo que a forma "episteme" marca também o saber atitudinal, assim como a forma "sofia" não está ausente do modo como o educador apreende os saberes específicos e o saber pedagógico.

A distinção entre a forma "sofia" e a forma "episteme" revela-se importante pelo fato de que ela evita que nós introduzamos o conceito de "saberes da experiência" como uma modalidade de conhecimentos ao lado daqueles outros saberes antes mencionados, como fazem alguns autores. A meu ver, porém, não se trata aí de um conteúdo diferenciado dos demais, mas de uma forma que pode estar referida indistintamente aos diferentes tipos de saber (ibidem, p. 262).

\footnotetext{
${ }^{100}$ Para uma caracterização destes tipos de saberes, ver as p. 261-262 das Interlocuções pedagógicas (SAVIANI, 2010) ou o artigo "A função docente e a produção do conhecimento" (idem, 1997).
} 
Esta fala, de certo modo, restitui a importância dos saberes teóricos para a formação docente, pois desloca os saberes de experiência - alçados a uma posição central, pelos proponentes da epistemologia da prática - para o mesmo nível ontológico dos demais saberes que compõem esta formação. Trata-se de uma fala de teor analítico, e que ainda não apresenta um posicionamento explícito por um dado modelo de formação de professores. Na próxima transcrição já não é isto o que acontece, e podemos observar Saviani defendendo com todas as letras a importância de uma "formação epistemológica", se podemos usar este termo:

o trabalho educativo se insere na prática social como uma mediação que é determinada pela forma como está organizada a sociedade, podendo concorrer tanto para a conservação como para a transformação das condições dominantes. Nesse sentido, os professores também sofrem as determinações da situação social em que vivem. Para que eles possam superar as limitações indicadas, é importante a formação educativa. Ou seja, também para eles, na fase de formação, o processo educativo deve operar como um trabalho que substitua os preconceitos pelos conceitos. Com efeito, preconceito, a palavra está dizendo, é uma ideia préconcebida. Corresponde, pois, à visão espontânea que se forma a partir do ambiente em que se vive [...] (idem, 2011, p. 33-34).

No âmbito de uma discussão sobre que tipo de profissionais deveriam ser formados no curso de Pedagogia, Saviani explicita o que compreenderia esta formação que "substitua os preconceitos pelos conceitos":

Se a gente conseguisse recuperar, pela ênfase na história, o sentido do clássico, nós poderíamos chegar a um modelo formativo consistente. Com efeito, o clássico fornece um critério para distinguir-se, na educação, o que é principal do que é secundário; o essencial, do acessório; o que é duradouro do que é efêmero; o que indica tendências estruturais daquilo que se reduz à esfera conjuntural. Por esse caminho nós podemos libertar a pedagogia e os pedagogos da quase irresistível atração pelas novidades, o que os torna presas fáceis de modismos e de propostas enganosas que surgem e se difundem com a aparência de grandes achados, mas que logo se desfazem como cortinas de fumaça sendo substituídas por novas ondas para onde os pedagogos passarão a flutuar. Hoje tudo é equivalente, tudo é considerado igualmente importante. Como eu vou dar conta de tudo? Então, resulta inevitável o mote pós-moderno: deixa fluir (ibidem, p. 171-172). ${ }^{101}$

Na segunda categoria, que abarca a proposta de uma formação que articule teoria e prática em uma práxis transformadora, Saviani parte de uma crítica explícita ao modelo da epistemologia da prática e, de modo geral, do aprender a aprender, entendendo se tratar de uma concepção que reedita aspectos do escolanovismo e da pedagogia tecnicista:

\footnotetext{
${ }^{101} \mathrm{Na}$ nota de rodapé 15 (seção 1.3 do capítulo 1), trascrevi um fragmento de Pedagogia Histórico-Crítica: primeiras aproximações em que Saviani fornece pistas sobre o que seriam alguns de tais clássicos, dentre a literatura educacional brasileira: Fernando de Azevedo, Lourenço Filho, Anísio Teixeira e Paulo Freire.
} 
Como ocorre com os trabalhadores de modo geral, também os professores são instados a se aperfeiçoarem continuamente num eterno processo de aprender a aprender. Acena-se, então, com cursos de atualização ou reciclagem referidos a aspectos fragmentários da atividade docente, todos eles aludindo a questões práticas do cotidiano. O mercado, e seus porta-vozes governamentais, parecem querer um professor ágil, leve, flexível; que, a partir de uma formação inicial ligeira, de curta duração e a baixo custo, prosseguiria sua qualificação no exercício docente lançando mão da reflexão sobre a sua própria prática, apoiado eventualmente por cursos rápidos, ditos também "oficinas"; estas, recorrendo aos meios informáticos, transmitiriam, em doses homeopáticas, as habilidades que o tornariam competente nas pedagogias da "inclusão excludente", do "aprender a aprender" e da "qualidade total". É a concepção produtivista que, tornando-se hegemônica desde a década de 1970, é agora refuncionalizada numa espécie de neoprodutivismo (idem, 2010, p. 65).

Suas contribuições mais substanciais ao tema, entretanto, se encontram em duas entrevistas registradas em Interlocuções pedagógicas, intituladas "Formação de professores" (2004) e "Sobre a relação entre teoria e prática na educação" (2005).

Na primeira - que será mais bem explorada quando tratarmos da próxima categoria - o

filósofo e educador defende que a formação docente seja a exata antítese do conteúdo da transcrição acima, a qual, infelizmente, aparece legitimada pelos dispositivos legais:

Infelizmente a política que se vem procurando implantar com o respaldo da nova LDB [Lei n. 9.394/1996] segue uma orientação pragmática voltada para se formarem professores em tempo curto, habilitando-os para o desempenho profissional junto aos alunos em sala de aula, abrindo mão de uma base teóricocientífica sólida. Ora, aquilo de que necessitamos é exatamente de professores cultos, com sólida formação, o que implica a realização de cursos de longa duração em que a formação profissional esteja firmemente ancorada no desenvolvimento da pesquisa (ibidem, p. 207-208).

Já na segunda entrevista, Saviani esclarece a questão aparentemente problemática da relação entre teoria e prática no âmbito da formação de professores:

Há alguns equívocos nessa contraposição comum, corrente, entre teoria e prática, especificamente no campo da educação: há uma tendência a valorizar-se a prática, contra a teoria. É muito comum, de modo geral, os alunos, e principalmente os de pedagogia, cobrarem dos professores que o curso é muito teórico e deveria ser mais prático. A lógica que está por trás disso é a lógica formal, corrente: teoria e prática são vistas como polos opostos, que se excluem reciprocamente. Se é teoria, não é prática, se é prática, não é teoria. É o princípio da identidade, da não contradição: o que é, é; o que não é, não é. De fato, caberia observar que teoria e prática são momentos de um mesmo processo (ibidem, p. 217-218, grifos do autor).

Para ele, a confusão reside na concepção de prática enquanto ativismo, e na de teoria como verbalismo. Com efeito, são estes os contrários que se opõem sem estabelecer unidade dialética: 
De fato, quando os alunos defendem a prática contra a teoria e os professores defendem a teoria contra a prática, acusando os alunos de serem imediatistas, nós vemos interferir aí uma outra noção. Nós temos a prática e o ativismo, que são dois conceitos ligados à ação, mas com conteúdos distintos. Do lado da teoria nós vamos ver que há a teoria o verbalismo, que também são distintos. Então, na verdade, em lugar de nós termos uma oposição desse tipo, teoria versus prática, como se fossem dois termos contrapostos, mutuamente excludentes, nós temos é um quadrilátero, não uma relação bipolar; a contraposição excludente dá-se em diagonal, entre a teoria e o ativismo e entre a prática e o verbalismo. Então, o que se opõe em termos excludentes à teoria é o ativismo, não a prática; e o que se opõe, em termos excludentes, à prática, é o verbalismo e a não a teoria. [...] $\mathrm{Na}$ verdade, os alunos defendem o ativismo em nome da prática contra o verbalismo que eles chamam de teoria; os professores, por sua vez, são levados a defender o seu verbalismo em nome da teoria contra o ativismo que eles chamam de prática (ibidem, p. 218-219).

Assim, a representação que Saviani invoca nessa passagem é a que apresentamos na Figura 40. Neste diagrama, são as linhas pontilhadas que assinalam oposições inconciliáveis entre termos (teoria/ativismo, prática/verbalismo). Outra leitura possível é considerar que a teoria se situa em um vértice entre os vértices da prática e do verbalismo, ou seja, que o verbalismo, banhado em prática, se converte em teoria; e, da mesma maneira, a prática se situa numa posição intermediária entre a teoria e o ativismo, pois este, iluminado pela teoria, se torna efetivamente uma prática.

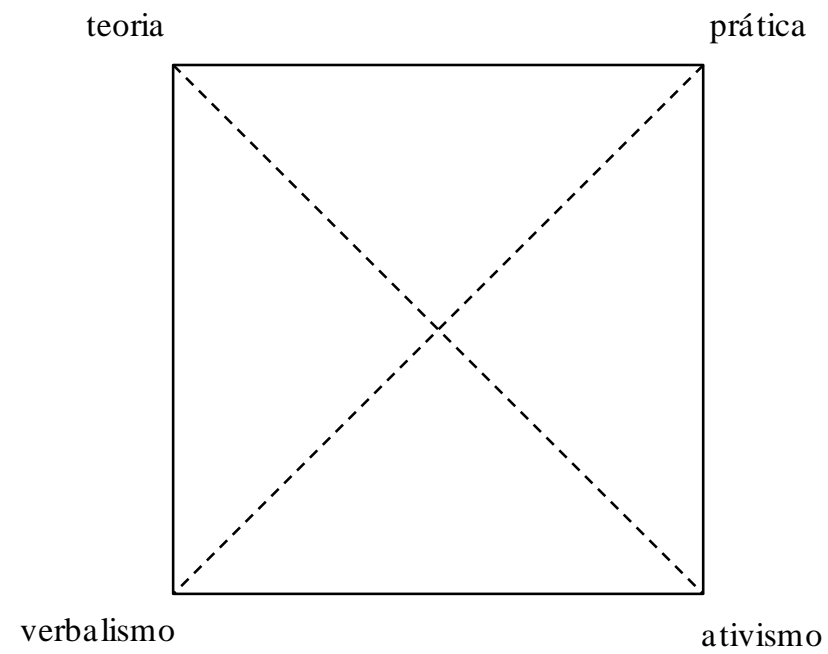

Figura 40: quadrilátero sobre as relações entre teoria, prática, ativismo e verbalismo.

Trata-se, portanto, de se superar a análise da questão sob o ponto de vista da lógica formal, avançando para uma compreensão alicerçada na lógica dialética, a lógica concreta, repleta de conteúdo, e por isso mesmo, aquela que efetivamente capta as contradições da realidade e possibilita a apreensão do movimento do mundo, com vistas a se aproximar cada vez mais da verdade objetiva: 
Então, na medida em que agente faz essa espécie de análise lógica dos conceitos, dos termos, essa análise da linguagem, distinguindo entre teoria e verbalismo e entre prática e ativismo, se esclarece o teor do problema, mostrando-se que o verbalismo é o blá blá blá, é o falar por falar, é aquilo que Paulo Freire chamava de "o culto da palavra oca". A teoria não é isso, é um esforço de explicitar conceitualmente, portanto ao nível do pensamento, as questões que a vida põe, as questões que a prática coloca. De outro lado, o ativismo é a prática sem teoria, é a prática espontaneísta. Com efeito, a prática, como tal, ganha coerência e tem sentido na medida em que ela é iluminada pela teoria (ibidem, p. 220, grifos do autor).

Finalmente, a terceira categoria de prescrições para a formação de professores, conforme o pensamento de Saviani especificamente sobre o tema, apresenta os aspectos operacionais que possibilitariam o cumprimento das prescrições anteriores. Para o pai da Pedagogia Histórico-Crítica, tal formação precisaria superar uma espécie de "estigma de cursos de segunda categoria":

E isso pode ser constatado não apenas no Brasil, onde se cristalizou a dualidade entre bacharelado e licenciatura nas Faculdades de Filosofia, Ciências e Letras, mas também nos outros países. Assim, as Universidades Pedagógicas têm, na América Latina, um status inferior às universidades tradicionais. Igualmente, as Escolas Superiores de Pedagogia na Alemanha e as Faculdades de Magistério na Itália, ambas hoje extintas, também tinham um status inferior em relação às faculdades tradicionais integrantes das grandes universidades desses países (ibidem, p. 208209).

Contrapondo-se ao modelo de formação aligeirada, em universidades que não fazem jus a esta denominação, Saviani irá defender, em diversas entrevistas, que a formação docente só possa ocorrer em cursos longos:

as políticas de formação docente supõem que preparar o professor para a sala de aula possa ser feito pela simplificação e redução dos currículos, em cursos de curta duração, despidos de maiores preocupações com a fundamentação teórica. Pensa-se, assim, em matar dois coelhos com uma só cajadada: conseguir a façanha de formar professores mais capazes de enfrentar as salas de aula e, ao mesmo tempo, reduzir os custos de sua formação, propondo reformas que visam ao máximo de resultados com o mínimo de dispêndio e dando preferência para os institutos superiores de educação em detrimento dos cursos oferecidos pelas universidades públicas. Ora, o professor de que precisamos necessita ter sólida cultura. Logo, só pode ser formado em cursos de longa duração (ibidem, p. 230).

Em entrevistas mais recentes, esta proposta será mais bem detalhada, estabelecendo-se uma analogia com a formação médica. Além disso, no entender do educador, não basta se alterar apenas o processo de formação docente: as condições de trabalho também devem ser elevadas. Assim, perguntado pelo Sindicado dos Professores de Guarulhos, em 2007, sobre como enxerga o futuro da profissão docente, Saviani responde: 
Sem encarar o problema do magistério, nenhuma reforma educacional terá chances de êxito. Trata-se de criar a carreira do magistério da educação básica tendo como itens básicos um piso salarial substantivamente elevado em relação aos padrões atuais $^{102}$ e jornada em tempo integral em uma única escola com $50 \%$ do tempo dedicado à docência das disciplinas e outra metade distribuída pelas demais atividades. Quanto à formação, deve ser provida por meio de cursos regulares de caráter presencial e de longa duração, ministrados por universidades que encarem a pesquisa sobre o magistério e a formação docente como projetos prioritários. Os dois aspectos, carreira e formação, interligam-se. Com efeito, salários dignos e condições de trabalho satisfatórias definem um status social elevado para o magistério. Transformada a docência numa profissão atraente socialmente em razão da sensível melhoria salarial e das condições de trabalho, para ela serão atraídos muitos jovens dispostos a investir seus recursos, tempo e energias numa alta qualificação obtida em graduações de longa duração e em cursos de pós-graduação. Não é isso o que ocorre hoje, de certo modo, com a medicina? (idem, 2011, p. 67).

Em outras entrevistas, cronologicamente próximas (de 2007 e de 2009, respectivamente), complementa:

A tarefa do educador é a formação humana. Mas a formação humana é algo muito complexo. Portanto, a formação do educador, isto é, daquele que será encarregado de formar os seres humanos, não pode ser de curta duração. Deverá, pois, necessariamente, ser organizada como um curso de longa duração. Para formar um médico leva-se seis anos aos quais se acrescenta o tempo de residência e de especialização. Consequentemente, para formar um educador, cuja tarefa, a de cuidar de gente, é bem mais séria do que cuidar da saúde, é necessário um tempo bem maior que aquele que tem sido destinado aos cursos de formação de profissionais da educação (ibidem, p. 172-173).

Se os jovens entendem que vale a pena concorrer a uma vaga nos cursos de medicina e se submeterem a um curso de seis anos acrescidos do período de residência e de estudos de especialização, isso ocorre porque se trata de uma profissão valorizada socialmente (ibidem, p. 236).

Em resumo, Saviani compreende que a formação de professores deve promover a elevação do nível cultural daqueles que se candidatam ao magistério, pois os docentes, antes de aspirarem à transmissão do saber erudito nas salas de aula, devem eles mesmos dominar este saber, constituindo-se como intelectuais. Para isso, o autor defende que os cursos de licenciatura e Pedagogia invistam em uma sólida formação científico-filosófica, assentada nos clássicos da literatura educacional, sem descurar de outros tipos de saberes (específicos,

\footnotetext{
${ }^{102}$ O caderno especial da Folha de S. Paulo, a que me referi na seção 7.1, reproduz alguns dados da Organização para a Cooperação e Desenvolvimento Econômico (OCDE), do Instituto Datafolha e do Governo do Estado de São Paulo sobre pisos salariais de diferentes profissões, no Brasil, considerando uma mesma jornada de trabalho. Assim, enquando um professor universitário no topo da carreira receberia, em média, um salário de $\mathrm{R} \$ 10.800$, e um médico clínico geral, $\mathrm{R} \$ 8.922$; um professor da educação básica, na rede pública, contentar-se-ia com apenas $\mathrm{R} \$ 2.299$ (cerca de $20 \%$ do salário do professor universitário). O salário médio do professor da educação básica estaria mais próximo do de profissionais com nível mais baixo de especialização, como os garçons ( $\mathrm{R}$ 1.405) e cozinheiros (R \$1.377). Acresce-se, no entanto, a alta insalubridade envolvida no trabalho diário em uma escola pública típica.
} 
didático-curriculares, crítico-contextuais e atitudinais). Esta formação deve superar as formas distorcidas que se exprimem ou pelo verbalismo, ou pelo ativismo, mediante a integração da teoria e da prática numa práxis educativa a serviço de uma prática social mais ampla (que se identifica com a práxis política, por vivernos ainda numa sociedade de classes). Tal formação só é possível em cursos de longa duração, sediados em universidades propriamente ditas. Porém, estes preceitos devem necessariamente se articular com o próprio exercício profissional, que deve estar respaldado por melhores salários e condições materiais, o que impulsionaria o prestígio social da profissão docente e dirigiria aos cursos de formação inicial jovens mais identificados com esta carreira.

Registradas algumas contribuições de Dermeval Saviani para este debate, vejamos agora como autores agremiados à Psicologia Histórico-Cultural poderiam fornecer outros subsídios às nossas análises.

\subsubsection{A formação de professores e a Psicologia Histórico-Cultural: em foco a teoria da atividade}

Para Martins (2010), em relação à epistemologia da prática, “urge a proposição de um modelo de formação alternativo, no qual a construção de conhecimentos se coloque a serviço do desvelamento da prática social", para se "promover o questionamento da realidade fetichizada e alienada que se impõe aos indivíduos" (p. 20). Entendemos que tanto a Pedagogia Histórico-Crítica quando a Psicologia Histórico-Cultural - especialmente quando consideradas de modo unitário - podem contribuir para este modelo.

No caso da psicologia soviética, há alguns pesquisadores brasileiros, com uma produção destacada, que têm se dedicado à tarefa de buscar nela os subsídios para um entendimento da formação de professores. Consideraremos, aqui, apenas algumas propostas em que o caminho desta derivação acaba por atravessar as ideias de Leontiev, expressas em sua teoria da atividade. Não se trata, entretanto, de um levantamento exaustivo. Para não nos alongarmos em demasia, desejamos apenas expor algumas das diversas perspectivas propostas por estes estudiosos, reservando a outros trabalhos a possibilidade de uma revisão mais criteriosa e abrangente delas. 
Assim, o primeiro nome que queremos destacar nesta subseção é o de José Carlos Libâneo, um dos pioneiros no estudo aprofundado dos autores da Psicologia HistóricoCultural. Num artigo que busca articular a teoria da atividade e a chamada "teoria do ensino desenvolvimental", de V. V. Davídov, para a compreensão do processo formativo de docentes (LIBÂNEO, 2004), ele assim considera a atuação do professor:

o professor desenvolve uma atividade prática, entendendo a prática no sentido de envolver uma ação intencional marcada por valores. O professor pode aprimorar seu trabalho apropriando-se de instrumentos de mediação desenvolvidos na experiência humana. Não se trata de voltar ao tecnicismo, mas de associar de modo mais efetivo o modo de fazer e o princípio teórico-científico que lhe dá suporte (p. 138).

A partir desta noção de "instrumentalidade", ficam claros o aspecto prático da profissão docente e sua caracterização enquanto atividade orientada para um fim (nos termos de Leontiev), e em que medida esta concepção contesta o modelo da epistemologia da prática:

O trabalho de professor é [...] um trabalho prático, entendido em dois sentidos, o de ser uma ação ética orientada para objetivos (envolvendo, portanto, reflexão) e o de ser uma atividade instrumental adequada a situações. A reflexão sobre a prática não resolve tudo, a experiência refletida não resolve tudo. São necessárias estratégias, procedimentos, modos de fazer, além de um sólido conhecimento teórico, que ajudam a melhor realizar o trabalho e melhorar a capacidade reflexiva sobre o que e como mudar (ibidem, loc. cit.).

Lembremos que, de acordo com Leontiev (1978), as atividades guia que caracterizam o desenvolvimento dos indivíduos na sociedade atual (delimitando períodos históricos para este desenvolvimento, diferentemente da periodização proposta por Piaget, em que esta historicidade não é levada em consideração) são quatro: a apropriação da realidade circundante pela criança, a brincadeira, a formação escolar e o trabalho. Pois bem, Libâneo leva em consideração que, no caso dos professores, existe a particularidade de que sua atividade guia, o trabalho, relaciona-se imediatamente com a atividade guia da idade escolar, isto é, a aprendizagem do saber sistematizado em um contexto institucional. Este aspecto singular deve ser levado em consideração em uma proposta para a formação dos professores:

Aplicando o ensino desenvolvimental à formação de professores, a atividade de aprendizagem da profissão consiste em que os professores adquiram conhecimento teórico, isto é, que reproduzam conscientemente as compreensões teóricas desenvolvidas em uma matéria, de modo a poder explicar as importantes relações estruturais que caracterizam essa matéria. Com efeito, se a atividade principal do futuro professor é a de promover a atividade de aprendizagem de seus futuros alunos, nada mais oportuno que o professor aprenda sua profissão na perspectiva em que irá ensinar aos seus alunos. Além disso, sendo correto entender que a base do 
ensino desenvolvimental é a estrutura psicológica da atividade, com base na qual são criadas tarefas para melhor promover a aprendizagem, será importante estabelecer as características da atividade profissional do professor, de modo que isso se constitua como referência para o currículo (LIBÂNEO, 2004, p. 135).

Deste ponto de vista, a atividade profissional dos professores envolveria o desenvolvimento simultâneo de três aspectos:

o primeiro, a apropriação teórico-crítica dos objetos de conhecimento, mediante o pensamento teórico e considerando os contextos concretos da ação docente; segundo, a apropriação de metodologias de ação e de formas de agir, a partir da explicitação da atividade de ensinar; o terceiro, a consideração dos contextos sociais, políticos, institucionais - práticas contextualizadas - na configuração das práticas escolares (ibidem, p. 141).

As considerações de Libâneo não pretendem refutar completamente o modelo do professor reflexivo. Como ele afirma em outro texto,

O "programa reflexivo" vem trazendo aportes valiosos para a pesquisa como a recusa do professor meramente técnico, a afirmação da prática docente como uma ação consciente e deliberada, a correspondência entre teoria e prática nas ações cotidianas, a aceitação da existência de pressupostos interpretativos e valorativos na atuação e nas decisões profissionais. Mas é preciso alargar esse campo de preocupações especialmente naqueles aspectos que vimos acentuando (idem, 2005, p. 76).

Este posicionamento talvez explique a sensação de que falta radicalidade à produção do Prof.

Libâneo dedicada à formação de professores. Além disso, sua interpretação da Psicologia

Histórico-Cultural acaba, invariavelmente, por aproximar a produção de Leontiev e, principalmente, de Davídov, das pedagogias do "aprender a aprender". Isto, que já fora acusado por Duarte (2006), aparece explicitamente em passagens como a esta:

A educação escolar constitui-se numa forma específica de atividade do aluno - a atividade de aprendizagem - cuja meta é a própria aprendizagem, ou seja, o objetivo do ensino é ensinar aos estudantes as habilidades de aprenderem por si mesmos, ou seja, a pensar (LIBÂNEO, 2004, p. 122). ${ }^{103}$

\footnotetext{
${ }^{103}$ Vale a pena reproduzir um esclarecimento de Libâneo sobre a questão: "Ensinar a pensar, aprender a pensar, são expressões que uso no sentido que lhes pode ser atribuído na teoria histórico-cultural de Vigotski, de que a escola é uma mediação cultural de significados. A escolarização significa a apropriação de significados sociais com sentido pessoal e, para que isso ocorra, é preciso aprender a pensar, é preciso propiciar o desenvolvimento cognitivo. Em outras palavras, o processo de internalização de significados requer a mesma abordagem, o aprender a aprender, como elemento do aprender a pensar. O aprender a aprender, cujo pleno sentido é saber buscar informação, é desenvolver autonomia de pensamento, desenvolver recursos próprios para uma educação continuada, não tem apenas o sentido excluído que muitos críticos lhe atribuem de uma forma mecanizada de aprender, tipo algoritmo" (LIBÂNEO, 2005, p. 71, nota de rodapé).
} 
Outra pesquisadora que vem buscando compreender o processo de ensino e a formação de professores a partir dos autores soviéticos é Andréa Maturano Longarezi, interessando-nos, aqui, o artigo - escrito com duas colaboradoras - "La sicologia historicocultural en la formacion del profesional docente" (LONGAREZI; ARAÚJO; FERREIRA, 2007). Neste estudo considera-se que são três os conceitos principais, oriundos da Psicologia Histórico-Cultural, que poderiam aclarar a questão da formação docente: a relação entre aprendizagem (instrução/obutchenie) e desenvolvimento, a zona de desenvolvimento iminente e a mediação semiótica da linguagem e da palavra (fala/retch).

Como faz Libâneo, as pesquisadoras também levam em consideração as contribuições de Davídov à teoria da atividade de Leontiev, que teriam evidenciado os aspectos reprodutivos e criativos implicados na atividade de ensino: "o desenvolvimento da psiquê humana decorre da apropriação pelo indivíduo dos resultados do desenvolvimento históricocultural realizado por meio de uma atividade reprodutiva que não deixa de ser criativa" (ibidem, p. 205, tradução das autoras) ${ }^{104}$. Veja-se que, da mesma forma que nós, Davídov entende que a educação escolar tem uma função reprodutiva - cujo lema, como assinalamos, é reproduzir o conhecimento para preservar a cultura -, o que de modo algum anula a capacidade criativa dos indivíduos, pelo contrário: somente da posse dos instrumentos culturais e da reprodução de certas operações criadas no decurso do desenvolvimento histórico (como a operação de ler um texto sem se prender à decifração dos signos visuais, podendo dirigir toda a atenção para o conteúdo das palavras) é que o indivíduo pode exercer sua criatividade livremente..$^{105}$

Longarezi, Araújo e Ferreira também situam a "atividade de ensino" como uma interseção entre as atividades guias das crianças em idade escolar e dos adultos que atuam no magistério, variando-se os sentidos pessoais que estes grupos atribuem a esta instrução sistematizada. Falando sobre a estrutura desta atividade, as autoras afirmam que ela

também tem presente uma necessidade (apropriação da cultura), um motivo (conhecimento historicamente acumulado), objetivos (ensinar e aprender) e condições (instituição escolar). A atividade de ensino é assim percebida na sua dimensão transformadora - como instrumento social desencadeador da formação do professor e do aluno (ibidem, p. 206).

\footnotetext{
${ }^{104}$ As autoras publicaram o mesmo texto em um periódico nacional (Série Estudos: periódico do Mestrado em Educação da UCBD), em língua portuguesa. Preferi referenciar o texto em castelhano pelo fato dele ser mais acessível, mas todas as transcrições literais seguirão a versão em português.

${ }^{105}$ Já falei sobre isto, rapidamente, na seção 4.1 do capítulo 4, em referência ao que Saviani (2008) discorre sobre a questão dos "automatismos".
} 
Esta passagem revela que as autoras entendem o processo de formação de professores como uma etapa de desenvolvimento. Afinal, é característica da atividade guia realizar o desenvolvimento do psiquismo, ainda que se considere a forma derradeira desta atividade, que é a atividade profissional (na sociedade dos tempos contemporâneos). Assim, a atividade de ensino provoca um duplo desenvolvimento:

a atividade de ensinar configura-se como unidade formadora do professor e do aluno. Do professor porque, ao realizar sua atividade de ensino, realiza um movimento de quem pretende ensinar para um movimento de quem também aprende. Do aluno porque, pela atividade de ensino, apropria-se de um conhecimento elaborado historicamente. Isto faz com que a atividade orientadora [guia] de ensino configure-se como um objeto social que possibilita tanto ao professor como ao aluno constituir-se como sujeito histórico (ibidem, loc. cit.).

$\mathrm{O}$ artigo, então, estabelece quatro proposições que decorreriam desta fundamentação teórica, esclarecendo que irá tratar, especificamente, da formação continuada de professores. A primeira se refere à participação do professor como princípio dos processos formativos em que se insere; a segunda, à sua alocação em práticas investigativas colaborativas; a terceira, a considerar que o lócus de seu processo formativo, em situação de trabalho, deve ser a própria escola; o quarto, finalmente, trata de reconhecer e valorizar o aspecto coletivo deste processo.

Observamos que o artigo não avança muito quanto à proposição de um modelo para a formação docente respaldado pela Psicologia Histórico-Cultural; com efeito, as quatro proposições acima também podem ser encontradas em outros modelos para a formação de professores. Trata-se, evidentemente, de diretrizes de caráter geral, e das quais dificilmente alguém seria capaz de discordar, mesmo do ponto de vista da epistemologia da prática.

Mesmo assim, o trabalho de Longarezi, Araújo e Ferreira tem seu mérito por chamar a atenção para o entendimento da atividade de ensino enquanto promotora do desenvolvimento tanto dos alunos quanto do professor. Este aspecto, se já havia sido reconhecido por Libâneo, não fora ainda tão bem dissecado, o que as pesquisadoras realizam ao iluminar a estrutura desta atividade, explicitando qual seria sua necessidade, seu motivo, seus objetivos e as condições em que ocorre.

Além disso, a interpretação da atividade de ensino enquanto atividade guia de professores e alunos favorece a que se considere o papel do ensino, da instrução, tanto no processo de formação docente quanto no processo de educação escolar. Lembremos que o ensino costuma ser visto como um aspecto depreciado pela epistemologia da prática, que prescreve um "aprender fazendo" aos professores em formação. 
Finalmente, há as indicações da obra de Facci (2004), também engajando a teoria da atividade em uma visão mais crítica da formação de professores. Se nas referências anteriores ressaltou-se a analogia entre as atividades de ensino executadas pelos professores (atividade guia profissional) e pelos alunos (atividade guia da educação escolar), bem como a estrutura de que elas compartilham, Facci chamará a atenção para os conceitos de "sentido" e "significado", que também integram a teoria da atividade de Leontiev.

Em consonância com autores associados à Pedagogia Histórico-Crítica, a pesquisadora partirá de uma apreciação favorável à sólida formação teórica dos professores:

\begin{abstract}
O desenvolvimento do pensamento teórico, de capacidades e habilidades intelectuais é o resultado fundamental da educação do aluno e também daquele que ensina. $\mathrm{Na}$ formação do professor, portanto, além do conhecimento de suas experiências pessoais e profissionais, dos saberes práticos, tem que haver uma ruptura com a forma de pensamento e ação próprios do conhecimento cotidiano. A humanização do aluno e do professor está limitada por relações e formas de ação presentes na prática educativa, que refletem a influência de relações mais amplas, presentes na prática social (ibidem, p. 246).
\end{abstract}

Então, Facci lembra que a prática docente compreende condições objetivas e subjetivas. As condições objetivas se referem ao significado que a atividade de ensinar assumiu em seu desenvolvimento histórico: o ato de possibilitar às novas gerações que se apropriem da cultura elaborada pelas gerações anteriores e, além disso, de estimular novas necessidades (carecimentos não-cotidianos) por parte destes sujeitos, impulsionando sua contínua apropriação de outros objetos da cultura. As condições subjetivas se manifestam pelo sentido pessoal que tal atividade assume para o sujeito que a pratica.

Em diferentes momentos desta tese abordamos rapidamente o tema da alienação. No capítulo 2, trouxemos as contribuições de Newton Duarte (2007), falando sobre a teoria do cotidiano de Agnes Heller. Ali, expusemos que a alienação se caracteriza por uma configuração das condições objetivas que impede a construção da individualidade para-si, vedando ao sujeito sua participação na genericidade humana. Ele não sente necessidade de romper com o cotidiano; a vida cotidiana abrange a totalidade de sua existência, resumida a subsistência, a mera satisfação dos imperativos biológicos. Também no capítulo 2 mencionamos que, do ponto de vista da teoria de Leontiev, a alienação se evidencia a partir da descoincidência entre o sentido de uma atividade (aspecto subjetivo) e o significado social atribuído a ela (aspecto objetivo). Já no capítulo 4, dissemos rapidamente que esta dissociação entre sentido pessoal/significado social, ainda de acordo com Leontiev em $O$ desenvolvimento do psiquismo, é fruto da divisão social do trabalho. Lembrando Marx, o psicólogo russo 
destaca a forma arquetípica desta dissociação (atividade prática versus atividade intelectual), e propõe que a internalização de tais relações provoca uma verdadeira "desintegração" (LEONTIEV, 1978, p. 126) da estrutura psicológica (internalizada) desta atividade alienada.

Facci, integrando estas considerações àquelas de outros autores que cita, conclui que "Quando o sentido pessoal do trabalho do professor se separa do significado dado socialmente, pode-se considerar esse trabalho alienado e este pode descaracterizar a prática educativa escolar" (2004, p. 249). Citando Basso (1998), ela acrescenta:

\begin{abstract}
se o sentido que o professor dá ao seu trabalho está ligado somente ao de garantir sua sobrevivência, de ter dinheiro para pagar suas despesas ao final do mês, sem ter consciência da sua participação na formação do gênero humano, no processo de apropriação e produção de novas objetivações por parte do aluno, há a cisão entre o significado fixado socialmente e o sentido do seu trabalho. A prática educativa entendida como aquela que tem uma função mediadora entre os alunos e os conhecimentos e instrumentos culturais que serão apropriados acaba descaracterizando-se (ibidem, loc. cit.).
\end{abstract}

Nesse sentido, a ascenção à individualidade para-si deve representar a "possibilidade de conhecer e modificar formas de pensamento e atividades que estão reproduzindo a alienação, tanto individualmente como também nas relações sociais" (ibidem, p. 248-249). Esta consideração enfatiza o polo subjetivo da genericidade para-si, mas não se pode esquecer de seu polo objetivo, e é aí que entram as reivindicações por melhores condições de exercício profissional para os atuantes no magistério:

a superação de um trabalho alienado não depende apenas das condições subjetivas, depende também das condições efetivas de trabalho que podem ou não auxiliar o professor na busca de relações sociais mais conscientes com a atividade social que desenvolve. Quando as condições objetivas de trabalho - recursos físicos das escolas, materiais didáticos, estudo coletivo, possibilidade de trocas de experiências, organização da escola em termos de planejamento, salários etc. - não permitem que o professor se realize como integrante do gênero humano, o seu trabalho traz desgaste psicológico e físico (ibidem, p. 249-250).

As questões da alienação e do papel da formação docente para a superação da individualidade em-si também foram expostas por Duarte (2007), que de modo perspicaz, observa:

A alienação no caso do trabalho educativo possui uma diferença em relação a outros tipos de trabalho. Em outros tipos de trabalho o produto pode não ser prejudicado pela alienação do processo. $O$ trabalhador pode se alienar, se esvaziar no processo de produção, mas o produto vir a enriquecer a sociedade. $O$ trabalhor pode se unilateralizar no processo e o produto contribuir para a universalização do gênero 
humano. ${ }^{106}$ Mas isso não ocorre no caso do trabalho educativo. Nesse caso, $a$ alienação do trabalhador perante o processo gerará também a alienação no que se refere ao produto, no caso, à formação do indivíduo educado. Assim, se o trabalho educativo se reduzir, para o educador, a um simples meio para a reprodução de sua existência, para a reprodução de sua cotidianidade alienada, esse trabalho não poderá se efetivar enquanto mediação consciente entre o cotidiano do aluno e a atuação desse aluno nas esferas não-cotidianas da atividade social. A atividade educativa se transformará, também ela, numa cotidianidade alienada, que se relacionará alienadamente com a reprodução da prática social (p. 56, grifo nosso).

Em resumo, as contribuições dos autores revistos nesta subseção reforçam as orientações da Pedagogia Histórico-Crítica para a formação de professores: trata-se de um processo que necessita ser orientado, adquirindo uma forma sistematizada, possibilitando a apropriação de um rico substrato teórico por parte dos profissionais do magistério. Da mesma forma que a atividade escolar implica na instrução das novas gerações (e só a instrução garante desenvolvimento, como diria Vigotski), a atividade docente também necessita dos momentos de direcionamento mediante o ensino: eis o papel da formação de professores, seja ela inicial ou continuada. A aquisição de uma cultura elevada é condição para se superar o cotidiano alienante, e nenhuma pedagogia crítica poderia aceitar a existência de um professor alienado: a alienação do educador é um impedimento para a desalienação do estudante.

\subsection{CONTRIBUIÇÕES DA EXPERIMENTOTECA}

Expostos os fundamentos da visão que adotamos para compreender a formação docente, vejamos, nesta seção final, de que maneiras a Experimentoteca pode contribuir para este processo, quer em sua modalidade inicial, que na modalidade continuada. A cada um destes aspectos, assim, será dedicada uma subseção.

Tentaremos aqui seguir um percurso bastante peculiar, em que estas duas divisões não serão análogas, ou seja, não tratarão de aspectos paralelos. Na verdade, desejamos mesmo que a primeira subseção se estruture de modo a abrir possibilidades a serem exploradas na segunda.

\footnotetext{
${ }^{106}$ Podemos relacionar esta oração, por exemplo, ao próprio processo de produção industrial de livros: apesar de um contingente enorme de trabalhadores se relacionar de modo alienado com a profissão de imprimir obras filosóficas e literárias, o conteúdo destas obras permanece encerrando possibilidades para a libertação do humanidade, independentemente desta alienação.
} 
Por isso, a subseção inicial, que tratará das contribuições da Experimentoteca para a formação de professores de ciências, será constituída por um estudo de revisão bibliográfica sobre boa parte do material que compôs o capítulo 5. Essencialmente, estes materiais pertencem a duas categorias: textos institucionais (produzidos pelo pessoal do CDCC), ainda que publicados na forma de capítulos de livros, artigos, trabalhos para congressos etc.; e textos acadêmicos, o que compreende as três dissertações de mestrado que tomaram a Experimentoteca como objeto de estudo.

Esta revisão levantará alguns problemas que poderão ser discutidos, efetivamente, na subseção final, dedicada às contribuições da Experimentoteca para a formação inicial de professores de Química. O material desta divisão será assegurado por mais uma visita a campo, desta vez para entrevistar uma pesquisadora universitária que tem muito a dizer sobre o tema, professora e ex-Coordenadora do curso de Licenciatura em Ciências Exatas, da USP campus de São Carlos.

Mais uma vez, como se pode notar, seguimos a orientação metodológica de caminhar do abstrato (âmbito mais geral do ensino de ciências e prescrições institucionais do CDCC para a formação de professores) para o concreto (âmbito mais específico do ensino de Química e possibilidades para contribuições efetivas da Experimentoteca para a formação inicial de químicos licenciados).

\subsubsection{Contribuições à formação de professores de ciências}

Revendo a literatura que tomou a Experimentoteca como objeto de investigação, apreende-se que as contribuições para a formação de professores de ciências, por parte projeto, podem ocorrer por três vias. Duas delas se referem a um tipo de formação não acadêmica e assistemática. A terceira, embora normalmente ocorra de modo não acadêmico e sistematizado, convive com insinuações de que deveria se "academicizar", passando a acontecer durante a formação inicial de professores.

A primeira contribuição à formação docente de modo não acadêmico e assistemático se refere ao fato da Experimentoteca, quando utilizada, levar a que docentes discutam e reflitam sobre o planejamento e a execução de atividades experimentais em sala de aula. Há um depoimento de Schiel a respeito disto, na dissertação de mestrado de Joaquim (1992): 
Quando planejamos a "Experimentoteca", praticamente nos concentramos no aluno mas, conforme fomos criando [...], nós percebemos que a Experimentoteca é tanto um instrumento de educação do aluno quanto do professor. É que a discussão que se faz de qualquer experiência acaba enriquecendo todo mundo. Foi um enriquecimento para nós também, que somos da Universidade e nunca demos aula em uma escola de $1^{o}$ grau. E todos, coordenação, monitores, professores [...] $e$ alunos, aprendemos com a Experimentoteca (JOAQUIM, 1992, p. 172).

Como afirma o pesquisador, estas contribuições incidem tanto sobre a formação continuada de professores da educação básica, em qualquer momento de sua carreira; quanto sobre a formação continuada de formadores de professores, na educação superior, em especial nos momentos de seu engajamento no Projeto Experimentoteca (isto é, na etapa de desenvolvimento e teste dos kits experimentais). No entanto, a literatura registra, sobre a questão, apenas este comentário de Schiel, não se aprofundando a investigá-la mais detidamente.

A segunda via pela qual a Experimentoteca contribuiria para a formação de professores de ciências, por uma modalidade não acadêmica e assistemática, se refere a seu incentivo à organização dos docentes enquanto classe mobilizada politicamente. Trata-se, evidentemente, do papel que a existência dos kits desempenha para que os professores da educação básica, em sua práxis pedagógica, venham a se tornar mais conscientes da estrutura educacional em que atuam. Neste sentido, parece-nos que a Experimentoteca interviria como uma mediação entre os professores e as questões relacionadas à materialidade da educação, conforme as enunciamos no capítulo 4 desta tese. Como no caso anterior, há apenas uma menção, na literatura, sobre este aspecto; novamente é Schiel quem o aborda, em seu depoimento para o trabalho de Joaquim:

[Sob o título "A Experimentoteca como fator de mobilização"] A gente percebeu, nos cursos nacionais, que a Experimentoteca se tornou um elemento mobilizador. Em todos os cursos que a gente tem dado em outros estados, ao se fazer uma reunião final de avaliação, a discussão maior, que usualmente surge, não é em cima da Experimentoteca, mas em cima das condições de trabalho que o professor enfrenta diante das Secretarias de Educação (JOAQUIM, 1992, p. 176-177).

Consideramos este tema interessantíssimo do ponto de vista acadêmico, podendo ser mais bem esclarecido em pesquisas futuras. Partindo de nossas contribuições para o entendimento das relações entre a Experimentoteca e organização da estrutura educacional - contribuições estas que se amparam principalmente na produção de Dermeval Saviani, e estão representadas pelo conjunto constituído pelos capítulos 4 e 5 -, tais pesquisas poderiam analisar o processo pelo qual os processores de ciências, usuários do material do CDCC, viriam a se organizar 
como classe para-si, categoria gramsciana. Dado que Saviani se inspira deveras em Antonio Gramsci para elaborar sua filosofia educacional, estas investigações certamente estariam imunes ao ecletismo, dispondo de uma sólida unidade epistemológica e política.

Finalmente, a terceria via pela qual a Experimentoteca contribuiria para a formação de professores, como afirmamos, caminha entre as modalidades não acadêmica/sistematizada e acadêmica/sistematizada. Estamos nos referindo às oficinas e cursos oferecidos pela equipe do CDCC, visando à capacitação de docentes para o uso dos kits. São diversos os trabalhos, de alguma forma ligados ao CDCC (por serem textos que descrevem ou divulgam as atividades deste centro de ciências, ou por seus autores participarem ou terem participado destas atividades), que mencionam tais oportunidades para a formação continuada de professores: "O programa Experimentoteca prevê a capacitação dos professores usuários do sistema em cursos específicos" (SCHIEL, 1998, p. 194; SCHIEL; CURVELO; FERREIRA, 2004, p. 149), sendo necessário o "treinamento adequado e continuado do professor usuário" (SCHIEL; CURVELO; FERREIRA, 2004, p. 150); “[são oferecidos no CDCC] Cursos de atualização e/ou aperfeiçoamento destinados a professores do ensino fundamental e médio. São realizados cerca de cinco cursos para uma média de duzentos professores” (FERREIRA; SCHIEL, 2001, p. 614); "Do contato com professores ficou evidente a necessidade da criação de programas de formação continuada [de professores no CDCC]" (FERREIRA et al., 2004, p. 55). Mas, como dissemos, os trabalhos fazem apenas menções aos cursos e oficinas, sem detalhá-los. A comunicação abaixo é uma exceção, que explicita também o comprometimento destas atividades com a pesquisa relacionada ao Projeto Experimentoteca para o ensino médio:

A fase inicial de implementação da Experimentoteca do Ensino Médio de Física, projeto Instrumentação para o ensino de Ciências da Natureza e da Matemática, em desenvolvimento no Centro de Divulgação Científica e Cultural, USP, São Carlos, é discutida neste trabalho, considerando os resultados parciais obtidos das avaliações realizadas pelos professores do ensino médio e alunos da graduação, participantes de oficinas realizadas. $\mathrm{O}$ objetivo principal das oficinas para a formação continuada e inicial dos professores é proporcionar um ambiente em que os participantes possam discutir opções para seu trabalho em sala de aula, introduzindo novas metodologias e novos materiais didáticos. No desenvolvimento dos kits e dos roteiros foram consideradas as diretrizes fornecidas pelos PCNEM, a contextualização do cotidiano dos alunos através de questões prévias colocadas no início de cada experimento e a introdução de temas atuais como a física moderna. Foram realizadas avaliações das oficinas pelos participantes com o intuito de verificar se os objetivos específicos colocados na proposta inicial tais como interdisciplinaridade, construção de conhecimento e outras, estavam presentes nos experimentos realizados (SCHIEL et al., 2007, p. 86). 
A educadora Vanilde de Fátima Bongiorno, contratada pela USP desde 1986 para atuar no CDCC, em depoimento à dissertação de mestrado de Canales (2006), confirma o oferecimento destes cursos: "Nós sempre estamos dando cursos para que os professores melhorem o desempenho e também damos cursos específicos para que utilizem o material da Experimentoteca, inclusive em outras cidades que adquirem o material' (p. 134).

De fato, a literatura registra o oferecimento de cursos para a formação continuada de professores de ciências, com foco no uso da Experimentoteca, em outro município além de São Carlos. Uma equipe coordenada pelo Prof. Sergio de Mello Arruda, da Universidade Estadual de Londrina, viabilizou a difusão da Experimentoteca para uma rede que compreende cerca de 100 municípios do norte do Estado do Paraná. Posteriormente, com a criação do Museu de Ciência e Tecnologia de Londrina, foi possível organizar os cursos de capacitação para o uso dos kits do CDCC, direcionados a professores dos ensinos fundamental e médio (ZAPPAROLI; BUENO; ARRUDA, 2005). Carvalho e colaboradores (2006) relatam as seguintes impressões sobre estes cursos:

\begin{abstract}
os professores mais velhos sentiam-se auto-suficientes para a utilização dos kits e os mais novos tinham mais disposição à mudança e utilização dos kits, incrementando inclusive as experiências. [...] de acordo com os monitores, a perspectiva do professor ao utilizar a Experimentoteca é de estar utilizando um instrumento (diferente) de ensino em sala de aula, uma experiência nova, que precisa ser realizada para saber se vai haver resultados ou não [...].

Outra observação interessante se remete ao fato de que nos primeiros cursos, onde só foi abordado o uso da Experimentoteca, ficou a sensação de que algo estava faltando. Nos outros cursos, nos quais a professora que ministrava o curso também ofereceu outras práticas e perspectivas, além do uso dos kits, a satisfação dos professores aumentou muito. [...] o professor através da participação do curso e utilização da Experimentoteca conseguem [sic] modificar a sua formação no que se refere ao ensino e aprendizagem, compreendendo que é possível ensinar o aluno por meio de outros instrumentos (p. 3185-3186).
\end{abstract}

Parece consenso, portanto, que a Experimentoteca pode participar da formação de professores de ciências, não apenas de formas incidentais (não acadêmicas/assistemáticas), mas também através da orientação intencional e clara por parte de parceiros mais experientes e organizados institucionalmente.

No entanto, uma análise mais minuciosa da literatura revela que esta possibilidade é, mais do que isso, uma necessidade. As referências sobre a Experimentoteca sugerem que, sob a pena de se afastá-la de sua principal finalidade (o atendimento às escolas públicas, que são carentes de laboratórios científicos estruturados e operantes), o oferecimento de cursos destinados a familiarizar licenciandos com os kits deve ser encarado de forma séria pelas instituições formadoras. Vejamos como os autores desenvolvem esta questão. 
A primeira menção a respeito deste aspecto parte do depoimento de Schiel à dissertação de Joaquim; o coordenador da Experimentoteca constatara, à época, uma redução na quantidade de empréstimos de kits:

[Sob o título "O projeto exige atenção constante"] Houve uma fase de decréscimo no uso. Não sei se ainda está havendo. Infelizmente a gente tem que estar sempre dando impulso. $O$ ideal seria um sistema que uma vez que você empurrou, ele continuasse pela própria inércia, mas isso não ocorre. Se você não estiver sempre se preocupando, o uso acaba diminuindo. A principal causa é a alta rotatividade dos professores. Os primeiros professores que foram treinados foram embora e a gente não teve fôlego para repetir o treinamento. Então de uns 02 anos para cá, nós usamos a Convocação para Serviços Extraordinários para que os professores revejam a Experimentoteca, porque não se pode trabalhar com 03 ou 04 professores, que chegam novos a cada ano (JOAQUIM, 1992, p. 177).

Mais de uma década mais tarde, o estudo de Canales (2006) retoma a questão. Realizando um levantamento quantitativo da relação entre empréstimos às escolas públicas e às escolas privadas, a autora conclui que

Apesar do objetivo inicial desta iniciativa ser a colaboração ao aprendizado de ciências de estudantes de escolas estaduais, muitas escolas particulares e fundações também usufruem o laboratório ambulante, e desde o ano de 2000, ultrapassaram a rede pública no uso do material [...] Nota-se que o número de ambas as extrações [empréstimos], estadual e outras, tende a crescer, mas que comparativamente há um declínio do uso da Experimentoteca pelas escolas estaduais a partir do ano de 2000 (p. 104).

Canales, então, toma o depoimento da educadora Vanilde, que declara:

Depende do professor querer utilizar o material em sala de aula. Percebemos que os professores das escolas estaduais talvez se mantenham na aula tradicional, enquanto os das escolas particulares buscam um ensino mais eficiente. Mas nós facilitamos muito o uso da Experimentoteca para a rede pública. Até carro a gente disponibiliza para levar e buscar o material (p. 133).

Respondendo a outra questão, Vanilde também se refere ao fato mencionado por Schiel, o de que a rotatividade do corpo docente, nas escolas públicas, pode constituir um entrave para a atendimento da Experimentoteca a estas instituições:

Muitos professores da $5^{a}$ e $6^{a}$ séries fizeram parte dos primeiros 10 anos do CDCC. Eles utilizavam o material, discutiam com a gente sobre os experimentos, eram bem atuantes. Acredito que boa parte já se aposentou (ibidem, loc. cit.).

A partir destes depoimentos, Canales conclui que 
é necessário que haja um novo incentivo para que os novos professores usem o material. Apesar pertinência da observação feita por [Vanilde de Fátima] Bongiorno, há também a possibilidade dos professores da oitava série aplicarem mais o material da Experimentoteca visando à preparação do aluno para a entrada no ensino médio, o que demonstra uma preocupação menor com o ensino fundamental (ibidem, p. 103).

O fragmento acima, além de defender algum tipo de "incentivo" para que os professores novos, egressos dos cursos de licenciatura, utilizem o material do CDCC, referese também a questões mais profundas, que não teremos a oportunidade de estudar aqui. Mas vale a pena comentá-las rapidamente. Parece-nos que uma das dificuldades para a utilização mais frequente e consciente dos kits da Experimentoteca, por parte dos professores, decorre da falta de clareza a respeito das finalidades dos graus de ensino que constituem a educação básica. Enquanto que alguns docentes concebem o ensino fundamental como etapa terminal, de modo a prover os cidadãos com um mínimo de conhecimentos para sua inserção na vida social, outros o concebem como momento de preparação para o ensino médio. Nas escolas privadas o médio, por sua vez, não é visto como etapa terminal; o ensino é direcionado para a aprovação de um grande contingente de alunos nos exames vestibulares. É lógico que diferentes concepções sobre as finalidades dos graus fundamental e médio podem decidir pelo uso (ou não uso) da Experimentoteca por parte destes professores. Trata-se de outra questão a ser investigada por trabalhos futuros.

Retomando, há uma declaração interessante de Canales a respeito do maior uso da Experimentoteca por parte dos professores de escolas privadas:

Em 1986, quando efetivamente teve início a utilização da Experimentoteca pelas escolas, nota-se que mais de $95 \%$ das retiradas eram realizadas pela rede pública. Em 2005, apenas cerca de 40\% das retiradas são das escolas estaduais. Podemos atribuir essa queda à falta de incentivo que o professor da rede pública tem para manter um ensino eficiente, desmotivação reforçada pela má remuneração e pelas condições precárias das escolas. Outro dado a considerar é a constatação de que grande parte dos atuais professores do ensino básico, inclusive das escolas públicas, foi formada pelo ensino superior particular que, como sabemos, não prioriza a pesquisa. Portanto, esses professores não têm a formação necessária para incentivar seus alunos a penetrarem no mundo da pesquisa científica (ibidem, p. 115).

É verdade que nenhuma das referências analisadas propõe, explicitamente, que a Experimentoteca passe a fazer parte da formação inicial de professores de ciências, através de cursos ministrados como disciplinas nas licenciaturas. No entanto, em seu conjunto, a transcrição acima e as anteriores parecem propor que esta possibilidade efetivamente se concretize. 
Dado que a Experimentoteca é uma iniciativa do CDCC, nada mais natural do que investigar se e como este projeto é contemplado no curso de formação inicial de professores mais próximo, institucional e geograficamente, deste centro de ciências. Estamos falando da Licenciatura em Ciências Exatas, mais especificamente, de sua Habilitação em Química. Este será o assunto principal da próxima subseção.

\subsubsection{Contribuições à formação inicial de professores de Química}

A Licenciatura em Ciências Exatas recebeu sua primeira turma de ingressantes em 1993. Com a duração ideal de oito períodos (quatro anos), este curso é composto de disciplinas ministradas por três unidades da USP, campus de São Carlos: o Instituto de Ciências Matemáticas e de Computação, o Instituto de Química de São Carlos e o Instituto de Física de São Carlos. Esta última unidade é aquela que sedia a estrutura técnicoadministrativa do curso, embora sua gestão seja conduzida por representantes dos três institutos.

O currículo desta graduação - que forma professores para as disciplinas de Ciências, no ensino fundamental, e de Matemática, Química e Física, no ensino médio - é estruturado por um núcleo comum (disciplinas de conteúdo generalista, cobrindo desde tópicos das ciências físicas e naturais até a parte pedagógica) e pelas habilitações (que são três, optando o aluno por apenas uma delas, que cobrirá os tópicos mais específicos da disciplina do ensino médio que for por ele escolhida, o que é feito ao final do quarto período do curso).

Como as aulas ocorrem no período noturno, espera-se que durante o dia o licenciando ocupe-se com atividades mais ou menos relacionadas à atuação no campo das ciências ou no magistério, como iniciação científica, monitorias (geralmente sediadas no CDCC), participação no Pibid, e outros projetos extracurriculares, cuja carga horária pode ser aproveitada para a contagem de créditos ou para atender à exigência de horas dedicadas a atividades acadêmico-científico-culturais.

Neste momento de nossa pesquisa, decidimos que a Licenciatura em Ciências Exatas, e sua Habilitação em Química, deveriam ser o foco investigado para obtermos informações sobre as contribuições da Experimentoteca à formação inicial de professores. Como dissemos há pouco, existe uma proximidade institucional e geográfica entre o curso e o CDCC, e em 
tese, portanto, qualquer interseção entre a formação docente e este centro se apresentaria de modo mais desenvolvido na licenciatura oferecida pela própria USP, campus de São Carlos.

A propósito, a Habilitação em Química da Licenciatura em Ciências Exatas é composta por um rol de disciplinas teóricas e práticas de conteúdo específico sobre o conhecimento químico (Química Inorgânica, Química Orgãnica, Química Analítica, Análise Instrumental e Bioquímica - os cursos de Química Geral e Físico-Química já integram o núcleo geral), mais cursos relacionados ao campo da Educação em Química propriamente dito, que atualmente são ministrados como três disciplinas: duas de Estágio Supervisionado em Ensino de Química, mais uma disciplina recente intitulada Química, Sociedade e Cotidiano. Até há pouco, as disciplinas de Estágio Supervisionado recebiam o nome de Prática do Ensino de Química, uma disciplina única, com duração anual.

São estes cursos de estágio que nos interessam aqui e, em realidade, não se tratam de disciplinas dedicadas apenas à gestão e ao controle dos estágios supervisionados dos licenciandos nas escolas do ensino médio. No caso da Licenciatura em Ciências Exatas, estes cursos abarcam também os tópicos que, em outras licenciaturas, são abordados em uma disciplina de Metodologia do Ensino de Química (ou Didática do Ensino de Química). Parece-nos, assim, que se há algum momento em que os licenciandos em Química podem ter contato com a Experimentoteca e demais iniciativas do CDCC relacionadas à transmissão do conhecimento químico, é no interior deste curso sobre os estágios ou a prática do ensino.

Por uma feliz coincidência, a docente que foi responsável por esta(s) disciplina(s) por quase dez anos (e que atualmente ministra o curso de Química, Sociedade e Cotidiano), exerceu também a função de Coordenadora do Curso de Licenciatura em Ciências Exatas. Isto se mostrou fundamental para que decidíssemos entrevistá-la à busca de mais informações sobre as contribuições da Experimentoteca para a formação docente, já que a professora/pesquisadora, além de deter um conhecimento aprofundado sobre as questões relacionadas às disciplinas de Estágio Supervisionado/Prática do Ensino de Química, também dispõe de uma visão abrangente sobre a licenciatura como um todo.

Assim, em junho de 2014 agendamos uma entrevista, do tipo semi-estruturado, com a docente em questão, realizada em sua sala no IQSC-USP. Embora rápida, nossa conversa forneceu informações importantes, mas pelo fato desta ser apenas uma primeira investigação sobre o tema, não será possível abordar com profundidade todas as questões tangenciadas em nosso diálogo ${ }^{107}$.

\footnotetext{
${ }^{107}$ A transcrição da entrevista, e demais documentos a ela relacionados, estão dispostos nos "Anexos" desta tese.
} 
Uma das primeiras declarações da entrevistada, a respeito dos conteúdos abordados nas disciplinas de Estágio Supervisionado/Prática do Ensino de Química, mencionou a necessidade de que elas contemplassem a iniciação dos licenciandos na área da Educação em Ciências:

Então, a disciplina de Prática do Ensino de Química, ela é aquela que a gente tem em todos os cursos de licenciatura. E no caso aqui da USP ela agrega tanto as horas de estágio, né (que o professor tem que cobrar do aluno), quanto a parte teórica (que é pra dar subsídio pra ele atuar na escola, né). Então ela tem esses dois... essas duas frentes aí. Na parte teórica, o que a gente vê, é basicamente estratégias de ensino, avaliação da aprendizagem... na época houve um pouco de Filosofia da Ciência... [...] o que deu pra perceber ao longo dessa... desses dez anos que eu tô aqui, é que nessa época (quando eu peguei os alunos da Licenciatura), era inacreditável a falta de conhecimento que eles tinham sobre esses assuntos aí. Eles nunca tinham escutado falar em CTS, jamais em tempo algum, nem aprendizagem significativa [teoria da aprendizagem verbal significativa, de David Ausubel], nada disso. Agora, se você vai dar aula [...] pro aluno nosso, seguramente, quando ele chega na Prática de Ensino, ele tá muito mais bem preparado. Então nesse tempo aí, de 2003, a gente tinha que realmente introduzir tudo, até aquela história de falar de como que tinha evoluído o ensino de ciências, tudo isso eles precisavam ouvir. Agora já começa a ficar redundante pra se falar isso nessa disciplina...

$\mathrm{Na}$ fala acima, a professora/pesquisadora faz referência ao fato de que, com a reformulação do currículo da Licenciatura em Ciências Exatas, operada há poucos anos, houve a introdução novas disciplinas que oportunizaram esta iniciação à área, em outros momentos do curso. Há inclusive uma disciplina totalmente dedicada a isto - Panorama das Pesquisas na Área de Ensino de Ciências -, introduzida no sétimo período da graduação, concomitantemente ao Estágio Supervisionado em Ensino de Química I. De qualquer maneira, as disciplinas de estágio também servem para o estudo de tópicos resultantes da pesquisa em Educação em Ciências/Química, e mesmo a abordagem das chamadas estratégias de ensino (principal conteúdo de Estágio Supervisionado/Prática do Ensino de Química) se aproveita das discussões no âmbito da pesquisa. É o que se apreende da fala da entrevistada, quando perguntada se a questão da experimentação no ensino é um tópico abordado:

a experimentação também é um tópico, e eles usam bastante, né... [...] eles fazem, né, propõem experimentos pros alunos do ensino médio. [...] É, [a atividade de experimentação é mais presente] quando eles vão organizar as regências, ou os minicursos... [...]. Você vê sobre experimentação o que que são os fundamentos, os estilos de aulas experimentais, e depois eles iam propor os experimentos pra usar nos minicursos, né (no CDCC) [...]. E... a... a parte também da... das... dessas horas aí do estágio eles podem fazer como apoio ao docente: às vezes eles montam experimento pro professor aplicar lá, ou então eles vão [...] organizar o laboratório [escolar], enfim... Então a experimentação entra mais ou menos por esse... não que eles tenham aulas experimentais de precisar trabalhar experimentação com eles. 
Aliás, a experimentação, de acordo com o depoimento da professora/pesquisadora, acaba participando das disciplinas em questão de modo inevitável. Mas, frequentemente, o uso que os licenciandos fazem desta estratégia de ensino aparece dissociado da abordagem mais "epistemológica" e comprometida com a pesquisa em Educação em Ciências, aludida acima. Os experimentos didáticos, conta a docente, acabam por servir como elemento motivador para os estudantes da educação básica, quando os professores em formação vão a campo para suas atividades de estágio:

a gente tenta, né - até porque minhas linhas de pesquisa são da parte de Linguística, de texto de divulgação científica, de leitura -, a gente procura fazer com que os alunos, né, pensem em montar aulas que estejam um pouco voltadas pra essas outras, outros recursos aí - que é mapa conceitual, que é texto de divulgação científica, e por aí vai. Aí, especificamente com relação a texto de divulgação científica, a gente teve uma experiência bem interessante, que era na tese da L. N., né, que ela dizia pros alunos o que era texto de divulgação, eles trabalhavam em sala de aula com texto de divulgação e na regência tinha que ter um texto de divulgação científica no contexto do que iria ser proposto por eles. Mas quase todos usavam texto mas eles não deixavam de fazer alguma coisa... ["Incluir a experimentação...", interrompe o entrevistador] ...é, não tinha como eles não fazerem isso. E depois a gente fez entrevistas e eles falavam que é porque eles achavam que sem a experimentação os alunos não iam ter interesse no... no que eles iam falar. Então a experimentação é como se fosse, vamos dizer assim, né, o... coringa deles pra tentar atrair a atenção dos alunos. Isso aí ficou muito claro no... no trabalho da L.: eles fazem o que você quer, mas eles fazem a experimentação também... por conta disso - isso é engraçado! [risos]

$\mathrm{A}$ atividade de estágio mais vinculada às atividades do CDCC - o oferecimento de minicursos para alunos da educação básica, totalmente planejados e executados pelos licenciandos, e sediados inteiramente nas dependências do centro de ciências - também abarca atividades com experimentação, e de acordo com esta perspectiva associada à motivação:

Nesses dez anos aí a gente sempre ofereceu os minicursos lá. E não dá pra você oferecer um minicurso de Química sem fazer experimentação. Isso aí é quase o que o pessoal do CDCC também fala pra eles. Eu não acredito muito nisso não; acho que até dá. Mas a tendência é fazer. Porque realmente tem o apelo de atrair os alunos da educação básica com isso aí.

É justamente nos oferecimentos de minicursos que, segundo a entrevistada, a Experimentoteca comparece com maior força neste processo de formação inicial dos professores de Química. Perguntada se a Experimentoteca é utilizada pelos alunos da disciplina de Eságio Supervisionado/Prática do Ensino de Química, ela responde: 
Sim, bastante. Sem nenhuma indicação, assim, minha, né... Eles têm... eles montam a proposta do minicurso, depois eles vão lá construindo na sala de aula o que que vai ter em cada dia do minicurso. E eles sempre procuram saber, né, se o tema que eles vão trabalhar pode ser, de alguma maneira, subsidiado por experimentos que já estejam lá na... na Experimentoteca. Porque facilita até o trabalho no CDCC e tudo mais...

Em outro momento da entrevista, perguntada se a Experimentoteca estaria devidamente integrada à formação de professores de Química na Licenciatura em Ciências Exatas, a professora/pesquisadora fornece uma resposta semelhante:

a Experimentoteca, ela tá... Tá não assi... ela tá espontaneamente, né, integrada, porque de fato... dificilmente você tem um minicurso desses dez anos (que por ano a gente oferece lá uns dois, três)... se você pensar em 30 minicursos, deve ter tido uns três que não tinham nada da Experimentoteca. Porque ela tá pelo papel que ela tem, assim, sem ninguém precisar mandar, entendeu?... o aluno usar a Experimentoteca. Ela tá porque ela de fato ela é importante e facilita essa... esse entrosamento aí com os alunos da escola pública. Então... eu acredito que sim.

Assim, a situação revelada pela entrevistada atesta que a Experimentoteca, efetivamente, possui alguma participação no curso de formação de professores investigado. Não se trata, entretanto, de uma presença planejada ou intencional. Os kits experimentais do CDCC não participam dos momentos em que a experimentação no ensino de ciências é analisada e discutida enquanto estratégia de ensino. Sua presença se mostra nas atividades que os próprios licenciandos organizam em suas investidas nas escolas da educação básica ou no próprio $\mathrm{CDCC}$, para o cumprimento de suas horas de estágio supervisionado. Eles recorrem à Experimentoteca principalmente pela facilidade de acesso ao material, mas não são explicitamente incentivados a isto pela professora responsável pela disciplina de estágio.

Do ponto de vista das categorias que vimos explorando nas seções iniciais deste capítulo, poderíamos dizer que a Experimentoteca participa da formação inicial dos professores de Química, no curso de Licenciatura em Ciências Exatas, de modo informal, ou assistemático. Ela comparece, nas palavras precisas de nossa entrevistada, "meio que pela tangente", que acrescenta: "Ela vem quando é preciso, né... os alunos entendem que é um recurso interessante. E acho que na escola eles vêem também os professores usando, né...”. Ou seja, a presença da Experimentoteca no cenário educacional de São Carlos, já há 30 anos, tornou difícil se pensar a educação científica neste município, quanto à prática ou quanto à formação docente, desconsiderando este recurso.

Isto não significa que a participação da Experimentoteca, na formação inicial de professores de ciências, não necessite ser incrementada. Como os dados da pesquisa de 
Canales (2006) sugerem, seria desejável que este projeto do CDCC estivesse mais bem contemplado no processo de formação docente, já preparando e familiarizando os professores que irão atuar na escola pública para a lida com os kits experimentais. Confrontada com estas inferências, de nossa parte, a professora/pesquisadora entrevistada concordou: “Sim. É... é provável, né. De fato. No caso da Química é isso aí [...]”".

Portanto, a necessidade de que a participação da Experimentoteca no processo de formação inicial de professores deva se sistematizar - como indicado pelo conjunto de pesquisas revisadas na subseção anterior - permanece como uma demanda a ser atendida, embora já existam os espaços para os projetos do CDCC na formação acadêmica sistematizada de docentes de Química, no curso de licenciatura da USP São Carlos.

O fato de que esta sistematização ainda não tenha ocorrido, apesar da proximidade entre a Licenciatura em Ciências Exatas e o CDCC, parece-nos, também, um reflexo de decisões tomadas em um contexto mais amplo que o das disciplinas de Estágio Supervisionado/Prática do Ensino de Química. Foi na tentativa de esclarecer este ponto que nos valemos da experiência da entrevistada como Coordenadora de curso. Assim, quando a perguntamos se, no seu entender, o CDCC e seus projetos estariam bem integrados à Licenciatura em Ciências Exatas, sua resposta foi:

Então, eu acho que poderia haver uma integração maior. Mas, seguramente, os alunos da Licenciatura, eles têm uma participação muito grande lá. A gente tem vários monitores que são do curso de Licenciatura. [silêncio] Isso aí sim... nesse sentido ele tá integrado. Com relação ao oferecimento de minicurso, que eu saibaeu precisaria perguntar pros outros professores da Física [Instituto de Física de São Carlos] se eles oferecem minicurso lá... - eu não sei, acho que não... Então assim, essa coisa dos alunos da Licenciatura oferecerem atividades pro público lá no CDCC, porque eles são alunos da Licenciatura, eu acho que não... não existe muito.

Como ressalta a professora/pesquisadora, muito da participação dos licenciandos no CDCC decorre de fatores contingentes, não necessariamente relacionados à especificidade de sua condição como professores de ciências em formação: “Existem os [licenciandos] que tão lá [no CDCC] porque participam daquele... clube de ciências, enfim. Eles são alunos da Licenciatura como poderiam ser de outros cursos."

No entanto, isso não configuraria, exatamente, o tipo de relação desejável entre o curso de graduação e o centro de ciências, apesar de não haver indicações formais/oficiais claras a respeito de como viabilizar efetivamente tal relação: 
Seguramente... inclusive nas ideias, né, que deram origem ao curso, essa noção de que o CDCC tinha que ter uma... um estreitamento muito grande com o curso de Licenciatura era clara, tá em todos os documentos, se fala isso aí, que eles iriam ter... eles ti... chegaram a ter aula de Biologia lá no CDCC, nos primeiros anos do curso... Mas por alguma razão que não se diz, né, porque não se escreve - não tá nas atas, e o [Prof. Dietrich] Schiel já morreu, talvez ele pudesse responder -, nunca se aproximou tanto o curso de Licenciatura do CDCC como se gostaria. [...] Porque você poderia ter uma integração maior... Agora, por que razão isso não aconteceu embora tivesse previsto, né, e fosse desejado... aí a gente não sabe.

Especificamente quanto à Experimentoteca, também não parece ter havido, até o momento, iniciativas que buscassem incluí-la entre os conteúdos das disciplinas da Licenciatura em Ciências Exatas. Quando sugerimos, no decorrer da entrevista, a possibilidade de uma disciplina, "um curso específico que pudesse tratar da Experimentoteca", a entrevistada não se recordou de que algo nesta direção tenha sido pautado nas reuniões da Comissão Coordenadora do curso:

Ó, na minha gestão não. Mas, assim, não sei se isso já aconteceu um pouco mais pra trás, né, quando de fato existia esse... Na minha gestão, eu acho que essa palavra nunca foi mencionada em nenhuma reunião da CoC $-a$ "Experimentoteca", acho que nunca, jamais.

Há várias hipóteses que justificam este afastamento - ou, melhor dizendo, a precariedade da aproximação - entre o CDCC e a Licenciatura em Ciências Exatas. Primeiramente, é preciso considerar que este curso de graduação é razoavelmente recente possui, atualmente, pouco mais que 20 anos de existência -, o que dificulta que ele se apresente de modo a satisfazer tantas demandas perante o conjunto das unidades do campus de São Carlos da USP. Lembremos que se trata de um curso interunidades, ou seja, cuja gestão deve resultar da atuação consertada de três institutos com naturezas bastante diferentes, embora todos atuem na grande área das ciências exatas. Atender às expectativas e projetos de três unidades já deve ser, por si só, um encargo portenhoso ao curso - que dirá atender, também, às perspectivas e necessidades do próprio CDCC.

Outro fator que dificulta um relacionamento mais intenso entre o curso de formação inicial dos professores de ciências e o CDCC, pensamos nós, é o fato de seus conselhos administrativos (a Comissão Coordenadora do curso e o Conselho Deliberativo do CDCC) serem constituídos por diferentes sujeitos. De fato há indivíduos que podem participar de ambos os conselhos, mas isso não implica que as decisões tomadas em um colegiado devam estar, necessariamente, em sinergia com as decisões tomadas no outro. 
Deve-se considerar, também, que esta demanda de que a Experimentoteca, e o próprio CDCC, estejam mais contemplados na Licenciatura em Ciências Exatas - ou seja, participem da formação acadêmica sistematizada dos professores de ciências - nunca fora apresentada, com o devido fundamento em informações científicas, aos gestores deste curso. Sendo assim, a Experimentoteca, por exemplo, até comparece na formação inicial dos docentes de ciências, mas conforme as palavras de nossa entrevistada: "Ela nunca teve muito destaque na minha disciplina não, embora eu reconheça o valor que tem..." Talvez seja nesta lacuna que o resultado da presente tese de doutorado adquira sentido perante as unidades que administram a Licenciatura em Ciências Exatas: o conjunto das conclusões a que chegamos respalda a necessidade de que o CDCC, e a Experimentoteca, se façam mais presentes na formação inicial dos professores de ciências - ao menos, daqueles que concluirão seus estudos na Habilitação em Química do referido curso. Esse respaldo, então, pode ter algum papel nas esferas decisivas, para que acréscimos ou alterações no currículo da Licenciatura possam ser propostos.

Afinal, não nos esqueçamos da imprescindibilidade de uma visão de conjunto: é preciso incrementar a participação da Experimentoteca na formação inicial docente, visando a que no futuro ela se faça também mais presente na prática destes professores; e supondo que este recurso didático coloque os estudantes da educação básica em melhores condições de aprenderem os conteúdos científicos, aumentando também seu interesse pelas ciências, poderíamos esperar futuramente mais e melhores candidatos ao ingresso nas carreiras científicas do nível superior, incluindo a própria Licenciatura em Ciências Exatas.

Infelizmente, viabilizar uma disciplina que abarcasse o uso dos kits da Experimentoteca - conforme sugerimos no decorrer da entrevista relatada nesta subseção -, visando também atender a preceitos contemporâneos da Educação em Ciências (como os que são contemplados n'O livro da Experimentoteca), não é tarefa simples.

No VIII Encontro Nacional de Pesquisa em Educação em Ciências apresentamos o relato de um estudo exploratório sobre esta possibilidade (FREITAS; MORI; CURVELO, 2011b). Com a adesão de estudantes da Licenciatura em Ciências Exatas, elaboramos algumas atividades, envolvendo materiais da Experimentoteca e as premissas do programa Mão na Massa, e analisamos sua participação na condução do famigerado "experimento da vela" 108 .

\footnotetext{
${ }^{108} \mathrm{O}$ experimento da vela vem sendo utilizado há tempos pelos professores de ciências do mundo todo. Trata-se de uma montagem simples: uma vela acesa dentro de uma tina parcialmente preenchida com água é coberta por um recipiente de vidro ou uma campânula. Como consequência, extingue-se a chama da vela e o nível de água da região coberta da tina eleva-se.
} 
Esta atividade foi considerada interessante, para a situação formulada por nós, por oportunizar grandes discussões quanto à natureza dos fenômenos envolvidos; apesar de simples, trata-se de uma montagem que encerra acontecimentos relacionados a uma miríade de variáveis físico-químicas. Ajustaria-se perfeitamente, julgávamos, à natureza investigativa das atividades do Mão na Massa, e os kits da Experimentoteca dariam conta de atender à demanda dos licenciandos por materiais experimentais para seu estudo. No entanto, observamos, ao final dos exercícios, que os futuros professores apresentaram enormes dificuldades em compreender as características e o papel das atividades que realizamos - no caso, atividades inspiradas nas premissas do Mão na Massa -, demonstrando também, o que era mais preocupante, deficiências na mobilização e no desenvolvimento do próprio conhecimento científico.

Chegando ao fim desta tese, é necessário que retomemos os desenvolvimentos alcançados no decorrer dos extensos sete capítulos que a compõem.

Antes, gostaria - pedindo licença ao leitor, pela última vez, para o uso da primeira pessoa - de evocar as características de um empreendimento de pesquisa alinhado à perspectiva crítico-dialética, o que busquei concretizar com este trabalho.

Como afirmei no capítulo 4, citando Gamboa (2004), a pesquisa crítico-dialética apresenta notáveis divergências em relação às pesquisas do tipo empírico-analíticas e do tipo fenomenológico-hermenêuticas. Pretensiosamente, busca mesmo é superar estas duas tradições investigativas, ou seja, nega seus traços negativos (especialmente, o empirismo e a metafísica), preserva suas contribuições ao desenvolvimento da ciência e eleva tais contribuições a uma nova condição. Que condição é essa? Marx, na mais conhecida das Teses sobre Feuerbach, assevera que "Os filósofos apenas interpretaram o mundo de diferentes maneiras; o que importa é transformá-lo" (MARX; ENGELS, 2009, p. 122, grifo do autor). Ora, como afirma Frigotto (2004), em seu texto sobre "O enfoque da dialética materialista histórica na pesquisa educacional",

A ruptura radical da filosofida da práxis, em relação ao pensamento filosófico anterior, é exatamente que a preocupação fundamental é refletir, pensar, analisar a realidade com o objetivo de transformá-la (p. 82). 
O mesmo Frigotto considera também haver apenas duas posturas orientadoras de métodos de investigação. Uma é a metafísica, que pode ser identificável nas abordagens “empiricistas, positivistas, idealistas, ecléticas e estruturalistas" (ibidem, p. 74), dedicada a estabelecer representações sobre a realidade; representações que, no entanto, "não atingem as leis de organização, desenvolvimento e transformação dos fatos sociais" (ibidem, loc. cit.). A outra perspectiva é a dialética, que pressupõe a existência de uma realidade objetiva independente do pensamento humano, e que pode ser apreendida subjetivamente, em suas leis, como reflexo no plano da organização nervosa superior.

Se a abordagem metafísica busca o fenômeno e caminha no mundo da aparência, a abordagem dialética visa à essência e se assenta no mundo real. Se a abordagem metafísica se envolve na trama da existência positiva dos fenômenos que investiga, congelando seu movimento, a abordagem dialética procura exatamente o conceito, em sua concreticidade (apreensão do movimento e das leis da realidade objetiva no pensamento, síntese de determinações e relações). Se a abordagem metafísica se deixa envolver pela ideologia (falsa consciência), e serve mesmo à sua reprodução, a abordagem dialética desenvolve a consciência real através da teoria e da crítica.

Para Frigotto,

O entendimento do que seja o método dialético materialista inicia sua explicitação mediante a questão: como se produz concretamente um determinado fenômeno social? Ou seja, quais as "leis sociais", históricas, quais as forças reais que o constituem enquanto tal? Esta questão indica, ao mesmo tempo, no âmbito das ciências humano-sociais, o caráter sincrônico e diacrônico dos fatos, a relação sujeito e objeto, em suma, o caráter histórico dos objetos que investigamos (ibidem, p. 78).

Sintetizando as falas destes autores que dissertaram sobre a dialética na pesquisa em educação - além de Gamboa e Frigotto, também Sanfelice (2008) e Geraldo (2009), todos citados no início da seção 4.2 do capítulo 4, a qual sugiro que o leitor releia -, as categorias interessantes à investigação orientada por tal perspectiva são totalidade, contradição, mediação, ideologia e práxis. Vejamos de que maneira elas aparecem contempladas em nossos resultados.

Primeiramente, discuti nos capítulos 1 e 2 algumas concepções sobre educação, sobre psicologia e sobre suas interrelações, deparando-me com uma espécie de "ideologia", fartamente reproduzida nos meios acadêmicos, inclusive por autores de grande renome. Tratase do escamoteamento do caráter reacionário da pedagogia nova e, principalmente, do modo 
como ela aparece reeditada e atualizada como a pedagogia construtivista. Com estes capítulos, busquei demonstrar que uma pedagogia progressista - isto é, colocada na direção do movimento histórico, contrária, portanto, à continuidade do capitalismo - só pode se apresentar como uma superação das pedagogias da essência (tradicional) e da existência (escolanovismo - ou, por que não?, construtivismo). Esta pedagogia superadora, dialética, socialista - a Pedagogia Histórico-Crítica - só tem a ganhar com as contribuições de uma psicologia para a qual valem os mesmos adjetivos, a Psicologia Histórico-Cultural. Por isso, também quis realizar um trabalho de crítica ao modo como este referencial psicológico vem sendo apropriado e difundido por uma comunidade em especial - a que estou inserido, a comunidade brasileira da Educação em Química. A revisão crítica de trabalhos produzidos por este corpo de pesquisadores apontou para a existência de outra ideologia - ou, quiçá, a mesma manifesta no caso pedagógico. Refiro-me à tentativa de distanciar este referencial de sua fundamentação materialista dialética, tanto pela ocultação do fato de que Vigotski e seus colaboradores floresceram em um contexto de efervescência cultural e desenvolvimento das ciências visando à sociedade do "novo homem" (o homem comunista), quanto pela usurpação de seus conceitos de modo a aproximá-lo de perspectivas biologizantes, idealistas e, finalmente, reacionárias - o próprio construtivismo.

No capítulo seguinte, procurei nadar contra esta correnteza, o que não teria sido possível sem o auxílio da miríade de autores ali mencionados. Colaboradores da Pedagogia Histórico-Crítica ou não, eles forneceram a base sobre a qual pude avançar para uma teoria sobre a experimentação no ensino de ciências que levasse em consideração a historicidade da formação do psiquismo humano, assim como a subordinação da práxis experimental reiterativa (ou seja, a própria atividade experimental didática) à práxis educativa - esta, por sua vez, subordinada à práxis social mais ampla. A proposta teórica elaborada neste capítulo 3, em última análise, também buscou questionar a antiga concepção, associada à divisão social do trabalho, que deprecia o trabalho manual e elege o trabalho intelectual como forma mais desenvolvida da atividade humana. Defendi, recorrendo de colaboradores da Psicologia Histórico-Cultural (especialmente Leontiev) a estudiosos da atividade humana mediada por instrumentos, que a alegada separação entre corpo e psiquismo inexiste. Da mesma forma que o uso de instrumentos moldou a mão humana no âmbito anatômico, e determinou a gênese das sucessivas relações de produção até o nascimento da sociedade capitalista, a atividade mediada por instrumentos, devidamente orientada por um parceiro mais experiente, também é capaz de provocar o desenvolvimento do psiquismo no âmbito da ontogênese. 
O capítulo 4 abarcou um estudo sobre a materialidade do ensino de ciências, tomando o caso do município de São Carlos. Neste momento da tese, foi possível conhecer o conjunto de mediações que determinam a possibilidade da atividade experimental integrar a práxis educativa dos professores de ciências atuantes no município. O conjunto de estudos de campo ali relatados demonstrou que, sobre a operacionalidade dos laboratórios didáticos de ciências existentes nesta localidade, incidem diversas forças. Algumas atuam de forma contrária a que a experimentação se constitua como uma estratégia de ensino adotada pelos professores; tratase dos aspectos relacionados à inexistência de um sistema educacional, à questão da estrutura organizacional da educação e à questão da (des)continuidade das iniciativas, de um modo geral. Outras forças atuaram e atuam de forma a promover o ensino experimental em São Carlos. A Experimentoteca surge, aí, como uma mediação fundamental: este projeto não apenas incentiva, ele mesmo, a realização de atividades experimentais nas escolas; mais do que isso, foi a existência deste projeto que, num passado recente, orientou que uma equipe de pesquisadores ligados do CDCC providenciasse, em colaboração com duas escolas, a construção de seus laboratórios de ciências. Eis que a categoria contradição aparece aqui de modo surpreendente: o senso comum atribui à Experimentoteca um caráter desmobilizador, na medida em que acomodaria os docentes à situação de penúria material constatada nas escolas, pois se trata de um projeto de provimento de recursos didáticos; no entanto, esta pesquisa demonstrou que, por sua natureza, tal projeto exige estar inserido em um movimento mais amplo de pesquisa em Educação em Ciências, o que demandou a existência de laboratórios escolares de qualidade, que foram então, finalmente, construídos naquelas escolas.

Marcando o momento em que passo a falar mais intensamente sobre a Experimentoteca, o capítulo 5 situou este projeto do CDCC em um contexto histórico mais amplo, em que os centros e museus de ciências passam a, progressivamente, ocupar mais espaços no processo de formação dos indivíduos para a vida social. A Experimentoteca se mostrou, assim, herdeira de outras iniciativas que floresceram no solo brasileiro, ao mesmo tempo em que fortemente ligada a interesses locais da comunidade de educadores de São Carlos. A revisão dos (poucos) trabalhos que estudaram a Experimentoteca mais detidamente levou a que se pintasse o seguinte quadro: trata-se de um projeto, sem dúvidas, com contribuições importantes para a melhoria do ensino de ciências em São Carlos e em outros municípios, mas ainda com desafios a encarar. Perscrutando a natureza destes desafios, mais uma vez se revelou a natureza contraditória desta iniciativa do CDCC: pensada para auxiliar 
na realização de atividades experimentais nas escolas públicas, vem sendo cada vez mais utilizada pela rede privada de ensino; e disposta a ampliar o interesse dos estudantes pelas ciências e pelas carreiras científicas, tem atingido este objetivo numa intensidade desapontante. Quando busquei analisar a natureza desta ação educativa do CDCC a partir da Pedagogia Histórico-Crítica, conclui que a Experimentoteca possui sim grande relevância para o ensino e para uma práxis educativa orientada a partir desta perspectiva pedagógica, apesar de emanar de um centro de ciências - contexto que não faz parte dos interesses da teoria educacional elaborada por Dermeval Saviani. Este estudo final apontou que, para realizar sua função educativa de modo a potencializar e valorizar o ensino escolar - no lugar de querer sobrepujá-lo ou substituí-lo -, os centros e museus de ciências devem atuar sob a orientação do lema comunicar o conhecimento para (re)produzi-lo. Este lema se associa a uma função extensiva, entendida a extensão, neste caso, como relação bidirecional entre saberes acadêmicos e saberes populares, benéfica para ambos.

O capítulo 6 analisa a publicação que expõe os fundamentos pedagógicos da Experimentoteca. Na verdade, o que consta n'O livro da Experimentoteca é uma tentativa de dispor a iniciativa do CDCC pari passu com as perspectivas teóricas mais contemporâneas da Educação em Ciências. Nesse sentido, a Experimentoteca pode ser considerada como um ativismo, de início, que aos poucos foi se banhando em teoria. Em parte, a tarefa d'O livro da Experimentoteca parece bem sucedida, dada a competência dos colaboradores que se reuniram para redigi-lo. Apontei, neste capítulo, algumas possibilidades para o avanço do projeto, considerando os rumos potenciais ditados pelas teorias n'O livro, como a tendência ao ensino com enfoque CTS, a tendência ao ensino por investigação e a tendência à teoria dos perfis conceituais (teoria que se encontra em um estágio interessantíssimo, no campo da Educação em Química, recebendo contribuições de um conjunto amplo de pesquisadores, e em incessante elaboração por parte de seus formuladores).

Tanto o capítulo 6 como o capítulo 7 trataram da importância da fundamentação teórica em qualquer forma de práxis educativa. O capítulo 7 , entretanto, ressaltou a crítica às pedagogias do "aprender a aprender", que já haviam sido questionadas no capítulo 2, especialmente. Agora, o foco foi o modelo da epistemologia da prática, que tem orientado diversos agentes - da mídia ao meio acadêmico - em suas considerações a respeito de como deveria se processar a formação de professores. Se o capítulo 5 acabou por iluminar o tema da educação em museus a partir da Pedagogia Histórico-Crítica, o capítulo 7 fez o mesmo em relação ao tema da formação docente. Discutindo também algumas contribuições da 
Psicologia Histórico-Cultural para o mesmo assunto, este momento final acabou se mostrando o mais inacabado e incipiente entre todas as divisões da tese. O estudo das contribuições da Experimentoteca para a formação de professores, apesar de já realizado de modo perfunctório para alguns pesquisadores, encontrava-se num estágio tão elementar que não tive como aprofundar a questão. Decerto que poderia fazê-lo, mas isso estenderia por demais este capítulo final. Decidi por deixar pontas soltas, neste momento - expondo-me conscientemente à crítica - por entender que a questão merece um estudo à parte, integralmente dedicado a desvendá-la. Apesar disso, entendo ter reunido dados interessantes, e que mais uma vez outorgam um caráter contraditório à Experimentoteca: apesar da desejável presença do CDCC e de seus projetos no curso de Licenciatura em Ciências Exatas - o curso de graduação mais próximo, em termos institucionais, desse centro de ciências -, os kits de experimentos só comparecem, ao menos na formação dos professores de Química, de modo incidental, fortuito. Evidências reunidas em estudos anteriores sugerem que esta situação necessita ser transformada: analisando a relação entre a formação e a prática docente - ou seja, partindo de um olhar sobre a totalidade da questão do ensino de ciências em São Carlos e em outras regiões -, a presença da Experimentoteca na formação inicial dos professores pode contribuir para que este projeto se faça mais presente, também, na futura atividade de ensino destes docentes; isso acontecendo, o conhecimento em ciências, e o interesse por uma carreira científica, pode se intensificar entre os discentes da educação básica, beneficiando a Licenciatura em Ciências Exatas e o próprio CDCC a médio e longo prazos.

Em resumo, o conjunto de resultados atingidos com o presente trabalho realiza um estado da arte do conhecimento sobre a Experimentoteca, atestando as contribuições deste projeto para uma educação orientada por ideais progressistas. Ao mesmo tempo, tais resultados apontam as insuficiências e contradições que, se não forem desatadas, continuarão atravancando o potencial desta ação educativa em prol do ensino público e de qualidade. Finalmente, este texto, especialmente em seus três capítulos finais, registra um conjunto extenso de lacunas que, espero, venham a instigar a produção de novos trabalhos sobre a Experimentoteca.

Felizmente, há notícias de que novas investigações já estão se iniciando. Que elas possam aclarar os aspectos não contemplados aqui, e que imbuídas de um ânimo polêmico e crítico, contribuam com novas sínteses sobre a Experimentoteca e os demais assuntos correlatos, de que tratei neste texto. 


\section{REFERÊNCIAS}

AMARAL, E. M. R. Avaliando contribuições para a formação docente: uma análise de atividades realizadas no PIBID-Química da UFRPE. Química Nova na Escola, São Paulo, v. 34, n. 4, p. 229-239, 2012.

ANDRADE, G. T. B. Percursos históricos de ensinar ciências através de atividades investigativas. Ensaio: Pesquisa em Educação em Ciências, Belo Horizonte, v. 13, n. 1, p. 121-138, 2011.

ANDRÉ, M. E. D. A. Estudo de caso em pesquisa e avaliação educacional. Brasília: Líber Livro, 2005. 70 p. (Série pesquisa, v. 13).

ANUNCIAÇÃO, B. C. P.; MORADILLO, E. F. Pedagogia Histórico-Crítica: a incorporação de conceitos científicos no discurso em sala de aula. In: ENCONTRO NACIONAL DE ENSINO DE QUÍMICA, 16., 2012, Salvador. Anais... Salvador: UFBA, 2012. Disponível em:

<http://www.portalseer.ufba.br/index.php/anaiseneq2012/article/view/7242>. Acesso em: 25 jun. 2014.

BAPTISTA, G. C. S. Importância da demarcação de saberes no ensino de ciências para sociedades tradicionais. Ciência \& Educação, Bauru, v. 6, n. 3, p. 679-694, 2010. 
BOGDAN, R. C.; BIKLEN, S. K. Investigação qualitativa em educação: uma introdução à teoria e aos métodos. Tradução de Maria João Alvarez, Sara Bahia dos Santos e Telmo Mourinho Baptista. Porto: Porto Editora, 1994. 336 p. (Ciências da educação, v. 12).

BOSS, S. L. B.; SOUZA FILHO, M. P.; MIANUTTI, J.; CALUZI, J. J. Inserção de conceitos e experimentos físicos nos anos iniciais do ensino fundamental: uma análise à luz da teoria de Vigotski. Ensaio: Pesquisa em Educação em Ciências, Belo Horizonte, v. 14, n. 3, p. 289 312, 2012.

BRASIL. Lei no 9.394, de 20 de dezembro de 1996. Estabelece as diretrizes e bases da educação nacional. Diário Oficial [da] República Federativa do Brasil, Brasília, 23 dez. 1996. Disponível em: <www.planalto.gov.br/ccivil_03/leis/19394.htm>. Acesso em: 25 jun. 2014.

. Lei no 12.504, de 11 de outubro de 2011. Confere ao Município de São Carlos, no Estado de São Paulo, o título de Capital Nacional da Tecnologia. Diário Oficial [da] República Federativa do Brasil, Brasília, 13 out. 2011. Disponível em: <http://www.planalto.gov.br/CCIVIL_03/_Ato2011-2014/2011/Lei/L12504.htm>. Acesso em: 25 jun 2014.

. Ministério da Educação. Secretaria de Educação Fundamental. Parâmetros curriculares nacionais: introdução aos parâmetros curriculares nacionais. Brasília: $\mathrm{MEC} / \mathrm{SEF}, 1997.126 \mathrm{p}$.

. Ministério da Educação. Secretaria de Educação Fundamental. Referenciais para formação de professores. Brasília: MEC/SEF, 1999. 177 p.

BRONCKART, J. P.; BOTA, C. Bakhtin desmascarado: história de um mentiroso, de uma fraude, de um delírio coletivo. Tradução de Marcos Marcionilo. São Paulo: Parábola, 2012. 511 p. (Lingua[gem], v. 45).

CAMILLO, J. Experiências em contexto: a experimentação numa perspectiva sócio-culturalhistórica. 2011. 175 f. Dissertação (Mestrado em Ensino de Ciências)-Instituto de Física, Instituto de Química, Instituto de Biociências, Faculdade de Educação, Universidade de São Paulo, São Paulo, 2011.

CANALES, R. P. O Centro de Divulgação Científica e Cultural da Universidade de São Paulo: um projeto de extensão universitária. 2006. 143 f. Dissertação (Mestrado em Educação)-Centro de Educação e Ciências Humanas, Universidade Federal de São Carlos, São Carlos, 2006. 
CARVALHO, J. S. F. Construtivismo: uma pedagogia esquecida da escola. Porto Alegre: Artmed, 2001. $132 \mathrm{p}$.

CARVAlHO, M. A.; BUENO, E. A. S.; ZAPPAROLI, F. V. D.; ARRUDA, S. M. Uma proposta de atividade didática na capacitação dos professores de ciências. In: EDUCERE CONGRESSO NACIONAL DE EDUCAÇÃO DA PUCPR, 6., 2006, Curitiba. Anais... Curitiba: Champagnat, 2006. p. 3179-3189. Disponível em:

$<$ http://www.pucpr.br/eventos/educere/educere2006/anaisEvento/docs/CI-293-TC.pdf $>$. Acesso em: 25 jun. 2014

CAZELLI, S.; MARANDINO, M.; STUDART, D. Educação e comunicação em museus de ciências: aspectos históricos, pesquisa e prática. In: GOUVÊA, G.; MARANDINO, M.; LEAL, M. C. (Org.). Educação e museu: a construção social do caráter educativo dos museus de ciências. Rio de Janeiro: Access/Faperj, 2003. p. 83-106.

CENTRO DE DIVULGAÇÃO CIENTÍFICA E CULTURAL. São Carlos: CDCC/USP, [200]. Disponível em: 〈http://cdcc.sc.usp.br>. Acesso em: 25 dez. 2013.

CHALMERS, A. F. O que é ciência, afinal? Tradução de Raul Fiker. São Paulo: Brasiliense, 1993. $225 \mathrm{p}$.

COLE, M. C.; JOHN-STEINER, V.; SCRIBNER, S.; SOUBERMAN, E. Prefácio dos organizadores da obra. In: VIGOTSKY, L. S. A formação social da mente: o desenvolvimento dos processos psicológicos superiores. Tradução de José Cipolla Neto, Luís Silveira Menna Barreto e Solange Castro Afeche. 7. ed. São Paulo: Martins Fontes, 2007. p. xii-xv. (Psicologia e pedagogia).

COLEN, J. 17 anos de Química Nova na Escola: notas de alguém que a leu como estudante no ensino médio e no ensino superior com aspirações à docência. Química Nova na Escola, São Paulo, v. 34, n. 1, p. 16-20, 2012.

CUNHA, L. A. A atuação de Dermeval Saviani na educação brasileira: um depoimento. In: SILVA JÚNIOR, C. A.; SEVERINO, A. J. (Org.). Dermeval Saviani e a educação brasileira: o simpósio de Marília. São Paulo: Cortez, 1994. p. 41-62.

CUNHA, M. B. Jogos no ensino de Química: considerações teóricas para sua utilização em sala de aula. Química Nova na Escola, São Paulo, v. 34, n. 2, p. 92-98, 2012.

DEWEY, J. Vida e educação: I. A criança e o programa escolar. II. Interesse e esforço. Tradução de Anísio Spínola Teixeira. 10. ed. São Paulo: Melhoramentos/Fundação Nacional de Material Escolar, 1978. 113 p. (Biblioteca de educação. Série “Iniciação e debate”). 
DIB, C. Z. Formal, non formal and informal education: concepts/applicability. American Institute of Physics Conference Proceedings, New York, v. 173, p. 300-315, 1988.

DINIZ, R. E. S. A experimentação e o ensino de ciências no $1^{\circ}$ grau: analisando a Experimentoteca de $7^{\mathrm{a}}$ série. 1992. 228 f. Dissertação (Mestrado em Educação)-Centro de Educação e Ciências Humanas, Universidade Federal de São Carlos, São Carlos, 1992.

DUARTE, N. Elementos para uma ontologia da educação na obra de Dermeval Saviani. In: SILVA JÚNIOR, C. A.; SEVERINO, A. J. (Org.). Dermeval Saviani e a educação brasileira: o simpósio de Marília. São Paulo: Cortez, 1994. p. 129-149.

. A escola de Vigotski e a educação escolar: algumas hipóteses para uma leitura pedagógica da psicologia histórico-cultural. Psicologia USP, São Paulo, v. 7, n. 1-2, p. 17-50, 1996.

. Vigotski e o "aprender a aprender": crítica às apropriações neoliberais e pósmodernas da teoria vigotskiana. 4. ed. Campinas: Autores Associados, 2006. 297 p.

Educação escolar, teoria do cotidiano e a escola de Vigotski. 4. ed. Campinas: Autores Associados, 2007. 115 p. (Polêmicas do nosso tempo, 55).

. Por que é necessário uma análise crítica marxista do construtivismo? In: LOMBARDI, J. C.; SAVIANI, D. (Org.). Marxismo e educação: debates contemporâneos. 2. ed. Campinas: Autores Associados/HISTEDBR, 2008. p. 203-221.

. Conhecimento tácito e conhecimento escolar na formação do professor (por que

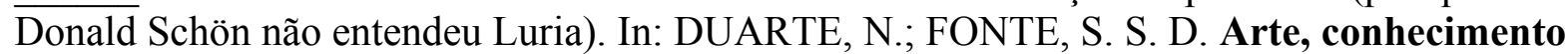
e paixão na formação humana: sete ensaios de pedagogia histórico-crítica. Campinas: Autores Associados, 2010a. p. 7-37. (Coleção educação contemporânea).

Por uma educação que supere a falsa escolha entre etnocentrismo e relativismo cultural. In: DUARTE, N.; FONTE, S. S. D. Arte, conhecimento e paixão na formação humana: sete ensaios de pedagogia histórico-crítica. Campinas: Autores Associados, 2010b. p. 101-120. (Coleção educação contemporânea).

DUARTE, N.; FERREIRA, B. J. P.; MALANCHEN, J.; MULLER, H. V. O. A pedagogia histórico-crítica e o marxismo: equívocos de (mais) uma crítica à obra de Dermeval Saviani. In: SAVIANI, D.; DUARTE, N. (Org.). Pedagogia histórico-crítica e luta de classes na educação escolar. Campinas: Autores Associados, 2012. p. 87-119. (Coleção polêmicas do nosso tempo). 
ECHEVERRÍA, A. R. Como os estudantes concebem a formação de soluções. Química Nova na Escola, São Paulo, n. 3, p. 15-18, 1996.

EL-HANI, C. N.; BIZZO, N. M. V. Formas de construtivismo: mudança conceitual e construtivismo contextual. Ensaio: Pesquisa em Educação em Ciências, Belo Horizonte, v. 4, n. 1, p. 1-25, 2002.

EL-HANI, C. N.; MORTIMER, E. F.; SILVA FILHO, W. J. As bases epistemológicas da teoria dos perfis conceituais. In: ENCONTRO NACIONAL DE PESQUISA EM

EDUCAÇÃO EM CIÊNCIAS, 9., 2013, Águas de Lindóia. Atas... São Paulo: Abrapec, 2013. Disponível em: <http:/www.nutes.ufrj.br/abrapec/ixenpec/atas/resumos/R0941-1.pdf>.

Acesso: 25 jun. 2014.

ENGELS, F. Dialéctica da natureza. Tradução de Joaquim José Moura Ramos e Eduardo Lúcio Nogueira. Lisboa: Presença; São Paulo: Martins Fontes, 1974. 341 p. (Colecção síntese, v. 5).

FACCI, M. G. D. Valorização ou esvaziamento do trabalho do professor?: um estudo crítico-comparativo da teoria do professor reflexivo, do construtivismo e da psicologia vigotskiana. Campinas: Autores Associados, 2004. 293 p. (Coleção formação de professores).

. Crítica às pedagogias do "aprender a aprender": a naturalização do desenvolvimento humano e a influência do construtivismo na educação. In: MARSIGLIA, A. C. G. (Org.). Pedagogia histórico-crítica: 30 anos. Campinas: Autores Associados, 2011. p. 121-146. (Coleção memória da educação).

FALK, J. H.; DIERKING, L. D. Learning from museums: visitor experiences and the making of meaning. Laham: AltaMira, 2000. 272 p.

FERREIRA, E. R. O.; CASTRO, A. C.; SANTOS, S. A. M.; SCHIEL, D. Características, estrutura e desenvolvimento do trabalho do Centro de Divulgação Científica e Cultural. Divulgações do Museu de Ciências e Tecnologia, Porto Alegre, n. 4, p. 55-60, 2004.

FERREIRA, E. R. O.; SCHIEL, D. Centro de Divulgação Científica e Cultural. In: CRESTANA, S.; HAMBURGER, E. W.; SILVA, D. M.; MASCARENHAS, S. (Org.). Educação para a ciência: curso de treinamento em centros e museus de ciência. São Paulo: Livraria da Física, 2001. p. 611-615.

FERREIRA, F. P.; PINTO JUNIOR, F. F.; MORI, R. C. Experimentação no ensino de ciências: práticas e concepções de docentes de escolas públicas e privadas do município de 
São Carlos. In: ENCONTRO PAULISTA DE PESQUISA EM ENSINO DE QUÍMICA, 5., 2009, Ribeirão Preto. Resumos... Ribeirão Preto: FFCLRP-USP, 2009. 1 v.

FOCETOLA, P. B. M. Os jogos educacionais de cartas como estratégia de ensino em Química. Química Nova na Escola, São Paulo, v. 34, n. 4, p. 248-255, 2012.

FRANCISCO JUNIOR, W. E.; FERREIRA, L. H; HARTWIG, D. Experimentação problematizadora: fundamentos teóricos e práticos para a aplicação em salas de aula de ciências. Química Nova na Escola, São Paulo, n. 30, p. 34-41, 2008.

FREIRE, P. Extensão ou comunicação? Tradução de Rosisca Darcy de Oliveira. Rio de Janeiro: Paz e Terra, 1977. 93 p. (O mundo hoje, v. 24).

FREITAS, J. F.; MORI, R. C.; CURVELO, A. A. S. Materiais didáticos voltados para o nível representacional da Química e possibilidades de emprego na formação inicial docente. In: ENCONTRO PAULISTA DE PESQUISA EM ENSINO DE QUÍMICA, 6., 2011, São Carlos. Anais... São Carlos: CDCC/USP, 2011a. 1 CD-ROM.

. O experimento da vela na formação inicial do professor de ciências. In: ENCONTRO NACIONAL DE PESQUISA EM EDUCAÇÃO EM CIÊNCIAS, 8., 2011, Campinas. Anais... Rio de Janeiro: Abrapec, 2011. Disponível em: $<$ http://www.nutes.ufrj.br/abrapec/viiienpec/resumos/R0795-1.pdf $>$. Acesso em: 25 jun. 2014.

FRIGOTTO, G. O enfoque da dialética materialista histórica na pesquisa educacional. In: FAZENDA, I. (Org.). Metodologia de pesquisa educacional. 9. ed. São Paulo: Cortez, 2004. p. 69-90. (Biblioteca da educação, série I, escola, v. 11).

FUNDAÇÃO PRÓ-MEMÓRIA DE SÃO CARLOS. Percursos. 2. ed. São Carlos: Prefeitura Municipal de São Carlos/Fundação Pró-Memória de São Carlos, 2013. v. 1, conjunto de 25 cartões ilustrados, $10 \mathrm{~cm} \times 15 \mathrm{~cm}$.

GAMBOA, S. A. S. A dialética na pesquisa em educação: elementos de contexto. In: FAZENDA, I. (Org.). Metodologia de pesquisa educacional. 9. ed. São Paulo: Cortez, 2004. p. 91-115. (Biblioteca da educação, série I, escola, v. 11).

GASPAR, A. Museus e centros de ciências: conceituação e proposta de um referencial teórico. 1993. 173 f. Tese (Doutorado em Educação)-Faculdade de Educação, Universidade de São Paulo, São Paulo, 1993.

. Experiências de ciências: para o ensino fundamental. São Paulo: Ática, 2003. 327 p. 
GASPAR, A. A teoria de Vigotski: um novo e fértil referencial para o ensino das ciências. 2006. 192 f. Tese (Livre docência)-Faculdade de Engenharia, Universidade Estadual Paulista Julio de Mesquita Filho, Guaratinguetá, 2006.

GEELAN, D. R. Epistemological anarchy and the many forms of constructivism. Science \& Education, Dordrecht, v. 6, n. 1-2, p. 15-28, 1997.

GERALDO, A. C. H. Didática de ciências naturais na perspectiva histórico-crítica. Campinas: Autores Associados, 2009. 171 p. (Coleção formação de professores).

HANFMANN, E.; VAKAR, G. Prefácio à tradução inglesa. In: VYGOTSKY, L. S. Pensamento e linguagem. Tradução de Jefferson Luiz Camargo; revisão técnica de José Cipolla Neto. 3. ed. São Paulo: Martins Fontes, 2005. p. xv-xvii.(Psicologia e pedagogia).

HERBART, J. F. Pedagogia geral. Tradução de Ludwig Scheidl. Lisboa: Fundação Calouste Gulbenkian, 2003. 230 p.

HOFSTEIN, A.; AIKENHEAD, G.; RIQUARTS, K. Discussions over STS at the fourth IOSTE symposium. International Journal of Science Education, Londres, v. 10, n. 4, p. 357-366, 1988.

INGOLD, T. Tool-use, sociality and intelligence. In: GIBSON, K. R.; INGOLD, T. (Ed.). Tools, language and cognition in human evolution. Cambridge: Cambridge University, 1994. p. 429-445.

JACOBUCCI, D. F. C. Contribuições dos espaços não-formais de educação para a formação da cultura científica. Em Extensão, Uberlândia, v. 17, p. 55-66, 2008.

JOAQUIM, C. L. M. Estudando a experimentação no ensino de ciências. 1992. 195 f. Dissertação (Mestrado em Educação)-Centro de Educação e Ciências Humanas, Universidade Federal de São Carlos, São Carlos, 1992.

KONDER, L. O que é dialética. 6. reimpr. da 28. ed. de 1998. São Paulo: Brasiliense, 2008. 87 p. (Coleção primeiros passos, v. 23).

KOSÍK, K. Dialética do concreto. Tradução de Célia Neves e Alderico Toríbio. 5. ed. Rio de Janeiro: Paz e Terra, 1989. 230 p. (Rumos da cultura moderna, v. 26). 
KRASILCHIK, M. O professor e o currículo das ciências. São Paulo: EPU, 1987. 84 p. (Temas básicos de educação e ensino).

LABURÚ, C. E.; SILVA, M. R. Do relativismo no ensino de física ao objetivismo na física. Investigações em Ensino de Ciências, Porto Alegre, v. 5, n. 2, p. 121-154, 2000.

LAVILLE, C.; DIONNE, J. A construção do saber: manual de metodologia da pesquisa em ciências humanas. Revisão técnica e adaptação por Lana Mara Siman. Belo Horizonte:

UFMG; Porto Alegre: Artmed, 1999. 340 p.

LEFEBVRE, H. Lógica formal, lógica dialética. Tradução de Carlos Nelson Coutinho. 3. ed. Rio de Janeiro: Civilização Brasileira, 1983. 301 p. (Coleção perspectivas do homem, v. 100).

LEONTIEV, A. N. ${ }^{109}$ O desenvolvimento do psiquismo. Tradução de Manuel Dias Duarte. Lisboa: Horizonte, 1978. 350 p. (Horizonte universitário, v. 14).

LIBÂNEO, J. C. Democratização da escola pública: a pedagogia crítico-social dos conteúdos. 6. ed. São Paulo: Loyola, 1988.149 p. (Educar, v. 1).

. Minha convivência com Dermeval Saviani. In: SILVA JÚNIOR, C. A.; SEVERINO, A. J. (Org.). Dermeval Saviani e a educação brasileira: o simpósio de Marília. São Paulo: Cortez, 1994. p. 22-31.

. A aprendizagem escolar e a formação de professores na perspectiva da psicologia

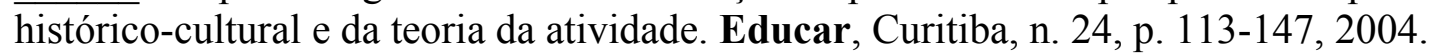

. Reflexividade e formação de professores: outra oscilação do pensamento pedagógico brasileiro?. In: PIMENTA, S. G.; GHEDIN, E. (Org.). Professor reflexivo no Brasil: gênese e crítica de um conceito. 3. ed. São Paulo: Cortez, 2005. p. 53-79.

LOMBARDI, J. C. Educação, ensino e formação profissional em Marx e Engels. In:

LOMBARDI, J. C.; SAVIANI, D. (Org.). Marxismo e educação: debates contemporâneos. 2. ed. Campinas: Autores Associados/HISTEDBR, 2008. p. 1-38.

LONGAREZI, A. M.; ARAÚJO, E. S.; FERREIRA, S. La sicologia histórico-cultural en la formacion del professional docente. Estudios Pedagógicos, Valdivia, v. 32, n. 2, p. 199-211, 2007.

\footnotetext{
${ }^{109}$ Consta apenas "Alexis Leontiev", tendo sido omitido o nome do meio "Nikolaevich".
} 
LOPES, A. R. C. Livros didáticos: obstáculos verbais e substancialistas ao aprendizado da ciência química. Revista Brasileira de Estudos Pedagógicos, Brasília, v. 74, n. 177, p. 309334, 1993.

LÜDKE, M.; ANDRÉ, M. E. D. A. Pesquisa em educação: abordagens qualitativas. São Paulo: EPU, 1988. 99 p. (Temas básicos de educação e ensino).

MACHADO, A. H.; MOURA, A. L. A. Concepções sobre o papel da linguagem no processo de elaboração conceitual em Química. Química Nova na Escola, São Paulo, n. 2, p. 27-30, 1995.

MANACORDA, M. A. Marx e a pedagogia moderna. Tradução de Newton Ramos-deOliveira, revisão técnica de Paolo Nosella, prefácio de Dermeval Saviani. 2. ed. rev. Campinas: Alínea, 2010. 216 p. (Educação em debate).

MARANDINO, M. (Org.). Educação em museus: a mediação em foco. São Paulo: Geenf/FEUSP. 2008. 38 p.

MARANDINO M.; SILVEIRA, R. V. M.; CHELINI, M. J.; FERNANDES, A. B.; RACHID, V.; MARTINS, L. C.; LOURENÇO, M. F.; FERNANDES, J. A.; FLORENTINO, H. A. A educação não formal e a divulgação científica: o que pensa quem faz. In: ENCONTRO NACIONAL DE PESQUISA EM EDUCAÇÃO EM CIÊNCIAS, 4., 2003, Bauru. Anais... Bauru: Abrapec, 2003. 1 CD-ROM.

MARTINS, J. B. A importância do livro Psicologia Pedagógica para a teoria históricocultural de Vigotski. Análise Psicológica, Lisboa, v. 28, n. 2, p. 343-357, 2010.

MARTINS, L. M. O legado do século XX para a formação de professores. In: MARTINS, L. M.; DUARTE, N. (Org.). Formação de professores: limites contemporâneos e alternativas necessárias. São Paulo: Unesp/Cultura Acadêmica, 2010. 191 p. Disponível em:

$<$ http://books.scielo.org/id/ysnm8>. Acesso em: 25 jun. 2014.

. Pedagogia histórico-crítica e psicologia histórico-cultural. In: MARSIGLIA, A. C. G. (Org.). Pedagogia histórico-crítica: 30 anos. Campinas: Autores Associados, 2011. p. 43-57. (Coleção memória da educação).

MARX, K. Manuscritos econômico-filosóficos e outros textos escolhidos. Seleção de textos de José Arthur Giannotti; tradução de José Carlos Bruni, José Arthur Giannotti e Edgard Malagodi. 4. ed. São Paulo: Nova Cultural, 1987. 215 p. (Os pensadores, v. 35). 
MARX, K. Contribuição à crítica da economia política. Introdução e tradução, a partir de versões em inglês, francês e espanhol, de Florestan Fernandes. 3 reimpr. da 2. ed. São Paulo: Expressão Popular, 2013. 288 p.

MARX, K.; ENGELS, F. A sagrada família: ou crítica da Crítica crítica contra Bruno Bauer e consortes. Tradução de Fiama Hasse Pais Brandão, João Paulo Casquilho e José Bettencourt. Lisboa/São Paulo: Presença/Martins Fontes, 1974a. 328 p. (Colecção síntese, v. 17).

Textos filosóficos. Tradução de Carlos Grifo. 2. ed. Lisboa: Presença, 1974b. 113 p. (Biblioteca de ciências humanas).

. Crítica da educação e do ensino. Introdução, tradução e notas de Roger Dangeville. Lisboa: Moraes, 1978. 265 p. (Psicologia e pedagogia).

. Manifesto do Partido Comunista. Traduzido do alemão por Marcus Vinicius Mazzari. Estudos Avançados, São Paulo, v. 12, n. 34, p. 7-46, 1998. $128 \mathrm{p}$. . A ideologia alemã. Tradução de Álvaro Pina. São Paulo: Expressão Popular, 2009.

MATTHEWS, M. R. Science teaching: the role of history and philosophy of science. New York: Routledge, 1994. 287 p.

. Construtivismo e o ensino de ciências: uma avaliação. Tradução de Claudia Mesquita e Roberto Nardi. Caderno Catarinense de Ensino de Física, Florianópolis, v. 17, n. 3, p. 270-294, 2000.

MAZZEU, L. T. B. A política educacional e a formação de professores: reflexões sobre os fundamentos teóricos e epistemológicos da reforma. In: MARSIGLIA, A. C. G (Org.). Pedagogia histórico-crítica: 30 anos. Campinas: Autores Associados, 2011. p. 146-167. (Coleção memória da educação).

McMANUS, P. Topics in museums and science education. Studies in Science Education, Leeds, v. 20, n. 1, p. 157-182, 1992.

MIZUKAMI, M. G. N. Ensino: as abordagens do processo. São Paulo: EPU, 1986. 119 p. (Temas básicos de educação e ensino). 
MEGID NETO, J. Tendências da pesquisa acadêmica sobre o ensino de ciências no nível fundamental. 1999. 2 v. Tese (Doutorado em Educação)-Faculdade de Educação,Universidade Estadual de Campinas, Campinas, 1999.

MORI, R. C. Análise de experimentos que envolvem Química presentes nos livros didáticos de Ciências de $1^{\mathrm{a}}$ a $4^{\mathrm{a}}$ séries do ensino fundamental avaliados no PNLD/2007. 2009. 202 f. Dissertação (Mestrado em Físico-Química)-Instituto de Química de São Carlos, Universidade de São Paulo, 2009.

MORTIMER, E. F. Para além das fronteiras da Química: relações entre filosofia, psicologia e ensino de Química. Química Nova, São Paulo, v. 20, n. 2, p. 200-207, 1997.

. Linguagem e formação de conceitos no ensino de ciências. Belo Horizonte: $\overline{\mathrm{UFMG}}, 2000.383$ p. (Aprender, v. 24).

. Dez anos de Química Nova na Escola: a consolidação de um projeto da Divisão de Ensino da SBQ. Química Nova na Escola, São Paulo, n. 20, p. 3-10, 2004.

MORTIMER, E. F.; CARVALHO, A. M. P. Referenciais teóricos para análise do processo de ensino de ciências. Cadernos de Pesquisa, São Paulo, n. 96, p. 5-14, 1996.

NOGUEIRA, M. A. Educação, saber, produção em Marx e Engels. Prefácio de Dermeval Saviani. 2. ed. São Paulo: Cortez, 1993. 220 p.

NOSELLA, P. Trabalho e perspectivas de formação dos trabalhadores: para além da formação politécnica. Revista Brasileira de Educação, Rio de Janeiro, v. 12, n. 34, p. 137-151, 2007.

PEDROSA, E. M. P.; LEITE, L. S. A epistemologia dialética materialista e o ensino de ciências naturais: algumas reflexões. Acta Tecnológica - Revista Científica, São Luís, v. 6, n. 2, p. 37-44, 2011.

PENHA, J. O que é existencialismo. 6. ed. São Paulo: Brasiliense, 1986. 123 p. (Coleção primeiros passos, v. 61).

PEREIRA, O. O que é teoria. 4. ed. São Paulo: Brasiliense, 1985. 92 p. (Coleção primeiros passos, v. 59).

PIAGET, J. Psicologia e pedagogia.Tradução de Dirceu Accioly Lindoso e Rosa Maria Ribeiro da Silva. Rio de Janeiro: Forense-Universitária, 1972. 182 p. 
PIAGET, J. A epistemologia genética: Sabedoria e ilusões da filosofia; Problemas de psicologia genética. Tradução de Nathanael C. Caixeiro, Zilda Abujamra Daeir e Celia E. A. Di Piero. São Paulo: Abril Cultural, 1978. 296 p. (Os pensadores, v. 51).

PINHO ALVES, J. Atividades experimentais: do método à prática construtivista. 2000. 312 f. Tese (Doutorado em Educação)-Centro de Ciências da Educação, Universidade Federal de Santa Catarina, Florianópolis, 2000a.

. Regras da transposição didática aplicadas ao laboratório didático. Caderno Brasileiro de Ensino de Física, Florianópolis, v. 17, n. 2, p. 174-188, 2000 b.

POSNER, G. J.; STRIKE, K. A.; HEWSON, P. W.; GERTOZG, W. A. Accommodation of a scientific conception: toward a theory of conceptual change. Science Education, New York, v. 66, n. 2 , p. $211-217,1982$.

PRESTES, Z. Quando não é quase a mesma coisa: as traduções de Lev Semionovitch Vigotski no Brasil. Campinas: Autores Associados, 2012. 272 p. (Coleção educação contemporânea).

REIS, J. C.; GUERRA, A.; BRAGA, M. Ciência e arte: relações improváveis? História, Ciências, Saúde - Manguinhos, Rio de Janeiro, v. 13 (suplemento), p. 71-87, 2006.

SAMPAIO, F. A. A.; CARVALHO, A. F. Com a palavra, o autor: em nossa defesa: um elogio à importância e uma crítica às limitações do Programa Nacional do Livro Didático. São Paulo: Sarandi, 2010. 432 p.

SÁNCHEZ VÁZQUEZ, A. Filosofia da práxis. Tradução de Maria Encarnación Moya. 2. ed. São Paulo: Expressão Popular, 2011. 448 p. (Pensamento social latino-americano).

SANFELICE, J. L. Dialética e pesquisa em educação. In: LOMBARDI, J. C.; SAVIANI, D. (Org.). Marxismo e educação: debates contemporâneos. 2. ed. Campinas: Autores Associados/HISTEDBR, 2008. p. 69-94.

SANTOS, C. F. Pedagogia histórico-crítica e movimentos sociais populares. In: MARSIGLIA, A. C. G.; BATISTA, E. L. (Org.). Pedagogia histórico-crítica: desafios e perspectivas para uma educação transformadora. Campinas: Autores Associados, 2012. p. 181-205. (Coleção educação contemporânea).

SANTOS, C. S. Ensino de ciências: abordagem histórico-crítica. Campinas: Armazém do Ipê (Autores Associados), 2005. 
SANTOS, W. L. P. Educação científica humanística em uma perspectiva freireana: resgatando a função do ensino de CTS. Alexandria Revista de Educação em Ciência e Tecnologia, Florianópolis, v. 1, n. 1, p. 109-131, 2008.

SANTOS, W. L. P.; SCHNETZLER, R. P. Educação em Química: compromisso com a cidadania. 3. ed. Ijuí: Unijuí, 2003. 144 p. (Coleção educação em química).

SAVIANI, D. Educação brasileira: estrutura e sistema. 2. ed. São Paulo: Saraiva, 1975. 146 p.

. Ensino público e algumas falas sobre universidade. 5. ed. São Paulo:

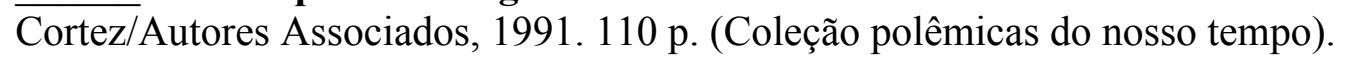

. Escola e democracia. 27. ed. Campinas: Autores Associados, 1993. 101 p. (Coleção polêmicas do nosso tempo).

. Desafios atuais da pedagogia histórico-crítica. In: SILVA JÚNIOR, C. A.;

SEVERINO, A. J. (Org.). Dermeval Saviani e a educação brasileira: o simpósio de Marília. São Paulo: Cortez, 1994. p. 243-286.

A função docente e a produção do conhecimento. Educação e Filosofia, Uberlândia, v. 11, n. 21-22, p. 127-140, 1997.

Pedagogia histórico-crítica: primeiras aproximações. 10. ed. rev. Campinas: Autores Associados, 2008. 160 p. (Coleção educação contemporânea).

. Educação: do senso comum à consciência filosófica. 18. ed. rev. Campinas: Autores Associados, 2009. 293 p. (Coleção educação contemporânea).

. Interlocuções pedagógicas: conversa com Paulo Freire e Adriano Nogueira e 30 entrevistas sobre educação. Campinas: Autores Associados, 2010. 290 p. (Coleção memória da educação).

Educação em diálogo. Campinas: Autores Associados, 2011. 323 p. (Coleção memória da educação).

. Marxismo, educação e pedagogia. In: SAVIANI, D.; DUARTE, N. (Org.).

Pedagogia histórico-crítica e luta de classes na educação escolar. Campinas: Autores Associados, 2012. p. 59-85. (Coleção polêmicas do nosso tempo). 
SCALCON, S. À procura da unidade psicopedagógica: articulando a psicologia históricocultural com a pedagogia histórico-crítica. Campinas: Autores Associados, 2002. 151 p.

SCHIEL, D. Centro de Divulgação Científica e Cultural de São Carlos: o centro de ciência em toda parte. In: CRESTANA, S.; CASTRO, M. G.; PEREIRA, G. R. M. (Org.). Centros e museus de ciência: visões e experiências: subsídios para um programa nacional de popularização da ciência. São Paulo: Saraiva, 1998. p. 189-195.

. Colocando a mão na massa. Brasiliana: a divulgação científica no Brasil. Rio de Janeiro, [200-]. Disponível em:

$<$ http://www.museudavida.fiocruz.br/brasiliana/cgi/cgilua.exe/sys/start.htm?infoid=84\&sid=3 1>. Acesso em: 25 jun. 2014.

. A construção do conhecimento pelo aluno no programa Experimentoteca. In:

CRESTANA, S.; HAMBURGER, E. W.; SILVA, D. M.; MASCARENHAS, S. (Org.).

Educação para a ciência: curso de treinamento em centros e museus de ciência.

São Paulo: Livraria da Física, 2001. p. 261-264.

SCHIEL, D.; CURVELO, A. A. S.; FERREIRA, L. H. Projeto Experimentoteca: a contribuição do design. Divulgações do Museu de Ciências e Tecnologia, Porto Alegre, n. 4, p. 149-154, 2004.

SCHIEL, D.; GUERRINI, I. M.; CASTRO, A. C.; FREITAS, D. Avaliação parcial da experimentoteca do ensino médio de física. In: SIMPÓSIO NACIONAL DE ENSINO DE FÍSICA, 17., 2007, São Luís. Resumos... São Paulo: Sociedade Brasileira de Física, 2007. p. 86.

SCHIEL, D.; ORLANDI, A. S. Ensino de ciências por investigação. São Carlos: Centro de Divulgação Científica e Cultural/Compacta Gráfica e Editora, 2009. 160 p.

SCHÖN, D. Educando o profissional reflexivo: um novo design para o ensino e a aprendizagem. Tradução de Roberto Cataldo Costa; consultoria, supervisão e revisão técnica de Beatriz Vargas Dorneles. Porto Alegre: Artmed, 2000. 256 p. (Biblioteca Artmed: fundamentos da educação).

SILVA, F. G; DAVIS, C. Conceitos de Vigotski no Brasil: produção divulgada nos Cadernos de Pesquisa. Cadernos de Pesquisa, São Paulo, v. 34, n. 123, p. 633-661, 2004.

SILVA, T. T. Documentos de identidade: uma introdução às teorias do currículo. 3. ed. Belo Horizonte: Autêntica, 2011. 153 p. 
SOUZA, R. F.; MORI, R. C.; AMAURO, N. Q.; CURVELO, A. A. S. Uma relação entre a metodologia do projeto "ABC na Educação Científica - Mão na Massa" e a teoria de Jean Piaget. In: ENCONTRO NACIONAL DE PESQUISA EM EDUCAÇÃO EM CIÊNCIAS, 8., 2011, Campinas. Anais... Rio de Janeiro: Abrapec, 2011. Disponível em:

$<$ http://www.nutes.ufrj.br/abrapec/viiienpec/resumos/R1196-2.pdf $>$. Acesso em: 25 jun. 2014.

SUCHODOLSKI, B. Teoria marxista da educação. Tradução de Maria Carlota Melo, José Magalhães e Francisco Paiva Boleo. Lisboa: Estampa, 1976. 3 v.

. A pedagogia e as grandes correntes filosóficas: pedagogia da essência e a pedagogia da existência. Tradução de Liliana Rombert Soeiro. 3. ed. Lisboa: Livros Horizontes, 1984. 124 p. (Biblioteca do educador profissional, v. 18).

SUCHTING, W. A. Constructivism deconstructed. Science \& Education, Dordrecht, v. 1, n. 3, p. 223-254, 1992.

TALANQUER, V. Macro, submicro, and symbolic: the many faces of the chemistry "triplet". International Journal of Science Education, Londres, v. 33, n. 2, p. 179-195, 2011.

TEIXEIRA, P. M. M. A educação científica na perspectiva da pedagogia histórico-crítica e do movimento CTS no ensino de ciências. Ciência \& Educação, Bauru, v. 9, n. 2, p. 177-190, 2003.

Educação Científica e Movimento CTS no quadro das tendências pedagógicas no Brasil. Revista Brasileira de Pesquisa em Educação em Ciências, Porto Alegre, v. 3, n. 1, p. 88-102, 2005.

TOLMAN, C. W. The basic vocabulary of Activity Theory. Multidisciplinary Newsletter for Activity Theory, Berlim, n. 1, p. 14-20, 1988.

TOMAZELLO, M. G. C.; SCHIEL, D. (Org.).O livro da Experimentoteca: educação para as ciências da natureza através de práticas experimentais. Piracicaba: VITAE/Unimep/USP, 2000. $2 \mathrm{v}$.

VALENTE, M. E. A.; MARANDINO, M. The combination of traditional and interactive objects in science museus. Museum Education and New Museology, Bruxelas, n. 17, p. 30$37,2003$. 
VERILLON, P. Cognition and artifacts: a contribution to the study of though in relation to instrumented activity. European Journal of Psychology of Education, Lisboa, v. 10, n. 1, p. 77-101, 1995.

VIGOTSKI, L. S. Obras escogidas III: problemas del desarrollo de la psique. Tradução de Lydia Kuper. Madri: Visor, 1995. 383 p. (Colección aprendizaje).

A construção do pensamento e da linguagem. Tradução de Paulo Bezerra. São Paulo: Martins Fontes, 2001. 496 p.

${ }^{110}$. Teoria e método em psicologia. Tradução do espanhol de Claudia Berliner. 3. ed. São Paulo: Martins Fontes, 2004. 524 p. (Psicologia e pedagogia).

. A brincadeira e seu papel no desenvolvimento psíquico da criança. Tradução e prefácio de Zoia Prestes. Revista Virtual de Gestão de Iniciativas Sociais, Rio de Janeiro, n. 11, p. 23-36, 2008.

${ }^{111}$. Psicologia pedagógica. Tradução de Paulo Bezerra. 3. ed. São Paulo: WMF

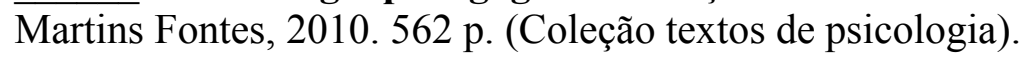

VOLOSHINOV, V. N ${ }^{112}$. O freudismo: um esboço crítico. Tradução de Paulo Bezerra. São Paulo: Perspectiva, 2004. 110 p. (Coleção estudos).

VOLOCHÍNOV, V. $\mathrm{N}^{113}$. Marxismo e filosofia da linguagem: problemas fundamentais do método sociológico na ciência da linguagem. Tradução de Michel Lahud e Yara Frateschi Vieira, com colaboração de Lúcia Teixeira Wisnik e Carlos Henrique D. Chagas Cruz. 11. ed. São Paulo: Hucitec, 2004. 196 p. (Linguagem e cultura, v. 3).

ZUIN, V. G.; FREITAS, D.; OLIVEIRA, M. R. G.; PRUDÊNCIO, C. A. V. Análise da perspectiva ciência, tecnologia e sociedade em materiais didáticos. Ciências \& Cognição, Rio de Janeiro, v. 13, n. 1, p. 56-64, 2008.

WASHBURN, S. L. Tools and human evolution. Scientific American, New York, v. 203, n. 3, p. 63-75, 1960.

\footnotetext{
${ }^{110} \mathrm{Na}$ ficha catalográfica da obra consta "Vygotsky, Lev Semenovitch". Na capa e em alguns de seus textos, no entanto, este nome é grafado como "Liev Semiónovitch Vigotski".

${ }^{111} \mathrm{Na}$ ficha catalográfica consta "Vigotsky, Lev Semenovich”. Já na capa consta "L. S. Vigotski”.

${ }^{112}$ Erroneamente atribuído a M. M. Bakhtin. Faço questão de referenciar a obra de acordo com a autoria original.

${ }^{113}$ A autoria consta, na verdade, como "Mikhail Bakhtin (V. N. Volochínov)". Como no caso anterior, trata-se de um engano, e faço questão de atribuir a obra somente a Voloshinov.
} 
ZAPPAROLI, F. V. D.; BUENO, E. A. S.; ARRUDA, S. M. A utilização da Experimentoteca na formação continuada de professores. In: ENCONTRO NACIONAL DE PESQUISA EM EDUCAÇÃO EM CIÊNCIAS, 5., 2005, Bauru. Caderno de Resumos... Bauru: Abrapec, 2005. Disponível em:

$<$ http://www.nutes.ufrj.br/abrapec/venpec/conteudo/artigos/3/pdf/p829.pdf $>$. Acesso em: 26 jun. 2014. 


\section{ANEXOS}

Os anexos que compõem esta divisão da tese são os documentos concernentes ao trabalho de campo, e aparecerão na ordem em que foram mencionados no corpo do trabalho. Aparecem, também, acompanhados de uma breve descrição. 


\section{A. CARTA AOS DIRETORES ESCOLARES DE SÃO CARLOS}

A carta foi encaminhada aos diretores de todas as escolas públicas que ofereciam o ensino médio em São Carlos no início de 2012. Seu objetivo era informar os gestores escolares de que gostaríamos de investigar a situação material dos laboratórios científicos dos estabelecimentos de ensino.

São Carlos, 27 de janeiro de 2012.

Prezado(a) Dirigente:

Meu nome é Rafael Cava Mori e sou doutorando junto ao programa de pós-graduação em Química, oferecido pelo Instituto de Química de São Carlos (IQSC), unidade da Universidade de São Paulo (USP). Desde 2006 venho desenvolvendo pesquisas na área de Educação em Química, tendo obtido o título de Mestre em Ciências, pela USP, com uma dissertação inserida neste campo do saber.

Atualmente sou orientado pelo Prof. Dr. Antonio Aprigio da Silva Curvelo, docente do IQSC e, até recentemente, Diretor do Centro de Divulgação Científica e Cultural (CDCC-USP). O projeto de pesquisa referente aо meu doutorado intitula-se Experimentação no ensino de Química: contribuições do Projeto Experimentoteca para a prática e para a formação docente.

Este projeto pretende reunir conhecimentos acerca desta iniciativa - a Experimentoteca, do CDCC -, considerando o contexto das escolas de ensino médio de nosso município. Para seu desenvolvimento, necessitamos coletar algumas informações junto a estes estabelecimentos de ensino, as quais pretendemos transformar em dados científicos.

Tenho contato com o Projeto Experimentoteca desde que fui aluno do ensino fundamental em escolas públicas de São Carlos, e acredito que este doutoramento poderá fornecer informações relevantes, até mesmo indispensáveis, para a reflexão sobre este projeto e para sua contínua evolução.

Assim, venho respeitosamente solicitar seu auxílio para a realização desta etapa de coleta de dados. Desejamos iniciar estes trabalhos de campo coletando informações sobre as condições materiais dos laboratórios científicos dos estabelecimentos públicos de ensino em nossa cidade, que ofereçam o ensino médio. Necessitamos, para tanto, visitar pessoalmente cada um destes estabelecimentos, observar as condições dos laboratórios (quando existentes, ainda que não estejam em pleno funcionamento), registrá-las em meios audiovisuais e tomar notas de campo.

Garantimos que seu nome e da instituição a que está vinculado serão mantidos em sigilo. Nos relatórios que viremos a elaborar, não apresentaremos informações, quanto aos registros audiovisuais, que possam permitir a identificação da escola a que pertencer o laboratório visitado. Ainda, garantimos que o estudo não oferecerá quaisquer formas de riscos ao bem estar de qualquer participante, e que seu consentimento à participação poderá ser retirado a qualquer momento, o que será atendido prontamente. Finalmente, esforçar-nos-emos para que as visitas sejam breves e não interfiram nos trabalhos correntes do estabelecimento.

Sua colaboração será muito valorizada e estará contribuindo imensamente para este projeto. Agradeço antecipadamente e coloco-me à disposição para qualquer esclarecimento. 


\section{B. TERMO DE CONSENTIMENTO LIVRE E ESCLARECIDO (VISITAS)}

O termo foi apresentado aos diretores/vice-diretores que autorizaram as visitas às suas escolas para que observássemos os laboratórios científicos.

\section{Termo de Consentimento Livre e Esclarecido}

Você, está sendo convidado(a) para participar do estudo sob o título provisório "O laboratório didático e a materialidade do ensino de ciências em São Carlos”, que compõe o projeto Experimentação no ensino de Química: contribuições do Projeto Experimentoteca para a prática e para a formação docente, que desenvolvo em meu doutoramento pelo Instituto de Química de São Carlos (IQSC-USP), sob orientação do Prof. Dr. Antonio Aprigio da Silva Curvelo.

A qualquer momento anterior à conclusão do estudo você poderá desistir de participar e retirar seu consentimento. Sua recusa não trará nenhum prejuízo em sua relação com o pesquisador ou com a instituição.

O objetivo central deste estudo é realizar um levantamento sobre as condições materiais dos laboratórios científicos dos estabelecimentos públicos de ensino em nossa cidade, que ofereçam o ensino médio. Necessitamos, para tanto, visitar pessoalmente cada um destes estabelecimentos, observar as condições dos laboratórios (quando existentes, ainda que não estejam em pleno funcionamento), registrá-las em meios audiovisuais e tomar notas de campo.

Não há riscos envolvidos quanto a sua participação no estudo. Salientamos que seu nome e da instituição a que está vinculado(a) serão alterados, garantindo sigilo. Nos relatórios que viremos a elaborar, não apresentaremos informações, quanto aos registros audiovisuais, que possam permitir a identificação da escola a que pertencer o laboratório visitado.

Espera-se que este estudo agregue informações sobre a realidade educacional deste município e subsidie políticas e ações para as transformações necessárias.

O pesquisador se compromete a compartilhar as informações coletadas, ao final do estudo, com toda a comunidade escolar, bastando que você entre em contato e informe o momento mais adequado para esta apresentação.

Você receberá junto deste termo os dados e o telefone do pesquisador, podendo tirar suas dúvidas sobre o projeto, agora ou a qualquer momento.

\section{Rafael Cava Mori}

Declaro que entendi os objetivos, riscos e benefícios de minha participação na pesquisa e concordo em participar.

São Carlos, $/ 2012$.

Nome do Sujeito da Pesquisa:

$(R G$ : /CPF: ) 


\section{TERMO DE CONSENTIMENTO LIVRE E ESCLARECIDO (ENTREVISTAS - PESQUISADOR E PESQUISADORA)}

O termo foi apresentado aos pesquisadores universitários que desenvolveram projetos sobre os laboratórios científicos escolares de São Carlos.

\section{Termo de Consentimento Livre e Esclarecido}

Você, está sendo convidado(a) para participar do estudo sob o título provisório "O laboratório didático e a materialidade do ensino de ciências em São Carlos”, que compõe o projeto Experimentação no ensino de Química: contribuições do Projeto Experimentoteca para a prática e para a formação docente, que desenvolvo em meu doutoramento pelo Instituto de Química de São Carlos (IQSC-USP), sob orientação do Prof. Dr. Antonio Aprigio da Silva Curvelo.

A qualquer momento anterior à conclusão do estudo você poderá desistir de participar e retirar seu consentimento. Sua recusa não trará nenhum prejuízo em sua relação com o pesquisador ou com a instituição.

O objetivo central deste estudo é realizar um levantamento sobre as condições materiais dos laboratórios científicos dos estabelecimentos públicos de ensino em nossa cidade, que ofereçam o ensino médio. Dada sua participação em projetos relacionados com nosso objeto de estudo, você está sendo convidado(a) a fornecer um depoimento, durante a realização de uma entrevista de tipo semi-estruturado, que será registrado na forma de gravação em áudio. A gravação será, posteriormente, transcrita e analisada, sendo a transcrição incluída nos relatórios que vierem a ser preparados.

Não há riscos envolvidos quanto a sua participação no estudo. Salientamos que seu nome e da instituição a que está vinculado(a) serão alterados, garantindo sigilo.

Espera-se que este estudo agregue informações sobre a realidade educacional deste município e subsidie políticas e ações para as transformações necessárias.

O pesquisador se compromete a compartilhar as informações coletadas, ao final do estudo, com você, bastando que você entre em contato e informe o momento mais adequado para esta apresentação.

Você receberá junto deste termo os dados e o telefone do pesquisador, podendo tirar suas dúvidas sobre o projeto, agora ou a qualquer momento.

\section{Rafael Cava Mori}

Declaro que entendi os objetivos, riscos e benefícios de minha participação na pesquisa e concordo em participar.

São Carlos, $/ 2012$.

Nome do Sujeito da Pesquisa:

$(R G$ : / CPF: )

Assinatura: 
O seguinte guia de observações foi preenchido durante as visitas aos laboratórios escolares das oito escolas que os possuíam.

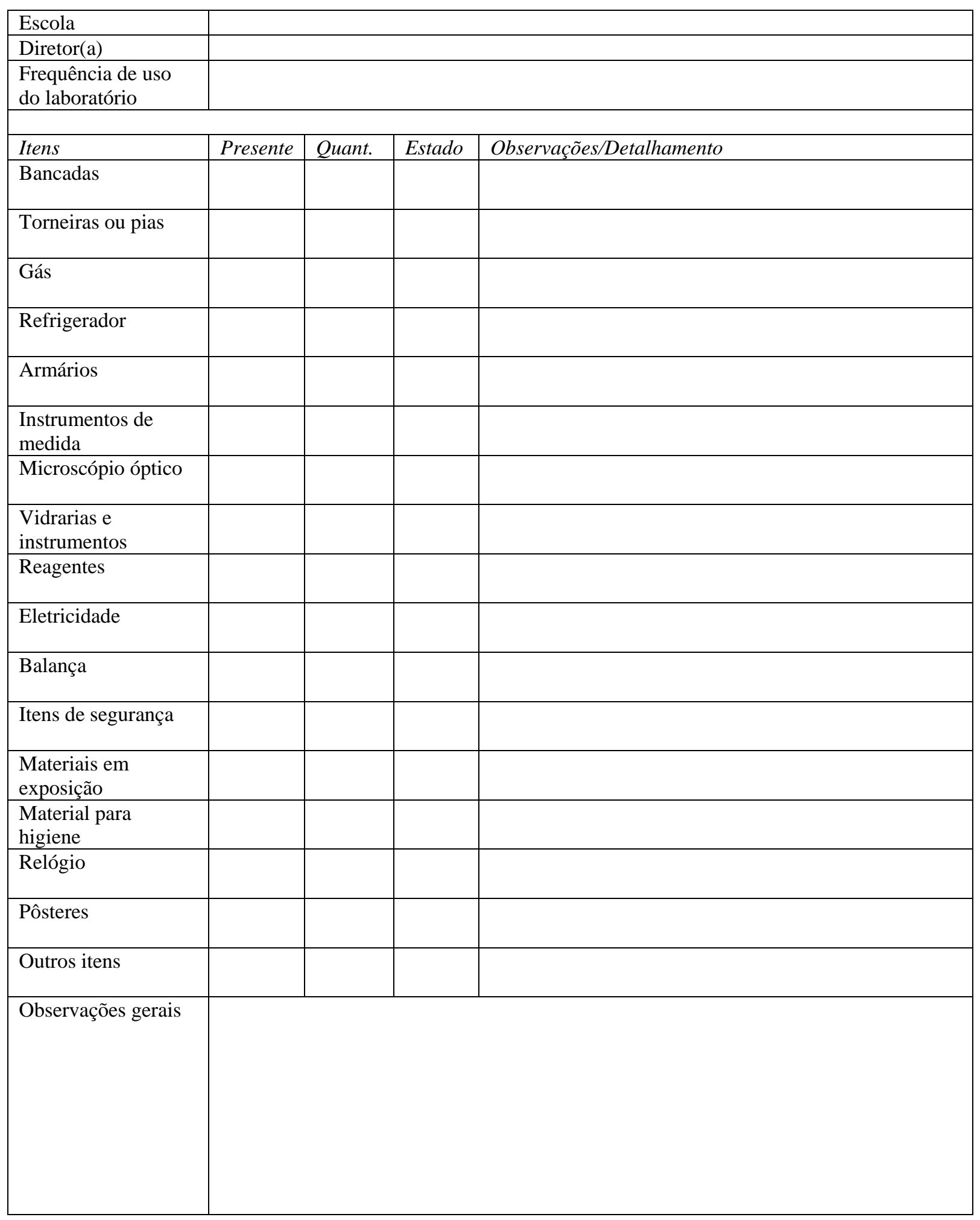




\section{E. ROTEIROS (ENTREVISTAS - PESQUISADOR E PESQUISADORA)}

Segue abaixo o roteiro com as perguntas principais que foram feitas aos pesquisadores universitários que desenvolveram projetos, no passado, relacionados com a questão dos laboratórios científicos escolares de São Carlos. Além destas perguntas, foram propostas também questões de aprofundamento e esclarecimento.

\section{Entrevistado(a):}

Início: $\quad$ Término:

Recentemente, tive conhecimento de seu envolvimento com ao menos um projeto relacionado à questão do laboratório de ciências nas escolas públicas de São Carlos. Este será o tema de nossa entrevista.

1. Fale-nos de seu interesse sobre a questão do ensino de ciências.

2. Você poderia comentar alguns dos projetos relacionados, a esta questão, de que você tenha participado? Quais os objetivos deles e quais resultados você destacaria?

3. Conte-nos sobre seu envolvimento com a questão do laboratório de ciências nas escolas públicas de São Carlos. De que maneira se deu este envolvimento?

4. Você poderia fornecer detalhes sobre os projetos de que tenha participado, relacionados a esta questão?

5. Como você avalia o sucesso destas iniciativas e de outras semelhantes?

6. Com relação a isto, que comentários você poderia fazer sobre a influência do contexto de nosso município?

7. Há algum comentário final sobre esta questão? 


\section{F. TRANSCRIÇÃO (ENTREVISTA - PESQUISADOR)}

Abaixo segue a transcrição do áudio da entrevista semi-estruturada com o pesquisador que coordenou o projeto com as Escolas A e B, envolvendo seus laboratórios científicos. No quadro da Figura 14, este material está identificado com o código "e1".

Infelizmente, muitas passagens da gravação foram interrompidas por cortes, mas que não comprometem o entendimento da entrevista como um todo.

No depoimento foram mencionados nomes de outras pessoas, o que poderia comprometer o sigilo da identidade do pesquisador e das escolas envolvidas em nossa pesquisa. Decidimos por abreviá-los, somente pelas iniciais, nesta transcrição. As menções a nomes de escolas visitadas na etapa de observações foram substituídas pela codificação apresentada na Figura 14 (Escola A, Escola B...). Houve menções à pesquisadora que coordenou o projeto com a Escola C; substituímos seu nome por "Pesquisadora".

Recentemente, tive conhecimento de seu envolvimento com ao menos um projeto relacionado à questão do laboratório de ciências nas escolas públicas de São Carlos. Este será o tema de nossa entrevista. A pergunta mais geral, a primeira, é pro senhor falar pra gente sobre o seu interesse no ensino de ciências...

Tá. É... como começou, alguma coisa assim?

Como começou, porque o senhor tem esse interesse...

Tá. É... Bom, na verdade é assim: eu me interessei, eu próprio né, por ciência, no antigo curso ginasial, equivalente à $7^{a}, 8^{a}$ série hoje. E eu sempre fui apaixonado pelas aulas de ciências. Então assim [corte] nas aulas de ciência. E depois quando eu vim fazer Química aqui na USP, a gente não tinha licenciatura e eu queria ser professor de Química. Mas não vi nenhum problema porque, na época, o MEC [Ministério da Educação] não exigia licenciatura pra dar aula de Química. "Então não tem problema, né, eu faço bacharelado e ao invés de ir pra indústria... Pra mim, eu quero dar aula, quero trabalhar com ensino, de Química". E então... eu tomei conhecimento... (eu era calouro ainda) eu tomei conhecimento de que um grupo de pessoas, aqui da USP, tavam trabalhando em torno de uma ideia... que na verdade tava nascendo, tava dando os primeiros passos, né, que era o CDCC. E eu falei: "Pô, é tudo o que eu quero! Eu quero fazer isso, começar já a trabalhar com ensino, fazer uma coisa assim e tal". E aí, ainda calouro, eu vim pro CDCC, fiz contato com esse grupo (o grupo era liderado pelo Prof. Schiel), e comecei voluntariamente a trabalhar... O CDCC nessa época, pra você ter ideia, ainda tava em processo de ocupação do prédio, porque a Química, hoje Instituto de Química [de São Carlos] era aqui [a entrevista foi realizada numa localidade próxima ao CDCC]: funcionava tudinho aqui. Então quando eu comecei a trabalhar voluntariamente no CDCC, nem laboratório a gente tinha, porque onde seria o laboratório nosso, da Química, tava sendo ocupado pela Eletroquímica. O Grupo de Eletroquímica foi um dos últimos a mudar pro campus né, e depois que esse grupo mudou, e daí, enfim... nós passamos a ter um laboratório no CDCC e nessas atividades do CDCC, tinha coisa boa. "Então é tudo o que eu quero, é contato com a escola, com o professor..." Enfim, é isso que eu precisava. Aí eu queria seguir carreira acadêmica, mas pra mim já tava definido, era assim: "Futuramente eu vou trabalhar com pesquisa na área de ensino". Então o CDCC teve um papel acho que importantíssimo nessa trajetória. Agora, se não fosse o CDCC, certamente eu ia buscar outros meios, né. Se o CDCC não existisse, eu ia ter que buscar outros meios porque pra mim tava muito claro que era isso mesmo que eu queria. Como calouro, né, você fica sabendo que tem um grupo, você já vai atrás, já se envolve... É o seguinte, é isso aqui mesmo, né. Então, isso foi o que definiu um pouco, ou facilitou trabalhar com ensino de ciências, mais especificamente com Química. 
Eu falei que já tô... que já sei que o senhor tem alguns projetos, mas o senhor pode comentar algum dos projetos relacionados com esta questão do ensino de ciências, de que o senhor tem participado? E aí, uma outra questão, dentro da mesma pergunta: quais os objetivos destes projetos e quais os resultados que o senhor tem chegado.

Bom, dos projetos que eu participei, pra falar bem a verdade, nem de cabeça eu acho que eu sei listar. Foram muitos, a maior parte deles no CDCC inclusive, ou com o CDCC, ou diretamente nele [toca o telefone e o pesquisador pede licença para atender]. Bom, mas enfim, então vamo, vamo pegar assim, os principais né, ou se tiver um... Eu acho que ter um projeto na área de ensino é importante, independente da dimensão que ele tenha, ou da abrangência, do número de escolas, de professores etc. Hã... mas alguns ocupam mais o tempo da gente, envolvem mais pessoas e etc. Então eu acho que vou citar alguns deles. É... Bom, enquanto eu tava no CDCC, eu acho que o mais conhecido, pelo menos né, fora de São Carlos, é a Experimentoteca. Eu participei disso de todas as etapas, desde a criação, a definição de temas, a elaboração do material, testes, né... Nós fizemos a testagem em escolas, aqui em São Carlos, deste material. Na verdade tem uma pesquisa, em paralelo, no desenvolvimento da Experimentoteca, que é pra ver aspectos didáticos mesmo. Então é assim: não adianta você pensar num kit, pensar num experimento se não sabe como isso vai funcionar em sala de aula, se de fato o aluno aprende, se o professor tem dificuldade, etc. Isso tudo caminhava em paralelo, né, dentro de um projeto grande que é a Experimentoteca. Depois dessa Experimentoteca do ensino fundamental, eu participava, não só na Química - eu coordenava toda a parte da Química -, mas também nas outras áreas. Isso era legal, que a equipe era bem interdisciplinar. Então é assim, eu trabalhava também os kits de Física, de Biologia e etc., e eu me dedicava muito ao de Química, aí eu tinha a equipe própria que trabalhava... Então esse é um projeto que acabou sendo mais conhecido. E depois também teve a Experimentoteca do ensino médio, só que ela vem bem depois. Na ocasião eu tava na USP de Ribeirão já, não tava mais aqui no CDCC e... aí também é a mesma história. O processo é semelhante. É lógico que os experimentos são outros e etc. Aí a gente teve diversos projetos que eram ligados à formação continuada de professores. Aí eu tinha na época do CDCC, outros já eu não tava mais no CDCC. Então eu tive projetos com a USP de Ribeirão, quando eu tava lá; projetos aqui na UFSCar, quando eu vim pra cá... Aí, tem... tem projeto com o CNPq, tem projeto com o Estado de São Paulo, Secretaria de Educação, e por aí vai... mas enfim, eu participava desses projetos também e nesses projetos, embora fosse formação continuada, a gente sempre fazia pesquisa junto com o professores. Eu cito um caso, de um destes cursos que tinha pesquisa com o aluno também, mas os professores tavam envolvidos nesta pesquisa. Bom, essa foi uma semente, né - esses projetos, né, de formação de professores... eles, pra mim significaram assim, uma semente, pra que futuramente eu criasse uma linha de pesquisa, agora com o meu grupo, na área de formação de professores. E aí entram os nossos projetos do grupo, agora com alunos de pós-graduação. Por exemplo, a A. C. fez o mestrado com formação de professores, que seria um trabalho envolvendo todas as universidades públicas do Estado de São Paulo, com os cursos de formação de professores - formação inicial. Por isso que eu falei que a semente é aquele trabalho de formação continuada. Ele me despertou o interesse por pesquisar a formação inicial. Teve a C., que fez o doutorado pesquisando também formação inicial em toda a região Norte do país. Ela pegou todos - desculpe, da região Nordeste - todos os cursos de universidades públicas da região Nordeste, aí desenvolveu uma pesquisa lá. Depois teve a C. que fez a mesma coisa na região Norte. Todos os estados, todos os cursos da região Norte. É... e qual é a ideia, né? Por que fazer isso por regiões? Porque a ideia é que, no fundo, a gente tá trabalhando num projeto maior ainda, que é fazer um mapeamento completo da situação da formação inicial de professores no Brasil. Então como é muito... o Brasil é muito grande, tem muito curso, pra um doutorado... então eu vou dividir por regiões, né, vão sair doutorados e a gente vai criando um panorama, entendendo melhor o panorama da formação inicial no país. Mas, enfim... Então retomando: isso é a semente que foi plantada com aqueles cursos, foi a semente dessa pesquisa e tal. Ainda no CDCC tem também outros projetos e que mais tarde iam criando essas linhas de pesquisa que eu mantenho hoje. Então na verdade tem outras sementes aí. A própria experimentação, pela Experimentoteca, então a própria experimentação, ela, mais tarde - as duas Experimentotecas, inclusive, a de ensino fundamental $e$ a do ensino médio também - elas me facilitaram criar uma linha de pesquisa na pós-graduação em experimentação. Então a gente tem também uns alunos que já defenderam e tem alunos trabalhando atualmente, inclusive, no doutorado, com experimentação... É... mas são projetos que, de certa forma, tiveram origem lá naquele passado. E material didático, que é a terceira linha de pesquisa do nosso grupo...

[interrompendo] $O$ desenvolvimento?

O desenvolvimento e a avaliação. Quer dizer, na verdade é desenvolvimento elou, porque tem pesquisas que a gente faz com material didático mas que não necessariamente a gente desenvolve. Então por exemplo, pesquisas com livro didático. Neste caso nós não desenvolvemos o livro, nós não escrevemos o livro, né, mas a gente usa os livros, aprovados ou não aprovados, enfim, mas nós vamos centrar a pesquisa ali. E tem pesquisas que é com material produzido por nós mesmos, pelo grupo mesmo. Então, por exemplo, nós temos um produto, que gerou 
uma patente com a Universidade Federal [de São Carlos], de um modelo molecular diferente dos modelos que existem. Ele abrange muito mais conceitos e etc. E... então teve um aluno que fez o mestrado tomando esse material didático como base da pesquisa de mestrado dele [inaudível] e tem um aluno que tá terminando o doutorado que também tá trabalhando com esse material. Enfim, então... eu tô fazendo um pouco essa ligação do passado com o presente porque mostra um pouco que projetos que a gente participou e que resultados que se tem depois, [corte] colhendo os frutos. É... mas enfim, então retomando... lá no CDCC eu participei de muitos projetos... então tem $o$ [ABC da Educação Científica] Mão na Massa, eu participei do começo do Mão na Massa, enfim, né. Na verdade, assim, o CDCC é muito legal porque, principalmente quando eu tava lá, eu não via muita separação nas atividades por área. Você tem liberdade de atuar de maneira multidisciplinar mesmo. É assim... multi e interdisciplinar. Que é assim, os projetos normalmente eles pegam mais de uma área. Então tem projeto que ele próprio pega Física, Química, Biologia, Matemática e tal. É... então ele é multidisciplinar. Mas a equipe trabalha interdisciplinarmente. Você, mesmo sendo químico, você tem participação lá na Biologia e entra nisso, desenvolve alguma coisa, e é algo que também ajuda na Química e por aí vai. E aí eu teria que saber um deles, que eu participei desde o começo, na verdade do CDCC, de 85 até 98... durante 13 anos eu participei certamente... durante 13 no CDCC eu participei de alguns... Mas aí tem uma luta... a cabeça nem vai lembrar! Mas enfim... E depois tem os projetos, agora, sem o CDCC, que são as pesquisas no grupo, que são coisas que eu desenvolvo na UFSCar. O foco acaba sendo mais o ensino da Química, porque lá eu não tenho essa equipe, essa infraestrutura que tem no CDCC, né, e também a gente atua na área de ensino de ciências. Por exemplo, a gente tá com uma expectativa de aprovação de um projeto muito, muito grande, com a Fapesp, pra ensino de ciências no ensino médio. Então vai pegar Física, Biologia, Química, e eu vou coordenar essa parte, por pelo menos quatro anos. E aí... é... enfim, a ideia é ter um projeto ligado ao ensino de ciências ou de Química, mais especificamente, o tempo todo. Então quer dizer, pelo menos um projeto tem que ter. Essa é a ideia pra manter a atividade no grupo e a atividade minha também. E daí, na medida do possível, na medida [inaudível] os alunos do grupo vão entrando e desenvolvendo subprojetos de um projeto maior. Na verdade, se você olhar cada pesquisa, né, de um aluno do grupo, só uma pesquisa, assim, como qualquer outra, que leve esse aluno a defender um mestrado, um doutorado, tem que fazer de maneira que a gente some, né, os resultados das diferentes pesquisas. Um exemplo disso é o que eu tava falando agora há pouco sobre formação de professores. Os alunos de mestrado e de doutorado trabalham com formação de professores num projeto maior, de tempo muito maior que um doutorado (não daria pra fazer num doutorado) que é um projeto de pelo menospelo menos - uns dez anos. Então a gente tem que... a gente tenta... ficou [claro]?

Ficou! E especificamente sobre essa questão da experimentação, né... é... como é que é que esse projeto que eu fiquei sabendo da sua participação tá relacionado com o laboratório de ciências em São Carlos?

A experimentação é assim: bom, primeiro - experimentação é... ela é polêmica, de maneira geral. Por quê? Porque é impressionante, mas todos os professores, e dentro da universidade também, e enfim... se atribui à experimentação o [corte] sem experimentação não se aprende [corte] ela não enxerga que o ensino é bem mais complexo, não é só experimentação... Com ela só você não aprende. E pior: com ela, da maneira como é feita, aí você aprende muito pouco. Então, existe um mito de que o experimento resolve tudo. Mas... é... nessa concepção, né, em uma abordagem mais tradicional e etc. e tal, né, que aquilo vai resolver tudo... Bom, enfim. E daí isso... é... embora não se falasse na época da Experimentoteca de abordagem investigativa, os testes que a gente fazia nas escolas, eles mostravam que tava faltando alguma coisa. Não é possível... é... ter... não sei, um... [corte] muito legal com aquele "entendo o conceito ou os conceitos envolvidos e etc." [inaudível] ficou muito bom mas vê isso sendo aplicado de uma maneira que foge ao controle, né, da equipe gestora [corte] começo meio e fim, e isso é limitado no tempo. O Projeto Experimentoteca acabou. Não a Experimentoteca, ela continua, com aportes cada vez mais fortes mas o Projeto, aquele né, que tinha a equipe inteira trabalhando no desenvolvimento, no teste nas escolas, esse projeto acabou, não existe mais. Então quando eu digo que foge ao controle é porque hoje o professor vai até o CDCC, retira a caixa mas eu não sei o que ele tá fazendo com ela. Né... Bom. Isso começou a ficar claro pra gente nessa ocasião do desenvolvimento da Experimentoteca. Então, o que começou a me incomodar é o seguinte: a gente tem que ter alguma coisa que sirva de piloto pra nós, mas que seja mais permanente. Que seja desvinculado com o desenvolvimento da Experimentoteca. Então teve um projeto, com a Fapesp, o nome eu não lembro exatamente...

[interrompendo] “A construção de um laboratório piloto para a escola de segundo grau...”

É, eu acho que é isso. Eu lembro que no nome tem o “piloto”...

Aham... 
Que era pra ser um piloto esse, né... mas... Essa ideia do laboratório piloto é um laboratório que a gente acompanha o tempo todo. Não apenas dentro do prazo de vigência do projeto Fapesp. O laboratório tá aqui em São Carlos; nós vamos ter acesso, contar com o professor, com direção, etc. é o tempo todo. Porque aí começou a interessar à pesquisa, e à acessória, à escola e etc. na área de metodologia, porque era assim: o laboratório já existe, então o problema não é o experimento, mas como é que você vai conduzir as aulas com esse laboratório e etc. A Fapesp aprovou esse projeto, então eu fiz... é... em duas escolas, né. E havia na época um envolvimento muito grande com essa ideia por parte da direção da Escola B e da direção da Escola A. A diretora da Escola A era a Prof. R. que adorou a ideia, se envolveu...

\section{Eu estudava lá nessa época!}

Ah, é? E ela apoiou e apoiou muito, e aí, enfim... Os professores se envolveram, então essa foi uma escola... é... escolhida. E a Escola B (depois a Prof. R. se aposentou, né? Aí mudou a direção da escola...), e a Escola B, na verdade ficou sabendo - eu não sei como - que eu tava trabalhando numa ideia desse tipo, aí me procuraram-e quem me procurou na verdade foi o diretor, que era o Prof. E. (que também já aposentou) - ele era diretor e abriu as portas da escola e ofereceu apoio, os professores tavam muito a fim de participar, e enfim. Então, foram... é... essas duas escolas por esse motivo: tinha que ter esse envolvimento. Porque se você falar pra qualquer escola "você quer um laboratório novo? Equipado, todo reformado, construído...", todo mundo vai falar que sim. Enfim... Mas sem o envolvimento, não adianta, você conserta e depois fica abandonado. E nessas escolas eu senti segurança, porque havia um envolvimento da parte da direção, do corpo docente e daí as duas coisas se uniram. Bom, aí a Fapesp aprovou esse projeto. Uma coisa era em comum [ou "incomum"?]... e que é muito comum em escola pública. Se você perguntar nas escolas se elas têm laboratório, a maior parte fala que tem. Isso no Brasil todo. "Não, tem laboratório". Só que você vai ver o laboratório, o que eles estão chamando de laboratório não é laboratório. Quando muito tem uma bancadinha, meia dúzia de vidro jogado num canto e muita carteira quebrada, mesa quebrada, caixa de papelão que você não sabe pra quê que serve, enfim. É um depósito, né. Eles falam "aqui é o laboratório”. É... Então essas duas escolas tinham coisa parecida e chamavam de laboratório. Na verdade, não era laboratório. Aí eu senti a necessidade de fazer a reforma completa de tudo, inclusive mudanças do espaço físico para um espaço adequado, enfim. Nas duas, era uma pequena sala, muito pequena, que eles chamavam de laboratório. Então nós organizamos um amplo local, que era um ambiente maior, fazendo toda a reforma, construção de bancadas... equipamos. Então... é... eu comprei na época todo o equipamento pra Química, vidraria, tinha reagente, geladeira, enfim... agitador e manta de aquecimento, eu já nem lembro mais, mas enfim... muito e muito tempo faz... E material pra aula de Física e Biologia. Então pra Biologia também tinha microscópio, um monte de coisa... A ideia era fazer não só com a Química. Química, Física e Biologia. Então teve que receber os equipamentos todos. $O$ investimento foi alto, não lembro agora quanto, mas... a Fapesp concedeu e por isso que começou a funcionar. E aí, por um período foi legal porque a gente tinha o desenvolvimento no CDCC das práticas, que eram discutidas com o professor e também a metodologia. Então é assim, o professor fazia o experimento antes da aula, junto com a gente, a gente discutia conceitos, procedimentos, etc. etc., e discutia como aplicar isso em aula no ensino médio. E aí... é... começou a funcionar legal por um tempo e aí a primeira escola que deu um problema foi a Escola A porque a diretora aposentou, mudou a direção, a direção não apoiava mais o projeto, porque não gostava do trânsito de alunos entre sala de aula e laboratório, então o projeto ficou prejudicado, mas a gente ainda conseguia tocar. Não do mesmo jeito, mas conseguia tocar. Na Escola B tava indo bem. Aí depois, na mesma época, com diferença muito pequena de tempo aí, aconteceu duas coisas. Eu fui pra USP de Ribeirão... e o projeto não era da USP de Ribeirão, o projeto era do CDCC. Porque aquela validade perante a Fapesp, de implantação dos laboratórios e etc. e tal, aquilo já tinha expirado. Então com a Fapesp já tinha acabado o assunto. Só que a ideia de fazer esse acompanhamento permanente é com o CDCC, até pela proximidade né. O fato de eu estar em Ribeirão Preto, acompanhando o laboratório daqui ia complicar. Aí depois, o Prof. E., também na Escola B, que era o diretor, ele aposentou e esse projeto começou aos poucos... ele foi sendo desativado. É uma pena, porque era uma oportunidade da gente trabalhar - e trabalhar muito forte - metodologia. Já não era problema aquilo que era problema pra toda escola, que é assim: ou não tem laboratório, ou não tem vidraria, não tem reagente, não tem equipamento. Tinha tudo: toda a vidraria, estoque de reagente, e etc. Podia concentrar e gastar energia apenas na pesquisa, apenas na metodologia e tal, porque o resto não era problema. Só que eu sei que praticamente foi desativado. Até onde eu sei, nas duas escolas o uso do laboratório depende da boa vontade do professor. Dependendo do professor - que tem uma rotatividade muito grande, né [inaudível] -, então, dependendo do professor ele usa, leva os alunos e tal. É... Gerou resultados interessantes. Gerou inclusive artigo na época, teve coisa interessante aí. Mas não teve continuidade. Eu acho que alguém tinha que retomar isso... ou eu consigo um tempo pra retomar, eu não sei...

Artigo, que o senhor se refere seria, por exemplo: tem acho que dois pelo menos na Química Nova na Escola, que são práticas de laboratório... 
São práticas de laboratório... teve... teve... são coisas dessa época, que era assim, a gente... a gente submetia porque pros professores isso era importante... e que fossem artigos ligados não à discussão pedagógica em si, porque isso não tinha preparo, eles não queriam entrar nisso. Então o importante não entrava. A ideia era trabalhar com o professor por um longo período. E no começo eles tinham pressa de resultados assim. Eles queriam ver... então a gente publicava como um roteiro de um experimento que eles... que a gente desenvolveu junto e eles aplicavam nas escolas. Então acabava sendo assim. E, mas... A ideia é que depois a gente colocasse em outras seções da Química Nova na Escola e em outras revistas também. Por exemplo, [na seção] Relatos em [de] Sala de Aula, como Pesquisa em Educação [refere-se à seção Pesquisa em Ensino de Química, também da revista Química Nova na Escola] e etc. E essa etapa, que a gente tava caminhando acho que rapidamente em direção a ela, foi interrompida. Depois começou a cair e... foi interrompida com essa ida minha pra Ribeirão e depois começou a cair e tal... Mas, enfim... é... Isso não é culpa do CDCC, não tem que culpar ter essas ideias. Porque também nas escolas a gente teve problemas com mudança de direção... Mudança de professor não era tanto problema, embora também tinha um processo. Porque você tá com um professor há um tempo, preparando esse professor, passando material pra leitura e fazendo discussão e etc. Quando você perde um professor entra um outro, você tem que começar tudo de novo, então é um problema. Mas o pior problema é mudança de diretor. Porque se o diretor não veste a camisa, não apoia o projeto, aí... aí não tem jeito, né. Porque dentro da escola tem uma hierarquia, o professor é subordinado à direção, e dá pra complicar de trocar... Ele é difícil, por natureza ele é difícil de ser mantido. Mas eu acredito, eu acho que uma hora eu próprio ou alguém vai pegar isso... Tem muita história, tem muita coisa bacana. Sem contar no benefício pros alunos. Pro aluno da escola... é muito bom! Ter o laboratório, poder frequentar esse laboratório... Ele não precisa nem saber que o professor tá testando metodologia diferente, que o professor também tá aprendendo com isso, que alguém da universidade tá colhendo dados de pesquisa e tal... mas, enfim, ele... ele tá usando o laboratório. Isso acho que é legal. Hoje, né, o que a gente poderia fazer, por exemplo, nesses laboratórios - eu até tenho feito, mas, por exemplo, só pra você ter a ideia... eu tentei ir nessas escolas (eu tenho um aluno trabalhando no doutorado com abordagem investigativa na experimentação)... e eu tentei ir nessas escolas e eu não consegui. Você entende o que eu tô querendo dizer, né? [inaudível] Se a direção não investe mesmo no caminho, você não consegue tocar um projeto. Esse aluno de doutorado teve que trabalhar em outras escolas, com outras condições etc., mas não usou essas escolas, né, os laboratórios, na pesquisa dele de doutorado. Ele teve que trabalhar inclusive com as escolas de São Carlos e de Ibaté. Vou retomar um pouco o que eu tava falando lá no começo; educação é muito complexo, né, as pessoas atribuem, assim, é... a experimentação como a salvação de tudo. Ela não é a salvação de tudo, porque educação envolve pessoas, envolve o ser humano. O ser humano é envolvido e... E então se a direção da escola não se envolve, não participa, não apoia, todo o projeto fica comprometido. Porque é assim, quando funciona muito bem a experimentação [corte] você não pode esquecer que teoria de aprendizagem, né, algumas você consegue usar experimentação [corte] Nesse caso específico, desse projeto o foco era experimentação. Esse era... É... até tem uma coisa que eu tô lembrando agora: depois que acabou a vigência do projeto Fapesp a direção de uma escola bem na periferia de São Carlos (hoje já não é tão periferia, né, porque a cidade tem crescido, mas na época tinha uma escola no limite da cidade, que é a Aracy Pereira Lopes...), e o diretor dessa escola ficou sabendo desse projeto e enfim, me procurou, eu fui até a escola conversar com ele e ele tava super interessado em a gente fazer isto lá também. Na época eu esclareci pra ele o seguinte: "Eu não tenho mais recurso da Fapesp”. Mas mesmo assim ele se mobilizou, junto à Secretaria de Educação, conseguiu um dinheiro e nós fizemos o projeto sem o financiamento da Fapesp. E ele chegou a usar até dinheiro de festa, de quermesse, de coisa do tipo que ele fez na escola, mas nós construímos lá também um laboratório e também enquanto esse diretor tava lá funcionou. Depois o diretor saiu, o laboratório tá lá - não sei se ainda tá em uso. Tem o mesmo padrão dos outros dois... mas enfim, é... Acabou chegando nessa escola também, na Aracy. Eu acho que é assim... Eu vou falar de direção, mas também da Secretaria de Educação, a parte da estrutura: ela tem uma estrutura bastante complexa, né. Primeiro porque o dirigente mesmo fica em São Paulo. Depois, lá dentro já tem: departamento, e etc... vinculado à Secretaria de Educação. Depois tem outra distribuição que é por diretorias regionais. Em São Carlos, por exemplo, tem uma; nós temos uma diretoria regional. E depois tem o diretor da escola, depois tem os professores, então, é assim, tem uma fila enorme. O começo desta fila (que começa lá pela Secretaria de Educação, lá em São Paulo e vem parar na diretoria regional)... essas pessoas muitas vezes nem querem tomar conhecimento desses projetos ou quando tomam conhecimento não oferecem apoio e etc. Então, o diretor, ele é a penúltima etapa, né, desse processo todo. Por isso que muitas vezes ele não apoia. Ele é cobrado por outras coisas - que não essas - então ele acaba não se envolvendo nessas. "Nessas eu não sou cobrado". Porque o interessante de projetos da universidade com a escola é que (eu sempre chamo isso, então eu faço muita questão de enfatizar) isso é parceria: não existe hierarquia. A universidade nunca tá acima da escola. A escola pode falar "não" à hora em que bem entender pra um projeto da universidade. Ele pode ou não aceitar um aluno nosso ou nós mesmos como pesquisadores, ela pode fechar as portas pra universidade. Então é interessante olhar pra esse lado: ou você estabelece parceria (e daí isso requer envolvimento, boa vontade, etc. e tal) ou então não funciona. Porque também na hierarquia do Estado isso não vem de cima, né, isso vem da relação direta da universidade com a escola. Eventualmente - e muito 
eventualmente - a gente consegue algum projeto direto com a Secretaria, e aí é diferente, porque a coisa chega na escola, porque tem uma ordem superior, aquilo foi mandado e etc. Mas também não é um caminho muito interessante ter a escola envolvida "porque o chefe mandou”. Então é difícil ter um projeto de médio e longo prazo com escola por isso. Porque ou você vai à escola e daí muitas vezes a escola não quer participar, ou você vai direto à escola e tem o envolvimento mas a rotatividade é muito grande: daí a pouco você perde o diretor, daí a pouco muda o professor, então é complicado. Projeto de médio a longo prazo é difícil de manter.

Tinha duas questões no meio: uma era sobre detalhes desses projetos, e o senhor já deu vários deles, então a gente pula; outra é como [o senhor] avalia os resultados dessas iniciativas, mas acho também... acho que já tá respondida: o senhor falou que elas eram bem sucedidas enquanto tavam vigentes...

Enquanto estão vigentes sim, né. E é... pra você ver como é complicado: quando esse diretor da Escola B aposentou... pouco antes dele aposentar ele mudou de escola. Na verdade eles não decidem isso, né. Direção não; professor até tem um pouco mais de poder de decisão em transferências. Professor, na atribuição de aulas, ele ainda consegue fazer as manobras, ir pra uma outra escola (ou às vezes até contra a vontade dele né, porque depende de pontos na carreira e tal. Às vezes ele perde a escola em que ele tava, contra a vontade dele)... mas enfim, ele tem mais poder de decisão - o professor. O diretor não, quase sempre é ordem superior. Então é assim: "Hoje você está na direção da escola A". E de repente chega uma ordem assim "Vá para a escola B". Não é porque você decidiu. É porque lá em cima alguém decidiu e você tem que ir praquela escola. Então quando o Prof. E., pouco antes dele aposentar até, mudaram ele de escola e aí ele até quis levar esse projeto pra outra escola [toca o telefone, o pesquisador pede licença e atende]. E daí a gente tava tentando descobrir os meios de levar pra outra escola, porque não tinha mais recursos financeiros pra construir o laboratório, pra equipar e etc. a outra escola. É... mas a gente tava estudando os meios, né. E... enfim, então... pra você ver quanto o envolvimento da direção é importante. Mas... o sucesso, vamos dizer, do projeto aí... ele foi bem sucedido enquanto tinha esse envolvimento, tinha essa parceria, tinha... ter participando ativamente o diretor, isso era muito legal. O diretor nas duas escolas, né, tanto o E. quanto a Prof. R., eles faziam questão de participar das nossas reuniões com os professores... Artigos que eu passava pra professores e livros, eles liam também, e depois participavam da discussão... e isso é fantástico! Isso é maravilhoso! Isso eu acho que é sucesso de um projeto, né. E não se deve a mim, se deve principalmente a eles, que arregaçaram as mangas, que compraram a ideia, que se envolveram e etc. Mas é... é muito frágil, né, um sistema que depende da boa vontade da pessoa. Você queria que ele não se aposenta[sse], porque alguém lá em cima tira o diretor da escola e põe em outra, porque acontece coisas desse tipo, né. E aí... nãa tem jeito. Por isso que eu acho que a situação não é tão simples, né. Eu não gosto também de imposição. Eu não gosto de a Secretaria de Educação impor a uma escola que ela vai ter que fazer um projeto com a universidade, porque também não funciona...

Tem algum comentário sobre a influência do contexto do nosso município, se a especificidade de São Carlos teria influenciado o sucesso ou não da iniciativa?

São Carlos tem... São Carlos é... é particular, né? É um município que tem características... não sou eu que tô falando, todo mundo fala, e de fato é verdade, os dados também mostram isso... É a "Capital da Tecnologia"... E não parece, mas a população incorpora essas ideias. Então, por exemplo, a mídia fala, explora bastante isso... "São Carlos é a cidade que tem o maior número de doutores... a relação número de doutores por habitante..." É... Essa meninada sabe disso. Essa criançada de ensino fundamental, de ensino médio ouve o tempo todo falar das universidades, de USP, de UFSCar, dos projetos, da pesquisa, da tecnologia, do conhecimento etc. É... os professores, obviamente, das escolas, e os diretores também. Então, isso acaba, de certa forma criando, por um lado, um clima favorável ao desenvolvimento de projetos... E... enfim, duas universidades que são importantes, são grandes, e enfim, elas colocam respeito, então de certa forma isso facilita um pouco. Por outro lado, a gente tem o CDCC, que tem uma relação muito estreita com as escolas inclusive com os alunos, né [inaudível] - coisa que nem toda cidade tem. Agora, a gente tem uma desvantagem também, em contrapartida: os projetos em São Carlos por número de escolas. Pode parecer estranho, mas, por exemplo: se você coloca alunos de graduação pra fazer uma pesquisa ou desenvolver um trabalho dentro de uma escola... essa escola fecha as portas porque ela fala: "Nós já temos muito estagiários, nós já temos projeto, trabalho com o CDCC, nós temos projeto com a Pesquisadora, a gente tem projeto com não sei quem... Não dá mais, né”. Então às vezes a gente não consegue por isso mesmo, a gente tem que ficar disputando essas escolas que nós temos, entre as universidades, entre os professores [universitários]. Porque aí dentro da universidade você tem a área de Física, a área de Matemática, tem Biologia, tem Química, tem, enfim... Pedagogia, e por aí vai, Psicologia... e todo mundo disputando as mesmas escolas. Agora, é exatamente o que eu tava falando agora há pouco: as escolas não são cobradas por isso. Na hierarquia deles eles são cobrados por outras coisas. Então, muitas vezes, a escola fala "não" porque: "Olha, não dá mais, a gente já tá com muito projeto, a gente tá com muito aluno estagiando, a gente tá com aluno oferecendo curso, porque não dá...” Quer dizer, então é 
assim... é... o lado bom, né, que é ter duas universidades, que é ter gente nas duas universidades pesquisando, trabalhando com educação (o que é muito bom), ter o CDCC (que é muito bom)... mas parece que... em alguns momentos eu acho que a cidade é pequena pra isso... porque as escolas... às vezes elas fecham a porta por isso. Eu vou dar um exemplo, né (que não é culpar a escola de maneira alguma): há um tempo atrás eu tentei fazer um projeto e tava procurando as escolas e fiz contato com a Escola C e eles negaram. E não é falta de boa vontade não, eles falaram "Nós estamos envolvidos até o pescoço com o projeto da Pesquisadora.". Então é assim, às vezes a gente tem que disputar esses espaços... Eu não consegui, tirei da lista a Escola C porque não tinha jeito. É... eu não acho ruim não... que a Pesquisadora. esteja lá desenvolvendo o projeto dela, eu acho ótimo, mas assim... pra gente também é uma disputa de espaço, né? Então tem esse outro lado. Se a Secretaria de Educação valorizasse mais o desenvolvimento dessas parcerias, desses projetos... porque muitas vezes ela quer implantar na escola projetos que estão fadados ao insucesso. Você vê projeto e você fala que isso não vai levar a nada, mas o professor tem que estar envolvido com aquilo, o diretor tem que estar envolvido com aquilo, eles são cobrados por aquilo, eles têm que apresentar relatório, eles têm que participar de reunião... E coisas que você fala "Pô, mas isso não leva a nada!". (Eu não tô dizendo de todos os projetos não). Tem projetos que são assim: que absorvem um tempo enorme e não levam a nada. E daí não cabe à universidade fazer parceria porque o projeto é deles e etc... Então, tem esse outro lado, né: é uma cidade relativamente pequena pra tudo isso. Eu senti muito isso na pele quando eu estive em Ribeirão. Na época em que eu estive lá a gente não tinha duas universidades públicas...

\section{Não tinha centro de ciências...}

...não tinha centro de ciências... e eu tinha 56 escolas de nível médio pra trabalhar! Pra quem tava em São Carlos, é o paraíso, né? 56 escolas e eu encontrava portas abertas porque era assim, sem contar que, na época em que eu tava lá, a gente tinha menos cursos dentro da USP. Então tinha menos gente... Por exemplo, a gente não tinha Pedagogia, que hoje tem. Então, esses espaços não eram tão disputados e o número de escolas era grande. Então era fácil desenvolver projetos em escolas, né. Porque quase nunca alguém procurava a escola, aquelas em particular. Porque lá você procura e ela te recebe de braços abertos: "Pô, vamo lá..." Aqui em São Carlos não; praticamente todas as escolas já participavam de no mínimo, no mínimo, um projeto com a universidade. No mínimo. E isso a gente fica disputando, e por isso que eu tenho um aluno desenvolvendo projeto em Ibaté. Eu já tenho que fazer esse tipo de coisa pra encontrar a escola disponível, o professor com mais tempo... Tem que ser uma escola que ninguém procura nunca, né, daí eles dão graças a Deus que a universidade tá vindo ali fazer parceria, que é o caso de Araraquara, de Itirapina, de Descalvado. Eu quero ir lá às vezes pra fugir um pouco daqui porque... Às vezes a gente fala com um professor de Química - eu até entendo, eu entendo de verdade - fala com o professor de Química e ele fala "Ah, mas eu já tô nesse projeto, eu tô participando com não sei quem e tal...” Tá bom, tudo bem, também não tem jeito de exigir que ele participe de todos os projetos que alguém da universidade vem aqui pedir participação. E aí a gente tem que encontrar um espaço... e é difícil, né. São Carlos tem essa característica. Por um lado isso é muito bom; e por outro lado o município é pequeno pra isso. Por incrível que pareça não existe escola pra tanto grupo, pra tanta gente, ainda mais agora né, com um monte de alunos de licenciatura, agora a gente orientando lá na Federal na pósgraduação, aqui na USP orientando na pós-graduação, e daí vira... pouca escola pra muita gente pesquisar, aplicar projeto de extensão, fazer estágio... tudo isso, tudo isso seria em parceria.

\section{O senhor teria algum comentário final, professor, sobre todo esse...}

Acho que o interesse seu, em geral, é sobre esses laboratórios escolares. Eu tenho esse interesse em pesquisar, acho que ela contribui bastante, uma experimentação bem feita e... enfim... no lugar do "tradicionalzão" que todo mundo adota... ela é fundamental pra um ensino de Química, um ensino de ciências de melhor qualidade, embora não vá resolver sozinha nunca esses problemas. Mas o que eu vejo é que falta política pública. A gente sempre vai ter o que fazer. Isso já mostra que o caminho é interessante, vale a pena investir nisso e etc., mas a gente não tem política pública pra isso. Então por exemplo, não existe verba pra gente investir em laboratório escolar. Se a gente quiser fazer algum projeto de laboratório escolar, qualquer que seja, tenha a escola ou não um laboratório, seja ou não equipado, se a gente quiser tocar nesse ponto, nós temos que fazer um projeto pra Fapesp ou pra CNPq ou pra não sei quem, envolvendo apenas essa escola, com recurso apenas praquela pesquisa, enfim, então tem uma limitação grande. Agora, nós temos alguma coisa em torno de 50 milhões de estudantes no Brasil entre o ensino fundamental e o médio. Os projetos de um de desses órgãos jamais vão conseguir atender 50 milhões. Jamais. Mesmo que todas as universidades se envolvessem, não dá pra trabalhar com todos. Então falta o outro lado, que é política pública, é investimento mesmo via governos estaduais, via governo federal... Não apenas dinheiro, mas valorizar o professor... E por aí tem todo um caminho longo pra ser seguido. 


\title{
G. TRANSCRIÇÃO (ENTREVISTA - PESQUISADORA)
}

\author{
Abaixo segue a transcrição do áudio da entrevista semi-estruturada com a \\ pesquisadora que coordenou o projeto com o laboratório científico da Escola C. No quadro da \\ Figura 14, este material está identificado com o código "e2". Por conta de um problema de \\ mal funcionamento do gravador, a formulação da pergunta inicial da pesquisa não foi \\ registrada.
}

Eu sempre tive interesse em educação. Não é uma coisa de agora. Inclusive tive uma fase muito grande, da década de meados de 60, até o fim de... até 2000, em que eu organizei muitos cursos, mas para pessoal de nível superior, na área de difração de raios-X, cristalografia, macromoléculas, moléculas pequenas, polímeros... Enfim, fiz muita coisa desse tipo inclusive participando às vezes de... atividades desse tipo... de educação, no âmbito da $S B B Q$ [Sociedade Brasileira de Bioquímica e Biologia Molecular], no âmbito da $S B Q$ [Sociedade Brasileira de Química], no âmbito da SBF [Sociedade Brasileira de Física]. Pronto: então isso tá respondido! [risos]

Tá! Com certeza! É... a senhora pode comentar... a senhora já comentou, na verdade, dos projetos relacionados a esta questão do ensino, né, que são todos os cursos de capacitação que a senhora organizou...

[interrompendo] É, até curso pra professores primários, né, que foi dado na Bahia...

É... Os objetivos desses cursos e os resultados, assim... a senhora pode fazer algum destaque sobre isso?

Desse cursos?

$\hat{E}$.

A maioria dos cursos foram destinados a professores em exercício, né. Inclusive eu nunca participei dos cursos de licenciatura...

\section{Eram pra formação continuada, então?}

É, eram pra formação continuada. Agora... quando chegou em... nesse início, com esses projetos Fapesp, eu cheguei à conclusão de que havia muitos cursos de capacitação. Mesmo gente da família participava muito desses cursos, né, meu cunhado, minha irmã que foi pra Unicamp. E eu me sentia um pouco desestimulada quanto ao verdadeiro rendimento que isso dava no ensino na sala de aula. Os professores vão lá, acham muito bonito fazer o curso, depois voltam pra sala de aula e continuam fazendo a mesma coisa até hoje. Muito poucos professores... quer dizer... não existe pra mim uma avaliação de quanto esses cursos de capacitação conseguiram melhorar. E como o que a gente vê é que o ensino está cada vez pior [risos], eu acho que não existe esse índice...

\section{É verdade...}

Não é verdade? Então foi assim: "Eu vou fazer uma coisa pequena, local, mas eu quero ter contato com os alunos da escola pública. Os professores serão meus parceiros. Mas nós vamos tentar fazer uma atividade em que nós entramos dentro da escola pública, e fazermos uma atividade em parceria com eles". E uma coisa continuada. Quer dizer, não é ir lá, fazer um curso de uma semana. É como eu te disse, nós ficamos lá na Escola $C$ durante vários anos. Inclusive a ponto de ter a turma de primeiro, segundo e o terceiro anos científicos simultaneamente sendo atendidas. E isso eu achei que nessa escala micro, que é uma escala em que você vai lidar... cê tem milhões de alunos; você vai lidar com... eu lidava com 40 de cada turma, 120 contando as três turmas... É valioso para esses alunos. E cheguei, mais ainda, à conclusão de que a nossa solução no ensino de ciência é acabar com esse ensino massificante que nós temos, em que todo mundo tem que aprender a mesma 
coisa: todos os milhões de alunos do ensino médio tem que ter as mesmas disciplinas, ou aquele pouquinho de aula de cada disciplina. Eu acho que se nós queremos ter um desenvolvimento científico-tecnológico no país, nós temos que fazer uma coisa que já se faz lá no exterior, que até já se fez no Brasil. Nós temos que separar em aqueles que gostam e têm vocação pra ciência (matemática, ciência, biologia) e dar a eles um curso mais puxado, um curso mais bem fundamentado, um curso que vai ser mais formativo, pra eles irem depois pro ensino superior com um background já pra poder fazer coisas valiosas lá dentro do ensino superior. O que acontece, a meu ver, no Brasil, é que eles têm essas "tinturas" de ensino de Física e Química, Matemática e Biologia no ensino secundário, sem nenhuma ênfase em coisa alguma, e eles entram... Na hora de escolher a carreira, por exemplo, eu acho que tinha que começar a pensar nisso aos 15 anos: "Vou fazer um curso científico ou vou fazer um curso de humanidades?" Eu fiz isso quando era jovem! E isso acabou. Por que é um pouco caro, é um pouco mais caro do que fazer essa coisa massificante pra todo mundo? Talvez seja, mas eu acho que era um dinheiro muito bem aplicado. Então eu acho que tem mesmo que separar. Tem que criar o que existe nos Estados Unidos que são as Science High Schools. A Science High School é uma escola em que os alunos não entram muito fácil não. Eles têm que ser bons alunos que terminaram o curso fundamental. E que têm boas notas e têm boa vocação para ciências. Aí eles vão fazer um curso muito mais forte sendo alunos dessas Science High Schools, que existem nos Estados Unidos e em muitos lugares. Eu acho que aqui no Brasil, qualquer lugar que tenha bairro, assim, conjunto de bairros, que já têm, sei lá, umas 100.000 pessoas, já tinha que ter uma Science High School. E começar a treinar os alunos, porque ainda mais hoje, que nós estamos numa era ainda muito mais científico-tecnológico do que a era da década de 40, quando eu fiz o meu científico. Eu fiz o clássico, aliás. É uma escolha que vai fazer quando você tem 15 anos. E que depois você pode até se reanalisar: "Olha, realmente não era... Adoro literatura, adoro música, adoro artes, mas não quero ficar na minha vida fazendo isso." E mudei pra fazer o vestibular pra Química. Entende? Então eu acho que... não é prematuro. Muita gente diz que o menino ou a menina de 15 anos não tem ainda a opção. Eles têm. E se eles fizerem a opção errada eles vão saber que fizeram a opção errada e eles vão se corrigir. A coisa mais importante da vida é você ir corrigindo sua rota. Você entra numa coisa, "é aquilo?" - você pensa que é, daqui a pouco não é. Muda a rota. Vai aperfeiçoando. E vai tendo uma bagagem cultural, não é? Porque nada é perdido do que você estuda. Então é isso que eu acho. Eu acho que o erro maior é esse negócio desse ensino massificante que não ensina nada, a rigor. E aí entra depois o vestibular que é outro massificante também, que não é grande... não é formativo. É uma competição em que quem chega primeiro é quem consegue fazer mais pontos e pronto. E aí você tem que... na decoreba, uma porção de regras mnemônicas que não significam nada, que os alunos ficam decorando pra poder fazer um bom vestibular. Eu não estou dizendo que bons alunos apesar de todo esse mal ensino - não consigam bons resultados. Porque aí quando você tem o bom aluno, não há muito que você precise fazer pra ele. Quando você tem aquele aluno com vocação, né. Até o próprio Feynman diz isso no fim do livro de Física dele, né, que ele foi dar aula e ele diz que para os bons alunos ele acha que ele não contribuiu praticamente nada. E para os desinteressados também ele não contribuiu [risos], não conseguiu tirá-los do marasmo! Então é isso!

\section{Agora eu vou entrar já na... na questão do... dos laboratórios, né. Eu queria que senhora contasse o seu} envolvimento com a questão do laboratório de ciências... Na verdade a senhora já falou, mas...

É... se você quiser que eu grave, eu falo em poucas palavras...

Poucas palavras... isso...

Eu acho que ensino de ciências sem ter parte experimental é uma coisa extremamente árida e nem tão interessante assim. Até que pode pra algumas pessoas ser interessante, mas não é muito interessante. Então, é... a primeira coisa que eu quis fazer lá na Escola $C$ foi colocar a sala que era chamada de laboratório em condições operacionais. Então fizemos desde a reforma física da sala, até a aquisição de equipamentos com o recurso generoso que a Fapesp forneceu. E enquanto nós estivemos trabalhando com os alunos lá, nós tínhamos alunos nossos de licenciatura, daqui da Licenciatura em Ciências Exatas, que eram bolsistas e que ajudavam o professor a preparar a aula prática. Preparar uma aula prática não é uma coisa que se faz com uma varinha mágica. Você tem que ter tempo. Às vezes você tem que ter uma tarde inteira juntando equipamento, vendo o que tá faltando, vendo se tem algum equipamento danificado, e isso daí gasta muito tempo. Então nossos alunos faziam isso. No final das contas, a conclusão a que nós chegamos, é que se nós não tivéssemos os nossos alunos lá, não havia aula prática. Foi isso que... a conclusão final lá. Por quê? O professor é o professor itinerante. Ele sai de uma sala, vai pra outra, vai numa sala, sai pra outra, tem muito pouco tempo livre pra planejar seu curso, pra planejar um experimento e pra dedicar ao laboratório. Então não é que o professor seja culpado. Ele simplesmente não tem condição - mesmo a gente deixando o laboratório bonito lá, bem organizado - de gastar o seu tempo preparando aulas. Então isso daí... Nós ainda mantivemos durante algum tempo esses alunos lá, mas vimos que se nós não tivermos os alunos lá, nós não conseguimos. Quer dizer: o que precisava ter é, pelo 
menos, eram os ajudantes de professores. Precisa ter dois professores na sala de aula. Inclusive, na hora do laboratório, você não pode ter um professor lá, com 20 alunos dentro do laboratório. A meninada vive... adolescente... é muito complicado. Até pra segurança. Então o fato de ter mais uma ou duas pessoas, lá dentro, ajudando, contribui para o bom resultado da aula prática.

Só um parêntese: eu fiz, quando... eu fiz licenciatura também, né, depois do bacharelado eu fiz... E eu ia fazer estágio lá em Ibaté numa escola que não tinha laboratório. Então eu levava a Experimentoteca...

...Isso...

...e fazia. E a professora falou assim: “Olha, se você puder fazer uma coisa por mim, é aula prática, porque eu não tenho condições.”

Exatamente.

E o que eu fazia? Eu chegava lá... a aula prática ia ser na segunda aula, então eu chegava na primeira e organizava toda a sala de aula...

...Pois é!

...depois eu limpava...

E você já levava o experimento pronto...

Pronto!

...da Experimentoteca. Então você vê. Precisa ter lá no CDCC gente que cuida daquelas maletas e que reponha o material que foi usado...

...Isso...

...faz tudo! É, da... a parte experimental é... não é assim tão tranquila de fazer. Não é que o professor não faz. porque não quer. Até o professor seu lá de Ibaté sentia falta. Mas como que ele vai fazer pra dar essas aulas?

Não, não tinha condições. E era noturno ainda...

Ih! Pois é!

Era uma aula... é... de 50 minutos...

Pois é, então! Então realmente... Agora: eu garanto que os alunos aproveitaram.

Sim. Com certeza. Bom, a senhora já deu vários detalhes. Eu... não vou fazer essa pergunta "Você poderia dar detalhes desse projeto" porque acho que senhora já falou bastante. O sucesso dessas iniciativas e de outras, a senhora avalia como tendo ocorrido?

Pois é. Eu acho que... ah... a nossa vida em geral é cíclica mesmo, né. Tem fases em que tudo vai bem, tem fases que começa a não ir tão bem... E eu percebi que não tava indo mais muito bem. Os nossos alunos iniciais, daquelas três primeiras turmas, eles queriam muito passar no vestibular, na USP, ou na Unesp, ou na UFSCar, então eles se dedicavam muito. Depois, eu até acho que foi um pouco esse ProUni, viu, que causou uma espécie assim de... relaxamento da tensão. "Ah, a gente pode fazer o Enem, a gente vai... vai conseguir uma vaga... uma bolsa parcial ou uma bolsa integral..." E teve vários alunos daqueles nossos que de fato conseguiram esse bom resultado. Na primeira vez que foi feito o Enem, sete alunos nossos conseguiram bolsa integral. Então eu achei que foi bom. Mas, a partir daquilo, houve um desinteresse. Era uma coisa gozada... Era uns... era...não tinha mais aquela frequência nas aulas de tarde. E eu não aguentei mais dois anos tentando. Depois eu resolvi que eu não ia mais fazer isso. Eu tava jogando dinheiro fora e o tempo de meus bolsistas fora. Porque eles iam lá, preparavam as aulas e não tinha aluno pra assistir. A própria direção da escola não fazia muita coisa, muita ênfase, né. Mudou a direção da escola, inclusive, nesse período. E os professores, eles são... eles mudam muito de escola. Então alguns professores eram, digamos assim, os que carregavam o piano lá, eles saíram, foram pra outra escola, e entrou gente muito desinteressada, que não queria fazer nada. Tem... teve um ano que não tinha 
professor de fato nem de Física nem de Química! Eram substitutos, daqueles temporários, que podem ser qualquer coisa! Então, era muito... foi muito desestimulante quando chegou esse pedaço. Então eu resolvi mudar. E nós resolvemos nos concentrar mais o esforço nessa área de difusão científica, que a gente faz através de nossa agência de difusão científica... e fazer experimentos, pedindo aos professores de várias escolas que indicassem alunos do curso secundário, do segundo grau, para serem bolsistas, nossos... e esses - eles já dão quatro alunos - e eles se encarregavam de estudar a matéria e preparar um bom experimento. Em geral isso levava um bimestre, cê acredita? Pra fazer um experimento, assim, muito simples... Mas eles não sabiam nada! E aí, depois que o experimento tá pronto, os alunos estão mais ou menos entendendo a matéria (a gente pensa pelo menos que eles tão entendendo) eles realizavam esse experimento várias vezes. Quando tão dominando o experimento a gente con... eles mesmos convidam colegas de turma pra virem assistir o experimento. Nós fazemos o experimento aqui, filmamos, e colocamos eles na rede. Então nós mudamos esse foco. Achando que chamando esses alunos que são alunos indicados pelos próprios professores das escolas, a gente pudesse fazer um trabalho que ia... é... pelo menos ser motivador. Quem sabe alguns alunos se motivassem, né, vendo o que os colegas estavam fazendo. E nós temos feito isso durante todo esse tempo. Até... de 2008 em diante nós temos trabalhado dessa maneira. Então teve um ano que nós fizemos experimentos de Física, que foi 2010; a gente chamou essa seção do site de "Experimentando a Física". Depois entrou o Ano Internacional da Química, então nós resolvemos voltar nosso interesse para a Química. E também em colaboração com os professores aqui do campus [a entrevista foi realizada na USP São Carlos], como Prof. Marcelo, aqui da Física, que é o professor de Prática do Ensino de Física, nós colaboramos na organização de minicursos. Esses minicursos são oferecidos a alunos do segundo grau (e professores que quiserem vir; enfim, é feita uma seleção, que é o Marcelo que faz) e apoiamos com os nossos bolsistas para irem lá ajudar. Então com isso foram feitos vários minicursos, que... é o minicurso, como tal, você deve saber, é uma coisa que acontece em torno de um dia inteiro e aborda um certo tema. Então os alunos vêm, nós fornecemos... vamos buscar os meninos lá... Em geral é aos sábados, então é marcado um encontro na porta das escolas. A gente pega uns dez alunos de cada escola, traz aí uns 40, 50 alunos e... a gente traz de ônibus, pagamos os cofee-breaks, pagamos os almoços, fazemos todo esse, essa infraestrutura, e quem dá o curso mesmo é o Marcelo com os seus alunos de Prática de Ensino. E é uma coisa que eu acho que é muito estimulante pra muita gente.

\section{É... sobre a questão dos laboratórios ainda, a senhora tem algum comentário a fazer sobre a influência do contexto do município? São Carlos teria algo diferenciado neste sentido?}

Olha, é... Eu acho que São Carlos poderia... Olha, nós somos assim chamados “a cidade da tecnologia”, né [inaudível], então eu acho que nós é... como é que eu poderia dizer?... Nós talvez pudéssemos ter alguma ação, nas escolas. E... algo... e... e realmente isso acontece. Acontece mas... é... a maioria são eventos transitórios. E eu acho que a educação não se faz só com coisas transitórias. Você precisa ter uma coisa focada mesmo. Por isso que eu entrei numa escola só. Porque você faz uma... um curso de um mês numa escola, depois numa outra mais 30 dias... Não é... nós precisávamos ter uma mudança radical, né. Quer dizer, é... o problema da educação nossa foi... tá sendo levado sempre de maneira a ter muito baixo rendimento. E nós sabemos disso. O governo sabe disso, o governo do Estado sabe disso, todos os levantamentos internacionais que são feitos, né (como... como o Pisa e tudo o mais), nos põem lá pra baixo de sei lá, de Trinidad e Tobago! [risos] E nós continuamos fazendo a mesma coisa! Eu acho que algumas coisas têm sido feitas, pelo governo federal e pelo governo estadual, mas elas infelizmente ainda não deram resultado. Agora: em educação nada dá resultado de um ano pro outro. Você não pode usar esse argumento como argumento eleitoral, digamos assim. A coisa tem que ser uma coisa muito mais sólida, feito um plano nacional, e que isso daí precisa um investimento constante de recursos, tanto na formação dos professores, como na manutenção das escolas. E, como eu já disse, a mudança filosófica: do segundo grau não ser esse ensino do tipo que é. Não adianta nem ter bom professor lá no segundo grau. Ele não tem tempo material pra fazer nada com os alunos. Ele tem muito poucas aulas. E aqui, ainda por cima, somos utópicos, né: "Vamos introduzir Espanhol. Vamos introduzir Filosofia. Vamos introduzir Sociologia." E o pessoal acha que isso daí se faz com varinha mágica. Onde tá o professor de Filosofia treinado pra dar Filosofia pro aluno de segundo grau? Não existe! E mesmo Espanhol. Nós temos aí uma comunidade de língua hispânica que poderia se... se mascarar de professor. Mas não é professor, né! Então nós temos essa falta de visão integrada do que é que a gente quer com a educação. Nós queremos ir pra que lado? Pra que coisa? Qual é o objetivo? Formar gente pra quê? "Tem que ser pra área técnica”?. Então nós tamos totalmente errados, o segundo grau não tá formando. Chega no ensino superior, quase tudo o que a gente faz nos dois primeiros anos de ensino superior, um aluno da Coréia ou da Índia ou da Inglaterra, já sabe! [risos] Então no ensino superior perdemos dois anos em geral!... fazendo os alunos chegarem até a um ponto em que eles podem começar a fazer alguma coisa. Então eu acho que nós tínhamos que olhar lá fora como é que as pessoas atuam... Existe uma dificuldade atual, para os nossos educadores aceitarem, que existe, em primeiro lugar, competitividade no mundo. E existe uma seleção, que é uma seleção dos melhores. Isso é inevitável! Não há como uma empresa contratar o pior! [risos] Ela vai contratar o melhor! E se não tiver o melhor, ela vai ter que 
treinar o melhor, alguns que tenham algum jeito de serem potencialmente bons, que ela vai treinar pra trabalhar dentro da indústria deles. Então isso... isso é o que nós tamos tendo, uma situação de extrema falta de objetividade e de planejamento. O que é que nós queremos pro país? Desenvolver que áreas? Turismo? Futebol? Esporte? Tudo bem! Então nós alienamos as outras áreas, né... E... então vamos fazer todos os cursos de Hotelaria, de Turismo, né... E... e vamos por esse lado. Agora: queremos criar engenheiros competentes? Físicos competentes? Químicos competentes? Químicos pra área de Química Industrial, que é tão importante? Temos que mudar um pouco esse enfoque, se é isso que nós queremos, né. E não podemos deixar o aluno chegar aos 18 anos ainda muito ingênuo em termos do que é a ciência, do que é a tecnologia. É isso o que eu acho.

A senhora foi muito rápida, viu professora! Eu já cheguei naquela questão assim, ó: “Há algum comentário final que a senhora queira deixar?"...

Algum comentário final?

...sobre toda essa conversa...

Humm... Olha, eu ainda tenho esperança, viu, senão eu não faria nada, né. Então eu acho que... é... quando você consegue iluminar a cabeça de um, dois alunos, que de repente vão fazer um bom curso de engenharia com um preparo melhor, você está dando uma contribuição. E eu acredito muito em que certas coisas são mais ou menos contagiosas, né. Se você começa a ter uma comunidade de gente muito bem preparada, essa comunidade daqui a pouco vai contagiar outras pessoas. Então... eu acho que nós temos que, aqui no Brasil, e em todas as áreas, nos convencermos de que nós temos que nos dedicar principalmente àquelas pessoas que querem trabalhar. Você quer ser pianista? Ora, não é tocando meia hora por dia! Você tem que tocar no mínimo cinco, seis horas por dia. Você quer ser historiador? Você vai ter que entrar nos arquivos, ficar estudando muito. Não há nada que seja resultado bom que não tenha um bom número de horas de trabalho. Então nós tínhamos que botar isso na cabeça das pessoas. Elas têm que trabalhar de uma maneira intensa e contínua. E não adianta querer ficar brincando de trabalhar, não é? Tem que ser trabalho intenso e contínuo. Tem um livro aí que dize mostra que não tem nenhuma pessoa bem sucedida que não trabalhou naquele tema em que ficou bem sucedida pelo menos 10.000 horas. [risos] É um livro que chama-se... como é que chama mesmo? Chama-se... Outliers, é um nome em inglês. "Você se sobressai das outliers"... Mas em português tem a tradução (eu recomendo que o pessoal leia), chama-se... (eu posso depois ver e complemento isso aí [apontando para a gravação])... chama-se Os fora de série, parece, uma coisa assim... E ele mostra que é isso: você não vai ter um cara formidável que não pôs todo o resto pra trás e se dedicou intensamente naquela área dele. Não é como um dom ser assim. E ele cita todos os exemplos dessas pessoas mais conhecidas, mais bem sucedidas. Pra ser bem sucedido não basta ser esperto. Nós temos um pouco a noção [d]isso: bem sucedido aqui no Brasil é uma pessoa bem espertalhona. Eu não diria nem "esperto" pra não confundir com "expert". É um espertalhão que vai fazendo uma coisa aqui e outra lá e vai conseguindo... né? Não, não é isso. O sucesso verdadeiro é na base de muito trabalho. É isso o que eu recomendo: muito trabalho pra quem quer ser, quem quer dar uma contribuição importante. 


\section{H. TERMO DE CONSENTIMENTO LIVRE E ESCLARECIDO (ENTREVISTA - PROFESSORA/PESQUISADORA)}

O termo foi apresentado à professora/pesquisadora universitária com envolvimento na formação de professores de Química no curso de Licenciatura em Ciências Exatas, da USP, campus de São Carlos.

\section{Termo de Consentimento Livre e Esclarecido}

Você, está sendo convidada para participar do projeto Experimentação no ensino de Química: contribuições do Projeto Experimentoteca para a prática e para a formação docente, que desenvolvo em meu doutoramento pelo Instituto de Química de São Carlos (IQSC-USP), sob orientação do Prof. Dr. Antonio Aprigio da Silva Curvelo.

A qualquer momento anterior à conclusão do estudo você poderá desistir de participar e retirar seu consentimento. Sua recusa não trará nenhum prejuízo em sua relação com o pesquisador ou com a instituição.

O objetivo central do estudo que ora desenvolvemos, no interior deste projeto, é averiguar quais são as contribuições da Experimentoteca para a formação inicial de professores de Química. Você está sendo convidada a fornecer um depoimento, durante a realização de uma entrevista de tipo semi-estruturado, que será registrado na forma de gravação em áudio. A gravação será, posteriormente, transcrita e analisada, sendo a transcrição incluída nos relatórios que vierem a ser preparados.

Não há riscos envolvidos quanto a sua participação no estudo. Salientamos seu nome e da instituição a que está vinculada poderão ser alterados, garantindo sigilo, se assim desejar.

Espera-se que este estudo agregue informações sobre a realidade educacional deste município e subsidie políticas e ações para as transformações necessárias.

O pesquisador se compromete a compartilhar as informações coletadas, ao final do estudo, com você, bastando que você entre em contato e informe o momento mais adequado para esta apresentação.

Você receberá uma cópia deste termo onde constam os dados documentais e o telefone do pesquisador, podendo tirar suas dúvidas sobre o projeto, agora ou a qualquer momento.

\section{Rafael Cava Mori}

Declaro que entendi os objetivos, riscos e benefícios de minha participação na pesquisa e concordo em participar.

São Carlos, 12014 .

Nome do Sujeito da Pesquisa:

$(R G$ : / CPF: ) 


\section{ROTEIRO (ENTREVISTA - PROFESSORA/PESQUISADORA)}

Segue abaixo o roteiro com as perguntas principais que foram feitas à professora/pesquisadores com envolvimento na formação inicial de professores de Química, graças a sua atuação no curso de Licenciatura em Ciências Exatas. Além destas perguntas, foram propostas também questões de aprofundamento e esclarecimento.

\section{Entrevistada:}

Início:

Término:

O tema de nossa entrevista será a participação da Experimentoteca, do CDCC, no processo de formação inicial de professores de Química. Mais especificamente, queremos falar sobre o contexto da disciplina Prática do Ensino de Química, do curso de Licenciatura em Ciências Exatas da USP, campus de São Carlos.

1. Fale-nos de seu interesse sobre a questão do ensino de ciências.

2. Você poderia comentar alguns dos projetos relacionados, a esta questão, de que você tenha participado? Quais os objetivos deles e quais resultados você destacaria?

3. Conte-nos sobre seu envolvimento com a questão do laboratório de ciências nas escolas públicas de São Carlos. De que maneira se deu este envolvimento?

4. Você poderia fornecer detalhes sobre os projetos de que tenha participado, relacionados a esta questão?

5. Como você avalia o sucesso destas iniciativas e de outras semelhantes?

6. Com relação a isto, que comentários você poderia fazer sobre a influência do contexto de nosso município?

7. Há algum comentário final sobre esta questão?

1. Quando você ingressou na USP, campus de São Carlos, como docente do Instituto de Química de São Carlos?

2. Em que circunstâncias?

3. Que disciplina(s) assumiu? Em que cursos?

4. Fale sobre a disciplina Prática do Ensino de Química: que conteúdos são trabalhados, de que maneira, como a disciplina se insere no currículo do curso de Licenciatura.

5. A experimentação no ensino de Química é abordada na disciplina? Se sim, de que maneira?

6. Como os licenciandos encaram a experimentação?

7. Eles incluem esta estratégia de ensino em suas atividades de estágio?

8. A Experimentoteca do CDCC é utilizada pelos alunos da disciplina, no desenvolvimento de suas atividades?

9. Você foi Coordenadora do curso de Licenciatura em Ciências Exatas por 2 anos. Você acha que o CDCC e seus projetos estão adequadamente integrados a este curso de formação inicial de professores?

10. De que maneiras a participação do CDCC poderia ser incrementada neste curso?

11. E quanto à Experimentoteca, você entende que ela já está devidamente integrada e participa efetivamente da formação de professores de Química, considerando não só o âmbito da disciplina de Prática do Ensino de Química?

12. De que maneiras a presença da Experimentoteca poderia ser aumentada no curso de Licenciatura em Ciências Exatas? 


\title{
J. TRANSCRIÇÃO (ENTREVISTA - PROFESSORA/PESQUISADORA)
}

\author{
Abaixo segue a transcrição do áudio da entrevista semi-estruturada com a \\ professora/pesquisadora com envolvimento na formação inicial de professores de Química. \\ No depoimento foram mencionados nomes de terceiros, o que poderia comprometer o \\ sigilo da identidade da entrevistada. Decidimos por abreviá-los, somente pelas iniciais, nesta \\ transcrição.
}

Então a primeira pergunta que eu vou te fazer é: quando você ingressou na USP, aqui no campus de São Carlos, como docente do Instituto de Química de São Carlos?

Em 2003, fevereiro.

E em que circunstâncias você ingressou?

Concurso, né, pra área de Ensino de Química especificamente mesmo, né, pra essa vaga.

Com... é... pensando em atuação no curso de Licenciatura em Ciências Exatas ou...?

É... quando a gente faz o concurso a gente não sabe, né, o que que é o co... A vaga era pra atuar na área de Educação em Química, então, a informação é essa. Mas com certeza o concurso foi... é... elaborado, né, pra pensar em contratar alguém pra atuar na Licenciatura.

Então que disciplinas você assumiu logo que você ingressou?

Quando eu entrei eu peguei a Prática de Ensino de Química, né (que na época tinha esse nome e agora tem outro nome)... é... uma optativa da Licenciatura que eram Problemas Educacionais Brasileiros. Ah, e a da pósgraduação.

Então foram essas em âmbito de...

...graduação...

...e a da pós foi aquela Prática de Ensino de Química para o Nível Superior...

...é, que também mudou de nome.

Então fala pra mim, por favor, sobre essa disciplina Prática de Ensino de Química: que conteúdos são trabalhados (ou pelo menos eram naquela época), de que maneira e como a disciplina se insere no currículo do curso de Licenciatura?

Então, a disciplina de Prática do Ensino de Química, ela é aquela que a gente tem em todos os cursos de licenciatura. E no caso aqui da USP ela agrega tanto as horas de estágio, né (que o professor tem que cobrar do aluno), quanto a parte teórica (que é pra dar subsídio pra ele atuar na escola, né). Então ela tem esses dois... essas duas frentes aí. Na parte teórica, o que a gente vê, é basicamente estratégias de ensino, avaliação da aprendizagem... na época houve um pouco de Filosofia da Ciência... E a gente faz um direcionamento pra o trabalho na escola, né, também. O que tem de... com o tempo, né... o que deu pra perceber ao longo dessa... desses dez anos que eu tô aqui, é que nessa época (quando eu peguei os alunos da Licenciatura), era inacreditável a falta de conhecimento que eles tinham sobre esses assuntos aí. Eles nunca tinham escutado falar em CTS, jamais em tempo algum, nem aprendizagem significativa, nada disso. Agora, se você vai dar aula (que 
a A. C. tá dando $\left.{ }^{114}\right)$ pro aluno nosso, seguramente, quando ele chega na Prática de Ensino, ele tá muito mais bem preparado. Então nesse tempo aí, de 2003, a gente tinha que realmente introduzir tudo, até aquela história de falar de como que tinha evoluído o ensino de ciências, tudo isso eles precisavam ouvir. Agora já começa a ficar redundante pra se falar isso nessa disciplina...

\section{Então ela já é mais... voltada pro estágio em si, digamos assim?}

É, ela é mais voltada pro estágio em si porque ela não tem... não... ela não tem o... você pode abordar outras coisas, né. O que eu quero dizer é: que quando os alunos chegavam no final da... da reta aqui, né, eles não tinham praticamente nenhum conhecimento da parte de Educação, embora existissem as disciplinas pra trás, porque a gente não tinha praticamente nenhum contingente aqui no campus, né, de professores dessa área de Educação em Química, aí. Em Química tinha o P. P., que havia sido contratado antes, que ficou pouco tempo aqui, e na Física não tinha a C., não tinha o M., enfim. Então essa entrada desse pessoal fez uma diferença bem grande, aparentemente, na formação dos alunos.

\section{E... eu perguntei de conteúdos... a experimentação no ensino é um tópico dessa disciplina?}

Também, a experimentação também é um tópico, e eles usam bastante, né... Aí é mais na... na parte de... eles fazem, né, propõem experimentos pros alunos do ensino médio. Então eles põem muito a mão na massa quando eles vão fazer a... a regência deles, né, de alguma forma.

Então é uma atividade mais vol... mais presente, a experimentação, assim, o conteúdo de experimentação, quando eles vão organizar as regências, você diria?

É, quando eles vão organizar as regências, ou os minicursos ${ }^{115}$... Pelo menos na época em que eu ministrava, né - cada professor tem a sua... a sua marca. Eles tinham que propor os experimentos, mas não de a gente fazer experimentos. Você vê sobre experimentação o que que são os fundamentos, os estilos de aulas experimentais, e depois eles iam propor os experimentos pra usar nos minicursos, né (no CDCC), ou nas regências na sala de aula lá, ou às vezes, agora - naquela época também não tinha muito isso -, pras atividades acadêmicocientífico-culturais (eles às vezes assistiam palestras sobre, né)... E... a... a parte também da... das... dessas horas aí do estágio eles podem fazer como apoio ao docente: às vezes eles montam experimento pro professor aplicar lá, ou então eles vão (como você fez) organizar o laboratório ${ }^{116}$, enfim... Então a experimentação entra mais ou menos por esse... não que eles tenham aulas experimentais de precisar trabalhar experimentação com eles.

\section{Entendi. É... e como os licenciandos encaram a experimentação? Assim, como que...?}

Ah, então, isso aí é interessante porque... Na verdade a gente tenta, né - até porque minhas linhas de pesquisa são da parte de Linguística, de texto de divulgação científica, de leitura -, a gente procura fazer com que os alunos, né, pensem em montar aulas que estejam um pouco voltadas pra essas outras, outros recursos aí - que é mapa conceitual, que é texto de divulgação científica, e por aí vai. Aí, especificamente com relação a texto de divulgação científica, a gente teve uma experiência bem interessante, que era na tese da L. N., né, que ela dizia pros alunos o que era texto de divulgação, eles trabalhavam em sala de aula com texto de divulgação e na regência tinha que ter um texto de divulgação científica no contexto do que iria ser proposto por eles. Mas quase todos usavam texto mas eles não deixavam de fazer alguma coisa...

[interrompendo] Incluir a experimentação...

...é, não tinha como eles não fazerem isso. E depois a gente fez entrevistas e eles falavam que é porque eles achavam que sem a experimentação os alunos não iam ter interesse no... no que eles iam falar. Então a

\footnotetext{
${ }^{114}$ Referência à professora que atualmente ministra a disciplina em questão.

${ }^{115}$ Entre as atividades previstas na disciplina Prática do Ensino de Química (atualmente, Estágio Supervisionado em Ensino de Química), está a elaboração de um minicurso a ser realizado no CDCC. O minicurso tem a duração de uma semana e é direcionado a estudantes do ensino médio que desejam se aprofundar no estudo da Química, a partir do desenvolvimento de um tema específico. Por exemplo, quando cursei a mencionada disciplina, minha equipe desenvolveu um minicurso sobre a química dos perfumes e das essências, tema que possibilitou o estudo de aspectos da Química Orgânica e de técnicas de laboratório para a extração de óleos essenciais.

${ }^{116}$ A entrevistada faz referência ao trabalho de campo que relato no capítulo 4 desta tese, do qual ela tomara conhecimento no ano de 2013. Entretanto, propriamente, não realizei a organização dos laboratórios que visitei.
} 
experimentação é como se fosse, vamos dizer assim, né, o... coringa deles pra tentar atrair a atenção dos alunos. Isso aí ficou muito claro no... no trabalho da L.: eles fazem o que você quer, mas eles fazem a experimentação também... por conta disso - isso é engraçado! [risos]

Então dificilmente você vai ter algum estagiário que não fez atividade de experimentação durante seu estágio?

[interrompendo] Ah, não, não vai ter nenhum!

\section{Nenhum?}

Todos fazem. Porque tem o minicurso no CDCC, né. Nesses dez anos aí a gente sempre ofereceu os minicursos lá. E não dá pra você oferecer um minicurso de Química sem fazer experimentação. Isso aí é quase o que o pessoal do CDCC também fala pra eles. Eu não acredito muito nisso não; acho que até dá. Mas a tendência é fazer. Porque realmente tem o apelo de atrair os alunos da educação básica com isso aí.

Mas nas escolas também - frequentemente tem uma atividade de experimentação na regência ou no apoio ao docente?

É... também. Aí a gente não acompanha tão de perto, né, porque assim, eles vão lá e eles têm que cumprir aqueles... aquelas “ $x$ ” horas. Então eu não tenho tudo registrado. Mas seguramente eles fazem também. Eles fazem... eles ajudam as feiras de ciências, né... isso também é muito comum: eles ajudam o professor na feira de ciências e às vezes tem... eles montam aquelas mesinhas, né, com experimentação...

Certo. [silêncio] Tá. É... A pergunta 7 já era... já foi respondida: eu perguntaria se os licenciandos incluem a estratégia de ensino da experimentação nas suas atividades de estágio. Já foi respondida. E aí já começa a entrar as questões referentes à Experimentoteca. A Experimentoteca, ela é utilizada pelos alunos da disciplina?

Sim, bastante. Sem nenhuma indicação, assim, minha, né... Eles têm... eles montam a proposta do minicurso, depois eles vão lá construindo na sala de aula o que que vai ter em cada dia do minicurso. E eles sempre procuram saber, né, se o tema que eles vão trabalhar pode ser, de alguma maneira, subsidiado por experimentos que já estejam lá na... na Experimentoteca. Porque facilita até o trabalho no CDCC e tudo mais...

[interrompendo] $O$ acesso ao material...

É, tudo fica mais... mais fácil.

A primeira... talvez o primeiro critério pra você... pra eles elaborarem alguma atividade seja haver o kit, né?

Não, não é porque eles... eles primeiro escolhem o tema, eles vão afunilando as coisas. Eles podem ter escolhido um tema que, no final das contas, não tinha nada a ver com o que tem lá na Experimentoteca.

É verdade...

Eles procuram ver se dá pra encaixar, né. "Vamos ver se tem. Se tem, beleza.” Mas não que eles vão... usar isso como critério pra propor um experimento.

Certo. Eu tô lembrando porque eu também já fiz. [minicurso] mas, de fato, a gente não fez assim: a gente pensou primeiro num tema...

[interrompendo] É... aí depois depende do tema que você pega...

[interrompendo] Mas aí a primeira... o primeiro recurso que a gente procurou...

É....

...pra verficiar se podia fazer alguma atividade seria a Experimentoteca...

É, “Eu tô querendo fazer isso... tem na Experimentoteca?” Cê tá [inaudível] mais ou menos essa sequência aí. 
Então ela entra mais nos minicursos?

Sim. É... até onde vai meu conhecimento, né? É como eu te falo: na escola, eles fazem as atividades de apoio ao docente. Aí se o docente agendou alguma coisa no CDCC e esse kit vai pra sala de aula, e eles tão lá e ajudam, aí já não... não sei te falar. Eu sei do que eles fazem no minicurso, que a gente acompanha de fato...

[interrompendo] Mais de perto, né?

[interrompendo] Muito mais de perto...

Mas pode ter alguma menção no relatório, né, nos relatórios de estágio?

Pode, mas aí eu não vou te afirmar porque eu nunca li prestando atenção nisso, entendeu? Se tinha Experimentoteca, se não tinha Experimentoteca...

\section{Entendi, entendi...}

Pode ser que tivesse, mas não... não era o foco meu.

É... você é atualmente Coordenadora do curso de Licenciatura?

Não...

\section{Você foi Coordenadora...}

Desde antes de ontem eu não sou mais! [risos]

\section{Ah, tá! Desde antes de ontem...}

Acabou meu mandato dia 2. E hoje não é 5? Fazem três dias que eu não sou mais Coordenadora. [brincando] "Ai, que bom!" [risos]

\section{E você ficou quanto tempo na Coordenação?}

Quatro anos.

Quatro anos? Certo. E você acha que o CDCC e os projetos do CDCC tão bem integrados ao curso de Licenciatura?

Então, eu acho que poderia haver uma integração maior. Mas, seguramente, os alunos da Licenciatura, eles têm uma participação muito grande lá. A gente tem vários monitores que são do curso de Licenciatura. [silêncio] Isso aí sim... nesse sentido ele tá integrado. Com relação ao oferecimento de minicurso, que eu saiba - eu precisaria perguntar pros outros professores da Física [Instituto de Física de São Carlos] se eles oferecem minicurso lá... - eu não sei, acho que não... Então assim, essa coisa dos alunos da Licenciatura oferecerem atividades pro público lá no CDCC, porque eles são alunos da Licenciatura, eu acho que não... não existe muito. Existem os que tão lá porque participam daquele... clube de ciências, enfim. Eles são alunos da Licenciatura como poderiam ser de outros cursos. Seguramente... inclusive nas ideias, né, que deram origem ao curso, essa noção de que o CDCC tinha que ter uma... um estreitamento muito grande com o curso de Licenciatura era clara, tá em todos os documentos, se fala isso aí, que eles iriam ter... eles ti... chegaram a ter aula de Biologia lá no CDCC, nos primeiros anos do curso... Mas por alguma razão que não se diz, né, porque não se escreve - não tá nas atas, e o [Prof. Dietrich] Schiel já morreu, talvez ele pudesse responder-, nunca se aproximou tanto o curso de Licenciatura do CDCC como se gostaria.

\section{“Nunca como se gostaria"?}

É, como se...

...como se almeja? 
É, “como se gostaria”, talvez o "gostaria” fosse meu, né. "Tanto quanto se poderia”, né? Porque você poderia ter uma integração maior... Agora, por que razão isso não aconteceu embora tivesse previsto, né, e fosse desejado... aí a gente não sabe.

\section{E você tem algum palpite de que maneiras a participação do CDCC poderia ser incrementada no curso?}

Então, é isso que eu tô te falando. Por exemplo, vocês, quando fizeram a disciplina, da Prática do Ensino de Química, vocês foram lá e ofereceram minicurso. Então, isso aí é uma maneira de você ter os alunos - porque eles são alunos, não é porque eles são bolsistas - oferecendo isso aí. Antigamente, existiam as monitorias também (de Química... agora acho que só tem a de Matemática, se eu não me engano, e a de Física). Isso aí também, não sei em que momento se perdeu nem porque se perdeu... mas coisas desse... dessa natureza aí, e até... talvez... A gente tá tendo o curso de especialização lá agora em Educação em Ciências; os alunos poderiam de alguma maneira participar desse curso, não sei, talvez assistindo algumas aulas, se fosse do interesse, mas não tem muito essa... esse estreitamento aí, entre CDCC e Licenciatura, como poderia, não.

E quanto à Experimentoteca em si: cê... você acha que ela tá já devidamente integrada e participa da formação inicial do professor de Química?

É, é o que eu tô te falando: a Experimentoteca, ela tá... Tá não assi... ela tá espontaneamente, né, integrada, porque de fato... dificilmente você tem um minicurso desses dez anos (que por ano a gente oferece lá uns dois, três)... se você pensar em 30 minicursos, deve ter tido uns três que não tinham nada da Experimentoteca. Porque ela tá pelo papel que ela tem, assim, sem ninguém precisar mandar, entendeu?... o aluno usar a Experimentoteca. Ela tá porque ela de fato ela é importante e facilita essa... esse entrosamento aí com os alunos da escola pública. Então... eu acredito que sim.

Você pensou, assim, alguma vez, é... num curso específico que pudesse tratar da Experimentoteca, assim...? Ou alguém numa reunião da CoC [Comissão Coordenadora do Curso de Licenciatura em Ciências Exatas ${ }^{117}$ ]... que tinha esse papel, assim, por exemplo, ter uma disciplina só sobre os recursos do CDCC, no curso de... de Licenciatura?

Ó, na minha gestão não. Mas, assim, não sei se isso já aconteceu um pouco mais pra trás, né, quando de fato existia esse... Na minha gestão, eu acho que essa palavra nunca foi mencionada em nenhuma reunião da CoCa "Experimentoteca", acho que nunca, jamais.

Então ela tem uma participação no curso que é incidental, assim... do fato dela existir e estar prontamente acessiviel...

É, exatamente. Não que ela se divulgue que ela existe... Outra opção... outra alternativa, que talvez você pudesse averiguar, é se no... nas Selics [Semanas da Licenciatura em Ciências Exatas] isso aí não acontece, ou não aconteceu. Pode ser que sim, pode ser que já tenha sido dado um curso pensando nisso. Mas, assim, em termos de gestão ali, né, de administração, isso aí nunca foi feito. [silêncio]. Na Química... é... talvez a... (porque a gente tá falando de Experimentoteca em Química - ela tem as outras áreas)... pode ser que, por exemplo, eles têm aquela disciplina que chama Instrumentação para o Ensino... pode ser que o professor de Física [a disciplina mencionada é de responsabilidade do Instituto de Física de São Carlos], em algum momento, pensou em fazer isso. Mas aí já é outra... outra história.

Eu fiz essa pergunta porque os trabalhos - lembra aqueles trabalhos desse artigo da Experimentoteca, né? ${ }^{118}$ -, alguns resultados desses trabalhos indicam que tem decrescido o uso da Experimentoteca em relação à participação do setor público. O percentual de escolas públicas que retiram [os kits] tem sido cada vez menor. Na rede privada...

[interrompendo] Isso aí foi pesquisa de quem, qual deles?

\footnotetext{
${ }_{117}^{11}$ A CoC é a comissão presidida pelo Coordenador do Curso.

118 Aqui, fiz referência ao artigo "A Experimentoteca do Centro de Divulgação Científica e Cultural (CDCCUSP): 30 anos de contribuições ao ensino de ciências”, publicado na Revista de Cultura e Extensão USP, e que apresenta parte do material do capítulo 5 desta tese. $\mathrm{O}$ artigo fora por mim mencionado, na entrevista, porque a entrevistada, antes de prestar seu depoimento, comentara ter lido e apreciado o texto, publicado havia pouco mais de um mês.
} 
Foi a Re... foi a pesquisa da Renata Canales, de 2006.

Ela fez o que? Fez um levantamento?

Fez um levantamento de todos os empréstimos, isso... por mais de dez anos, se não me engano. Ela viu que a participação do setor público tem diminuído. Uma das hipóteses do estudo dela é que não há um... uma presença tão grande, da Experimentoteca, nos cursos de formação inicial desses professores que vão atuar... nessas escolas, né.

Sim. É... é provável, né. De fato. No caso da Química é isso aí, não existe a... não sei, aí tem que ver... agora depois desses dez anos a gente tem a A. C. A A. C. é mais no foco da experimentação; pode ser que ela acabe... E acho que ela tá envolvida com a... com o projeto da Experimentoteca que tá rodando no CDCC agora de... enfim, fazer algum tipo de melhoramento, lá. Então eu acho que a A. C. - inclusive o que tinha no nome dela eu passei [referência da entrevistada a seu período como presidente da $\mathrm{CoC}$ ] -, acho que ela tá envolvida de alguma forma. Pode ser que agora se insira um pouco mais isso. E nas disciplinas de Instrumentação... a parte da Física pode ser que também... em algum momento o pessoal utilize.

Mas na Química é isso que você disse: ela está muito presente porque...?

[interrompendo] É, porque...

[interrompendo] ...os licenciandos procuram, né...

É, é... mas ela nunca foi, por exemplo, em nenhuma aula minha desses dez anos aí, eu cheguei e falei: "Olha, vamos pegar a Experimentoteca...” Aliás, minto! Teve uma... uma... é, agora lembrei... Aquele artigo da L. N. e do E....

[interrompendo] ...do "jigsaw"?"119

É... aí teve uma época em que a gente fazia um "jigsaw" na sala de aula com os alunos da Licenciatura. Então por causa disso a Experimentoteca ia lá. Mas... aliás, nem sei se ia, viu Miyage...

Ia sim, porque eu fui aluno.

Você lembra? Então... aí sim. É a única... mas ela tava lá, de novo, né... uma coisa... meio que pela tangente, né. Não era ela por ela própria; era porque ela tava dando condições para fazermos nossa estratégia.

Certo. Tem uma outra questão... ela não tá aqui, mas eu conversando com outros licenciandos, fazendo um... um exploratório com eles... é... eles falaram que em algumas disciplinas de estágios de... que não eram estágio de Química, mas que eles eram um pouco dissuadidos de usar a Experimentoteca. Por quê? Porque era muito fácil! O professor queria que eles elaborassem uma atividade e não pegasse... O que você acha disso?

É, eu não vejo nada de... de demérito em usar porque tá pronto. Você... é uma coisa que tá pronta que você pode incrementar da maneira que você... Igual a gente falou agora do "jigsaw”: quer dizer, ela tá tendo um papel numa estratégia que é super... que o aluno é ativo, que tem uma série de vantagens... e ela funciona bem ali. Então não é porque tá pronto que você só pode usar aquilo ali. Você pode pensar em outras maneiras. Aí vai de cada um, da concepção de ensino, sei lá, de aprendizagem, que muitos professores têm pra pensar sim ou não [inaudível].

Certo. Você tem mais alguma coisa a acrescentar sobre esse assunto?

Acho que não... É como eu te falei: eu nunca trabalhei muito com ela, então, assim... eu vou aprender mais com o que você fale, com o seu artigo, do que eu que vou... [risos] Ela nunca teve muito destaque na minha disciplina não, embora eu reconheça o valor que tem...

\footnotetext{
${ }^{119}$ Referência a um artigo, de autoria do grupo de pesquisa da entrevistada, que apresenta a estratégia de ensino baseada no método "jigsaw" para o trabalho em grupo. Enquanto aluno da disciplina Prática do Ensino de Química, lembro-me de que em uma das aulas, em 2010, pudemos vivenciar esta estratégia, utilizando os kits da Experimentoteca como material de apoio.
} 
Seguramente ela participa...

[interrompendo] Ah, sim!

...participou muito, né...

[interrompendo] Bastante...

...da formação dos professores. Embora não numa forma orientada para o uso dela...

É, orientada para o uso dela. Ela vem quando é preciso, né... os alunos entendem que é um recurso interessante. E acho que na escola eles vêem também os professores usando, né... então...

\section{Certo.}

